ISSN 2082-064X

$4(68) \cdot 2020$

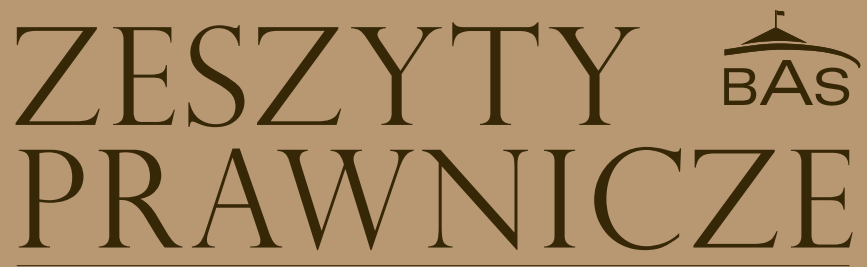

Biura Analiz Sejmowych Kancelarii Sejmu

Funkcjonowanie nieruchomości niezamieszkałych

Kształtowanie składu Senatu w Belgii

Zatwierdzenie regulaminu strzelnicy 


\section{ZESZYTY PRAWNICZE}

BIURA ANALIZ SEJMOWYCH

ROK XVII - 4(68) - 2020 


\section{Rada programowa}

dr Ziemowit Cieślik, Uniwersytet Kardynała Stefana Wyszyńskiego w Warszawie - przewodniczący - dr Piotr Czarny, Uniwersytet Jagielloński w Krakowie - prof. zw. dr hab. Cezary Mik, Uniwersytet Kardynała Stefana Wyszyńskiego w Warszawie - drhab. Adam Szafrański, Uniwersytet Warszawski - prof. zw. dr hab. Andrzej Szmyt, Uniwersytet Gdański - prof.zw. dr hab. Marek Szydło, Uniwersytet Wrocławski

\section{Zespół redakcyjny}

dr Przemysław Sobolewski, Uniwersytet Warszawski - redaktor naczelny - dr Wojciech Arndt, Akademia Ignatianum w Krakowie - Paweł Bachmat, Instytut Wymiaru Sprawiedliwości, Biuro Analiz Sejmowych Kancelarii Sejmu RP - dr Piotr Chybalski, Uniwersytet Kardynała Stefana Wyszyńskiego w Warszawie . dr Ewelina Gierach, Uniwersytet Kardynała Stefana Wyszyńskiego w Warszawie - dr hab. Robert Jastrzębski, prof. UW, Uniwersytet Warszawski - dr Adam Karczmarek, Uniwersytet Kardynała Stefana Wyszyńskiego w Warszawie - dr Krzysztof Kozłowski, Uniwersytet Jagielloński w Krakowie - Bartosz Pawłowski, Biuro Analiz Sejmowych Kancelarii Sejmu RP, Warszawa - dr hab. Jadwiga Potrzeszcz, prof. KUL, Katolicki Uniwersytet Lubelski Jana Pawła II w Lublinie - dr Zofia Szpringer, Biuro Analiz Sejmowych Kancelarii Sejmu RP, Warszawa - drhab. Michał Warciński, Uniwersytet Warszawski - Marta Kopeć - sekretarz redakcji

\section{Redakcja tematyczna}

Paweł Bachmat - prawo karne - dr Ewelina Gierach - prawo konstytucyjne - dr Adam Karczmarek prawo administracyjne - drPrzemysław Sobolewski - prawo cywilne i handlowe - dr Zofia Szpringer prawo finansowe

\section{Redakcja językowa Teresa Muś}

\section{Redakcja tekstów w języku angielskim}

Jerzy Adamko

\section{Skład}

Janusz Świnarski

\section{Na okładce}

„Sprawiedliwość" - płaskorzeźba autorstwa Aleksandra Żurakowskiego, znajdująca się w Sali Posiedzeń Sejmu, fot. Mariusz Wideryński

\section{Kontakt z redakcja}

e-mail: marta.kopec@sejm.gov.pl

Biuro Analiz Sejmowych Kancelarii Sejmu

00-441 Warszawa, ul. Zagórna 3

tel. (+48 22) 6941845

faks (+48 22) 6941865

e-mail: punkt_konsultacyjny@sejm.gov.pl

e-mail:wydawnictwa_BAS@sejm.gov.pl

(c) Copyright by Kancelaria Sejmu

Warszawa 2020

Wszelkie prawa zastrzeżone. Całość opracowania ani żadna jego część nie mogą być bez zgody wydawcy -

Kancelarii Sejmu - reprodukowane, użyte do innej publikacji oraz przechowywane w jakiejkolwiek bazie danych.

\section{ISSN 2082-064X}

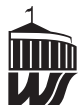

Wydawnictwo Sejmowe 


\section{SPIS TREŚCI}

\section{$1 \quad$ ARTYKUŁY}

\section{Artur K. Modrzejewski}

Problemy funkcjonowania nieruchomości niezamieszkałych po wejściu w życie ustawy z 19 lipca 2019 r. o zmianie ustawy o utrzymaniu czystości i porządku $\mathrm{w}$ gminach oraz niektórych innych ustaw $\ldots \ldots \ldots \ldots \ldots$

\section{Andrzej Jackiewicz}

Szósta reforma państwa: zmiana sposobu kształtowania składu Senatu jako element ewolucji federalizmu w Królestwie Belgii . . . . . . . . . . . . . .

Bartosz Nowakowski

Kompetencje organu administracji publicznej w zakresie zatwierdzania regulaminu strzelnicy. Propozycje zmian de lege ferenda . . . . . . . . . . . . . .

\section{OPINIE BAS}

\section{A ZAGADNIENIA PRAWA KONSTYTUCYJNEGO}

\section{Rafał Dubowski}

Możliwość pozwania Skarbu Państwa z tytułu przebywania na kwarantannie w związku z epidemią COVID-19 w sytuacji, gdy nie został wprowadzony stan nadzwyczajny

Danuta Adamiec, Justyna Branna, Dobromir Dziewulak, Natalia Firlej, Kamila Groszkowska, Marta Karkowska, Daniela Kupis, Marcin Mróz, Jarosław Szymanek, Angelina Tazuszel, Łukasz Żołądek

Uregulowania dotyczące wniosków formalnych zawarte w regulaminach parlamentów wybranych państw członkowskich UE, Wielkiej Brytanii, Stanów Zjednoczonych i Parlamentu Europejskiego . . . . . . . . . . . . . . . .

\section{B ZAGADNIENIA PRAWA MIĘDZYNARODOWEGO}

\section{EUROPEJSKIEGO}

\section{Justyna Łacny}

Ocena zgodności z prawem międzynarodowym poselskiego projektu ustawy o równości małżeńskiej . . . . . . . . . . . . . . . . . .

\section{Bartosz Pawłowski}

Ocena zgodności z prawem Unii Europejskiej poselskiego projektu nowelizacji ustawy o ochronie zwierząt oraz niektórych innych ustaw . . . . . . . . . . . Jacek Kulicki, Zofia Szpringer, Marek Jaśkowski

Ocena zmienionego wniosku dotyczącego decyzji Rady w sprawie systemu zasobów własnych Unii Europejskiej . . . . . . . . . . . . . . . .

\section{OPINIE LEGISLACYJNE}

\section{Kamilla Kurczewska}

Ocena zgodności z Konstytucją poselskiego projektu ustawy o jawności przychodów kościołów i związków wyznaniowych oraz zniesieniu ich przywilejów

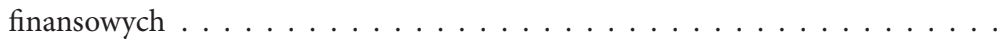




\section{Ewelina Gierach}

Ocena zgodności z Konstytucją poselskiego projektu ustawy o jawności przychodów kościołów i związków wyznaniowych oraz zniesieniu ich przywilejów

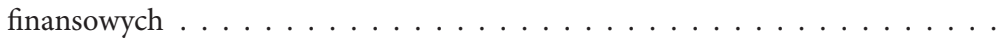

Robert Jastrzębski

Dopuszczalność drogi sądowoadministracyjnej od orzeczeń Komisji Regulacyjnej ds. Polskiego Autokefalicznego Kościoła Prawosławnego . . . . . . . . . . .

D WSPÓŁPRACA MIĘDZYNARODOWA KANCELARII SEJMU

Beata Bińkowska-Artowicz

Restitution of Cultural Heritage Goods . . . . . . . . . . . . . . . . .

\section{E SPRAWY POSELSKIE}

\section{Wojciech Odrowąż-Sypniewski}

Tryb postępowania $\mathrm{z}$ wniesionym w VIII kadencji wnioskiem o wyrażenie przez Sejm zgody na pociągnięcie do odpowiedzialności cywilnej posłów . . . . . . .

F VARIA

\section{Natalia Podraza}

Społeczny oraz prawny obowiązek zawiadomienia o przestępstwie ściganym $\mathrm{z}$ urzędu . . . . . . . . . . . . . . . . . . . .

\section{Dorota Dzienisiuk}

Możliwość zawarcia umowy o pracę przez osobę ubezwłasnowolnioną całkowicie lub przez jej opiekuna prawnego $\ldots \ldots \ldots \ldots \ldots$

Dobromir Dziewulak

Edukacja prawna w szkolnictwie podstawowym i średnim w Polsce, wybranych państwach Unii Europejskiej oraz w Serbii i Wielkiej Brytanii . . . . . . . . . . .

\section{STANOWISKA SEJMU W SPRAWACH PRZED TRYBUNAŁEM KONSTYTUCYJNYM}

\section{Katarzyna Miaskowska-Daszkiewicz}

Zgodność z Konstytucją przepisu nowelizacji ustawy o odnawialnych źródłach energii oraz niektórych innych ustaw w zakresie terminu wejścia w życie . . . .

\section{Bogusław Przywora}

Zgodność z Konstytucją przepisu ustawy o Straży Granicznej w zakresie określenia czasu wolnego lub wynagrodzenia w zamian za czas służby przekraczający normy służby 


\section{CONTENTS}

\section{ARTICLES}

\section{Artur K. Modrzejewski}

Problems with the functioning of uninhabited real estates after the entry into force of the Act of 19th July 2019 amending the Act on Maintaining Cleanliness and Order in Municipalities and Certain Other Acts . . . . . . . . . . . .

\section{Andrzej Jackiewicz}

The Sixth State Reform: transformation of the composition of the Senate as a component of the evolution of federalism in the Kingdom of Belgium . . . . .

Bartosz Nowakowski

Competence of the public administration authority regarding the approval of shooting range regulations. Proposals for de lege ferenda changes . . . . . . . . .

\section{OPINIONS OF THE BUREAU OF RESEARCH (BAS)}

\section{A CONSTITUTIONAL LAW ISSUES}

\section{Rafał Dubowski}

Possibility of Suing the State Treasury due to being in quarantine because of the COVID-19 epidemic in a situation where none of extraordinary measures has been declared

Danuta Adamiec, Justyna Branna, Dobromir Dziewulak, Natalia Firlej, Kamila Groszkowska, Marta Karkowska, Daniela Kupis, Marcin Mróz, Jarosław Szymanek, Angelina Tazuszel, Łukasz Żołądek

Regulations concerning 'points of order' stipulated in the rules of procedure in selected EU Member States, the United Kingdom, the United States and the European Parliament . . . . . . . . . . . . . . . . .

\section{B EUROPEAN AND INTERNATIONAL LAW ISSUES}

\section{Justyna Lacny}

Assessment of compliance with international law of the Deputies' Bill on Marital

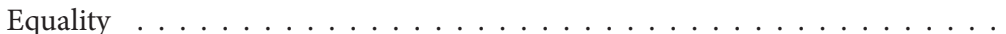

Bartosz Pawłowski

Assessment of compliance with European Union law of the Deputies' Bill on Amending the Act on Animal Protection and Some Other Acts . . . . . . . . .

Jacek Kulicki, Zofia Szpringer, Marek Jaśkowski

Assessment of the amended proposal for a Council Decision on the System of Own Resources of the European Union . . . . . . . . . . . . . . . . . . . . .

\section{LEGISLATIVE OPINIONS}

\section{Kamilla Kurczewska}

Assessment of compliance with the Constitution of the Republic of Poland of the Deputies' Bill on the Transparency of Revenues of Churches and Religious Associations and the Abolition of Their Financial Privileges . . . . . . . . . . . 


\section{Ewelina Gierach}

Assessment of compliance with the Constitution of the Republic of Poland of the Deputies' Bill on the Transparency of Revenues of Churches and Religious Associations and the Abolition of Their Financial Privileges . . . . . . . . .

Robert Jastrzębski

Admissibility of initiating the judicial-administrative procedure against the decisions of the Regulatory Commission of the Polish Autocephalous Orthodox Church . . . . . . . . . . . . . . . . . . . . .

\section{INTERNATIONAL COOPERATION OF THE CHANCELLERY OF THE SEJM}

Beata Bińkowska-Artowicz

Restytucja dóbr dziedzictwa kulturowego $\ldots \ldots \ldots \ldots \ldots \ldots$

\section{E DEPUTIES' AFFAIR}

\section{Wojciech Odrowąż-Sypniewski}

Procedure for dealing with the motion submitted in the course of the $8^{\text {th }}$ term of the Sejm requesting the Sejm to grant consent to bringing Deputies to a civil law

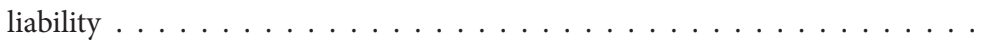

\section{F MISCELLANEA}

\section{Natalia Podraza}

Social and legal obligation to notify about an offense prosecuted ex officio . . .

\section{Dorota Dzienisiuk}

Admissibility of concluding an employment contract by a completely legally incapacitated person or through the legal guardian . . . . . . . . . . .

\section{Dobromir Dziewulak}

Legal education in primary and secondary education stages in Poland, selected Member States of the European Union, as well as in Serbia and in the United Kingdom . . . . . . . . . . . . . . . . . .

\section{THE SEJM'S POSITIONS ON CASES BEFORE THE CONSTITUTIONAL TRIBUNAL}

\section{Katarzyna Miaskowska-Daszkiewicz}

Conformity to the Constitution of a provision of the Bill to Amend to the Act on Renewable Energy Sources and Certain other Acts in Respect of the Date of Entry into Force . . . . . . . . . . . . . . . . . .

\section{Bogusław Przywora}

Conformity to the Constitution of the provision of the Act on the Border Guard in the aspect of determining time off or remuneration in exchange for service time exceeding service standards $\ldots \ldots \ldots \ldots \ldots \ldots$ 


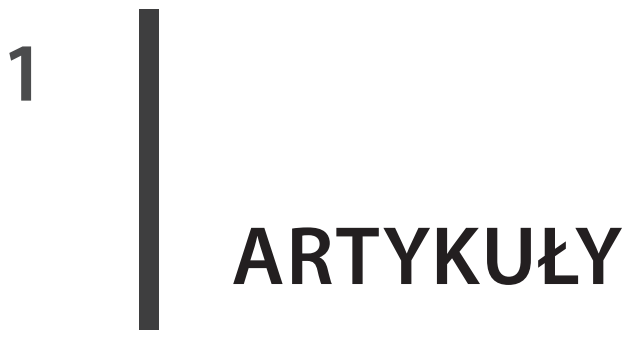



Artur K. Modrzejewski

\title{
Problemy funkcjonowania nieruchomości niezamieszkałych po wejściu w życie ustawy z 19 lipca 2019 r. o zmianie ustawy o utrzymaniu czystości i porządku w gminach oraz niektórych innych ustaw
}

\author{
Problems with the functioning of uninhabited real estates after the entry \\ into force of the Act of 19th July 2019 amending the Act on Maintaining \\ Cleanliness and Order in Municipalities and Certain Other Acts
}

\begin{abstract}
The article contains a description of the relationship between the consent of the owner of uninhabited real estate and the public law obligations resulting from the submitted declaration concerning the amount of the fee for municipal waste management. The author negatively assesses the legal solutions that give owners of uninhabited real estates the freedom to choose whether they want to be included in the municipal waste management system. Given the massive scale of performance of the service of waste collection and management, the tightness of the system is important, which is not guaranteed by the regulations adopted by the legislator.
\end{abstract}

Keywords: real estate, municipal waste

\footnotetext{
W artykule opisano wzajemną relację pomiędzy zgodą właściciela nieruchomości niezamieszkałej a obowiązkami publicznoprawnymi wynikającymi ze złożonej deklaracji o wysokości opłaty za gospodarowanie odpadami komunalnymi. Autor negatywnie ocenia rozwiązania prawne, które dają właścicielom nieruchomości niezamieszkałych swobodę wyboru, czy chcą być objęci gminnym systemem gospodarki odpadami. Przy masowej skali realizacji usługi odbioru i zagospodarowania odpadów istotna jest szczelność systemu, czego nie gwarantują przyjęte przez ustawodawcę regulacje.
}

Słowa kluczowe: nieruchomość, odpady komunalne

Doktor nauk prawnych, radca prawny, adiunkt •

Uniwersytet w Białymstoku, Wydział Prawa, Katedra Prawa i Postępowania

Administracyjnego, BIAŁYSTOK, POLSKA •

a.modrzejewski@uwb.edu.pl • https://orcid.org/0000-0002-3849-4208

\section{Wstęp}

System gospodarki odpadami komunalnymi podlega ciągłym zmianom. Spowodowane to jest przede wszystkim koniecznością wdrażania wymogów zawartych w dyrektywie w sprawie odpadów z 2008 r. ${ }^{1}$. Przywołany akt prawa UE

1 Dyrektywa Parlamentu Europejskiego i Rady 2008/98/WE z 19 listopada 2008 r. w sprawie odpadów oraz uchylająca niektóre dyrektywy, Dz.Urz. UE L 312/3 z 22 listopada $2008 \mathrm{r}$. 
zapoczątkował bowiem kierunek zmian w tej dziedzinie i wykreował obecny kształt systemu gospodarki odpadami komunalnymi. Dalsze zmiany wynikały z jednej strony ze zgłaszanych zastrzeżeń przez jednostki samorządu terytorialnego, jako nadzorców systemu i głównych odpowiedzialnych za jego wdrażanie, z drugiej - był to efekt dążenia prawodawcy do optymalizacji tego systemu. Niestety owa optymalizacja, zakładana jako punkt wyjścia, bardzo często w praktyce powoduje trudności interpretacyjne, a nawet wiązać się może z cofnięciem w rozwoju systemu. Do tego rodzaju działań zaliczyć należy regulacje w systemie gospodarki odpadami komunalnymi w zakresie statusu prawnego nieruchomości niezamieszkałych. Problem polega na tym, że nie tylko nie jest do końca jasne i precyzyjne, jakie nieruchomości zaliczone powinny być do kategorii nieruchomości niezamieszkałych, ale również nie jest jasne, czy wszystkie te nieruchomości wchodzą do stworzonego przez gminę systemu. Zagadnienie to nabiera znaczenia w kontekście unijnych dyrektyw odpadowych odnoszących się do tworzenia systemu gospodarki odpadami w obiegu zamkniętym² ${ }^{2}$, gdzie konieczne jest objęcie jednorodnym i szczelnym systemem wszystkich źródeł powstawania odpadów.

Przedmiotem niniejszego opracowania jest analiza statusu prawnego nieruchomości niezamieszkałych w ramach systemu gospodarowania odpadami komunalnymi ze szczególnym uwzględnieniem zmian, jakie dokonano na mocy ustawy z 19 lipca 2019 r. o zmianie ustawy o utrzymaniu czystości i porządku w gminach oraz niektórych innych ustaw (Dz.U. poz. 1579). Stawiam przy tym hipotezę, że aktualny status tego rodzaju nieruchomości jest na tyle nieprecyzyjny, że z punktu widzenia gmin ogólną tendencją może być odstępowanie od obejmowania tego rodzaju nieruchomości systemem. Dodatkowo istotne rozbieżności pomiędzy pierwotnym zamierzeniem ustawodawcy a finalnym kształtem rozwiązań prawnych nie pozwalają na jednoznaczne określenie tego, jakimi względami kierowano się, przyjmując określony model rozwiązań. Analizowany problem, wbrew pozorom, nie ma charakteru krótkotrwałego, tzn. powiązanego z aktualnym stanem po wejściu w życie nowelizacji ustawy o utrzymaniu czystości i porządku w gminach ${ }^{3}$, przyjęcie określonej koncepcji powiązanej z momentem, od którego konieczne będzie składanie zgód na objecie systemem, determinować może zakres podmiotowy gminnego systemu gospodarowania odpadami komunalnymi na długie lata.

2 Dyrektywa Parlamentu Europejskiego i Rady (UE) 2018/851 z 30 maja 2018 r. zmieniająca dyrektywę 2008/98/WE w sprawie odpadów, Dz.Urz. UE L 150/109 z 14 czerwca $2018 \mathrm{r}$.

3 Ustawa z 13 września 1996 r. o utrzymaniu czystości i porządku w gminach, t.j. Dz.U. 2018, poz. 1454; dalej: ustawa o utrzymaniu czystości w gminach lub u.c.p.g. 


\section{Nieruchomość niezamieszkała i mieszana}

Zgodnie $z$ art. $6 c$ ust. 1 i 2 u.c.p.g. gminy zobowiązane są objąć systemem tzw. nieruchomości zamieszkałe, zaś w przypadku nieruchomości niezamieszkałych istnieje w tym zakresie dowolność 5 . O objęciu systemem nieruchomości niezamieszkałych rada gminy decyduje w drodze uchwały. W orzecznictwie jako kryterium różnicujące oba rodzaje nieruchomości (zamieszkałe i niezamieszkałe) przyjmuje się często odwołanie do norm prawa cywilnego. W tym znaczeniu pojęcie „nieruchomości, na których nie zamieszkują mieszkańcy” oznacza nieruchomości, na których nie zamieszkują mieszkańcy w rozumieniu art. 25 Kodeksu cywilnego, a jedynie przebywają na niej. Wyrażane są również poglądy odmienne, zgodnie z którymi pojęcie „nieruchomości, na której zamieszkują mieszkańcy”, w kontekście konieczności zorganizowania odbioru odpadów komunalnych, należy wiązać z faktycznym jej zamieszkiwaniem, a nie odwoływać się do wąskiego rozumienia terminu „zamieszkiwania”, jakie przypisuje się mu na gruncie Kodeksu cywilnego ${ }^{7}$.

W mojej ocenie, o ile istotny jest fakt zamieszkiwania (pobytu) na nieruchomości, to ważna jest również (a może przede wszystkim) spełniana przez taką nieruchomość funkcja. Nieruchomość mieszkalna (np. dom jednorodzinny) przez sam fakt tylko czasowego zamieszkiwania w nim, nie staje się automatycznie nieruchomością niezamieszkałą, tzn. jeśli nieruchomość ze swej natury nie jest przeznaczona do stałego na niej zamieszkiwania, mieściła się będzie w kategorii nieruchomości niezamieszkałych. Jeśli dom jednorodzinny będzie zamieszkiwany np. okresowo (będzie przeznaczony pod wynajem) - to i tak traktowany powinien być jako nieruchomość zamieszkała - taka jest bowiem jego funkcja. Jeśli zaś w tym samym domu stworzony zostanie hotel (pensjonat), to zmienia się jego przeznaczenie i w tym zakresie traktowany powinien być jako nieruchomość niezamieszkała. Powiązanie charakteru nieruchomości tylko z czynnikiem „zamieszkiwania” na niej podważa sens wprowadzonego przez ustawodawcę

4 A. Barczak, Pozycja prawna wójta w ochronie środowiska [w:] Pozycja ustrojowa organów wykonawczych jednostek samorządu terytorialnego, red. K. Małysa-Sulińska, M. Stec, 2014, LEX.

$5 \quad$ P. Czepiel, Gospodarowanie odpadami komunalnymi w obliczu zmian wprowadzonych ustawa $z 1$ lipca 2011 r., „Samorząd Terytorialny” 2013, nr 5, s. 45.

6 Zob. wyroki WSA w Gorzowie Wielkopolskim: z 6 marca 2019 r., sygn. akt I SA/Go 36/19; z 12 września 2019 r., sygn. akt I SA/Go 281/19, www.orzeczenia.nsa.gov.pl; dalej: CBOSA.

7 Zob. wyrok WSA w Szczecinie z 14 lutego 2018 r., sygn. akt I SA/Sz 992/17, CBOSA; por. także M. Kropiwnicka, Zasady odbioru i gospodarowania odpadami komunalnymi na gruncie znowelizowanej ustawy o utrzymaniu czystości i porządku w gminach, „Przegląd Prawa Ochrony Środowiska” 2012, nr 4, s. 45; J. Klatka, M. Kuźniak, Gospodarowanie odpadami komunalnymi. Poradnik dla gmin, 2012, LEX. 
podziału nieruchomości. Zauważyć bowiem należy, że ustawa przewiduje różne metody określania wysokości opłaty w zależności od charakteru nieruchomości - wybór metody (spośród określonych w art. 6j ust. 1 i 2 - uprzednio wskazanej przez radę gminy, i metody „od pojemnika” na podstawie $6 \mathrm{j}$ ust. 3 u.c.p.g.) nie może zależeć do subiektywnego postrzegania kategorii zamieszkiwania przez właściciela tej nieruchomości. Warto przy tym - jako czynnik pomocniczy - w rozstrzyganiu o charakterze nieruchomości traktować przeznaczenie określonego budynku zapisane $\mathrm{w}$ dokumentach i rejestrach ewidencyjnych oraz podatkowych ${ }^{8}$.

Ustawodawca pewne kategorie nieruchomości niejako automatycznie zaliczył do nieruchomości niezamieszkałych, przyznając im szczególny status, objawiający się czy to obligatoryjnym objęciem (jeśli gmina decyduje się uprzednio podjąć uchwałę na podstawie art. $6 c$ ust. 2 w związku $z$ art. $6 c$ ust. 3 u.c.p.g.), czy też możliwością wyboru co do zastosowanej metody bądź włączenia do systemu. Spośród tych nieruchomości na szczególną uwagę zasługują domy letniskowe. W orzecznictwie sądowo-administracyjnym zauważa się, że pojęciom domku letniskowego oraz nieruchomości wykorzystywanych na cele rekreacyjno-wypoczynkowe należy nadać znaczenie przyjęte w języku potocznym. Domki letniskowe nie służą do zaspokojenia podstawowych potrzeb mieszkaniowych tylko do celów związanych z wypoczynkiem. Zasadniczo nieruchomości, na których znajdują się domki letniskowe lub inne nieruchomości wykorzystywane na cele rekreacyjno-wypoczynkowe, nie są wykorzystywane do zamieszkania, tylko w celu czasowego przebywania w związku z wypoczynkiem. Dlatego też są zaliczane do kategorii nieruchomości, na których nie zamieszkują mieszkańcy, ale powstają na nich odpady komunalne. Istotne jest tu nie przeznaczenie nieruchomości (np. w miejscowych planach zagospodarowania przestrzennego), tylko faktyczne funkcje, jakie pełnią, faktyczny sposób ich wykorzystania ${ }^{9}$. To z kolei oznacza, że ustalenie wysokości opłaty zryczałtowanej za tę kategorię nieruchomości (zgodnie z art. 6j ust. $3 b$ u.c.p.g) powinno opierać się na uwzględnieniu średniej ilości odpadów powstających na nieruchomościach letniskowych na obszarze gminy wyrażonej w liczbie pojemników oraz stawki opłaty za gospodarowanie odpadami komunalnymi odnoszącej się do nieruchomości niezamieszkałych ${ }^{10}$. Względem domów letniskowych nie ma również zastosowania przepis dający właścicielowi takiej nieruchomości prawo do decydowania o przystąpie-

8 A.K. Modrzejewski, Właściciel i nieruchomość w świetle znowelizowanej ustawy o utrzymaniu czystości i porządku w gminach, „Samorząd Terytorialny” 2013, nr 1-2, s. $88-98$.

9 Wyrok WSA w Gorzowie Wielkopolskim z 7 czerwca 2017 r., sygn. akt I SA/Go 150/17; wyrok WSA w Opolu z 8 listopada 2017 r., sygn. akt I SA/Op 242/17, CBOSA.

10 Taki sposób obliczenia stawki przewidywał wprost art. $6 \mathrm{j}$ ust. $3 \mathrm{c}$ w brzemieniu ustawy o utrzymaniu czystości w gminach przed 6 września 2019 r. 
niu do systemu - w przypadku objęcia tym systemem wszystkich nieruchomości niezamieszkałych.

Nowelizacja ustawy o utrzymaniu czystości w gminach z 6 września 2019 r. zmieniła treść art. $6 \mathrm{j}$ ust. $3 \mathrm{~b}$ tej ustawy, odnosząc się do maksymalnej wysokości zryczałtowanej stawki opłaty (odchodząc od wskazania sposobu wyliczenia stawki zryczałtowanej), ale nie zmieniła charakteru nieruchomości letniskowych jako nieruchomości niezamieszkałych. Obejmując systemem nieruchomości niezamieszkałe, brakuje podstaw, by wyszczególnić w specjalny sposób domy letniskowe (np. przez wskazanie, że oprócz nieruchomości niezamieszkałych systemem obejmuje się domy letniskowe). Jeśli gmina nie podjęła uchwały na podstawie art. $6 c$ ust. 2 u.c.p.g. (bądź też nie zastosowała wybiórczego objęcia systemem tylko niektórych kategorii nieruchomości niezamieszkałych na podstawie art. $6 c$ ust. 3 u.c.p.g. - w powiązaniu $\mathrm{z}$ art. $6 \mathrm{c}$ ust. 2 u.c.p.g.), właściciele domów letniskowych muszą zawrzeć stosowne umowy cywilne na odbiór odpadów komunalnych.

Praktyka wskazuje, że do nieruchomości niezamieszkałych zaliczyć należy np. budynki użyteczności publicznej, placówki oświatowe, lokale handlowe, gastronomiczne, zakłady rzemieślnicze, usługowe, produkcyjne, hotele, szpitale, akademiki, internaty, ogródki działkowe, targowiska, cmentarze itp. ${ }^{11}$. Precyzyjne odniesienie się do tego, z jaką nieruchomością mamy do czynienia, istotne jest w kontekście art. $6 \mathrm{c}$ ust. 3 u.c.p.g., zgodnie z którym uchwała obejmująca nieruchomości niezamieszkałe może dotyczyć wszystkich właścicieli nieruchomości lub właścicieli określonych nieruchomości, w szczególności nieruchomości, na których jest prowadzony określony rodzaj działalności. W kontekście wprowadzonej zgody właścicieli nieruchomości niezamieszkałych na objęcie systemem (o czym szerzej w dalszych rozważaniach) organizacyjnie pożytecznym rozwiązaniem dla gmin może okazać się objęcie systemem nieruchomości np. stanowiących budynki użyteczności publicznej czy też prowadzonych przez różnego rodzaju jednostki organizacyjne gminy.

Objęcie systemem nieruchomości niezamieszkałych powoduje, że pojawia się trzecia kategoria nieruchomości, są to tzw. nieruchomości mieszane, czyli takie, które w części stanowią nieruchomości zamieszkałe, a w części nieruchomości niezamieszkałe (art. $6 \mathrm{c}$ ust. 2 b i art. $6 \mathrm{j}$ ust. 4 u.c.p.g.). Jeśli gmina nie obejmuje systemem nieruchomości niezamieszkałych (rezygnuje $\mathrm{z}$ obejmowania systemem nieruchomości niezamieszkałych) - z punktu widzenia gminnego systemu gospodarowania odpadami komunalnymi nie ma kategorii nieruchomości mieszanych - w systemie są tylko nieruchomości zamieszkałe (wynika to z powiązania art. $6 c$ ust. 1 i ust. 2 u.c.p.g.). W przypadku podjęcia uchwały na podstawie art. $6 c$ ust. 2 u.c.p.g. - w zakresie nieruchomości mieszanych nie ma zastosowania art. $6 c$ ust. $2 c$ - właściciele nieruchomości niezamieszkałych $\mathrm{w}$ ramach nie-

11 Wyrok WSA w Gdańsku z 6 lutego 2019 r., sygn. akt II SA/Gd 786/18, CBOSA. 
ruchomości mieszanych otrzymują możliwość dobrowolnego przystąpienia do gminnego systemu gospodarowania odpadami komunalnymi. Jeśli gmina chce, by w systemie pozostały nieruchomości mieszane, np. znajdujące się w zasobach spółdzielni czy wspólnot mieszkaniowych, ale jednocześnie nie chce systemem obejmować innych nieruchomości niezamieszkałych (ze względu na możliwość swobodnego wstępowania i występowania z sytemu i powiązany z tym brak stabilności finansowej i określenia strumienia odpadów), to zasadne jest podjęcie stosownej uchwały na podstawie art. 6 c ust. 2 w związku z ust. 3 u.c.p.g. - ze wskazaniem, że systemem objęte są tylko nieruchomości niezamieszkałe, stanowiące część nieruchomości mieszanych.

W doktrynie wyrażany jest także pogląd, zgodnie z którym ustawodawca postanowił doprecyzować kwestię nieruchomości częściowo zamieszkałych i częściowo niezamieszkałych w taki sposób, że wyłączył tę grupę nieruchomości spod stosowania art. 6 c ust. 2a i 2c u.c.p.g, ucinając wcześniejsze wątpliwości i sygnalizując, że te nieruchomości muszą byś traktowane w całości tak jakby były zamieszkane $^{12}$.

W mojej ocenie pogląd ten nie jest do końca uzasadniony. Jak zostało bowiem wcześniej wykazane, dla powstania kategorii nieruchomości mieszanych konieczne jest pierwotne podjęcie uchwały o objęciu nieruchomości niezamieszkałych systemem (na podstawie art. 6c ust. 2 u.c.p.g.), w innym przypadku nie ma kategorii nieruchomości mieszanych. Oczywiście jeśli gmina obejmie systemem nieruchomości niezamieszkałe i pojawia się kategoria nieruchomości mieszanych, to nie znajduje zastosowania art. $6 c$ ust. 2 a u.c.p.g. oraz art. $6 c$ ust. $2 c$ u.c.p.g., ale chodzi o sposób przeprowadzenia zamówienia publicznego na odbieranie odpadów komunalnych (wybór określonego trybu) i możliwości dowolnego przystąpienia do systemu właściciela takiej nieruchomości. Wątpliwości, co do sposobu traktowania tego rodzaju nieruchomości, pojawiały się głównie na gruncie sposobu organizacji odbioru odpadów z tych nieruchomości (możliwości zastosowania zamówienia w trybie tzw. in house $)^{13}$. W kontekście udzielania zamówienia publicznego ustawodawca wyjaśnił wcześniejsze wątpliwości, wprowadzając art. 6c ust. 2b. Nie oznacza to jednak, że te nieruchomości zawsze zostają objęte systemem i są tożsame z nieruchomościami zamieszkałymi. O tym, że nieruchomości mieszane nie są przez ustawodawcę traktowane jako nieruchomości zamieszkałe, świadczy również art. 6j ust. 4 u.c.p.g, który wyraźnie stanowi, że w przypadku nieruchomości, która w części stanowi nieruchomość, o której mowa w art. 6c ust. 1, a w części nieruchomość, o której mowa w art. 6c ust. 2, opłata za gospodarowanie odpadami komunalnymi stanowi sumę opłat

12 A. Jezierska-Markocka, M. Markocki, Ustawa o utrzymaniu czystości i porządku w gminach, Warszawa 2019, art. 6c.

13 A. Specht-Schampera, In house a odbiór odpadów z nieruchomości mieszanych, „Przegląd Komunalny" 2018, nr 2, s. 30-33. 
obliczonych zgodnie z ust. 1-3 - czyli jest to suma opłat obliczanych dla części zamieszkałej i niezamieszkałej. Dopiero na mocy uchwały rada gminy może zadecydować o zastosowaniu jednego sposób obliczania opłaty na terenie takich nieruchomości. Gdyby zamiarem ustawodawcy było automatyczne zrównanie nieruchomości mieszanych $\mathrm{z}$ kategorią nieruchomości zamieszkałych, legislacyjnie zbędne byłoby wprowadzenie rozróżnień dla tej kategorii nieruchomości. W mojej ocenie, w przypadku chęci pozostawienia nieruchomości mieszanych $\mathrm{w}$ systemie konieczne jest podjęcie przez radę uchwały na podstawie art. $6 \mathrm{c}$ ust. 2 u.c.p.g. w związku $\mathrm{z}$ art. $6 c$ ust. 3 u.c.p.g.

\section{Fakultatywne przystąpienie do systemu}

Jak wcześniej wskazano, dla objęcia nieruchomości niezamieszkałych gminnym systemem gospodarowania odpadami komunalnymi konieczne jest uprzednie podjęcie uchwały na podstawie art. $6 \mathrm{c}$ ust. 3 u.c.p.g. w związku $\mathrm{z}$ art. $6 \mathrm{c}$ ust. 2 u.c.p.g. Zgodnie $z$ art. $6 c$ ust. $2 c$ u.c.p.g. przystąpienie właściciela nieruchomości, na której nie zamieszkują mieszkańcy, z wyłączeniem właściciela nieruchomości, o której mowa w art. $6 \mathrm{j}$ ust. 3b, do zorganizowanego przez gminę systemu gospodarowania odpadami komunalnymi jest dobrowolne i następuje na podstawie zgody właściciela nieruchomości wyrażonej w formie pisemnej.

Już samo założenie o dobrowolności przystąpienia do sytemu właściciela nieruchomości niezamieszkałej budzi wątpliwości. Na mocy tegoż oświadczenia właściciel nieruchomości wyraża bowiem chęć objęcia reżimem prawnym funkcjonującym w ramach prawa podatkowego i publicznoprawnych opłat. Powiązanie oświadczenia ze złożoną deklaracją w sprawie wysokości opłaty za gospodarowanie odpadami opisane zostanie w dalszych rozważaniach.

Ustawodawca nie przewidział szczególnej formy, w jakiej przystąpienie do systemu miałoby nastąpić, ale niewątpliwie oświadczanie o przystąpieniu do sytemu odróżnić należy od złożonej deklaracji w sprawie wysokości opłaty za gospodarowanie odpadami. Oświadczenie to staje się pewnym elementem dodatkowym obok samej deklaracji - można stwierdzić, że warunkuje skuteczność złożenia deklaracji, skoro ustawodawca w sposób wyraźny wprowadził oświadczenie jako element dodatkowy. W przypadku gdyby oświadczenie nie zawierało wszelkich elementów niezbędnych do tego, by uznać je za skuteczne, np. podpisu osoby upoważnionej do reprezentowania właściciela nieruchomości niezamieszkałej, konieczne będzie wezwanie do uzupełniania braków, tutaj zasadne byłoby raczej powoływanie się na przepisy ordynacji podatkowej ${ }^{14}$, na podstawie bowiem tej ustawy prowadzone są postępowania w zakresie opłaty za gospodarowanie odpadami komunalnymi.

14 Ustawa z 29 sierpnia 1997 r. - Ordynacja podatkowa, t.j. Dz.U. 2019, poz. 900; dalej: o.p. 
Charakter prawny takiego oświadczania jest interesujący również z tego względu, że w ten sposób założono dobrowolność objęcia obowiązkiem publicznoprawnym wnoszenia opłaty i, w moim przekonaniu, w pewnym stopniu zrównano prowadzenie przez gminę sytemu gospodarowania odpadami komunalnymi z samą usługą odbierania tych odpadów. Tymczasem wysokość opłaty nie jest powiązana jedynie z kosztami odbioru odpadów, a wiąże się z koniecznością partycypowania w kosztach funkcjonowania całego systemu gospodarowania odpadami komunalnymi.

Zgodnie z treścią art. 6r ust. 2 u.c.p.g. z pobranych opłat za gospodarowanie odpadami komunalnymi gmina pokrywa koszty funkcjonowania systemu gospodarowania odpadami komunalnymi, które obejmują koszty:

- odbierania, transportu, zbierania, odzysku i unieszkodliwiania odpadów komunalnych,

- tworzenia i utrzymania punktów selektywnego zbierania odpadów komunalnych,

- obsługi administracyjnej tego systemu,

- edukacji ekologicznej w zakresie prawidłowego postępowania z odpadami komunalnymi.

W tym kontekście pojawia się problem braku spójności rozwiązań i szczelności systemu. Jeśli bowiem gmina podejmuje uchwałę na mocy art. 6c ust. 2 u.c.p.g., daje właścicielom nieruchomości niezamieszkałych możliwości korzystania np. z punktów selektywnej zbiórki odpadów komunalnych (PSZOK). Właściciel nieruchomości, który nie wyrazi zgody o przystąpieniu do systemu, $\mathrm{w}$ praktyce nie będzie pozbawiony prawa korzystania $\mathrm{z}$ gminnych punktów selektywnego zbierania odpadów komunalnych. Złożenie deklaracji o wysokości opłaty za gospodarowanie odpadami objęte jest tajemnicą skarbową ${ }^{15}$. Powstaje wątpliwość, czy w związku z tym tajemnica ta nie rozciąga się również na zgodę o przystąpieniu do systemu gospodarowania odpadami (skoro oba te dokumenty są ze sobą nierozerwalnie związane i złożenie jednego powiązane jest z koniecznością złożenia następnego).

Jak wywodzi W. Stachurski, tajemnica skarbowa stanowi wyłączenie jawności indywidualnych danych zawartych we wszelkich dokumentach, jakie podatnik, płatnik, inkasent składa organowi podatkowemu, a także jakie znajdują się

15 Por. K. Teszner, Realizacja opłat za gospodarowanie odpadami komunalnymi a obowiązek przestrzegania tajemnicy skarbowej, „Prawo Finansów Publicznych” 2013, nr 10, s. 22-28; idem, Tajemnica skarbowa i odpowiedzialność administracji gminnej za jej naruszenie w kontekście przepisów ustawy o utrzymaniu czystości i porządku w gminach, cz. 1, „Przegląd Podatków Lokalnych i Finansów Samorządowych” 2013, nr 7, s. 15-19; idem, Tajemnica skarbowa i odpowiedzialność administracji gminnej za jej naruszenie w kontekście przepisów ustawy o utrzymaniu czystości i porządku w gminach, cz. 2, „Przegląd Podatków Lokalnych i Finansów Samorządowych” 2013, nr 8, s. $31-36$. 
w dokumentach tego organu lub pozyskanych przez organ informacji na temat tych danych ${ }^{16}$. Oznacza to, że również oświadczenia o objęciu systemem, jako indywidualne dane zawarte $\mathrm{w}$ dokumentach składanych organowi podatkowemu, objęte powinny być tajemnicą skarbową.

Żaden zaś przepis nie upoważnia prowadzącego PSZOK do weryfikowania przy przyjęciu odpadów, czy właściciel nieruchomości niezamieszkałej złożył stosowną deklarację (a w związku z tym czy złożył również zgodę na objęcie systemem $)^{17}$, tym bardziej żaden przepis nie upoważnia prowadzącego PSZOK np. do legitymowania osób dostarczających odpady ${ }^{18}$.

Do tej pory problem ten rozstrzygany był na poziomie systemowym, tzn. jeśli gmina objęła systemem nieruchomości niezamieszkałe, to każdy właściciel takiej nieruchomości mógł deponować odpady w PSZOK, ale również automatycznie partycypował w kosztach funkcjonowania całego systemu. Założona fakultatywność uczestniczenia w gminnym systemie gospodarowania odpadami komunalnymi prowadzić może do konieczności gospodarowania przez gminę odpadami pochodzącymi z nieruchomości niezamieszkałych, przy jednoczesnym braku współuczestniczenia w kosztach tego systemu ze strony właścicieli tej kategorii nieruchomości. Przedstawiony problem dotyczył będzie nie tylko funkcjonowania PSZOK, ale w znacznej mierze wystąpić może jako zjawisko generalne, powiązane z podrzucaniem do altan śmietnikowych nieruchomości zamieszkałych odpadów pochodzących z nieruchomości niezamieszkałych - celem obniżenia wysokości wnoszonych opłat do przedsiębiorców odbierających odpady na podstawie umów.

Przyznanie właścicielom nieruchomości niezamieszkałych swobody wyboru tego, czy przystąpić do gminnego systemu gospodarowania odpadami komunalnymi, rodzi zasadnicze pytanie o to, w jaki sposób postępować - po wejściu w życie znowelizowanych przepisów - w sytuacji, jeśli gmina przed wejściem w życie ustawy zmieniającej na podstawie art. 6c u.c.p.g. objęła systemem nieruchomości niezamieszkałe.

16 W. Stachurski [w:] Ordynacja podatkowa. Komentarz aktualizowany, red. L. Etel, 2019, LEX.

17 Art. $294 \$ 1$ o.p. wskazuje na podmioty zobowiązane do przestrzegania tajemnicy skarbowej, $₫ 4$ odnosi się do wszystkich innych osób, którym udostępniono informacje objęte tą tajemnicą - przy tym chodzi tu głównie o pracowników innych organów i instytucji, w tym sądów, którym w związku z wykonywaniem ich zadań przekazywane są informacje objęte tajemnicą skarbową. Dotyczy to również innych osób, które $\mathrm{z}$ racji współpracy z organami podatkowymi mają dostęp do danych objętych tajemnicą skarbową, np. biegli. Wątpliwe jest jednoznaczne uznanie, że do grupy tych osób zaliczyć można prowadzących punkty selektywnej zbiórki odpadów, nie współpracują oni z organami podatkowymi, a przeprowadzają czynność zbierania odpadów.

18 Rozstrzygnięcie nadzorcze Wojewody Podkarpackiego NR P-II.4131.2.9.2018 z 18 stycznia 2018 r., http://edziennik.rzeszow.uw.gov.pl/WDU_R/2018/305/oryginal/ akt.pdf. 
Czy zgodnie z art. 6c ust. 2c u.c.p.g. należy uznać, że z dniem wejścia w życie nowelizacji z 19 lipca 2019 r. o zmianie ustawy o utrzymaniu czystości i porządku w gminach oraz niektórych innych ustaw każdy właściciel nieruchomości niezamieszkałej automatycznie znajduje się poza gminnym systemem gospodarki odpadami i konieczne jest złożenie stosownego oświadczenia o przystąpieniu do tego systemu, ewentualnie zawarcie stosownej umowy na odbiór odpadów? Powiązany z tym jest byt prawny złożonych wcześniej deklaracji o wysokości opłaty za gospodarowanie odpadami oraz o ewentualne podstawy wygaszenia tych deklaracji.

Ustawodawca założył, że art. $6 c$ ust. 2c u.c.p.g. wchodzi w życie po upływie 14-dniowego terminu vacatio legis, bezpośrednio nie zastosowano żadnych okresów przejściowych. Przy tym przyjęte przez ustawodawcę założenie, że konieczne jest przystąpienie od sytemu, pozostaje w całkowitej sprzeczności z mechanizmem przewidzianym pierwotnie w uzasadnieniu projektu ustawy.

W uzasadnieniu zakładano bowiem, że uchwała o objęciu nieruchomości niezamieszkałych systemem wywołuje skutek powszechny (względem wszystkich tego rodzaju nieruchomości), chyba że w ciągu 30 dni od dnia publikacji uchwały właściciel nieruchomości złoży oświadczenie o wyłączeniu się z systemu odbierania odpadów komunalnych zorganizowanego przez gminę i pozbywaniu się odpadów na podstawie umowy, o której mowa w art. 6 ust. 1. Gmina, organizując postępowanie o udzielenie zamówienia publicznego na odbieranie odpadów komunalnych z tych nieruchomości, dysponowałaby danymi, z ilu nieruchomości, na których nie zamieszkują mieszkańcy, będą odbierane odpady przez przedsiębiorcę wyłonionego w tym postępowaniu. Przepis miał wejść w życie w terminie 14 dni od dnia ogłoszenia, a jego zastosowanie byłoby możliwe w przypadku podjęcia nowej uchwały rady gminy lub podpisania nowej umowy w wymienionym wyżej zakresie.

Zakładano, że aby zapewnić stabilność systemu, rezygnacja z wyłączenia się z systemu odbierania odpadów komunalnych zorganizowanego przez gminę lub wyłączenie się właściciela nieruchomości będzie ponownie możliwe w związku z upływem okresu, na jaki została zawarta umowa w sprawie zamówienia publicznego na odbieranie odpadów komunalnych.

Wójt, burmistrz lub prezydent miasta, przystępując do przeprowadzenia następnego postępowania o udzielenie zamówienia publicznego na odbieranie odpadów komunalnych, byłby obowiązany zamieścić na stronie internetowej urzędu gminy oraz w sposób zwyczajowo przyjęty informację o tym zamiarze oraz o terminie, nie krótszym niż 30 dni od zamieszczenia informacji na stronie internetowej urzędu gminy, składania oświadczeń o:

- rezygnacji z wyłączenia się z systemu odbierania odpadów komunalnych zorganizowanego przez gminę, jeżeli właściciel nieruchomości dokonał poprzednio zawiadomienia o wyłączeniu się, 
- wyłączeniu się właściciela nieruchomości z systemu odbierania odpadów komunalnych zorganizowanego przez gminę, jeżeli właściciel nieruchomości jest objęty tym systemem ${ }^{19}$.

Rozbudowany mechanizm objęcia systemem nieruchomości niezamieszkałych został w konsekwencji sprowadzony tylko do złożenia przez właściciela nieruchomości niezamieszkałej oświadczenia o przystąpieniu do niego. Przez co nie jest możliwe ustalenie intencji normodawcy poprzez zwykłe sięgnięcie do treści uzasadnienia ustawy. Określony prawem publicznym obowiązek, polegający na uczestnictwie w zorganizowanym przez gminę systemie gospodarowania odpadami komunalnymi, został zastąpiony przez oświadczenie woli składane przez każdego $\mathrm{z}$ właścicieli z osobna. Oświadczenie takie, ze względu na brak ograniczeń ustawowych, w każdej chwili można złożyć i wycofać. Wraz z oświadczeniem składana powinna być deklaracja o wysokości opłaty za gospodarowanie odpadami komunalnymi. Pomijając dywagacje dotyczące praktycznych aspektów tak daleko posuniętej swobody właścicieli nieruchomości co do objęcia systemem (wyobrazić można sobie bowiem sytuację, w której w każdym miesiącu składane jest oświadczenie o przystąpieniu do sytemu, a następnie jest wycofywane), to istotne wydaje się ustalenie, czy tego rodzaju oświadczenie konieczne jest już po wejściu w życie ustawy z 19 lipca 2019 r.?

Zauważyć przy tym należy, że w analizowanym przypadku nie chodzi o określenie momentu wejścia w życie ustawy z 19 lipca 2019 r. o zmianie ustawy o utrzymaniu czystości i porządku w gminach oraz niektórych innych ustaw, bo termin ten został określony zgodnie z art. 4 ustawy z 20 lipca 2000 r. o ogłaszaniu aktów normatywnych i niektórych innych aktów prawnych (t.j. Dz.U. 2019, poz. 1461) i nie budzi zasadniczych wątpliwości, ale o wsteczny skutek, jaki wywołuje art. $6 \mathrm{c}$ ust. $2 \mathrm{c}$ u.c.p.g. Konsekwencją zastosowania przewidzianego w nim mechanizmu jest bowiem zachwianie stabilności gminnego systemu gospodarki odpadami, poprzez, po pierwsze, obniżenie wolumenu odpadów przyjmowanych $\mathrm{z}$ terenu gminy, po drugie, przez odpływ środków zakładanych z tej kategorii nieruchomości $\mathrm{z}$ opłaty za gospodarowanie odpadami komunalnymi. Jeśli z dniem wejścia w życie ustawy wszyscy właściciele nieruchomości pozostają poza systemem, bez wątpienia wpływa to na zawartą przed dniem wejścia $\mathrm{w}$ życie nowelizacji umowę na odbiór odpadów komunalnych. $\mathrm{O}$ ile więc art. $6 \mathrm{c}$ ust. $2 \mathrm{c}$ bezpośrednio wywołuje skutek na przyszłość wobec właścicieli nieruchomości niezamieszkałych, to pośrednio retroaktywnie oddziałuje na gminy jako zarządzających systemem.

W tym kontekście pojawić się może zarzut naruszenia przez nowelizację z 19 lipca 2019 r. zasady lex retro non agit. Zasada ta oznacza, że nie należy sta-

19 Uzasadnienie rządowego projektu ustawy o zmianie ustawy o utrzymaniu czystości i porządku w gminach oraz niektórych innych ustaw, http://www.sejm.gov.pl/sejm8. nsf/druk.xsp?nr=3495 [dostęp 19 grudnia 2019 r.]. 
nowić norm prawnych (w tym także intertemporalnych) nakazujących stosowanie nowo ustanowionych norm do zdarzeń zaistniałych przed wejściem w życie tych nowych norm, z którymi prawo nie wiązało dotąd skutków prawnych przewidzianych przez te normy. W razie wątpliwości należy więc przyjąć, że każdy przepis normuje przyszłość, a nie przeszłośćco ${ }^{20}$ Niedopuszczalne jest bowiem stanowienie norm z mocą wsteczną, jeśli podmioty, których te normy dotyczą, nie mogły racjonalnie przewidzieć tego rodzaju decyzji, a nadzwyczajne okoliczności czy dobra, podlegające ochronie konstytucyjnej, decyzji takiej nie usprawiedliwiają $^{21}$. Dopuszcza się wyjątki od tej zasady, gdy wymagają tego względy sprawiedliwości społecznej albo gdy chodzi o modyfikację prawa podmiotowego na korzyść obywateli ${ }^{22}$.

Do stosunków prawnych między gminą a przedsiębiorcą odbierającym odpady komunalne, zawartych przed dniem wejścia w życie ustawy z 19 lipca 2019 r. o zmianie ustawy o utrzymaniu czystości i porządku w gminach oraz niektórych innych ustaw, odnosi się jej art. 11, zgodnie z którym umowy o udzielenie zamówienia publicznego na odbieranie oraz na odbieranie i zagospodarowanie odpadów komunalnych od właścicieli nieruchomości, a także umowy na prowadzenie PSZOK, zawarte przed dniem wejścia w życie niniejszej ustawy zachowują ważność przez okres, na jaki zostały zawarte. Wywodzona $z$ art. 2 Konstytucji RP zasada zaufania obywateli do państwa i prawa, jak również wynikające z niej zasady bardziej szczegółowe, takie jak zasada ochrony praw nabytych, ochrony ekspektatywy maksymalnie ukształtowanej, ochrony interesów w toku oraz lex retro non agit, nie zakazują ustawodawcy zmiany prawa, nawet w sposób niekorzystny dla obywateli, lecz nakazują poszanowanie ich zaufania do prawa już obowiązującego $^{23}$. Literalnie więc nowelizacja nie narusza zakazu retroaktywności, ale gdyby przyjąć założenie, że z dniem wejścia nowych przepisów wszyscy właściciele nieruchomości niezamieszkanych wyłączeni zostają z gminnego systemu gospodarki odpadami, taki negatyw skutek wsteczny - względem gmin i przedsiębiorców odbierających odpady - miałby miejsce. Przy tym strony umowy na odbiór odpadów nie miałyby zagwarantowanego czasu na odpowiednie ułożenie wzajemnych stosunków.

Odstąpienie od zasady zakazu retroaktywności prawa można by upatrywać w takiej zmianie regulacji prawnych, która z założenia ma być korzystna dla obywateli (właścicieli nieruchomości niezamieszkałych) - dając im możliwość wyboru, co do uczestnictwa w gminnym systemie. Pamiętać jednak należy, że stroną

20 J. Zimmermann, Prawo administracyjne, Warszawa 2012, s. 96; A. Spotowski, Zasada lex retro non agit (geneza, uzasadnienia, zasię), „Palestra” 2019, nr 9, s. 14.

21 J. Kornaszewska, Zasada „lex retro non agit”. Czy prawo nie działa wstecz?, „Przegląd Prawa Konstytucyjnego" 2018, nr 2(42), s. 172.

23 M. Florczak-Wątor, Art. 2 [w:] Konstytucja Rzeczypospolitej Polskiej. Komentarz, red. P. Tuleja, 2019, LEX. 
umowy o odbieranie odpadów komunalnych zawartych przez gminy są również przedsiębiorcy i to oni ponieśliby negatywne skutki prezentowanej wykładni.

Konsekwencją wprowadzonych rozwiązań jest sytuacja, w której nowelizacja wprost nie powinna wpływać na zawarte przed dniem jej wejścia w życie umowy na odbiór odpadów, jednakże nie można przyjąć, że właściciele nieruchomości niebędący stronami umów na odbiór odpadów pomiędzy gminą a przedsiębiorcą świadczącym usługę odbioru, byliby związani treścią art. 11 ustawy 19 lipca 2019 r. o zmianie ustawy o utrzymaniu czystości i porządku w gminach oraz niektórych innych ustaw. To znaczy, że zakaz ingerencji w zawarte umowy powodowałby więź łączącą gminę z właścicielem nieruchomości do czasu zakończenia okresu obowiązywania umów na odbiór. Nie można uznać, że właściciele nieruchomości znajdowaliby się poza systemem gospodarki odpadami dopiero po zakończeniu dotychczas obowiązujących umów i by dopiero wówczas zobowiązani byli do składania oświadczeń o przystąpieniu do systemu. Odrębną kwestią jest to, że nawet tego rodzaju interpretacja nie rozwiąże praktycznego problemu, który pojawi się po zakończeniu dotychczasowych umów, a nawet wcześniej, na etapie planowania nowych przetargów, polegającego na tym, że z określonym dniem zakończania obowiązywania umów na odbiór wszyscy właściciele nieruchomości niezamieszkałych znajdowaliby się poza systemem i nie jest możliwe ustalenie liczby właścicieli, którzy z tego gminnego systemu chcieliby korzystać.

\section{Deklaracja o wysokości opłaty za gospodarowanie odpadami komunalnymi}

Literalna wykładania art. 6c ust. 2c u.c.p.g. prowadzić może do wniosku, że każdy właściciel nieruchomości niezamieszkałej chcący uczestniczyć w gminnym systemie zobowiązany jest do złożenia zgody o objęciu go systemem. Tu jednak pojawia się kolejna wątpliwość wpływu nowelizacji na dotychczas złożone deklaracje o wysokości opłaty za gospodarowanie odpadami, a przez to ewentualnego obowiązku złożenia nowych deklaracji obok dotychczas funkcjonujących.

Żaden przepis ustawy z 19 lipca 2019 r. o zmianie ustawy o utrzymaniu czystości i porządku w gminach oraz niektórych innych ustaw nie prowadzi do wygaszenia skutku, jaki wywierały dotychczas funkcjonujące deklaracje o wysokości opłaty za gospodarowanie odpadami. Samo oświadczenie o przystąpieniu do systemu - odnoszące się do prawa prywatnego, będące konsekwencją uznania, że gmina wykonuje usługę odbioru odpadów, z której można nie korzystać - nie zastępuje deklaracji o wysokości opłaty za gospodarowanie odpadami. Przyjmując więc nawet, że nowelizacja automatycznie wyłączyła z systemu wszystkich właścicieli nieruchomości niezamieszkałych, to nie doprowadziła do wygaszenia skutku deklaracji o wysokości opłaty za gospodarowanie odpadami - taki bowiem skutek nie wynika wprost $\mathrm{z}$ przepisów prawa i brak jest podstaw, by go 
domniemywać. Prowadzi to do wniosku, że właściciele nieruchomości dotychczas objęci systemem, którzy złożyli deklaracje i uiszczali opłaty, dalej są objęci obowiązkiem wynikającym z treści deklaracji.

Można założyć, że dodany art. 6c ust. 2c należy interpretować w ten sposób, iż pozostaje on bez wpływu na złożone wcześniej deklaracje o wysokości opłaty za gospodarowanie odpadami komunalnymi i gmina zobowiązana jest realizować usługi odbioru od właścicieli nieruchomości niezamieszkałych, którzy takie deklaracje złożyli. Ci zaś z kolei, nie mają możliwości wystąpienia z systemu. Dodana treść art. $6 c$ ust. $2 c$ nie przewiduje bowiem możliwości rezygnacji z uczestnictwa w systemie, a jedynie przystąpienie do systemu - co z kolei prowadzić może do wniosku, że przepis ten skierowany jest tylko do tych właścicieli nieruchomości niezamieszkałych, którzy do tej pory systemem objęci nie byli - np. nowo podejmowane działalności gospodarcze. Tego rodzaju interpretacja może być zmodyfikowana o możliwość złożenia przez właściciela rezygnacji z uczestnictwa w gminnym systemie gospodarki odpadami - przez np. wycofanie deklaracji. Tu jednak, mając na względzie wcześniejsze wywody, pojawia się pytanie o to, czy jest to możliwe w każdym okresie, czy np. dopiero po zakończeniu obowiązujących gminnych umów na odbiór odpadów (ewentualnie ich zagospodarowanie) - w związku z treścią art. 11 ust. 1 ustawy z 19 lipca 2019 r.?

Skutkiem złożenia deklaracji o wysokości opłaty jest po stronie właściciela nieruchomości konieczność uiszczania opłaty wyliczonej w deklaracji (art. 6h u.c.p.g.), zaś po stronie gminy realizacja usługi odbioru odpadów. Jeśli właściciel nieruchomości nie uiszcza opłaty, opłata ta podlega egzekucji administracyjnej na podstawie złożonej deklaracji. Na gruncie postępowania egzekucyjnego można rozważyć, czy możliwe byłoby uznanie, iż przez wejście w życie ustawy nowelizującej zniweczono skutek prawny złożonej deklaracji, a w konsekwencji nie może ona stanowić podstawy do wystawienia tytułu wykonawczego.

Jako zasadę ustawodawca przyjął, że wysokość zobowiązania z tytułu opłaty za gospodarowanie odpadami komunalnymi określana jest na podstawie danych podanych przez samego właściciela nieruchomości w deklaracji oraz że zobowiązanie w tak określonej wysokości zachowuje aktualność do momentu korekty deklaracji lub zmiany stawki opłat. Przy czym na właścicielu ciąży z mocy prawa obowiązek zaktualizowania deklaracji, w przypadku wskazanych w art. $6 \mathrm{~m}$ ust. 2, tj. zmiany danych będących podstawą ustalenia wysokości należnej opłaty za gospodarowanie odpadami komunalnymi lub określonej w deklaracji ilości odpadów - w terminie do 10 dnia miesiąca następującego po miesiącu, w którym nastąpiła zmiana. W razie zmiany stawek opłaty, wysokość ta może też być określona w zawiadomieniu wysyłanym do właściciela nieruchomości na podstawie art. $6 \mathrm{~m}$ ust. 2a u.c.p.g. W pozostałych przypadkach - w tym także w razie niewykonania przez właściciela obowiązku złożenia deklaracji - wysokość zobowiązania $\mathrm{z}$ tego tytułu jest określana w drodze decyzji właściwego organu (art. 6o u.c.p.g.). 
Niewycofanie deklaracji powoduje więc obowiązek uiszczania opłaty, a w razie zaprzestania rodzi możliwość dochodzenia po stronie gminy należnych środków na drodze postępowania egzekucyjnego.

Zgodnie $\mathrm{z}$ art. 3a $\$ 1$ pkt 6 ustawy o postępowaniu egzekucyjnym w administracji $^{24}$ deklaracja opłaty za gospodarowanie odpadami komunalnymi stanowi podstawę do wystawienia tytułu wykonawczego (o ile zawarto w niej stosowne pouczenie w tej kwestii) i dochodzenia należności w trybie egzekucji administracyjnej po doręczeniu zobowiązanemu upomnienia ${ }^{25}$.

\section{Dotychczas obowiązujące uchwały}

Analizując problem zgody właścicieli nieruchomości niezamieszkałych na objęcie systemem gospodarowania odpadami komunalnymi, Minister Środowiska wyraził stanowisko, zgodnie z którym wejście w życie wskazanej regulacji w przypadku nieruchomości niezamieszkałych objętych systemem zorganizowanym przez gminę na podstawie uchwał podjętych przed dniem 6 września 2019 r. nie powoduje automatycznego wyłączenia $\mathrm{z}$ tą datą wskazanych nieruchomości z systemu zorganizowanego przez gminę. A także, co za tym idzie, konieczności natychmiastowego podpisywania umów na odbiór odpadów komunalnych z przedsiębiorcą posiadającym wpis do rejestru działalności regulowanej w danej gminie przez właścicieli tych nieruchomości, automatycznego wygaśnięcia wcześniej złożonych przez nich deklaracji o wysokości opłaty za gospodarowanie odpadami komunalnymi i konieczności składania nowych deklaracji ${ }^{26}$.

Minister Środowiska zanegował jednocześnie koncepcję wiążącą możliwość złożenia zgody na objęcie systemem od okresu, na jaki zawarte zostały umowy na odbieranie odpadów, zauważając, że na dostosowanie dotychczasowych (wydanych przed dniem 6 września 2019 r.) uchwał rada gminy ma 12 miesięcy od dnia wejścia w życie ustawy z 19 lipca 2019 r. o utrzymaniu czystości i porządku w gminach oraz niektórych innych ustaw. Ustawa ta przez regulację zawartą w art. 9 ust. 1, określając obowiązek dostosowania uchwał rady gminy do znowelizowanych przepisów, pozostawiła uchwały systemowe w mocy. Zdaniem Ministra Środowiska do czasu wejścia w życie nowych uchwał obowiązują dotychczasowe akty prawa miejscowego i w gminie, która na podstawie dotychczasowych przepisów postanowiła o odbieraniu odpadów komunalnych z nieruchomości,

24 Ustawa z 17 czerwca 1966 r. o postępowaniu egzekucyjnym w administracji, t.j. Dz.U. 2019, poz. 1438.

25 Zob. wyrok WSA we Wrocławiu z 3 października 2018 r., sygn. akt III SA/Wr 165/18, CBOSA.

26 Pismo Ministra Środowiska z 15 października 2019 r., znak: DGO-III.021.402.2019. JM, niepubl. 
na których nie zamieszkują mieszkańcy, funkcjonują dotychczasowe zasady odbierania odpadów komunalnych z tych nieruchomości.

Interpretacja ta prowadzi do wniosku, że przez czas, jaki gmina ma na dostosowanie prawa miejscowego do znowelizowanej ustawy (tj. najdłużej przez 12 miesięcy od dnia wejścia wżycie nowelizacji), nic w systemie się nie zamieniło, tzn. nie jest możliwe składanie zgód na przystąpienie do systemu gospodarowania odpadami komunalnymi, systemem tym objęte będą wszystkie nieruchomości niezamieszkałe (oczywiście pod warunkiem uprzedniego podjęcia uchwały na podstawie art. $6 c$ ust. 2 u.c.p.g.).

Interpretacja ta zdaje się pomijać całkowicie fakt, że jeśli przed wejściem w życie nowelizacji gmina podjęła uchwałę o objęciu nieruchomości niezamieszkałych systemem, to nie ma żadnych uzasadnionych podstaw, by domagać się dostosowania jej treści do unormowań nowelizacji. W zakresie tej uchwały nie zaszły bowiem żadne zmiany, które takiego dostosowania by wymagały. Oznacza to, że jeśli gmina przed dniem wejścia w życie nowelizacji podjęła uchwałę o objęciu nieruchomości niezamieszkałych gminnym systemem, to do czasu ewentualnych zmian tej uchwały w systemie nic się nie zmienia, tzn. wciąż te same nieruchomości niezamieszkałe objęte są poprzednimi unormowaniami i nie jest wymagana żadna zgoda na przystąpienie do systemu. Jedynie w tych gminach, gdzie uchwały o objęciu nieruchomości niezamieszkałych gminnym systemem podjęte zostały po dniu 6 września 2019 r., funkcjonuje konieczność składania zgód na przystąpienie do tego systemu. Pozostaje jedynie problem nieruchomości niezamieszkałych nowo powstałych - te bowiem, składając deklarację o wysokości opłaty za gospodarowanie odpadami, powinny złożyć - wymaganą obecnym prawem - zgodę.

\section{Wnioski}

Powyższe rozważania prowadzą do wniosku, że jeszcze przed nowelizacją ustawy o utrzymaniu czystości w gminach z 19 lipca 2019 r. istniały znaczne wątpliwości co do tego, jakie nieruchomości kwalifikować można do kategorii nieruchomości niezamieszkałych, przy tym wątpliwości te potęguje praktyka stosowania prawa. W trakcie wspomnianej nowelizacji ustawodawca zdecydował, że istotniejsze niż uszczelnienie systemu gospodarowania odpadami, czyli osiągnięcia efektu środowiskowego, jest zapewnienie właścicielom nieruchomości niezamieszkałych swobody wyboru podmiotu świadczącego usługi w zakresie gospodarowania odpadami. Przy tym zauważyć należy, że uchwały o objęciu nieruchomości niezamieszkałych nie są automatycznie objęte obowiązkiem dostosowania do nowych regulacji prawnych - w zakresie tych uchwał nic się bowiem nie zmieniło. Jeśli więc uchwały takie nie zostają na nowo podjęte, to właściciele nieruchomości niezamieszkałych wciąż pozostają objęci gminnym systemem gospodarowania odpadami. 
Wyłączenie nieruchomości niezamieszkałych z gminnego systemu gospodarki odpadami może prowokować do podrzucania odpadów (w szczególności jeśli chodzi o nieruchomości niezamieszkałe położone w bezpośrednim sąsiedztwie nieruchomości zamieszkałych), rozszczelnienia systemu - przy braku jednoznacznie określonej ekonomicznej opłacalności po stronie właścicieli nieruchomości niezamieszkałych. Dodatkowo dochodzą kontrowersje związane z możliwością korzystania z gminnego systemu gospodarowania odpadami (np. w postaci PSZOK-ów), bez jednoczesnego zagwarantowania gminom wystarczających instrumentów weryfikacji tego, czy dany podmiot objęty jest systemem, czy nie. W okresie początkowym zmian systemu gospodarki odpadami komunalnymi kwestia objęcia system nieruchomości niezamieszkałych budziła znaczne trudności praktyczne - ze względu na koszty odbioru odpadów, ich ilość i wiele innych czynników. Można jednak stwierdzić, że relacje między właścicielami tej kategorii nieruchomości, a organami gminy zaczęly kształtować się poprawnie i obie strony dostosowały się do nowych realiów prawnych. W kontekście przywołanych w artykule argumentów, w mojej ocenie, negatywnie należy ocenić rozwiązania prawne, które dają właścicielom nieruchomości niezamieszkałych swobodę wyboru tego, czy chcą być objęci gminnym systemem gospodarki odpadami. Przy masowej skali realizacji usługi odbioru i zagospodarowania odpadów istotna jest szczelność systemu, czego nie gwarantują przyjęte przez ustawodawcę regulacje.

\section{Bibliografia}

Barczak A., Pozycja prawna wójta w ochronie środowiska [w:] Pozycja ustrojowa organów wykonawczych jednostek samorządu terytorialnego, red. K. Małysa-Sulińska, M. Stec, 2014, LEX.

Czepiel P., Gospodarowanie odpadami komunalnymi w obliczu zmian wprowadzonych ustawa $z 1$ lipca 2011 r., „Samorząd Terytorialny” 2013, nr 5.

Florczak-Wątor M., Art. 2 [w:] Konstytucja Rzeczypospolitej Polskiej. Komentarz, red. P. Tuleja, 2019, LEX.

Jezierska-Markocka A., Markocki M., Ustawa o utrzymaniu czystości i porządku w gminach, Warszawa 2019.

Klatka J., Kuźniak M., Gospodarowanie odpadami komunalnymi. Poradnik dla gmin, 2012, LEX.

Kornaszewska J., Zasada „lex retro non agit”. Czy prawo nie działa wstecz?, „Przegląd Prawa Konstytucyjnego" 2018, nr 2(42), https://doi.org/10.15804/ppk.2018.02.09.

Kropiewnicka M., Zasady odbioru i gospodarowania odpadami komunalnymi na gruncie znowelizowanej ustawy o utrzymaniu czystości i porządku w gminach, „Przegląd Prawa Ochrony Środowiska" 2012, nr 4.

Modrzejewski A.K., Właściciel i nieruchomość w świetle znowelizowanej ustawy o utrzymaniu czystości i porząku w gminach, „Samorząd Terytorialny” 2013, nr 1-2. 
A. Specht-Schampera A., In house a odbiór odpadów z nieruchomości mieszanych, „Przegląd Komunalny" 2018, nr 2.

Spotowski A., Zasada lex retro non agit (geneza, uzasadnienia, zasięg), „Palestra” 1985, nr 29/9. Stachurski W. [w:] Ordynacja podatkowa. Komentarz aktualizowany, red. L. Etel, 2019, LEX. Teszner K., Realizacja opłat za gospodarowanie odpadami komunalnymi a obowiązek przestrzegania tajemnicy skarbowej, „Prawo Finansów Publicznych” 2013, nr 10.

Teszner K., Tajemnica skarbowa i odpowiedzialność administracji gminnej za jej naruszenie w kontekście przepisów ustawy o utrzymaniu czystości i porządku w gminach, cz. 1, „Przegląd Podatków Lokalnych i Finansów Samorządowych” 2013, nr 7.

Teszner K., Tajemnica skarbowa i odpowiedzialność administracji gminnej za jej naruszenie w kontekście przepisów ustawy o utrzymaniu czystości i porządku w gminach, cz. 2, „Przegląd Podatków Lokalnych i Finansów Samorządowych” 2013, nr 8.

Zimmermann J., Prawo administracyjne, Warszawa 2012.

\section{Akty prawne}

Dyrektywa Parlamentu Europejskiego i Rady 2008/98/WE z 19 listopada 2008 r. w sprawie odpadów oraz uchylająca niektóre dyrektywy, Dz.Urz. UE L 312/3 z 22 listopada $2008 \mathrm{r}$.

Dyrektywa Parlamentu Europejskiego i Rady (UE) 2018/851 z 30 maja 2018 r. zmieniająca dyrektywę 2008/98/WE w sprawie odpadów, Dz.Urz. UE L 150/109 z 14 czerwca $2018 \mathrm{r}$.

Ustawa z 17 czerwca 1966 r. o postępowaniu egzekucyjnym w administracji, t.j. Dz.U.2019, poz. 1438.

Ustawa z13 września 1996 r. o utrzymaniu czystości i porządku w gminach, t.j. Dz.U. 2018, poz. 1454.

Ustawa z 29 sierpnia 1997 r. - Ordynacja podatkowa, t.j. Dz.U. 2019, poz. 900.

Ustawa z 20 lipca 2000 r. o ogłaszaniu aktów normatywnych i niektórych innych aktów prawnych, t.j. Dz.U. 2019, poz. 1461.

Ustawa z 19 lipca 2019 r. o zmianie ustawy o utrzymaniu czystości i porządku w gminach oraz niektórych innych ustaw, Dz.U. Poz. 1579.

\section{Orzecznictwo}

Wyrok WSA w Gorzowie Wielkopolskim z 6 marca 2019 r., sygn. akt I SA/Go 36/19, CBOSA.

Wyrok WSA w Gorzowie Wielkopolskim z 12 września 2019 r., sygn. akt I SA/Go 281/19, CBOSA.

Wyrok WSA w Szczecinie z 14 lutego 2018 r., sygn. akt I SA/Sz 992/17, CBOSA.

Wyrok WSA w Gorzowie Wielkopolskim z 7 czerwca 2017 r., sygn. akt I SA/Go 150/17, CBOSA.

Wyrok WSA w Opolu z 8 listopada 2017 r., sygn. akt I SA/Op 242/17, CBOSA. Wyrok WSA w Gdańsku z 6 lutego 2019 r., sygn. akt II SA/Gd 786/18, CBOSA. Wyrok WSA we Wrocławiu z 3 października 2018 r., sygn. akt III SA/Wr 165/18, CBOSA. 


\title{
Szósta reforma państwa: zmiana sposobu kształtowania składu Senatu jako element ewolucji federalizmu w Królestwie Belgii
}

\author{
The Sixth State Reform: transformation of the composition of the Senate \\ as a component of the evolution of federalism in the Kingdom of Belgium
}

Analysis of the direction of changes in the composition of the Senate indicates that the political idea is to shape the Senate according to the most common model of a second chamber in federal states, formed by federal entities and limited in their competence to matters that are most important from the point of view of the entire federation and the interests of federal entities. The future of the Senate will depend on the activity and functioning of this chamber, especially if it turns out to be a functional bridge of communication between the entities of the federation, which is probably the most serious Belgian political challenge.

Keywords: Belgium, Senate, federalism, Sixth State Reform

Analiza kierunku zmian w składzie Senatu wskazuje, że ideą jest nadanie Senatowi najczęściej spotykanego modelu izby drugiej w państwach federalnych, kształtowanych przez podmioty federalne i ograniczonych w kompetencjach do spraw najistotniejszych z punktu widzenia całej federacji i interesów podmiotów federalnych. To od aktywności i sposobu funkcjonowania tej izby zależeć będzie jej przyszłość, szczególnie jeśli okaże się funkcjonalnym pomostem komunikacji pomiędzy podmiotami federacji, co jest chyba najpoważniejszym wyzwaniem ustrojowym Belgii.

Słowa kluczowe: Belgia, Senat, federalizm, szósta reforma państwa

Doktor hab. nauk prawnych, adiunkt -

Uniwersytet w Białymstoku, Wydział Prawa, Katedra Prawa Konstytucyjnego i Systemów

Politycznych, BIAŁYSTOK, POLSKA -

jackiewicz@uwb.edu.pl . https://orcid.org/0000-0001-6957-3139

\section{Wstęp}

Skład Senatu Królestwa Belgii oraz sposób jego kształtowania jest symptomatycznym odzwierciedleniem skomplikowanego kształtu federalizmu belgijskiego. Zarówno przed szóstą reformą państwa ${ }^{1}$, jak i po niej, wyraża oryginalność i zło-

1 Pierwszą reformą państwa (1970 r.) wprowadzono do belgijskiego ustroju politycznego trzy wspólnoty kulturalne oraz stworzono podstawy konstytucyjne do utworzenia trzech regionów. Druga reforma (1980 r.) przekształciła wspólnoty kulturalne we wspólnoty, poszerzając ich zakres zadań o tzw. sprawy osobowe. Utworzono wówczas dwa regiony: Region Flamandzki i Region Waloński. Trzeci region - Region Stołeczny 
żoność tego ustroju konstytucyjnego, który funkcjonuje w warunkach wyjątkowo zbipolaryzowanego społeczeństwa. Wspomniana reforma ustrojowa, która miała miejsce w latach 2012 i 2014, dotyczyła m.in. izby drugiej belgijskiego parlamentu, poważnie ograniczając jej pozycję ustrojową, przy jednoczesnej zmianie sposobu kształtowania tej izby ${ }^{2}$.

Chcąc dostosować strukturę artykułu do wymagań, jakie przed autorem stawia czytelna analiza tytułowej problematyki, dalszy tekst podzielono na cztery części. W pierwszej części przedstawiono zarys szóstej reformy państwa, po czym zasygnalizowano sposób, w jaki kształtowany był skład Senatu do czasu reformy, a więc do roku 2014. Następnie dokonano rekonstrukcji aktualnych normatywnych mechanizmów kształtowania składu tej izby. W części ostatniej podjęto próbę oceny przeprowadzonych zmian w tym zakresie, z uwzględnieniem perspektywy pro futuro.

\section{Szósta reforma państwa}

Szósta reforma państwa, czyli kolejna reorganizacja belgijskiego systemu konstytucyjnego, była odpowiedzią na sytuację długotrwałego napięcia politycznego, które nasiliło się po przeprowadzonych 13 czerwca 2010 r. federalnych wyborach parlamentarnych. Po raz kolejny dał o sobie znać kluczowy czynnik ewolucji ustroju belgijskiego, czyli bipolaryzacja społeczna, polityczna i kulturowa (językowa) tego państwa $^{3}$. Rywalizacja pomiędzy zamieszkującymi Belgię dwiema dużymi wspól-

Bruksela został utworzony na mocy trzeciej reformy państwa (1988-1989), kiedy to poszerzono również zakres zadań i kompetencji wspólnot i regionów. Czwarta reforma państwa (1993 r.) była swoistym uporządkowaniem dotychczasowych zmian ustrojowych, przekształcając formalnie Belgię w państwo federalne (art. 1 konstytucji). Wprowadzono wybory bezpośrednie parlamentów części składowych, nadal poszerzał się zakres spraw, za które odpowiedzialne stawały się wspólnoty i regiony. Nastąpiły też modyfikacje relacji instytucji centralnych w duchu charakterystycznym dla państw federalnych. Piąta reforma państwa (2001 r.) transferowała kolejne materie na rzecz wspólnot i regionów oraz dotyczyła zmian instytucjonalnych w zakresie ustroju Regionu Stołecznego Brukseli.

2 O szóstej reformie państwa piszę w: A. Jackiewicz, Sixth State Reform - A Belgian Copernican Revolution or a Missed Opportunity?, „Przegląd Prawa Konstytucyjnego” 2019, nr 6 (52), s. 237-251.

3 W. Swenden, M. Brans, L. De Winter, The Politics of Belgium: Institutions and Policy Under Bipolar and Centrifugal Federalism, „West European Politics” 2006, nr 29/5, s. 863, 869-871; C. Romainville, Dynamics of Belgian Plurinational Federalism: A Small State Under Pressure, „Boston College International and Comparative Law Review” 2015, nr 2(38), s. 228; P. Popelier, B. Cantillon, Bipolar Federalism and the Social Welfare State: A Case for Shared Competences, „Publius. The Journal of Federalism” 2013, nr 4(43), s. 626-629. 
notami językowymi: niderlandzkojęzyczną (około 6,5 mln osób, przede wszystkim w regionie Flandrii) oraz francuskojęzyczną (około 3,6 mln osób - przede wszystkim w regionie Walonii) ${ }^{4}$, jest bowiem signum specificum ustroju belgijskiego ${ }^{5}$, stając się najistotniejszym źródłem ewolucji belgijskiego federalizmu konsocjalnego ${ }^{6}$.

Najważniejszymi płaszczyznami kryzysu były tym razem rozbieżności pomiędzy dwiema grupami językowymi w zakresie kierunków reformy państwa, kwestia dystryktu Brussels-Halle-Vilvoorde oraz implikowane tymi kwestiami trudności w sformowaniu większości parlamentarnej i wyłonieniu rządu ${ }^{7}$. Było to powodowane wynikami wspomnianych wyborów, których rezultatem była pofragmentowana i wewnętrznie podzielona Izba Reprezentantów ${ }^{8}$. Dojście do porozumienia utrudniało zatem to, że w izbie tej reprezentowane było aż 11 partii politycznych, z których żadna nie zdobyła więcej niż 20\% mandatów. Mimo iż monarcha sześciokrotnie powoływał uznanych polityków jako mediatorów, nie udawało się dojść do porozumienia9. Proces formowania większości parlamentarnej trwał

4 Skomplikowaną strukturę społeczeństwa belgijskiego pogłębia oficjalnie dwujęzyczny Region Stołeczny Bruksela (ok. 1,2 mln osób). Znacznie mniejszą rolę, będąc na marginesie tej swoistej rywalizacji, odgrywa mniejszość niemiecka, która liczy zaledwie ok. 75 tys. osób). Dane statystyczne podaję za stroną internetową belgijskiego Urzędu Statystycznego, https://statbel.fgov.be/en/themes/population/structure-population [dostęp 31 października 2019 r.].

$5 \quad$ Ponadto istotnym czynnikiem polaryzującym Belgię jest fakt, że przynależność do poszczególnych wspólnot językowych jest silnie skorelowana z poczuciem tożsamości narodowej poszczególnych mieszkańców Belgii. Zob. P. Popelier, B. Cantillon, Bipolar Federalism, op. cit., s. 628-630; J. Billiet, B. Maddens, A.P. Frognier, Does Belgium (Still) Exist? Differences in Political Culture Between Flemings and Walloons, „West European Politics" 2006, nr 29, s. 912-916; C. Romainville, Dynamics of Belgian Plurinational, op. cit., s. 229.

$6 \quad$ Kolejne modyfikacje ustroju konstytucyjnego były wynikiem trudnych negocjacji pomiędzy grupami językowymi. Zmiany w zakresie wzajemnych relacji znajdowały następnie odbicie w zmianach instytucjonalnych, takich jak m.in. podział członków Izby Reprezentantów na grupy językowe czy tzw. procedura alarmowa.

$7 \quad$ Problemy związane z ukształtowaniem się stabilnej większości parlamentarnej są trwałym elementem belgijskiej rzeczywistości politycznej, uzasadniając tendencję do powoływania rządów mniejszościowych. Zob. E. Kużelewska, Status ustrojowy władzy wykonawczej w Belgii, „Przegląd Politologiczny” 2017, nr 1, s. 29.

$8 \quad$ Na częste rozbicie sceny politycznej wpływa system wyborczy, który zakłada podział mandatów w „walońskich” oraz „flamandzkich” prowincjach. Rywalizacja następuje odrębnie, bowiem w Walonii rywalizują partie walońskie, a we Flandrii flamandzkie, konkuruje zwykle kilkadziesiąt list wyborczych, a mandaty zdobywa kilkanaście z nich. Zob. R. Klepka, Parlament w państwie federalnym na przykładzie Austrii, Belgii, Niemiec i Szwajcarii. Analiza porównawcza, Warszawa 2013, s. 166.

9 Zgodnie art. 99 konstytucji Rada Ministrów może liczyć maksymalnie piętnastu członków, składając się w równej liczbie z ministrów flamandzkojęzycznych i francu- 
aż 541 dni $^{10}$. Uznaje się go za zakończony w dniu 11 października 2011 r., wraz z zawarciem przez osiem partii politycznych umowy o instytucjonalnej reformie państwa ${ }^{11}$. Osiągnięty kompromis jest najczęściej określany jako „porozumienie motyla” (nid. Vlinderakkoord; fr. Accord papillon), co wzięło swą nazwę od muchy, która była elementem stroju ogłaszającego sukces negocjacyjny premiera Elio Di Rupo $^{12}$. Porozumienie to zostało następnie zrealizowane zmianami w konstytucji oraz ustawach, określonymi właśnie jako szósta reforma państwa.

Zasygnalizować należy również ekstraordynaryjny tryb zmiany konstytucji, zastosowany w celu realizacji politycznego „porozumienia motyla”. Zgodnie

skojęzycznych, z możliwym odstępstwem od tej zasady na rzecz premiera. Zob. także E. Zieliński, Rząd Królestwa Belgii [w:] Rządy w państwach Europy, t. 1, red. E. Zieliński, I. Bokszczanin, Warszawa 2003, s. 32; K. Prokop, Odpowiedzialność członków Rządu Federalnego w Belgii, „Przegląd Prawa Konstytucyjnego” 2018, nr 2, s. 46-47; E. Kużelewska, Status ustrojowy, op. cit., s. 27. Niezależnie od tego parytetu, od premiera oczekuje się postawy bezstronnej i podejmowania decyzji w oparciu o kryteria obiektywne. Ponadto, jak pisze Patrick Peeters, jest kwestią utrwalonej praktyki konstytucyjnej, iż rozstrzygnięcia w ramach rządu są podejmowane na drodze konsensusu. Jeżeli jest on ostatecznie niemożliwy, a dany minister wciąż sprzeciwia się większości członków Rady Ministrów, ma on wtedy wybór między akceptacją takiej decyzji w ramach solidarności rządowej, albo dymisją. Zasada konsensusu gwarantuje skuteczny udział mniejszości francuskojęzycznej w polityce federalnej, co autor ten uznaje za skuteczniejsze od zasady parytetu. Zob. P. Peeters, Reflections on the Belgian federal state [w:] Multinational federations, red. M. Burgess, J. Pinder, Abingdon 2007, s. 36; Y. Lejeune, Droit constitutionnel belge: Fondements et institutions, Bruksela 2017, s. 697. Co uznaje się za „nieoficjalny rekord świata”, który wcześniej należał do Kambodży, gdzie w latach 2003-2004, nie udawało się powołać rządu przez 353 dni.

11 K. Deschouwer, M. Reuchamps, The Belgian federation at a crossroad, „Regional \& Federal Studies” 2013, nr 3(23), s. 261-270. Warto odnotować, że porozumienie poparte przez socjaldemokratów, chadeków oraz liberałów, zarówno po stronie niderlandzkiej, jak i francuskiej, nie zostało podpisane przez N-VA, co miało w przyszłości zaowocować brakiem większości w niderlandzkiej grupie językowej. Formalnie w składzie koalicji rządowej nie znalazły się także dwie partie proekologiczne (Groen i Ecolo), które jednak poparły powołanie rządu oraz zapewniły uzyskanie większości $2 / 3$, niezbędnej do zmiany konstytucji.

12 Szerzej zob. D. Caluwaerts, M. Reuchamps, Combining federalism with consociationalism: Is Belgian consociational federalism digging its own grave?, „Ethnopolitics” 2015, nr 3(14), s. 277-295; C. Devos, D. Sinardet, Governing without a government: the Belgian experiment, „Governance” 2012, nr 2 (25), s. 167-171; R. Klepka, Kryzys polityczny lat 2010-2011 w Królestwie Belgii - geneza i możliwe następstwa [w:] Na tropach twórczości i czasów minionych. Księga jubileuszowa ofiarowana Profesorowi Damianowi Tomczykowi, red. M. Cetwiński, A. Czajkowska, Częstochowa 2012, s. 453 i n.; A.L. Verbeke, Belgium, A Broken Marriage [w:] Federalism and Legal Unification: A Comparative Empirical Investigation of Twenty Systems, red. D. Halberstam, M. Reimann, Dordrecht 2013, s. 124-125. 
Z art. 195 zdanie pierwsze konstytucji rewizja ustawy zasadniczej może nastąpić w następstwie złożenia przez władzę ustawodawczą deklaracji ${ }^{13}$ o wystąpieniu powodów do dokonania określonych zmian w konstytucji (wskazanie konkretnych przepisów) ${ }^{14}$. Następnie izby parlamentarne rozwiązują się z mocy prawa. Dopiero nowo wybrane izby podejmują decyzje, jednak wyłącznie w zakresie przepisów wskazanych deklaracjami. W analizowanym przypadku konieczna była jednak rewizja przepisów, które nie były objęte dopuszczalną szerokością zmian. Jednak w związku z tym, że wśród przepisów konstytucyjnych, które w świetle uprzednich deklaracji mogły podlegać zmianom, znajdował się art. 195, ustalający procedurę zmiany konstytucji, partie polityczne, które zawarły „porozumienie motyla”, dysponując większością konstytucyjną, zdecydowały się dodać do tego artykułu postanowienia przejściowe, obowiązujące tylko podczas ówczesnej kadencji parlamentu. Postanowienia te umożliwiały zmiany wskazanych tam przepisów konstytucji, bez konieczności przeprowadzania fazy deklaracji rewizji konstytucji oraz przeprowadzania wyborów ${ }^{15}$. Wprowadzone w dniu 29 marca 2012 r. postanowienia przejściowe zawierały listę piętnastu materii konstytucyjnych, które stały się materią możliwą do natychmiastowej rewizji. Przyjęte rozwiązanie zostało uznane jako niezwykle kontrowersyjne i choć dopuszczalne $\mathrm{z}$ formalnego punktu widzenia, to niezgodne $\mathrm{z}$ ratio legis art. 195 konstytucji ${ }^{16}$.

Szósta reforma państwa na szczeblu konstytucyjnym została zrealizowana dwiema rewizjami - z 19 lipca 2012 r. oraz z 6 stycznia 2014 r. Obie rewizje były uzupełnione przyjęciem ustaw realizujących „porozumienie motyla” ${ }^{17}$. Urzeczywistnienie ustrojowe tego paktu koncentrowało się na trzech kwestiach. Poza interesującą z punktu widzenia przedmiotu artykułu reformą kształtowania składu Senatu, zmiany dotyczyły transferu kompetencji na rzecz wspólnot i regionów, modyfikacji systemu finansów publicznych, a także kompromisu wokół dystryktu Brussels-Halle-Vilvoorde.

13 Deklaracje rewizji konstytucji są dwie. Jedna przyjmowana przez Izbę Reprezentantów oraz przez Senat, a druga podpisywana przez króla i kontrasygnowana.

14 R. Grabowski, Zasady zmiany Konstytucji Królestwa Belgii w świetle postanowień przejściowych z 2012 r., „Przegląd Prawa Konstytucyjnego” 2013, nr 4, s. 44-45; Y. Lejeune, Droit constitutionnel belge, op. cit., s. 86; F. Delpérée, The Process for Amending the Belgian Constitution, „Canadian Parliamentary Review” 1991, nr 14(3), s. 19; $\mathrm{Ch}$. Behendt, The process of constitutional amendment in Belgium [w:] Engineering Constitutional Change: A Comparative Perspective on Europe, Canada and the USA, red. X. Contiades, New York 2013, s. 9.

15 J. Goossens, P. Cannoot, Belgian Federalism after the Sixth State Reform, „Perspectives on Federalism" 2015, nr 7(2), s. 32-33.

16 C. Romainville, Dynamics of Belgian Plurinational, op. cit., s. 241-243, oraz powołana tam literatura. Inaczej R. Grabowski, Zasady zmiany Konstytucji, op. cit., s. 48.

17 A.L. Verbeke, Belgium, op. cit., s. 124-125. 


\section{Skład Senatu przed szóstą reformą państwa}

Do roku $2014^{18}$, zgodnie z postanowieniami art. 67 belgijskiej konstytucji, Senat składał się z 71 senatorów ${ }^{19}$. Na liczbę tę składało się:

- dwudziestu pięciu senatorów wybieranych bezpośrednio przez wyborców należących do niderlandzkiej grupy językowej,

- piętnastu senatorów wybieranych bezpośrednio przez wyborców należących do francuskiej grupy językowej,

- dziesięciu senatorów desygnowanych ze swego grona przez Parlament Wspólnoty Flamandzkiej,

- dziesięciu senatorów desygnowanych ze swego grona przez Parlament Wspólnoty Francuskiej,

- jeden senator desygnowany ze swego grona przez Parlament Wspólnoty Niemieckojęzycznej,

- sześciu senatorów dokooptowanych przez senatorów niderlandzkiej grupy językowej, a więc przez senatorów wybieranych bezpośrednio przez wyborców należących do niderlandzkiej grupy językowej oraz przez dziesięciu senatorów desygnowanych ze swego grona przez Parlament Wspólnoty Flamandzkiej,

- czterech senatorów dokooptowanych przez senatorów francuskiej grupy językowej, a więc przez piętnastu senatorów wybieranych bezpośrednio przez

18 Taka kompozycja Senatu funkcjonowała od wyborów przeprowadzonych w 1995 r., będących następstwem reformy konstytucyjnej, która miała miejsce w $1993 \mathrm{r}$.

19 Poza konstytucyjnie określoną liczbą 71 mandatów wspomnieć należy także o obecnej przed szóstą reformą państwa instytucji senatorów z mocy prawa. Zaliczano do nich dzieci monarchy, które ukończyły 18 lat, lub, jeśli ich nie było, belgijskich potomków głównej linii dynastii królewskiej, o ile złożyli ślubowanie. Ratio legis tego rozwiązania była chęć wdrażania przyszłych panujących w mechanizmy demokracji. Senatorowie tej kategorii na mocy konwenansu konstytucyjnego nie uczestniczyli jednak w głosowaniach, mimo że teoretycznie uzyskiwali takie prawo wraz z ukończeniem wieku 21 lat (pierwotnie było to 25 lat). Ich obecność, czy raczej brak obecności, nie wpływała na wymagane kworum, które było liczone od konstytucyjnej liczby 71 senatorów, a więc dla ważności głosów musiało być obecnych 36 senatorów. Historia belgijskiego Senatu pokazuje jednak, że wystąpienia senatorów tej kategorii miały niegdyś miejsce - np. przyszły monarcha Leopold III w latach 1927-1934 występował trzykrotnie. W momencie gdy przeprowadzano szóstą reformę państwa nie było senatorów z mocy prawa, ponieważ dzieci króla Filipa były w wieku poniżej 18 lat. Natomiast sam król Filip, gdy jeszcze był następcą tronu (od 1994 r.), a więc gdy na tronie zasiadał król Albert II, wraz z księżniczką Astrid (od 1996 r.) i księciem Laurentem ( od 2000 r.) byli zaliczani do tej kategorii senatorów. Łącznie od 1831 r. było zaledwie siedmiu senatorów z mocy prawa. Zob. także C. Sägesser, C. Istasse, Le Sénat et ses réformes successives, „Courrier hebdomadaire du CRISP” 2014, nr 2219-2220, s. $14,31,45$. 
wyborców należących do francuskiej grupy językowej oraz przez dziesięciu senatorów desygnowanych ze swego grona przez Parlament Wspólnoty Francuskiej $^{20}$.

Z wyliczenia powyższego wynikała konkluzja, że ustrojodawca starał się relatywnie wiernie oddać zróżnicowanie Królestwa Belgii. Po pierwsze, uwzględniał podział mandatów senatorskich pomiędzy kandydatów pochodzących $\mathrm{z}$ wyborów bezpośrednich oraz pośrednich, a po drugie, w ramach tego podziału, dalszą dystrybucję pomiędzy grupy językowe i to jeszcze na dwa sposoby. Była to jedna z najbardziej skomplikowanych kompozycji izb drugich, którą można było traktować jako jeden z przejawów nietypowego systemu federalnego Królestwa Belgii, innymi słowy - jakimi posłużył się Ferdynand Kinsky - „zawiłego i oryginalnego wyniku", jaki osiągnęły instytucje federacji belgijskiej ${ }^{21}$.

\section{Kompozycja Senatu ukształtowana szóstą reformą państwa}

Obecnie, po reformie z roku 2014, skład Senatu został zmniejszony do 60 senatorów. Zgodnie z obowiązującym brzmieniem art. 67 ust. 1 i 2 belgijskiej konstytucji izbę drugą tworzy:

- dwudziestu dziewięciu senatorów desygnowanych przez Parlament Flamandzki ze swego grona lub z grona niderlandzkiej grupy językowej Parlamentu Regionu Stołecznego Brukseli,

- dziesięciu senatorów desygnowanych ze swego grona przez Parlament Wspólnoty Francuskiej,

- ośmiu senatorów desygnowanych ze swego grona przez Parlament Regionu Walońskiego,

- dwóch senatorów desygnowanych ze swego grona przez francuską grupę językową Parlamentu Regionu Stołecznego Brukseli,

- jeden senator desygnowany ze swego grona przez Parlament Wspólnoty Niemieckojęzycznej,

- sześciu dodatkowych senatorów dokooptowanych przez senatorów, którzy zostali desygnowani przez Parlament Flamandzki,

- czterech dodatkowych senatorów, którzy zostali dokooptowani przez senatorów, którzy zostali desygnowani przez Parlament Wspólnoty Francuskiej, Parlament Regionu Walońskiego oraz przez francuską grupę językową Parlamentu Regionu Stołecznego Brukseli ${ }^{22}$.

20 F. Amez, Le bicaméralisme après la sixième réforme de l'État, CDPK 2015, nr 2, s. $191-$ 192.

21 F. Kinsky, Federalizm. Model ogólnoeuropejski, Kraków 1999, s. 128.

22 O dwóch kategoriach senatorów dokooptowanych Marc Verdussen pisze jako o relikcie dawnego Senatu. Zob. M. Verdussen, La dernière réforme du Sénat de Belgique, 
Konstytucja Królestwa Belgii przewiduje ponadto dwa dodatkowe warunki, które muszą być uwzględnione przy rozdysponowywaniu mandatów senatorskich. Po pierwsze, zgodnie z art. 67 ust. 2, co najmniej jeden z senatorów desygnowanych przez Parlament Flamandzki ze swego grona lub z grona niderlandzkiej grupy językowej Parlamentu Regionu Stołecznego Brukseli winien zamieszkiwać w chwili swego wyboru w dwujęzycznym Regionie Stołecznym Brukseli $^{23}$, a trzech senatorów desygnowanych ze swego grona przez Parlament Wspólnoty Francuskiej powinno być członkami francuskiej grupy językowej Parlamentu Regionu Stołecznego Brukseli, przy czym jeden z nich nie musi być członkiem Parlamentu Wspólnoty Francuskiej, co sama konstytucja określa literalnie jako wyjątek. Oznacza to tym samym, że pozostałych siedmiu z tej grupy ma pochodzić z Walonii ${ }^{24}$. Po drugie, zgodnie z art. 67 ust. 2, Senat nie może się

„Revista catalana de dret públic” 2015, nr 51, s. 80. Mechanizm kooptacji, jak piszą J. Goossens, P. Cannoot, był pierwotnie pomyślany jako sposób na zaangażowanie w prace Senatu ekspertów, których zadaniem było podnoszenie jakości debaty oraz stanowionego prawa. Niestety, współcześnie służy to przede wszystkim zapewnieniu mandatów politykom, którzy nie mieliby szans na bezpośredni wybór. Mechanizm ten został utrzymany w 2014 r. jako zadośćuczynienie za podział dystryktu Halle-Vilvoorde, aby zapewnić niderlandzkim politykom z Brukseli dalszą możliwość uzyskania mandatu w Senacie. Autorzy ci jednoznacznie uznają zachowanie tego mechanizmu za błędne. Zob. J. Goossens, P. Cannoot, Belgian Federalism, op. cit., s. 39. O aktualnej kompozycji Senatu zob. także F. Amez, Le bicaméralisme après, op. cit., s. 202-208.

23 Zgodnie z materiałami informacyjnymi opublikowanymi przez belgijski Senat użyte w przepisie sformułowanie „dzień wyboru” nawiązuje do poprzedniej redakcji tego przepisu, ale powinno być rozumiane jako dzień desygnowania danego senatora, a nie jako dzień wyborów tego zgromadzenia. Zob. Composition du Sénat. Le renouvellement du Sénat à l'issue des élections simultanées du 25 mai 2014, s. 1, https://www. senate.be/actueel/homepage/Elections_2014/140424-renouvellement_Senat.pdf oraz Le renouvellement du Sénat à l'issue des élections simultanées du 26 mai 2019, https:// www.senate.be/home/sections/focus/20190404-elections2019/2019-renouvellement-Senat.pdf [dostęp 14 grudnia 2019 r.].

24 Composition du Sénat..., s. 1; C. van Wynsberghe, The Belgian Senate: little damage, little use, VerfBlog, 2014/10/23, https://verfassungsblog.de/belgian-senate-little-damagelittle-use-2/ [dostęp 21 października 2019 r.]. Przed reformą z roku 2014 konstytucja zastrzegała (art. 67 ust. 2), że co najmniej jeden z senatorów niderlandzkiej grupy językowej winien zamieszkiwać w chwili swego wyboru w dwujęzycznym Regionie Stołecznym Brukseli, oraz że co najmniej sześciu senatorów francuskiej grupy językowej winno zamieszkiwać w chwili wyboru w tym regionie. Natomiast, jeżeli co najmniej czterech senatorów francuskiej grupy językowej, którzy byli wybierani bezpośrednio, nie zamieszkiwali w dniu wyboru w dwujęzycznym Regionie Stołecznym Brukseli, to co najmniej dwóch senatorów, desygnowanych ze swego grona Parlament Wspólnoty Francuskiej winno mieć w tym rejonie stałe miejsce zamieszkania. 
składać w części większej niż 2/3 z senatorów tej samej płci (w latach 2014-2019 był zachowany idealny parytet 1 do 1 , a po wyborach z 26 maja 2019 r. jest 28 kobiet i 32 mężczyzn $)^{25}$.

Szósta reforma państwa w zakresie sposobu kształtowania składu Senatu zmodyfikowała także samą procedurę desygnowania senatorów realizowaną w ramach poszczególnych kategorii. Na podstawie art. 68 ust. 1 konstytucji Królestwa Belgii dwadzieścia dziewięć mandatów senatorskich, rozdysponowywanych przez Parlament Flamandzki pomiędzy swoimi członkami lub z grona niderlandzkiej grupy językowej Parlamentu Regionu Stołecznego Brukseli, jest rozdzielanych pomiędzy listami wyborczymi partii politycznych ${ }^{26}$, które zdobyły co najmniej jeden mandat w wyborach do Parlamentu Flamandzkiego, a także które przekroczyły pięcioprocentowy próg wyborczy ${ }^{27}$. Alokacja tych mandatów odbywa się na zasadzie proporcjonalności (system d'Hondta - art. 210 kodeksu wyborczego), na podstawie wyników wyborczych tych list uzyskanych w poszczególnych okręgach wyborczych w wyborach do Parlamentu Flamandzkiego. Mandaty francuskiej grupy językowej są rozdysponowywane w analogicznym trybie, przy uwzględnieniu wyników wyborczych w wyborach do Parlamentu Regionu Walońskiego, a także wyników wyborczych francuskiej grupy językowej w wyborach do Parlamentu Regionu Stołecznego Brukseli. Również w tych przypadkach bierze się pod uwagę tylko listy tych podmiotów, które zdobyły co najmniej jedno miejsce do, odpowiednio, Parlamentu Wspólnoty Francuskiej, Parlamentu Walonii i francuskiej grupy językowej Parlamentu Regionu Stołecznego Brukseli. Ponadto partia musi uzyskać co najmniej 5\% ogólnej sumy głosów ważnie oddanych ${ }^{28}$.

Zachowanie warunków konstytucyjnych wymaga więc współpracy i konsultacji partii politycznych, które desygnują senatorów, co może być szczególnie trudne ze względu na dwie kwestie. Po pierwsze, ostatecznie decyzję podejmują partie polityczne w ramach liczby mandatów, którymi dysponują w poszczególnych zgromadzeniach. Po drugie, w ramach francuskiej grupy językowej mandaty są dystrybuowane przez trzy parlamenty ${ }^{29}$.

Zob. także F. Amez, Le bicaméralisme après, op. cit., s. 206.

Konstytucja posługuje się w art. 68 terminem „lista”, który w świetle tytułu VII Kodeksu wyborczego powinien być rozumiany jako partia polityczna - Code Electoral z 15 kwietnia 1984 r. (wielokrotnie zmieniany); tekst Kodeksu jest dostępny za pośrednictwem elektronicznego belgijskiego systemu informatycznego: http://www.ejustice.just.fgov.be/eli/loi/1894/04/12/1894041255/justel [dostęp 27 września 2019 r.].

Liczony łącznie dla wszystkich głosów oddanych na daną partię polityczną, a nie w skali okręgu wyborczego, co ma z kolei znaczenie dla podziału mandatów do Parlamentu Flamandzkiego.

F. Amez, Le bicaméralisme après, op. cit., s. 202-205; C. Sägesser, C. Istasse, Le Sénat et sesréformessuccessives, op. cit., s. 60-61.

9 Composition du Sénat..., s. 13. 
Dialogu może wymagać również zachowanie konstytucyjnie określonego parytetu płci. Procedura zapewnienia parytetu płci zakłada dwa etapy. Po pierwsze, partie wybierają senatorów ze składu zgromadzeń podmiotów federacji, robiąc to co do zasady w sposób swobodny. Po drugie, przy podejmowaniu decyzji w sprawie dokooptowania senatorów partie powinny tak dobierać płeć senatorów, aby doprowadzić do zachowania konstytucyjnego parytetu. W związku z tym, że w procedurze tej pierwszeństwo mają większe partie, może się tak zdarzyć, że mniejsze partie będą zmuszone dokonywać wyboru senatorów z określonej, niedostatecznie reprezentowanej płci. W wyborach przeprowadzonych w $2014 \mathrm{r}$. w pierwszej fazie wybrano więcej kobiet (54\%), więc w drugiej fazie partie miały w tym względzie swobodę. Pomimo tego, jak już wspomniano, ostatecznie osiągnięto idealny parytet $1: 1^{30}$.

W zakresie szczegółowych zasad desygnowania senatorów w poszczególnych podmiotach belgijska konstytucja odsyła do ustawy, którą jest belgijski kodeks wyborczy (tytuł VII), oraz w zakresie szczegółowych rozwiązań - do ustaw stanowionych odrębnie przez parlamenty wspólnot w trybie przewidzianym w art. 68 konstytucji (większością dwóch trzecich głosów oddanych pod warunkiem, że większość członków danego parlamentu była obecna). W przypadku Parlamentu Wspólnoty Niemieckojęzycznej mandat nie jest automatycznie przypisany do listy kandydatów, którzy uzyskali najwyższą liczbę wyborców w wyborach tego parlamentu, a zgromadzenie to desygnuje ze swego grona senatora bezwzględną większością oddanych głosów. Kadencja poszczególnych kategorii senatorów jest uzależniona od kadencji poszczególnych podmiotów dokonujących desygnacji.

Konstytucja przewiduje także postanowienia odnoszące się do dystrybucji mandatów senatorów, którzy mają być dokooptowani (art. 68 ust. 2). Są one rozdysponowywane w systemie proporcjonalnym, na zasadzie „największej reszty” (konstytucja odsyła przy tym do art. 63 ust. 2) ${ }^{31}$, przy uwzględnieniu wyników wyborów, jakie uzyskały listy partii politycznych w wyborach do Izby Reprezentantów $^{32}$. W ramach danej grupy językowej łączna liczba ważnych głosów

30 R. Dandoy, J. Dodeigne, M. Reuchamps, A. Vandeleene, The New Belgian Senate. A (Dis)Continued Evolution of Federalism in Belgium?, „Representation” 2015, vol. 51, nr 3, s. 331.

31 Artykuł 63 ust. 2. „Każdy okręg wyborczy posiada tyle mandatów, ile razy liczba jego mieszkańców mieści w sobie dzielnik federalny, dzielnik ten otrzymuje się, dzieląc liczbę mieszkańców Królestwa przez sto pięćdziesiąt. Pozostałe mandaty przydzielane są okręgom wyborczym posiadającym najwyższą resztę ludności niereprezentowanej”.

32 Taka metoda, nawiązująca do wyników wyborów do Izby Reprezentantów, jest sprzeczna, jak twierdzą J. Goossens oraz P. Cannoot, z koncepcją Senatu jako izby podmiotów federalnych. W szczególności biorąc pod uwagę poważną redukcję kompetencji ustawodawczych tej izby, uznają, że właściwsze byłoby zastosowanie procedury kooptacji w odniesieniu do izby pierwszej. J. Goossens, P. Cannoot, Belgian Federalism, op. cit., s. 39. 
oddanych na wszystkie listy jest dzielona przez liczbę miejsc przeznaczonych do dystrybucji w tej grupie językowej (sześć lub cztery). Otrzymany iloraz jest dzielnikiem wyborczym, przez który dzielony jest wynik partii politycznych. Otrzymane w wyniku podziału „ilorazy wyborcze” partii politycznych decydują o liczbie mandatów senatorskich, jakie dana partia polityczna obsadza w Senacie. Pozostałe mandaty trafiają do partii politycznych, których iloraz wyborczy ma największą resztę (po przecinku).

Konstytucja odsyła przy tym do ustawy (art. 217 kodeksu wyborczego), która definiuje, które okręgi wyborcze bierze się pod uwagę przy dystrybucji mandatów należących do niderlandzkiej ${ }^{33}$ oraz francuskiej grupy językowej ${ }^{34}$. Kadencja dokooptowanych senatorów zależy więc od kadencji Izby Reprezentantów. Wybory do izby pierwszej są więc podstawą do dokooptowania nowych senatorów stosownie do tych wyników. Biorąc więc pod uwagę, że kadencja desygnowanych senatorów jest uzależniona od kadencji legislatyw podmiotów federacji, całkowite odnowienie składu Rady Federacji wymagałoby koincydencji wyborczej dotyczącej wszystkich tych organów ${ }^{35}$.

Warto także zwrócić uwagę na zawartą w art. 67 ust. 4 belgijskiej ustawy zasadniczej procedurę zastępczą, która choć jest swoistym ewenementem, to wpisującym się w ton reformy bikameralizmu belgijskiego, w której pierwsze skrzypce odgrywa Izba Reprezentantów. Procedura ta dotyczy sytuacji, w której nie udałoby się dokooptować senatorów w trybie art. 68 ust. 2 konstytucji z tego powodu, że w Senacie nie jest reprezentowana lista opcji politycznej, która w rezultacie wyniku wyborów do Izby Reprezentantów nabyła prawa do dokooptowania senatorów. W takiej sytuacji senatorowie mogą zostać dokooptowani przez deputowanych Izby Reprezentantów, którzy zostali wybrani z listy, której wynik uprawnia do dokooptowania senatorów.

Z powyższych rozważań wyłania się obraz Senatu jako izby parlamentarnej, w skład której nie wchodzą już senatorowie pochodzący z wyborów bezpośrednich. Pięćdziesięciu senatorów jest obecnie wyznaczanych przez parlamenty wspólnot i regionów, w ramach konstytucyjnie określonego parytetu, a rozdział poszczególnych mandatów uwzględnia wyniki wyborów do tych zgromadzen ${ }^{36}$.

33 Okręgi wyborcze: Antwerpia, Limburgia, Flandria Wschodnia, Flandria Zachodnia, Brabancja Flamandzka i Bruksela.

34 Okręgi wyborcze: Hainaut, Liege, Luksemburg, Namur, Brabancja Walońska i Bruksela. Szczególna regulacja dotyczy Brabancji Flamandzkiej, w odniesieniu dla głosów oddanych w dystrykcie Halle-Vilvoorde, które są uwzględniane w procesie obliczania łącznego wyniku wyborczego partii politycznych francuskiej grupy językowej.

35 Zob. także M. Verdussen, La dernière réforme du Sénat, op. cit., s. 80; F. Amez, Le bicaméralisme après, op. cit., s. 203-208.

36 Mimo że ideą reformy było przekształcenie Senatu w klasyczną izbę reprezentującą interesy części składowych federacji, to należy dostrzec, że art. 42 konstytucji nadal stanowi, że senatorowie reprezentują cały naród. Warto także zwrócić uwagę na 
Dziesięć pozostałych mandatów jest przeznaczonych dla senatorów, którzy uzupełniają skład izby na zasadzie stosowanej już wcześniej techniki kooptacji ${ }^{37}$. Nie brak przy tym jednak głosów krytycznych wobec zarówno tej techniki ${ }^{38}$, jak i generalnej koncepcji kształtowania składu tej izby ${ }^{39}$.

\section{Podsumowanie}

Mimo tego że dokonano istotnych zmian, cechami charakterystycznymi sposobu kształtowania składu Senatu pozostała wielopłaszczyznowość i złożoność ${ }^{40}$. Rezultaty pierwszych po reformie wyborów z 2014 r. wykazały, że zakładane efekty reformy, która miała reprezentować poszczególne podmioty federacji w poszanowaniu różnych płaszczyzn ich funkcjonowania i różnych interesów, nie zostały osiągnięte, a, jak ocenia to Marc Verdussen, rezultat jest wręcz rozczarowujący. Mimo że skład drugiej izby został ukształtowany przez zgromadzenia podmiotów federacji, to i tak układ sił opiera się na rozdziale na dwie grupy językowe, co odzwierciedla kluczowy podział wśród Belgów. W związku z tym, że jest to powtórzenie konfiguracji, która występuje w Izbie Reprezentantów, pojawia się, zdaniem tego autora, pytanie o rzeczywiste znaczenie belgijskiego bikameralizmu, choć jak sam zauważa, w Belgii nigdy nie było politycznych planów likwidacji izby drugiej ${ }^{41}$. Taka konfiguracja sił w Senacie, której osią jest belgijska bipolaryzacja, została potwierdzona ukształtowaniem i sposobem funkcjonowania tej izby po wyborach przeprowadzonych 26 maja 2019 r. Senat jest ponadto

fakt, że przed reformą nie było reprezentantów regionów, a o ile można było mówić o mandacie senatorów wspólnoty, którzy byli wyznaczani przez parlamenty wspólnot ze swojego składu, o tyle należy podkreślić, że podstawą do dystrybucji tego rodzaju mandatów były wyniki wyborów do Senatu. Mandatów tego rodzaju było zaledwie dwadzieścia jeden. Zob. J. Goossens, P. Cannoot, Belgian Federalism, op. cit., s. 38-41. Pierwotnie uzasadnieniem kooptacji była chęć zapewnienia w składzie izby czynnika eksperckiego, czyli senatorów o określonej wiedzy merytorycznej wspierających jakość debaty oraz uchwalanego prawa. Praktyka zweryfikowała to założenie. Okazało się bowiem, że stało się to drogą wprowadzenia do Senatu niepopularnych polityków, którzy nie mogli liczyć na mandat w wyborach bezpośrednich do parlamentu federalnego czy parlamentów części składowych.

K. Muylle, De hervorming van de Senaaten de samenvallendeverkiezingen: eenprocessie van Echternachnaar de federale (model)staat? [w:] Het federale België na de Zesde Staatshervorming, red. A. Alen et al., Brugge 2014, s. 103-124.

C. Romainville, Dynamics of Belgian Plurinational, op. cit., s. 244-245.

Częstym zjawiskiem wśród samych Belgów jest niezrozumienie zawiłości tego syste$\mathrm{mu}$, a pierwszym wyborom towarzyszyły kontrowersje dotyczące interpretacji rozwiązań prawa wyborczego. Zob. R. Dandoy, J. Dodeigne, M. Reuchamps, A. Vandeleene, The New Belgian Senate, op. cit., s. 333.

41 M. Verdussen, La dernière réforme du Sénat, op. cit., s. 74-76, 83-84. 
niemalże lustrzanym odbiciem układu sił politycznych w Izbie Reprezentantów. Poszczególne partie, zarówno walońskie, jak i flamandzkie, mają niemalże identyczną reprezentację w obu izbach (np. flamandzkie Nieuw-Vlaamse Alliantie 16\% w Izbie Reprezentantów i 15\% w Senacie; Vlaams Belang 12\% i 11,66\%; walońskie Parti socialiste 13,33\% i 11,66\%; Mouvement Réformateur 9,33\% i $10 \%)^{42}$. Potwierdza to Caroline van Wynsberghe, która pisząc o belgijskim Senacie po jego reformie, zwraca uwagę, że aktualna dystrybucja mandatów dość wiernie odpowiada językowej strukturze Belgii ${ }^{43}$.

Ocena tytułowej zmiany powinna uwzględniać również fakt, że szósta reforma państwa zredefiniowała pozycję ustrojową Senatu. Przede wszystkim zasygnalizować więc należy, że Senat utracił charakter izby działającej w trybie permanentnym (art. 44 konstytucji) i odbywa posiedzenia plenarne tylko około dziesięciu razy $\mathrm{w}$ roku ${ }^{44}$. Wiąże się to $\mathrm{z}$ tym, że ograniczone zostało zaangażowanie Senatu w proces stanowienia prawa. Podstawowa procedura ustawodawcza ma teraz bowiem charakter jednoizbowy i przebiega w Izbie Reprezentantów, a Senat utrzymał w tym zakresie jedynie prawo ewokacji i to tylko w odniesieniu do materii wskazanych w konstytucji (art. 78 konstytucji). W związku z tym, że owa procedura podstawowa ma szerokie zastosowanie, wykaz tych materii, w zakresie których może włączyć się Senat, jest dość ograniczony ${ }^{45}$, a ponadto Izba Reprezentantów może odrzucić poprawki Senatu, uprawnione wydaje się stwierdzenie, że Senat (a za jego pośrednictwem podmioty federacji) utracił wpływ na bieżące ustawodawstwo. Jednakże, z drugiej strony, należy zauważyć, że Senat kontroluje wskazane w konstytucji tzw. sprawy instytucjonalne. Zgody Senatu wymaga więc m.in. deklarowanie potrzeby zmiany konstytucji i uchwalanie takiej zmiany, uchwalanie wskazanych w konstytucji tzw. ustaw specjalnych (organicznych), ustaw dotyczących finansowania partii politycznych oraz wydatków ponoszonych $\mathrm{w}$ związku $\mathrm{z}$ wyborami czy też ustaw dotyczących samej organizacji tej izby oraz statusu senatorów (art. 77 konstytucji). W tym dość ograniczonym zakresie Senat jest więc izbą równą Izbie Reprezentantów ${ }^{46}$. W związku z powyższym w belgijskiej nauce prawa konstytucyjnego dominuje stanowisko,

42 Do analizy używam danych dotyczących rozdziału mandatów po wyborach z 26 maja 2019 r., dostępnych na stronach internetowych Izby Reprezentantów oraz Senatu, https://www.lachambre.be/doc/FLWB/PDF/55/0003/55K0003002.pdf, https://www. senate.be/home/sections/focus/20190404elections2019/Repartition_des_sieges_au_ Senat_27052019.pdf.

43 C. van Wynsberghe, The Belgian Senate, op. cit.

44 Liczba posiedzeń oraz warunki ich zwoływania są określone przez regulamin tej izby.

45 Są to np. takie sprawy, jak: podział państwa na prowincje, federalne sądownictwo administracyjne, wywiązywanie się państwa ze zobowiązań międzynarodowych.

46 O procedurach ustawodawczych piszę w: A. Jackiewicz, Konstytucyjne funkcje izb pierwszych parlamentów federalnych a zasada federalizmu w państwach europejskich, Białystok 2019, s. 137-140. 
że pozycja ustrojowa Senatu uległa ograniczeniu. Niektórzy autorzy podnoszą, że ustrojowa rola tej izby nie została precyzyjnie zdefiniowana, a sama izba nie zapewnia partycypacji części składowych federacji w procesie podejmowania decyzji na szczeblu federalnym ${ }^{47}$.

Skłania to do konkluzji, że wprowadzone szóstą reformą państwa zmiany w składzie kształtowania Senatu potwierdzają ewolucyjny charakter belgijskiego federalizmu. Jednocześnie nie są finiszem na drodze poszukiwania pozycji ustrojowej tej izby w tym skomplikowanym systemie konstytucyjnym. Analiza kierunku zmian oznacza przy tym, że ideą jest nadanie Senatowi najczęściej spotykanego modelu izby drugiej w państwach federalnych, kształtowanych przez podmioty federalne i ograniczonych w kompetencjach do spraw najistotniejszych z punktu widzenia całej federacji i interesów podmiotów federalnych. W opinii autora niniejszego artykułu spodziewać się można kolejnej, siódmej reformy państwa. Aktualna pozycja ustrojowa Senatu powoduje, że izba ta - choć osłabiona - to wciąż ma możliwość włączenia się w proces ewolucji belgijskiego federalizmu ${ }^{48}$. To od aktywności i sposobu funkcjonowania samej izby drugiej zależeć będzie jej przyszłość, szczególnie jeśli okaże się funkcjonalnym pomostem komunikacji między podmiotami federacji, co jest chyba najpoważniejszym wyzwaniem ustrojowym Belgii. W kontekście tytułowego zagadnienia szczególnym zadaniem w tym zakresie będzie albo kolejna rewizja w zakresie kształtowania składu izby, albo określenie sposobu realizacji konstytucyjnego parytetu w kształtowaniu izby na drodze ustawy specjalnej (organicznej), tak by odzwierciedlało to reprezentację poszczególnych terytoriów (być może prowincji) ${ }^{49}$, a nie było niemalże identycznym powtórzeniem zbipolaryzowanego układu sił w Izbie Reprezentantów. Innymi słowy, jeżeli belgijski Senat nie wykaże swojej przydatności, a na płaszczyźnie rozdziału mandatów będzie lustrzanym odbiciem izby pierwszej, może się okazać, że Belgia stanie się państwem federalnym $\mathrm{z}$ unikameralnym parlamentem.

47 G. Van Der Biesen, De nieuwe wetgevingsprocedure [w:] Het federale België na de Zesde Staatshervorming, red. A. Alen et al., Brugge 2014, s. 132; P. Popelier, Het kaduke masker van de Senaat: tussen deelstaatfederalisme en multinationaal confederalisme [w:] De Zesde Staatshervorming. Instellingen, bevoegdheden en middelen, red. J. Velaers et al., Antwerpen 2014, s. 90; F. Amez, Le bicaméralisme après, op. cit., s. 201-202; F. Delpérée, Le nouveau Sénat. Quellesréalités? Quelles perspectives?, „La Revue Générale” 2014, nr 9-10, s. 9-11.

48 F. Judo, De Zesde Staatshervormingen het confederalisme [w:] Het federale België na de Zesde Staatshervorming, red. A. Alen et al., Brugge 2014, s. 623.

49 Takie rozwiązanie, czyli wybór części senatorów na szczeblu prowincji, był praktykowany w Belgii w latach 1894-1991, gdy rady poszczególnych prowincji wybierały senatorów w liczbie zależnej od liczby ludności prowincji. Zob. C. Sägesser, C. Istasse, Le Sénat et sesréformessuccessives, op. cit., s. 23-24, 29-30. 


\section{Bibliografia}

Amez F., Le bicaméralismeaprès la sixième réforme de l'État, CDPK 2015, nr 2.

Behendt Ch., The process of constitutional amendment in Belgium [w:] Engineering Constitutional Change: A Comparative Perspective on Europe, Canada and the USA, red. X. Contiades, New York 2013, https://doi.org/10.4324/9780203094990-10.

Billiet J., Maddens B., Frognier A.P., Does Belgium (Still) Exist? Differences in Political Culture Between Flemings and Walloons, „West European Politics” 2006, nr 29(5).

Caluwaerts D., Reuchamps M., Combining federalism with consociationalism: Is Belgian consociational federalism digging its own grave, „Ethnopolitics” 2015, nr 14(3), https:// doi.org/10.1080/17449057.2014.986866.

Composition du Sénat. Le renouvellement du Sénat à l'issue des électionssimultanées du 25 mai 2014, https://www.senate.be/actueel/homepage/Elections_2014/140424-renouvellement_Senat.pdf.

Dandoy R., Dodeigne J., Reuchamps M., Vandeleene A., The New Belgian Senate. A (Dis) Continued Evolution of Federalism in Belgium?, „Representation” 2015, vol. 51, nr 3, https://doi.org/10.1080/00344893.2015.1108358.

Delpérée F., The Process for Amending the Belgian Constitution, „Canadian Parliamentary Review" 1991, nr 14(3).

Delpérée F., Le nouveau Sénat. Quellesréalités? Quelles perspectives?, „La Revue Générale" 2014, nr 9-10.

Deschouwer K., Reuchamps M., The Belgian federation at a crossroad, „Regional \& Federal Studies" 2013, nr 23(3), https://doi.org/10.1080/13597566.2013.773896.

Devos C., Sinardet D., Governing without a government: the Belgian experiment, „Governance" 2012, nr 25(2), https://doi.org/10.1111/j.1468-0491.2012.01580.x.

Grabowski R., Zasady zmiany Konstytucji Królestwa Belgii w świetle postanowień przejściowych z 2012 r., „Przegląd Prawa Konstytucyjnego” 2013, nr 4(16), https://doi. org/10.15804/ppk.2013.04.02.

Goossens J., Cannoot P., Belgian Federalism after the Sixth State Reform, „Perspectives on Federalism" 2015, nr 7(2), https://doi.org/10.1515/pof-2015-0009.

Jackiewicz A., Konstytucyjne funkcje izb pierwszych parlamentów federalnych a zasada federalizmu w państwach europejskich, Białystok 2019.

Jackiewicz A., Sixth State Reform - A Belgian Copernican Revolution or a Missed Opportunity?, „Przegląd Prawa Konstytucyjnego” 2019, nr 6(52), https://doi.org/10.15804/ ppk.2019.06.18.

Judo F., De Zesde Staatshervormingen het confederalisme [w:] Het federale België na de Zesde Staatshervorming, red. A. Alen et al., Brugge 2014.

Kinsky F., Federalizm. Model ogólnoeuropejski, Kraków 1999.

Klepka R., Kryzys polityczny lat 2010-2011 w Królestwie Belgii - geneza i możliwe następstwa [w:] Na tropach twórczości i czasów minionych. Księga jubileuszowa ofiarowana Profesorowi Damianowi Tomczykowi, red. M. Cetwiński, A. Czajkowska, Częstochowa 2012. 
Klepka R., Parlament $w$ państwie federalnym na przykładzie Austrii, Belgii, Niemiec i Szwajcarii. Analiza porównawcza, Warszawa 2013.

Kużelewska E., Status ustrojowy władzy wykonawczej w Belgii, „Przegląd Politologiczny” 2017, nr 1, https://doi.org/10.14746/pp.2017.22.1.2.

Lejeune Y., Droit constitutionnelbelge: Fondements et institutions, Brusells 2017.

Le renouvellement du Sénat à l'issue des électionssimultanées du 26 mai 2019, https:// www.senate.be/home/sections/focus/20190404-elections2019/2019-renouvellement-Senat.pdf.

Muylle K., De hervorming van de Senaaten de samenvallendeverkiezingen: eenprocessie van Echternachnaar de federale (model)staat? [w:] Het federale België na de Zesde Staatshervorming, red. A. Alen et al., Brugge 2014.

Peeters P., Reflections on the Belgian federal state [w:] Multinational federations, red. M. Burgess, J. Pinder, Abingdon 2007.

Popelier P., Het kaduke masker van de Senaat: tussen deelstaatfederalisme en multinationaal confederalisme [w:] De Zesde Staatshervorming. Instellingen, bevoegdhedenenmiddelen, red. J. Velaers et al., Antwerpen 2014.

Popelier P., Cantillon B., Bipolar Federalism and the Social Welfare State: A Case for Shared Competences, „Publius The Journal of Federalism” 2013, nr 43(4), https://doi. org/10.1093/publius/pjt005.

Prokop K., Odpowiedzialność członków Rządu Federalnego w Belgii, „Przegląd Prawa Konstytucyjnego" 2018, nr 2(42), https://doi.org/10.15804/ppk.2018.02.02.

Romainville C., Dynamics of Belgian Plurinational Federalism: A Small State Under Pressure, „Boston College International and Comparative Law Review” 2015, nr 38(2).

Sägesser C., Istasse C., Le Sénat et sesréformessuccessives, „Courrierhebdomadaire du CRISP” 2014, nr 2219-2220.

Swenden W., Brans M., De Winter L., The Politics of Belgium: Institutions and Policy Under Bipolar and Centrifugal Federalism, „West European Politics” 2006, nr 5(29), https:// doi.org/10.1080/01402380600968729.

Van der Biesen G., De nieuwewetgevingsprocedure [w:] Het federale België na de Zesde Staatshervorming, red. A. Alen et al., Brugge 2014.

Van Wynsberghe C., The Belgian Senate: little damage, little use, VerfBlog, 2014/10/23, https://verfassungsblog.de/belgian-senate-little-damagelittle-use-2/.

Verbeke A.L., Belgium, A Broken Marriage [w:] Federalism and Legal Unification: A Comparative Empirical Investigation of Twenty Systems, red. D. Halberstam, M. Reimann, Dordrecht 2013, https://doi.org/10.1007/978-94-007-7398-1_5.

Verdussen M., La dernièreréforme du Sénat de Belgique, „Revistacatalana de dretpúblic” 2015, nr 51.

Zieliński E., Rząd Królestwa Belgii [w:] Rządy w państwach Europy, t. 1, red. E. Zieliński, I. Bokszczanin, Warszawa 2003. 
Bartosz Nowakowski

\section{Kompetencje organu administracji publicznej w zakresie zatwierdzania regulaminu strzelnicy. Propozycje zmian de lege ferenda}

Competence of the public administration authority regarding the approval of shooting range regulations. Proposals for de lege ferenda changes

\footnotetext{
This disputable issue was regulated in the provisions of the Act on Arms and Ammunition. The article contains numerous references to the jurisprudence of the Supreme Administrative Court and provincial (voivodeship) administrative courts. The author presented the administrative solutions to this issue and presented controversial and doubtful regulations. The presented delege ferenda conclusions are aimed at introducing a precise and compatible procedure for approving shooting range regulations by the head of a commune, mayor or president of a city, in order to eliminate discretion in this respect.
}

Keywords: administrative proceedings, administrative court, shooting range

Dyskusyjna kwestia została uregulowana w przepisach ustawy o broni i amunicji. Artykuł zawiera liczne odniesienia do orzecznictwa Naczelnego Sądu Administracyjnego oraz wojewódzkich sądów administracyjnych. Przedstawia obowiązujące rozwiązania administracyjne w tej materii oraz prezentuje regulacje dyskusyjne i budzące wątpliwości. Przedstawione wnioski de lege ferenda idą w kierunku wprowadzenia precyzyjnej i kompatybilnej procedury zatwierdzenia regulaminu strzelnicy przez wójta, burmistrza czy prezydenta miasta, aby wyeliminować uznaniowość w tym zakresie.

Słowa kluczowe: postępowanie administracyjne, sąd administracyjny, strzelnica

Doktor hab. nauk prawnych, profesor uczelni Uniwersytet Przyrodniczo-Humanistyczny w Siedlcach, Wydział Nauk Społecznych, Instytut Nauk o Polityce i Administracji, SIEDLCE, POLSKA • bartosz.nowakowski@uph.edu.pl • https://orcid.org/0000-0002-7182-4600

\section{Wprowadzenie}

Pod koniec roku 2018 ówczesny wiceminister obrony narodowej Michał Dworczyk na konferencji „Sokół - strzelnica w powiecie”, która odbyła się w dniach 9-10 grudnia 2018 r., zapowiedział realizację programu „Strzelnica w powiecie”. Inicjatywa zakładała dofinansowanie przez MON budowy i rewitalizacji strzelnic w Polsce. Skierowana została do jednostek samorządu terytorialnego i organizacji pozarządowych ${ }^{1}$. Była ona kontynuacją ogłoszonego 16 kwietnia $2018 \mathrm{r}$.

1 Zob. szerzej na ten temat: http://strzelnicawpowiecie.pl/ [dostęp 7 stycznia 2020 r.]; J. Lewandowski, Sokół - strzelnica w powiecie, Strzał.pl 1/2018, s. 92-95. Ponadto wy- 
na stronach Rządowego Centrum Legislacji projektu rozporządzenia Ministra Obrony Narodowej w sprawie zakresu, sposobu i trybu dofinansowania z budżetu państwa zadań związanych z budową, remontami i utrzymaniem strzelnic oraz rozwijaniem sportu strzeleckiego w szczególności wśród dzieci i młodzieży oraz organizacji proobronnych, objętych dofinansowaniem z budżetu państwa, a także określała sposób i tryb udzielania dotacji na te zadania ${ }^{2}$. Pomijając w niniejszym artykule niezwykle ważki aspekt znaczenia obronnego i sportowego wspomnianej inicjatywy, na szczególną uwagę zasługuje próba zintegrowania działań administracji rządowej, samorządowej oraz oddolnych, tzn. społecznych, inicjatyw obywatelskich. Projekt tym bardziej cenny, że na gruncie styku tych trzech sektorów nie zawsze dochodzi do jednolitej wizji postrzegania działań mających swoje źródło w polityce państwa. Ostatecznie zróżnicowane próby przedmiotowych rozwiązań znajdują swoje odzwierciedlenie w orzecznictwie sądów administracyjnych lub w konieczności nowelizacji ustawodawstwa. Taka sytuacja - od pewnego czasu - ma miejsce w odniesieniu do jednego z aspektów powstawania strzelnic, a mianowicie procedury administracyjnej $\mathrm{w}$ zatwierdzaniu ich regulaminu.

Jak zauważył poseł Jarosław Stawiarski w interpelacji z 9 lutego 2017 r. skierowanej do Ministra Spraw Wewnętrznych i Administracji (dalej: MSWiA), osoby zamierzające zorganizować strzelnicę napotykają w praktyce liczne trudności. Często polegają one na odmowie ze strony wójtów (burmistrzów i prezydentów miast) zatwierdzenia regulaminu strzelnicy oraz żądaniu przedstawienia bądź uzyskania decyzji o dopuszczeniu strzelnicy do użytkowania. Można domniemywać, wskazuje autor interpelacji, że zazwyczaj trudności te nie wynikają ze złej woli organów wykonawczych gmin, ale są spowodowane niejasnością i brakiem komplementarności obowiązujących przepisów ${ }^{3}$.

stąpienie wiceministra MON Michała Dworczyka: https://www.youtube.com/playlist ?list=PLnkYgipjfYdbrd21gsemsiV3Yq6ShTmW8 [dostęp 7 stycznia 2020 r.]. Zob. także A. Turczyn, MON ogłasza konkurs pn. „Strzelnica w powiecie” na dofinansowanie zadań związanych z budowa lub remontem strzelnic, https://trybun.org.pl/2018/08/30/ mon-oglasza-konkurs-pn-strzelnica-w-powiecie-na-dofinansowanie-zadan-zwiazanych-z-budowa-lub-remontem-strzelnic/ [dostęp 7 stycznia 2020 r.].

2 Zob. A. Turczyn, Projekt rozporządzenia MON w sprawie dofinansowania $z$ budżetu państwa zadań zwiąanych $z$ budowa, remontami $i$ utrzymaniem strzelnic oraz rozwijaniem sportu strzeleckiego, https://trybun.org.pl/2018/04/18/projekt-rozporzadzenia-mon-w-sprawie-dofinansowania-z-budzetu-panstwa-zadan-zwiazanych-z-budowa-remontami-i-utrzymaniem-strzelnic-oraz-rozwijaniem-sportu-strzeleckiego/ [dostęp 7 stycznia 2020 r.].

3 Zob. J. Stawiarski, Interpelacja nr 10011 do ministra spraw wewnętrznych i administracji w sprawie wzorcowego regulaminu strzelnic, 9 lutego 2017 r., http://www.sejm.gov. pl/Sejm8.nsf/InterpelacjaTresc.xsp?key=13829D7B [dostęp 7 stycznia 2020 r.]. 


\section{Zakres kompetencji wójta (burmistrza, prezydenta miasta) w zatwierdzaniu regulaminu strzelnicy}

Na podstawie art. 47 ustawy o broni i amunicji ${ }^{4}$ regulamin strzelnicy podlega zatwierdzeniu przez wójta, (burmistrza, prezydenta miasta) właściwego ze względu na lokalizację tego obiektu i następuje w drodze decyzji administracyjnej. Jak podkreśla S. Maj, prowadzący strzelnicę opracowuje projekt regulaminu strzelnicy i przedkłada go wraz z wnioskiem do organu zatwierdzającego wydającego decyzję. Wraz z wnioskiem składa dowód uiszczenia opłaty skarbowej ${ }^{6}$. Natomiast od decyzji właściwego organu przysługuje odwołanie do samorządowego kolegium odwoławczego (art. 17 Kodeksu postępowania administracyjnego) ${ }^{7}$. Warto podkreślić, że nałożony przez ustawodawcę na właściciela lub zarządcę strzelnicy obowiązek opracowania regulaminu obiektu daje możliwość uszczegółowienia lub określenia dodatkowych wymogów i zasad bezpieczeństwa. Nie mogą one jednak być niezgodne z rozporządzeniem Ministra Spraw Wewnętrznych i Administracji z 20 marca 2000 r. dotyczącym wzorcowego regulaminu strzelnic ${ }^{8}$, a kwestie owej zgodności bada organ administracji samorządowej i w zależności od rezultatu weryfikacji podejmuje decyzję aprobującą lub odmowną.

W kontekście przeprowadzonej analizy warto podkreślić fakt, że przywołana obowiązująca regulacja prawna została wprowadzona nowelizacją z 10 lipca 2003 r. ${ }^{9}$. Prawodawca w kompetencji organu administracji samorządowej pozostawił wyłącznie zatwierdzenie regulaminu strzelnicy, odstępując od wcześniejszego obowiązku dodatkowego dopuszczenia do jej użytkowania. Oznacza to, zdaniem Joanny Majo, że wójt (burmistrz, prezydent miasta), któremu przedstawiono do zatwierdzenia regulamin strzelnicy, nie jest uprawniony do badania innych kwestii niż jedynie treść regulaminu. Jego rola została ograniczona do oceny tego regulaminu $\mathrm{z}$ punktu widzenia zgodności z wzorcem normatywnym określonym w rozporządzeniu MSWiA z 15 marca 2000 r. w sprawie wzorcowe-

Ustawa z 21 maja 1999 r. o broni i amunicji, Dz.U. nr 53, poz. 549; dalej także u.o.b.a.

$5 \quad$ Zob. B. Barszczewska, Regulamin strzelnicy musi być zatwierdzony przez wójta, Prawo. pl, 18 października 2016 r., https://www.prawo.pl/samorzad/regulamin-strzelnicy-musi-byc-zatwierdzony-przez-wojta,106908.html [dostęp 7 stycznia 2020 r.].

6 Ustawa z 9 września 2000 r. o podatku od czynności cywilnoprawnych, Dz.U. nr 86, poz. 959, art. 15; S. Maj, Ustawa o broni i amunicji. Komentarz, art. 47, LEX nr 16836326.

7 Zob. także S. Maj, Ustawa o broni i amunicji, op. cit.

8 Rozporządzenie MSWiA z 15 marca 2000 r. w sprawie wzorcowego regulaminu strzelnic, Dz.U. nr 18, poz. 234. Zob. H. Kowalik, Aspekty formalne projektu „Strzelnica w powiecie" [w] Obrona Narodowa, Sokót - Strzelnica w powiecie. Publikacja po konferencji 9-10 grudnia 2017 w Warszawie, Warszawa 2017, s. 29.

9 Art. 47 zmieniony przez art. 5 ustawy z 27 marca 2003 r. o zmianie ustawy - Prawo budowlane oraz o zmianie niektórych ustaw, Dz.U. nr 80, poz. 718, z dniem 11 lipca $2003 \mathrm{r}$. 
go regulaminu strzelnic, a więc pod kątem przyjęcia odpowiednich rozwiązań dotyczących sposobu korzystania ze strzelnicy i obchodzenia się na niej z bronią. Poza kompetencjami wójta (burmistrza, prezydenta miasta) pozostaje więc weryfikowanie pozostałych dokumentów związanych ze strzelnicą, wymaganych przez inne niż ustawa o broni i amunicji przepisy, w tym prawa budowlanego, zagospodarowania przestrzennego czy ochrony środowiska. W konsekwencji kwestie położenia strzelnicy czy poziomu hałasu powstającego podczas jej użytkowania są oddzielnym zagadnieniem, które nie podlega weryfikacji w toku postępowania o zatwierdzenie regulaminu strzelnicy. Te sprawy - jako wynikające z przepisów odrębnych - podlegają rozpatrzeniu w trybie i na zasadach określonych $\mathrm{w}$ tychże przepisach, a nie w postępowaniu prowadzonym na podstawie ustawy o broni i amunicji ${ }^{10}$. Jakiekolwiek działania wójta (burmistrza, prezydenta miasta) wykraczające poza ten zakres stanowią przekroczenie własnych kompetencji.

Analogiczny pogląd wyraził A. Turczyn, według którego z przepisów prawa nie wynika, by decyzja w sprawie zatwierdzenia regulaminu strzelnicy była aktem finalnym, kończącym i niejako podsumowującym z punktu widzenia zgodności z prawem cały proces organizowania strzelnicy, a w konsekwencji stanowiącym wyłączną podstawę przystąpienia do jej legalnego użytkowania, co zbliżałoby tę decyzję w swej konstrukcji do sui qeneris zezwolenia na prowadzenie strzelnicy. Przeciwnie, sam fakt zatwierdzenia regulaminu strzelnicy jako zgodnego z wzorcem określonym w rozporządzeniu z 15 marca 2000 r., wcale nie przesądza, że strzelnica spełnia wszystkie określone prawem w danych okolicznościach faktycznych wymogi, a zatem, że będzie funkcjonować legalnie. Ocena dokonywana przez wójta (burmistrza, prezydenta miasta) na podstawie art. 47 u.o.b.a. w związku z $\$ 1$ rozporządzenia MSWiA w sprawie wzorcowego regulaminu strzelnic zgodnie $\mathrm{z}$ literalnym brzmieniem tego przepisu ograniczona jest do samej treści przedkładanego regulaminu, tym bardziej że - jak to wynika z normatywnego wzoru regulaminu - jego treść obejmuje jedynie warunki korzystania ze strzelnicy, sposobu obchodzenia się z bronią oraz sposobu zachowania się osób przebywających na strzelnicy. Nie regulują więc całości problematyki związanej z legalnym funkcjonowaniem strzelnicy, w tym zwłaszcza kwestii jej lokalizacji i konstrukcji. Na taki - ograniczony przedmiotowo - charakter wydanego na podstawie art. 47 u.o.b.a. rozstrzygnięcia wskazują także jego skutki. Decyzja zatwierdzająca regulamin konkretyzuje jedynie uprawnienia i obowiązki osoby prowadzącej strzelnicę, a pośrednio także osób korzystających ze strzelnicy, w zakresie objętym treścią regulaminu ${ }^{11}$.

10 Zob. J. Majo, Zatwierdzenie regulaminu strzelnicy - według sadu, Strzał.pl 6/2019, s. 81.

11

Zob. A. Turczyn, Organ (wójt, burmistrz, prezydent miasta) zatwierdzający regulamin strzelnicy nie jest uprawniony do badania innych kwestii niż sama treść regulaminu, https://trybun.org.pl/2019/05/22/organ-wojt-burmistrz-prezydent-miasta-zatwier- 
Mając powyższe na uwadze, z treści art. 47 u.o.b.a. nie sposób wywieść wniosku o możliwości wydania decyzji o dopuszczeniu strzelnicy do użytku przez wymienione organy administracji. Trafna w tym kontekście jest uwaga A. Lipińskiego, że rozwiązania wyznaczające właściwość organu administracji muszą być interpretowane w sposób ścisły. W szczególności zaś właściwości tej nie można domniemywać. Milczenie ustawy, która nie zawiera rozwiązania wskazującego na właściwość danego organu w określonej kategorii, spraw musi być traktowane jako argument przemawiający przeciwko jego kompetencji w tym zakresie. W istocie bowiem właściwość organu administracji to nic innego jak jego zdolność prawna (a niekiedy obowiązek) do działania w danej kategorii spraw. Naruszenie tej właściwości skutkuje nieważnością podejmowanych rozstrzygnięć ${ }^{12}$. $\mathrm{Na}$ identycznym stanowisku stoi W. Chróścielewski, konstatując, iż na gruncie przepisów Kodeksu postępowania administracyjnego, a zwłaszcza jego art. 156 $\S 1$ pkt 1 , należy mówić nie o jakiejś abstrakcyjnej właściwości organu administracji do rozpoznawania $\mathrm{z}$ góry założonej kategorii spraw, ale o właściwości organu do rozpatrzenia i załatwienia indywidualnej (podwójnie konkretnej) sprawy będącej przedmiotem wszczynanego postępowania administracyjnego $^{13}$. Tym samym jakiekolwiek działania organu wykraczające poza określone prawem kompetencje skutkują nieważnością decyzji administracyjnej na podstawie art. $156 \$ 1$ pkt 1 Kodeksu postępowania administracyjnego. Podkreśla to stanowczo również J. Goleniowska-Gałgan. Zdaniem tej autorki prawodawca w takiej sytuacji nie mógł inaczej postąpić, jak nałożyć sankcję nieważności za naruszenie przepisów o właściwości. Podyktowane zostało to faktem, że w tymże przypadku brakuje podmiotu legitymującego do zawiązania stosunku prawnego. Legitymacja jest zaś niezbędnym warunkiem prawidłowości rozstrzygania sprawy. Tylko organ administracji, działając w ramach przyznanych kompetencji, może z trwałym skutkiem regulować prawne stosunki ${ }^{14}$. Zatem jakiekolwiek próby wydania decyzji administracyjnej dopuszczające (lub nie) strzelnice do użytkowania (a nie oscylujące jedynie w granicach zatwierdzenia regulaminu strzelnicy) ipso iure będą nieważne. Ta kwestia będzie miała także swoje reperkusje w odniesieniu do obowiązku wywieszania decyzji o dopuszczeniu strzelnicy do użytkowania, o czym będzie jeszcze mowa w dalszej części naszych rozważań.

dzajacy-regulamin-strzelnicy-nie-jest-uprawniony-do-badania-innych-kwestii-niz-sama-tresc-regulaminu/ [dostęp 7 stycznia 2020 r.]. Także O. Rudak, Czy zatwierdzenie regulaminu strzelnicy jest pierwszym - czy ostatnim - etapem organizacji obiektu?, Lege Artis, 27 listopada 2019 r., https://czasopismo.legeartis.org/2019/11/zatwierdzenie-regulaminu-strzelnicy.html [dostęp 7 stycznia 2020 r.].

12 Zob. A. Lipiński, Z problematyki właściwości rzeczowej organów administracji geologicznej, LEX nr 151169595.

13 Zob. W. Chróścielewski, Z problematyki właściwości organów w postępowaniu administracyjnym, LEX nr 151145294.

14 Zob. J. Goleniowska-Gałgan, Właściwość organów administracji, LEX nr 151109885. 
Sformułowane w taki sposób przez prawodawcę przepisy prawne oraz stanowisko doktryny nie zabezpieczają jednak ipso iure przed przekroczeniem granic kompetencyjnych w tej materii przez administrację samorządową, jak również są przyczyną rozbieżnych stanowisk sądów administracyjnych oscylujących wokół dwóch wariantów: równoległego, nazywanego również rozproszonym, oraz liniowego, określanego często szeregowym.

Dobrym przykładem interpretacji równoległej (rozproszonej) może być wyrok Wojewódzkiego Sądu Administracyjnego w Gdańsku z 14 marca 2019 r. ${ }^{15}$ w sprawie dotyczącej strzelnicy Skorpion w miejscowości Korne k/Kościerzyny ${ }^{16}$, w którym WSA podzielił stanowisko wcześniej wyrażone przez Samorządowe Kolegium Odwoławcze (SKO) w przedmiocie odmowy stwierdzenia nieważności decyzji wójta dotyczącej zatwierdzenia regulaminu strzelnicy. Sąd, powołując się na uzasadnienie SKO podkreślił, że „organ prowadzący postępowanie w oparciu o art. 47 ustawy o broni i amunicji nie jest uprawniony do badania innych kwestii niż sama treść regulaminu. Zgodnie z tym stanowiskiem kwestia, czy i jakiego rodzaju obiektem budowlanym jest strzelnica nie należy do zakresu badania w postępowaniu dotyczącym zatwierdzenia «regulaminu strzelnicy». Przedmiotem oceny dokonywanej w powyższym zakresie nie jest także spełnienie wymogów ochrony środowiska określonych w rozporządzeniu Ministra Środowiska z dnia 4 kwietnia 2000 r. w sprawie wymagań w zakresie ochrony środowiska dotyczących budowy i użytkowania strzelnic. Wymogi te badane są przez organy właściwe w sprawie ochrony środowiska. [...] Rażące naruszenie prawa zachodzi w przypadku naruszenia przepisu, którego treść bez żadnych wątpliwości interpretacyjnych może być ustalona w bezpośrednim rozumieniu. Regulacja zawarta w art. 47 u.b.a. [ustawie o broni i amunicji - dopisek B.N.] nie uzależnia wprost zatwierdzania regulaminu strzelnicy od badania wszelkich warunków funkcjonowania strzelnicy na danym terenie i w ujęciu szerszym niż tylko ograniczonym do samego tekstu regulaminu. Skoro na konieczność taką wskazuje orzecznictwo sądów administracyjnych w procesie wykładni prawa, Sąd podziela pogląd Kolegium, że Wójtowi Gminy nie można postawić skutecznego zarzutu wydania kwestionowanej decyzji z rażącym naruszeniem prawa" ${ }^{17}$.

15 Wyrok WSA w Gdańsku z 14 marca 2019 r., sygn. akt III SA/Gd 915/18, LEX nr 2650936. Zob. także A. Turczyn, Przełomowy wyrok sądu administracyjnego, który rozprawia się ze wszystkimi naruszeniami prawa w sprawach o zatwierdzanie regulaminów strzelnic, https://trybun.org.pl/2018/01/03/przelomowy-wyrok-sadu-administracyjnego/ [dostęp 7 stycznia 2020 r.].

16 Szerzej na temat tej sprawy w: A. Turczyn, Strzelnica padła ofiarq walki politycznej, https://trybun.org.pl/2018/07/30/strzelnica-padla-ofiara-walki-politycznej/ [dostęp 7 stycznia $2020 \mathrm{r}$.].

17 Wyrok WSA w Gdańsku z 14 marca 2019 r., sygn. akt III SA/Gd 915/18, LEX nr 2650936. 
W podobnym tonie wypowiedział się również Wojewódzki Sąd Administracyjny w Lublinie w wyroku z 15 listopada 2017 r. ${ }^{18}$. Na marginesie należy zaznaczyć, że powołany wyżej wyrok WSA w Gdańsku powołuje się na uzasadnienie prawne WSA w Lublinie. Sąd ten wskazał jednoznacznie, że „przedmiotem badania w sprawie zatwierdzenia regulaminu strzelnicy jest przedstawiony przez właściciela lub zarządcę strzelnicy regulamin, opracowany na podstawie wzorcowego regulaminu strzelnic, stanowiącego załącznik do rozporządzenia. Decyzja o zatwierdzeniu regulaminu powinna zatem zostać podjęta po analizie postanowień regulaminu i ocenie ich zgodności z regulaminem wzorcowym oraz wymogami zapewnienia bezpieczeństwa osób korzystających ze strzelnicy i osób przebywających na strzelnicy. Ustawa nie uzależnia zatwierdzenia regulaminu strzelnicy od spełnienia dodatkowych warunków, w szczególności od przedstawienia pozwolenia na budowę czy decyzji o dopuszczeniu strzelnicy do użytkowania, jak twierdzą organy obu instancji w sprawie niniejszej. Regulamin dotyczy strzelnicy jako obiektu przeznaczonego do prowadzenia strzelań szkoleniowych, sportowych i rekreacyjnych oraz treningów strzeleckich ( $\$ 2$ pkt 1 rozporządzenia w sprawie wzorcowego regulaminu). Kwestia, czy i jakiego rodzaju obiektem budowlanym jest strzelnica nie należy do zakresu badania w postępowaniu dotyczącym zatwierdzenia regulaminu strzelnicy. Ocena, czy strzelnica jest obiektem budowlanym oraz czy spełnia wymogi dotyczące budowy i utrzymania obiektów budowlanych, określone w ustawie z dnia 7 lipca 1994 r. - Prawo budowlane (Dz.U. z 2017 r. poz. 1332 z późn. zm.), należy do organów administracji architektoniczno-budowlanej i organów nadzoru budowlanego. [...] Nie jest także przedmiotem oceny w sprawie zatwierdzenia regulaminu strzelnicy spełnienie wymogów ochrony środowiska, określonych w rozporządzeniu Ministra Środowiska z dnia 4 kwietnia 2000 r. w sprawie wymagań w zakresie ochrony środowiska dotyczących budowy i użytkowania strzelnic (Dz.U. Nr 27, poz. 341). Wymogi te badane są przez organy właściwe w sprawie ochrony środowiska"19.

Zgoła odmienne stanowisko sądów administracyjnych można spotkać w tzw. ujęciu liniowym lub szeregowym. Zakłada ono, że podjęcie określonej działalności możliwe jest dopiero po spełnieniu określonych prawem warunków potwierdzanych kolejno uzyskiwanymi rozstrzygnięciami organów administracji publicznej, z których wcześniejsze warunkują wydanie kolejnych. W tym wypad-

18 Wyrok WSA w Lublinie z 15 listopada 2017 r., sygn. akt III SA/Lu 216/17, LEX nr 2407704.

19 Wyrok WSA w Lublinie z 15 listopada 2017 r., sygn. akt III SA/Lu 216/17, LEX nr 2407704. Podobne stanowisko wyraził WSA w Lublinie w wyroku z 17 października 2019 r., sygn. akt III SAB/Lu 28/19, CBOSA: „W ocenie Sądu, z powołanych powyżej przepisów nie można wyprowadzić wniosku, że decyzja o dopuszczeniu strzelnicy do użytkowania jest warunkiem formalnym wniosku o zatwierdzenie regulaminu strzelnicy, bez którego nie można nadać wnioskowi dalszego biegu”. Zob. także wyrok WSA w Szczecinie z 13 września 2018 r., sygn. akt II SA/Sz 216/18, CBOSA. 
ku podejmując rozstrzygnięcie w zakresie swoich kompetencji, kolejne organy zobowiązane są ustalić, czy i jak zakończyły się wcześniejsze postępowania oraz czy inwestor legitymuje się wcześniej uzyskanymi pozytywnymi orzeczeniami. W tę linię orzeczniczą wpisuje się wyrok Wojewódzkiego Sądu Administracyjnego w Poznaniu z 25 października 2005 r., poddający krytyce działanie Burmistrza Gminy i Miasta W., który w decyzji z dnia [...] lipca 2003 r., nr [...], zatwierdził regulamin pewnej strzelnicy myśliwsko-sportowej, wskazując jako jej podstawę prawną art. 47 ustawy z 21 maja 1999 r. o broni i amunicji (Dz.U. nr 53, poz. 549, ze zm.). WSA w Poznaniu nie zgodził się z uzasadnieniem powyższej decyzji (idącej po linii interpretacji rozproszonej) i poddał je surowej krytyce, zauważając, że „organ pierwszej instancji orzekający w niniejszej sprawie w ogóle nie ustalał, czy właściciel strzelnicy uzyskał pozwolenie na jej budowę (co wydaje się wątpliwe wobec treści umowy dzierżawy terenu z dnia [...].10.2001 r. oraz przeznaczenia terenu w planie miejscowym zagospodarowania przestrzennego na lasy) oraz czy uzyskał nadto pozwolenie na jej użytkowanie od organu nadzoru budowlanego. Organ zatem, zatwierdzając regulamin strzelnicy należącej do skarżącego, w ogóle nie zainteresował się czy taki obiekt powstał zgodnie z przepisami prawa" ${ }^{20}$.

Podobne stanowisko zajął Wojewódzki Sąd Administracyjny w Bydgoszczy w wyroku z 21 listopada 2016 r., stwierdzając, że „zasadne jest, aby organ, któremu przedłożono wniosek o zatwierdzenie regulaminu strzelnicy, najpierw poczynił ustalenia, czy obiekt, którego regulamin ma być zatwierdzony, rzeczywiście jest strzelnicą, tj. obiektem budowlanym wzniesionym zgodnie z przepisami prawa, przeznaczony do użytkowania jako strzelnica. [...] Strzelnica jest tego rodzaju obiektem, który należy kwalifikować jako obiekt budowlany, w konsekwencji daje to podstawę nie do oceny całego procesu budowlanego (w taki sposób jak czynią to organy architektoniczno-budowlane czy nadzoru budowlanego), ale jedynie do żądania, aby wnioskujący o zatwierdzenie regulaminu strzelnicy (tj. szczególnego rodzaju zasad użytkowania obiektu, nie ujętych w Prawie budowlanym) wykazał się posiadaniem stosownych dokumentów (np. pozwoleniem na budowę, dowodem zgłoszenia, pozwoleniem na użytkowanie), świadczących o tym, że ten konkretny obiekt jest w sposób legalny przeznaczony do użytkowania jako strzelnica. Trudno byłoby bowiem zaakceptować np. sytuację, że organizator strzelnicy może uzyskać zatwierdzenie regulaminu strzelnicy zorganizowanej w obiekcie będącym samowolą budowlaną, tj. w obiekcie, który zgodnie z prawem w ogóle nie może być użytkowany. Prawo nie może wynikać z bezprawia" ${ }^{21}$.

20 Wyrok WSA w Poznaniu z 25 października 2005 r., sygn. akt II SA/Po 2807/03, Legalis $\mathrm{nr} 2207003$.

21 Wyrok WSA w Bydgoszczy z 24 stycznia 2018 r., sygn. akt II OSK 1462/17, LEX nr 2446376. 
Wyrok ten nie zakończył jednak sprawy, która w drodze skargi kasacyjnej trafiła do Naczelnego Sądu Administracyjnego. Ten, analizując sprawę, zajął stanowisko jak Wojewódzki Sąd Administracyjny w Bydgoszczy, konkludując, że „Sąd I instancji dokonał prawidłowej wykładni art. 46 ust. 1 i 2 w zw. z art. 47 ustawy o broni i amunicji, zgodnie z którą wójt gminy posiada kompetencję do weryfikowania (badania), czy strzelnica zbudowana jest $\mathrm{z}$ zachowaniem wymogów prawa budowlanego oraz czy jest dopuszczona do użytku w rozumieniu przepisów, m.in. przez żądanie przedłożenia przez wnioskodawcę pozwolenia na użytkowanie obiektu. [...] W tym zakresie w trakcie postępowania dotyczącego zatwierdzenia regulaminu strzelnicy wójt może dokonać ustaleń odnośnie faktu, czy wnioskodawca posiada uprawnienie do zlokalizowania strzelnicy w danym miejscu, czy strzelnica powstała zgodnie z prawem na podstawie odpowiednich zgód m.in. organów architektoniczno-budowlanych [...]. Są to zatem okoliczności, które powinny być przedmiotem postępowania wyjaśniającego prowadzonego na podstawie art. 7 i art. $77 \$ 1$ k.p.a., które Wójt powinien ustalić przed zatwierdzeniem regulaminu strzelnicy"22.

Jeszcze bardziej zaskakująca jest dalsza część prawna uzasadnienia wyroku. Naczelny Sąd Administracyjny uznał, że „strona skarżąca kasacyjnie nie wykazała, aby istniał jakikolwiek przepis obowiązującego prawa, który w odniesieniu do strzelnic wyłączałby zastosowanie zasad wynikających w ww. ustaw. Takiego wyraźnego wyłączenia nie zawiera zaś ustawa o broni i amunicji. To, że na podstawie art. 5 ustawy z dnia 27 marca 2003 r. o zmianie ustawy - Prawo budowlane oraz o zmianie niektórych ustaw «zdjęto» $\mathrm{z}$ wójta (burmistrza, prezydenta miasta) kompetencję do dopuszczenia strzelnicy do użytkowania nie oznacza, że aktualnie tego rodzaju zagadnienie nie jest w sposób prawny uregulowane. Mają bowiem w tym zakresie zastosowanie ogólne reguły wynikające z Prawa budowlanego. [...] Stąd zatem wynikało uprawnienie Wójta do ustalenia w okolicznościach tej sprawy, czy wnioskodawca może użytkować strzelnicę zgodnie z prawem"23.

Wreszcie zarówno Wojewódzki Sąd Administracyjny w Gliwicach, jak i Wojewódzki Sąd Administracyjny w Białymstoku explicite odcięły się od orzeczeń prezentujących linię równoległą (rozproszoną). Pierwszy z wymienionych wyroków, z 22 listopada 2018 r., powołując się na przytoczony wyżej wyrok Naczelnego Sądu Administracyjnego z 24 stycznia 2018 r., wskazał, że „chybione są zarzuty skargi dotyczące przekroczenia kompetencji organów orzekających w tej sprawie. Nie oceniały one bowiem zgodności lokalizacji budowy, czy użytkowania

22 Wyrok NSA z 24 stycznia 2018 r., sygn. akt II OSK 1462/17, LEX nr 2446376.

23 Wyrok NSA z 24s tycznia 2018 r., sygn. akt II OSK 1462/17, LEX nr 2446376. W podobnym duchu również: wyrok WSA w Gliwicach z 22 listopada 2018 r., sygn. akt IV SA/GI 797/18, LEX nr 2600526, oraz wyrok WSA w Rzeszowie z 27 marca 2018 r., sygn. akt II SA/Rz 66/18, LEX nr 2485969. 
strzelnicy z odrębnymi przepisami lecz stwierdziły, że skarżący nie przedstawił dokumentów potwierdzających taką zgodność. Nie do przyjęcia jest pogląd skarżącego, że stosowanie art. 47 u.o.b.a., polegać ma wyłącznie na sprawdzeniu, czy zapisy objętego wnioskiem regulaminu są zgodne $z$ regulaminem wzorcowym. Zatwierdzeniu podlega bowiem regulamin strzelnicy, a więc konkretnego obiektu. [...] zatwierdzenie regulaminu nie może się odnosić abstrakcyjnie do mającej dopiero powstać strzelnicy. W przeciwnym razie wnioskować można byłoby zatwierdzenie regulaminu strzelnicy projektowanej w dowolnym miejscu, nawet w sposób oczywisty nie nadającym się na jej urządzenie. [...] Dla zatwierdzenia regulaminu niezbędne jest zatem uprzednie potwierdzenie legalności lokalizacji i budowy strzelnicy oraz możliwości przystąpienia do jej użytkowania"24. W drugim z wymienionych wyroków, z 17 października 2019 r., Sąd zauważył, że „prezentując powyższe stanowisko skład orzekający nie podziela tym samym poglądu prezentowanego w niektórych orzeczeniach sądów administracyjnych, w których wskazuje się, że zatwierdzenie regulaminu strzelnicy nie jest uzależnione od istnienia formalnoprawnych zgód na realizację strzelnicy (np. III SA/ Lu 216/17 czy III SA/Gd 915/18, CBOSA)"25.

\section{Obowiązek umieszczenia w widocznym miejscu decyzji o dopuszczeniu strzelnicy do użytkowania}

Spore kontrowersje wzbudza również znajdujący się w rozporządzeniu MSWiA o wzorcowym regulaminie bezpiecznego funkcjonowania strzelnic obowiązek umieszczenia w widocznym miejscu decyzji o dopuszczeniu strzelnicy do użytkowania $^{26}$. Przepis ten ${ }^{27}$ powinien zostać usunięty z rozporządzenia z $2000 \mathrm{r}$.,

24 Wyrok WSA w Gliwicach z 22 listopada 2018 r., sygn. akt IV SA/GI 797/18, LEX nr 2600526. Analogiczna linia orzecznicza prezentowana jest m.in. w: wyrok WSA w Bydgoszczy z 21 listopada 2016 r., sygn. akt II SA/Bd 416/16, CBOSA; wyrok WSA w Kielcach z 13 lutego 2020 r., sygn. akt II SA/Ke 1117/19, CBOSA („W ocenie Sądu nie może budzić wątpliwości to, że zatwierdzenie regulaminu strzelnicy jest ostatnim etapem na drodze do rozpoczęcia użytkowania takiego obiektu oraz, że postępowanie mające na celu zatwierdzenie regulaminu strzelnicy nie jest jedynym postępowaniem administracyjnym, poprzedzającym możliwość rozpoczęcia jej faktycznego użytkowania."); wyrok WSA w Szczecinie z 7 marca 2019 r., sygn. akt II SA/Sz 1108/18, CBOSA; wyrok WSA w Bydgoszczy z 19 grudnia 2018 r., sygn. akt II SA/Bd 971/17, CBOSA; wyrok WSA w Rzeszowie z 27 marca 2018 r., sygn. akt II SA/Rz 66/18, LEX nr 2485969.

25 Wyrok WSA w Białymstoku z 17 października 2019 r., sygn. akt II SA/Bk 484/19, LEX nr 2738260.

Rozporządzenie MSWiA w sprawie wzorcowego regulaminu strzelnic, dokument cyt. 
ponieważ nie ma umocowania w ustawie o broni i amunicji. W czasie wprowadzania w życie rozporządzenia w ustawie o broni i amunicji funkcjonowało pojęcie „dopuszczenie strzelnicy do użytkowania”. Przepis rozporządzenia odnosił się właśnie do tego punktu ustawy o broni i amunicji. Jednak po nowelizacji ustawy o broni i amunicji w 2003 r. - o czym wspomniano już wyżej - z art. 47 u.o.b.a. został wykreślony fragment dotyczący dopuszczenia strzelnicy do użytkowania, a pozostawiono jedynie wymóg zatwierdzenia regulaminu strzelnicy przez wójta (burmistrza, prezydenta miasta). Zatem zmiana merytoryczna art. 47 u.o.b.a. spowodowała określone skutki, mianowicie zawężono kompetencje organu administracji. W związku z powyższym w trakcie prowadzenia postępowania w sprawie zatwierdzenia regulaminu strzelnicy nie jest zasadne żądanie przez wójta (burmistrza, prezydenta miasta) dostarczenia decyzji o dopuszczenia obiektu do użytkowania ${ }^{28}$. Pojawia się pytanie: jaki organ administracji miałby ją wydać, skoro ustawodawca takowego nie wskazuje? Co więcej, konieczne byłoby uregulowanie tej materii przynajmniej na poziomie ustawowym, gdyż normy kompetencyjne dotyczące organów administracji publicznej w Rzeczpospolitej tego wymagają. Tym samym również nie ma zastosowania przepis mówiący o umieszczeniu takiej decyzji na strzelnicy, gdyż nie ma on w chwili obecnej umocowania w obowiązującej ustawie o broni i amunicji.

Ponadto, jak zaznacza we wspomnianej już na wstępie interpelacji do MSWiA poseł Jarosław Stawiarski, zmiana ta, za sprawą zaniechania legislacyjnego, nie znalazła odzwierciedlenia w załączniku do rozporządzenia MSWiA z 15 marca 2000 r. i wymóg umieszczenia na strzelnicy w widocznym miejscu decyzji o dopuszczeniu strzelnicy do użytkowania nadal figuruje. Z uwagi na fakt, że przepis rozporządzenia jest sprzeczny $z$ aktem prawnym wyższego rzędu, jakim jest unormowanie ustawowe, należy wskazać, iż decyzja o dopuszczeniu strzelnicy do użytkowania nie musi (i nie może) być wywieszona na strzelnicy, ponieważ decyzji takich nie wydaje się ${ }^{29}$. W niespełna miesiąc później sekretarz stanu MSWiA Jarosław Zieliński (z up. Ministra Spraw Wewnętrznych i Administracji) poinformował, że „obecnie w MSWiA nie jest planowane podjęcie prac legislacyjnych mających na celu zmianę rozporządzenia w sprawie wzorcowego regulaminu strzelnic, niemniej kwestia dotycząca wymogu umieszczania na strzelnicy w widocznym miejscu decyzji o dopuszczeniu strzelnicy do użytkowania wymaga rozważenia"30. Warto na marginesie zaznaczyć, że od tamtej pory, czyli od ponad trzech lat, w sprawie tej nie podjęto żadnych zmian legislacyjnych.

28 Zob. H. Kowalik, Aspekty formalne projektu „Strzelnica w powiecie”, op. cit., s. 29.

29 Zob. J. Stawiarski, Interpelacja nr 10011 do ministra spraw wewnętrznych i administracji, op. cit.

30 J. Zieliński, sekretarz stanu w Ministerstwie Spraw Wewnętrznych i Administracji, Odpowiedź na interpelacje $\mathrm{nr} 10011 \mathrm{w}$ sprawie wzorcowego regulaminu strzelnic, 14 marca 2017 r., http://www.sejm.gov.pl/Sejm8.nsf/InterpelacjaTresc.xsp?key=2AE714C2 [dostęp 7 stycznia 2020 r.]. 
Podobne stanowisko zajął również Wojewódzki Sąd Administracyjny w Lublinie w wyroku z 15 listopada 2017 r.: „zawarte we wzorcowym regulaminie postanowienie dotyczące umieszczenia w widocznym miejscu decyzji o dopuszczeniu strzelnicy do użytkowania straciło na aktualności, ponieważ przepis art. 47 ustawy, który przewidywał wydanie przez wójta gminy decyzji o dopuszczeniu strzelnicy do użytkowania zmieniony został z dniem 11 lipca 2003 r. przez art. 5 ustawy z 27 marca 2003 r. o zmianie ustawy - Prawo budowlane oraz o zmianie niektórych ustaw (Dz.U. nr 80, poz. 718). Skoro ustawa nie przewiduje już wydawania przez wójta decyzji o dopuszczeniu strzelnicy do użytkowania, zbędne jest zamieszczanie tego postanowienia w regulaminie" ${ }^{31}$.

Niestety, analogicznie jak w odniesieniu do procedury zatwierdzenia regulaminu strzelnicy, tak i w tym przypadku mamy do czynienia $\mathrm{z}$ diametralnie rozbieżnym stanowiskiem w orzecznictwie i doktrynie. Naczelny Sąd Administracyjny w wyroku z 24 stycznia 2018 r. skonstatował, że „uzyskanie w tym zakresie stosownej zgody właściwego organu, z uwagi także na cele Prawa budowlanego, stanowi potwierdzenie użytkowania obiektu, w tym strzelnicy, zgodnie z wymogami bezpieczeństwa i ochrony środowiska. Ponadto Sąd I instancji prawidłowo ocenił, że prawidłowe funkcjonowanie strzelnicy uzależnione jest od [...] zatwierdzenia regulaminu strzelnicy, zgodnie z którym prowadzący strzelnicę powinien na strzelnicy w widocznym miejscu umieścić m.in. decyzję o dopuszczeniu strzelnicy do użytkowania. Brak takiej decyzji stanowi zatem przeszkodę do stwierdzenia czy przedstawiony do zatwierdzenia regulamin strzelnicy będzie rzeczywiście spełniał wymogi związane $\mathrm{z}$ odpowiednim funkcjonowaniem strzelnicy"32. Odmienne stanowisko jeszcze dobitniej wybrzmiało w wyroku Wojewódzkiego Sądu Administracyjnego w Białymstoku z 17 października 2019 r., gdzie podkreślono, że rzeczywiście „Z dniem 11 lipca 2003 r. doszło do zmiany treści art. 47 u.b.a. Obecnie organ zatwierdzający regulamin strzelnicy nie dopuszcza strzelnicy do użytkowania, ale wyłącznie zatwierdza regulamin. Nie oznacza to jednak, że wymóg formalnoprawnego dopuszczenia do użytkowania przestał być wymogiem prawnym. W ust. 3 pkt 2 załącznika do rozporządzenia w sprawie wzorcowego regulaminu strzelnic sformułowano wprost obowiązek uzyskania decyzji o dopuszczeniu strzelnicy do użytkowania. Ustawodawca zatem także i w tym przepisie potwierdził, że realizacja strzelnicy wymaga formalnoprawnych zgód, w tym zezwalających na użytkowanie strzelnicy"33.

W linię przytoczonego odmiennego orzecznictwa wpisuje się również S. Maj, który w komentarzu do ustawy o broni i amunicji stwierdza, że od 31 marca

31 Wyrok WSA w Lublinie z 15 listopada 2017 r., sygn. akt III SA/Lu 216/17, LEX nr 2407704.

32 Wyrok NSA z 24 stycznia 2018 r., sygn. akt II OSK 1462/17, LEX nr 2446376.

33 Wyrok WSA w Białymstoku z 17 października 2019 r., sygn. akt II SA/Bk 484/19, LEX nr 2738260. 
2002 r., kiedy to w pkt 3 ppkt 2 - Wzorcowego regulaminu bezpiecznego funkcjonowania strzelnic, treść „aktualny atest strzelnicy” zmieniono na „decyzję o dopuszczeniu strzelnicy do użytkowania”, nie wymaga się od strzelnicy atestu, a jedynie decyzji o dopuszczeniu jej do użytkowania w rozumieniu prawa budowlanego. Taką decyzję umieszcza się na widocznym miejscu strzelnicy, podobnie jak regulamin, plan strzelnicy, wykaz sygnałów alarmowych, informację o możliwości i sposobie połączenia się z najbliższym punktem pomocy medycznej. Tyle mówią przepisy powszechnie obowiązującego prawa, które określają niezbędne minimum ${ }^{34}$.

\section{Podsumowanie}

Nie ulega wątpliwości, że inicjatywa władz państwowych związana z budową, remontami i utrzymaniem strzelnic oraz rozwijaniem sportu strzeleckiego, w szczególności wśród dzieci i młodzieży, oraz organizacji proobronnych jest wartościowym i perspektywicznym współdziałaniem administracji państwowej i samorządowej, a korzyści z tego płynące są wielopłaszczyznowe i nie do przecenienia. Ponadto szczególnie cenne wydaje się zaktywizowanie potencjału zwykłych obywateli, dla których program państwa stał się impulsem do działań oddolnych środowisk lokalnych. Niestety w wielu sytuacjach działaniom tym na przeszkodzie staje nieprecyzyjny stan prawny, a także rozbieżności w jego interpretacji oraz w orzecznictwie sądów administracyjnych. Analizowane wcześniej regulacje prawne dotyczące zasad funkcjonowania i lokalizowania strzelnic zostały opracowane kilkanaście lat temu. Jak zauważył H. Kowalik, niektóre z nich stoją w chwili obecnej w sprzeczności ze sobą lub ich umocowanie w ustawie o broni i amunicji wygasło. Wydaje się zatem zasadne rozważenie możliwości wprowadzenia pewnych zmian oraz dostosowanie ich do obecnych potrzeb. $\mathrm{Ma}$ to istotne znaczenie $\mathrm{w}$ kwestii wprowadzenia precyzyjnej i kompatybilnej procedury zatwierdzenia regulaminu strzelnicy przez danego wójta, burmistrza czy prezydenta miasta, aby wyeliminować uznaniowość w tym zakresie ${ }^{35}$. W tym miejscu należy również podkreślić, że w aktualnym stanie prawnym wójt (burmistrz, prezydent miasta) nie ma kompetencji do wydawania decyzji o dopuszczeniu strzelnicy do użytkowania, co oznacza, że taka decyzja jest nieważna. Zatem obowiązek uregulowany w rozdziale 1 pkt 3 ppkt 2 rozporządzenia w sprawie wzorcowego regulaminu strzelnic jest w istocie kuriozalny. Nie ulega również wątpliwości, że także formalny aspekt dopuszczenia strzelnicy do użytkowania wymaga rewizji. W formie integralnej nie jest on jednak przedmiotem niniejszej analizy, którym pozostaje wyłącznie jeden z jego aspektów - czynność

34 S. Maj, Ustawa o broni i amunicji, op. cit., art. 46.

35 Zob. H. Kowalik, Aspekty formalne projektu „Strzelnica w powiecie”, op. cit., s. 30. 
administracyjna zatwierdzenia regulaminu strzelnicy. Niezależnie od formy rozwiązań prawnych, jakie zostaną podjęte w przyszłości, słuszne wydaje się oparcie ich na stanowisku teorii równoległej (rozproszonej) z kilku względów.

Po pierwsze, prawodawca w kompetencji organu administracji samorządowej pozostawił wyłącznie zatwierdzenie regulaminu strzelnicy, odstępując od konieczności wcześniejszego dodatkowego dopuszczenia do jej użytkowania. Oznacza to, że organ nie jest uprawniony do badania innych kwestii niż tylko treść regulaminu. Jego rolą jest wyłącznie ocena regulaminu strzelnicy z punktu widzenia zgodności z wzorcem normatywnym określonym w rozporządzeniu MSWiA z 15 marca 2000 r. w sprawie wzorcowego regulaminu strzelnic, a więc pod kątem przyjęcia odpowiednich rozwiązań dotyczących sposobu korzystania ze strzelnicy i obchodzenia się na niej z bronią. Poza kompetencjami organu pozostaje zatem weryfikowanie pozostałych dokumentów związanych ze strzelnicą, wymaganych przez inne niż ustawa o broni i amunicji przepisy, np. prawa budowlanego, zagospodarowania przestrzennego, ochrony środowiska. Te sprawy jako wynikające z przepisów odrębnych - podlegają rozpatrzeniu w trybie i na zasadach określonych w tychże przepisach, a nie w postępowaniu prowadzonym na podstawie ustawy o broni i amunicji.

Po drugie, z przepisów obowiązującego prawa nie wynika, aby decyzja w sprawie zatwierdzenia regulaminu strzelnicy była aktem finalnym (jak twierdzą niektóre sądy administracyjne), kończącym i niejako podsumowującym z punktu widzenia zgodności z prawem cały proces organizowania strzelnicy, a w konsekwencji stanowiącym wyłączną podstawę przystąpienia do jej legalnego użytkowania, co zbliżałoby tę decyzję w swej konstrukcji do swoistego zezwolenia na prowadzenie strzelnicy.

Po trzecie, znajdujący się w rozporządzeniu MSWiA o wzorcowym regulaminie bezpiecznego funkcjonowania strzelnic zapis o umieszczeniu w widocznym miejscu decyzji o dopuszczeniu strzelnicy do użytkowania powinien zostać usunięty, ponieważ nie ma umocowania w ustawie o broni i amunicji. Wprawdzie w czasie wydawania rozporządzenia w ustawie o broni i amunicji funkcjonował zapis o „dopuszczeniu strzelnicy do użytkowania”, jednak po nowelizacji ustawy o broni i amunicji w 2003 r. z art. 47 u.o.b.a. został on wykreślony, a pozostawiono jedynie wymóg zatwierdzenia regulaminu strzelnicy przez wójta (burmistrza, prezydenta miasta).

W związku z dyrektywą Parlamentu Europejskiego i Rady (UE) 2017/853 z 17 maja 2017 r. zmieniającą dyrektywę Rady 91/477/EWG w sprawie kontroli nabywania i posiadania broni ${ }^{36}$ Polska została zobowiązana do przeprowadzenia nowelizacji ustawy o amunicji i broni. Ma ona na celu przede wszystkim dostoso-

36 Dyrektywa Parlamentu Europejskiego i Rady (UE) 2017/853 zmieniająca dyrektywę Rady 91/477/EWG w sprawie kontroli nabywania i posiadania broni, 17 maja 2017 r., Dz.Urz. UE L 137/22-39 z 2017 r. 
wanie przepisów prawa dostępu do broni i jej posiadania przez obywateli Rzeczpospolitej Polskiej do wymogów, które zostały zawarte w dyrektywie. Trudno zatem wyobrazić sobie lepszy moment do przeprowadzenia de lege ferenda tych słusznych, koniecznych i pilnych zmian jak ten, którego ramy czasowe zakreśla wspomniana dyrektywa.

\section{Bibliografia}

\section{Literatura}

Barszczewska B., Regulamin strzelnicy musi być zatwierdzony przez wójta, Prawo.pl 18.10.2016, https://www.prawo.pl/samorzad/regulamin-strzelnicy-musi-byc-zatwierdzony-przez-wojta,106908.html

Chróścielewski W., Z problematyki właściwości organów w postępowaniu administracyjnym, LEX nr 151145294.

Goleniowska-Gałgan J., Właściwość organów administracji, LEX nr 151109885.

Kowalik H., Aspekty formalne projektu „Strzelnica w powiecie” [w:] Obrona Narodowa, Sokót - Strzelnica w powiecie. Publikacja po konferencji 9-10 grudnia 2017 w Warszawie, Warszawa 2017.

Lewandowski J., Sokót - strzelnica w powiecie, Strzał.pl 1/2018.

Lipiński A., Z problematyki właściwości rzeczowej organów administracji geologicznej, LEX nr 151169595.

Maj S., Ustawa o broni i amunicji. Komentarz, art. 47, LEX nr 16836326.

Majo J., Zatwierdzenie regulaminu strzelnicy - według sądu, Strzał.pl 6/2019.

Rudak O., Czy zatwierdzenie regulaminu strzelnicy jest pierwszym - czy ostatnim - etapem organizacji obiektu?, Lege Artis, 27 listopada 2019, https://czasopismo.legeartis. org/2019/11/zatwierdzenie-regulaminu-strzelnicy.html.

Stawiarski J., Interpelacja nr 10011 do ministra spraw wewnętrznych $i$ administracji w sprawie wzorcowego regulaminu strzelnic, 9.02.2017 r., http://www.sejm.gov.pl/Sejm8.nsf/ InterpelacjaTresc.xsp?key=13829D7B.

Turczyn A., MON ogłasza konkurs pn. „Strzelnica w powiecie” na dofinansowanie zadań zwiazanych $z$ budowa lub remontem strzelnic, https://trybun.org.pl/2018/08/30/mon-oglasza-konkurs-pn-strzelnica-w-powiecie-na-dofinansowanie-zadan-zwiazanych-z-budowa-lub-remontem-strzelnic.

Turczyn A., Organ (wójt, burmistrz, prezydent miasta) zatwierdzający regulamin strzelnicy nie jest uprawniony do badania innych kwestii niż sama treść regulaminu, https:// trybun.org.pl/2019/05/22/organ-wojt-burmistrz-prezydent-miasta-zatwierdzajacy-regulamin-strzelnicy-nie-jest-uprawniony-do-badania-innych-kwestii-niz-sama-tresc-regulaminu.

Turczyn A., Projekt rozporządzenia MON w sprawie dofinansowania z budżetu państwa zadań związanych $z$ budowa, remontami $i$ utrzymaniem strzelnic oraz rozwijaniem sportu strzeleckiego, https://trybun.org.pl/2018/04/18/projekt-rozporzadzenia-mon- 
-w-sprawie-dofinansowania-z-budzetu-panstwa-zadan-zwiazanych-z-budowa-remontami-i-utrzymaniem-strzelnic-oraz-rozwijaniem-sportu-strzeleckiego.

Turczyn A., Przełomowy wyrok sądu administracyjnego, który rozprawia się ze wszystkimi naruszeniami prawa $w$ sprawach o zatwierdzanie regulaminów strzelnic, https://trybun.org.pl/2018/01/03/przelomowy-wyrok-sadu-administracyjnego.

Turczyn A., Strzelnica padła ofiara walki politycznej, https://trybun.org.pl/2018/07/30/ strzelnica-padla-ofiara-walki-politycznej.

Zieliński J., sekretarz stanu w Ministerstwie Spraw Wewnętrznych i Administracji, Odpowiedź na interpelacje $n r 10011 \mathrm{w}$ sprawie wzorcowego regulaminu strzelnic, 14 marca 2017, http://www.sejm.gov.pl/Sejm8.nsf/InterpelacjaTresc.xsp?key=2AE714C2.

\section{Akty prawne}

Dyrektywa Parlamentu Europejskiego i Rady (UE) 2017/853 zmieniająca dyrektywę Rady 91/477/EWG w sprawie kontroli nabywania i posiadania broni, 17 maja 2017 r., Dz.Urz. UE L 137 z 2017 r., s. 22-39.

Ustawa z 21 maja 1999 r. o broni i amunicji, Dz.U. nr 53, poz. 549.

Ustawa z 9 września 2000 r. o podatku od czynności cywilnoprawnych, Dz.U. nr 86, poz. 959.

Ustawa z 27 marca 2003 r. o zmianie ustawy - Prawo budowlane oraz o zmianie niektórych ustaw, Dz.U. nr 80, poz. 718.

Rozporządzenie MSWiA z 15 marca 2000 r. w sprawie wzorcowego regulaminu strzelnic, Dz.U. nr 18, poz. 234.

\section{Orzecznictwo}

Wyrok WSA w Poznaniu z 25 października 2005 r., sygn. akt II SA/Po 2807/03, Legalis nr 2207003.

Wyrok WSA w Bydgoszczy z 21 listopada 2016 r., sygn. akt II SA/Bd 416/16, CBOSA. Wyrok WSA w Lublinie z 15 listopada 2017 r., sygn. akt III SA/Lu 216/17, LEX nr 2407704. Wyrok NSA z 24 stycznia 2018 r., sygn. akt II OSK 1462/17, LEX nr 2446376.

Wyrok WSA w Bydgoszczy z 24 stycznia 2018 r., sygn. akt II OSK 1462/17, LEX nr 2446376. Wyrok WSA w Szczecinie z 7 marca 2019 r., sygn. akt II SA/Sz 1108/18, CBOSA. Wyrok WSA w Rzeszowie z 27 marca 2018 r., sygn. akt II SA/Rz 66/18, LEX nr 2485969. Wyrok WSA w Szczecinie z 13 września 2018 r., sygn. akt II SA/Sz 216/18, CBOSA. Wyrok WSA w Gliwicach z 22 listopada 2018 r., sygn. akt IV SA/GI 797/18, LEX nr 2600526.

Wyrok WSA w Bydgoszczy z 19 grudnia 2018 r., sygn. akt II SA/Bd 971/17, CBOSA. Wyrok WSA w Gdańsku z 14 marca 2019 r., sygn. akt III SA/Gd 915/18, LEX nr 2650936. Wyrok WSA w Białymstoku z 17 października 2019 r., sygn. akt II SA/Bk 484/19, LEX nr 2738260.

Wyrok WSA w Lublinie z 17 października 2019 r., sygn. akt III SAB/Lu 28/19, CBOSA. Wyrok WSA w Kielcach z 13 lutego 2020 r., sygn. akt II SA/Ke 1117/19, CBOSA. 
\begin{tabular}{l|l}
2 & OPINIE BAS
\end{tabular}

\begin{tabular}{l|l} 
A & \\
ZAGADNIENIA PRAWA \\
KONSTYTUCYJNEGO
\end{tabular} 

Rafał Dubowski

\title{
Możliwość pozwania Skarbu Państwa z tytułu przebywania na kwarantannie w związku z epidemią COVID-19 w sytuacji, gdy nie został wprowadzony stan nadzwyczajny ${ }^{1}$
}

\author{
Possibility of Suing the State Treasury due to being in quarantine because \\ of the COVID-19 epidemic in a situation where none of extraordinary \\ measures has been declared
}

\begin{abstract}
The opinion presents legal grounds regarding the application of quarantine and liability for damages of the State Treasury. Simultaneously, the conditions required for the State Treasury to be liable for damages in a specific case of quarantine were indicated and discussed. In addition, the opinion highlights the possibility of pursuing claims for infringement of moral rights if the quarantine is unlawfully applied (e.g. by a wrong authority or in the absence of legal grounds for its application to a specific person).
\end{abstract}

Keywords: coronavirus, quarantine, compensation, State Treasury

W opinii przedstawiono podstawy prawne zastosowania kwarantanny oraz odpowiedzialności odszkodowawczej Skarbu Państwa. Jednocześnie wskazano i omówiono przesłanki, które musiałyby być spełnione, aby w konkretnym przypadku zastosowania kwarantanny Skarb Państwa ponosił z tego tytułu odpowiedzialność odszkodowawczą. Ponadto w opinii zwrócono uwagę na możliwość dochodzenia roszczeń z tytułu naruszenia dóbr osobistych, jeśli kwarantannę zastosowano niezgodnie z prawem (tj. np. przez niewłaściwy organ albo w sytuacji braku podstaw prawnych do jej zastosowania wobec określonej osoby).

Słowa kluczowe: koronawirus, kwarantanna, odszkodowanie, Skarb Państwa

Doktor nauk prawnych, ekspert ds. legislacji Biura Analiz Sejmowych •

Kancelaria Sejmu, Biuro Analiz Sejmowych, Wydział Analiz Prawnych, Zespół Prawa

Prywatnego, WARSZAWA, POLSKA -

rafal.dubowski@sejm.gov.pl • https://orcid.org/0000-0001-7852-4275

\section{Przedmiot opinii}

Opinia prawna zawiera odpowiedź na pytanie: „[c]zy jest możliwość pozwania Skarbu Państwa $\mathrm{z}$ tytułu przebywania na kwarantannie podczas gdy nie jest wprowadzony stan nadzwyczajny?”.

$1 \quad$ Opinia prawna w sprawie możliwości pozwania Skarbu Państwa z tytułu przebywania na kwarantannie $w$ związku z epidemiq COVID-19 w sytuacji gdy nie został wprowadzony stan nadzwyczajny sporządzona 18 maja 2020 r. na zlecenie posła Klubu Parlamentarnego Koalicja Obywatelska - Platforma Obywatelska, Nowoczesna, Inicjatywa Polska, Zieloni; BAS-WAP-761/20. 
W opinii uwzględniono stan prawny na dzień jej sporządzenia. Nie odnosi się ona do żadnego konkretnego zdarzenia, lecz stanowi analizę stanu prawnego pod kątem problemu przedstawionego w pytaniu. Zaprezentowane w niej stanowisko nie wiąże ani organów władzy publicznej, ani innych podmiotów prawa.

W niniejszej opinii powołano postanowienia następujących aktów prawnych:

- Konstytucja Rzeczypospolitej Polskiej z 2 kwietnia 1997 r., Dz.U. nr 78, poz. 483, ze zm.,

- ustawa z 23 kwietnia 1964 r. - Kodeks cywilny, t.j. Dz.U. 2019, poz. 1145, ze zm.; dalej: k.c.,

- ustawa z 5 grudnia 2008 r. o zapobieganiu oraz zwalczaniu zakażeń i chorób zakaźnych u ludzi, t.j. Dz.U. 2019, poz. 1239, ze zm.; dalej: ustawa o zapobieganiu i zwalczaniu zakażeń,

- rozporządzenie Ministra Zdrowia z 6 kwietnia 2020 r. w sprawie chorób zakaźnych powodujących powstanie obowiązku hospitalizacji, izolacji lub izolacji w warunkach domowych oraz obowiązku kwarantanny lub nadzoru epidemiologicznego, Dz.U. poz. 607; dalej: rozporządzenie Ministra Zdrowia z 6 kwietnia 2020 r.,

- rozporządzenie Rady Ministrów z 2 maja 2020 r. w sprawie ustanowienia określonych ograniczeń, nakazów i zakazów w związku z wystąpieniem stanu epidemii, Dz.U. poz. 792; dalej: rozporządzenie Rady Ministrów z 2 maja 2020 r.

\section{Uzasadnienie}

\section{Podstawy prawne zastosowania kwarantanny}

Zgodnie z art. 2 pkt 12 ustawy o zapobieganiu i zwalczaniu zakażeń kwarantanna to „odosobnienie osoby zdrowej, która była narażona na zakażenie, w celu zapobieżenia szerzeniu się chorób szczególnie niebezpiecznych i wysoce zakaźnych". Jak przewidziano w art. 33 ust. 1 tej ustawy, państwowy powiatowy inspektor sanitarny lub państwowy graniczny inspektor sanitarny może, w drodze decyzji, nałożyć m.in. na osobę podejrzaną o zakażenie lub chorobę zakaźną lub osobę, która miała styczność ze źródłem biologicznego czynnika chorobotwórczego, obowiązki określone w art. 5 ust. 1 ustawy o zapobieganiu i zwalczaniu zakażeń. Natomiast według art. 5 ust. 1 pkt 1 lit. f tej ustawy jednym z tych obowiązków jest obowiązek poddania się kwarantannie. Oprócz tego zgodnie z art. 34 ust. 2 tej ustawy „[o]soby, które były narażone na chorobę zakaźną lub pozostawały w styczności ze źródłem biologicznego czynnika chorobotwórczego, a nie wykazują objawów chorobowych, podlegają obowiązkowej kwarantannie lub nadzorowi epidemiologicznemu, jeżeli tak postanowią organy inspekcji sanitarnej przez okres nie dłuższy niż 21 dni, licząc od dnia następującego po ostatnim dniu odpowiednio narażenia albo styczności”. Przy czym zgodnie z $\$ 5$ rozporządzenia Ministra Zdrowia z 6 kwietnia 2020 r. osoby, o których mowa w art. 34 
ust. 2 ustawy o zapobieganiu oraz zwalczaniu zakażeń, narażone na chorobę wywołaną wirusem SARS-COV-2 (COVID-19) lub pozostające w styczności ze źródłem biologicznych czynników chorobotwórczych ją wywołujących podlegają 14-dniowej kwarantannie ${ }^{2}$.

Ponadto obowiązek poddania się kwarantannie w związku z epidemią COVID-19 wynika z przepisów rozdziału II rozporządzenia Rady Ministrów z 2 maja 2020 r. w sprawie ustanowienia określonych ograniczeń, nakazów i zakazów w związku z wystąpieniem stanu epidemii. Na podstawie $\$ 2$ ust. 2 pkt 2 tego rozporządzenia osoba przekraczająca granicę państwową, w celu udania się do swojego miejsca zamieszkania lub pobytu na terytorium Rzeczypospolitej Polskiej, jest obowiązana odbyć, po przekroczeniu granicy państwowej, obowiązkową kwarantannę, o której mowa w przepisach wydanych na podstawie art. 34 ust. 5 ustawy o zapobieganiu i zwalczaniu zakażeń, trwającą 14 dni, licząc od dnia następującego po przekroczeniu tej granicy, wraz z osobami wspólnie zamieszkującymi lub gospodarującymi. Obowiązek, o którym mowa w $\$ 2$ ust. 2 pkt 2 rozporządzenia Rady Ministrów z 2 maja 2020 r., jest równoważny z obowiązkiem wynikającym z art. 34 ust. 2 ustawy o zapobieganiu i zwalczaniu zakażeń, a w stosunku do osób objętych tym obowiązkiem organ inspekcji sanitarnej nie wydaje decyzji ( $\$ 4$ ust. 1 rozporządzenia Rady Ministrów z 2 maja 2020 r.).

Do odbycia kwarantanny może skierować także lekarz. Jak przewidziano w art. 35 ust. 1 ustawy o zapobieganiu i zwalczaniu zakażeń, „[w] przypadku podejrzenia lub rozpoznania zachorowania na chorobę szczególnie niebezpieczną i wysoce zakaźną, lekarz przyjmujący do szpitala, kierujący do izolacji, kwarantanny lub zlecający izolację w warunkach domowych, kierując się własną oceną stopnia zagrożenia dla zdrowia publicznego, poddaje osobę podejrzaną o zachorowanie, chorą na chorobę szczególnie niebezpieczną i wysoce zakaźną lub osobę narażoną na zakażenie hospitalizacji, izolacji, kwarantannie, badaniom lub zleca izolację w warunkach domowych, również w przypadku, gdy brak jest decyzji, o której mowa w art. 33 ust. 1, a osoba podejrzana o zachorowanie, chora lub narażona na zakażenie nie wyraża zgody na hospitalizację, izolację, kwarantannę, wykonanie badania lub izolację w warunkach domowych". Przy czym w tej

2 Istnieją wyjątki w tym zakresie, zob. np. art. 34 ust. 3 ustawy o zapobieganiu i zwalczaniu zakażeń, który stanowi: „[o]bowiązkowa kwarantanna lub nadzór epidemiologiczny mogą być stosowane wobec tej samej osoby więcej niż raz, do czasu stwierdzenia braku zagrożenia dla zdrowia lub życia ludzkiego", a także $\$ 3$ ust. 6 rozporządzenia Rady Ministrów z 2 maja 2020 r., w którym przewidziano: „[p]aństwowy inspektor sanitarny właściwy ze względu na miejsce zamieszkania lub pobytu, w których ma być obowiązkowa kwarantanna, o której mowa w przepisach wydanych na podstawie art. 34 ust. 5 ustawy z dnia 5 grudnia 2008 r. o zapobieganiu oraz zwalczaniu zakażeń i chorób zakaźnych u ludzi, lub inny upoważniony przez Głównego Inspektora Sanitarnego państwowy inspektor sanitarny, w uzasadnionych przypadkach, decyduje o skróceniu lub zwolnieniu z obowiązku jej odbycia”. 
sytuacji lekarz jest obowiązany niezwłocznie zawiadomić właściwego państwowego powiatowego inspektora sanitarnego (art. 35 ust. 2 ustawy o zapobieganiu i zwalczaniu zakażeń).

Reasumując, według obowiązujących regulacji obowiązek poddania się kwarantannie może powstać na skutek indywidualnych rozstrzygnięć organów inspekcji sanitarnej, z mocy prawa oraz na skutek skierowania danej osoby do odbycia kwarantanny przez lekarza.

\section{Odpowiedzialność odszkodowawcza Skarbu Państwa za niezgodne z prawem działanie lub zaniechanie przy wykonywaniu władzy publicznej}

Zgodnie z art. 77 ust. 1 Konstytucji „[k]ażdy ma prawo do wynagrodzenia szkody, jaka została mu wyrządzona przez niezgodne z prawem działanie organu władzy publicznej”. Regulacja konstytucyjna została rozwinięta w szczególności przez art. 417 oraz art. $417^{1}$ k.c., które określają podstawy prawne odpowiedzialności odszkodowawczej Skarbu Państwa za niezgodne z prawem działania albo zaniechania przy wykonywaniu władzy publicznej.

Jak przewidziano w art. $417 \$ 1$ k.c., „[z]a szkodę wyrządzoną przez niezgodne z prawem działanie lub zaniechanie przy wykonywaniu władzy publicznej ponosi odpowiedzialność Skarb Państwa lub jednostka samorządu terytorialnego lub inna osoba prawna wykonująca tę władzę z mocy prawa”. Natomiast $\$ 2$ tego artykułu dodaje, że w przypadku, gdy „wykonywanie zadań z zakresu władzy publicznej zlecono, na podstawie porozumienia, jednostce samorządu terytorialnego albo innej osobie prawnej, solidarną odpowiedzialność za wyrządzoną szkodę ponosi ich wykonawca oraz zlecająca je jednostka samorządu terytorialnego albo Skarb Państwa”.

Przesłanki odpowiedzialności odszkodowawczej w świetle art. 417 są następujące:

- szkoda,

- szkoda ta musi być wyrządzona przez niezgodne z prawem działanie lub zaniechanie przy wykonywaniu władzy publicznej (w sferze imperium),

- istnienie normalnego, adekwatnego związku przyczynowego między działaniem lub zaniechaniem przy wykonywaniu władzy a powstaniem szkody ${ }^{3}$.

Analizując przesłanki odpowiedzialności odszkodowawczej, należy wyjaśnić, że samo niezgodne z prawem działanie lub zaniechanie przy wykonywaniu władzy publicznej w zakresie dotyczącym stosowania kwarantanny nie uzasadniałoby jeszcze roszczenia odszkodowawczego. Oprócz tego zarówno na grun-

3 Zob. np. P. Sobolewski, Art. 417 [w:] Kodeks cywilny. Komentarz, red. K. Osajda, Warszawa 2017, pkt 18; Z. Banaszczyk, Odpowiedzialność za szkodę wyrządzona przy wykonywaniu władzy publicznej [w:] System prawa prywatnego, t. 6, Prawo zobowiązań część ogólna, Warszawa 2018, nb 28. 
cie art. 417, jak i art. $417^{1}$ k.c. niezgodne z prawem działanie lub zaniechanie określone w tych przepisach musi być przyczyną szkody, tj. musi wywoływać uszczerbek w majątku poszkodowanego ${ }^{4}$, a ponadto związek przyczynowy pomiędzy czynnikiem szkodzącym, a szkodą musi spełniać warunki normalnego, adekwatnego związku przyczynowego, o którym mowa w art. $361 \$ 1$ k.c.

Szczególną formą niezgodnego z prawem działania przy wykonywaniu władzy publicznej jest wydanie niezgodnego $\mathrm{z}$ prawem prawomocnego orzeczenia lub ostatecznej decyzji, co $\mathrm{w}$ związku z pytaniem sformułowanym na początku opinii może odnosić się np. do ostatecznej decyzji o objęciu kwarantanną. Zgodnie $\mathrm{z}$ art. $417^{1} \$ 2$ zdanie pierwsze k.c. w przypadku, gdy szkoda została wyrządzona przez wydanie prawomocnego orzeczenia lub ostatecznej decyzji, jej naprawienia co do zasady można żądać dopiero po stwierdzeniu we właściwym postępowaniu ich niezgodności z prawem. Dochodząc odszkodowania przed sądem cywilnym na podstawie art. $417^{1} \$ 2$ zdanie pierwsze k.c., poszkodowany musi - oprócz uzyskania prejudykatu - wykazać:

- szkodę,

- zaistnienie szkody w wyniku wydania niezgodnego z prawem prawomocnego orzeczenia lub ostatecznej decyzji,

- istnienie adekwatnego związku przyczynowego pomiędzy wydaniem takiego orzeczenia lub decyzji a wyrządzeniem szkody ${ }^{5}$.

A zatem, w sytuacji gdy objęcie danej osoby kwarantanną byłoby (normalną) przyczyną szkody (uszczerbku majątkowego), kluczową rolę przy ocenie zasadności zasądzenia odszkodowania od Skarbu Państwa na podstawie art. 417 lub art. $417^{1} \$ 2$ zdanie pierwsze k.c. odgrywałaby przesłanka niezgodnego z prawem działania przy wykonywaniu władzy publicznej. Innymi słowy, art. 417 k.c. mógłby stanowić podstawę odpowiedzialności Skarbu Państwa za szkodę wyrządzoną przez działanie lub zaniechanie przy wykonywaniu władzy publicznej w zakresie dotyczącym stosowania kwarantanny, jeżeli szkoda powstałaby na skutek działania lub zaniechania niezgodnego z prawem, a w szczególności niezgodnego z przepisami ustawy o zapobieganiu oraz zwalczaniu zakażeń oraz przepisami aktów wykonawczych wydanych na jej podstawie. Przy czym, jeżeli szkoda zostałaby wyrządzona przez wydanie prawomocnego orzeczenia lub ostatecznej decyzji o objęciu kwarantanną, jej naprawienia można byłoby żądać na podstawie art. $417^{1} \$ 2$ zdanie pierwsze k.c. po stwierdzeniu we właściwym postępowaniu ich niezgodności z prawem.

4 Przez szkodę rozumie się różnicę pomiędzy stanem majątku poszkodowanego a stanem, jaki istniałby, gdyby brak było czynnika szkodzącego, zob. np. P. Sobolewski, Art. 361 [w:] Kodeks cywilny. Komentarz, red. K. Osajda, Warszawa 2017, pkt 46.

5 Por. J. Kuźmicka-Sulikowska, Art. $417^{1}$ [w:] Kodeks cywilny. Komentarz, red. E. Gniewek, P. Machnikowski, Warszawa 2019, pkt II.1; wyrok SA w Warszawie z 26 października 2017 r., sygn. akt I ACa 1319/16, Legalis nr 1696400. 
Inną kwalifikowaną formą działania niezgodnego z prawem przy wykonywaniu władzy publicznej jest wydanie aktu normatywnego niezgodnego z Konstytucją, ratyfikowaną umową międzynarodową lub ustawą. Jak stanowi art. $417^{1}$ $\$ 1$ k.c., „[j] eżeli szkoda została wyrządzona przez wydanie aktu normatywnego, jej naprawienia można żądać po stwierdzeniu we właściwym postępowaniu niezgodności tego aktu z Konstytucją, ratyfikowaną umową międzynarodową lub ustawą". Komentując ten przepis, w piśmiennictwie prawniczym trafnie wskazuje się, iż „[f]ormalnym warunkiem przyznania odszkodowania za bezprawie legislacyjne jest stwierdzenie we właściwym postępowaniu niezgodności z prawem aktu normatywnego, którego wydanie lub zastosowanie było źródłem szkody. Rozpoznając sprawę cywilną o odszkodowanie, sąd nie może samodzielnie dokonać oceny zgodności aktu normatywnego z aktami hierarchicznie wyższego rzędu. Przed wystąpieniem o odszkodowanie poszkodowany uzyskać powinien stwierdzenie niezgodności aktu normatywnego z aktem zajmującym wyższe miejsce w hierarchii aktów prawnych"6. Co do zasady do badania zgodności aktów prawnych obowiązujących na terytorium RP, w tym ustaw i rozporządzeń, z normami prawnymi hierarchicznie wyższymi właściwy jest Trybunał Konstytucyjny ${ }^{7}$.

$\mathrm{W}$ piśmiennictwie prawniczym wskazuje się, że hipoteza art. $417^{1} \$ 1$ k.c. obejmuje również przypadki niezgodności aktu normatywnego z prawem unijnym, które stanowi część polskiego porządku prawnego ${ }^{8}$. Jednocześnie jednak prezentowane są odmienne stanowiska w kwestii tego, czy uzyskanie prejudykatu stwierdzającego tę niezgodność jest niezbędnym warunkiem dochodzenia odszkodowania za szkodę wyrządzoną wydaniem krajowego aktu normatywnego sprzecznego z prawem UE $\mathrm{UE}^{9}$.

Mając powyższe na uwadze, należy stwierdzić, że art. $417^{1} \$ 1$ k.c. mógłby stanowić podstawę odpowiedzialności Skarbu Państwa za szkodę wyrządzoną przez objęcie kwarantanną, m.in. jeśli przepisy prawa nakładające obowiązek odbycia kwarantanny zostałyby uznane we właściwym postępowaniu za niezgodne z Konstytucją, ratyfikowaną umową międzynarodową lub ustawą. W szczególności przepis ten mógłby stanowić podstawę roszczeń wówczas, gdyby Trybunał Konstytucyjny stwierdził, że regulacje dotyczące obowiązku kwarantanny są niezgodne z Konstytucją, np. z uwagi na to, że uznałby, iż tego rodzaju ogranicze-

6 Zob. np. P. Sobolewski, Art. $417^{1}$ [w:] Kodeks cywilny. Komentarz, red. K. Osajda, Warszawa 2017, pkt III.16.

$7 \quad$ Zob. ibidem, pkt III.17.

8 Zob. np. A. Olejniczak, Art. $417^{1}$ [w:] Kodeks cywilny. Komentarz, t. III, Zobowiqzania - część ogólna, red. A. Kidyba, 2014, LEX, pkt 7; Z. Banaszczyk, Art. 417² [w:] Kodeks cywilny, t. I, Komentarz. Art. 1-44910, red. K. Pietrzykowski, Warszawa 2018, nb 6.

9 Zob. A. Olejniczak, Art. 417¹, op. cit., pkt 8; J. Kremis, Art. $417^{1}$ [w:] Kodeks cywilny. Komentarz, red. E. Gniewek, P. Machnikowski, Warszawa 2016, nb 15. Odmiennie: Z. Banaszczyk, Art. 417 ${ }^{1}$, op. cit., nb 6. 
nia są dopuszczalne tylko podczas stanu nadzwyczajnego. Przy czym, mając na względzie art. $417^{1} \$ 2$ k.c. ${ }^{10}$, w sytuacji gdy na podstawie aktu normatywnego zakwestionowanego przez Trybunał zostałoby wydane prawomocne orzeczenie lub ostateczna decyzja o objęciu kwarantanną, poszkodowany w celu dochodzenia odszkodowania musiałby uzyskać stwierdzenie niezgodności z prawem tego orzeczenia lub decyzji. Ponadto na podstawie art. $417^{1} \$ 1$ k.c. sąd mógłby przyznać odszkodowanie gdyby, rozpoznając sprawę, miał przesłanki do tego, aby przyjąć, że regulacje dotyczące obowiązku kwarantanny są sprzeczne z prawem UE, a między tymi regulacjami a szkodą istnieje adekwatny związek przyczynowy.

Szczególną formą niezgodnego z prawem zaniechania przy wykonywaniu władzy publicznej jest tzw. zaniechanie legislacyjne. Możliwość zasądzania odszkodowania za szkodę wyrządzoną zaniechaniem legislacyjnym jest wywodzona $\mathrm{z}$ art. $417^{1} \$ 4$ k.c., który stanowi: „[j]eżeli szkoda została wyrządzona przez niewydanie aktu normatywnego, którego obowiązek wydania przewiduje przepis prawa, niezgodność z prawem niewydania tego aktu stwierdza sąd rozpoznający sprawę o naprawienie szkody”. W kontekście problemu sformułowanego w pytaniu przedstawionym na początku opinii można rozważyć, czy niewydanie rozporządzenia wprowadzającego stan nadzwyczajny mogłoby uzasadniać odszkodowanie za szkodę wyrządzoną zastosowaniem kwarantanny, nawet gdyby założyć, że epidemia COVID-19 uzasadnia wprowadzenie stanu wyjątkowego a wszystkie lub przynajmniej niektóre regulacje dotyczące obowiązku kwarantanny są konstytucyjnie dopuszczalne jedynie podczas stanu nadzwyczajnego.

W pierwszej kolejności należy zauważyć, że w przypadku zastosowania kwarantanny źródłem ewentualnej szkody nie byłoby niewydanie aktu wprowadzającego stan nadzwyczajny, lecz wydanie aktów normatywnych nakładających obowiązek kwarantanny. Innymi słowy, nawet przy przyjęciu powyższych założeń, art. $417^{1} \$ 4$ k.c. nie mógłby stanowić podstawy odpowiedzialności odszkodowawczej, ponieważ między brakiem stanu nadzwyczajnego a szkodą nie istniałby związek przyczynowo-skutkowy.

Ponadto wątpliwe jest to, czy brak rozporządzenia wprowadzającego stan wyjątkowy może być uznany za „niewydanie aktu normatywnego”. Aktem normatywnym jest bowiem tylko taki akt, na podstawie którego można zrekonstruować normy generalne i abstrakcyjne ${ }^{11}$. Przy czym akt normatywny w rozumieniu art. $417^{1}$ k.c. nie powinien być utożsamiany z „całym aktem normatywnym”.

10 Przepis ten stanowi: „[j]eżeli szkoda została wyrządzona przez wydanie prawomocnego orzeczenia lub ostatecznej decyzji, jej naprawienia można żądać po stwierdzeniu we właściwym postępowaniu ich niezgodności z prawem, chyba że przepisy odrębne stanowią inaczej. Odnosi się to również do wypadku, gdy prawomocne orzeczenie lub ostateczna decyzja zostały wydane na podstawie aktu normatywnego niezgodnego z Konstytucją, ratyfikowaną umową międzynarodową lub ustawą".

11 M. Wiącek, Art. 87 [w:] Konstytucja RP. Komentarz, t. II, Art. 87-243, red. M. Safjan, L. Bosek, Warszawa 2016, nb 40; M. Wiącek, Art. 93 [w:] Konstytucja RP. Komen- 
Akt normatywny jest tradycyjnie definiowany materialnie, jako norma prawna lub reguła abstrakcyjno-generalna ${ }^{12}$. Innymi słowy, na gruncie art. $417^{1} \$ 4$ k.c. „niewydanie aktu normatywnego" oznacza brak przepisów, na podstawie których można zrekonstruować określoną normę prawną o charakterze generalnym i abstrakcyjnym. Przeciwieństwem aktu normatywnego jest akt stosowania prawa. Natomiast, jak wynika z orzecznictwa TK oraz piśmiennictwa prawniczego, wprowadzenie stanu nadzwyczajnego jest właśnie aktem stosowania prawa ${ }^{13}$. Tym samym wydaje się, że brak przepisów wprowadzających stan nadzwyczajny nie stanowi „niewydania aktu normatywnego" w rozumieniu art. $417^{1} \$ 4$ k.c. W związku z tym trzeba stwierdzić, że nawet przy przyjęciu określonych założeń możliwość zasądzania odszkodowania - na podstawie art. $417^{1} \S 4$ k.c. - za szkodę wyrządzoną objęciem kwarantanną wydaje się wątpliwa.

\section{Odpowiedzialność odszkodowawcza Skarbu Państwa za zgodne z prawem wykonywanie władzy publicznej}

Dotychczas omówiono podstawy odpowiedzialności odszkodowawczej Skarbu Państwa za niezgodne działania lub zaniechania przy wykonywaniu władzy publicznej. Obowiązujące regulacje przewidują również możliwość uzyskania odszkodowania za działania zgodne z prawem. A mianowicie, jak stanowi art. $417^{2}$ k.c., „[j]eżeli przez zgodne z prawem wykonywanie władzy publicznej została wyrządzona szkoda na osobie, poszkodowany może żądać całkowitego lub częściowego jej naprawienia oraz zadośćuczynienia pieniężnego za doznaną krzywdę, gdy okoliczności, a zwłaszcza niezdolność poszkodowanego do pracy lub jego ciężkie położenie materialne, wskazują, że wymagają tego względy słuszności”.

tarz, t. II, Art. 87-243, red. M. Safjan, L. Bosek, Warszawa 2016, nb 12; P. Sobolewski, Art. $417^{1}$, op. cit., pkt II.13.

12 P. Sobolewski, Art. $417^{1}$, op. cit., pkt II.12; L. Bosek, Odpowiedzialność za wydanie albo niewydanie aktu normatywnego [w:] System prawa administracyjnego, t. 2, Konstytucyjne podstawy funkcjonowania administracji publicznej, red. R. Hauser, A. Wróbel, Z. Niewiadomski, Warszawa 2012, nb 188.

13 Zob. pkt III.1 uzasadnienia wyroku TK z 16 marca 2011 r., sygn. akt K 35/08, w którym stwierdzono: „[z]daniem Trybunału, wprowadzenie stanu wojennego ( $\$ 1$ uchwały) powinno być klasyfikowane jako akt stosowania prawa. Akt wprowadzenia stanu wojennego nie ustanawiał nowych norm prawnych, ale był zdarzeniem przesądzającym o tym, że znajdują zastosowanie normy prawne przewidziane na wypadek takiego stanu”. Jak dodał TK: „[w] podobny sposób na temat rozporządzeń wprowadzających stany nadzwyczajne wypowiadają się przedstawiciele nauki prawa na gruncie obecnego stanu prawnego (por. K. Działocha, Komentarz do art. 228 [w:] Konstytucja Rzeczypospolitej Polskiej. Komentarz, red. L. Garlicki, t. IV, Warszawa 2005, s. 6; M. Brzeziński, Stany nadzwyczajne w polskich konstytucjach, Warszawa 2007, s. 187)”. Por. M. Wiącek, Art. 87, op. cit., nb 41; P. Radziewicz, Art. 87 [w:] Konstytucja Rzeczypospolitej Polskiej. Komentarz, red. P. Tuleja, 2019, LEX, pkt 4. 
Przepis ten stanowi podstawę prawną odpowiedzialności odszkodowawczej Skarbu Państwa lub innego podmiotu (np. jednostki samorządu terytorialnego) oraz zadośćuczynienia za krzywdę na zasadzie słuszności za legalne działanie (tzw. szkoda legalna) władzy publicznej ${ }^{14}$. Jak wynika $z$ literalnego brzmienia tego przepisu, odpowiedzialnością na gruncie art. $417^{2}$ k.c. ustawodawca objął jedynie szkody na osobie. Ponadto, normując w art. $417^{2}$ k.c. możliwość przyznania odszkodowania lub zadośćuczynienia na zasadzie słuszności, pozostawił on sądom pewien zakres swobody w kwestii oceny indywidualnych okoliczności danego przypadku. Jedynie przykładowo wskazał, że takimi okolicznościami, które sądy w szczególności powinny brać pod uwagę w ramach tej oceny, są niezdolność poszkodowanego do pracy lub jego ciężkie położenie materialne ${ }^{15}$.

Mając powyższe na uwadze, trzeba stwierdzić, że nie jest wykluczone przyznanie przez sąd zadośćuczynienia oraz odszkodowania za szkodę na osobie wyrządzoną przez zgodne z prawem wykonywanie władzy publicznej w zakresie stosowania kwarantanny. W każdym przypadku będzie on musiał jednak ocenić, czy zachodzą wszystkie przesłanki z art. $417^{2}$ k.c., a przede wszystkim czy za zasądzeniem odszkodowania oraz zadośćuczynienia przemawiają względy słuszności.

\section{Naruszenie dóbr osobistych}

Zastosowanie kwarantanny wobec określonej osoby może niekiedy uzasadniać dochodzenie roszczeń z tytułu naruszenia jej dóbr osobistych. Zgodnie z art. 23 k.c. „[d]obra osobiste człowieka, jak w szczególności zdrowie, wolność, cześć, swoboda sumienia, nazwisko lub pseudonim, wizerunek, tajemnica korespondencji, nietykalność mieszkania, twórczość naukowa, artystyczna, wynalazcza i racjonalizatorska, pozostają pod ochroną prawa cywilnego niezależnie od ochrony przewidzianej w innych przepisach". Z przepisu tego wynika, że jednym z dóbr osobistych jest wolność. Jest ona rozumiana m.in. jako „swoboda poruszania się, jak i jako swoboda decyzji" ${ }^{16}$. W związku z tym wydaje się, że objęcie obowiązkową kwarantanną może stanowić naruszenie tego dobra.

Jak stanowi art. $24 \$ 1$ k.c.: „[t]en, czyje dobro osobiste zostaje zagrożone cudzym działaniem, może żądać zaniechania tego działania, chyba że nie jest ono bezprawne. $W$ razie dokonanego naruszenia może on także żądać, ażeby

14 Zob. np. P. Sobolewski, Art. $417^{2}$ [w:] Kodeks cywilny. Komentarz, red. K. Osajda, Warszawa 2020.

15 J. Kuźmicka-Sulikowska, Art. $417^{2}$ [w:] Kodeks cywilny. Komentarz, red. E. Gniewek, P. Machnikowski, Warszawa 2019, nb 3.

16 Zob. P. Machnikowski, Art. 23 [w:] Kodeks cywilny. Komentarz, red. E. Gniewek, P. Machnikowski, Warszawa 2019, nb 6. Por. J. Regan (Balcarczyk), Art. 23 [w:] Kodeks cywilny. Komentarz, red. M. Załucki, Warszawa 2019, nb 3; J. Panowicz-Lipska, Art. 23 [w:] Kodeks cywilny, t. I, Komentarz do art. 1-352, red. M. Gutowski, Warszawa 2018, nb 10. 
osoba, która dopuściła się naruszenia, dopełniła czynności potrzebnych do usunięcia jego skutków, w szczególności ażeby złożyła oświadczenie odpowiedniej treści i w odpowiedniej formie. Na zasadach przewidzianych w kodeksie może on również żądać zadośćuczynienia pieniężnego lub zapłaty odpowiedniej sumy pieniężnej na wskazany cel społeczny”. Jedną z przesłanek zastosowania środków ochrony, które ten przepis przewiduje, jest bezprawność działania ${ }^{17}$. W orzecznictwie oraz piśmiennictwie przyjmuje się, że bezprawne jest zachowanie sprzeczne $\mathrm{z}$ prawem lub zasadami współżycia społecznego ${ }^{18}$. Przy czym działanie na podstawie prawa wyklucza bezprawność ${ }^{19}$. A zatem, dochodzenie roszczeń z tytułu naruszenia dóbr osobistych danej osoby przez objęcie jej kwarantanną jest możliwe, o ile kwarantanna została zastosowana niezgodnie z prawem (tj. np. przez niewłaściwy organ albo w sytuacji braku podstaw prawnych do jej zastosowania wobec określonej osoby).

\section{Podsumowanie}

- Według obowiązujących regulacji obowiązek poddania się kwarantannie może powstać na skutek indywidualnych rozstrzygnięć organów inspekcji sanitarnej, z mocy prawa oraz na skutek skierowania danej osoby do obycia kwarantanny przez lekarza.

- Podstawy prawne odpowiedzialności odszkodowawczej Skarbu Państwa formułuje art. 417 , art. $417^{1}$ oraz art. $417^{2}$ Kodeksu cywilnego.

- Artykuł 417 k.c. mógłby stanowić podstawę odpowiedzialności Skarbu Państwa za szkodę wyrządzoną przez działanie lub zaniechanie przy wykonywaniu władzy publicznej w zakresie dotyczącym stosowania kwarantanny, jeżeli szkoda powstałaby na skutek działania lub zaniechania niezgodnego z prawem, a w szczególności niezgodnego z przepisami ustawy o zapobieganiu oraz zwalczaniu zakażeń i chorób zakaźnych u ludzi oraz przepisami aktów wykonawczych wydanych na jej podstawie. Przy czym jeżeli szkoda zostałaby wyrządzona przez wydanie prawomocnego orzeczenia lub ostatecznej decyzji o objęciu kwa-

17 Dodatkowe przesłanki mogą się różnić w zależności od tego, czy dochodzone są roszczenia niemajątkowe czy majątkowe. Zob. np. art. 448 k.c. (roszczenia majątkowe) oraz wątpliwości interpretacyjne, które on budzi w piśmiennictwie (np. A. Olejniczak, Art. 448 [w:] Kodeks cywilny. Komentarz, t. III, Zobowiązania - część ogólna, red. A. Kidyba, 2014, LEX, pkt 8; P. Sobolewski, Art. 448 [w:] Kodeks cywilny. Komentarz, red. K. Osajda, Warszawa 2017, pkt A.2.

18 P. Sobolewski, Art. 24 [w:] Kodeks cywilny. Komentarz, red. K. Osajda, Warszawa 2017, pkt VI.16; wyrok SN z 25 października 1982 r., sygn. akt I CR 239/82, Legalis nr 23387.

19 Zob. P. Sobolewski, Art. 24, op. cit., pkt VII.2; J. Regan (Balcarczyk), Art. 24 [w:] Kodeks cywilny. Komentarz, red. M. Załucki, Warszawa 2019, nb 3. 
rantanną, jej naprawienia można byłoby żądać na podstawie art. $417^{1} \S 2$ zdanie pierwsze k.c. po stwierdzeniu we właściwym postępowaniu ich niezgodności z prawem.

- Artykuł $417^{1} \S 1$ k.c. mógłby stanowić podstawę odpowiedzialności Skarbu Państwa za szkodę wyrządzoną przez objęcie kwarantanną, m.in. jeśli przepisy prawa nakładające obowiązek odbycia kwarantanny zostałyby uznane we właściwym postępowaniu za niezgodne z Konstytucją, ratyfikowaną umową międzynarodową lub ustawą. W szczególności przepis ten mógłby stanowić podstawę roszczeń wówczas, gdy Trybunał Konstytucyjny stwierdziłby, iż regulacje dotyczące obowiązku kwarantanny są niezgodne z Konstytucją. Przy czym, mając na względzie art. $417^{1} \$ 2$ k.c., w sytuacji gdy na podstawie aktu normatywnego zakwestionowanego przez Trybunał zostałoby wydane prawomocne orzeczenie lub ostateczna decyzja o objęciu kwarantanną, poszkodowany w celu dochodzenia odszkodowania musiałby uzyskać stwierdzenie niezgodności z prawem tego orzeczenia lub decyzji. Ponadto na podstawie art. $417^{1} \$ 1$ k.c. sąd mógłby przyznać odszkodowanie gdyby miał przesłanki do tego, aby przyjąć, że regulacje dotyczące obowiązku kwarantanny są sprzeczne z prawem UE, a pomiędzy tymi regulacjami a szkodą w danym przypadku istnieje adekwatny związek przyczynowy. Przy czym kwestia konieczności uzyskania prejudykatu właściwego organu stwierdzającego tę sprzeczność jest w doktrynie prawa dyskusyjna.

- Możliwość zasądzania odszkodowania za szkodę wyrządzoną objęciem kwarantanną na podstawie art. $417^{1} \$ 4$ k.c., który ustanawia odpowiedzialność za tzw. zaniechanie legislacyjne, wydaje się wątpliwa.

- Jeżeli przez zgodne z prawem wykonywanie władzy publicznej w zakresie stosowania kwarantanny zostałaby wyrządzona szkoda na osobie, poszkodowany mógłby - na podstawie art. $417^{2}$ k.c. - żądać całkowitego lub częściowego jej naprawienia oraz zadośćuczynienia pieniężnego za doznaną krzywdę, gdy okoliczności, a zwłaszcza niezdolność poszkodowanego do pracy lub jego ciężkie położenie materialne, wskazywałyby, że wymagają tego względy słuszności.

- Zastosowanie kwarantanny wobec określonej osoby może uzasadniać dochodzenie roszczeń z tytułu naruszenia jej dóbr osobistych. Przy czym jedną z przesłanek dochodzenia roszczeń z tego tytułu jest zastosowanie kwarantanny niezgodnie z prawem (tj. np. przez niewłaściwy organ albo w sytuacji braku podstaw prawnych do jej zastosowania wobec określonej osoby).

\section{Bibliografia}

Banaszczyk Z., Art. $417^{1}$ [w:] Kodeks cywilny, t. I, Komentarz. Art. 1-449 ${ }^{10}$, red. K. Pietrzykowski, Warszawa 2018. 
Banaszczyk Z., Odpowiedzialność za szkodę wyrządzona przy wykonywaniu władzy publicznej [w:] System prawa prywatnego, t. 6, Prawo zobowiązań - część ogólna, Warszawa 2018.

Bosek L., Odpowiedzialność za wydanie albo niewydanie aktu normatywnego [w:] System prawa administracyjnego, t. 2, Konstytucyjne podstawy funkcjonowania administracji publicznej, red. R. Hauser, A. Wróbel, Z. Niewiadomski, Warszawa 2012.

Kremis J., Art. 417¹ [w:] Kodeks cywilny. Komentarz, red. E. Gniewek, P. Machnikowski, Warszawa 2016.

Kuźmicka-Sulikowska J., Art. 417 , art. $417^{2}$ [w:] Kodeks cywilny. Komentarz, red. E. Gniewek, P. Machnikowski, Warszawa 2019.

Machnikowski P., Art. 23 [w:] Kodeks cywilny. Komentarz, red. E. Gniewek, P. Machnikowski, Warszawa 2019.

Olejniczak A., Art. 417¹ art. 448 [w:] Kodeks cywilny. Komentarz, t. III, Zobowiązania część ogólna, red. A. Kidyba, 2014, LEX.

Panowicz-Lipska J., Art. 23 [w:] Kodeks cywilny, t. I, Komentarz do art. 1-352, red. M. Gutowski,Warszawa 2018.

Radziewicz P., Art. 87 [w:] Konstytucja Rzeczypospolitej Polskiej. Komentarz, red. P. Tuleja, 2019, LEX.

Regan (Balcarczyk) J., Art. 23, art. 24 [w:] Kodeks cywilny. Komentarz, red. M. Załucki, Warszawa 2019.

Sobolewski P., Art. 24, art. 361, art. 417, art. 417 , art. 448 [w:] Kodeks cywilny. Komentarz, red. K. Osajda, Warszawa 2017.

Sobolewski P., Art. $417^{2}$ [w:] Kodeks cywilny. Komentarz, red. K. Osajda, Warszawa 2020.

Wiącek M., Art. 87, art. 93 [w:] Konstytucja RP. Komentarz, t. II, Art. 87-243, red. M. Safjan, L. Bosek, Warszawa 2016. 


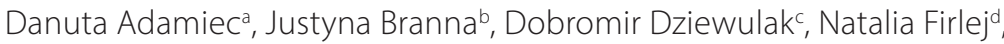
Kamila Groszkowskae, Marta Karkowskaf, Daniela Kupis's, Marcin Mróz' Jarosław Szymanek', Angelina Tazuszeli, Łukasz Żołądek ${ }^{k}$

\title{
Uregulowania dotyczące wniosków formalnych zawarte w regulaminach parlamentów wybranych państw członkowskich UE, Wielkiej Brytanii, Stanów Zjednoczonych i Parlamentu Europejskiego $^{1}$
}

\author{
Regulations concerning 'points of order' stipulated in the rules \\ of procedure in selected EU Member States, the United Kingdom, \\ the United States and the European Parliament
}

\begin{abstract}
The paper concerns selected issues related to parliamentary procedures. The primary aim is to investigate a particular category of motions, defined by rules of procedure of the Polish parliament as points of order (literally "formal motions"). In Poland, points of order are recognised as a separate category of motions. They may be submitted only in respect of matters being the subject of the orders of the day or the proceedings in a sitting and include, inter alia, motions to: suspend, postpone or close the sitting; close the discussion; alter the procedure of the discussion; close the list of speakers; limit the time of speeches; confirm a quorum. The authors examine how motions of similar subject scope are regulated in foreign national parliaments.
\end{abstract}

Keywords: point of order, standing orders of parliament, parliament

W opracowaniu omówiono przepisy regulaminów parlamentów narodowych wybranych państw członkowskich UE, a także Wielkiej Brytanii, Stanów Zjednoczonych i regulaminu Parlamentu Europejskiego, odnoszące się do kwestii objętych w regulaminie Sejmu RP pojęciem „wniosków formalnych". Pojęcie to nie zostało wyodrębnione we wszystkich omówionych regulaminach parlamentarnych. W wielu z nich regulacja odpowiadająca przedmiotowo poszczególnym wnioskom formalnym wyodrębnionym na gruncie regulaminu Sejmu pozostaje rozproszona. Z kolei w niektórych regulaminach, choć pojęcie wniosku formalnego zostało wyodrębnione, to nie zostało ono zdefiniowane i nie przewidziano zamkniętego katalogu takich wniosków.

Słowa kluczowe: wniosek formalny, regulamin parlamentu, parlament

Doktor nauk prawnych, specjalista ds. informacji europejskiej •

Kancelaria Sejmu, Biuro Analiz Sejmowych, Wydział Analiz Prawa Międzynarodowego

i Zagranicznych Systemów Prawnych, WARSZAWA, POLSKA •

danuta.adamiec@sejm.gov.pl • https://orcid.org/0000-0002-6600-4309

1 Informacja na temat uregulowań dotyczacych wniosków formalnych zawartych $w$ regulaminach parlamentów wybranych państw członkowskich UE, Wielkiej Brytanii, Stanach Zjednoczonych i Parlamentu Europejskiego sporządzona 9 grudnia 2020 r. na zlecenie Dyrektora Biura Analiz Sejmowych, BAS-ZSP-2671/20. 
b Specjalista ds. informacji europejskiej -

Kancelaria Sejmu, Biuro Analiz Sejmowych, Wydział Analiz Prawa Międzynarodowego i Zagranicznych Systemów Prawnych, WARSZAWA, POLSKA •

justyna.branna@sejm.gov.pl • https://orcid.org/0000-0002-9653-9996

c Doktor nauk humanistycznych, adiunkt

Uniwersytet Warszawski, Wydział Pedagogiczny, Katedra Dydaktyki i Pedeutologii, WARSZAWA, POLSKA

dobromir.dziewulak@uw.edu.pl • https://orcid.org/0000-0002-7974-8024

d Specjalista ds. informacji europejskiej •

Kancelaria Sejmu, Biuro Analiz Sejmowych, Wydział Analiz Prawa Międzynarodowego i Zagranicznych Systemów Prawnych, WARSZAWA, POLSKA •

natalia.firlej@sejm.gov.pl • https://orcid.org/0000-0002-9522-5522

e Specjalista ds. międzynarodowych

Kancelaria Sejmu, Biuro Analiz Sejmowych, Wydział Analiz Prawa Międzynarodowego ¡ Zagranicznych Systemów Prawnych, WARSZAWA, POLSKA .

kamila.groszkowska@sejm.gov.pl • https://orcid.org/0000-0002-8618-1302

f Doktor nauk humanistycznych, adiunkt -

Polska Akademia Nauk, Instytut Filozofii i Socjologii, WARSZAWA, POLSKA •

mkarkowska@ifispan.edu.pl • https://orcid.org/0000-0003-0747-4332

g Specjalista ds. informacji europejskiej •

Kancelaria Sejmu, Biuro Analiz Sejmowych, Wydział Analiz Prawa Międzynarodowego

i Zagranicznych Systemów Prawnych, WARSZAWA, POLSKA •

daniela.kupis@sejm.gov.pl . https://orcid.org/0000-0003-0075-9837

h Specjalista ds. międzynarodowych

Kancelaria Sejmu, Biuro Analiz Sejmowych, Wydział Analiz Prawa Międzynarodowego

i Zagranicznych Systemów Prawnych, WARSZAWA, POLSKA •

marcin.antoni.mroz@gmail.com • https://orcid.org/0000-0001-5033-2132

Doktor hab. nauk humanistycznych, specjalista ds. społecznych •

Kancelaria Sejmu, Biuro Analiz Sejmowych, Wydział Analiz Społecznych i Ekonomicznych, WARSZAWA, POLSKA -

jaroslaw.szymanek@sejm.gov.pl • https://orcid.org/0000-0002-0590-5218

Specjalista ds. informacji europejskiej

Kancelaria Sejmu, Biuro Analiz Sejmowych, Wydział Analiz Prawa Międzynarodowego

i Zagranicznych Systemów Prawnych, WARSZAWA, POLSKA •

angelina.tazuszel@sejm.gov.pl • https://orcid.org/0000-0003-2436-256X

k Specjalista ds. międzynarodowych •

Kancelaria Sejmu, Biuro Analiz Sejmowych, Wydział Analiz Prawa Międzynarodowego

i Zagranicznych Systemów Prawnych, WARSZAWA, POLSKA •

lukasz.zoladek@sejm.gov.pl • https://orcid.org/0000-0001-5247-6228 


\section{Przedmiot opracowania}

W opracowaniu przedstawiono informacje na temat uregulowań dotyczących wniosków formalnych zawartych w regulaminach 19 parlamentów wybranych państw: państw członkowskich UE (Austrii, Belgii, Czech, Danii, Estonii, Finlandii, Francji, Hiszpanii, Irlandii, Luksemburga, Łotwy, Niderlandów, Niemiec, Portugalii, Słowacji, Szwecji, Włoch), a także Stanów Zjednoczonych, Wielkiej Brytanii oraz Parlamentu Europejskiego (dalej: PE). W przygotowaniu niniejszej informacji wykorzystano obcojęzyczne akty prawne oraz obcojęzyczną i polską literaturę przedmiotu. Przeanalizowano regulaminy izb oraz informacje dostępne na stronach internetowych poszczególnych parlamentów. Posiłkowano się także materiałami znajdującymi się w bazie Europejskiego Centrum Badań i Dokumentacji Parlamentarnej (European Centre for Parliamentary Research and Documentation, ECPRD).

\section{Wnioski z opracowania}

Kategoria wniosków formalnych, niezależnie od tego jak nazwanych, jest obecna w większości przepisów regulaminowych parlamentów świata. Nie zawsze jednak wnioski takie nazywane są wprost wnioskami formalnymi czy - co występuje bodajże najczęściej - wnioskami proceduralnymi bądź porządkowymi, a częstą praktyką jest ich określenie przedmiotowe (np. wniosek o zamknięcie obrad, wniosek o odesłanie do komisji, wniosek o przestrzeganie regulaminu, wniosek o zmianę sposobu głosowania).

Konfrontując uwagi porównawcze z przepisami art. 184 regulaminu Sejmu, należy jednak zwrócić uwagę, że, po pierwsze, bardzo rzadko wnioski o charakterze formalnym są przedmiotem uregulowania w jednym obszernym artykule (wyjątkiem jest PE oraz - w mniejszym stopniu - Słowacja i Włochy). Najczęściej są one rozproszone w całym tekście regulaminu. Po drugie, w wielu wypadkach są one istotnie limitowane i sprowadzone do kluczowych spraw, stąd też polskie rozwiązanie przewidujące aż 12 typów wniosków formalnych (czy też zakresów, jakich mogą one dotyczyć) jest ewenementem. Zazwyczaj w regulaminach parlamentarnych przewidzianych jest kilka (ok. pięciu) spraw, które odpowiadają polskiemu wnioskowi formalnemu. Są to najczęściej wnioski o:

- zmianę porządku obrad,

- zmianę sposobu głosowania lub odroczenie głosowania,

- zamknięcie debaty,

- odesłanie do komisji,

- przestrzeganie regulaminu.

Po trzecie, bardzo często występują rozmaitego rodzaju ograniczenia związane z dopuszczalnością wniosku formalnego. Ograniczenia takie zazwyczaj sprowadzają się do: 
- wskazania minimalnej liczby posłów, którzy z wnioskiem mogą wystąpić (np. w Luksemburgu co najmniej 5 posłów),

- ograniczenia możliwości wystąpienia z jednym rodzajem wniosku formalnego w trakcie trwania jednego posiedzenia (np. Słowacja),

- wyraźnego zastrzeżenia, że nie jest możliwe zgłoszenie wniosku w sprawie podobnej czy identycznej, jeśli wniosek został już wcześniej odrzucony (np. Niemcy),

- ograniczenia czasu na przedstawienie wniosku formalnego (od minuty do kilku minut, np. w Parlamencie Europejskim maksymalnie jedna minuta, w niemieckim Bundestagu 5 minut),

- ograniczenia ewentualnej dyskusji nad wnioskiem (we Włoszech maksymalnie do 5 minut),

- całkowitego wyłączenia dyskusji nad wnioskiem (Słowacja),

- możliwości odebrania głosu przez przewodniczącego w sytuacji, kiedy mówca odbiega od meritum (PE),

- ograniczenia czasowego związanego z przedkładaniem niektórych wniosków (np. wnioski o zmianę porządku posiedzenia muszą być złożone przed jego rozpoczęciem - Austria, Włochy),

- nakazu pisemnego sformułowania wniosku (np. Czechy, Słowacja, Łotwa),

- konieczności wskazania przepisu regulaminowego, który został naruszony w razie wniosku o złamanie regulaminu (Stany Zjednoczone, PE),

- przyznania przewodniczącemu izby pewnej uznaniowości w dopuszczaniu posłów do zgłaszania wniosków (Belgia, Dania, Hiszpania, USA, Luksemburg),

- przyznania przewodniczącemu izby fakultatywności w poddawaniu wniosków pod głosowanie, co jest skorelowane z założeniem, że dysponentem wniosku jest przewodniczący a nie izba (Włochy),

- prawa każdego członka izby do wystąpienia z żądaniem przedstawienia wniosku w formie pisemnej (USA),

- niepoddawania wniosków pod głosowanie w razie przekonania, że większość członków izby popiera go, czyli domniemanie jego przyjęcia (Słowacja),

- preferencyjnego traktowania wniosków formalnych zgłoszonych np. przez rząd (Francja).

Należy ponadto zauważyć, że poszczególne rozwiązania dotyczące wniosków formalnych najczęściej nie są samoistne. Wiążą się one m.in.: a) z ogólną koncepcją roli przewodniczącego izby (podmiot niezależny albo osoba wspierająca większość parlamentarną); b) dopuszczeniem innych niż sam regulamin sposobów uregulowania pracy izby i, co za tym idzie, odwoływanie się do praktyki, zwyczajów i obyczajów parlamentarnych; c) mechanizmami organizacji dyscypliny partyjnej w obrębie klubów parlamentarnych. 


\section{Pojęcie wniosku formalnego}

Treścią regulacji zawartej w art. 184 regulaminu Sejmu jest instytucja tzw. wniosku formalnego. Wniosek formalny jest szczególnego rodzaju wnioskiem. Podstawą formalną wniosku materialnego jest art. 14 ust. 1 pkt 1 ustawy o wykonywaniu mandatu posła i senatora, który stanowi, że w wykonywaniu swoich obowiązków poselskich poseł w szczególności ma prawo „zgłaszać wnioski w sprawach rozpatrywanych na posiedzeniach Sejmu i Senatu i jego organów”. Oznacza to, że „wnioski materialne, tam gdzie ich stawianie przez posłów (indywidualnie lub grupowo) jest dopuszczalne, służą wprost realizacji kompetencji Sejmu"'.

$\mathrm{W}$ przeciwieństwie do wniosków materialnych wnioski formalne są w istocie wnioskami, których celem nie jest oddziaływanie na treść rozstrzygnięć podejmowanych przez izbę, tylko skorygowanie toku pracy izby. Istotą każdego wniosku formalnego jest to, że jego przyjęcie „oznacza ingerencję i z reguły skorygowanie toku obrad nad poszczególnymi punktami porządku dziennego, odejście od toku wzorcowego, który polega na swobodzie kierowania obradami przez Marszałka Sejmu” ${ }^{3}$. Ponadto należy mieć na uwadze, że wnioski formalne „mogą dotyczyć wyłącznie spraw będących przedmiotem porządku dziennego i przebiegu posiedzenia" (art. 184 ust. 2 regulaminu). Oznacza to, że rozstrzygnięcie podjęte na podstawie zgłoszonego wniosku formalnego odnosi się wyłącznie do konkretnej sprawy porządku dziennego.

$\mathrm{W}$ efekcie wniosek formalny to wniosek składany w toku plenarnego posiedzenia Sejmu, poza porządkiem obrad, wyłącznie w sprawach będących przedmiotem porządku dziennego i przebiegu posiedzenia, którego zakres przedmiotowy jest enumeratywnie zapisany w treści art. 184 regulaminu Sejmu ${ }^{4}$.

W art. 184 regulaminu Sejmu wskazano, że do wniosków formalnych zalicza się wnioski o 12 różnych czynności, m.in. wniosek o przerwanie, odroczenie lub zamknięcie posiedzenia; wniosek o uchwalenie tajności posiedzenia; wniosek o stwierdzenie kworum; wniosek o odesłanie do komisji; wniosek o zmianę w sposobie prowadzenia dyskusji; wniosek o przeliczenie głosów. Artykuł 184 regulaminu Sejmu określa tryb postępowania w odniesieniu do wniosków formalnych, m.in. zgłoszenie ustne $\mathrm{w}$ trakcie obrad (co do zasady), rozstrzyganie większością głosów, wystąpienie trwające nie dłużej niż 2 minuty.

W regulaminach parlamentów wybranych państw członkowskich UE oraz Parlamentu Europejskiego, które przedstawiono w niniejszym opracowaniu,

2 P. Sarnecki, Art. 184 [w:] Komentarz do Regulaminu Sejmu Rzeczypospolitej Polskiej, red. A. Szmyt, Warszawa 2018, s. 832.

3 Ibidem, s. 184.

4 Por. P. Chybalski, Wniosek formalny [w:] Wielki słownik parlamentarny, red. J. Szymanek, Warszawa 2018, s. 1081. 
wnioski formalne, tak lub podobnie nazwane, stanowią odrębną kategorię w Belgii, Estonii, Francji, Luksemburgu, Niderlandach, Niemczech, we Włoszech i na Słowacji. Poza tym kategoria wniosku formalnego, pod nazwą wniosku proceduralnego, występuje też na gruncie regulaminu Parlamentu Europejskiego. Natomiast niektóre czynności wymienione w art. 184 regulaminu Sejmu, które odpowiadają kwestiom tradycyjnie podejmowanym we wnioskach formalnych, w regulaminach parlamentów Austrii, Czech, Danii, Finlandii, Hiszpanii, Irlandii, Łotwy i Szwecji są przedmiotem wniosków proceduralnych lub porządkowych. W tym ostatnim przypadku nie są one jednak skategoryzowane i objęte jednym wspólnym mianem ani jednakowym trybem postępowania. Często z uwagi na specyfikę określonych czynności do każdej z nich stosuje się pewne odmienności proceduralne. Ponadto są one ujęte w różnych przepisach regulaminów parlamentów i nie składają się na jedną kategorię podlegającą temu samemu trybowi postępowania.

\section{Przegląd porównawczy}

\section{AUSTRIA - Rada Narodowa (Nationalrat)}

W parlamencie Austrii odpowiednikiem regulaminu Sejmu jest akt prawny o nazwie „Ustawa o porządku obrad Rady Narodowej” - Bundesgesetz über die Geschäftsordnung des Nationalrates (w skrócie ustawa o porządku obrad - Geschäftsordnungsgesetz 1975, GOG-NR) ${ }^{5}$. Ustawa ta nie zawiera terminu czy kategorii „wniosek formalny”. Nie znalazł tu także zastosowania tzw. wniosek porządkowy (Geschäftsordnungsantrag) ${ }^{6}$, z jakim mamy do czynienia np. w niemieckim Bundestagu ${ }^{7}$.

$\mathrm{W}$ regulaminie poświęcono odrębne miejsce jedynie wybranym kwestiom dotyczącym zmian $\mathrm{w}$ porządku dziennym posiedzenia lub sprawom mającym wpływ na przebieg posiedzeń. Zawarto je głównie w $\$ 49$ i $\$ 50$, zaś kluczowym kwestiom poświęcono fragment $\$ 49$ ust. 5 ustawy o porządku obrad, który dotyczy zmian w porządku obrad (Tagesordnung).

Zgodnie z tym przepisem Rada Narodowa może zdecydować większością 2/3 głosów o tym, że punkt porządku obrad zostanie z niego usunięty lub że punkt nieuwzględniony w porządku obrad zostanie poddany debacie. Taka decyzja podejmowana jest na wniosek przewodniczącego izby lub na wniosek posła na samym początku posiedzenia, wyłącznie przed ogłoszeniem przejścia do porządku obrad (Vor Eingang in die Tagesordnung). Zaznaczyć należy, że zgodnie z $\$ 49$ ust. 4 ustawy o porządku obrad przed przejściem do porządku obrad przewod-

5 Https://www.ris.bka.gv.at/GeltendeFassung.wxe?Abfrage=Bundesnormen\&Gesetzes nummer $=10000576$.

6 Https://www.ris.bka.gv.at.

7 Zob. informacja dotycząca wniosku formalnego w Niemczech. 
niczący może zmienić kolejność lub połączyć kilka punktów porządku obrad, by przeprowadzić nad nimi jedną debatę. W razie sprzeciwu co do takich zmian przedstawionego przez posłów, Rada Narodowa podejmuje decyzję bez debaty w zwykłym trybie (większością głosów).

W $₫ 49$ ust. 6 wskazano też, że przewodniczący, po konsultacji z członkami Konferencji Prezydialnej Rady Narodowej (Präsidialkonferenz dem Nationalrat) ${ }^{8}$, którą tworzą przewodniczący Rady Narodowej oraz przedstawiciele klubów parlamentarnych, może zaproponować Radzie Narodowej usunięcie jednego lub więcej punktów z porządku obrad już w trakcie posiedzenia, po przejściu do porządku obrad. Ostatecznie przedstawienie takiej propozycji leży wyłącznie w gestii przewodniczącego izby i jest jego samodzielną decyzją. Po ogłoszeniu takiej propozycji finalną decyzję $\mathrm{w}$ sprawie usunięcia jednego lub więcej punktów z porządku obrad bez debaty podejmuje Rada Narodowa większością dwóch trzecich głosów.

Do kwestii związanych z porządkiem dziennym obrad już po jego ustaleniu, ale przed otwarciem porządku dziennego obrad, nawiązano także w kolejnym paragrafie, gdzie mowa o sprzeciwie do porządku dziennego ogłoszonego przez przewodniczącego izby.

Zgodnie z $\$ 50$ istnieje możliwość zgłoszenia przez posłów sprzeciwu do ogłoszonego wcześniej porządku obrad. Wynika to z regulaminu, w którym mowa o tym, że przewodniczący co do zasady ogłasza dzień, godzinę i - jeśli to możliwe - porządek obrad następnej zaplanowanej sesji na koniec każdego takiego spotkania Rady. Zgodnie z $\$ 50$ ust. 1 może to również zrobić za pomocą pisemnego zawiadomienia rozesłanego $\mathrm{w}$ sali plenarnej.

W razie wniesienia takiego sprzeciwu dotyczącego porządku obrad i w sytuacji, gdy przewodniczący nie przyłączy się do niego, to Rada Narodowa decyduje o przyjęciu lub odrzuceniu sprzeciwu (w zwykłym trybie). Decyzję poprzedza ogólna debata nad wszystkimi zgłoszonymi w takim wypadku sprzeciwami. Jest ona obligatoryjna. Parlamentarzyści mogą zgłosić sprzeciw wobec jednego punktu, ale też kilku. Przewodniczący może ograniczyć czas wypowiedzi poszczególnych posłów do 5 minut, a liczbę mówców do trzech na klub. Na wniosek pięciu posłów należących do tego samego klubu odbywa się odrębna debata dotycząca wszystkich zastrzeżeń zgłoszonych przez ten klub, przy czym przewodniczący może ograniczyć czas wystąpień i liczbę mówców w taki sam sposób jak w ogólnej debacie. W przypadku większej liczby zastrzeżeń przewodniczący ustala kolejność debat nad kolejnymi sprzeciwami, biorąc pod uwagę ogólne za-

8 Konferencja Prezydialna Rady Narodowej jest organem doradczym przy opracowywaniu planów pracy Rady Narodowej, ustalaniu porządków obrad i terminów posiedzeń oraz koordynowaniu prac komisji. Jego rola jako organu arbitrażowego ma kluczowe znaczenie dla prac parlamentarnych: zwłaszcza w przypadku konfliktów dotyczących interpretacji i stosowania regulaminu. 
sady, o których mowa w $\$ 60$ ust. $3^{9}$. Wszystkie zgłoszone zastrzeżenia muszą być poddane pod głosowanie po odbyciu debaty lub w przypadku debat wielokrotnych - po ostatniej z nich. Wobec braku sprzeciwu większości posłów co do sposobu prowadzenia obrad (np. kolejności poruszanych spraw w przypadku debat wielokrotnych) przyjmuje się propozycję przewodniczącego w tej sprawie.

\section{BELGIA - Izba Reprezentantów (Ia Chambre)}

Regulacje dotyczące wniosków formalnych (un rappel au Règlement) w regulaminie Izby Reprezentantów (Règlement de la Chambre ${ }^{10}$ ) zostały określone w art. 44 ust. 7 oraz art. 49 ust. 2.

Zgodnie z ogólną zasadą wyrażoną w art. 44 ust. 1 regulaminu deputowany nie może zabierać głosu podczas posiedzenia, o ile nie zostanie zarejestrowany lub o ile przewodniczący izby nie udzieli mu głosu na jego prośbę. Artykuł 44 ust. 7 regulaminu określa, że przewodniczący izby może ${ }^{11}$ zezwolić deputowanemu na przerwanie osobie, której przyznano prawo głosu, tylko z powodu zgłoszenia wniosku formalnego, jest to jednak zawsze swobodna decyzja przewodniczącego. Może on udzielić także zgody na krótką interwencję, o ile dotyczy ona omawianego właśnie tematu. Jeżeli taki deputowany odbiega od tematu, przewodniczący pozbawia go prawa głosu. Deputowany, który został pozbawiony głosu, nie może złożyć kolejnego wniosku formalnego lub przerwać wypowiedzi innej osoby po raz drugi w czasie tego samego posiedzenia. Jeżeli deputowany nie przerywa swojej wypowiedzi, mimo pozbawienia go prawa głosu przez przewodniczącego izby, przewodniczący może zadecydować o nieuwzględnianiu wypowiedzi deputowanego w protokole posiedzenia.

Zgodnie z art. 49 ust. 2 regulaminu deputowany może zawsze zwrócić się do przewodniczącego o udzielenie prawa głosu w celu zgłoszenia wniosku formalnego, w celu zajęcia stanowiska w debacie na temat porządku obrad, ustalania treści pytań lub przyznania priorytetu określonemu punktowi obrad. Artykuł 49 nie określa, ile wniosków formalnych można wnieść, nie precyzuje również, ile czasu deputowany ma na zabranie głosu.

9 Przewodniczący ustala kolejność, w jakiej wypowiadają się posłowie, o ile rozstrzygająca nie jest kolejność zgłoszeń. Jeżeli dwóch lub więcej mówców „za” lub dwóch lub więcej mówców „przeciw” zarejestruje się w tym samym czasie, przewodniczący ustala kolejność tak, by jako pierwszy głos zabrał mówca „przeciw”, a następnie, na przemian mówili posłowie „za” i „przeciw”. Przewodniczący jest też zobowiązany prowadzić debatę w taki sposób, aby w jej trakcie mogły być zaprezentowane wszystkie punkty widzenia dotyczące danej kwestii. Jest też zobowiązany wziąć pod uwagę siłę klubu i różnorodność mówców z każdego z nich.

10 Règlement de la Chambre, https://www.dekamer.be/kvvcr/pdf_sections/publications/reglement/reglementFR.pdf.

11 „Le président peut autoriser un membre à interrompre un orateur uniquement pour un rappel au Règlement ou pour une courte intervention sur le fond de la question”. 


\section{CZECHY - Izba Poselska (Poslanecká sněmovna)}

W regulaminie czeskiej Izby Poselskiej ${ }^{12}$ kwestię składania wniosków przez posłów uregulowano $\mathrm{w} \$ 63. Przepis ten przewiduje różne rodzaje wniosków ${ }^{13}$, a ich przedmiot w niektórych wypadkach może stanowić odpowiednik spraw, które obejmuje wniosek formalny określony w art. 184 regulaminu Sejmu (np. wniosek o odesłanie do innego organu Izby Poselskiej).

Zgodnie z $\$ 63$ ust. 1 poseł może podczas debaty przedstawiać wnioski - mają one odnosić się do konkretnej omawianej sprawy i musi z nich wynikać, jaką Izba ma podjąć decyzję. Przewodniczący może poprosić posła o doprecyzowanie wniosku lub przedłożenie go na piśmie. Zgodnie z $\$ 65$ wnioskujący przedstawia wniosek w swoim języku ojczystym. Jeżeli wnioskujący nie mówi po czesku, jego wystąpienie jest tłumaczone na język czeski, o ile zwróci się o to przynajmniej jeden poseł.

Ponadto w regulaminie Izby Poselskiej w $\$ 60$ przewidziano możliwość wygłoszenia przez posła tzw. uwagi faktycznej (faktická poznámka), w której reaguje on na przebieg debaty. Za uwagę faktyczną uznaje się również wniosek proceduralny (procedurální návrh) odnoszący się do sposobu rozpatrzenia danego punktu porządku obrad. W ramach uwagi faktycznej nie można przedstawiać merytorycznego stanowiska w omawianej sprawie. Poseł, który zgłasza się do uwagi faktycznej, otrzymuje głos w pierwszej kolejności, jednak bez przerywania osobie, która właśnie zabiera głos ${ }^{14}$. Z brzmienia $\$ 60$ ust. 1 wynika, że przewodniczący udziela głosu posłowi, który zgłasza się do wygłoszenia uwagi faktycz-

12 Jednací řád Poslanecké sněmovny, https://www.psp.cz/docs/laws/1995/90_index.html.

13 Wyróżnia się następujące rodzaje wniosków (návrhy):

1) wniosek o odroczenie (poseł proponuje rozpatrzenie omawianego projektu w późniejszym terminie),

2) wniosek o odrzucenie (w wyniku przyjęcia takiego wniosku projekt nie będzie już przedmiotem debaty ani głosowania),

3) wniosek o odesłanie do innego organu Izby Poselskiej (ze wskazaniem terminu na zakończenie przez ten organ prac),

4) wniosek w sprawie rozpatrzenia innego projektu (gdy w tej samej sprawie przedłożono więcej niż jeden projekt, izba decyduje, który rozpatrzyć),

5) wniosek zmieniający (zmiana, pominięcie lub uzupełnienie pierwotnego tekstu, przy czym do wniosku zmieniającego nie można złożyć kolejnego wniosku zmieniającego),

6) wniosek ewentualny (gdy rozstrzygnięcie danej sprawy wymaga rozstrzygnięcia innej sprawy),

7) wniosek dodatkowy (rozszerzenie lub uzupełnienie pierwotnego tekstu, jeżeli nie można złożyć wniosku zmieniającego),

8) wniosek warunkowy (uzależnia ważność uchwały od spełnienia określonego warunku, przy czym wniosek warunkowy nie może być przyjęty przy uchwalaniu projektu ustawy),

9) wniosek o usunięcie części projektu (sekcji, paragrafu, akapitu itp.).

14 „Poslanec, který se přihlásil k faktické poznámce, dostane slovo přednostně”. 
nej. W regulaminie nie wprowadzono ograniczenia ilościowego $\mathrm{w}$ odniesieniu do zgłaszania uwag faktycznych. Zgodnie z $\$ 60$ ust. 2 czas na przedstawienie uwagi faktycznej nie może przekroczyć 2 minut (tyle samo czasu przewidziano na ewentualną odpowiedź na uwagę faktyczną). Jeżeli wypowiedź posła nie jest uwagą faktyczną lub gdy poseł przekroczy czas przewidziany na wygłoszenie uwagi faktycznej, przewodniczący może odebrać głos posłowi. Decyzja przewodniczącego w tej sprawie ma charakter ostateczny ( $\$ 60$ ust. 3).

\section{DANIA - Folketing}

W regulaminie Folketingu ${ }^{15}$ nie ma odrębnego artykułu opisującego wnioski formalne, niemniej regulamin pozwala, choć w ograniczonej formie, wystąpić z wnioskiem poza kolejnością mówców, w wybranych sprawach proceduralnych, wskazanych wprost w poszczególnych przepisach regulaminowych.

Zgodnie $\mathrm{z}$ art. 28 regulaminu Folketingu przewodniczący udziela głosu deputowanym w kolejności, w jakiej zostali oni zgłoszeni, przy czym pierwszeństwo ma m.in. sprawozdawca. Przewodniczący może zmienić kolejność udzielania głosu, m.in. z powodów praktycznych. Niezależnie od ustalonego porządku i czasu wystąpień przewodniczący może, na ile jest to uzasadnione, udzielić głosu deputowanemu w celu wygłoszenia krótkich uwag, przy czym wprowadzono ograniczenie liczby i czasu takich wystąpień. Deputowany może wygłosić dwie krótkie uwagi - pierwszą 1-minutową, drugą 30-sekundową. W szczególnych okolicznościach przewodniczący może udzielić głosu w celu wygłoszenia krótkiej uwagi więcej razy lub na dłuższy czas.

Ponadto w regulaminie Folketingu w poszczególnych artykułach zostały uregulowane wybrane zagadnienia związane $\mathrm{z}$ kwestiami formalnymi, jak np.: a) w art. 31 regulaminu Folketingu przewidziano, że 17 deputowanych może zwrócić się na piśmie o zamknięcie punktu porządku dziennego bez debaty; b) w art. 35 przewidziano, że 17 deputowanych może złożyć wniosek o przeprowadzenie głosowania imiennego.

\section{ESTONIA - Riigikogu}

$\mathrm{W}$ regulaminie estońskiego parlamentu (Riigikogu) ${ }^{16}$ nie zawarto postanowień dotyczących treści wniosków formalnych. Regulacje zapisane w $\$ 74$ regulaminu dotyczą przede wszystkim sposobu zgłaszania zastrzeżeń oraz pytań związanych $\mathrm{z}$ porządkiem obrad (protests and questions concerning points of order), które od-

15 Standing Orders of the Danish Parliament, 2018, https://www.ft.dk/ /media/sites/ $\mathrm{ft} /$ pdf/publikationer/engelske-publikationer-pdf/forretningsorden_engelsk_2018_ samlet_web.ashx.

16 Riigikogu Rules of Procedure and Internal Rules Act (angielskie tłumaczenie aktu prawnego zamieszone na stronie internetowej Riigikogu), RT I 2007, 44, 316, https:// www.riigiteataja.ee/en/eli/521032019014/consolide. 
noszą się do stwierdzenia przez posła naruszenia przepisów regulujących przebieg posiedzenia.

Zgodnie z postanowieniami $\$ 74$ regulaminu posłowie mogą zgłaszać przewodniczącemu posiedzenia: a) zastrzeżenia związane ze stwierdzeniem naruszenia przepisów regulujących przebieg posiedzenia; b) pytania związane z porządkiem obrad.

Poseł sygnalizuje przewodniczącemu chęć zgłoszenia zastrzeżenia lub zadania pytania przez podniesienie ręki. Przewodniczący udziela posłowi zgody na przedstawienie uwag, nie włączając jednak tego wystąpienia do porządku obrad. Przewodniczący niezwłocznie rozpatruje zgłoszone zastrzeżenie lub udziela odpowiedzi na zadane pytanie. W regulaminie Riigikogu nie ma postanowień dotyczących czasu przeznaczonego na zgłoszenie zastrzeżenia lub zadanie pytania związanego z porząadkiem obrad. Przepisy $\$ 74$ nie wskazują też liczby zastrzeżeń lub pytań, z jakimi mogą wystąpić posłowie.

\section{FINLANDIA - Eduskunta}

W regulaminie Eduskunty ${ }^{17}$ brak jest odrębnej kategorii „wniosków formalnych”, które można by uznać za odpowiednik wniosków formalnych w rozumieniu art. 184 regulaminu Sejmu.

Regulamin fińskiego parlamentu jest zwięzłym aktem prawnym (81 artykułów), ustanawia ogólne zasady pracy izby i jej organów oraz przebiegu procesu legislacyjnego. Niektóre czynności wymienione w art. 184 regulaminu Sejmu są unormowane także w regulaminie Eduskunty. Nie przynależą one jednak do szerszej kategorii stanowiącej odpowiednik sejmowych „wniosków formalnych” każda z tych czynności jest czynnością odrębną, funkcjonującą według trybu innego niż pozostałe. Na przykład kwestia tajności posiedzenia jest określona w art. 67 regulaminu Eduskunty, który stanowi, że jeśli przewodniczący Eduskunty uzna, że sprawa ze względu na swój charakter nie może stanowić przedmiotu jawnych obrad, lub jeśli 25 parlamentarzystów złoży wniosek o uchwalenie tajności obrad, przewodniczący Eduskunty zarządza usunięcie publiczności z galerii w sali posiedzeń, a Eduskunta rozstrzyga o tajności obrad.

\section{FRANCJA - Zgromadzenie Narodowe (I'Assemblée Nationale)}

Problematykę wniosków formalnych wyznacza art. 58 regulaminu Zgromadzenia Narodowego ${ }^{18}$. Wnioski formalne, a właściwie wnioski porządkowe (les rappels au Règlement) oraz wnioski o udzielenie głosu w sprawie prywatnej (les deman-

17 Parliament's Rules of Procedure (angielskie tłumaczenie aktu prawnego dostępne na stronie internetowej Eduskunty), https://www.eduskunta.fi/EN/naineduskuntatoimii/Documents/RulesofProcedure_20150416.pdf.

18 Règlement de l'Assemblée Nationale, http://www.assemblee-nationale.fr/connaissance/reglement.pdf. 
des de parole pour fait personnel) zawsze mają pierwszeństwo przed głównym pytaniem/tematem debaty i z mocy prawa wstrzymują przebieg debaty. Prawo głosu zostaje przyznane każdemu deputowanemu składającemu taki wniosek, od razu lub po zakończeniu przez niego wcześniejszej wypowiedzi ${ }^{19}$.

Wnioski formalne muszą być składane na podstawie przepisów regulaminu Zgromadzenia Narodowego. Jeżeli wniosek nie ma podstaw w regulaminie, ma na celu ponowne zakwestionowanie ustalonego porządku dnia lub dotyczy tej samej sprawy, w której zgłoszono już wniosek formalny, przewodniczący odbiera deputowanemu głos. Jeśli wielu deputowanych należących do tej samej grupy składa jednocześnie wnioski formalne, których celem jest zakwestionowanie ustalonego porządku dnia, przewodniczący może odmówić przyznania im głosu (art. 58 ust. 4 regulaminu). Wnioski o zawieszenie posiedzenia zależą od decyzji Zgromadzenia Narodowego, chyba że zgłoszone są przez rząd, przez przewodniczącego lub sprawozdawcę komisji, przez przewodniczącego grupy (klubu) lub osobę przez niego wyznaczoną (art. 58 ust. 5 regulaminu). W takich wypadkach wniosek jest skuteczny od razu, jednakże z tym ograniczeniem, że można z niego skorzystać maksymalnie dwa razy w ciągu trwania sesji podczas rozpatrywania tego samego tekstu (par séance au cours de l'examen d'un même texte), chyba że przewodniczący izby zadecyduje inaczej. Deputowany może uzyskać prawo głosu na maksymalnie 2 minuty (art. 58 ust. 6 regulaminu). Regulamin nie określa, ile wniosków z art. 58 regulaminu francuskiego Zgromadzenia Narodowego może złożyć deputowany. Regulamin nie określa też wyraźnej różnicy między wnioskami porządkowymi (formalnymi) a wnioskami w sprawach prywatnych. To regulują zwyczaje parlamentarne.

\section{HISZPANIA - Kongres Deputowanych (Congreso de los Diputados)}

$\mathrm{W}$ regulaminie Kongresu Deputowanych ${ }^{20}$ (Reglamento del Congreso de los Diputados) używa się przynajmniej czterech terminów na określenie polskiego „Wniosku” w rozumieniu prośby, żądania czy wezwania do zrobienia czegoś. Najczęściej używany jest termin solicitud (żądanie, prośba, wniosek). Zdarza się też użycie w dokładnie tym samym, jak się wydaje, znaczeniu terminu petición (prośba, wniosek, art. 76 regulaminu). Niekiedy używa się też terminu moción (wniosek). Jest tak w przypadku wniosku o wotum nieufności (moción de censura, art. 175 i n. regulaminu) czy też w przypadku wniosku o zajęcie przez izbę

19 „La parole est accordée à tout député qui la demande à cet effet soit sur-le-champ, soit, si un orateur a la parole, à la fin de son intervention".

20 Resolución de 24 de febrero de 1982 por la que se ordena la publicación en el „Boletín Oficial del Estado" del nuevo Reglamento del Congreso de los Diputados [TEXTO CONSOLIDADO. Última modificación: 7 de febrero de 2020], https://www.boe.es/buscar/ pdf/1982/BOE-A-1982-5196-consolidado.pdf; REGLAMENTO DEL CONGRESO DE LOS DIPUTADOS DE 10 DE FEBRERO DE 1982 [ostatnia zmiana: 5 lutego 2020], http://www.congreso.es/portal/page/portal/Congreso/Congreso/Hist_Normas/ Norm/reglam_congreso.pdf. 
stanowiska w sprawie interpelacji (art. 184 regulaminu). Czasem stosuje się też termin propuesta (propozycja, projekt), np. w przypadku wniosku o wotum zaufania (propuesta de confianza, art. 174.4 regulaminu) czy wniosków nominacyjnych (art. 204 i n. regulaminu).

Nie wyróżnia się w regulaminie hiszpańskiego Kongresu Deputowanych osobnej kategorii wniosków formalnych. Niemniej niektóre z przewidzianych w regulaminie wniosków można funkcjonalnie wyróżnić jako wnioski dotyczące spraw proceduralnych odnoszących się do porządku dziennego. Przez to spełniają one cechę definicyjną wniosku formalnego, tzn. są zgłaszane poza ustaloną kolejnością i dotyczą innych spraw niż kwestie merytoryczne związane z rozpatrywanym punktem porządku obrad. Tego rodzaju wnioski określane są w regulaminie ogólnym terminem solicitud lub - jeśli taki termin w odpowiednim przepisie nie pojawia się $\mathrm{w}$ formie rzeczownikowej lub zastąpiony jest zupełnie innym słowem - mogłyby być zapewne takim terminem określone.

Przykładami tego rodzaju wniosków są:

- wniosek o tajność obrad (solicitud de sesión secreta), art. 63.3 regulaminu ${ }^{21}$,

- wniosek (solicitud) deputowanego do Prezydium o pozwolenie mu na zdalne głosowanie elektroniczne (procedimiento telemático), art. 82.2 regulaminu $^{22}$,

- wniosek o głosowanie publiczne imienne lub głosowanie tajne (votación será pública por llamamiento o secreta cuando así [...] lo soliciten [...]), art. 85.1 regulaminu ${ }^{23}$,

- wniosek (petición) grupy parlamentarnej o zamknięcie debaty, art. 76 regula$\operatorname{minu}^{24}$,

- zmiana porządku dziennego na wniosek (a propuesta) przewodniczącego lub na wniosek (a petición) dwóch grup parlamentarnych lub 1/5 członków izby, art. 68.1 regulaminu.

W trakcie debaty żaden deputowany nie może zabierać głosu bez poproszenia o głos i udzielenie mu go przez przewodniczącego (art. 70.1 regulaminu).

21 Z inicjatywy Prezydium Kongresu, rządu, dwóch grup parlamentarnych lub 1/5 członków Kongresu.

22 Deputowany składa wniosek na piśmie, kierując go do Prezydium Izby, które powiadamia go o swojej decyzji.

${ }^{23}$ Głosowanie imienne lub tajne przeprowadzane jest w przypadkach przewidzianych regulaminem albo na wniosek dwóch grup parlamentarnych lub 1/5 deputowanych. W przypadku „zbiegnięcia się przeciwstawnych wniosków przeważa głosowanie tajne”. W żadnym wypadku nie może być przeprowadzone tajne głosowanie w postępowaniu ustawodawczym.

24 Debatę może zawsze zamknąć przewodniczący w porozumieniu z Prezydium, jeśli uzna, że sprawa została wystarczająco przedyskutowana. Zamknięcie debaty może nastąpić też na wniosek rzecznika grupy parlamentarnej. W sprawie takiego wniosku może zabrać głos tylko jeden mówca przeciwny wnioskowi i jeden popierający go, każdy z nich przez maksymalnie 5 minut. 
Dotyczy to również wniosków o charakterze formalnym przedstawionych wyżej, z wyjątkiem przykładu drugiego, w którym przewidziano explicite, że wniosek jest składany w formie pisemnej do Prezydium, a składający go nie uczestniczy osobiście w głosowaniu i, jak można przyjąć, również nie bierze osobiście udziału w debacie. Nie ma w regulaminie przepisu, który nakazywałby przewodniczącemu udzielenie głosu wnioskodawcom w pozostałych czterech przypadkach. Niemniej nie ma też w regulaminie przepisu, który jednoznacznie pozwalałby przewodniczącemu udzielać w tych przypadkach głosu w sposób dyskrecjonalny, co oznacza, że sposób działania przewodniczącego warunkowany jest kulturą parlamentarną, zwyczajami oraz aktualną sytuacją. Niezależnie jednak od sposobu działania decyzje przewodniczącego są szanowane, co jest elementem kultury parlamentarnej i prestiżu jego urzędu.

We wskazanych przypadkach wniosków o charakterze formalnym nie jest $\mathrm{w}$ regulaminie explicite określone ograniczenie czasowe wystąpienia wnioskodawców. Do ogólnych uprawnień przewodniczącego należy „zwiększanie lub redukowanie liczby i czasu wystąpień grup parlamentarnych i deputowanych, jak również akumulowanie - ze względu na okoliczności związane z grupami parlamentarnymi i materiami - wszystkich tych [wystąpień], które w określonej sprawie mogą odpowiadać jednej grupie parlamentarnej” (art. 73.2 regulaminu).

Nie ma w regulaminie specyficznego ograniczenia liczby składanych przez jeden podmiot (grupę parlamentarną lub deputowanego) wskazanych wyżej wniosków o charakterze formalnym.

\section{IRLANDIA - Zgromadzenie Irlandii (Dáil Éireann)}

W regulaminie Dáil Éireann ${ }^{25}$ brak jest odrębnej kategorii wniosków formalnych, które można by uznać za dokładny odpowiednik wniosków formalnych w rozumieniu art. 184 regulaminu Sejmu.

Pewne czynności wskazane w art. 184 regulaminu Sejmu są zawarte w regulaminie parlamentu irlandzkiego, jednak nie są to elementy składające się na kategorię stanowiącą odpowiednik polskich wniosków formalnych. Każda z tych czynności jest czynnością odrębną, funkcjonującą według trybu innego niż pozostałe. Na przykład kwestia zamknięcia dyskusji jest określona w art. 68 zatytułowanym „Zakończenie debaty” (Closure of debate), zgodnie z którym parlamentarzysta wnioskuje o zamknięcie dyskusji, wypowiadając formułę: That the question be now put (w wolnym tłumaczeniu: Już czas przejść do sprawy).

Jeżeli zdaniem przewodniczącego prowadzącego obrady taki wniosek nie narusza w żaden sposób regulaminu Dáil Éireann, jest on niezwłocznie realizowany, a decyzję podejmuje się bez debaty.

25 Standing Orders Relative to Public Business, https://data.oireachtas.ie/ie/oireachtas/ parliamentaryBusiness/standingOrders/dail/2019/2019-01-11_consolidated-dail-eireann-standing-orders-january-2019_en.pdf. 


\section{LUKSEMBURG - Izba Deputowanych (Chambre des députés)}

Regulamin Izby Deputowanych Luksemburga ${ }^{26}$ reguluje kwestie zgłaszania wniosków związanych z pracami Izby Deputowanych, tzw. wniosków porządkowych (des motions dordre), w art. 44. Postanowienia art. 44 regulaminu nie zawierają szczegółowego katalogu spraw, które mogą być adresowane w ramach wniosku porządkowego. Każdy poseł może w trakcie debaty poprosić o udzielenie mu głosu w ramach wniosku porządkowego, a procedura obejmuje następujące elementy:

- wniosek musi być podpisany przez przynajmniej 5 deputowanych,

- wniosek uznany za zgodny z regulaminem jest przedstawiany w czasie wyznaczonym przez przewodniczącego Izby; zgodnie z postanowieniami regulaminu Izby Deputowanych przewodniczący może uznać wniosek za niezgodny z regulaminem - jeżeli to postanowienie nie satysfakcjonuje wnioskodawcy, decyzję podejmuje Izba w formie głosowania (bez debaty, przez podniesienie rąk),

- w trakcie debaty nad wnioskiem porządkowym głos zabrać może wnioskodawca oraz po jednym członku każdej z grup czy kół politycznych,

- wnioskodawca ma 5 minut na wystąpienie, członkowie grup politycznych także mają na wystąpienie 5 minut, a członkowie kół politycznych - 2 minuty. Pewne kwestie, których przedmiot może stanowić odpowiednik spraw objętych wnioskiem formalnym określonym $\mathrm{w}$ art. 184 regulaminu Sejmu, przewidziano także w art. 41 regulaminu Izby Deputowanych Luksemburga dotyczącym tzw. pytań wstępnych (des questions préalables). Kategoria pytań wstępnych obejmuje m.in.:

- kwestie dotyczące tygodniowego porządku prac Izby,

- wnioski (une demande) o zmianę dziennego porządku obrad,

- wnioski (une demande) o głosowanie podzielone lub przerwanie głosowania,

- kwestie związane z odroczeniem obrad,

- uwagi o braku konieczności przeprowadzenia debaty,

- kwestie związane z przerwaniem i odroczeniem debaty.

Pytania wstępne są rozpatrywane przed zagadnieniem głównym debaty i nie są uwzględniane $\mathrm{w}$ obliczaniu przydzielonego posłom czasu wystąpień. Autor pytania ma 5 minut na wygłoszenie swojego wniosku i jego uzasadnienie, członkowie grup politycznych mają na wystąpienie 5 minut, a członkowie kół politycznych - 2 minuty. Jeżeli tematyka wygłaszanego wniosku nie dotyczy w rzeczywistości kwestii wskazanych w art. 41 regulaminu, przewodniczący odbiera posłowi głos. Jeżeli przewodniczący Izby uzna, że wygłaszane pytanie

26 Reglement de la chambre des deputes, 11 juillet 2019, https://www.chd.lu/wps/wcm/ connect/public/5abf3456-f398-4259-a831-20788c0f208c/reglementjuli2019.pdf?MO $\mathrm{D}=\mathrm{AJPERES} \&$ ContentCache $=\mathrm{NONE} \& \mathrm{CACHE}=\mathrm{NONE} \& \mathrm{CVID}=\mathrm{mOb} 0 \mathrm{p} 1 \mathrm{~W} \& \mathrm{CVI}$ $\mathrm{D}=\mathrm{mOb} 0 \mathrm{p} 1 \mathrm{~W}$. 
wstępne zawierające wniosek o odroczenie obrad ma w istocie na celu jedynie utrudnienie prac parlamentu, może je niezwłocznie (bez debaty) poddać pod głosowanie.

W regulaminie Izby Deputowanych nie zawarto przepisów określających liczbę składanych wniosków porządkowych czy pytań wstępnych. Regulamin nie zawiera też bezpośredniego wskazania dotyczącego obligatoryjności lub fakultatywności decyzji przewodniczącego Izby w sprawie udzielenia posłowi głosu w celu złożenia wniosku porządkowego lub pytania wstępnego. Co do zasady (art. 36 regulaminu), żaden poseł nie może zabrać głosu, dopóki w tym celu nie zarejestruje się lub nie wystąpi z odpowiednią prośbą do przewodniczącego Izby i nie uzyska jego zgody.

\section{ŁOTWA - Saeima}

W regulaminie Saeimy ${ }^{27}$ występują dwie kategorie wniosków, które można uznać za odpowiedniki wniosków formalnych w rozumieniu art. 184 regulaminu Sejmu.

W pierwszym przypadku uregulowania łotewskiej Saeimy odnoszą się do kwestii zabierania głosu podczas posiedzenia. Zgodnie z postanowieniami regulaminu prawo do zabrania głosu poza kolejnością może zostać przyznane mówcy, który odnosi się do nieprzestrzegania regulaminu izby lub wypowiada się na temat sposobu dalszego procedowania danej sprawy (art. 66). Zgodnie z art. 67 mówca, który chciałby wystąpić z pilną wypowiedzią poza porządkiem obrad, musi uprzednio wskazać w pisemnym wniosku temat swojego wystąpienia. Decyzję o udzieleniu głosu w tym wypadku podejmuje przewodniczący posiedzenia; w razie uzyskania zgody czas wypowiedzi nie może przekroczyć 3 minut. Według art. 56 ust. 1 regulaminu zgoda na zabranie głosu z mównicy udzielana jest przez przewodniczącego, po uprzednim otrzymaniu wniosku w tej sprawie prośby o zabranie głosu mogą być zgłaszane na piśmie lub przy wykorzystaniu elektronicznego systemu głosowania. Artykuł 56 ust. 1 określa katalog osób, które mogą zabrać głos bez pisemnego wniosku (wśród nich znajdują się m.in: sprawozdawca; mówcy biorący udział w debacie nad projektem ustawy lub projektem uchwały; osoby udzielające odpowiedzi na pytanie).

Niektóre kwestie wymienione w art. 184 regulaminu Sejmu, czyli postanowienia dotyczące zgłaszania wniosków związanych z przedmiotem porządku dziennego i przebiegu posiedzenia, zostały uregulowane w regulaminie Saeimy w sposób odmienny od konstrukcji klasycznego wniosku formalnego, co przejawia się m.in. w kolektywnej formule ich zgłaszania (w większości przypadków). Do takich przypadków należą na przykład wnioski w sprawach:

${ }^{27}$ Informacja przygotowana na podstawie regulaminu Saeimy w języku angielskim, który jest dostępny na stronie łotewskiego parlamentu pod adresem: https://www. saeima.lv/en/about-saeima/work-of-the-saeima/rules-of-procedure/. 
- zawieszenia lub zamknięcia posiedzenia - z wyjątkiem określonych przypadków posiedzenie może zostać zawieszone i zamknięte tylko na podstawie decyzji podjętej przez Saeimę; o zawieszenie lub zamknięcie posiedzenia może wnioskować przewodniczący posiedzenia lub co najmniej 5 posłów (art. 49),

- ograniczenia czasu wystąpień i zamknięcia listy mówców - na wniosek co najmniej 10 posłów Saeima może postanowić o skróceniu czasu wystąpień lub zamknięciu listy mówców (art. 65 ust. 1),

- zamknięcia debaty - na wniosek co najmniej 20 posłów Saeima może zadecydować o zamknięciu debaty (art. 65 ust. 5),

- uchwalenia tajności obrad - na wniosek złożony przez m.in. 10 posłów, Saeima może zadecydować większością co najmniej 2/3 głosów obecnych posłów o utajnieniu posiedzenia (art. 77).

W powyższych sytuacjach decyzja podejmowana jest w drodze głosowania, przy czym tylko dwóch posłów ma możliwość zabrania głosu przed głosowaniem (wystąpienia nie mogą przekroczyć 5 minut) - poseł popierający wniosek oraz poseł przeciwny temu wnioskowi (art. 54).

Zgodnie z art. 47 regulaminu Saeimy przewodniczący obradom może, według własnego uznania lub na wniosek 5 posłów, ogłosić rejestrację posłów $\mathrm{w}$ celu stwierdzenia kworum.

W regulaminie Saeimy nie zawarto przepisów określających liczbę składanych wniosków związanych z przedmiotem porządku dziennego i przebiegu posiedzenia.

\section{NIDERLANDY - Izba Reprezentantów (Tweede Kamer)}

$\mathrm{W}$ regulaminie Izby Reprezentantów ${ }^{28}$ przewidziano odrębną kategorię wniosków formalnych (point/matter of order), jednak nie zawarto jej definicji ani katalogu spraw mogących być przedmiotem takiego wniosku. W art. 56 regulaminu Izby Reprezentantów stwierdza się jedynie, że porządek wystąpień może zostać przerwany m.in. wtedy, gdy deputowany zgłosi wniosek formalny. Wniosek formalny może zostać zgłoszony przez przewodniczącego Izby lub deputowanego. Ponadto zgodnie z art. 63 regulaminu Izby Reprezentantów czas wystąpienia w ramach wniosków formalnych nie jest wliczany do czasu wystąpień przewidzianego dla wystąpień na dany temat. W regulaminie Izby Reprezentantów nie zawarto przepisów określających liczbę składanych wniosków formalnych.

Jednocześnie niektóre kwestie wymienione w art. 184 regulaminu Sejmu, czyli postanowienia dotyczące zgłaszania wniosków związanych z przedmiotem porządku dziennego i przebiegu posiedzenia, zostały uregulowane $\mathrm{w}$ regulaminie Izby Reprezentantów odrębnie, np.:

28 House of Representatives of the Netherlands - Rules of Procedure, June 2018, https:// www.houseofrepresentatives.nl/sites/default/files/atoms/files/180626-reglement_ van_orde_engels.pdf. 
- w art. 67 przewidziano, że deputowany obecny na posiedzeniu może wnioskować (propose) o zamknięcie dyskusji; wniosek taki nie jest uzasadniany i nie podlega debacie,

- w art. 68 przewidziano, że deputowany obecny na posiedzeniu może wnioskować (propose) o zamknięcie dyskusji w określonym czasie; wniosek taki nie podlega debacie,

- w art. 90 i 119 uregulowano kwestie kierowania projektów ustaw lub innych dokumentów do właściwych komisji przez przewodniczącego, pierwszego wiceprzewodniczącego i drugiego wiceprzewodniczącego; jeśli decyzja taka nie była podjęta przez nich jednomyślnie, projekt ustawy lub inny dokument nie może zostać skierowany do komisji dopóki informacja o tym nie zostanie przekazana na publicznym posiedzeniu Izby Reprezentantów; Izba Reprezentantów może podjąć inną decyzję; wniosek w tej sprawie może złożyć każdy deputowany.

\section{NIEMCY - Bundestag}

Kwestie związane ze składaniem w Bundestagu wniosków odpowiadających kategorii wniosku formalnego, o którym mowa w regulaminie Sejmu, zostały określone przede wszystkim w $\$ 29$ regulaminu wewnętrznego niemieckiego Bundestagu ${ }^{29}$. Paragraf 29 regulaminu Bundestagu odnosi się do zgłaszania tzw. wniosków dotyczących porządku obrad (Geschäftsordnungsantrag), a także wniosków dotyczących przebiegu posiedzenia czy przedmiotu debaty, zgłaszanych w trakcie trwania posiedzenia. Takie wnioski można określić jako wnioski porządkowe. Wniosek porządkowy wskazany w regulaminie w odniesieniu do wybranych czynności odpowiada więc w dużym stopniu kategorii wniosku formalnego $\mathrm{z}$ art. 184 regulaminu Sejmu ${ }^{30}$.

Wnioski porządkowe traktowane są w Bundestagu jako te, które nie zostały zgłoszone i przyjęte do porządku dziennego zgodnie z regulaminem. Ta kwestia została uregulowana w $\$ 20$ regulaminu, zatytułowanym Tagesordnung (porządek dzienny).

W kolejnych punktach $\$ 29$ regulaminu Bundestagu stwierdzono:

- przewodniczący Bundestagu nadaje pierwszeństwo każdemu wnioskowi w sprawie wniosku porządkowego; wniosek taki musi dotyczyć przedmiotu debaty lub porządku obrad,

- przewodniczący może ograniczyć liczbę wniosków dotyczących porządku obrad do wniosku przedstawionego przez jednego wnioskodawcę, o ile treści tych wniosków pokrywają się; w razie zgłoszenia wielu różnych wniosków, wnioski takie przedstawiają rzecznicy frakcji parlamentarnych,

29 Regulamin porządku obrad niemieckiego Bundestagu (Geschäftsordnung des Deutschen Bundestages) [tłumaczony także jako Regulamin wewnętrzny niemieckiego Bundestagu], https://www.gesetze-im-internet.de/btgo_1980/_29.html.

30 Komentarz do Regulaminu Sejmu Rzeczypospolitej Polskiej, red. A. Szmyt, Warszawa 2018. 
- jeżeli członek Bundestagu wypowiada się w sprawie porządku obrad, nie zgłaszając, że chce mówić w tej sprawie lub nie chcąc wystąpić z wnioskiem dotyczącym porządku obrad, przewodniczący udziela mu głosu według własnego uznania,

- indywidualny mówca nie może wypowiadać się w sprawie porząaku obrad dłużej niż 5 minut.

W regulaminie Bundestagu nie stworzono zamkniętego katalogu spraw, w których mogą być zgłaszane wnioski formalne (porządkowe) ${ }^{31}$. Prawo do zgłaszania wniosków porządkowych należy do członków Bundestagu (parlamentarzystów), a także do rzeczników poszczególnych frakcji, którzy reprezentują poszczególne grupy parlamentarzystów.

Zaznaczyć należy, że zgodnie $\mathrm{z} \$ 20$ ust. 1 regulaminu termin i porządek obrad każdego posiedzenia Bundestagu ustalane są przez Radę Seniorów (Ältestenrat ${ }^{32}$ ), chyba że Bundestag zadecyduje o nim wcześniej lub przewodniczący ustali je samodzielnie, na podstawie $\$ 21$ ust. $1^{33}$.Zgodnie $\mathrm{z} \$ 20$ ust. 3, jeżeli przewodniczący samodzielnie zaplanował posiedzenie w innych sprawach lub uzupełnił porządek obrad, musi uzyskać zgodę Bundestagu ${ }^{34}$ na te zmiany na początku posiedzenia.

Zgodnie $\mathrm{z} \$ 20$ ust. 2 porządek obrad jest przekazywany członkom Bundestagu, Bundesratu oraz członkom Rządu Federalnego. Jeżeli nie ma sprzeciwu, uważa się, że został on przyjęty w momencie wywołania punktu pierwszego. Każdorazowo po otwarciu posiedzenia plenarnego, ale przed przejściem do porząaku dziennego każdy poseł do Bundestagu może wnieść o zmianę porządku obrad. Musi przy tym wcześniej przedłożyć wniosek w tej sprawie u przewodniczącego do godziny 18:00 dnia poprzedniego.

Zgodnie z $\$ 20$ ust. 3 po ustaleniu porządku obrad inne sprawy winny być omawiane tylko wtedy, gdy: sprzeciwu nie wniesie grupa 5 ze 100 obecnych na posiedzeniu członków Bundestagu, sprzeciwu nie wniesie jedna $\mathrm{z}$ frakcji lub jeśli regulamin dopuszcza możliwość dyskusji poza porządkiem obrad. Bundestag może w każdej chwili usunąć punkt z porządku obrad.

31 Komentarz do Regulaminu Sejmu Rzeczypospolitej Polskiej, red. A. Szmyt, op. cit., s. 834.

32 Ältestenrat (Rada Seniorów) składa się z przewodniczącego Bundestagu, jego zastępców i 23 innych, doświadczonych deputowanych. Rada doradza przewodniczącemu Bundestagu w jego pracy oraz zapewnia skoordynowany i płynny przebieg prac w Bundestagu. Na przykład (w dłuższej perspektywie) ustala terminy posiedzeń, a następnie na bieżąco uzgadnia porządek obrad. Rada Seniorów to także miejsce, gdzie dyskutuje się i rozstrzyga spory.

33 Przewodniczący samodzielnie ustala termin i porządek obrad, jeżeli upoważni go do tego Bundestag albo wtedy, gdy z jakiegoś powodu takie upoważnienie nie może być wydane.

34 Zgodnie z artykułem 42 ust 2 niemieckiej Ustawy Zasadniczej decyzje w Bundestagu są podejmowane większością oddanych głosów, o ile Ustawa Zasadnicza nie stanowi inaczej. 


\section{PORTUGALIA - Zgromadzenie Republiki (Assembleia da República)}

Regulamin Zgromadzenia Republiki (Regimento da Assembleia da República) ${ }^{35}$ nie przewiduje odrębnej kategorii wniosków formalnych. Niemniej w rozdziale poświęconym obradom plenarnym stanowi się, że „deputowanym udzielany jest głos” w kilkunastu przypadkach, wśród których wymienia się 3 o charakterze wniosków formalnych. Są to: powołanie się na regulamin lub interpelacja czy też zapytanie do Prezydium (invocar o Regimento ou interpelar a Mesa), przedstawienie wezwania (fazer requerimentos) i złożenie odwołania czy też skargi (interpor recursos) (art. 76.1, odpowiednio litery f, g, j).

Deputowani mogą interpelować do Prezydium, gdy mają wątpliwości co do jego decyzji lub co do kierunku prac. Deputowany, proszący o głos w celu powołania się na regulamin, wskazuje normę, która została naruszona, oraz zgłasza niezbędne uwagi. Wystąpienie w celu powołania się na regulamin lub przedstawienie interpelacji nie może przekraczać 2 minut (art. 80).

Jako wezwania do Prezydium dopuszczalne są jedynie wnioski czy też żądania (pedidos) dotyczące procedury przedstawiania, dyskusji i głosowania jakiejkolwiek sprawy lub też funkcjonowania posiedzenia. Wezwania można zgłaszać na piśmie bądź ustnie. Wezwania pisemne są bezzwłocznie ogłaszane przez Prezydium i dystrybuowane między grupami parlamentarnymi. Wezwania ustne, jak również lektura wezwań pisemnych, jeśli się jej zażąda, nie mogą przekraczać 2 minut. Wezwanie, po jego przyjęciu, jest niezwłocznie głosowane bez debaty. Głosowania nad wezwaniami odbywa się w kolejności ich zgłoszenia (art. 81 regulaminu). Zgodnie z innym artykułem regulaminu do przewodniczącego Zgromadzenia należy w szczególności „przyjmowanie lub odrzucanie [...] wezwań, po weryfikacji ich poprawności regulaminowej, bez uszczerbku do prawa odwołania się [recurso] do Zgromadzenia” (art. 16.1 lit. C regulaminu).

Każdy deputowany może składać zażalenie (reclamar) na decyzję przewodniczącego Zgromadzenia lub Prezydium lub odwoływać się (recorrer) od nich do plenum Zgromadzenia. Deputowany, który złożył odwołanie, ma prawo zabrać głos w celu jego uzasadnienia w czasie nieprzekraczającym 3 minut. W przypadku odwołania przedstawionego przez więcej niż jednego deputowanego, z uzasadnieniem wystąpić może tylko jeden z nich, niezależnie od tego, czy należą do tej samej grupy parlamentarnej, czy nie. W przypadku wielu odwołań dotyczących tego samego przedmiotu wystąpić z uzasadnieniem może tylko jeden deputowany z każdej z grup parlamentarnych, do których należą wnioskodawcy. Ponadto głos może zabrać przez czas nie dłuższy niż 3 minuty deputowany z każdej grupy parlamentarnej, która nie składała odwołania w danej sprawie (art. 82).

W czasie posiedzeń plenarnych do kompetencji przewodniczącego Zgromadzenia należy „udzielanie głosu deputowanym i członkom rządu oraz zapewnia-

35 Regimento da Assembleia da República, Assembleia da República, https://www.parlamento.pt/Legislacao/Documents/Legislacao_Anotada/RegimentoAR_Simples.pdf. 
nie porząaku w obradach” (art. 17.1 lit b regulaminu). Jednocześnie „od decyzji przewodniczącego Zgromadzenia podjętych $\mathrm{w}$ trakcie posiedzenia plenarnego zawsze przysługuje zażalenie [reclamação], jak również odwołanie [recurso] do plenum Zgromadzenia" (art. 17.3).

\section{SŁOWACJA - Rada Narodowa (Národná Rada)}

Regulamin słowackiej Rady Narodowej ${ }^{36}$ zna kategorię osobnego wniosku formalnego pod nazwą wniosku porządkowego lub proceduralnego (procedurálny návrh). Przepisy art. 34 regulaminu nie tylko przewidują ten rodzaj wniosku, ale również określają go przedmiotowo, stanowiąc, że członkowie Rady Narodowej mają prawo złożenia wniosku porządkowego, dotyczącego trybu rozpatrywania danej sprawy, terminów i innych kwestii związanych z metodą pracy izby. Wniosek porządkowy składany jest poza kolejnością mówców, a czas na jego zgłoszenie nie może przekroczyć 2 minut. Wniosek taki jest przedstawiany ustnie, niemniej wymaga niezwłocznego (bezprostredne) przedstawienia go przewodniczącemu izby również w formie pisemnej. Nad wnioskiem porządkowym głosuje się bez dyskusji ( $\$ 38$ ust. 1). Regulamin słowackiej Rady Narodowej dopuszcza jednocześnie możliwość niepoddania wniosku porządkowego pod głosowanie. Wymaga to jednak, aby wniosek taki miał „oczywiste poparcie” (zrejmú podporu) całej izby. W takim przypadku przewodniczący Rady Narodowej zwraca się z pytaniem, czy ktoś ma jakąś uwagę (sprzeciw) co do wniosku. Brak uwagi, względnie uwaga tylko jednego posła oznacza przyjęcie wniosku bez głosowania. Z kolei nad wnioskami, które nie mają oczywistego poparcia (ktorý nemá zrejmú podporu), głosuje się niezwłocznie. Jednocześnie regulamin przewiduje, że wnioski porządkowe, które zostały zgłoszone w sytuacji, gdy analogiczne wnioski zostały przez izbę wcześniej odrzucone, pozostają bez rozpatrzenia. Obok ogólnej kategorii wniosków porządkowych przepisy $\$ 39$ przewidują również szczególną postać tego rodzaju wniosku, jaką jest „protest przeciwko wynikowi głosowania z powodu awarii urządzeń technicznych do liczenia głosów" (námietku proti výsledku hlasovania $z$ dôvodu nefunkčnosti technického zariadenia). Protest w tej sprawie może zgłosić każdy poseł. W takiej sytuacji Rada rozstrzyga o wniosku w głosowaniu, a przyjęcie wniosku oznacza konieczność powtórzenia głosowania. Innym szczególnym wnioskiem proceduralnym, przewidzianym $\mathrm{w} \$ 39$ regulaminu, jest wniosek o przeprowadzenie głosowania tajnego. Wniosek taki może zgłosić grupa co najmniej 15 posłów. Jednocześnie wniosek musi zostać zgłoszony w określonym czasie, tj. nie później niż do rozpoczęcia dyskusji w sprawie, która miałaby być objęta głosowaniem tajnym.

36 Rokovací poriadok Národnej rady Slovenskej republiky, https://www.nrsr.sk/web/ Static/sk-SK/NRSR/Doc/zd_rokovaci-poriadok-20190821.pdf. 


\section{SZWECJA - Riksdag}

Regulamin Riksdagu (Riksdagsordningen 2014:801, The Riksdag Act 2014:801 ${ }^{37}$ ) nie przewiduje kategorii wniosków formalnych, które stanowiłyby odpowiednik wniosków formalnych sprecyzowanych w regulaminie polskiego Sejmu.

Ogólne uregulowanie zawarte w art. 15 rozdz. 6 regulaminu Riksdagu, dotyczące prawa do zabierania głosu, stanowi, że każdy członek Riksdagu i każdy minister ma prawo do swobodnego wypowiadania się na posiedzeniu we wszystkich sprawach będących przedmiotem obrad oraz w sprawie legalności wszystkiego, co ma miejsce na posiedzeniu. Zgodnie $\mathrm{z}$ art. 16 rozdz. 6 osoba zabierająca głos ogranicza swoje wystąpienie do kwestii, które są przedmiotem dyskusji. W sytuacji, w której mówca nie stosuje się do tego ograniczenia oraz do upomnień przewodniczącego, przewodniczący izby może pozbawić go głosu.

Przewodniczący izby ustala kolejność wystąpień mówców podczas debaty na posiedzeniu plenarnym, spośród tych, którzy przed przystąpieniem do omawiania danej sprawy zawiadomią o chęci zabrania głosu; posłowie proszący o pozwolenie na zabranie głosu podczas obrad zabierają głos w takiej kolejności, w jakiej poinformowali o chęci zabrania głosu. Niezależnie od ustalonej kolejności mówców i bez uprzedzenia, przewodniczący izby może udzielić głosu m.in. posłowi, który wcześniej zabierał głos, w celu ustosunkowania się do wystąpienia poprzedniego mówcy (art. 22 rozdz. 6).

\section{WŁOCHY - Izba Deputowanych (Camera dei Deputati)}

Regulamin włoskiej Izby Deputowanych (Il Regolamento della Camera) ${ }^{38}$ w rozdz. VIII pt. „O dyskusji” (della Discussione) w części pierwszej obszernie reguluje problematykę wystąpień z wnioskami o charakterze formalnym. Regulamin nie posługuje się przy tym jednym wspólnym określeniem na wnioski formalne i najczęściej typizuje je w zależności od tego, czego dotyczą (np. wniosek o przestrzeganie regulaminu, wniosek w sprawie sposobu głosowania). Zarazem art. 36 ust. 3 regulaminu wyraźnie postanawia, że żaden deputowany nie może zabrać głosu bez zgody przewodniczącego Izby (Nessuno può parlare senza il permesso del Presidente). Regulamin Izby Deputowanych wyodrębnia zasadniczo dwa rodzaje wniosków, którym przypisać można formalny charakter.

Pierwszym są tzw. pytania wstępne (la questione pregiudiziale), unormowane $\mathrm{w}$ art. 40 regulaminu. Obejmują one trzy kluczowe kwestie proceduralne, tj. wniosek o to, aby dane zagadnienie nie było dyskutowane w czasie posiedzenia (quella cioè che un dato argomento non debba discutersi), wniosek o przesunięcie danego punktu porządku obrad (quella cioè che la discussione debba rinviarsi) i wnio-

37 Informacja sporządzona na podstawie angielskiego tłumaczenia regulaminu Riksdagu, które jest dostępne pod adresem: https://www.riksdagen.se/globalassets/07.-dokument--lagar/the-riksdag-act-2015.pdf.

38 Https://www.camera.it/leg18/437? conoscerelacamera=237. 
sek o zawieszenie posiedzenia (questione sospensiva). Wniosek taki (a właściwie pytanie wstępne) może zgłosić każdy deputowany przed rozpoczęciem danego punktu porządku obrad. Jeśli dany punkt zaczął już być rozpatrywany, złożenie pytania wstępnego jest dopuszczalne, ale pod warunkiem, że podpisze się pod nim minimum 10 deputowanych, w tym co najmniej 3 z komisji, która zajmowała się daną sprawą. Przedstawienie pytania i jego uzasadnienie może trwać nie dłużej niż 10 minut, a cała dyskusja nad nim nie dłużej niż 5 minut.

Drugim rodzajem wniosków formalnych są wnioski, o których stanowi art. 41 regulaminu. Obejmują one różne kwestie, w tym np. wniosek o przestrzeganie regulaminu (richiami al Regolamento), wniosek dotyczący porządku dziennego posiedzenia (per l'ordine del giorno o per l'ordine dei lavori), wniosek o kolejność głosowania (per la priorità delle votazioni). Wszystkie te wnioski mają pierwszeństwo przed innymi. Deputowany składa wniosek ustnie i w dyskusji nad nim może wystąpić jeden oponent wniosku. Każdy z mówców wypowiadających się w sprawie wniosku ma maksymalnie 5 minut na wystąpienie. Dysponentem wniosku, zgodnie z art. 41 ust. 1, jest przewodniczący Izby, który, jeśli uzna za stosowane, poddaje wniosek pod głosowanie. W takim wypadku głosowanie odbywa się przez podniesienie ręki (bez udziału elektronicznego systemu liczenia głosów).

Artykuł 43 regulaminu Izby Deputowanych wyłącza wszystkie wystąpienia na podstawie art. 40 i 41 z generalnej zasady ograniczającej możliwość zabrania głosu przez deputowanego w danym punkcie porządku obrad tylko do jednego razu. Z wyłączenia tego korzystają też tzw. wypowiedzi osobiste deputowanego, przewidziane w art. 42 regulaminu. Dotyczą one sytuacji, w których błędnie przywołano wypowiedź deputowanego lub ją źle zinterpretowano albo zniekształcono. W takim wypadku deputowany może zabrać dodatkowo głos, ale w pierwszej kolejności musi wskazać, na czym polega jej osobisty charakter (la parola deve indicare in che consiste il fatto personale).

\section{STANY ZJEDNOCZONE - Izba Reprezentantów (House of Representatives)}

Zgodnie z postanowieniami regulaminu Izby Reprezentantów Stanów Zjednoczonych $^{39}$ członkowie Izby dysponują możliwością zgłoszenia wniosków lub żądań, które pozwalają im np. na zgłoszenie naruszenia regulaminu czy na wnioskowanie o przeprowadzenie głosowania imiennego. W regulaminie brak jest odrębnej kategorii wniosków formalnych, które można by uznać za odpowiednik wniosków formalnych w rozumieniu art. 184 regulaminu Sejmu, jednak wybrane narzędzia, którymi dysponują członkowie Izby, odpowiadają pewnym czynnościom czy też zakresom spraw wskazanym w art. 184 regulaminu Sejmu.

39 Rules of the House of Representatives for the 116th Congress, 11.01.2019, https://rules. house.gov/sites/democrats.rules.house.gov/files/documents/116-House-Rules-Clerk.pdf. 
Wszystkie wnioski (motions), które są składane przez członków Izby Reprezentantów, są skuteczne wyłącznie po zatwierdzeniu (w drodze głosowania) przez Izbę. Ponadto członkowie mogą także zgłaszać żądania (requests), w sprawach, w których nie rozstrzyga się w drodze głosowania, ale decyzję podejmuje przewodniczący Izby lub wymagana jest zgoda izby (np. żądanie wykreślenia $\mathrm{z}$ debaty wypowiedzi innego członka Izby) ${ }^{40}$.

W większości przypadków wniosek lub żądanie mogą być złożone przez każdego członka Izby, który ma głos lub któremu zgody na złożenie udzielił przewodniczący obrad. Wnioski wymagające przeprowadzenia debaty podlegają ogólnym regułom czasowym debat w Izbie Reprezentantów, a debata rozpoczyna się po odczytaniu wniosku. W przypadku większości wniosków każdy członek Izby może zażądać przedstawienia wniosku w formie pisemnej. Zwyczajowo wnioski o odroczenie obrad, a także żądania są składane w formie ustnej ${ }^{41}$.

Jako pewnego rodzaju odpowiedniki czynności wymienionych w art. 184 regulaminu Sejmu wskazać można m.in. następujące wnioski sformułowane w regulaminie Izby Reprezentantów USA, składane w trakcie debaty w Izbie, przedstawione według kolejności ich zgłaszania i rozpatrywania (zgodnie z postanowieniami działu [Rule] XVI, pkt 4(a) regulaminu izby):

- wniosek o odroczenie obrad Izby (motion to adjourn, w sprawie wniosku o odroczenie nie przeprowadza się debaty),

- wniosek o przełożenie rozpatrywania na inny dzień (motion to postpone to a day certain, wniosek taki nie może być złożony w danej sprawie ponownie tego samego dnia na tym samym etapie procedury),

- wniosek o odroczenie rozpatrywania na czas nieokreślony (motion to postpone indefinetly, wniosek taki nie może być złożony w danej sprawie ponownie tego samego dnia na tym samym etapie procedury).

W regulaminie Izby Reprezentantów wskazano także inne czynności mogące stanowić odpowiednik wniosków formalnych, z których każda funkcjonuje według odrębnego, indywidualnego trybu. Jako przykłady wskazać można:

- wniosek o ponowne rozpatrzenie przez Izbę kwestii, nad którą przeprowadzono już głosowanie (motion to reconsider), uregulowano $\mathrm{w}$ dziale XIX (Rule XIX), pkt 3 i 4; wniosek taki złożyć może członek Izby, który głosował tak jak większość, w tym samym dniu, w którym odbyło się głosowanie lub dzień po głosowaniu,

- wniosek o przeprowadzenie głosowania imiennego (motion for recorded vote, dział XX [Rule XX], pkt 1(b)), który wymaga od wnioskodawcy uzyskania poparcia $1 / 5$ kworum (44 członków Izby),

40 Ch.M. Davis, Commonly Used Motions and Requests in the House of Representatives. Report prepared for Members and Committees of Congress, Congressional Research Service, 16.09.2015, s. 1; https://fas.org/sgp/crs/misc/RL32207.pdf.

41 Ch.M. Davis, Commonly Used Motions, op. cit., s. 2. 
- wniosek o przerwanie debaty i przeprowadzenie głosowania w danej sprawie (motion for the previous question, dział XIX [Rule XIX], pkt 1); jeżeli wniosek został złożony w sprawie, co do której regulamin przewiduje debatę, a takiej debaty nie przeprowadzono przed wpłynięciem wniosku, przed głosowaniem należy odbyć debatę trwającą 40 minut (równo podzielonych między wnioskodawcę i jego oponenta); wniosek o przerwanie debaty i głosowanie uniemożliwia np. zgłaszanie dalszych poprawek lub wniosków do danej kwestii będącej przedmiotem obrad ${ }^{42}$,

- wniosek o odesłanie sprawy do ponownego rozparzenia przez komisję lub komisje (dział XIX [Rule XIX], pkt 2) może być tzw. wnioskiem prostym (motion to recommit) lub wnioskiem $\mathrm{z}$ instrukcjami (motion to recommit with instructions); wniosek o odesłanie do komisji składany jest przed ostatecznym głosowaniem w sprawie przyjęcia danego środka, a pierwszeństwo w sprawie jego złożenia przewodniczący obrad przyznaje członkowi Izby, który jest przeciwko debatowanej kwestii; ewentualne instrukcje dołączone do wniosku mogą zawierać wyłącznie nakaz, aby komisja niezwłocznie zgłosiła Izbie wszelkie proponowane poprawki.

Ponadto członkowie Izby Reprezentantów mogą zgłaszać tzw. uwagi porządkowe (points of order), będące twierdzeniem (wygłaszanym $\mathrm{z}$ sali), że w danym momencie naruszono regulamin Izby. Przewodniczący obrad udziela pierwszeństwa głosu członkowi, który chce wystąpić z uwagą porządkową i który musi dokładnie wskazać naruszony przepis regulaminu ${ }^{43}$. Zgodnie z postanowieniami działu I (Rule I), pkt 5, przewodniczący Izby rozstrzyga wszystkie uwagi porządkowe, a członkowie Izby mogą się od jego decyzji odwołać. W sprawie odwołania się od danej decyzji dotyczącej zgłoszonej uwagi porządkowej członek Izby może przemawiać bez zgody Izby tylko raz. We wskazanych w regulaminie Izby sytuacjach i pod określonymi warunkami przewodniczący może odmówić przyjęcia uwagi porządkowej, np. w przypadku uwagi dotyczącej braku kworum podczas debaty ogólnej (dział [Rule] XVIII, pkt 6(b) regulaminu Izby).

\section{WIELKA BRYTANIA - Izba Gmin (House of Commons ${ }^{44}$ )}

W brytyjskiej Izbie Gmin jej członkowie uprawnieni są do zgłaszania uwag formalnych (point of order). W regulaminie Izby Gmin (Standing Orders of the House of Commons $)^{45}$ nie ma odrębnego artykułu regulującego uwagi formalne.

Uwaga formalna jest wnioskiem do przewodniczącego o wyjaśnienie lub rozstrzygnięcie kwestii proceduralnej w Izbie Gmin. Członek Izby Gmin przedstawia

42 Ibidem, s. 8.

43 Ibidem, s. 5.

44 Https://www.parliament.uk/business/commons/.

45 Https://publications.parliament.uk/pa/cm201919/cmstords/341/so_341_051119_ web.pdf. 
powody, dla których uważa, że regulamin Izby został naruszony, a przewodniczący podejmuje decyzję w tej sprawie ${ }^{46}$. W Przewodniku dotyczącym procedury dla członków Izby Gmin (MPs' Guide to Procedure) wskazano, że deputowany może zgłosić uwagę formalną dotyczącą danego zdarzenia w każdej chwili bezpośrednio po tym zdarzeniu, wygłaszając formułę: On a point of order, Mr Speaker. Inne uwagi formalne, niezwiązane $\mathrm{z}$ daną debatą lub wystąpieniem innego parlamentarzysty, zwykle są zgłaszane po czasie przeznaczonym na pytania, pytania w sprawach pilnych lub oświadczenia ustne ${ }^{47}$. Nie przewidziano ograniczenia ilościowego ani czasowego dotyczącego zgłaszania przez członka Izby Gmin uwag formalnych.

Ponadto pewne czynności wskazane w art. 184 regulaminu Sejmu są odrębnie unormowane w regulaminie parlamentu brytyjskiego, jednak nie składają się na jedną kategorię wniosków. Na przykład: a) złożenie wniosku o tajność posiedzenia Izby lub komisji uregulowano w art. 163 zatytułowanym „Wnioski o tajność posiedzenia" (Motions to sit in private), przy czym wniosek taki może zostać zgłoszony tylko raz podczas posiedzenia ${ }^{48}$; b) kwestia zamknięcia dyskusji jest określona w art. 36 zatytułowanym „Zakończenie debaty” (Closure of debate), zgodnie z którym parlamentarzysta wnioskuje o zamknięcie dyskusji, wypowiadając w pozycji stojącej ze swojego miejsca wskazaną formułę ${ }^{49}$.

\section{PARLAMENT EUROPEJSKI}

W Parlamencie Europejskim (dalej: Parlament lub PE) istnieje kilka rodzajów wniosków, które zbliżają się w swojej postaci do polskiego wniosku formalnego $\mathrm{z}$ art. 184 regulaminu Sejmu. Warto wspomnieć, że w regulaminie $\mathrm{PE}^{50}$ istnieje bardzo rozbudowana systematyka wniosków formalnych, czego potwierdzeniem jest okoliczność uregulowania całości zagadnienia dotyczącego wniosków formalnych w osobnym rozdziale szóstym regulaminu pt. „Wnioski w sprawie przestrzegania regulaminu i wystąpienia w sprawach proceduralnych”.

Pierwszym, podstawowym wnioskiem formalnym przewidzianym przez art. 195 regulaminu PE jest wniosek w sprawie przestrzegania regulaminu. Zgod-

46 Zgodnie $\mathrm{z}$ informacją zawartą w glosariuszu na stronie internetowej Izby Gmin, A point of order is an appeal to the Chair or Speaker for clarification or for a ruling on a matter of procedure in the House of Commons. The MP must explain their reasons for believing the rules of the House have been broken and the Speaker decides whether it is a valid point of order or not, https://www.parliament.uk/site-information/glossary/ point-of-order/. Https://guidetoprocedure.parliament.uk/articles/f1Oqrfli/points-of-order.

Członek Izby Gmin zgłasza wniosek, wypowiadając formułę: That the House sit in private. Szerzej na temat tych wniosków zob. MPs' Guide to Procedure, https://guidetoprocedure.parliament.uk/articles/vh8F2aPq/motion-to-sit-in-private. That the question be now put. Szerzej na temat tych wniosków zob. MPs' Guide to Procedure, https://guidetoprocedure.parliament.uk/articles/SaPSvNmb/how-to-move-the-closure. Https://www.europarl.europa.eu/doceo/document/lastrules/TOC_PL.html?redirect. 
nie $\mathrm{z}$ dyspozycją art. 195 ust. 1 poseł może zabrać głos w celu zwrócenia uwagi przewodniczącego na nieprzestrzeganie regulaminu PE. Na początku swojego wystąpienia poseł wskazuje artykuł, do którego się odnosi. Wnioski tego rodzaju mają pierwszeństwo przed innymi wnioskami o udzielenie głosu lub pozostałymi wnioskami proceduralnymi. Czas wystąpienia jest w tym wypadku ograniczony do jednej minuty (art. 195 ust. 3). W przypadku wniosku w sprawie przestrzegania regulaminu przewodniczący niezwłocznie podejmuje decyzję w tej sprawie zgodnie z postanowieniami regulaminu i ogłasza ją bezpośrednio po zgłoszeniu wniosku. Przewodniczący może oświadczyć, że jego decyzja zostanie ogłoszona później, jednakże nie może jej ogłosić w terminie przekraczającym 24 godziny po zgłoszeniu wniosku w sprawie przestrzegania regulaminu. Przełożenie terminu podjęcia decyzji nie pociąga za sobą odroczenia debaty.

Obok podstawowego wniosku, jakim jest wniosek o przestrzeganie regulaminu, w PE istnieje też pięć szczegółowych postaci wniosków o charakterze wniosków formalnych. Pierwszym takim rodzajem jest tzw. wniosek proceduralny. Odpowiada on w największym stopniu polskiemu wnioskowi formalnemu. Artykuł 196 regulaminu PE wyodrębnia pięć rodzajów wniosków proceduralnych. Pierwszym jest wniosek o stwierdzenie niedopuszczalności (szczegółowo uregulowany w art. 197). Drugim jest wniosek o odesłanie do komisji (art. 198). Trzecim jest wniosek o zamknięcie debaty (art. 199). Czwartym jest wniosek o odroczenie debaty lub głosowania (art. 200). Ostatnim, piątym rodzajem wniosku proceduralnego jest wniosek o zawieszenie lub przerwanie posiedzenia (art. 201). Cechą wspólną wszystkich wniosków proceduralnych jest to, że w celu ich zgłoszenia posłom PE udziela się głosu poza kolejnością. W sprawie tych wniosków głos zabierać mogą, poza wnioskodawcą, jedynie jeden mówca będący przeciw, jak również przewodniczący lub sprawozdawca właściwej komisji, która zajmowała się sprawą objętą wnioskiem. Zgodnie z przepisem art. 196 ust. 2 czas wystąpienia w przypadku każdego wniosku proceduralnego jest ograniczony do jednej minuty.

Artykuł 197 regulaminu PE określa osobno wniosek o stwierdzenie niedopuszczalności. W momencie otwarcia debaty nad danym punktem porządku dziennego grupa polityczna lub posłowie w liczbie stanowiącej co najmniej niski próg ${ }^{51}$ mogą wystąpić $\mathrm{z}$ wnioskiem o stwierdzenie niedopuszczalności tego punktu porządku dziennego. Głosowanie nad tym wnioskiem przeprowadza się niezwłocznie. Należy jednak dodać, że w przeciwieństwie do polskiego wniosku formalnego, zamiar złożenia wniosku o stwierdzenie niedopuszczalności powinien być zgłoszony co najmniej 24 godziny wcześniej przewodniczącemu, który informuje o nim niezwłocznie Parlament. Jeśli wniosek został przyjęty, posłowie przechodzą od razu do następnego punktu porządku dziennego. Podobnie jest

51 Co oznacza $1 \frac{1}{20}$ całkowitej liczby posłów do PE lub grupę polityczną - zob. art. 179 ust. 1 regulaminu PE. 
z kolejnym rodzajem wniosku proceduralnego, tj. wnioskiem o odesłanie do komisji. Co do zasady także i w tym wypadku (art. 198) zamiar złożenia wniosku o odesłanie do komisji jest zgłaszany co najmniej 24 godziny wcześniej przewodniczącemu, który niezwłocznie informuje o nim Parlament. O odesłanie sprawy do komisji może wnioskować grupa polityczna lub posłowie w liczbie stanowiącej co najmniej niski próg podczas ustalania porządku dziennego lub przed otwarciem debaty. Niemniej w tym wypadku regulamin dopuszcza możliwość wnioskowania o odesłanie do komisji także i nagle, tj. przed głosowaniem lub w jego trakcie. Wniosek taki jest niezwłocznie poddawany pod głosowanie. Zarazem wniosek o odesłanie do komisji może być zgłoszony tylko raz na każdym z etapów procedury (art. 198 ust. 3). Odesłanie do komisji zawiesza rozpatrywanie danego punktu. Parlament może wyznaczyć komisji termin, w jakim powinna ona przedstawić swoje wnioski. Artykuł 199 regulaminu PE określa również kategorię wniosku o zamknięcie debaty. W tym wypadku przewodniczący, na wniosek grupy politycznej lub posłów w liczbie stanowiącej co najmniej niski próg, może zaproponować zamknięcie debaty, zanim zabiorą głos wszyscy mówcy figurujący na liście. Głosowanie nad propozycją lub wnioskiem przeprowadza się niezwłocznie. Jeżeli propozycja lub wniosek zostaną przyjęte, głos może zabrać tylko jeden poseł z każdej grupy, która nie wzięła jeszcze udziału w debacie. Po tych wystąpieniach następuje zamknięcie debaty i Parlament przystępuje do głosowania nad omawianym punktem, chyba że wcześniej został ustalony inny termin głosowania. Jeśli wniosek odrzucono, może być on powtórnie przedstawiony w czasie tej samej debaty jedynie przez przewodniczącego. Jeszcze inną postacią wniosku proceduralnego jest wniosek z art. 200, tj. wniosek o odroczenie debaty lub głosowania. Wniosek taki może zgłosić grupa polityczna lub posłowie w liczbie stanowiącej co najmniej niski próg w chwili trwania debaty nad danym punktem porządku dziennego. Jednocześnie zamiar złożenia wniosku o odroczenie debaty powinien być zgłoszony co najmniej 24 godziny wcześniej przewodniczącemu, który informuje o nim niezwłocznie Parlament. Głosowanie nad takim wnioskiem przeprowadza się niezwłocznie. Jeżeli wniosek został przyjęty, Parlament przechodzi do następnego punktu porządku dziennego. Odroczona debata jest podejmowana w wyznaczonym terminie. Jeżeli wniosek odrzucono, nie może być on przedstawiony ponownie w trakcie tej samej sesji miesięcznej.

Ostatnim wnioskiem proceduralnym jest wniosek o zawieszenie lub zamknięcie posiedzenia. Posiedzenie może zostać zawieszone lub zamknięte w trakcie debaty lub głosowania, jeżeli decyzję taką podejmie Parlament na podstawie propozycji przewodniczącego lub na wniosek posłów lub grupy politycznej (grup politycznych) w liczbie stanowiącej co najmniej wysoki próg ${ }^{52}$. Głosowanie

52 Wysoki próg oznacza $1 / 5$ całkowitej liczby posłów do PE, tworzoną przez jedną lub więcej grup politycznych bądź przez poszczególnych posłów lub przez kombinację obu tych opcji. 
nad tą propozycją lub wnioskiem przeprowadza się niezwłocznie. Jednocześnie w przypadku złożenia wniosku o zawieszenie lub zamknięcie posiedzenia procedurę głosowania nad tym wnioskiem wszczyna się bez zbędnej zwłoki. Stosuje się zwyczajowe środki ogłaszania głosowań plenarnych i zgodnie z obecną praktyką zapewnia się posłom dość czasu na dotarcie do sali obrad plenarnych.

\section{Bibliografia}

Chybalski P., Wniosek formalny [w:] Wielki słownik parlamentarny, red. J. Szymanek, Warszawa 2018.

Davis Ch.M., Commonly Used Motions and Requests in the House of Representatives. Report prepared for Members and Committees of Congress, Congressional Research Service, 16 września 2015.

Komentarz do Regulaminu Sejmu Rzeczypospolitej Polskiej, red. A. Szmyt, Warszawa 2018. Sarnecki P., Art. 184 [w:] Komentarz do Regulaminu Sejmu Rzeczypospolitej Polskiej, red. A. Szmyt, Warszawa 2018. 

\begin{tabular}{l|l}
2 & OPINIE BAS
\end{tabular}

B

ZAGADNIENIA PRAWA MIĘDZYNARODOWEGO I EUROPEJSKIEGO 

Justyna Łacny

\title{
Ocena zgodności z prawem międzynarodowym poselskiego projektu ustawy o równości małżeńskiej ${ }^{1}$
}

\author{
Assessment of compliance with international law of the Deputies' Bill \\ on Marital Equality
}

\begin{abstract}
The Deputies' Bill on Marital Equality provides for the possibility of marriage between two people regardless of their sex. It introduces the possibility of adopting children by a single-sex couple. It does not regulate matrimonial property relationships. The opinion presents the jurisprudence of the ECtHR and international regulations which indicate that they do not contain a clear and commonly accepted definition of marriage. As a result, it cannot be claimed that the parliamentary draft law breaches, international law.
\end{abstract}

Keywords: international law, marriage, bill

Poselski projekt ustawy o równości małżeńskiej przewiduje możliwość zawarcia małżeństwa przez dwie osoby niezależnie od ich płci. Wprowadza możliwość adopcji dzieci przez osoby pozostające w małżeństwach jednopłciowych. W projekcie nie uregulowano natomiast problematyki małżeńskich stosunków majątkowych. W opinii przedstawiono orzecznictwo Europejskiego Trybunału Praw Człowieka i międzynarodowe przepisy, z których wynika, że w obrocie międzynarodowym nie została ustanowiona powszechnie akceptowana, jednoznaczna definicja małżeństwa. W związku z powyższym nie można uznać, że projekt ustawy jest sprzeczny z prawem międzynarodowym.

Słowa kluczowe: prawo międzynarodowe, małżeństwo, projekt ustawy

Doktor hab. nauk prawnych, prof. PW -

Politechnika Warszawska, Wydział Administracji i Nauk Społecznych, WARSZAWA, POLSKA • j.lacny@pw.edu.pl • https://orcid.org/0000-0001-7985-4882

\section{Przedmiot opinii}

Opinia dotyczy oceny zgodności z prawem międzynarodowym poselskiego projektu ustawy o równości małżeńskiej (dalej: projekt). Opinia uwzględnia stan prawny na dzień jej sporządzenia.

Ocena zgodności projektu ustawy z prawem Unii Europejskiej została przedstawiona w opinii Biura Analiz Sejmowych z 30 czerwca 2020 r. (BAS-WAPM-1360/20). W konkluzji tej opinii stwierdzono, że projekt ustawy o równości małżeńskiej nie jest sprzeczny z prawem UE.

$1 \quad$ Opinia $w$ sprawie zgodności z prawem międzynarodowym poselskiego projektu ustawy o równości małżeńskiej sporządzona 27 lipca 2020 r. na zlecenie Szefa Kancelarii Sejmu; BAS-WAPM-1506/20. 


\section{Przedmiot projektu}

Poselski projekt ustawy o równości małżeńskiej przewiduje umożliwienie zawarcia małżeństwa dwóm osobom niezależnie od ich płci. W tym celu projekt ustawy przewiduje nowelizację następujących ustaw:

- z 25 lutego 1964 r. - Kodeks rodzinny i opiekuńczy, t.j. Dz.U. 2019, poz. 2086, ze zm., dalej: k.r.o.,

- z 17 listopada 1964 r. - Kodeks postępowania cywilnego, t.j. Dz.U. 2019, poz. 1460 , ze zm.,

- z 28 listopada 2014 r. - Prawo o aktach stanu cywilnego, t.j. Dz.U. 2020, poz. 463 , ze zm.

Umożliwienie zawierania małżeństw przez pary osób tej samej płci miałoby nastąpić przez zmianę art. 1 k.r.o., który reguluje zdolność do zawarcia tego związku. Ze względu na tę zmianę projektodawcy proponują wprowadzić modyfikacje terminologiczne, polegające na zastąpieniu określeń wskazujących na płeć małżonków (mąż i żona) określeniami neutralnymi płciowo (małżonek, małżonkowie).

Projekt przewiduje również możliwość przysposabiania dzieci przez małżeństwa osób tej samej płci. Projekt nie zmienia majątkowych ustrojów małżeńskich oraz praw i obowiązków małżonków. W projekcie proponuje się, aby orzekanie o przyznaniu władzy rodzicielskiej małżonkowi rodzica było rozstrzygane na rozprawie przez sąd.

W związku z otwarciem instytucji małżeństwa dla par osób tej samej płci projektodawcy zmierzają do nowelizacji przepisów dotyczących relacji między dzieckiem a małżonkiem jego rodzica (niebędącym rodzicem dziecka) oraz przepisów prawa prywatnego o nazwisku dziecka. Wprowadzane zmiany dotyczące nazwisk dzieci mają polegać na zastąpieniu zasady, zgodnie z którą, w przypadku braku zgodnego oświadczenia małżonków o nazwisku dziecka, dziecko będzie nosić nazwisko składające się z nazwiska matki i dołączonego do niego nazwiska ojca. Projekt przewiduje, że w takiej sytuacji nazwisko dziecka składać się będzie z nazwisk małżonków połączonych w kolejności alfabetycznej.

Projekt nie zawiera przepisów przejściowych.

Projektowana ustawa ma wejść w życie po upływie 6 miesięcy od dnia ogłoszenia.

\section{Stan prawa międzynarodowego w materii objętej projektem ustawy}

Prawo międzynarodowe nie reguluje ustroju małżeńskiego, w tym kwestii zawierania małżeństw jednopłciowych, pozostawiając tę problematykę do ustalenia w przepisach poszczególnych państw. Wytwarzana w tym obszarze praktyka 
odzwierciedla różnorodność krajowych tradycji, obyczajów i przekonań aksjologicznych ${ }^{2}$.

Wymaga jednak odnotowania, że umowy międzynarodowe odnoszą się do problematyki małżeństw pośrednio, zapewniając ochronę życiu rodzinnemu i prywatnemu.

1. Gwarancje takie zawiera art. 8 Konwencji o ochronie praw człowieka i podstawowych wolności, sporządzonej w Rzymie 4 listopada 1950 r. (Dz.U. 1993, nr 61, poz. 284, ze zm.; dalej: EKPC). Wynikające $\mathrm{z}$ tego przepisu standardy ochrony życia rodzinnego są wyjaśniane w orzecznictwie Europejskiego Trybunału Praw Człowieka (dalej: ETPC). W wyroku z 24 czerwca 2010 r. w sprawie Schalk i Kopf vs. Austria (skarga nr 30141/04) ETPC orzekł, że w świetle przemian społecznych, prawo do ochrony życia rodzinnego przysługuje także partnerom tej samej płci. ETPC podkreślił, że pary osób tej samej płci są tak samo zdolne do stworzenia trwałego i zaangażowanego związku jak pary osób różnej płci, a zatem znajdują się w podobnej do nich sytuacji co do potrzeby prawnego uznania wzajemnych relacji. Stanowisko to zostało potwierdzone w kolejnych orzeczeniach ETPC ${ }^{3}$.

W wyroku z 21 lipca 2015 r. w sprawie Oliari vs. Włochy (skargi nr 18766/11, 36030/11) ETPC stwierdził naruszenie art. 8 EKPC z uwagi na niezrealizowanie obowiązku zapewnienia partnerom trwałych związków tej samej płci adekwatnych ram prawnych, takich jak zarejestrowany związek partnerski lub małżeństwo. Natomiast w wyroku z 9 czerwca 2016 r. w sprawie Chapin i Charpentier vs. Francja (skarga nr 40183/07) ETPC uznał jednak, że nie doszło do naruszenia art. 8 EKPC poprzez uniemożliwienie skarżącym zawarcia związku małżeńskiego, ponieważ brak jest europejskiego konsensusu co do równości małżeńskiej. ETPC odnotował, że we Francji od 2013 r. możliwe jest zawieranie małżeństw przez osoby tej samej płci. Wskazał, że w momencie składania skargi skarżący mieli możliwość zinstytucjonalizowania swojego związku w formie przewidzianej przez kodeks cywilny (fr. un pacte civil de solidarité), która przyznaje partnerom prawa i obowiązki fiskalne, majątkowe i socjalne.

2. Analogiczne przepisy ustalono w Międzynarodowym pakcie praw gospodarczych, społecznych i kulturalnych, otwartym do podpisu w Nowym Jorku 19 grudnia 1966 r. (Dz.U. 1977, nr 38, poz. 169; dalej: MPPGSiK), zawartym pod auspicjami Organizacji Narodów Zjednoczonych. Zgodnie z art. 10 MPPGSiK „należy udzielić jak najszerszej ochrony i pomocy rodzinie jako naturalnej i podstawowej komórce społeczeństwa, w szczególności przy jej zakładaniu i w okresie trwania odpowiedzialności rodziny za opiekę i wychowanie dzieci pozostających na jej utrzymaniu. Związek małżeński powinien być zawierany przy swobodnie wyrażonej zgodzie przyszłych małżonków". W komentarzu do tego artykułu wskazuje

2 Por. M. Wojewoda, Małżeństwa jednopłciowe i związi partnerskie w polskim rejestrze stanu cywilnego?, „Studia Prawno-Ekonomiczne” 2017, t. CIII, s. 135.

3 Wyrok ETPC z 7 listopada 2013 r., Vallianatos vs. Grecja, skargi nr 29381/09, 32684/09. 
się, że rodzina jest swoistym podmiotem prawa, chroni się ją bowiem jako grupę społeczną złożoną z co najmniej 2 osób ze względu na łączącą te osoby więź fizyczną i prawną. Z punktu widzenia zapewnienia rodzinie ochrony i pomocy, bezpośrednimi podmiotami chronionymi na mocy art. 10 MPPGSiK są jej członkowie, ze względu na łączące ich wzajemne relacje i związane z tym funkcje rodzinne. Pojęcie „rodzina”, o którym stanowi art. 10 MPPGSiK, dotyczy w pierwszym rzędzie rodziny opartej na małżeństwie w jedynej jego postaci, którą znali twórcy tekstu, czyli monogamicznego związku kobiety z mężczyzną, zawartego w sposób przewidziany przez prawo ${ }^{4}$. W toku prac nad MPPGSiK pojawiły się głosy, by ochronę zapewnić małżeństwom. Wobec tego, że taka redakcja wykluczyłaby z kręgu ochrony wiele grup, np. rodziny niepełne, wdowy i wdowców, od zamiaru tego odstąpiono.

Obecnie przyjmuje się, przy uwzględnieniu innych przepisów umów międzynarodowych ustalających gwarancje ochrony życia rodzinnego, że pojęcie „rodzina” powinno być interpretowane szeroko, w zależności od przypisywanych mu w danym państwie znaczeń, gdyż rozumienie tego pojęcia może różnić się $\mathrm{w}$ pewnych zakresach między państwami, a nawet między regionami jednego państwa. Z tych względów trudno obecnie sformułować jedną, standardową definicję pojęcia „rodzina”.

3. Prawo do ochrony życia rodzinnego ustala również Międzynarodowy pakt praw obywatelskich i politycznych, otwarty do podpisu w Nowym Jorku 16 grudnia 1966 r. (Dz.U. 1977, nr 38, poz. 167; dalej: MPPOiP). W myśl art. 23 MPPOiP rodzina jest naturalną i podstawową komórką społeczeństwa i ma prawo do ochrony ze strony społeczeństwa i państwa. W artykule tym uznano prawo mężczyzn i kobiet w wieku małżeńskim do zawarcia małżeństwa i założenia rodziny. Żaden związek małżeński nie może być zawarty bez swobodnie wyrażonej i pełnej zgody przyszłych małżonków. Państwa strony MPPOiP zobowiązały się podjąć odpowiednie kroki w celu zapewnienia równych praw i obowiązków małżonków w odniesieniu do zawarcia małżeństwa, podczas jego trwania i przy jego rozwiązaniu. W przypadku rozwiązania małżeństwa zobowiązane są również podjąć środki w celu zapewnienia dzieciom niezbędnej ochrony. Podobnie jak inne przytoczone umowy międzynarodowe MPPOiP nie definiuje pojęcia małżeństwa.

\section{Ocena proponowanych rozwiązań}

Jak wyżej wskazano, normy prawa międzynarodowego nie definiują pojęcia małżeństwa. Oznacza to, że instytucję małżeństwa reguluje prawo krajowe, określa-

4 A.N. Szulc, Komentarz do art. 10 [w:] Międzynarodowy Pakt Praw Gospodarczych, Społecznych i Kulturalnych. Komentarz, red. Z. Kędzia, A. Hernandez-Połczyńska, Warszawa 2018, s. 457-458.

5 Ibidem, s. 460. 
jąc podmioty uprawnione do jego zawarcia, stosowane w tym celu tryby, a także inne związane z tym zagadnienia, np. małżeńskie ustroje majątkowe, kwestię nazwisk oraz wzajemne relacje między małżonkami i dziećmi.

\section{Wniosek}

Poselski projekt ustawy o równości małżeńskiej nie jest sprzeczny z prawem międzynarodowym.

\section{Bibliografia}

Szulc A.N, Komentarz do art. 10 [w:] Międzynarodowy Pakt Praw Gospodarczych, Społecznych i Kulturalnych. Komentarz, red. Z. Kędzia, A. Hernandez-Połczyńska, Warszawa 2018.

Wojewoda M., Małżeństwa jednoptciowe i związki partnerskie w polskim rejestrze stanu cywilnego?, „Studia Prawno-Ekonomiczne” 2017, t. CIII, https://doi.org/10.26485/ spe/2017/103/8. 


\title{
Bartosz Pawłowski
}

\section{Ocena zgodności z prawem Unii Europejskiej poselskiego projektu nowelizacji ustawy o ochronie zwierząt oraz niektórych innych ustaw ${ }^{1}$}

\author{
Assessment of compliance with European Union law of the Deputies' Bill \\ on Amending the Act on Animal Protection and Some Other Acts
}

\begin{abstract}
In the author's opinion, the Bill concerns issues partially regulated by the EU law and interferes with the freedom of establishment and the freedom of services guaranteed by the treaties. This does not constitute a breach of the EU law, but the introduced restrictions do not have a proper justification in terms of their proportionality to the intended purpose of the regulation. An argument that similar legal solutions are in force in other Member States was not recognized to be such a justification. According to the author, although the changes contained in the Bill may serve the overriding general interest, that is animal well-being, the compliance of the provisions with the EU law may be challenged. In the remaining scope, the Bill is compliant with the EU law, with an exception of the amendments to the Act on Animal Protection that ban slaughter without stunning in an abattoir or a slaughterhouse.
\end{abstract}

Keywords: animal protection, Bill, European Union

\begin{abstract}
W ocenie autora projekt dotyczy kwestii częściowo regulowanych prawem unijnym i ingeruje w zagwarantowane traktatowo swobodę przedsiębiorczości i swobodę usług. Nie stanowi to naruszenia prawa unijnego, jednak wprowadzane ograniczenia nie mają należytego uzasadnienia pod kątem ich proporcjonalności względem zamierzonego celu regulacji. Za takie uzasadnienie nie uznano argumentu o obowiązywaniu analogicznych rozwiązań prawnych w innych krajach członkowskich. Zdaniem autora, mimo że zmiany zawarte w projekcie mogą służyć realizacji nadrzędnego interesu ogólnego, jakim jest dobrostan zwierząt, zgodność przepisów z prawem UE może zostać zakwestionowana. W pozostałym zakresie projekt jest zgodny z prawem unijnym, wyłączając zmiany w ustawie o ochronie zwierząt wykluczające dokonywanie uboju bez ogłuszania w rzeźni lub ubojni.
\end{abstract}

Słowa kluczowe: ochrona zwierząt, projekt ustawy, Unia Europejska

Ekspert ds. legislacji Biura Analiz Sejmowych •

Kancelaria Sejmu, Biuro Analiz Sejmowych, Wydział Analiz Prawa Międzynarodowego

¡ Zagranicznych Systemów Prawnych, WARSZAWA, POLSKA •

bartosz.pawlowski@sejm.gov.pl • https://orcid.org/0000-0002-8764-6474

$1 \quad$ Opinia $w$ sprawie zgodności z prawem Unii Europejskiej poselskiego projektu ustawy o zmianie ustawy o ochronie zwierząt oraz niektórych innych ustaw sporządzona 15 września 2020 r. na zlecenie Marszałka Sejmu Rzeczypospolitej Polskiej; BAS-WAPM-1935/20. 


\section{Przedmiot projektu ustawy}

W art. 1 projektu ustawy proponuje się znowelizowanie ustawy z 21 sierpnia $1997 \mathrm{r}$. o ochronie zwierząt (t.j. Dz.U. 2020, poz. 638; dalej: u.o.z.). Przedstawione propozycje dotyczą m.in. wprowadzenia nowych definicji, w tym pojęć: „pies rasowy”, „kot rasowy” (art. 4 u.o.z.), poszerzenia katalogu działań i zaniechań uznawanych za znęcanie się nad zwierzętami (art. 6 ust. 2 u.o.z.), rozbudowania procedury odebrania zwierzęcia właścicielowi lub opiekunowi (art. 7 u.o.z.), modyfikacji zakazu trzymania zwierząt domowych na uwięzi w sposób stały (art. 9 ust. 2 u.o.z.), uregulowania warunków tymczasowego trzymania zwierząt domowych na uwięzi oraz trzymania zwierząt w kojcu (art. 9 ust. 3-7 u.o.z.), doprecyzowania zakazu wprowadzania do obrotu psów i kotów poza miejscem ich chowu lub hodowli oraz wprowadzenia zakazu zbywania zwierząt domowych małoletnim (art. 10a u.o.z.), modyfikacji zadań gminy w zakresie zapewniania opieki bezdomnym zwierzętom (art. 11 u.o.z.), wprowadzenia zakazu chowu lub hodowli określonych zwierząt futerkowych w celu pozyskiwania z nich futer (art. 12 ust. 4c u.o.z.), wprowadzenia regulacji, zgodnie z którą dozwolone będą pokazy i wystawy zwierząt polegające wyłącznie na prezentowaniu cech danej rasy zwierząt, przy czym sposób organizacji wystaw i pokazów nie będzie mógł zagrażać życiu i zdrowiu zwierząt ani powodować cierpienia (art. 16a u.o.z.), wprowadzenia zakazu wykorzystywania zwierząt w celach widowiskowych i rozrywkowych (art. 17 ust. 1 u.o.z.), wymogów dotyczących poddawania zwierząt szczególnym sposobom uboju przewidzianym przez obrządki religijne związków wyznaniowych o uregulowanej sytuacji prawnej funkcjonujących na terytorium RP na potrzeby wyłącznie ich członków (art. 34 ust. 3a, ust. 3 b i ust. 7 u.o.z.), modyfikacji zasad nadzoru i kontroli nad przestrzeganiem przepisów o ochronie zwierząt (art. 34a-34c u.o.z.), powołania i określenia zadań, składu i trybu pracy Rady do spraw Zwierząt (rozdział 10b u.o.z. w związku $\mathrm{z}$ art. 11 projektu ustawy), dodania nowych przepisów proceduralnych (rozdział 10c u.o.z.), oraz kar za naruszenie przepisów ustawy (art. 37 i 40 u.o.z.).

Ponadto projekt przewiduje nowelizację ustaw:

- z 17 listopada 1964 r. - Kodeks postępowania cywilnego, t.j. Dz.U. 2019, poz. 1460, ze zm.,

- z 13 września 1996 r. o utrzymaniu czystości i porządku w gminach, t.j. Dz.U. 2020, poz. 1439,

- z 6 czerwca 1997 r. - Kodeks postępowania karnego, t.j. Dz.U. 2020, poz. 30, ze zm.,

- z 24 sierpnia 2001 r. - Kodeks postępowania w sprawach o wykroczenia, t.j. Dz.U. 2020, poz. 729, ze zm.,

- z 29 czerwca 2007 r. o organizacji hodowli i rozrodzie zwierząt gospodarskich, t.j. Dz.U. 2017, poz. 2132; dalej: ustawa o hodowli i rozrodzie.

Artykuły 7-12 projektu ustawy zawierają przepisy o charakterze dostosowującym oraz przejściowym. 
Zgodnie $\mathrm{z}$ art. 13 projektowanej ustawy ma ona wejść w życie po upływie 30 dni od dnia ogłoszenia, z wyjątkiem określonych przepisów, mających wejść w życie po upływie 6 albo 12 miesięcy od dnia ogłoszenia.

\section{- Stan prawa Unii Europejskiej w materii objętej projektem ustawy}

$\mathrm{Z}$ uwagi na to, że projekt ustawy dotyczy częściowo zagadnień regulowanych prawem Unii Europejskiej, dokonując jego oceny, należy uwzględnić:

- art. 49 i art. 56 Traktatu o funkcjonowaniu Unii Europejskiej; dalej: TFUE,

- art. 13 TFUE,

- dyrektywę Rady 98/58/WE z 20 lipca 1998 r. dotyczącą ochrony zwierząt hodowlanych, Dz.Urz. UE L 221 z 8 sierpnia1998 r., s. 23; dalej: dyrektywa 98/58,

- dyrektywę 2006/123/WE Parlamentu Europejskiego i Rady z 12 grudnia 2006 r. dotyczącą usług na rynku wewnętrznym, Dz.Urz. UE L 376 z 27 grudnia 2006 r., s. 36; dalej: dyrektywa 2006/123,

- rozporządzenie Rady (WE) nr 1099/2009 z 24 września 2009 r. w sprawie ochrony zwierząt podczas ich uśmiercania, Dz.Urz. UE L 303 z 18 listopada 2009 r., s. 1; dalej: rozporządzenie 1099/2009,

- dyrektywę 2015/1535 Parlamentu Europejskiego i Rady z 9 września 2015 r. ustanawiającą procedurę udzielania informacji $\mathrm{w}$ dziedzinie przepisów technicznych oraz zasad dotyczących usług społeczeństwa informacyjnego, Dz.Urz. UE L 241 z 17 września 2015 r., s. 1; dalej: dyrektywa 2015/1535.

1. Artykuł 49 TFUE stanowi, że ograniczenia swobody przedsiębiorczości obywateli jednego państwa członkowskiego na terytorium innego państwa członkowskiego są zakazane; swoboda przedsiębiorczości obejmuje podejmowanie i wykonywanie działalności prowadzonej na własny rachunek, jak również zakładanie i zarządzanie przedsiębiorstwami na warunkach określonych przez ustawodawstwo państwa przyjmującego dla własnych obywateli. Swoboda przedsiębiorczości umożliwia zatem obywatelom UE trwałe i ciągłe uczestniczenie w życiu gospodarczym innego państwa członkowskiego niż państwo ich pochodzenia. Możliwość stosowania przepisów o swobodzie przedsiębiorczości warunkuje stała obecność w przyjmującym państwie członkowskim, wskazująca na zintegrowanie z jego życiem gospodarczym.

Z kolei swoboda przepływu usług, o której mowa w art. 56 TFUE, umożliwia obywatelom UE i ich przedsiębiorstwom, utworzonym zgodnie z prawem państw członkowskich, oferowanie świadczeń odpłatnych, legalnych i czasowych na terenie innych państw członkowskich niż państwo ich pochodzenia (czynna swoboda przepływu usług). Swoboda ta umożliwia też korzystanie ze świadczeń oferowanych przez podmioty z innych państw członkowskich (bierna swoboda przepływu usług).

Swoboda przedsiębiorczości i swoboda przepływu usług są ze sobą związane - łączy je krąg beneficjentów (obywatele UE) oraz przedmiot (działalność gospodarcza), różni natomiast element czasu, który w przypadku swobody 
przedsiębiorczości jest z zasady nieograniczony, podczas gdy w ramach swobody świadczenia usług działalność podmiotu pochodzącego $\mathrm{z}$ jednego państwa członkowskiego na terytorium innego państwa członkowskiego ma z zasady charakter tymczasowy. Swobody te różnią się także pod względem treści, gdyż inne są uprawnienia usługodawcy w ramach każdej ze swobód i inne mogą być wymagania stawiane przez prawo krajowe migrującym przedsiębiorcom, w zależności od tego, z której swobody pragną skorzystać.

Korzystanie z podstawowych swobód rynku wewnętrznego nie ma jednak charakteru absolutnego i może podlegać ograniczeniom na mocy prawa UE, jak i prawa krajowego. Przepisy krajowe, których skutkiem mogłoby być utrudnienie lub zniechęcenie do korzystania z tych swobód, muszą jednak być (1) niedyskryminujące wobec podmiotów $\mathrm{z}$ innych państw członkowskich, (2) uzasadnione koniecznością ochrony nadrzędnych wymogów interesu ogólnego, (3) adekwatne z punktu widzenia przyjętego celu i (4) konieczne ( $\mathrm{tj}$. nienakładające ograniczeń wykraczających poza to, co jest niezbędne dla osiągnięcia zakładanego celu regulacji) ${ }^{2}$. Państwa członkowskie korzystają w tym zakresie $\mathrm{z}$ pewnego marginesu uznania co do wyboru najwłaściwszego środka, zaś okoliczność, że $\mathrm{w}$ danym państwie członkowskim ustanowiono bardziej rygorystyczne wymogi niż w innych, nie oznacza sama przez się, że wymogi te są nieproporcjonalne ${ }^{3}$.

2. Analizując kwestie związane $\mathrm{z}$ traktatowymi swobodami przedsiębiorczości oraz usług, należy mieć także na uwadze postanowienia dyrektywy 2006/123. Zgodnie z art. 16 tej dyrektywy państwo członkowskie, w którym świadczona jest usługa, zapewnia możliwość swobodnego podjęcia i prowadzenia działalności usługowej na swoim terytorium. Ewentualne wymogi stawiane usługodawcom muszą być niedyskryminacyjne, konieczne i proporcjonalne. Wymóg ma charakter niedyskryminacyjny, jeżeli ani bezpośrednio, ani pośrednio nie dyskryminuje ze względu na przynależność państwową, lub w przypadku osób prawnych ze względu na państwo członkowskie, w którym prowadzą przedsiębiorstwo. Konieczność wymogu jest rozumiana jako uzasadnienie go względami porządku publicznego, bezpieczeństwa publicznego, zdrowia publicznego lub ochrony środowiska naturalnego, przy czym zgodnie z motywem 41 preambuły dyrektywy 2006/123 pojęcie „porządek publiczny” obejmuje ochronę przed rzeczywistym lub wystarczająco poważnym zagrożeniem jednego $\mathrm{z}$ podstawowych interesów publicznych i może dotyczyć szczególnie kwestii związanych z m.in. dobrostanem zwierząt, natomiast pojęcie "nadrzędnego interesu publicznego" zawiera w sobie m.in. zdrowie zwierząt (motyw 56 preambuły oraz art. 4 pkt 8 dyrektywy 2006/123). W końcu wymóg jest proporcjonalny, jeżeli jest odpowiedni dla osiągnięcia wyznaczonego celu i nie wykracza poza to, co niezbędne do jego osiągnięcia.

2 Wyrok Trybunału Sprawiedliwości Unii Europejskiej (dalej: TSUE) z 30 listopada 1995 r. w sprawie C-55/94, Gebhard, pkt 37.

3 Wyrok TSUE z 10 lutego 2009 r. w sprawie C-110/05, Komisja vs. Republika Włoska, pkt 65. 
Artykuł 15 ust. 7 dyrektywy 2006/123/WE określa wymogi notyfikacyjne. Zgodnie z tym przepisem „państwa członkowskie powiadamiają Komisję o wszelkich nowych przepisach ustawowych, wykonawczych lub administracyjnych, które ustanawiają określone w tej dyrektywie wymogi oraz o przyczynach wprowadzenia takich wymogów. Komisja informuje inne państwa członkowskie o takich przepisach. Powiadomienie takie nie stanowi przeszkody w przyjęciu tych przepisów przez państwa członkowskie. W ciągu 3 miesięcy od daty wpływu powiadomienia Komisja bada zgodność wszelkich nowych wymogów z prawem wspólnotowym [obecnie: unijnym - uwaga B.P.], a w odpowiednich przypadkach podejmuje decyzję wzywającą dane państwo członkowskie do odstąpienia od ich przyjęcia lub do ich uchylenia”.

3. Przepisy dotyczące swobód rynku wewnętrznego należy odczytywać z uwzględnieniem art. 13 TFUE dotyczącego dobrostanu zwierząt. W artykule tym postanowiono, że przy formułowaniu i wykonywaniu polityki rolnej, rybołówstwa i transportu Unii oraz polityk dotyczących rynku wewnętrznego, badań i rozwoju technologicznego oraz przestrzeni kosmicznej Unia i państwa członkowskie w pełni uwzględniają wymagania w zakresie dobrostanu zwierząt jako istot zdolnych do odczuwania, przy równoczesnym przestrzeganiu przepisów prawnych i administracyjnych oraz zwyczajów państw członkowskich związanych w szczególności z obyczajami religijnymi, tradycjami kulturowymi i dziedzictwem regionalnym. $Z$ punktu widzenia materii regulowanej w projekcie ustawy na uwagę zasługuje to, że przy formułowaniu i wykonywaniu polityk dotyczących rynku wewnętrznego państwa członkowskie zobowiązane są uwzględniać wymagania dotyczące dobrostanu zwierząt.

4. Zgodnie $\mathrm{z}$ art. 4 ust. 1 zdanie pierwsze rozporządzenia 1099/2009 zwierzęta są uśmiercane wyłącznie po uprzednim ogłuszeniu zgodnie z metodami i szczegółowymi wymogami związanymi ze stosowaniem tych metod określonymi w załączniku I. Jak stanowi art. 4 ust. 4 rozporządzenia 1099/2009, w przypadku zwierząt poddawanych ubojowi według szczególnych metod wymaganych przez obrzędy religijne wymogi art. 4 ust. 1 tego rozporządzenia nie mają zastosowania, pod warunkiem że ubój ma miejsce w rzeźni. W motywie 18 preambuły rozporządzenia 1099/2009 wskazano, iż: „Odstępstwo od ogłuszania w przypadku odbywającego się w rzeźni uboju zgodnego z obrzędami religijnymi zostało przyznane przez dyrektywę 93/119/WE. Ponieważ przepisy wspólnotowe mające zastosowanie do uboju zgodnego z obrzędami religijnymi były transponowane w różny sposób, zależnie od kontekstu krajowego, oraz biorąc pod uwagę fakt, iż przepisy krajowe uwzględniają kwestie wychodzące poza cel niniejszego rozporządzenia, ważne jest utrzymanie odstępstwa od ogłuszania zwierząt przed ubojem, pozostawiając jednak każdemu państwu członkowskiemu pewien poziom swobody. W rezultacie niniejsze rozporządzenie respektuje wolność wyznania i prawo do uzewnętrzniania religii lub przekonań poprzez uprawianie kultu, nauczanie, praktykowanie i uczestniczenie w obrzędach, co zapisano w art. 10 Karty praw podstawowych Unii Europejskiej”. 
5. Projekt ustawy wymaga także oceny w świetle dyrektywy 2015/1535. Pojęcie „przepisy techniczne” obejmuje m.in. przepisy ustawowe, wykonawcze i administracyjne państw członkowskich, zakazujące produkcji, przywozu, wprowadzania do obrotu lub stosowania produktu lub zakazujące świadczenia bądź korzystania z usługi lub ustanawiania dostawcy usług (art. 1 ust. 1 lit. f dyrektywy 2015/1535).

Zgodnie z art. 5 ust. 1 dyrektywy 2015/1535 państwa członkowskie niezwłocznie przekazują Komisji wszelkie projekty przepisów technicznych, z wyjątkiem tych, które w pełni stanowią transpozycję normy międzynarodowej lub europejskiej, w którym to przypadku wystarczająca jest informacja dotycząca odpowiedniej normy. Ponadto państwa członkowskie obowiązane są przekazać Komisji także uzasadnienie konieczności przyjęcia takich przepisów technicznych, jeżeli uzasadnienie to nie zostało wyraźnie ujęte w projekcie. Komisja i pozostałe państwa członkowskie są uprawnione do zgłaszania swoich uwag do danego projektu, a państwo, które dokonało notyfikacji, obowiązane jest do możliwie pełnego uwzględnienia tych uwag.

Przepis art. 6 dyrektywy 2015/1535 nakazuje państwom członkowskim wstrzymać przyjmowanie notyfikowanego aktu prawnego. Dyrektywa przewiduje, że takie zawieszenie prac może trwać od 3 do 18 miesięcy, w zależności od opisanych w niej przypadków. W uzasadnionych, niecierpiących zwłoki przypadkach państwa członkowskie mogą przyjąć akty zawierające przepisy techniczne bez zachowania procedury notyfikacyjnej (art. 6 ust. 7 dyrektywy).

\section{Analiza przepisów projektu ustawy pod kątem ustalonego stanu prawa Unii Europejskiej}

1. Projekt zawiera przepisy, które mogą zostać uznane za ograniczające uregulowane w prawie UE swobodę przedsiębiorczości i swobodę świadczenia usług.

- Projektowana modyfikacja art. 11 u.o.z. zakłada, że schroniska dla zwierząt mogłyby być tworzone lub prowadzone wyłącznie przez jednostki samorządu terytorialnego bądź ich jednostki organizacyjne lub organizacje społeczne, których statutowym celem działania jest ochrona zwierząt, które nie działają w celu osiągnięcia zysku, posiadające status organizacji pożytku publicznego.

- Dodawany w art. 12 u.o.z. ust. 4c przewiduje zakaz chowu i hodowli zwierząt futerkowych, o których mowa w art. 2 pkt 3 ustawy z 29 czerwca 2007 r. o organizacji hodowli i rozrodzie zwierząt gospodarskich (t.j. Dz.U. 2017, poz. 2132$)^{4}$, z wyjątkiem królika, w celu pozyskiwania $\mathrm{z}$ nich futer.

4 Przywołany przepis obejmuje następujące zwierzęta futerkowe: lisa pospolitego ( $V u l-$ pes vulpes), lisa polarnego (Alopex lagopus), norkę amerykańską (Mustela vison), tchórza (Mustela putorius), jenota (Nyctereutes procyonoides), nutrię (Myocastor coypus), szynszylę (Chinchilla lanigera) i królika (Oryctolagus cuniculus). 
- Przewidziane modyfikacje art. 15 i 17 u.o.z. przewidują zakaz wykorzystywania zwierząt w celach widowiskowych i rozrywkowych, co oznacza w szczególności zakaz organizowania i prowadzenia występów cyrkowych z udziałem zwierząt.

- Dodawany w art. 34 u.o.z. ust. 3a dopuszcza szczególny sposób uboju przewidziany przez obrządki religijne związków wyznaniowych o uregulowanej sytuacji prawnej, funkcjonujących na terytorium RP (tzw. ubój bez ogłuszania), jednak wyłącznie na potrzeby członków tych związków wyznaniowych.

$\mathrm{Z}$ art. 49 i z art. 56 TFUE wywodzone są określone wnioski orzecznicze (zob. pkt $1 \mathrm{w}$ podrozdz. „Stan prawa Unii Europejskiej w materii objętej projektem ustawy”). Uwzględniając orzecznictwo TSUE, można stwierdzić, że w projektowanych przepisach nie wprowadza się dyskryminacji bezpośredniej (jawnej), ponieważ nie różnicuje się w nich w sposób wyraźny sytuacji prawnej podmiotów objętych jego regulacją w zależności od ich przynależności państwowej. Wynikające z proponowanych przepisów ograniczenia możliwości prowadzenia działalności oraz świadczenia usług, odnoszą się w jednakowym stopniu do przedsiębiorców z Polski, jak i pozostałych państw członkowskich.

Nie wyczerpuje to jednak analizy zgodności projektu z art. 49 i art. 56 TFUE. Należy bowiem rozważyć, czy proponowane przepisy nie wprowadzają dyskryminacji pośredniej (ukrytej) lub innych ograniczeń swobody przedsiębiorczości lub swobody świadczenia usług o charakterze niedyskryminacyjnym. Dyskryminacja pośrednia ma miejsce, gdy pozornie neutralny przepis, stosowany niezależnie od przynależności państwowej, stawia w niekorzystnej sytuacji przede wszystkim lub w znacznej większości przedsiębiorców z innych państw członkowskich ${ }^{5}$. W odniesieniu do projektowanych regulacji brak jest przesłanek do stwierdzenia dyskryminacji pośredniej, bowiem nie przewidują one rozwiązań, które w praktyce stawiałyby w gorszej sytuacji podmioty $z$ innych państw członkowskich ${ }^{6}$.

Zgodnie z orzecznictwem TSUE wszelkie podjęte przez państwa członkowskie środki, które uniemożliwiają, utrudniają lub czynią mniej atrakcyjnymi korzystanie ze swobód traktatowych, stanowią bariery w ramach rynku wewnętrznego - nawet jeżeli te ograniczenia są stosowane bez rozróżnienia wobec podmiotów z państwa przyjmującego i z innych państw członkowskich ${ }^{7}$.

W szczególności należy uwzględnić utrwaloną linię orzeczniczą TSUE, zgodnie z którą zakaz wyrażony w art. 49 TFUE nie ogranicza się do dyskryminacji ze względu na przynależność państwową, ale obejmuje również niedyskrymi-

Zob. np. wyrok TSUE z 8 stycznia 2007 r. w sprawie C-332/05, Celozzi, pkt 24.

6 Por. wyrok TSUE z 8 czerwca 2017 r. w sprawie C-580/15, Maria Eugenia Van der Weegen $i$ in. vs. Belgische Staat, pkt 29.

7 Wyroki TSUE z 28 lutego 2008 r. w sprawie C-293/06, Deutsche Shell GmbH vs. Finanzamt für Großunternehmen in Hamburg, pkt 2, oraz z 3 czerwca 2010 r. w sprawie C-258/08, Ladbrokes Betting \& Gaming Ltd i Ladbrokes International Ltd vs. Stichting de Nationale Sporttotalisator, pkt 15. 
nacyjne ograniczenia swobody przedsiębiorczości. Państwa członkowskie mogą bowiem wprowadzać regulacje w zakresie określania zasad dotyczących prowadzenia działalności gospodarczej, lecz pod pewnymi warunkami. Jak wynika z orzecznictwa TSUE, środki krajowe, które mogłyby utrudnić lub uczynić mniej atrakcyjnym korzystanie z podstawowej swobody, jaką jest swoboda przedsiębiorczości, powinny spełniać cztery warunki: muszą być stosowane w sposób niedyskryminujący; muszą być usprawiedliwione nadrzędnymi wymogami interesu ogólnego; muszą być odpowiednie do zapewnienia realizacji zamierzonego celu i nie mogą wykraczać poza to, co konieczne dla realizacji tego celu ${ }^{8}$.

W odniesieniu do proponowanych zmian art. 11, 12, 15, 17 i 34 u.o.z., jak odnotowano wyżej, nie ma mowy o dyskryminowaniu podmiotów z innych państw członkowskich. Pierwszy warunek dopuszczalności projektowanych ograniczeń jest zatem spełniony. Jeżeli chodzi o interes ogólny podlegający ochronie, to projektodawcy wskazują, że proponowane rozwiązanie ma przede wszystkim zagwarantować odpowiedni poziom opieki nad zwierzętami, a zatem będzie to służyć polepszeniu dobrostanu zwierząt oraz ochrony zdrowia zwierząt. Są to względy zmierzające do osiągnięcia słusznych celów zgodnych $z$ art. 13 TFUE i uzasadnionych nadrzędnym względem interesu ogólnego, wobec czego - w świetle orzecznictwa TSUE - państwa członkowskie mogą powoływać się na nie, aby uzasadnić odstępstwa od swobód rynku wewnętrznego ${ }^{9}$. Drugi i trzeci warunek również należy uznać za spełnione. W świetle danych zawartych w uzasadnieniu projektu wprowadzenie proponowanych ograniczeń umożliwi przeciwdziałanie opisanym w nim negatywnym zjawiskom, co pozwala uznać, że proponowane przepisy mają charakter celowy (adekwatny).

W odniesieniu do czwartego warunku (konieczność) trzeba odnotować, że choć omawiane zakazy (projektowane art. 11, 12, 15, 17 i 34 u.o.z.) stanowią najdalej idące ograniczenia, to projektodawcy nie wykazali w uzasadnieniu projektu ustawy analizy możliwości i skutków wprowadzenia alternatywnych, mniej surowych ograniczen ${ }^{10}$. W przypadku gdy państwo członkowskie nie wykazało ani niezbędnego charakteru, ani proporcjonalności spornych środków w stosunku do zamierzonego celu, ograniczenie przez takie środki traktatowej swobody przedsiębiorczości uznaje się za niedopuszczalne ${ }^{11}$.

8 Zob. m.in. wyroki TSUE z: 30 listopada 1995 r. w sprawie C-55/94, Gebhard, pkt 37; 10 marca 2009 r. w sprawie C-169/07, Hartlauer, pkt 44, oraz 11 marca 2010 r. w sprawie C-384/08, Attanasio Group, pkt 51.

9 Por. np. wyroki TSUE z: 11 marca 2010 r. w sprawie C-384/08, Attanasio Group, pkt 50, oraz 25 października 2007 r. w sprawie C-464/05, Geurts $i$ Vogten, pkt 24.

10 Por. wyroki TSUE w sprawach C-320/03, Komisja vs. Republika Austrii, pkt 87; C-110/05, Komisja vs. Republika Włoska, pkt 66;C-265/06, Komisja vs. Portugalia, pkt 39, oraz w sprawie C-150/11, Komisja vs. Królestwo Belgii, pkt 55, C-147/03, Komisja vs. Republika Austrii, pkt 63.

11 Wyrok TSUE w sprawie C-438/08, Komisja vs. Republika Portugalska, pkt 49. 
W przypadku ograniczeń dotyczących prowadzenia schronisk dla zwierząt, ze względu na szczególny charakter działalności, której dotyczy ograniczenie, projektowane rozwiązanie można uznać za niesprzeczne z zasadą proporcjonalności. Wymaga podkreślenia, że celem prowadzenia działalności w zakresie prowadzenia schronisk dla zwierząt ma być zapewnienie właściwego poziomu opieki nad zwierzętami, a nie osiąganie zysku, wobec czego ograniczenie kręgu podmiotów prowadzących taką działalność do podmiotów wskazanych przez projektodawców jest uzasadnione ${ }^{12}$.

W przypadku projektowanego zakazu chowu i hodowli zwierząt futerkowych w celu pozyskania z nich futer można wskazać, że nie przeanalizowano rozwiązań polegających na zapewnieniu odpowiednich warunków chowu i hodowli takich zwierząt.

W przypadku projektowanego art. 12 ust. 4c u.o.z. analiza możliwych środków alternatywnych jest tym bardziej wymagana, że autorzy projektu ustawy wskazują w uzasadnieniu na konkretne niedociągnięcia, które powodują negatywne skutki. Konieczne jest w takiej sytuacji rozważenie, czy bardziej proporcjonalnym środkiem nie byłyby działania zmierzające do zapewnienia skuteczniejszego egzekwowania obowiązujących obecnie przepisów. Wymaga wskazania, że w tym obszarze właściwym aktem jest m.in. dyrektywa Rady 98/58/WE z 20 lipca 1998 r. dotycząca ochrony zwierząt hodowlanych (Dz.Urz. UE L 221 z 8 sierpnia 1998 r., s. 23), wdrożona do polskiego porządku prawnego na mocy ustawy o ochronie zwierząt. Należy także podkreślić, że zasadniczo względy o charakterze czysto administracyjnym (jak np. problemy z zapewnieniem właściwego nadzoru) nie mogą zostać uznane za wystarczające uzasadnienie odstępstwa od swobód rynku wewnętrznego ${ }^{13}$.

Wobec powyższego proponowany art. 12 ust. 4c u.o.z. może zostać uznany za daleko idące ograniczenie swobody przedsiębiorczości, co samo w sobie nie stanowi naruszenia prawa UE. Jednak wobec braku wymaganego uzasadnienia

12 W tym kontekście można przywołać wyrok TSUE z 11 grudnia 2014 r. w sprawie C-113/13, ASL Spezzino. Przedmiotem rozstrzygnięcia były wprawdzie regulacje z zakresu zamówień publicznych, lecz dokonano w nim także wykładni art. 49 TFUE w związku z kategorią podmiotów działających w określonej formie i w określonym celu. TSUE uznał w tym wyroku, iż „art. 49 TFUE i art. 56 TFUE należy interpretować $\mathrm{w}$ ten sposób, że postanowienia te nie stoją na przeszkodzie uregulowaniom krajowym, które, tak jak te rozpatrywane w postępowaniu głównym, przewidują, iż świadczenie usług transportu sanitarnego i ratownictwa medycznego musi być powierzane w pierwszej kolejności i w drodze bezpośredniego udzielenia zamówienia, bez jakiegokolwiek ogłoszenia o zamówieniu, organizacjom wolontariackim objętym umowami, o ile ramy prawne i umowne, w których prowadzona jest działalność tychże organizacji faktycznie przyczyniają się do celu społecznego i do realizacji celów solidarności oraz efektywności budżetowej, na których opierają się te uregulowania”. Wyrok TSUE w sprawie C-356/08, Komisja vs. Republika Austrii, pkt 46. 
konieczności wprowadzenia projektowanych rozwiązań przepis ten budzi wątpliwości co do zgodności z art. 49 TFUE w rozumieniu nadanym mu w orzecznictwie TSUE.

W odniesieniu do zakazu wykorzystywania zwierząt do celów rozrywkowych i widowiskowych trzeba podkreślić, że wprowadzenie proponowanego zakazu zalicza się z pewnością do najdalej idących ograniczeń, przy czym projektodawcy nie przeanalizowali w uzasadnieniu projektu możliwości i skutków wprowadzenia alternatywnych, mniej surowych ograniczeń (np. w postaci uregulowania wzmocnienia mechanizmów kontrolnych i sankcji zabezpieczających stosowanie obowiązujących przepisów). Konieczność dokonania takiej oceny w celu uzasadnienia wprowadzanego ograniczenia swobody traktatowej wynika $z$ orzecznictwa TSUE przytoczonego wyżej. Podobnie należy ocenić zakaz działalności polegającej na dokonywaniu uboju bez ogłuszania w celu eksportu. Brak uzasadnienia konieczności wprowadzania tak daleko idących ograniczeń rodzi wątpliwości co do zgodności proponowanych rozwiązań z art. 49 i art. 56 TFUE.

2. W myśl projektowanych zmian art. 11 u.o.z. schroniska dla zwierząt będą mogły być tworzone lub prowadzone wyłącznie przez jednostki samorządu terytorialnego bądź ich jednostki organizacyjne lub organizacje społeczne, których statutowym celem działania jest ochrona zwierząt, które nie działają w celu osiągnięcia zysku, posiadające status organizacji pożytku publicznego. Przepisy te można zakwalifikować jako określające obowiązek przyjęcia określonej formy prawnej, w rozumieniu art. 15 ust. 2 lit. b dyrektywy 2006/123/WE. W myśl art. 15 ust. 7 dyrektywy 2006/123/WE wprowadzenie takiego wymogu podlega obowiązkowi notyfikacyjnemu.

3. Zgodnie z art. 34 ust. 1 u.o.z. zwierzę kręgowe w ubojni może zostać uśmiercone tylko po uprzednim nieodwracalnym pozbawieniu świadomości przez osoby posiadające odpowiednie kwalifikacje. W myśl projektowanych art. 34 ust. 3a i 3b u.o.z. wymóg ten ma nie być stosowany przy poddawaniu zwierząt szczególnym sposobom uboju przewidzianym przez obrządki religijne związków wyznaniowych o uregulowanej sytuacji prawnej funkcjonujących na terytorium RP na potrzeby wyłącznie jej członków, z tym że w takim wypadku nie będzie zezwolone stosowanie systemów krępujących bydło przez umieszczenie w odwrotnym położeniu lub w dowolnym innym nienaturalnym położeniu.

Proponowana regulacja dotyczy zagadnienia będącego przedmiotem art. 4 ust. 4 rozporządzenia 1099/2009, który w przypadku zwierząt poddawanych ubojowi według szczególnych metod wymaganych przez obrzędy religijne zezwala na odstępstwo od wymogów określonych w art. 4 ust. 1 tego rozporządzenia 1099/2009, pod warunkiem że ubój ma miejsce w rzeźni. Ponadto należy uwzględnić art. 26 ust. 2 lit. c rozporządzenia 1099/2009, w myśl którego państwa członkowskie mogą przyjąć przepisy krajowe, które służą zapewnieniu dalej idącej ochrony zwierząt podczas ich uśmiercania w porównaniu z przepisami zawartymi w tym rozporządzeniu, w dziedzinie uboju i działania związanego 
z uśmiercaniem zwierząt zgodnie z art. 4 ust. 4 tego rozporządzenia. Państwa członkowskie są obowiązane do powiadomienia Komisji Europejskiej o takich przepisach krajowych.

Z przywołanych przepisów wynika, że projektowane art. 34 ust. 3a i 3b w związku z art. 34 ust. 1 u.o.z. nie gwarantują zgodności z określonym w art. 4 ust. 4 rozporządzenia 1099/2009 wymogiem dokonywania uboju bez ogłuszania w rzeźni (ubojni). W tym zakresie projektowane przepisy mogą być uznane za niezgodne $z$ art. 4 ust. 4 rozporządzenia 1099/2009.

4. Proponowany art. 12 ust. 4c u.o.z. przewiduje zakaz chowu i hodowli określonych zwierząt hodowanych w celu pozyskiwania $z$ nich futer. Przepis ten może zostać uznany za przepis techniczny w rozumieniu dyrektywy 2015/1535, gdyż dotyczy on zakazu produkcji pewnej kategorii produktów. Także nowelizacja art. 34 u.o.z. ograniczająca możliwość dokonywania uboju bez ogłuszania prowadzi w znacznym stopniu do zakazu produkcji określonych produktów, może zatem zostać uznana za przepis techniczny w rozumieniu dyrektywy 2015/1535. W związku z tym projekt ustawy należy uznać za podlegający notyfikacji projekt przepisów technicznych. Notyfikacja Komisji odbywa się za pośrednictwem ministra właściwego do spraw gospodarki, który jest koordynatorem krajowego systemu notyfikacji norm i aktów prawnych ${ }^{14}$.

5. Odnosząc się do zawartych w uzasadnieniu argumentów dotyczących obowiązujących w innych państwach członkowskich UE ograniczeń i zakazów, należy stwierdzić, że zgodnie z orzecznictwem TSUE ${ }^{15}$ państwo członkowskie nie może powoływać się na niewykonanie zobowiązań w obszarze jednolitego rynku przez inne państwo członkowskie w celu usprawiedliwienia własnego zaniechania działania. Zgodnie z orzecznictwem TSUE skutki zaniechań państw członkowskich nie znoszą się bowiem wzajemnie, lecz kumulują, zaś szkodliwe konsekwencje dla jednolitego rynku są coraz większe. Tym samym Trybunał odrzuca taką argumentację.

\section{Wniosek}

Poselski projekt ustawy o zmianie ustawy o ochronie zwierząt oraz niektórych innych ustaw dotyczy częściowo kwestii regulowanych prawem Unii Europejskiej.

Projekt przewiduje niedyskryminacyjne ograniczenia określonej w przepisach art. 49 i n. oraz art. 56 i n. TFUE swobody przedsiębiorczości i swobody

14 Paragraf 1 ust. 3 rozporządzenia Rady Ministrów z 23 grudnia 2002 r. w sprawie sposobu funkcjonowania krajowego systemu notyfikacji norm i aktów prawnych. Dz.U. nr 239, poz. 2039, ze zm.

15 Wyrok TSUE 22 marca 1977 r. w sprawie C-78/76, Steinike \& Weinlig vs. République Fédérale d'Allemagne, ECLI:EU:C:1977:52, pkt 24. 
świadczenia usług. Należy uznać, że zmiany projektowane w przepisach art. 12, 15, 17 i 34 u.o.z. służą realizacji nadrzędnego interesu ogólnego, jakim jest ochrona dobrostanu zwierząt. W projekcie nie uzasadniono jednak w wymagany sposób konieczności (proporcjonalności) przewidzianych rozwiązań dla zamierzonego celu. Brak wymaganego uzasadnienia może doprowadzić do zakwestionowania zgodności tych przepisów z prawem Unii Europejskiej.

Zmiany projektowane w art. 34 u.o.z. w zakresie, w jakim nie zapewniają dokonywania uboju bez ogłuszania w rzeźni (ubojni), mogą być uznane za niezgodne $\mathrm{z}$ art. 4 ust. 4 rozporządzenia 1099/2009.

W pozostałym zakresie projekt ustawy nie narusza prawa Unii Europejskiej.

Projekt ustawy podlega notyfikacji Komisji Europejskiej w trybie dyrektywy $2015 / 1535$. 
Jacek Kulicki ${ }^{\mathrm{a}}$, Zofia Szpringer ${ }^{\mathrm{b}}$, Marek Jaśkowskic

\title{
Ocena zmienionego wniosku dotyczącego decyzji Rady w sprawie systemu zasobów własnych Unii Europejskiej ${ }^{1}$
}

\author{
Assessment of the amended proposal for a Council Decision on the System \\ of Own Resources of the European Union
}

The purpose of the proposed decision is to raise the limit of the annual own resources in relation to the national income (GNI) of the EU Member States and to empower the Commission to borrow up to EUR 750 billion at 2018 prices on the capital markets on behalf of the EU. These borrowed funds would be dedicated solely to combating the consequences of the COVID-19 pandemic. According to the authors of the opinion, the proposal is valid and rational from the perspective of protection and development of the internal market as an important Community element and does not raise doubts as to its compliance with the principle of subsidiarity. Its compatibility with Article 310 TFEU may however be disputed.

Keywords: budget, budget deficit, coronavirus, European Union

Celem projektowanej decyzji jest podniesienie pułapu rocznych zasobów własnych w odniesieniu do dochodu narodowego (DNB) państw członkowskich UE oraz upoważnienie Komisji do zaciągnięcia w imieniu UE pożyczek na rynkach kapitałowych do wysokości 750 mld euro w cenach z 2018 r. Środki te mają służyć wyłącznie zwalczaniu skutków pandemii COVID-19. Zdaniem autorów opinii projekt jest uzasadniony i racjonalny z punktu widzenia ochrony i rozwoju rynku wewnętrznego jako istotnego elementu wspólnotowego oraz nie budzi wątpliwości co do zgodności z zasadą pomocniczości, jego zgodność z art. 310 ust. 1 TFUE jest natomiast dyskusyjna.

Słowa kluczowe: budżet, deficyt budżetowy, koronawirus, Unia Europejska

a Doktor nauk prawnych -

ekspert ds. finansów publicznych Biura Analiz Sejmowych Kancelaria Sejmu, Wydział Analiz Społecznych i Ekonomicznych, Zespół Studiów Ekonomicznych, WARSZAWA, POLSKA -

jacek.kulicki@sejm.gov.pl • https://orcid.org/0000-0003-2631-6428

b Doktor nauk ekonomicznych -

naczelnik Wydziału Analiz Społecznych i Ekonomicznych w Biurze Analiz

Sejmowych, Kancelaria Sejmu, Biuro Analiz Sejmowych, Wydział Analiz Społecznych

i Ekonomicznych, WARSZAWA, POLSKA •

zofia.szpringer@sejm.gov.pl • https://orcid.org/0000-0002-8265-4440

$1 \quad$ Opinia w sprawie zmienionego wniosku dotyczącego decyzji Rady w sprawie systemu zasobów własnych Unii Europejskiej (COM(2020) 445 final) sporządzona 14 lipca 2020 r. na zlecenie Przewodniczącego Komisji do Spraw Unii Europejskiej; BAS-WASiE/ WAPM-1350/20. 
Doktor nauk prawnych, adiunkt -

Uniwersytet Kardynała Stefana Wyszyńskiego w Warszawie, Wydział Prawa

i Administracji, Katedra Prawa Międzynarodowego i Europejskiego, WARSZAWA,

POLSKA -

m.jaskowski@uksw.edu.pl • https://orcid.org/0000-0001-6598-810X

\section{Opinia merytoryczna}

\section{Przedmiot dokumentu UE}

\section{- Cel i treść dokumentu UE}

Przedmiotem oceny jest zmieniony wniosek Komisji dotyczący decyzji Rady w sprawie systemu zasobów własnych Unii Europejskiej (COM(2020) 445 final; dalej: projekt).

Celem projektowanej decyzji jest podniesienie pułapu rocznych zasobów własnych w odniesieniu do dochodu narodowego (DNB) państw członkowskich UE oraz upoważnienie Komisji do zaciągnięcia w imieniu UE pożyczek na rynkach kapitałowych do wysokości 750 mld euro w cenach z 2018 r.

Projekt zakłada zmianę wcześniejszego wniosku (zob. COM(2018) 325 final) $\mathrm{w}$ pięciu aspektach.

Po pierwsze, zawiera upoważnienie do zaciągnięcia przez Komisję w imieniu UE pożyczek na rynkach kapitałowych do wysokości 750 mld euro w cenach z 2018 r., które to środki będą mogły być wykorzystane - jako nadzwyczajny i tymczasowy środek służący finansowaniu działań przeciwdziałających kryzysowi związanemu z COVID-19 - na pożyczki dla państw członkowskich do wysokości 250 mld euro oraz na wydatki (wsparcie bezzwrotne dla państw członkowskich) do wysokości 500 mld euro w cenach z 2018 r., a także zasady spłaty tej pożyczki (nowy art. 3b),

Po drugie, wprowadza zasadę zabraniającą wykorzystywania przez UE środków pożyczonych na rynkach kapitałowych do finansowania wydatków operacyjnych (nowy art. 3a), z tym że z zasady tej wyłączone mają być pożyczki zaciągnięte w celu złagodzenia skutków kryzysu związanego z COVID-19 (art. 3b pkt 1 lit. b),

Po trzecie, w projekcie zaproponowano zwiększenie o 0,11 pkt proc. pułapu środków na pokrycie zobowiązań i płatności, odpowiednio z 1,35\% do 1,46\% (zobowiązania) i z 1,29\% do 1,40\% (płatności) DNB wszystkich państw członkowskich (zmiana art. 3 ust. 1 i 2 pierwotnego projektu decyzji),

Po czwarte, projekt zawiera uregulowanie podwyższające czasowe limity (pułapy) środków własnych opartych na DNB o 0,6 pkt proc. w celu pokrycia wszystkich zobowiązań UE wynikających z zaciągniętych pożyczek na złagodzenie skutków kryzysu gospodarczego, aż do momentu wygaśnięcia wszystkich tych zobowiązań, najpóźniej do 31 grudnia 2058 r. (nowy art. 3c), 
Po piąte, wprowadza zasadę zobowiązującą państwa członkowskie do udostępnienia Komisji niezbędnych zasobów w celu spłaty zaciągniętych przez UE pożyczek, jeżeli środki zapisane w budżecie okażą się niewystarczające do wypełnienia przez UE tych zobowiązań (nowy ust. $4 \mathrm{w}$ art. 6).

Pozostałe regulacje pierwotnego wniosku pozostają bez zmian (określenie kategorii zasobów własnych, w tym propozycja włączenia do nich zasobów opartych na podatku dochodowym od przedsiębiorstw, unijnym systemie handlu uprawnieniami do emisji, odpadach opakowaniowych z tworzyw sztucznych, obniżki i rabaty dla państw członkowskich, przenoszenie nadwyżki dochodów nad wydatkami występującej w roku budżetowym na następny rok budżetowy, pobór zasobów własnych UE, zakres środków wykonawczych związanych z zasobami własnymi UE) ${ }^{2}$.

\section{- Geneza dokumentu UE}

Przedstawiony przez Komisję wniosek związany jest z kryzysem zdrowia publicznego wywołanym przez COVID-19 oraz będącym jego skutkiem kryzysem gospodarczym prowadzącym - według szacunków Komisji - do obniżenia PKB UE w 2020 r. o ok. 7,5\% i wzrostu bezrobocia do 9\%, czemu towarzyszy ryzyko pogłębienia się ubóstwa i nierówności.

Zdaniem Komisji zaproponowane rozwiązanie (zaciągnięcie pożyczki na rynkach kapitałowych przez UE jako całość i rozłożenie jej spłaty na co najmniej 31 lat, począwszy od 1 stycznia 2028 r.) stanowi uzupełnienie dyskrecjonalnych środków gospodarczych i finansowych podejmowanych przez państwa członkowskie w celu przeciwdziałania negatywnym skutkom pandemii COVID-19. Upoważnienie Komisji do zaciągnięcia w imieniu UE pożyczek na rynkach kapitałowych umożliwi znaczne zwiększenie środków finansowych w celu wsparcia odbudowy potencjału gospodarczego UE.

\section{- Informacja o stanie prawa obowiązującego w Polsce w materii objętej treścią dokumentu UE}

Przyjęcie projektowanych zmian w zakresie systemu zasobów własnych Unii Europejskiej nie wywołuje bezpośrednich skutków legislacyjnych.

Po przyjęciu przez Radę decyzja będzie podlegała ratyfikacji zgodnie z wymogami Konstytucji RP.

2 Zob. opinia BAS z 13 czerwca 2018 r. odnoszącą się do wniosku dotyczącego decyzji Rady w sprawie systemu zasobów własnych Unii Europejskiej (COM(2018) 325 final), sygn. BAS-WASiE/WAPM-1197/18, http://www.sejm.gov.pl/sejm8.nsf/EDLS.xsp?vie $\mathrm{w}=1 \&$ docId=4A5A5CC2AD00F508C12584A80039B33D\&lang=PL [dostęp: 3 lipca 2020 r.]. 


\section{Ocena dokumentu UE}

\section{- Ocena skutków dokumentu UE}

Projektowana decyzja wprowadza istotne zmiany do pierwotnego projektu decyzji dotyczącej zasobów własnych UE, która ma zagwarantować środki na realizację wydatków w ramach perspektywy finansowej na lata 2021-2027 (zob. $\operatorname{COM}(2018) 325$ final). W istocie dotyczą one dwóch zasadniczych elementów. Po pierwsze, podniesienia wkładu państw członkowskich opartego na DNB (zmiana ust. 1 i $2 \mathrm{w}$ art. 3), po drugie, zwiększenia środków UE przez zaciągnięcie pożyczek na rynkach kapitałowych (nowy art. 3b).

O ile zwiększenie środków UE przez zaciągnięcie pożyczek na rynkach kapitałowych stanowi nadzwyczajny i tymczasowy instrument finansowy, o tyle podniesienie wkładu państw członkowskich w odniesieniu do DNB ma charakter stały. Zauważyć przy tym należy, że regulacja dotycząca wpłat własnych państw członkowskich opartych na DNB zawarta jest w dwóch przepisach. Pierwszy (art. 3 ust. 1 i 2) odnosi się do określenia łącznej kwoty zasobów własnych przydzielonych UE na pokrycie rocznych środków na płatności i zobowiązania, jako elementu stałego kształtującego system zasobów własnych UE. Zgodnie z propozycją Komisji zarówno limit na płatności, jak i limit na zobowiązania mają być podniesione o 0,11 pkt proc.: dla płatności z 1,29\% do 1,40\% DNB wszystkich państw członkowskich (art. 3 ust. 1), dla zobowiązań z 1,35\% do 1,46\% DNB wszystkich państw członkowskich (art. 3 ust. 2). Ta zmiana, jak wynika z nowego motywu 13a, ma na celu zachowanie ,wystarczającego marginesu w ramach pułapów wskazanych w decyzji w sprawie zasobów własnych, tak aby Unia mogła pokryć wszystkie swoje zobowiązania finansowe i warunkowe, których termin zapadalności przypada na dany rok" i jest związana po części z przewidywanym spowolnieniem gospodarczym wynikającym z COVID-19. Niemniej należy zauważyć, że jeżeli propozycja podwyższenia limitu wpłat opartych na DNB związana jest jedynie z przewidywanym spowolnieniem gospodarczym, to projekt powinien zawierać - w przypadku powrotu do stanu sprzed wybuchu epidemii COVID-19 - mechanizm umożliwiający powrót do pierwotnych limitów. Jest to o tyle uzasadnione, że projekt zawiera dwie następne regulacje dotyczące wpłat państw członkowskich. Obie związane są z upoważnieniem Komisji do zaciągnięcia w imieniu UE pożyczek na rynkach kapitałowych w celu sfinansowania walki ze skutkami pandemii COVID-19. Pierwsza polega na czasowym podwyższeniu (o 0,6 pkt proc.) wkładu państw członkowskich opartego na DNB (art. 3c), druga zobowiązuje państwa członkowskie do udostępnienia Komisji niezbędnych zasobów w celu spłaty zaciągniętych przez UE pożyczek, jeżeli środki zapisane w budżecie okażą się niewystarczające do wypełnienia przez UE tych zobowiązań (nowy ust. $4 \mathrm{w}$ art. 6). Kwoty te mogą być przeznaczone wyłącznie na pokrycie zobowiązań UE z tytułu zaciągniętych pożyczek. Tym samym przepisy dotyczące zasobów własnych UE gwarantują środki na spłatę zobowiązań UE z tytułu za- 
ciągniętych przez nią pożyczek. Dodatkowy margines w tym zakresie wydaje się w przypadku powrotu wzrostu gospodarczego zbędny, o ile UE nie będzie chciała przeznaczyć ich na inne cele niż spłatę zobowiązań związanych z zaciągniętymi pożyczkami.

W odniesieniu do zwiększenia środków UE przez zaciągnięcie pożyczek na rynkach kapitałowych należy zauważyć, że możliwość taka ma mieć charakter nadzwyczajny i tymczasowy. Środki te mogą służyć wyłącznie celom złagodzenia skutków kryzysu związanego z COVID-19. W decyzji określono jedynie, co zrozumiałe w przypadku decyzji dotyczącej dochodów budżetowych, limit pożyczek (750 mld euro), kwotę przeznaczoną na pożyczki dla państw członkowskich (250 mld euro) i wydatki stanowiące pomoc bezzwrotną dla państw członkowskich (500 mld euro), zasadę spłaty pożyczki i odsetek z budżetu ogólnego UE, zasadę planowości, zasadę należytego zarządzania finansami, okres spłaty pożyczki (od 1 stycznia 2028 r. do 31 grudnia 2058 r.), roczny limit spłaty kwoty głównej (7,5\% kwoty pożyczki, którą UE może maksymalnie zaciągnąć).

Upoważnienie do zaciągnięcia pożyczki należy ocenić przede wszystkim w kontekście zasad traktatowych. Zgodnie z art. 311 akapit pierwszy traktatu o funkcjonowaniu Unii Europejskiej (TFUE) Unia pozyskuje środki niezbędne do osiągnięcia swoich celów i należytego prowadzenia swoich polityk. Jednym $\mathrm{z}$ celów UE jest ustanowienie jednolitego rynku (art. 3 ust. 3 traktatu o Unii Europejskiej,TUE), a więc obszaru bez granic wewnętrznych, w którym jest zapewniony swobodny przepływ towarów, osób, usług i kapitału, zgodnie z postanowieniami traktatowymi (art. 26 ust. 2 TFUE). Pandemia COVID-19 niewątpliwie stanowi istotne zagrożenie dla funkcjonowania rynku wewnętrznego, swobody przepływu przede wszystkim towarów, osób i usług. Z tego względu UE ma obowiązek podejmować działania przeciwdziałające erozji rynku wewnętrznego, nie tylko spadku DNB, ale również powodującego wszelkie formy wykluczenia obywateli UE i przedsiębiorstw, będącego następstwem nie tylko czynników obiektywnych, związanych w tym przypadku z pandemią COVID-19, ale również protekcjonistycznej polityki poszczególnych państw członkowskich chroniących swoje rynki. Ochrona rynku wewnętrznego jako istotnego elementu wspólnotowego wymaga odpowiednich środków finansowych, które będą mogły być przeznaczone na cele przeciwdziałania skutkom pandemii COVID-19. Zaproponowane regulacje środki takie zapewniają. $Z$ tego punktu widzenia projektowane rozwiązanie należy uznać za uzasadnione i racjonalne. Warto przy tym wskazać, że zaciągnięta pożyczka będzie zobowiązaniem długoterminowym i obciąży budżet UE i budżety państw członkowskich przez kilka perspektyw finansowych (do końca 2058 r.). W związku z tym słusznie wskazano w projekcie stanowiska rządu RP, że: „Istotną słabością propozycji jest brak uwzględnienia źródeł finansowania spłaty pożyczek, która ma nastąpić od początku $2028 \mathrm{r}$. Zapowiedź KE, iż spłata pozyskanych środków nastąpi z przyszłych budżetów długoterminowych w formie m.in. nowych zasobów własnych, zwiększonych 
składek krajowych, refinansowania pożyczek, ograniczenia polityk lub kombinacji tych możliwości, nie pozwala na obecnym etapie na ocenę, czy składki na pokrycie zobowiązań będą w sposób sprawiedliwy obciążały wszystkie państwa członkowskie, co jest bardzo istotne dla Polski”.

Odrębną kwestią jest podział między państwa członkowskie środków pochodzących z pożyczek oraz cele, na jakie te środki będą mogły być przeznaczone, co nie jest przedmiotem opiniowanej decyzji i powinno podlegać szczególnej kontroli parlamentarnej.

Możliwość zaciągnięcia pożyczek na rynkach kapitałowych oznaczać może odejście od ważnej zasady zrównoważonego budżetu unijnego. Do tej pory bowiem dochody tego budżetu, w których dominowały środki pochodzące ze składek państw członkowskich, tzw. zasoby własne UE, musiały odpowiadać wydatkom (środkom na płatności). Potrzeba zaciągania pożyczek wynika $\mathrm{z}$ tego, że zakłada się, iż w danym okresie wieloletnich ram finansowych 2021-2027 brakować będzie wystarczających dochodów na pokrycie zaplanowanych wydatków na złagodzenie skutków kryzysu związanego z COVID-19, stąd brakujące środki należy pozyskać na rynku. Jest to $\mathrm{w}$ istocie zaciągnięcie długu, który wraz z należnymi odsetkami będą musiały spłacić państwa członkowskie. Obecnie nie wiadomo dokładnie, według jakich zasad to nastąpi, ale niewątpliwie takie działanie może pociągać za sobą różne ryzyka (np. wynikające ze zmian stóp procentowych czy kursu walutowego) i być obciążeniem dla przyszłych pokoleń.

W zakresie regulacji zawartych w pierwotnym projekcie decyzji dotyczącej zasobów własnych UE, niezmienionych opiniowanym projektem, aktualne pozostają uwagi BAS zawarte w przywołanej wyżej opinii z 13 czerwca 2018 r. $^{3}$.

\section{- Ocena zgodności działań UE, o których mowa w dokumencie UE, z zasadą pomocniczości}

Co prawda opiniowany dokument podlega ocenie parlamentów narodowych pod względem zgodności z zasadą pomocniczości w trybie określonym w protokole (nr 2), jednak zaznaczyć należy, że państwa członkowskie Unii Europejskiej, każde odrębnie, nie dysponują kompetencją do określenia poszczególnych kategorii zasobów własnych UE. Zgodnie z art. 311 akapit pierwszy TFUE Unia pozyskuje środki niezbędne do osiągnięcia swoich celów i należytego prowadzenia swoich polityk. Akapit drugi tego artykułu stanowi, że budżet UE finansowany jest z zasobów własnych. Określenie poszczególnych kategorii zasobów własnych UE należy do kompetencji Rady i wchodzi w życie po zatwierdzeniu przez państwa członkowskie zgodnie z ich wymogami konstytucyjnymi.

Tym samym należy uznać, że projekt decyzji Rady w sprawie zasobów własnych Unii Europejskiej jest zgodny z zasadą pomocniczości.

3 Ibidem. 


\section{- Ustosunkowanie się do projektu stanowiska RP}

Rząd w projekcie stanowiska RP, przyjętym 10 czerwca 2020 r., popiera zawarte w projekcie zmian decyzji propozycje odnoszące się do możliwości zaciągnięcia przez UE pożyczek na rynkach kapitałowych w celu zapewnienia dodatkowych środków finansowych dla budżetu UE w związku z COVID-19. Rząd RP uznaje za uzasadnione rozłożenie spłaty tych zobowiązań na jak najdłuższy okres (do 2058 r.) oraz popiera nadzwyczajne i tymczasowe podniesienie pułapu zasobów własnych o 0,6 pkt proc. DNB UE w celu pokrycia wszystkich zobowiązań UE wynikających z zaciągniętych pożyczek w związku z COVID-19.

Rząd RP popiera również stałe podniesienie pułapu zasobów własnych do poziomu 1,40\% DNB UE-27 (dla płatności) i 1,46\% (dla zobowiązań), co ma stanowić gwarancję wywiązywania się przez UE z jej zobowiązań.

Rząd RP również pozytywnie ocenia ujęcie w decyzji zasady, zgodnie z którą wydatki operacyjne budżetu UE nie są finansowane z pożyczek, co nadaje uprawnieniu Komisji do zaciągania pożyczek charakter nadzwyczajny i jednorazowy.

Rząd RP ocenia, że łączne koszty spłaty kapitału w ramach pożyczki w kwocie 500 mld euro wynosiłyby w przypadku Polski - w zależności od zakładanego poziomu wzrostu gospodarczego - od ok. 21,5 mld euro do 25,0 mld euro w cenach stałych z 2018 r.

Stanowisko to jest uzupełnieniem stanowiska Polski przyjętego wobec propozycji zmiany decyzji w sprawie systemu zasobów własnych UE z 4 maja 2018 r., z uwzględnieniem dotychczasowych postępów negocjacyjnych.

Stanowisko rządu dotyczące opiniowanej decyzji, wyrażone w projekcie stanowiska RP, nie budzi zastrzeżeń.

\section{- Wniosek dotyczący działań przedstawiciela RP w odniesieniu do dokumentu UE}

Przedłożony projekt zasługuje na poparcie przez przedstawiciela Polski na forum Rady UE.

\section{Opinia prawna}

\section{Podstawa prawna dokumentu UE}

\section{- Wskazanie podstawy prawnej dokumentu UE}

Decyzja ma zostać przyjęta na podstawie art. 311 akapit trzeci TFUE, oraz art. 106a Traktatu ustanawiającego Europejską Wspólnotę Energii Atomowej (TEWEA), który stanowi, że wymienione w nim przepisy zawarte w TUE i TFUE (w tym art. 311 TFUE), stosuje się do TEWEA.

Zgodnie $\mathrm{z}$ art. 311 TFUE Rada przyjmuje decyzję określającą przepisy mające zastosowanie do systemu zasobów własnych Unii. W tym kontekście można 
ustanawiać nowe lub uchylać istniejące kategorie zasobów własnych. Artykuł 311 TFUE wymaga zastosowania specjalnej procedury ustawodawczej, przyjęta $\mathrm{w}$ tym trybie decyzja będzie więc miała rangę aktu ustawodawczego.

\section{- Ocena legalności dokumentu UE}

Artykuł 310 ust. 1 TFUE przewiduje, że wszystkie dochody i wydatki Unii powinny być wpisane do budżetu (zasada jedności budżetu UE) oraz że budżet UE powinien być zrównoważony w odniesieniu do dochodów i wydatków (zasada zrównoważonego budżetu UE). Zasady te zostały uszczegółowione w rozporządzeniu finansowym $\mathrm{UE}^{4}$, które stanowi, że w budżecie na każdy rok budżetowy prognozowane są i zatwierdzane wszystkie dochody i wydatki uznane za niezbędne dla Unii (art. 7 ust. 1) oraz że dochody i środki na płatności muszą znajdować się w równowadze, a Unia oraz jej organy nie mogą zaciągać pożyczek w ramach budżetu (art. 17).

Opiniowany dokument nie jest co prawda projektem budżetu, jednak z uwagi na przewidzianą w projektowanym art. 3b możliwość zaciągnięcia przez Komisję w imieniu Unii pożyczek, które następnie miałyby być spłacane z budżetu ogólnego Unii, należy ocenić, czy jest on zgodny z zasadami wskazanymi w poprzedzającym akapicie. Problem ten został co prawda pominięty przez Komisję Europejską w uzasadnieniu projektu, jednak KE ustosunkowała się do tych wątpliwości w dokumencie Pytania i odpowiedzi: Next Generation EU - konstrukcja prawna z 9 czerwca 2020 r. ${ }^{5}$ (dalej: konstrukcja prawna). Zagadnienie zostało również dostrzeżone i poddane głębszej analizie w opinii Służby Prawnej Rady (dalej: SPR) ${ }^{6}$.

Zdaniem KE „pożyczone środki stanowią wyjątkowe i jednorazowe kwoty mające charakter dodatkowy do budżetu rocznego jako zewnętrzne dochody przeznaczone na określony cel (na wydatki) i nie stanowią one części dochodów ani wydatków w ramach budżetu rocznego”. Zaciągnięcie pożyczek miałoby być zgodne z ograniczeniami określonymi w art. 310 TFUE, ponieważ „decyzja

4 Rozporządzenie Parlamentu Europejskiego i Rady (UE, Euratom) 2018/1046 z 18 lipca 2018 r. w sprawie zasad finansowych mających zastosowanie do budżetu ogólnego Unii, zmieniające rozporządzenia (UE) nr 1296/2013, (UE) nr 1301/2013, (UE) nr 1303/2013, (UE) nr 1304/2013, (UE) nr 1309/2013, (UE) nr 1316/2013, (UE) nr 223/2014 i (UE) nr 283/2014 oraz decyzję nr 541/2014/UE, a także uchylające rozporządzenie (UE, Euratom) nr 966/2012, Dz.Urz. UE L 193, 30 lipca 2018 r., s. 1.

$5 \quad$ Https://ec.europa.eu/commission/presscorner/detail/en/qanda_20_1024.

6 Opinia Służby Prawnej Rady UE z 24 czerwca 2020 r., 9062/20: Proposals on Next Generation EU Compatibility of the package with the Union's principles of budgetary balance and discipline under Article 310 TFEU Compatibility of the package with the integrity of the system of own resources (Article 311 TFEU) Suitability of Article 122 TFEU as legal basis for the Recovery Instrument proposal Compatibility of the package with Article 125(1) TFEU (no bail-out clause). Opinia, pierwotnie objęta klauzulą „LIMITE”, została upubliczniona 3 lipca 2020 r. (zob. dokument ST 90622020 COR 1). 
w sprawie zasobów własnych będzie już gwarantować środki finansowe potrzebne na spłatę pożyczek”. Komisja przekonuje, że w istocie „państwa członkowskie zgadzają się na udostępnienie zasobów finansowych Unii, ale ponieważ obecnie dysponują tylko ograniczoną przestrzenią fiskalną, „odraczają” czy też „opóźniają” to „udostępnienie”. Podobne stanowisko zajęła SPR (pkt 46 jej opinii), uznając, że pożyczone kwoty zostaną przekazane na dane wydatki jako „zewnętrzne dochody przeznaczone na określony cel (external assigned revenue)". Jako takie $\mathrm{z}$ natury mają charakter dodatkowy i z budżetowego punktu widzenia nie pociągają za sobą konsekwencji w postaci nierównowagi budżetowej. Ponadto zwrot długu zaciągniętego przez UE ma być gwarantowany dzięki zarezerwowaniu na ten cel środków, do wniesienia których państwa członkowskie będą zobowiązane na mocy projektowanej decyzji. Jednocześnie, oceniając zgodność takiego podejścia z zasadą jedności budżetu UE, SPR uznała m.in., że:

- projekt jest proponowany jako wyjątkowy, tymczasowy i jednorazowy instrument mający na celu ożywienie gospodarcze w duchu solidarności, będącej podstawową zasadą leżącą u podstaw traktatów,

- do prawodawcy Unii należy ustalenie, jakie środki finansowe są niezbędne do właściwej realizacji celu; w tym zakresie ma on margines swobody, który obejmuje możliwość skorzystania z pożyczki, która stanowi zewnętrzne dochody przeznaczone na określony cel; ten margines swobody jest jednak ograniczony koniecznością poszanowania integralności systemu zasobów własnych Unii,

- ze względu na znaczną kwotę, którą reprezentowałyby zewnętrzne dochody przeznaczone na proponowany cel, należy zapewnić odpowiednie zabezpieczenia w celu ochrony integralności systemu zasobów własnych Unii i systemu budżetowego; wyjątkowy charakter kryzysu, jednorazowy charakter i ograniczony czas trwania proponowanych rozwiązań, co odzwierciedlono w poszczególnych wnioskach, stanowią takie odpowiednie zabezpieczenia ${ }^{7}$.

Powyższa argumentacja Komisji i SPR zmierza do wykazania zgodności projektu z art. 310 TFUE. Należy jednak zauważyć, że opiniowany projekt ma na celu umożliwienie zaciągnięcia pożyczek, które miałyby w znacznym stopniu zostać wykorzystane do finansowania działalności operacyjnej UE i które byłyby spłacane $\mathrm{z}$ unijnego budżetu. W tym zakresie projekt może budzić wątpliwości co do zgodności z ograniczeniami wynikającymi z art. 310 ust. 1 akapit 3 TFUE.

Potraktowanie całej operacji jako czegoś zewnętrznego w stosunku do budżetu UE może wywołać wątpliwości co do zgodności z zasadą jedności budżetu UE, wyrażoną w art. 310 ust. 1 akapit 1 TFUE. Wskazane wyżej argumenty zawarte w opinii SPR w dużej mierze odnoszą się do wyjątkowego charakteru proponowanych środków. Nie jest to jednak argumentacja, która w sposób kompleksowy rozstrzyga o dopuszczalności proponowanych rozwiązań na płaszczyźnie prawnej.

\footnotetext{
$7 \quad$ Zob. szerzej pkt 63-70 opinii SPR.
} 
Konkludując, należy stwierdzić, że projekt może budzić wątpliwości co do zgodności z art. 310 ust. 1 TFUE ${ }^{8}$.

\section{Skutki prawne}

Zgodnie z art. 288 TFUE decyzja wiąże w całości. Poza określonymi w decyzji wyjątkami ma ona być stosowana od 1 stycznia $2021 \mathrm{r}$.

\section{Kwestie proceduralne}

\section{- Procedura przyjmowania dokumentu UE}

Pierwotny projekt decyzji został przyjęty przez Komisję 2 maja 2018 r. i tego samego dnia został przekazany do Rady i Parlamentu Europejskiego. Zmieniony projekt został przyjęty przez Komisję 28 maja 2020 r. i tego samego dnia został przekazany do Rady i Parlamentu Europejskiego. Dokument UE będzie przyjmowany przez Radę w specjalnej procedurze ustawodawczej. Rada stanowi jednomyślnie, po konsultacji z Parlamentem Europejskim.

Decyzja wchodzi w życie dopiero po jej zatwierdzeniu przez państwa członkowskie, zgodnie z ich odpowiednimi wymogami konstytucyjnymi. W prawie polskim wymóg ratyfikacji aktów prawnych Unii Europejskiej przyjętych na podstawie art. 311 akapit trzeci TFUE wynika z art. 12 ust. 2a ustawy z 14 kwietnia 2000 r. o umowach międzynarodowych (Dz.U. 2020, poz. 127).

Proponowana regulacja, jako projekt aktu ustawodawczego, jest przekazywana także parlamentom narodowym, zgodnie $\mathrm{z}$ art. 2 protokołu (nr 1) w sprawie roli parlamentów narodowych w Unii Europejskiej. Pierwotny projekt decyzji został przekazany Sejmowi w języku polskim 4 maja 2018 r., natomiast opiniowana modyfikacja - 28 maja 2020 r.

\section{- Działania Komisji ds. Unii Europejskiej}

Zgodnie z art. 7 ust. 1 ustawy z 8 października 2010 r. o współpracy Rady Ministrów z Sejmem i Senatem w sprawach związanych z członkostwem Rzeczypospolitej Polskiej w Unii Europejskiej (Dz.U. nr 213, poz. 1395; dalej: ustawa kooperacyjna) Rada Ministrów przekazuje Sejmowi projekty stanowisk Rzeczypospolitej Polskiej w sprawie projektów aktów ustawodawczych Unii Europejskiej, biorąc pod uwagę terminy wynikające z prawa Unii Europejskiej, nie później jednak niż w terminie 14 dni od dnia otrzymania tych projektów. Rada Ministrów przekazała Sejmowi projekt stanowiska RP odnoszący się do projektowanego aktu prawnego UE 10 czerwca 2020 r., dochowując terminu ustawowego.

8 Zob. podobnie P. Leino, Next Generation EU: Breaking a taboo or breaking the law?, CEPS in Brief, Centre for European Policy Studies, 2020, https://www.ceps.eu/next-generation-eu. 
Komisja ds. Unii Europejskiej może, działając w trybie art. 7 ust. 4 ustawy kooperacyjnej, wyrazić opinię o projekcie decyzji w terminie 49 dni od dnia przekazania Sejmowi projektu aktu UE. Jeżeli Komisja wyda we wskazanym trybie opinię, powinna ona stanowić podstawę stanowiska Rzeczypospolitej Polskiej (art. 13 ust. 1 ustawy kooperacyjnej). Termin na wyrażenie przez Komisję ds. Unii Europejskiej opinii o projekcie decyzji upływa więc 16 lipca 2020 r.

Zgodnie $\mathrm{z}$ art. 6 protokołu (nr 2) w sprawie stosowania zasad pomocniczości i proporcjonalności Sejm może, w terminie ośmiu tygodni od daty przekazania projektu aktu ustawodawczego w językach urzędowych Unii, przesłać przewodniczącym Parlamentu Europejskiego, Rady i Komisji uzasadnioną opinię zawierającą powody, dla których uznaje, że dany projekt nie jest zgodny z zasadą pomocniczości. Zgodnie z listem Sekretarza Generalnego Komisji Europejskiej wszystkie wersje językowe projektowanej decyzji zostały przekazane parlamentom narodowym oraz izbom parlamentów narodowych państw członkowskich 29 maja 2020 r. Termin na przesłanie uzasadnionej opinii w sprawie projektu rozporządzenia upływa zatem 24 lipca $2010 \mathrm{r}$.

W niniejszej sprawie Komisja ds. UE może więc wnieść projekt uchwały w sprawie uznania projektu aktu ustawodawczego UE za niezgodny z zasadą pomocniczości. W takim wypadku do projektu uchwały powinna być załączona uzasadniona opinia zawierająca powody, dla których Sejm uznaje, że projekt aktu ustawodawczego UE nie jest zgodny z zasadą pomocniczości (art. 148cc ust. 1 i 2 regulaminu Sejmu).

Zgodnie $\mathrm{z}$ informacją zamieszczoną w bazie IPEX do dnia sporządzenia niniejszej opinii uzasadniona opinia została przedłożona tylko przez parlament Szwecji (Riksdag). Uzasadnienie stanowiska parlamentu Szwecji zawiera argumenty nie ograniczające się do zasady pomocniczości, natomiast w zakresie, w jakim odnosi się do tej zasady, wskazuje, że nie zostało jasno uzasadnione, dlaczego pożyczki na ograniczenie skutków pandemii mają być zaciągane na poziomie UE, a nie państw członkowskich. Na marginesie warto zauważyć, że Riksdag przedłożył uzasadnioną opinię również w odniesieniu do pierwotnego projektu decyzji, tj. COM(2018) 325.

W ocenie Biura Analiz Sejmowych projekt nie budzi zastrzeżeń co do zgodności z zasadą pomocniczości (zob. podrozdział zatytułowany „Ocena zgodności działań UE, o których mowa w dokumencie UE, z zasadą pomocniczości” niniejszej opinii).

\section{Podsumowanie}

- Celem projektowanej decyzji jest podniesienie pułapu rocznych zasobów własnych w odniesieniu do dochodu narodowego UE oraz upoważnienie Komisji do zaciągnięcia w imieniu UE pożyczek na rynkach kapitałowych do wysokości 750 
mld euro w cenach z 2018 r., które to środki będą mogły służyć wyłącznie celom złagodzenia skutków kryzysu związanego z COVID-19.

- Projektowane rozwiązanie należy uznać za uzasadnione i racjonalne z punktu widzenia ochrony i rozwoju rynku wewnętrznego jako istotnego elementu wspólnotowego.

- Projekt nie budzi wątpliwości co do zgodności z zasadą pomocniczości.

- Przy odrzuceniu argumentacji Służby Prawnej Rady projekt może budzić wątpliwości co do zgodności z art. 310 ust. 1 TFUE. 

2

OPINIE BAS

C

OPINIE LEGISLACYJNE 

Kamilla Kurczewska

\title{
Ocena zgodności z Konstytucją poselskiego projektu ustawy o jawności przychodów kościołów i związków wyznaniowych oraz zniesieniu ich przywilejów finansowych $^{1}$
}

\author{
Assessment of compliance with the Constitution of the Republic of Poland \\ of the Deputies' Bill on the Transparency of Revenues of Churches \\ and Religious Associations and the Abolition of Their Financial Privileges
}

\begin{abstract}
In the opinion of the author, the provision of the Bill, which introduces an obligation to record and disclose all benefits for churches and religious associations by units of the public finance sector, is compliant with the Constitution. However, the introduction of provisions on the rights of churches and religious associations without observing the consensual procedure provided for in the Constitution may become the basis for an effective allegation of non-compliance with the Constitution, and - in the case of relations with the Catholic Church - also of non-compliance with provisions of a ratified international agreement.
\end{abstract}

Keywords: Catholic Church, church, religious association, transparency, public finances, Constitution, concordat

Zdaniem autorki przepis projektu ustawy, wprowadzający obowiązek ewidencjonowania i ujawniania przez jednostki sektora finansów publicznych wszystkich przysporzeń dokonywanych na rzecz kościołów i związków wyznaniowych, jest zgodny z Konstytucją. Natomiast wprowadzenie zmian przepisów dotyczących uprawnień kościołów i związków wyznaniowych bez zachowania trybu konsensualnego przewidzianego w Konstytucji może stać się podstawą postawienia skutecznego zarzutu niezgodności z ustawą zasadniczą, oraz - w przypadku stosunków z Kościołem katolickim - również zarzutu nierespektowania przepisów ratyfikowanej umowy międzynarodowej.

Słowa kluczowe: Kościół katolicki, kościół, związek wyznaniowy, jawność, finanse publiczne, Konstytucja, konkordat

Doktor nauk prawnych, magister filozofii, ekspert ds. systemu gospodarczego Biura Analiz Sejmowych -

Kancelaria Sejmu, Biuro Analiz Sejmowych, Wydział Analiz Społecznych i Ekonomicznych, Zespół Oceny Regulacji Prawnych, WARSZAWA, POLSKA •

kamilla.kurczewska@sejm.gov.pl • https://orcid.org/0000-0001-9088-1419

$1 \quad$ Opinia prawna $w$ sprawie zgodności $z$ Konstytucja RP poselskiego projektu ustawy o jawności przychodów kościołów i związków wyznaniowych oraz zniesieniu ich przywilejów finansowych sporządzona 24 września 2020 r. na zlecenie Szefa Kancelarii Sejmu; BAS-WASiE-1853/20. 


\section{Przedmiot opinii}

Opinia stanowi odpowiedź na pytanie dotyczące zgodności projektu ustawy z Konstytucją RP z 2 kwietnia 1997 r. Projekt ustawy zawiera rozwiązania zapewniające transparentność przysporzeń dokonywanych na rzecz kościołów i związków wyznaniowych (dalej: KiZW) przez jednostki sektora finansów publicznych (dalej: JSFP), jawność przychodów KiZW oraz likwiduje niektóre uprawnienia KiZW.

\section{Wnioski opinii}

- Przepis projektu ustawy wprowadzający obowiązek ewidencjonowania wszystkich przysporzeń dokonywanych na rzecz kościołów i związków wyznaniowych przez jednostki sektora finansów publicznych i ujawniania ich w Biuletynach Informacji Publicznej tych jednostek jest zgodny z Konstytucją.

- Wprowadzenie w projekcie przepisów nakazujących ewidencjonowanie i ujawnianie wszystkich przychodów KiZW organom Krajowej Administracji Skarbowej oraz przepisów likwidujących uprawnienia KiZW bez zachowania trybu konsensualnego, przewidzianego w art. 25 ust. 4 i 5 Konstytucji, może stać się podstawą postawienia skutecznego zarzutu niezgodności z Konstytucją, oraz, w przypadku stosunków z Kościołem katolickim, również zarzutu nierespektowania przepisów umowy międzynarodowej (tj. art. 27 i 28 jak również art. 22 ust. 2 konkordatu), hierarchicznie wyższej niż ustawa (zgodnie $\mathrm{z}$ art. 91 ust. 2 Konstytucji).

- Wprowadzenie do projektu przepisów likwidujących prawo osób fizycznych i prawnych do zmniejszenia kwoty podatku dochodowego przez odliczenie od dochodu kwoty darowizn przekazanych na cele kultu religijnego można rozpatrywać jako zawężanie uprawnień wbrew sugestiom wynikającym z konstytucyjnej zasady pomocniczości nakazującej umacniać uprawnienia obywateli i ich wspólnot (preambuła, wiersz 19 Konstytucji).

- Wprowadzenie do projektu przepisów likwidujących możliwość dotowania i subwencjonowania KiZW przez jednostki samorządu terytorialnego oraz dokonywania przysporzeń majątkowych pod tytułem darowizny KiZW przez spółki prawa handlowego z udziałem Skarbu Państwa, państwowych jednostek organizacyjnych lub jednostek samorządu terytorialnego należy ocenić w kontekście zgodności z konstytucyjną zasadą równości. Takie wykluczające sformułowanie przepisu - bez wskazania kryteriów innych niż „rodzaj podmiotu” - jest podstawą do postawienia zarzutu naruszenia art. 32 ust. 1 Konstytucji.

- Okoliczność w postaci przypuszczenia, że KiZW otrzymały równowartość przejętych przez państwo „nieruchomości ziemskich związków wyznaniowych”, po jej zweryfikowaniu, jest, w przypadku Kościoła katolickiego, podstawą do 
stwierdzenia potrzeby „koniecznych zmian” ustawodawstwa polskiego i uruchomienia trybu, o którym mówi art. 22. ust. 2 konkordatu.

- Wskazana jest kompleksowa ocena zgodności całościowych ram normatywnych działalności służącej celom humanitarnym, charytatywno-opiekuńczym, naukowym i oświatowo-wychowawczym, prowadzonej przez instytucje państwowe $\mathrm{z}$ ramami normatywnymi prowadzenia takiej działalności przez kościelne osoby prawne Kościoła katolickiego - w kontekście art. 22 ust. 1 konkordatu "zrównującego" tę działalność „pod względem prawnym”, tj. pod względem uprawnień i obowiązków oraz ewentualne uruchomienie specjalnego trybu, $\mathrm{w}$ celu uzgodnienia zmian uznanych za konieczne.

\section{Uzasadnienie}

1. Artykuł 5 projektu ustawy wprowadzający obowiązek ewidencjonowania (informowania) i ujawniania wszystkich przysporzeń dokonywanych na rzecz KiZW przez JSFP jest rozwiązaniem operacjonalizującym konstytucyjne prawo obywatela do informacji o działalności organów władzy publicznej, wynikające wprost $\mathrm{z}$ art. 61 ust. 1 zdanie pierwsze Konstytucji ${ }^{2}$, co oznacza zgodność tego przepisu $\mathrm{z}$ ustawą zasadniczą.

Wprowadzenie obowiązku ewidencjonowania i ujawniania wszystkich przysporzeń dokonywanych na rzecz KiZW przez państwowe osoby prawne oraz spółki prawa handlowego, w których Skarb Państwa, podmioty sektora finansów publicznych lub państwowe osoby prawne posiadają przynajmniej 30\% udziałów albo akcji, należy oceniać w kontekście brzmienia art. 61 ust. 1 zdanie drugie Konstytu$\mathrm{cji}^{3}$. Podkreślenia wymaga fakt, że interpretacja projektowanego przepisu zgodna $\mathrm{z}$ art. 61 ust. 1 zdanie drugie Konstytucji, ograniczy obowiązek ujawnienia tylko do tych przysporzeń, które mają związek z gospodarowaniem mieniem komunalnym lub majątkiem Skarbu Państwa i wykonywaniem zadań władzy publicznej.

2. Projektowane przepisy:

- wprowadzające obowiązek ewidencjonowania przychodów przez jednostki organizacyjne kościołów, związków wyznaniowych oraz inne kościelne osoby prawne, informowania o nich naczelników urzędów skarbowych oraz publikowania zbiorczych informacji o tych przychodach w Biuletynie Informacji Publicznej przez Szefa Krajowej Administracji Skarbowej (art. 4 projektu),

2 „Obywatel ma prawo do uzyskiwania informacji o działalności organów władzy publicznej oraz osób pełniących funkcje publiczne”.

3 „Prawo to [do informacji, przyp. K.K.] obejmuje również uzyskiwanie informacji o działalności organów samorządu gospodarczego i zawodowego, a także innych osób oraz jednostek organizacyjnych w zakresie, w jakim wykonują one zadania władzy publicznej i gospodarują mieniem komunalnym lub majątkiem Skarbu Państwa”. 
- likwidujące Fundusz Kościelny (art. 14 projektu),

- likwidujące opłacanie składek na ubezpieczenie emerytalne, rentowe i wypadkowe duchownych, członków zakonów kontemplacyjnych klauzurowych, misjonarzy w okresach pracy na terenach misyjnych przez Fundusz Kościelny (art. 31 projektu),

- likwidujące opłacanie składek na ubezpieczenie zdrowotne duchownych oraz alumnów wyższych seminariów duchownych i teologicznych, postulantów, nowicjuszy i juniorystów oraz ich odpowiedników, z wyłączeniem osób duchownych będących podatnikami podatku dochodowego od osób fizycznych lub zryczałtowanego podatku dochodowego od przychodów osób duchownych, przez Fundusz Kościelny, dotowany przez budżet państwa w tym zakresie (art. 33 projektu),

- likwidujące prawo realizacji inwestycji kościelnych, nie służących bezpośrednio celom sakralnym (art. 16, 17, 20, 21, 23, 24, 25, 27, 28, 29 projektu),

- likwidujące zwolnienie podatkowe - w odniesieniu do podatku od nieruchomości od nieruchomości używanej do celów niemieszkalnych z wyjątkiem części zajmowanej na wykonywanie działalności gospodarczej (art. 15, 16, 17, $20,21,22,23,24,25,26,27,28,29$ projektu),

- ograniczające zwolnienie z podatku dochodowego dochodów z działalności gospodarczej osób prawnych kościołów i związków wyznaniowych do dochodów przeznaczonych - w przypadku inwestycji - na inwestycje, których wyłącznym przedmiotem są punkty katechetyczne i zakłady charytatywno-opiekuńcze oraz remonty tych obiektów ${ }^{4}$ (art. 15, 16, 17 projektu) ${ }^{5}$,

$4 \quad \mathrm{~W}$ obecnym stanie prawnym zwolnienie z podatku dochodowego obejmuje - obok dochodów przeznaczonych na cele kultowe, oświatowo-wychowawcze, naukowe, kulturalne, działalność charytatywno-opiekuńczą, punkty katechetyczne, konserwację zabytków - również dochody przeznaczone na inwestycje sakralne i inwestycje kościelne, których przedmiotem są punkty katechetyczne i zakłady charytatywno-opiekuńcze, jak również remonty tych obiektów (por. art. 13 ust. 5 ustawy o gwarancjach wolności sumienia i wyznania, art. 55 ust. 3 ustawy o stosunku Państwa do Kościoła Katolickiego w Rzeczypospolitej Polskiej oraz art. 40 ust. 3 ustawy o stosunku Państwa do Polskiego Autokefalicznego Kościoła Prawosławnego). Projekt zachowuje pozostałe warunki zwolnienia z podatku.

5 Projektowana ustawa uchyla również art. 55 ust. 2 ustawy o stosunku Państwa do Kościoła Katolickiego w Rzeczypospolitej Polskiej oraz art. 40 ust. 2 ustawy o stosunku Państwa do Polskiego Autokefalicznego Kościoła Prawosławnego, które zwalniają kościelne osoby prawne od opodatkowania z tytułu przychodów z ich działalności niegospodarczej oraz z obowiązku prowadzenia w tym zakresie dokumentacji wymaganej przez przepisy o zobowiązaniach podatkowych. W mocy pozostaje jednak przepis ogólny dotyczący tych zwolnień zawarty w art. 13 ust. 2 ustawy o gwarancjach wolności sumienia i wyznania, stosowany do wszystkich kościołów i związków wyznaniowych (zob. też art. 3 ust. 2 ustawy o stosunku Państwa do Kościoła Katolickiego w Rzeczypospolitej Polskiej i art. 3 ust. 2 ustawy o stosunku Państwa do Polskiego 
- likwidujące uprawnienie do nieodpłatnego nabywania własności przez osoby prawne Kościoła katolickiego (które po dniu 8 maja 1945 r. podjęły działalność na tzw. ziemiach zachodnich i północnych) gruntów znajdujących się w zasobach Państwowego Funduszu Ziemi albo w Zasobie Własności Rolnej Skarbu Państwa (art. 16 projektu),

- likwidujące uprawnienie nabycia w drodze bezprzetargowej w sytuacji zbycia nieruchomości kościołom i związkom wyznaniowym na cele działalności sakralnej (art. 30 projektu),

- likwidujące uprawnienie do otrzymania bonifikaty od ceny sprzedaży nieruchomości w drodze bezprzetargowej, w sytuacji sprzedaży nieruchomości kościołom i związkom wyznaniowym na cele działalności sakralnej (art. 30 projektu),

- likwidujące ochronę przed prawem pierwokupu Skarbu Państwa w obrocie nieruchomościami między kościelnymi osobami prawnymi Kościoła katolickiego (art. 16 projektu),

- likwidujące ochronę przed prawem pierwokupu gminy w sytuacji sprzedaży nieruchomości lub prawa użytkowania wieczystego następującego między osobami prawnymi tego samego kościoła lub związku wyznaniowego (art. 30),

- likwidujące uprawnienie do nabycia nieruchomości rolnej przez osoby prawne działające na podstawie przepisów o stosunku państwa do Kościoła katolickiego w Rzeczypospolitej Polskiej, o stosunku państwa do innych kościołów i związków wyznaniowych oraz o gwarancjach wolności sumienia i wyznania (art. 32),

- likwidujące ochronę przed prawem wykupu przez Krajowy Ośrodek działający na rzecz Skarbu Państwa w sytuacji, gdy przeniesienie własności nieruchomości rolnej następuje między osobami prawnymi tego samego kościoła lub związku wyznaniowego (art. 32),

- likwidujące ochronę przed prawem dzierżawcy do pierwokupu dzierżawionej nieruchomości rolnej w sytuacji sprzedaży tej nieruchomości pomiędzy osobami prawnymi tego samego kościoła lub związku wyznaniowego (art. 32). należy ocenić szczególnie w kontekście:

- $\quad$ art. 25 ust. 4 i ust. 5 Konstytucji formułującego układowy model trybu regulacji stosunków między Rzecząpospolitą Polską a Kościołem katolickim oraz innymi kościołami i związkami wyznaniowymi ${ }^{6}$,

Autokefalicznego Kościoła Prawosławnego), który projektodawcy zachowują w niezmienionym brzmieniu (zob. art. 15 pkt 2 projektu nadający nowe brzmienie ust. 5 i uchylający ust. 6). Skutki wskazanego pominięcia w postaci bezskuteczności działań projektodawcy są omówione w OSR analizowanej ustawy w pkt V (1419-20).

6 Ust. 4. „Stosunki między Rzecząpospolitą Polską a Kościołem Katolickim określają umowa międzynarodowa zawarta ze Stolicą Apostolską i ustawy”; ust. 5. „Stosunki między Rzecząpospolitą Polską a innymi kościołami oraz związkami wyznaniowymi 
- $\quad$ art. 25 ust. 1 Konstytucji formułującego zasadę równouprawnienia $\mathrm{KiZW}^{7}$,

- w przypadku Kościoła katolickiego - art. 91 ust. 2 Konstytucji ${ }^{8}$ formułującego zasadę pierwszeństwa umowy międzynarodowej ratyfikowanej za uprzednią zgodą wyrażoną w ustawie przed ustawą oraz w kontekście art. 22 ust. 2, 27 i 28 konkordatu9 , zawierających postanowienia o: powoływaniu komisji, regulacji nowych lub dodatkowych rozwiązań w drodze nowych umów oraz o usuwaniu różnic dotyczących interpretacji lub stosowania konkordatu na drodze dyplomatycznej.

Wymienione wyżej przepisy wskazują bezspornie na konsensualny tryb kształtowania stosunków między państwem a KiZW (art. 25 ust. 4 i 5 Konstytucji oraz w przypadku Kościoła katolickiego - również art. 22 ust. 2 oraz art. 27 i 28 konkordatu), natomiast różnie wyznaczany jest zakres spraw wymagający użycia tego trybu ze względu na przyjmowanie szerokiego lub zawężanego rozumienia pojęć „stosunków”, „autonomii”, „niezależności”, „nowych”, „dodatkowych”. Rozumienie pojęcia „stosunki” jako obejmujące swym zakresem kwestie finansowania i wymagające zastosowania trybu układowego przyjmują: D. Walencik ${ }^{10}$, M. Zawiślak ${ }^{11}$, P. Stanisz ${ }^{12}$,

określają ustawy uchwalone na podstawie umów zawartych przez Radę Ministrów z ich właściwymi przedstawicielami”.

7 „Kościoły i inne związki wyznaniowe są równouprawnione”.

8 „Umowa międzynarodowa ratyfikowana za uprzednią zgodą wyrażoną w ustawie ma pierwszeństwo przed ustawą, jeżeli ustawy tej nie da się pogodzić z umową".

9 Konkordat między Stolicą Apostolską i Rzecząpospolitą Polską, podpisany w Warszawie 28 lipca 1993 r., Dz.U. 1998, nr 51, poz. 318. Art. 27. „Sprawy wymagające nowych lub dodatkowych rozwiązań będą regulowane na drodze nowych umów między Układającymi się Stronami albo uzgodnień między Rządem Rzeczypospolitej Polskiej i Konferencją Episkopatu Polski upoważnioną do tego przez Stolicę Apostolską"; art. 28. „Układające się Strony będą usuwać na drodze dyplomatycznej zachodzące między nimi różnice dotyczące interpretacji lub stosowania niniejszego Konkordatu”. D. Walencik, Konkordat a sfera finansowo-majątkowa Kościoła Katolickiego w Polsce [w:] Konkordat Polski, red. P. Borecki, C. Janik, M. Winiarczyk-Kossakowska, Warszawa 1993, s. 150, oraz D. Walencik, Finansowanie Kościoła Katolickiego w Polsce [w:] Konkordat: ocena z perspektywy 15 lat obowiązywania w Polsce w świetle art. 22 i 27 konkordatu oraz prac komisji konkordatowych - perspektywa zmian, red. P. Kroczek, seria „Annales Cannonici. Monographiae”, Kraków 2014, s. 64, i inne publikacje tego autora.

11 M. Zawiślak, Zmiana systemu finansowania Kościoła Katolickiego w świetle Konstytucji RP i Konkordatu [w:] Układowe formy regulacji stosunków między państwem a związkami wyznaniowymi (art. 25 ust. 4-5 Konstytucji RP), red. P. Stanisz, M. Ordon, Lublin 2013, s. 417-418.

12 P. Stanisz, Perspektywy zmiany systemu finansowania kościołów i innych związków wyznaniowych $w$ Polsce, "Studia z Prawa Wyznaniowego” 2009, t. 12, s. 14, oraz P. Stanisz, Naczelne zasady instytucjonalnych relacji Państwo-Kościół [w:] A. Mezglewski, H. Misztal, P. Stanisz, Prawo wyznaniowe, Warszawa 2008, s. 70-71. 
J. Krukowski ${ }^{13}$, P. Sobczyk ${ }^{14}$, P. Czarny ${ }^{15}$, P. Chybalski ${ }^{16}$, J. Lipski ${ }^{17}$. Pogląd ten jest wzmocniony brzmieniem punktu 5 oświadczenia rządowego podpisanego w Warszawie w dniu 28 lipca 1993 r., w którym Rada Ministrów deklaruje, że: „Konkordat uznaje określone ustawodawstwem polskim kompetencje organów państwowych do regulowania kwestii finansowych i podatkowych kościelnych osób prawnych i fizycznych. W tym celu strona państwowa zapozna się z opinią strony kościelnej w łonie odpowiedniej Komisji, o której mowa w artykule 22 ust. 2 i 3"18.

Odmienne rozumienie zakresu materii objętej nakazem zastosowania trybu układowego, prowadzące do wniosku, że kwestie danin na rzecz państwa oraz regulacje zaszłości majątkowych na styku państwo-związek wyznaniowy mogą być normowane bez zastosowania trybu bilateralnego, prezentują P. Borecki ${ }^{19}$

13 J. Krukowski, Konstytucyjny system relacji między państwem a Kościołem katolickim oraz innymi kościołami i zwiąkami wyznaniowymi [w:] Ustrój konstytucyjny Rzeczypospolitej Polskiej, red. R. Mojak, Lublin 2000, s. 105-106, oraz J. Krukowski, Realizacja Konkordatu z 1993 r. w polskim porzadku prawnym [w:] Konkordat polski w 10 lat po ratyfikacji, red. J. Wroceński, H. Pietrzak, Warszawa 2008, s. 128-129.

14 P. Sobczyk, Proceduralna niekonstytucyjność nowelizacji ustawy o stosunku Państwa do Kościoła Katolickiego w Rzeczypospolitej Polskiej, „Studia Politologiczne” 2012, nr 23, http://www.studiapolitologiczne.pl/pdf-117287-46482?filename=Proceduralna.pdf [dostęp: 18 września 2020 r.].

15 P. Czarny, Opinia prawna $z$ dnia 8 października 2012 r. w sprawie obowiązku zasiegania opinii co do zmian w ustawach regulujacych stosunek państwa do poszczególnych kościołów i związków wyznaniowych, „Zeszyty Prawnicze BAS” 2012, nr 4(36), s. 86.

16 P. Chybalski, Opinia prawna $z$ dnia 2 lutego 2012 r. w sprawie zakresu obowiazku przeprowadzenia konsultacji dotyczacych poselskiego projektu ustawy o zmianie ustawy o przejęciu przez Państwo dóbr martwej ręki, poręczeniu proboszczom gospodarstw rolnych i utworzeniu Funduszu Kościelnego oraz niektórych innych ustaw; BAS-WAUiP-122/12, niepubl.

17 J. Lipski, Opinia prawna na temat poselskiego projektu ustawy o zmianie ustawy o przejęciu przez Państwo dóbr martwej ręki, poręczeniu proboszczom posiadania gospodarstw rolnych i utworzeniu Funduszu Kościelnego oraz niektórych innych ustaw (druk nr 1216); BAS-WAL-841/13, niepubl.

18 Pogląd ten jest wzmocniony brzmieniem pkt 5 oświadczenia rządowego z 26 stycznia 1998 r. w sprawie deklaracji rządu Rzeczypospolitej Polskiej z 15 kwietnia 1997 r. w celu zapewnienia jasnej wykładni przepisów konkordatu między Stolicą Apostolską a Rzecząpospolitą Polską (M.P. nr 4, poz. 51). Zob. też wskazującą na art. 27 konkordatu i art. 25 ust. $5 \mathrm{w}$ odniesieniu do innych KiZW jako podstawę działań odpowiedź na interpelację nr 2238 w sprawie prac nad zmianą modelu finansowania Kościoła katolickiego z budżetu państwa. Odpowiadający: podsekretarz stanu w Ministerstwie Spraw Wewnętrznych i Administracji Sebastian Chwałek, Warszawa, 11 maja 2016 r., http://sejm.gov.pl/sejm8.nsf/InterpelacjaTresc.xsp?key=6959F9BE [dostęp: 18 września 2020 r.].

19 P. Borecki, Respektowanie polskiego konkordatu z 1993 roku. Wybrane problemy, Warszawa 2012. 
i A. Czochara ${ }^{20}$. Odnotować również należy, że w okresie obowiązywania art. 25 Konstytucji rzeczywiście uchwalano ustawy dotyczące tych zagadnień bez zastosowania trybu bilateralnego ${ }^{21}$.

Analizy sformułowań użytych w obu aktach i ich wyniki interpretacyjne obecne w literaturze, praktyce ustawodawczej oraz orzecznictwie Trybunału Konstytucyjnego prowadzą do rozbieżnych wniosków, jednakże poza wszelką wątpliwością projektowane przepisy wprowadzane jednostronnie, bez uprzednich umownych uzgodnień $\mathrm{z}$ KiZW, są narażone na skuteczny zarzut niezgodności z Konstytucją 22 .

3. Wprowadzenie do projektu przepisów likwidujących prawo osób fizycznych i prawnych do zmniejszenia kwoty podatku dochodowego przez odliczenie od dochodu kwoty darowizn przekazanych na cele kultu religijnego (art. 18 i 19 projektu) można rozpatrywać jako zawężanie uprawnień wbrew sugestiom wynikającym z konstytucyjnej zasady pomocniczości nakazującej umacniać uprawnienia obywateli i ich wspólnot (preambuła, wiersz 19 Konstytucji).

Sformułowanie projektowanego przepisu likwidującego możliwość dotowania i subwencjonowania KiZW przez jednostki samorządu terytorialnego oraz dokonywania przysporzeń majątkowych pod tytułem darowizny KiZW przez spółki prawa handlowego z udziałem Skarbu Państwa, państwowych jednostek organizacyjnych lub jednostki samorządu terytorialnego (art. 15 projektu) należy ocenić w kontekście zgodności z konstytucyjną zasadą równości (art. 32 ust. 1 Konstytucji). Z artykułu tego wynika pozytywny obowiązek ustawodawcy do podejmowania działań mających na celu możliwie najszerszą realizację za-

20 A. Czohara, Specyfika ugód i orzeczeń w postępowaniu regulacyjnym [w:] A. Czohara, T.J. Zieliński, Ustawa o stosunku Państwa do gmin wyznaniowych żydowskich $w$ Polsce. Komentarz, Warszawa 2012, s. 255-265, za: T.J. Zieliński, Implikacje art. 25 ust. 5 Konstytucji RP dla procedury parlamentarnej [w:] Układowe formy regulacji stosunków między państwem a związkami wyznaniowymi (art. 25 ust. 4-5 Konstytucji RP), red. P. Stanisz, M. Ordon, Lublin 2013, s. 318.

21 Najmocniejszym przykładem jest ustawa z 16 grudnia 2010 r. o zmianie ustawy o stosunku Państwa do Kościoła Katolickiego w Rzeczypospolitej Polskiej (Dz.U. 2011, nr 18, poz. 89) znosząca Komisję Majątkową.

22 Zob. wyrok Trybunału Konstytucyjnego z 2 kwietnia 2003 r., sygn. akt K 13/02, Dz.U. nr 62, poz. 577: „Z art. 25 Konstytucji wynika ponadto dla organów władzy publicznej obowiązek poszukiwania w sferze stosunków z kościołami i związkami wyznaniowymi rozwiązań prawodawczych o charakterze konsensualnym, które znajdują akceptację adresatów. Ustawodawca nie może zatem podejmować jednostronnych ingerencji w sferę stosunków między poszczególnymi kościołami i związkami wyznaniowymi” oraz wyrok TK z 16 kwietnia 2009 r., sygn. akt P 11/08, dotyczący oceny aspektu proceduralnego przy badaniu konstytucyjności prawa, stwierdzający niezgodność aktu ze wskazanymi przepisami Konstytucji „przez to że został uchwalony przez Sejm bez dochowania trybu wymaganego do jego wydania”. 
sady równości, w tym w odniesieniu również do podmiotów innych niż osoby fizyczne ${ }^{23}$. W mojej opinii nie można uznać za uzasadnione wykluczenie osób prawnych KiZW w stosunku do innych rodzajów osób prawnych tylko na podstawie posiadania statusu „osoby prawnej KiZW” bez odniesienia do rodzajów aktywności ${ }^{24}$. Takie wykluczające brzmienie przepisu - bez wskazania kryteriów innych niż „rodzaj podmiotu” - jest podstawą do postawienia zarzutu naruszenia konstytucyjnej zasady równości.

4. Okoliczność w postaci przypuszczenia, że KiZW otrzymały równowartość przejętych przez państwo „nieruchomości ziemskich związków wyznaniowych” ${ }^{25}$, po jej zweryfikowaniu ${ }^{26}$, jak również występowanie praktyk ocenianych jako niemających uzasadnienia $\mathrm{w}$ ratio legis wprowadzanych przepisów ${ }^{27}$, jest, w przy-

23 Komentarz do art. 32 Konstytucji Rzeczypospolitej Polskiej, red. L. Garlicki, M. Zubik, 2016, LEX, teza 19 i 23.

24 Kryteria różnicowania uzasadniające odmienne traktowanie podmiotów podobnych zob. orzeczenie TK z 3 września 1996 r., sygn. akt K 10/96, OTK 1996, nr 4, poz. 33.

25 Przejęcie na podstawie ustawy z 20 marca 1950 r. o przejęciu przez Państwo dóbr martwej ręki, poręczeniu proboszczom posiadania gospodarstw rolnych i utworzeniu Funduszu Kościelnego, Dz.U. nr 9, poz. 87.

26 Dostępne dane są niepełne i różnokontekstowe, przez co niewystarczające do formułowania adekwatnych wniosków. Sprawozdanie o stanie mienia Skarbu Państwa według stanu na dzień 31 grudnia 2018 r., s. 43, http://orka.sejm.gov.pl/Druki9ka.nsf/0/ E0AC574E0DB6F2A3C12584CF003ECFED/\%24File/72.pdf. [dostęp: 18 września 2020 r.]; wskazuje stan własności nieruchomości KiZW w jednym momencie czasowym i jest to 139416 ha, z kolei odpowiedź J. Ardanowskiego na interpelację nr 3393 w sprawie nieodpłatnego przekazania gruntów Zasobu Własności Rolnej Skarbu Państwa (ZWRSP) na rzecz kościelnych osób prawnych informuje, że od dnia 1 stycznia 1992 r. do dnia 31 grudnia 2019 r. z Zasobu Własności Rolnej Skarbu Państwa przekazano nieodpłatnie na rzecz kościelnych osób prawnych 90263 ha, http://www.sejm. gov.pl/Sejm9.nsf/interpelacja.xsp?typ=INT\&nr=3393 [dostęp: 18 września 2020 r.]. Informacje o nieruchomościach i ich obecnym gospodarczym wykorzystaniu pochodzą głównie z doniesień medialnych (np. T. Resler, A. Filak, Raport Stowarzyszenia Obywatelskich Inicjatyw Społecznych i Historycznych. Jak Trybunał Konstytucyjny usankcjonował bezterminowe uwłaszczanie Kościoła katolickiego na państwowych gruntach rolnych na tzw. Ziemiach Zachodnich i Pólnocnych, http://www.soish.pl/ wp-content/uploads/2020/01/Jak-wyrok-Trybunału-Konstytucyjnego-usankcjonował-bezterminowe-uwłaszczanie-Kościoła-katolickiego-na-państwowych-gruntach-rolnych_af.pdf [dostęp: 18 września 2020 r.]; i kolejny przykład: Mieszkanie od parafii, biuro od zakonu, „Rzeczpospolita” z 18 lipca 2020 r., https://www.rp.pl/ Mieszkaniowe/307189878-Mieszkanie-od-parafii--biuro-od-zakonu.html [dostęp: 18 września 2020 r.]. Zwraca uwagę brak scentralizowanej, kompletnej i uporządkowanej informacji pozwalającej formułować należycie uzasadnione wnioski.

27 Szczególnie art. 70a ustawy z 17 maja 1989 r. o stosunku Państwa do Kościoła Katolickiego w Rzeczypospolitej Polskiej (t.j. Dz.U. 2019, poz. 1347) „1. Osobom prawnym Kościoła Katolickiego, które po dniu 8 maja 1945 r. podjęły działalność na 
padku Kościoła katolickiego, podstawą do stwierdzenia potrzeby „koniecznych zmian" ustawodawstwa polskiego i uruchomienia trybu, o którym mówi art. 22. ust. $2^{28}$ konkordatu.

Wskazana jest również kompleksowa ocena zgodności całościowych ram normatywnych działalności służącej celom humanitarnym, charytatywno-opiekuńczym, naukowym i oświatowo-wychowawczym (dotyczących obowiązków sprawozdawczych, zwolnień i ulg podatkowych, innych uprawnień), prowadzonej przez instytucje państwowe ${ }^{29} \mathrm{z}$ ramami normatywnymi prowadzenia takiej działalności przez kościelne osoby prawne Kościoła katolickiego - w kontekście art. 22 ust. 1 konkordatu „zrównującego” tę działalność „pod względem prawnym”, tj. pod względem uprawnień i obowiązków oraz ewentualne uruchomienie specjalnego trybu ${ }^{30}$, w celu uzgodnienia koniecznych zmian $^{31}$.

\section{Bibliografia}

Borecki P., Dopuszczalna wysokość odliczeń darowizn na działalność charytatywno-opiekuńczą kościołów. Glosa do uchwały NSA z dnia 14 marca 2004 r., „Glosa” 2006, nr 2.

Borecki P., Respektowanie polskiego konkordatu z 1993 roku. Wybrane problemy, Warszawa 2012.

Chybalski P., Opinia prawna $z$ dnia 2 lutego 2012 r. w sprawie zakresu obowiązku przeprowadzenia konsultacji dotyczacych poselskiego projektu ustawy o zmianie ustawy o prze-

Ziemiach Zachodnich i Północnych, mogą być, na ich wniosek, przekazane nieodpłatnie na własność grunty znajdujące się w zasobach Państwowego Funduszu Ziemi albo w Zasobie Własności Rolnej Skarbu Państwa. Jeżeli grunty te znajdują się w zarządzie lub użytkowaniu osób prawnych, przekazanie na własność może nastąpić wyłącznie za zgodą tych osób”. Przepis ten jest nazywany obrazowo „perpetuum mobile", umożliwiając wielokrotne występowanie o przyznanie ustawowego areału i obrót otrzymanymi nieruchomościami rolnymi. C. Łazarewicz Prześwietlamy majatek Kościoła, „Polityka” z 18 marca 2018 r. https://www.polityka.pl/tygodnikpolityka/ kraj/1509032,1,przeswietlamy-majatek-kosciola.read [dostęp: 18 września 2020 r.].

„Przyjmując za punkt wyjścia w sprawach finansowych instytucji i dóbr kościelnych oraz duchowieństwa obowiązujące ustawodawstwo polskie i przepisy kościelne Układające się Strony stworzą specjalną komisję, która zajmie się koniecznymi zmianami. Nowa regulacja uwzględni potrzeby Kościoła biorąc pod uwagę jego misję oraz dotychczasową praktykę życia kościelnego w Polsce".

Zob. P. Borecki Dopuszczalna wysokość odliczeń darowizn na działalność charytatywno-opiekuńczą kościołów. Glosa do uchwały NSA z dnia 14 marca 2004 r., „Glosa” 2006, nr 2, poz. 119.

30 Zob. przypis 15

31 Wprowadzanie zmian w sytuacji KiZW innych niż Kościół katolicki wymaga stosowania trybów opiniowania przewidzianych w ustawach regulujących wzajemne stosunki tych KiZW z państwem. 
jęciu przez Państwo dóbr martwej ręki, poręczeniu proboszczom gospodarstw rolnych i utworzeniu Funduszu Kościelnego oraz niektórych innych ustaw; BAS-WAUiP-122/12, niepubl.

Czarny P., Opinia prawna z dnia 8 października 2012 r. w sprawie obowiąku zasięgania opinii co do zmian w ustawach regulujących stosunek państwa do poszczególnych kościołów i związków wyznaniowych, „Zeszyty Prawnicze BAS” 2012, nr 4(36).

Czohara A., Specyfika ugód i orzeczeń w postępowaniu regulacyjnym [w:] A. Czohara, T.J. Zieliński, Ustawa o stosunku Państwa do gmin wyznaniowych żydowskich w Polsce. Komentarz, Warszawa 2012.

Komentarz do art. 32 Konstytucji Rzeczypospolitej Polskiej, red. L. Garlicki, M. Zubik, 2016, LEX.

Krukowski J., Konstytucyjny system relacji między państwem a Kościołem katolickim oraz innymi kościołami i związkami wyznaniowymi [w:] Ustrój konstytucyjny Rzeczypospolitej Polskiej, red. R. Mojak, Lublin 2000.

Krukowski J., Realizacja Konkordatu z 1993 r.w polskim porządku prawnym [w:] Konkordat polski w 10 lat po ratyfikacji, red. J. Wroceński, H. Pietrzak, Warszawa 2008.

Lipski J., Opinia prawna na temat poselskiego projektu ustawy o zmianie ustawy o przejęciu przez Państwo dóbr martwej ręki, poręczeniu proboszczom posiadania gospodarstw rolnych i utworzeniu Funduszu Kościelnego oraz niektórych innych ustaw (druk nr 1216); BAS-WAL-841/13, niepubl.

Łazarewicz C., Prześwietlamy majątek Kościoła, „Polityka” z 18 marca 2018 r. https://www. polityka.pl/tygodnikpolityka/kraj/1509032,1,przeswietlamy-majatek-kosciola.read.

Mieszkanie od parafii, biuro od zakonu, „Rzeczpospolita” z 18 lipca 2020 r., https://www. rp.pl/Mieszkaniowe/307189878-Mieszkanie-od-parafii-biuro-od-zakonu.html.

Resler T., Filak A., Raport Stowarzyszenia Obywatelskich Inicjatyw Społecznych i Historycznych. Jak Trybunat Konstytucyjny usankcjonowat bezterminowe uwłaszczanie Kościoła katolickiego na państwowych gruntach rolnych na tzw. Ziemiach Zachodnich $i$ Północnych, http://www.soish.pl/wp-content/uploads/2020/01/Jak-wyrok-Trybunału-Konstytucyjnego-usankcjonował-bezterminowe-uwłaszczanie-Kościoła-katolickiego-na-państwowych-gruntach-rolnych_af.pdf.

Sobczyk P., Proceduralna niekonstytucyjność nowelizacji ustawy o stosunku Państwa do Kościoła Katolickiego w Rzeczypospolitej Polskiej, „Studia Politologiczne” 2012, nr 23, http://www.studiapolitologiczne.pl/pdf-117287-46482?filename=Proceduralna.pdf.

Sprawozdanie o stanie mienia Skarbu Państwa według stanu na dzień 31 grudnia 2018 r., http://orka.sejm.gov.pl/Druki9ka.nsf/0/E0AC574E0DB6F2A3C12584CF003ECFED/ \%24File/72.pdf.

Stanisz P., Perspektywy zmiany systemu finansowania kościołów i innych związków wyznaniowych $w$ Polsce, „Studia z Prawa Wyznaniowego” 2009, t. 12.

Stanisz P., Naczelne zasady instytucjonalnych relacji Państwo-Kościół [w:] A. Mezglewski, H. Misztal, P. Stanisz, Prawo wyznaniowe, Warszawa 2008.

Walencik D., Finansowanie Kościoła Katolickiego w Polsce [w:] Konkordat: ocena z perspektywy 15 lat obowiązywania $w$ Polsce $w$ świetle art. 22 i 27 konkordatu oraz prac 
komisji konkordatowych - perspektywa zmian, red. P. Kroczek, seria „Annales Cannonici. Monographiae”, Kraków 2014.

Walencik D., Konkordat a sfera finansowo-majątkowa Kościoła Katolickiego w Polsce [w:] Konkordat Polski, red. P. Borecki, C. Janik, M. Winiarczyk-Kossakowska, Warszawa 1993.

Zawiślak M., Zmiana systemu finansowania Kościoła Katolickiego w świetle Konstytucji RP i Konkordatu [w:] Układowe formy regulacji stosunków między państwem a związkami wyznaniowymi (art. 25 ust. 4-5 Konstytucji RP), red. P. Stanisz, M. Ordon, Lublin 2013.

Zieliński T.J., Implikacje art. 25 ust. 5 Konstytucji RP dla procedury parlamentarnej [w:] Układowe formy regulacji stosunków między państwem a związkami wyznaniowymi (art. 25 ust. 4-5 Konstytucji RP), red. P. Stanisz, M. Ordon, Lublin 2013. 
Ewelina Gierach

\title{
Ocena zgodności z Konstytucją poselskiego projektu ustawy o jawności przychodów kościołów i związków wyznaniowych oraz zniesieniu ich przywilejów finansowych ${ }^{1}$
}

\author{
Assessment of compliance with the Constitution of the Republic of Poland \\ of the Deputies' Bill on the Transparency of Revenues of Churches and \\ Religious Associations and the Abolition of Their Financial Privileges
}

\begin{abstract}
The author raises arguments in favour of considering the proposed solutions unconstitutional. The amendments to the provisions of particular statutes, envisaged in the Bill, which regulate the relations between the State and individual churches and religious associations, do not meet the constitutional requirement of consensual regulation of relations. Furthermore, it should be considered whether the vacatio legis proposed in the bill is sufficient for the addressees of the regulation to adapt to the new solutions. Legislative shortcomings of the draft were also indicated.
\end{abstract}

Keywords: Catholic Church, church, religious association, transparency, public finances, Constitution, concordat

Autorka podnosi argumenty przemawiające za uznaniem proponowanych rozwiązań za niekonstytucyjne. Przewidziane w projekcie zmiany w przepisach ustaw partykularnych, regulujących stosunki państwa z poszczególnymi kościołami i związkami wyznaniowymi, nie spełniają wynikającego z Konstytucji wymogu konsensualnej regulacji stosunków. Należy ponadto rozważyć, czy zaproponowana w projekcie vacatio legis jest wystarczająca do tego, aby adresaci regulacji dostosowali się do nowych rozwiązań. Wskazano także mankamenty legislacyjne projektu.

Słowa kluczowe: Kościół katolicki, kościół, związek wyznaniowy, jawność, finanse publiczne, Konstytucja, konkordat

Doktor nauk prawnych, adiunkt Uniwersytet Kardynała Stefana Wyszyńskiego w Warszawie, Wydział Prawa i Administracji, Katedra Prawa Konstytucyjnego, WARSZAWA, POLSKA • e.gierach@uksw.edu.pl • https://orcid.org/0000-0002-2689-786X

\section{Przedmiot opinii}

Opinia dotyczy zgodności z Konstytucją RP poselskiego projektu ustawy o jawności przychodów kościołów i związków wyznaniowych oraz zniesieniu ich przywilejów finansowych; dalej: projekt. Opinia uwzględnia stan prawny na dzień jej sporządzenia.

$1 \quad$ Opinia prawna $w$ sprawie zgodności z Konstytucja poselskiego projektu ustawy o jawności przychodów kościołów i związków wyznaniowych oraz zniesieniu ich przywilejów finansowych sporządzona 28 września 2020 r. na zlecenie Szefa Kancelarii Sejmu; BAS-WAP-1853/20. 


\section{Zakres proponowanych zmian ${ }^{2}$}

Przedmiotem projektowanej ustawy jest:

- wprowadzenie obowiązku ewidencjonowania i ujawniania organom Krajowej Administracji Skarbowej i następnie publikowania w Biuletynie Informacji Publicznej (dalej: BIP) informacji o przysporzeniach przekazywanych kościołom i związkom wyznaniowym przez jednostki sektora finansów publicznych (art. 3 i art. 5 projektu),

- wprowadzenie obowiązku ewidencjonowania i ujawniania przychodów przez jednostki organizacyjne kościołów, związków wyznaniowych oraz inne kościelne osoby prawne organom Krajowej Administracji Skarbowej i następnie publikowania w BIP (art. 4 projektu).

- zmiany przepisów 21 ustaw, w następstwie których nastąpi:

- likwidacja Funduszu Kościelnego (art. 14 projektu),

- likwidacja opłacania składek na ubezpieczenie emerytalne, rentowe i wypadkowe duchownych, członków zakonów kontemplacyjnych klauzurowych, misjonarzy w okresach pracy na terenach misyjnych przez Fundusz Kościelny (art. 31 projektu),

- likwidacja opłacania składek na ubezpieczenie zdrowotne duchownych oraz alumnów wyższych seminariów duchownych i teologicznych, postulantów, nowicjuszy i juniorystów oraz ich odpowiedników, z wyłączeniem osób duchownych będących podatnikami podatku dochodowego od osób fizycznych lub zryczałtowanego podatku dochodowego od przychodów osób duchownych przez Fundusz Kościelny, dotowany przez budżet państwa w tym zakresie (art. 33 projektu),

- likwidacja prawa realizacji inwestycji kościelnych, tj. niesłużących bezpośrednio celom sakralnym (art. 16, 17, 20, 21, 23, 24, 25, 27, 28, 29 projektu),

- likwidacja zwolnienia od opodatkowania z tytułu przychodów ze swojej działalności niegospodarczej (art. 16, 17 projektu),

- likwidacja zwolnienia z obowiązku prowadzenia dokumentacji wymaganej przez przepisy o zobowiązaniach podatkowych w przypadku przychodów ze swojej działalności niegospodarczej (art. 16, 17 projektu),

- likwidacja zwolnienia podatkowego z podatku od nieruchomości używanej do celów niemieszkalnych $\mathrm{z}$ wyjątkiem części zajmowanej na wykonywanie działalności gospodarczej (art. 15, 16, 17, 20, 21, 22, 23, 24, 25, 26, 27, 28, 29 projektu),

2 Wykaz projektowanych zmian przytaczam za: K. Kurczewska, Ocena skutków regulacji zawartych $w$ poselskim projekcie ustawy o jawności przychodów kościołów i związków wyznaniowych oraz zniesieniu ich przywilejów finansowych, BAS-WASiE-1419/20, niepubl. 
- uwyraźnienie braku zwolnienia podatkowego dochodów z działalności gospodarczej osób prawnych kościołów i związków wyznaniowych przeznaczonych na inwestycje kościelne inne niż punkty katechetyczne i zakłady charytatywno-opiekuńcze (art. 15, 16, 17 projektu),

- likwidacja uprawnienia do nieodpłatnego nabywania własności przez osoby prawne Kościoła katolickiego - które po dniu 8 maja 1945 r. podjęły działalność na tzw. ziemiach zachodnich i północnych - gruntów znajdujących się w zasobach Państwowego Funduszu Ziemi albo w Zasobie Własności Rolnej Skarbu Państwa (art. 16 projektu),

- likwidacja możliwości dotowania i subwencjonowania kościołów i związków wyznaniowych przez jednostki samorząa terytorialnego oraz dokonywania przysporzeń majątkowych pod tytułem darowizny kościołom i związkom wyznaniowym przez spółki prawa handlowego z udziałem Skarbu Państwa, państwowych jednostek organizacyjnych lub jednostki samorządu terytorialnego bez wyraźnej podstawy w ustawie (art. 15 projektu),

- likwidacja prawa obywateli do zmniejszenia kwoty podatku dochodowego od osób fizycznych przez odliczenie od dochodu kwoty darowizn przekazanych na cele kultu religijnego - w wysokości dokonanej darowizny, do kwoty stanowiącej 6\% dochodu (art. 18 projektu),

- likwidacja prawa osób prawnych do zmniejszenia kwoty podatku dochodowego od osób prawnych przez odliczenie od dochodu kwoty darowizn przekazanych na cele kultu religijnego - do kwoty 10\% dochodu (art. 19 projektu),

- likwidacja uprawnień nabycia $\mathrm{w}$ drodze bezprzetargowej w sytuacji zbycia nieruchomości kościołom i związkom wyznaniowym na cele działalności sakralnej (art. 30 projektu),

- likwidacja uprawnień do otrzymania bonifikaty od ceny sprzedaży nieruchomości w drodze bezprzetargowej, w sytuacji sprzedaży nieruchomości kościołom i związkom wyznaniowym na cele działalności sakralnej (art. 30 projektu),

- likwidacja ochrony przed prawem pierwokupu Skarbu Państwa w obrocie nieruchomościami między kościelnymi osobami prawnymi Kościoła katolickiego (art. 16 projektu),

- likwidacja ochrony przed prawem pierwokupu gminy w sytuacji sprzedaży nieruchomości lub prawa użytkowania wieczystego następującego między osobami prawnymi tego samego kościoła lub związku wyznaniowego (art. 30 projektu),

- likwidacja uprawnień do nabycia nieruchomości rolnej przez osoby prawne działające na podstawie przepisów o stosunku państwa do Kościoła katolickiego w Rzeczypospolitej Polskiej, o stosunku państwa do innych kościołów i związków wyznaniowych oraz o gwarancjach wolności sumienia i wyznania (art. 32 projektu), 
- likwidacja ochrony przed prawem wykupu przez Krajowy Ośrodek działający na rzecz Skarbu Państwa w sytuacji, gdy przeniesienie własności nieruchomości rolnej następuje między osobami prawnymi tego samego kościoła lub związku wyznaniowego (art. 32 projektu),

- likwidacja ochrony przed prawem dzierżawcy do pierwokupu dzierżawionej nieruchomości rolnej w sytuacji sprzedaży tej nieruchomości między osobami prawnymi tego samego kościoła lub związku wyznaniowego (art. 32 projektu).

\section{Ocena konstytucyjności proponowanych rozwiązań}

1. Opiniowany projekt dotyczy materii stosunków między państwem a kościołami i związkami wyznaniowymi. Na poziomie konstytucyjnym relacje te normuje art. 25 ustawy zasadniczej, który w kolejnych ustępach określa zasady nimi rządzące. Są to:

- równouprawnienie kościołów i innych związków wyznaniowych (ust. 1),

- bezstronność władz publicznych w sprawach przekonań religijnych, światopoglądowych i filozoficznych (ust. 2),

- wzajemne poszanowanie niezależności i autonomii państwa oraz kościołów i innych związków wyznaniowych (ust. 3),

- współdziałanie państwa z kościołami i innymi związkami wyznaniowymi (ust. 3),

- konsensualna regulacja stosunków między państwem a kościołami i innymi związkami wyznaniowymi, w formach odpowiadających ich specyfice (ust. 4 i ust. 5$)^{3}$.

Dla oceny zgodności z Konstytucją projektowanej regulacji szczególne znaczenie ma ostatnia ze wskazanych wyżej zasad. Jest ona „konsekwencją uznania autonomii i niezależności wspólnot religijnych i wymaga, by - w sprawach tą autonomią i niezależnością objętych [...] - określanie stosunków państwa z kościołami i innymi związkami wyznaniowymi nie następowało w sposób

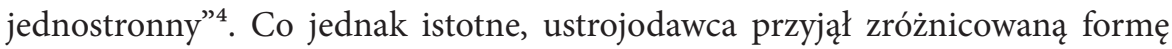
regulacji stosunków z Kościołem katolickim i z pozostałymi kościołami i związkami wyznaniowymi.

2. W myśl art. 25 ust. 4 Konstytucji stosunki między Rzeczpospolitą Polską a Kościołem katolickim określają umowa międzynarodowa zawarta ze Stolicą Apostolską oraz ustawy. Oceniając konstytucyjność projektowanych regulacji,

3 Zob. wyroki TK z: 2 kwietnia 2003 r., sygn. akt K 13/02; 14 grudnia 2009 r., sygn. akt K 55/07.

4 L. Garlicki, Komentarz do art. 25 [w:] Konstytucja Rzeczypospolitej Polskiej. Komentarz, t. V, red. L. Garlicki, Warszawa 2005, s. 20. 
należy zatem w pierwszej kolejności zwrócić uwagę na ich zgodność z przepisami konkordatu między Stolicą Apostolską a Rzecząpospolitą Polską podpisanego w Warszawie 28 lipca 1993 r. (Dz.U. 1998, nr 51, poz. 318; dalej: konkordat). Konkordat jest bowiem umową międzynarodową ratyfikowaną na podstawie uprzedniej zgody wyrażonej w ustawie i - zgodnie z art. 91 ust. 1 i 2 Konstytucji - stanowi część krajowego porządku prawnego i ma pierwszeństwo stosowania wobec regulacji zawartych w ustawach zwykłych i aktach podustawowych. Regulację tę dopełniają przepisy ustawy z 17 maja 1989 r. o stosunku Państwa do Kościoła Katolickiego w Rzeczypospolitej Polskiej (Dz.U. 2019, poz. 1347).

Zgodnie z art. 22 ust. 2 konkordatu: „Przyjmując za punkt wyjścia w sprawach finansowych instytucji i dóbr kościelnych oraz duchowieństwa obowiązujące ustawodawstwo polskie i przepisy kościelne Układające się Strony stworzą specjalną komisję, która zajmie się koniecznymi zmianami. Nowa regulacja uwzględni potrzeby Kościoła biorąc pod uwagę jego misję oraz dotychczasową praktykę życia kościelnego w Polsce”. Ponadto: „Władzom państwowym wskazana zostanie instytucja kościelna lub instytucje kościelne kompetentne w sprawach wymienionych w ustępie 2" (ust. 3). Kolejny art. 22 ust. 4 konkordatu stanowi, że: „Rzeczpospolita Polska w miarę możliwości udziela wsparcia materialnego w celu konserwacji i remontowania zabytkowych obiektów sakralnych i budynków towarzyszących, a także dzieł sztuki stanowiących dziedzictwo kultury".

Rada Ministrów zawarła swoje stanowisko w sprawie interpretacji cytowanych wyżej postanowień konkordatu w deklaracji rządu Rzeczpospolitej Polskiej z 15 kwietnia 1997 r. w celu zapewnienia jasnej wykładni przepisów konkordatu między Stolicą Apostolską a Rzecząpospolitą Polską, podpisanego w Warszawie w dniu 28 lipca 1993 r. (M.P. 1998, nr 4, poz. 51; dalej: deklaracja z 15 kwietnia 1997 r.). Rada Ministrów stwierdziła w ust. 6 wymienionej deklaracji, że: „Konkordat uznaje określone ustawodawstwem polskim kompetencje organów państwowych do regulowania kwestii finansowych i podatkowych kościelnych osób prawnych i fizycznych. W tym celu strona państwowa zapozna się z opinią strony kościelnej w łonie odpowiedniej Komisji, o której mowa w artykule 22 ust. 2 i 3".

Z kolei art. 27 konkordatu stanowi: „Sprawy wymagające nowych lub dodatkowych rozwiązań będą regulowane na drodze nowych umów między Układającymi się Stronami albo uzgodnień między Rządem Rzeczypospolitej Polskiej i Konferencją Episkopatu Polski upoważnioną do tego przez Stolicę Apostolskąa". Rada Ministrów w cytowanej deklaracji z 15 kwietnia 1997 r. wyraziła stanowisko, że „zasady wyrażone w artykule 27 i 28 Konkordatu będą stosowane przy poszanowaniu konstytucyjnie określonych kompetencji Rządu Rzeczypospolitej Polskiej oraz poszanowaniu kompetencji Stolicy Apostolskiej i Konferencji Episkopatu Polski”.

Przywołany art. 22 konkordatu przewiduje dostosowanie prawodawstwa polskiego w sprawach finansowych instytucji i dóbr kościelnych oraz duchowieństwa do potrzeb kościoła przy uwzględnieniu jego misji i dotychczasowej 
praktyki życia kościelnego w Polsce. W tym celu strony mają powołać specjalną komisję, która ma zająć się koniecznymi zmianami. Celem rozważanego przepisu nie jest unormowanie trybu wykonywania szczegółowych rozwiązań zawartych w innych postanowieniach konkordatu, ale trybu wprowadzenia szerokich zmian prawodawczych wykraczających poza zakres wymienionych postanowień. W literaturze przedmiotu zwraca się uwagę, że przepis ten dotyczy przede wszystkim ubezpieczenia społecznego duchownych i wynagradzania duchownych pracujących w duszpasterstwie, ustalenia wysokości świadczeń z Funduszu Kościelnego na rzecz potrzeb Kościoła oraz ustalenia zasad rozgraniczania działalności gospodarczej i niegospodarczej kościelnych osób prawnych ${ }^{5}$.

Artykuł 27 konkordatu dotyczy zaś wyłącznie spraw wymagających nowych lub dodatkowych rozwiązań. Regulacje takie wymagają nowej umowy między układającymi się stronami albo uzgodnień między rządem Rzeczypospolitej Polskiej i Konferencją Episkopatu Polski upoważnioną do tego przez Stolicę Apostolską.

Na tym tle należy odnotować, że w zakresie odnoszącym się do sytuacji prawnej Kościoła katolickiego w Polsce projektowane zmiany nie spełniają sformułowanego w art. 25 Konstytucji oraz w przepisach konkordatu wymogu konsensualnej regulacji stosunków. Z przywołanych wyżej przepisów konkordatu wynika, że szeroko pojęte sprawy finansowe instytucji i dóbr kościelnych oraz duchowieństwa wymagają zapoznania się z opinią strony kościelnej lub zawarcia nowych umów albo uzgodnień między rządem Rzeczypospolitej Polskiej i Konferencją Episkopatu Polski. Bez wątpienia przewidziane w opiniowanym projekcie uregulowania przewidujące w szczególności obowiązek ewidencjonowania i upubliczniania informacji o przychodach otrzymywanych przez kościoły i związki wyznaniowe, likwidację Funduszu Kościelnego; kwestię opłacania składek na ubezpieczenie emerytalne, rentowe i wypadkowe oraz zdrowotne duchownych, zakaz realizacji inwestycji kościelnych czy też likwidację uprawnień do nabycia nieruchomości rolnej i do nieodpłatnego nabywania własności gruntów przez osoby prawne Kościoła katolickiego na ziemiach zachodnich i północnych, są objęte tym nakazem.

3. Opiniowany projekt przewiduje ponadto zmiany przepisów tzw. ustaw partykularnych regulujących stosunek państwa do poszczególnych kościołów i związków wyznaniowych. Tymczasem ustawy te, uchwalone często jeszcze przed wejściem w życie Konstytucji z 1997 r., przewidują uprawnienia organów związków religijnych, których dotyczą, do opiniowania zmian w nich ustanawianych $^{6}$.

Zob. J. Krukowski, Konkordat polski. Znaczenie i realizacja, Lublin 1999, s. 172-174.

Zob. W. Odrowąż-Sypniewski, Opinia prawna w sprawie potrzeby przeprowadzenia konsultacji z kościołami i związkami wyznaniowymi projektu ustawy o Komisji prawdy i zadośćuczynienia $w$ sprawach związanych $z$ zachowaniami o charakterze pedofilskim 
Obowiązek zasięgania opinii wspólnoty religijnej przed dokonaniem zmiany ustawy przewidziany jest w następujących ustawach:

- art. 1 ust. 3 ustawy z 13 maja 1994 r. o stosunku Państwa do Kościoła Ewangelicko-Reformowanego w Rzeczypospolitej Polskiej (Dz.U. 2015, poz. 483), który przewiduje, że „zmiany niniejszej ustawy wymagają uprzedniej opinii Konsystorza Kościoła",

- art. 5 ust. 2 ustawy z 13 maja 1994 r. o stosunku Państwa do Kościoła Ewangelicko-Augsburskiego w Rzeczypospolitej Polskiej (Dz.U. 2015, poz. 43), który przewiduje, że „zmiany niniejszej ustawy wymagają uprzedniej opinii Synodu Kościoła",

- art. 1 ust. 3 ustawy z 30 czerwca 1995 r. o stosunku Państwa do Kościoła Ewangelicko-Metodystycznego w Rzeczypospolitej Polskiej (Dz.U. 2014, poz. 1712), który przewiduje, że „wszelkie zmiany niniejszej ustawy wymagają uprzedniej opinii Rady Kościoła",

- art. 1 ust. 3 ustawy z 30 czerwca 1995 r. o stosunku Państwa do Kościoła Chrześcijan Baptystów w Rzeczypospolitej Polskiej (Dz.U. 2015, poz. 169), który stanowi, że „wszelkie zmiany niniejszej ustawy wymagają uprzedniej opinii Prezydium Rady Kościoła",

- art. 1 ust. 3 ustawy z 30 czerwca 1995 r. o stosunku Państwa do Kościoła Polskokatolickiego w Rzeczypospolitej Polskiej (Dz.U. 2014, poz. 1599), który przewiduje, że „wszelkie zmiany niniejszej ustawy wymagają uprzedniej opinii Rady Synodalnej",

- art. 1 ust. 3 ustawy z 30 czerwca 1995 r. o stosunku Państwa do Kościoła Adwentystów Dnia Siódmego w Rzeczypospolitej Polskiej (Dz.U. 2014, poz. 1889), który przewiduje, że „wszelkie zmiany niniejszej ustawy wymagają uprzedniej opinii Zarządu Kościoła”,

- art. 1 ust. 3 ustawy z 20 lutego 1997 r. o stosunku Państwa do żydowskich gmin wyznaniowych w Rzeczypospolitej Polskiej (Dz.U. 2014, poz. 1798), który przewiduje, że „wszelkie zmiany ustawy wymagają uprzedniej opinii zarządu Związku Gmin Wyznaniowych Żydowskich”,

- art. 1 ust. 3 ustawy z 20 lutego 1997 r. o stosunku Państwa do Kościoła Katolickiego Mariawitów w Rzeczypospolitej Polskiej (Dz.U. 2015, poz. 44), który przewiduje, że „wszelkie zmiany niniejszej ustawy wymagają uprzedniej opinii Rady Przełożonych Kościoła",

- art. 1 ust. 3 ustawy z 20 lutego 1997 r. o stosunku Państwa do Kościoła Starokatolickiego Mariawitów w Rzeczypospolitej Polskiej (Dz.U. 2015, poz. 14), który przewiduje, że „wszelkie zmiany niniejszej ustawy wymagają uprzedniej opinii Rady Kościoła”,

osób duchownych (przedstawiciel wnioskodawców poseł Joanna Scheuring-Wielgus), BAS-WAP-1864/20, niepubl. W tej części analizy szeroko korzystam z ustaleń poczynionych w niniejszej opinii. 
- art. 1 ust. 3 ustawy z 20 lutego 1997 r. o stosunku Państwa do Kościoła Zielonoświątkowego w Rzeczypospolitej Polskiej (Dz.U. 2015, poz. 13), który przewiduje, że „wszelkie zmiany niniejszej ustawy wymagają uprzedniej opinii Prezydium Naczelnej Rady Kościoła",

Jednocześnie odnotować należy, że brak jest analogicznych postanowień w kilku innych przedkonstytucyjnych powszechnie obowiązujących aktach partykularnych, tj. w:

- ustawie z 17 maja 1989 r. o stosunku Państwa do Kościoła Katolickiego w Rzeczypospolitej Polskiej,

- ustawie z 4 lipca 1991 r. o stosunku Państwa do Polskiego Autokefalicznego Kościoła Prawosławnego (Dz.U. nr 66, poz. 287, ze zm.),

- ustawie z 21 kwietnia 1936 r. o stosunku Państwa do Muzułmańskiego Związku Religijnego w Rzeczypospolitej Polskiej (Dz.U. nr 30, poz. 240),

- ustawie z 21 kwietnia 1936 r. o stosunku Państwa do Karaimskiego Związku Religijnego w Rzeczypospolitej Polskiej (Dz.U. nr 30, poz. 241, ze zm.),

- rozporządzeniu Prezydenta Rzeczypospolitej Polskiej z mocą ustawy z 28 marca 1928 r. o stosunku Państwa do Wschodniego Kościoła Staroobrzędowego (Dz.U. nr 38, poz. 363, ze zm.).

Wynikająca z art. 25 ust. 5 Konstytucji zasada regulacji stosunków między państwem a kościołami i związkami wyznaniowymi w drodze dwustronnej oznacza, że warunkiem uchwalenia bądź zmiany ustawy regulującej stosunek państwa do poszczególnych wspólnot religijnych (niezależnie od tego, czy sama ustawa takie regulacje zawiera) jest wymóg zawarcia wcześniejszej umowy między Radą Ministrów a przedstawicielami danego kościoła. Umowa zawierana przez Radę Ministrów z właściwymi przedstawicielami kościołów i związków wyznaniowych determinuje lub wręcz przesądza treść przyszłej ustawy partykularnej ${ }^{7}$.

Zakres przedmiotowy art. 25 ust. 5 Konstytucji obejmuje ogół spraw właściwych wzajemnym relacjom państwa i danego związku wyznaniowego. Ramy konstytucyjne merytorycznej treści ustaw partykularnych wyznaczają zasady: autonomii i niezależności, współdziałania państwa i związków wyznaniowych, a także zasada swobody umów ${ }^{8}$. Chodzi zarazem o sprawy wynikające z natury wspólnoty religijnej. Obowiązek konsensualnej regulacji „nie odnosi się do sfer, w których wspólnota ta występuje jako „normalny” podmiot prawa czy uczestnik stosunków prawnych"”. Treść art. 25 ust. 5 Konstytucji przesądza o tym, że przepis ten „nie dotyczy stanowienia przepisów, wyrażających normy o charak-

$7 \quad$ Z. Witkowski, Opinia w sprawie zagadnień prawnych wynikajacych $z$ art. 25 ust. 5 Konstytucji RP, „Przegląd Legislacyjny” 2000, nr 2, s. 104, a także wyrok TK z 2 kwietnia 2003 r., sygn. akt K 13/02.

8 D. Walencik, Zakres przedmiotowy umowy z art. 25 ust. 5 Konstytucji RP [w:] Układowe formy regulacji stosunków między państwem a związkami wyznaniowymi (art. 25 ust. 4-5 Konstytucji RP), red. P. Stanisz, M. Ordon, Lublin 2013, s. 266.

$9 \quad$ L. Garlicki, Komentarz do art. 25, op. cit., s. 22-23. 
terze generalnym, dotyczących w ogóle kościołów i innych związków wyznaniowych jako pewnej kategorii adresatów norm prawnych czy wspólnot religijnych, o ile są zaliczane do kategorii adresatów norm prawnych, niewyodrębnionych na podstawie kryterium konfesyjnego, np. jako przedsiębiorcy czy podatnicy. Przyjęcie odmiennej interpretacji musiałoby skutkować absurdalnym wymogiem uzgadniania przez Radę Ministrów z zainteresowanymi związkami wyznaniowymi każdej ustawy potencjalnie dotyczącej tych podmiotów"10.

W ocenie Trybunału Konstytucyjnego z art. 25 Konstytucji wynika dla organów władzy publicznej obowiązek poszukiwania w sferze stosunków z kościołami i związkami wyznaniowymi rozwiązań prawodawczych o charakterze konsensualnym. „Ustawodawca nie może zatem podejmować jednostronnych ingerencji w sferę stosunków między poszczególnymi kościołami i związkami wyznaniowymi"11. Standard wynikający z art. 25 ust. 5 odnosi się przy tym zarówno do „pierwotnie” uchwalonych ustaw partykularnych normujących po raz pierwszy sytuację prawną danej wspólnoty religijnej, jak i co do zasady do ustaw nowelizujących ustawy partykularne. W piśmiennictwie wskazuje się przykładowo, że zmiany tych postanowień ustawy o gwarancjach wolności sumienia i wyznania, które prowadziłyby do modyfikacji relacji pomiędzy państwem a konkretnymi związkami religijnymi określonymi w indywidualnych aktach ustawodawczych, jeżeli miałyby wiązać się z redukcją uprawnień wspólnot religijnych, mogą być ocenione jako wymagające zgody zainteresowanych związków wyznaniowych wyrażonej w formie umownej ${ }^{12}$. Można zatem przyjąć, że „reżim” art. 25 ust. 5 Konstytucji rozciąga się na wszelkie postanowienia ustawowe prowadzące do unormowania w sposób ogólny sytuacji kościołów i innych związków wyznaniowych, które wywierałyby skutki: (1) w sferze objętej autonomią związków religijnych o statusie unormowanym w ustawie partykularnej lub (2) w sferze objętej treścią tych ustaw ${ }^{13}$.

W konsekwencji w świetle art. 25 ust. 5 Konstytucji uregulowanie w szczególności spraw majątkowych, podatkowych, kwestii ubezpieczenia duchownych kościołów i związków wyznaniowych, a także innych wymienionych wcześniej w niniejszej opinii zmian wymaga zawarcia uprzedniego porozumienia między Radą Ministrów a poszczególnymi wspólnotami religijnymi.

4. Zgodnie z projektem ustawa miałaby wejść w życie w terminie 6 miesięcy od dnia jej ogłoszenia. Wyjątkiem byłyby przepisy dotyczące likwidacji prawa obywateli oraz osób prawnych do zmniejszenia kwoty podatku dochodowego

10 P. Borecki, Artykuł 25 ust. 5 Konstytucji RP a ustawa o gwarancjach wolności sumienia i wyznania [w:] Układowe formy regulacji stosunków między państwem a związkami wyznaniowymi (art. 25 ust. 4-5 Konstytucji RP), red. P. Stanisz, M. Ordon, Lublin 2013, s. 370.

11 Wyrok TK z 2 kwietnia 2003 r., sygn. akt K 13/02.

12 P. Borecki, Artykuł 25 ust. 5, op. cit., s. 374.

13 Por. ibidem, s. 376. 
przez odliczenie od dochodu kwoty darowizn przekazanych na cele kultu religijnego, które miałyby wejść w życie z dniem 1 stycznia 2021 r.

Jak wskazuje Trybunał Konstytucyjny, nakaz zachowania odpowiedniej vacatio legis stanowi jedną z norm składających się na treść zasady demokratycznego państwa prawnego i wynika wprost $\mathrm{z}$ zasady zaufania do państwa ${ }^{14}$. Celem odpowiedniej vacatio legis jest zapewnienie adresatom prawa czasu na przystosowanie się do zmienionych regulacji i na podjęcie odpowiednich decyzji co do dalszego postępowania $^{15}$. W odniesieniu do różnych regulacji „odpowiednia” będzie różna vacatio legis ${ }^{16}$. W ocenie Trybunału „ «odpowiedniość» vacationis legis należy rozpatrywać w kontekście możliwości zapoznania się z treścią nowych przepisów przez adresatów i pokierowania swoimi sprawami z ich uwzględnieniem"17. Ostateczna ocena zależy od wszystkich okoliczności, w tym od przedmiotu i treści nowych unormowań, a także kręgu podmiotów, których dotyczą ustanowione unormowania $^{18}$.

Niezależnie od powyższego swoboda regulacyjna ustawodawcy ograniczona jest innymi wymogami wynikającymi z art. 2 Konstytucji. Do standardów tych należy w szczególności zasada ochrony zaufania jednostki do państwa i stanowionego przez nie prawa, a także ochrony praw nabytych oraz ochrony interesów w toku ${ }^{19}$. Trybunał stoi na stanowisku, że „zasada ochrony interesów w toku zapewnia ochronę jednostki w sytuacjach, w których rozpoczęła ona określone przedsięwzięcia na gruncie dotychczasowych przepisów. Chociaż zasada ta nie ma charakteru bezwzględnego, na ustawodawcy ciąży szczególny obowiązek ochrony interesów w toku w sytuacji wystąpienia następujących przesłanek: «1) przepisy prawa wyznaczają pewien horyzont czasowy dla realizowania określonych przedsięwzięć; 2) dane przedsięwzięcie ma charakter rozłożony w czasie; 3) jednostka faktycznie rozpoczęła realizację danego przedsięwzięcia w okresie obowiązywania danej regulacji» (sygn. K 45/01). Obowiązkiem ustawodawcy, ze względu na ochronę interesów w toku, jest ustanowienie przepisów, które umożliwią dokończenie przedsięwzięć rozpoczętych stosownie do przepisów obowiązujących w chwili ich rozpoczynania albo stworzą inną możliwość dostosowania się do zmienionej regulacji prawnej (zob. np. wyrok TK z 5 stycznia 1999 r., sygn. akt K 27/98, OTK ZU nr 1/1999, poz. 1)"20.

14 Zob. np. wyrok z 22 września 2005 r., sygn. akt KP 1/05.

15 Np. wyroki z: 12 grudnia 2012 r., sygn. akt K 1/12; 15 grudnia 1997 r., sygn. akt K 13/97; 4 stycznia 2000 r., sygn. akt K 18/99.

16 Zob. wyrok z 15 lutego 2005 r., sygn. akt K 48/04.

17 Zob. orzeczenie TK z 11 września 1995 r., sygn. akt P 1/95.

18 Tak: wyrok TK z 12 grudnia 2012 r., sygn. akt K 1/12, oraz przywołane tam orzecznictwo.

19 Wyrok TK z 25 czerwca 2002 r., sygn. akt K 45/01.

20 Wyrok TK z 10 lutego 2015 r., sygn. akt P 10/11. 
Biorąc pod uwagę charakter projektowanych zmian - w szczególności wprowadzenie zakazu realizacji inwestycji kościelnych niesłużących bezpośrednio celom sakralnym oraz inne regulacje powodujące $\mathrm{w}$ istocie znaczne uszczuplenie przywilejów podmiotów objętych zakresem ustawy przekładające się wprost na ich sytuację finansową - należałoby rozważyć, czy zaproponowana w projekcie vacatio legis jest wystarczająca do tego, aby adresaci regulacji dostosowali się do nowych rozwiązań. Likwidacja Funduszu Kościelnego; likwidacja opłacania składek na ubezpieczenie emerytalne, rentowe i wypadkowe duchownych, likwidacja opłacania składek na ubezpieczenie zdrowotne duchownych, likwidacja prawa realizacji inwestycji kościelnych, likwidacja uprawnień do nabycia nieruchomości rolnej i likwidacja uprawnienia do nieodpłatnego nabywania własności gruntów przez osoby prawne Kościoła katolickiego na ziemiach zachodnich i północnych w krótkim terminie wskazanym w projekcie ustawy, bez uwzględnienia konieczności opracowania nowych podstaw prawnych dla samodzielności i samowystarczalności ekonomicznej kościołów i związków wyznaniowych oraz ich osób prawnych może godzić w wynikający z art. 2 Konstytucji nakaz zastosowania odpowiedniej vacatio legis.

Uwagę zwraca ponadto brak przepisów przejściowych odnoszących się do rozpoczętych już inwestycji kościelnych, których zakończenie nie jest możliwe przed wejściem w życie projektowanej regulacji.

Wątpliwości budzi ponadto określenie dnia wejścia w życie wskazanych wyżej przepisów konkretną, stosunkowo bliską, datą 1 stycznia 2021 r. Uchwalenie projektowanej ustawy przed upływem tego terminu nie jest pewne. Biorąc pod uwagę obszerność projektu, tempo prac parlamentarnych, może okazać się zbyt wolne, aby ustawa mogła wejść w życie w tym terminie. Ponadto z uwagi na fakt, że w tym przypadku przepisy dotyczą prawa podatkowego szczególnego znaczenia nabiera nakaz zachowania odpowiedniej vacatio legis, który powinien być traktowany restryktywnie. Nawet zatem uchwalenie ustawy przed upływem wskazanej w projektowanym przepisie daty może budzić zastrzeżenia.

5. Niezależnie od powyższych zastrzeżeń należy podkreślić, że w projekcie występują - w mojej ocenie możliwe do usunięcia na dalszych etapach postępowania ustawodawczego - wady legislacyjne, mogące powodować niespójność obowiązujących ustawowych regulacji. W szczególności uwagę zwraca treść art. 1 projektu ustawy, który wskazuje zakres przedmiotowy aktu, wymieniając zaledwie jedno spośród wszystkich projektowanych zagadnień. Zwraca także uwagę wprowadzenie w art. 2 pkt 4 projektu niejasnego i mogącego wywoływać trudności interpretacyjne sformułowania „transakcja nie ekwiwalentna”.

Należy ponadto zauważyć, że projektowane zmiany przewidziane $\mathrm{w}$ art. 16 i 17 projektu dotyczące kwestii zwolnień od opodatkowania z tytułu przychodów z działalności niegospodarczej są niespójne z obowiązującym art. 13 ust. 2 ustawy o gwarancjach wolności sumienia i wyznania, który nie jest objęty zmianami przewidzianymi w projekcie. W efekcie należy uznać za bezskuteczne usunięcie 
z systemu art. 55 ustawy o stosunku Państwa do Kościoła Katolickiego w Rzeczypospolitej Polskiej i art. 40 ust. 2 ustawy o stosunku Państwa do Polskiego Autokefalicznego Kościoła Prawosławnego.

\section{Bibliografia}

Borecki B., Artykuł 25 ust. 5 Konstytucji RP a ustawa o gwarancjach wolności sumienia i wyznania [w:] Układowe formy regulacji stosunków między państwem a związkami wyznaniowymi (art. 25 ust. 4-5 Konstytucji RP), red. P. Stanisz, M. Ordon, Lublin 2013.

Garlicki L., Komentarz do art. 25 [w:] Konstytucja Rzeczypospolitej Polskiej. Komentarz, t. V, red. L. Garlicki, Warszawa 2005.

Krukowski J., Konkordat polski. Znaczenie i realizacja, Lublin 1999.

Kurczewska K., Ocena skutków regulacji zawartych w poselskim projekcie ustawy o jawności przychodów kościołów i związków wyznaniowych oraz zniesieniu ich przywilejów finansowych, BAS-WASiE-1419/20, niepubl.

Odrowąż-Sypniewski W., Opinia prawna w sprawie potrzeby przeprowadzenia konsultacji $z$ kościołami i związkami wyznaniowymi projektu ustawy o Komisji prawdy i zadośćuczynienia w sprawach związanych z zachowaniami o charakterze pedofilskim osób duchownych (przedstawiciel wnioskodawców poseł Joanna Scheuring-Wielgus), BAS-WAP-1864/20, niepubl.

Walencik D., Zakres przedmiotowy umowy z art. 25 ust. 5 Konstytucji RP [w:] Układowe formy regulacji stosunków między państwem a związkami wyznaniowymi (art. 25 ust. 4-5 Konstytucji RP), red. P. Stanisz, M. Ordon, Lublin 2013.

Witkowski Z., Opinia w sprawie zagadnień prawnych wynikających $z$ art. 25 ust. 5 Konstytucji $R P$, „Przegląd Legislacyjny” 2000, nr 2. 


\title{
Dopuszczalność drogi sądowoadministracyjnej od orzeczeń Komisji Regulacyjnej ds. Polskiego Autokefalicznego Kościoła Prawosławnego ${ }^{1}$
}

\author{
Admissibility of initiating the judicial-administrative procedure against \\ the decisions of the Regulatory Commission of the Polish Autocephalous \\ Orthodox Church
}

\begin{abstract}
The article contains a historical and legal outline, taking into account the evolution of the jurisprudence of the Constitutional Tribunal and the Supreme Administrative Court. The admissibility of initiating the judicial-administrative procedure against the decisions of the Regulatory Commission of the Polish Autocephalous Orthodox Church is closely related to the judgments of these bodies. The author concluded that, in accordance with the provisions of the Act on the State's Relationship to the Polish Autocephalous Orthodox Church, the ruling of the Regulatory Committee should be recognized as an administrative decision issued in a single-instance procedure. Such a decision is a final one, against which a party has the right to lodge a complaint to a voivodeship (i.e. provincial) administrative court.
\end{abstract}

Keywords: public administration, church, Supreme Administrative Court, Constitutional Tribunal, administrative proceedings

\footnotetext{
Artykuł zawiera rys historyczny i prawny, uwzględniający ewolucję orzecznictwa Trybunału Konstytucyjnego i Naczelnego Sądu Administracyjnego. Dopuszczalność drogi sądowoadministracyjnej od orzeczeń Komisji Regulacyjnej Polskiego Autokefalicznego Kościoła Prawosławnego jest ściśle związana z wyrokami tych organów. Autor uznał, że zgodnie z przepisami ustawy o stosunku Państwa do Polskiego Autokefalicznego Kościoła Prawosławnego, orzeczenie Komisji Regulacyjnej należy zaliczyć do decyzji administracyjnych, wydawanych w postępowaniu jednoinstancyjnym. Taka decyzja jest decyzją ostateczną, od której stronie przysługuje prawo wniesienia skargi do wojewódzkiego sądu administracyjnego.
}

Słowa kluczowe: administracja publiczna, kościół, Naczelny Sąd Administracyjny, Trybunał Konstytucyjny, postępowanie administracyjne

Doktor hab. nauk prawnych, profesor UW .

Uniwersytet Warszawski, Wydział Prawa i Administracji, Zakład Historii Administracji, Pracownia Prawa Polskiego XX wieku, WARSZAWA, POLSKA -

robert.jastrzebski@sejm.gov.pl . https://orcid.org/0000-0002-7265-0614

$1 \quad$ Opinia prawna na temat dopuszczalności drogi sadowoadministracyjnej od orzeczeń Komisji Regulacyjnej Polskiego Autokefalicznego Kościoła Prawosławnego sporządzona 27 kwietnia 2020 r. na zlecenie posła Klubu Parlamentarnego Koalicja Obywatelska Platforma Obywatelska, Nowoczesna, Inicjatywa Polska, Zieloni; BAS-WAP-667/20. 


\section{Przedmiot opinii}

Przedmiotem opinii jest zagadnienie prawne dotyczące dopuszczalności drogi sądowoadministracyjnej od orzeczeń Komisji Regulacyjnej ds. Polskiego Autokefalicznego Kościoła Prawosławnego w związku z treścią art. 48a ust. 12 ustawy z 4 lipca 1991 r. o stosunku Państwa do Polskiego Autokefalicznego Kościoła Prawosławnego (tj. Dz.U. 2014, poz. 1726; dalej: ustawa o stosunku Państwa do Polskiego Autokefalicznego Kościoła Prawosławnego).

\section{Uzasadnienie prawne}

Na wstępie należy zaznaczyć, że kwestie restytucji mienia należącego do poszczególnych kościołów oraz wyznań, w tym Polskiego Autokefalicznego Kościoła Prawosławnego, miały miejsce zarówno przed drugą wojną światową, jak i po niej². W szczególności wpływ na współczesne rozwiązania prawne miał okres po 1989 r., czyli już od rozpoczęcia prac przygotowawczych nad projektem ustawy o stosunku państwa polskiego do Polskiego Autokefalicznego Kościoła Prawosławnego ${ }^{3}$. Tryb regulacyjny związany z powstaniem Komisji Regulacyjnej ds. Polskiego Autokefalicznego Kościoła Prawosławnego został wprowadzony w związku z nowelizacją ustawy z 26 czerwca 1997 r. o zmianie ustawy o gwarancjach wolności sumienia i wyznania oraz o zmianie niektórych ustaw (Dz.U. nr 59, poz. 375). Na podstawie art. 3 ustawy wprowadzono zmiany w ustawie o stosunku Państwa do Polskiego Autokefalicznego Kościoła Prawosławnego, do których należy m.in. zaliczyć dodanie do jej treści art. 48a-48e, czyli normujących funkcjonowanie Komisji Regulacyjnej ds. Polskiego Autokefalicznego Kościoła Prawosławnego. Komisja Regulacyjna była wzorowana na katolickiej Komisji Majątkowej ${ }^{4}$.

Warto podkreślić, że sprawa braku możliwości zaskarżania orzeczeń Komisji od samego początku jej powstania budziła wątpliwości natury prawnej. Podobnie rzecz miała się z innymi postępowaniami regulacyjnymi przewidzianymi

2 Zob. S. Kiryłowicz, Z dziejów prawosławia w II Rzeczypospolitej Polskiej. Niektóre problemy na tle polityki wyznaniowej państwa 1918-1939, Warszawa 1985, s. 21 i n.; W. Bendza, Regulacja kościelnych spraw majątkowych na przykładzie Kościoła prawosławnego w Polsce, Warszawa 2009, s. 22-49.

3 Szerzej zob. W. Bendza, Regulacja kościelnych spraw majątkowych, op. cit., s. 50 i n.

$4 \quad$ Szerzej zob. W. Bendza, Komisja Regulacyjna do Spraw Polskiego Autokefalicznego Kościoła Prawosławnego w świetle przepisów prawa i orzecznictwa, „Prawo i Religia” 2007, t. 1; D. Walencik, Postępowanie regulacyjne przed Komisja Regulacyjna do Spraw Polskiego Autokefalicznego Kościoła Prawosławnego, „Śląskie Studia Historyczno-Teologiczne" 2008, t. 41, z. 1; W. Bendza, Regulacja kościelnych spraw majątkowych, op. cit., s. $145-160$. 
w ustawach konfesyjnych, które dotyczyły poszczególnych kościołów lub wyznań. W szczególności wynikało to z brzmienia art. 45 ust. 1 Konstytucji Rzeczypospolitej Polskiej z 2 kwietnia 1997 r., zgodnie z którym każdy ma prawo do sprawiedliwego i jawnego rozpatrzenia sprawy bez nieuzasadnionej zwłoki przez właściwy, niezależny, bezstronny i niezawisły sąd ${ }^{5}$. Twierdzono explicite, że: „Pozbawienie orzeczeń Komisji jakiejkolwiek kontroli instancyjnej, a tym samym brak możliwości ich zaskarżenia stanowi niewątpliwie zagadnienie prawne budzące kontrowersje" . Ponadto zwracano uwagę na brak ochrony prawnej podmiotów nieuczestniczących w postępowaniu regulacyjnym ${ }^{7}$.

Zwracano przede wszystkim uwagę, że ustawy normujące działalność komisji regulacyjnych zostały uchwalone przed wejściem w życie Konstytucji z 2 kwietnia 1997 r., czyli w okresie obowiązywania Konstytucji Polskiej Rzeczypospolitej Ludowej z 22 lipca 1952 r. Podkreślano przy tym m.in., że komisje regulacyjne, mimo iż nie są organami władzy sądowniczej, to, zgodnie z przepisami ustaw wyznaniowych, ugody zawarte przed nimi oraz orzeczenia przez nie wydane miały moc sądowych tytułów egzekucyjnych, w tym te ugody i orzeczenia stanowiły podstawę do dokonywania wpisów w księgach wieczystych i ewidencji gruntów ${ }^{8}$. W szczególności krytykowano działalność Komisji Majątkowej ds. Kościoła Katolickiego9

Zagadnienie prawne dopuszczalności drogi sądowoadministracyjnej jest ściśle związane z treścią art. 48a ust. 12 ustawy o stosunku Państwa do Polskiego Autokefalicznego Kościoła Prawosławnego, zgodnie z którym od orzeczenia zespołu orzekającego nie przysługuje odwołanie. Przepis ten dotyczy postępowania regulacyjnego, które przeprowadza Komisja Regulacyjna ds. Polskiego Autokefalicznego Kościoła Prawosławnego. Działalność Komisji została unormowana w dziale IV Przepisy przejściowe i końcowe, rozdz. 1 Regulacja spraw majątkowych Kościoła (art. 46-50 ustawy o stosunku Państwa do Polskiego Autokefalicznego Kościoła Prawosławnego). Postępowanie regulacyjne jest wszczynane z chwilą złożenia wniosku w Komisji, a uczestnikami postępowania regulacyjnego są, oprócz wnioskodawcy, wszystkie zainteresowane jednostki państwowe, samorządowe i kościelne. Warto podkreślić, że ugody zawarte przed zespołem orzekającym jak i jego orzeczenia mają moc sądowych tytułów egzekucyjnych. Ponadto funkcjonowanie Komisji reguluje rozporządzenie Ministra Spraw We-

Zob. W. Bendza, Regulacja kościelnych spraw majątkowych, op. cit., s. 215 i n.

$6 \quad$ W. Bendza, Komisja Regulacyjna, op. cit., s. 95.

7 Zob. Z. Strus, Postępowanie regulacyjne a ochrona praw osób trzecich, „Przegląd Sądowy" 1998, nr 3; W. Bendza, Komisja Regulacyjna, op. cit., s. 95-100.

$8 \quad$ Zob. D. Walencik, Czy działalności komisji regulacyjnych jest niezgodna z Konstytucja Rzeczypospolitej Polskiej? [w:] Pro bono Reipublicae. Ksiega jubileuszowa Profesora Michała Pietrzaka, red. P. Borecki, A. Czohara, T.J. Zieliński, Warszawa 2009.

9 Zob. P. Borecki, Konstytucyjność wybranych regulacji spraw majątkowych Kościoła Katolickiego [w:] Pro bono Reipublicae. Ksiega jubileuszowa Profesora Michała Pietrzaka, red. P. Borecki, A. Czohara, T.J. Zieliński, Warszawa 2009. 
wnętrznych i Administracji z 14 maja 1999 r. w sprawie szczegółowego trybu postępowania Komisji Regulacyjnej do Spraw Polskiego Autokefalicznego Kościoła Prawosławnego (Dz.U. nr 45, poz. 456). Tak w bardzo dużym skrócie można scharakteryzować postępowanie regulacyjne, które ma charakter szczególny, związany z regulacją stosunków między państwem polskim a Polskim Autokefalicznym Kościołem Prawosławnym ${ }^{10}$. Należy dodać, że umieszczenie przez ustawodawcę regulacji z zakresu spraw majątkowych Kościoła w tzw. przepisach przejściowych i końcowych ustawy świadczy o ich wyjątkowym znaczeniu.

Ustawa o stosunku Państwa do Polskiego Autokefalicznego Kościoła Prawosławnego stanowi jedną z wielu ustaw normujących stosunki państwa polskiego ze związkami wyznaniowymi. Ustawy takie ukazały się w latach 90. i także normowały sprawy majątkowe tych wyznań. Wcześniej jednak te kwestie zostały określone w stosunku do Kościoła katolickiego, bo już w ustawie z 17 maja 1989 r. o stosunku Państwa do Kościoła Katolickiego w Rzeczypospolitej Polskiej (tj. Dz.U. 2018, poz. 380). Co istotne, rozwiązania przyjęte w tej ustawie były wzorem dla innych ustaw wyznaniowych, tzn. regulujących sprawy majątkowe między państwem polskim a innymi związkami wyznaniowym, w tym Polskim Autokefalicznym Kościołem Prawosławnym ${ }^{11}$.

W przedmiotowej sprawie chodzi o brzmienie już nieobowiązującego art. 63 ust. 8 ustawy z 17 maja 1989 r. o stosunku Państwa do Kościoła Katolickiego w Rzeczypospolitej Polskiej, zgodnie z którym od orzeczenia zespołu orzekającego nie przysługuje odwołanie. Nieobowiązywanie tego przepisu stwierdził Trybunał Konstytucyjny w wyroku z 8 czerwca 2011 r. (sygn. akt K 3/09, Dz.U. nr 129, poz. 748), zgodnie z którym „skoro ustawa zmieniająca z 16 grudnia 2010 r. wprost stanowi, że znosi się Komisję Majątkową, to znaczy, że przepisy dotyczące jej udziału w postępowaniu regulacyjnym nie będą miały zastosowania do jakiejkolwiek sytuacji w przyszłości” ${ }^{12}$. Według Trybunału Konstytucyjnego „również art. 63 ust. 8 ustawy o stosunku Państwa do Kościoła Katolickiego jest przepisem, który po wejściu w życie ustawy zmieniającej z 16 grudnia 2010 r. nie będzie mógł być zastosowany do przyszłych zdarzeń i stanów faktycznych. Skoro więc

10 Szerzej zob. P. Derdej, Status prawny Polskiego Autokefalicznego Kościoła Prawosławnego w III Rzeczypospolitej, Warszawa-Białystok 2005, s. 80-91; W. Bendza, Regulacja kościelnych spraw majątkowych, op. cit., s. 161 i n.; A. Kusztal, Główne Kościoły chrześcijańskie w Polsce wobec integracji Rzeczypospolitej Polskiej z Unią Europejska, Opole 2014, s. 152-153.

11 Zob. dział IV Przepisy przejściowe i końcowe rozdz. 1. Regulacja spraw majątkowych Kościoła art. 60-71 ustawy z 17 maja 1989 r. o stosunku Państwa do Kościoła Katolickiego w Rzeczypospolitej Polskiej, Dz.U. nr 29, poz. 154.

12 Chodzi o ustawę z 16 grudnia 2010 r. o zmianie ustawy o stosunku Państwa do Kościoła Katolickiego w Rzeczypospolitej Polskiej, Dz.U. nr 18, poz. 89; zgodnie z art. 1 został uchylony m.in. art. 63 ust. 8 oraz zgodnie $\mathrm{z}$ art. 2 ust. $1 \mathrm{z}$ dniem 1 marca $2011 \mathrm{r}$. została zniesiona Komisja Majątkowa. 
kończy działalność Komisja Majątkowa i ustawodawca znosi postępowanie regulacyjne, nie można mówić o obowiązywaniu art. 63 ust. 8 tejże ustawy. Dlatego Trybunał Konstytucyjny stwierdził, że regulacja ta utraciła moc obowiązującą w rozumieniu art. 39 ust. 1 pkt 3 ustawy o TK" (OTK-A ZU 2011, nr 5, poz. 39).

Postępowanie z zakresu zwrotu nieruchomości dotyczyło także innych kościołów oraz związków wyznaniowych, do których należy zaliczyć:

- Kościół ewangelicko-augsburski (ustawa z 13 maja 1994 r. o stosunku Państwa do Kościoła Ewangelicko-Augsburskiego w Rzeczypospolitej Polskiej, tj. 2015, poz. 43; rozdz. 5. Sprawy majątkowe, art. 40-45),

- Kościół ewangelicko-reformowany (ustawa z 13 maja 1994 r. o stosunku Państwa do Kościoła Ewangelicko-Reformowanego w Rzeczypospolitej Polskiej, tj. Dz.U. 2015, poz. 483; rozdz. 5. Przepisy przejściowe i końcowe, art. 23-27a),

- Kościół Adwentystów Dnia Siódmego (ustawa z 30 czerwca 1995 r. o stosunku Państwa do Kościoła Adwentystów Dnia Siódmego w Rzeczypospolitej Polskiej, tj. Dz.U. 2014, poz. 1889; rozdz. 5. Przepisy przejściowe i końcowe, art. 33a-35),

- Kościół polskokatolicki w Rzeczypospolitej Polskiej (ustawa z 30 czerwca 1995 r. o stosunku Państwa do Kościoła Polskokatolickiego w Rzeczypospolitej Polskiej, tj. Dz.U. 2014, poz. 1599; rozdz. 5. Przepisy przejściowe i końcowe, art. 33-35),

- Kościół ewangelicko-metodystyczny (ustawa z 30 czerwca 1995 r. o stosunku Państwa do Kościoła Ewangelicko-Metodystycznego w Rzeczypospolitej Polskiej, tj. Dz.U. 2014, poz. 1712; rozdz. 5. Przepisy przejściowe i końcowe, art. 35-40),

- Kościół Chrześcijan Baptystów (ustawa z 30 czerwca 1995 r. o stosunku Państwa do Kościoła Chrześcijan Baptystów w Rzeczypospolitej Polskiej, tj. Dz.U. 2015, poz. 169; rozdz. 5. Przepisy przejściowe i końcowe, art. 39-44),

- gminy wyznaniowe żydowskie (ustawa z 20 lutego 1997 r. o stosunku Państwa do gmin wyznaniowych żydowskich w Rzeczypospolitej Polskiej, tj. Dz.U. 2014, poz. 1798; rozdz. 5. Przepisy przejściowe i końcowe, art. 28-35) ${ }^{13}$,

- Kościół zielonoświątkowy (ustawa z 20 lutego 1997 r. o stosunku Państwa do Kościoła Zielonoświątkowego w Rzeczypospolitej Polskiej, tj. Dz.U. 2015, poz. 13; rozdz. 5. Przepisy przejściowe i końcowe, art. 35-37),

- Kościół katolicki mariawitów (ustawa z 20 lutego 1997 r. o stosunku Państwa do Kościoła Katolickiego Mariawitów w Rzeczypospolitej Polskiej, tj. Dz.U. 2015, poz. 44; rozdz. 5. Przepisy przejściowe i końcowe, art. 29-31),

- Starokatolicki Kościół Mariawitów (ustawa z 20 lutego 1997 r. o stosunku Państwa do Kościoła Starokatolickiego Mariawitów w Rzeczypospolitej Polskiej, tj. Dz.U. 2015, nr 14; rozdz. 5. Przepisy przejściowe i końcowe, art. 32-34).

13 Szerzej: D. Walencik, Status prawny gmin wyznaniowych żydowskich w Rzeczypospolitej Polskiej, „Prawo i Religia” 2011, t. 2. 
Takie samo brzmienie jak art. 48a ust. 12 ustawy o stosunku Państwa do Polskiego Autokefalicznego Kościoła Prawosławnego mają:

- art. 44 ust. 5 ustawy z 13 maja 1994 r. o stosunku Państwa do Kościoła Ewangelicko-Augsburskiego w Rzeczypospolitej Polskiej,

- art. 33 ust. 5 ustawy z 20 lutego 1997 r. o stosunku Państwa do gmin wyznaniowych żydowskich w Rzeczypospolitej Polskiej.

W obydwu zresztą przypadkach, na podstawie wymienionych wyżej ustaw, zostały powołane komisje regulacyjne. Ponadto na podstawie ustawy z 17 maja 1989 r. o gwarancjach wolności sumienia i wyznania (tj. Dz.U. 2017, poz. 1153), została utworzona Międzykościelna Komisja Regulacyjna (dział IIIa Regulacja spraw majątkowych niektórych kościołów; art. 38a-38g ustawy). Co istotne, art. 38d ust. 9 tej ustawy ma takie samo brzmienie jak art. 48a ust. 12 ustawy o stosunku Państwa do Polskiego Autokefalicznego Kościoła Prawosławnego. Wynika z tego, że ustawodawca zastosował na zasadzie argumentum a simili takie samo rozwiązanie w zakresie odwołania od orzeczenia zespołu orzekającego zarówno w przypadku ustawy o stosunku Państwa do Polskiego Autokefalicznego Kościoła Prawosławnego jak i niektórych innych kościołów oraz wyznań.

Istotne znaczenie w przedmiotowej sprawie miało i ma orzecznictwo Naczelnego Sądu Administracyjnego (dalej: NSA) oraz Trybunału Konstytucyjnego (dalej: Trybunał lub TK), które przeszło daleko idącą ewolucję. NSA w postanowieniu z 26 września 1991 r. (sygn. akt I SA 768/91) stwierdził, że: „[k]omisja Majątkowa, działająca na podstawie ustawy z 17 maja 1989 r. o stosunku Państwa do Kościoła Katolickiego w Rzeczypospolitej Polskiej (Dz. U. Nr 29, poz. 154) nie jest organem administracji państwowej (ani samorządowej) w rozumieniu art. $1 \$ 1$ pkt 1 k.p.a. [Kodeksu postępowania administracyjnego - dopisek R.J.] ani innym organem powołanym $\mathrm{z}$ mocy prawa do załatwiania spraw ze sfery administracji państwowej na zasadzie art. $1 \$ 2$ k.p.a.”, a „orzeczenie Komisji Majątkowej nie ma cech decyzji administracyjnej i nie jest na nie dopuszczalna skarga do Naczelnego Sądu Administracyjnego" "14. Z kolej w wyroku z 20 grudnia 2007 r. (sygn. akt II OSK 1570/06) NSA stwierdził, że: „[o]rzeczenie Komisji Regulacyjnej do Spraw Gmin Wyznaniowych Żydowskich wydane na podstawie art. 33 ust. 2 i 3 ustawy z dnia 20 lutego 1997 r. o stosunkach Państwa do gmin wyznaniowych żydowskich w Rzeczypospolitej Polskiej (Dz. U. Nr 41, poz. 251 ze zm.) nie jest decyzją administracyjną wydaną przez «inny podmiot» w rozumieniu art. 1 lit. 2 k.p.a. i nie można zaskarżyć go do sądu administracyjnego" (CBOSA). Co istotne, NSA uznał, że „[p]odstawowym założeniem zawartych w tych ustawach uregulowań prawnych jest obowiązek poszukiwania w sferze stosunków z kościołami i związkami wyznaniowymi rozwiązań o charakterze konsensualnym”.

Jednocześnie NSA zwrócił uwagę na dwa wcześniejsze orzeczenia TK, tj. uchwałę z 24 czerwca 1992 r. (sygn. akt W 11/91, OTK ZU 1992, poz. 18) oraz

14 Zawarte w: Centralna Baza Orzeczeń Sądów Administracyjnych; dalej: CBOSA. 
wyrok z 2 kwietnia 2003 r. (sygn. akt K 13/02, OTK-A ZU 2003, poz. 28). Uchwała Trybunału dotyczyła wykładni art. 61 ustawy z 17 maja 1989 r. o stosunku Państwa do Kościoła Katolickiego w Rzeczypospolitej Polskiej. W uzasadnieniu do uchwały TK uznał, że postępowanie regulacyjne przed Komisją Majątkową zastępuje postępowanie sądowe lub administracyjne i przypomina w pewnym stopniu postępowanie polubowne, w którym jest rozpatrywane roszczenie quasi-windykacyjne. Do podobnych wniosków doszedł Trybunał w wyroku z 2 kwietnia 2003 r., który dotyczył ustawy o stosunku Państwa do Polskiego Autokefalicznego Kościoła Prawosławnego. W uzasadnieniu do tego wyroku TK uznał m.in., że sporne kwestie majątkowe między państwem polskim a kościołami i związkami wyznaniowymi miały być rozstrzygane w postępowaniach regulacyjnych, prowadzonych przez specjalne komisje regulacyjne (majątkowe).

W kolejnym orzeczeniu, tj. wyroku z 20 grudnia 2007 r. (sygn. akt II OSK 1570/06), NSA stwierdził, że: „[o]rzeczenie Komisji Regulacyjnej do Spraw Gmin Wyznaniowych Żydowskich, wydane na podstawie art. 33 ust. 2 i 3 ustawy z dnia 20 lutego 1997 r. o stosunku Państwa do gmin wyznaniowych żydowskich w Rzeczypospolitej Polskiej (Dz. U. Nr 41, poz. 251 ze zm.), nie jest decyzją administracyjną wydaną przez «inny podmiot» w rozumieniu art. 1 pkt 2 k.p.a. i nie można zaskarżyć go do sądu administracyjnego" (CBOSA). Do wyroku NSA została sporządzona glosa, której autor zgodził się z cytowaną wyżej in extenso sentencją, zwracając przy tym uwagę, iż utrwaliło się w ten sposób stanowisko w orzecznictwie TK i NSA, dodając jednocześnie, że „[ż]adna z ustaw indywidualnych regulujących prawne położenie kościołów i innych związków wyznaniowych w Polsce w zakresie postępowania regulacyjnego nie przewiduje, że są to sprawy z kategorii sądowoadministracyjnych, a więc nie można domniemywać, że będą podlegać jurysdykcji sądów administracyjnych"15.

W związku z tym Andrzej Czohara uznał, że brak instancyjności postępowania określony w art. 33 ust. 5 ustawy z 20 lutego 1997 r. o stosunku Państwa do gmin wyznaniowych żydowskich w Rzeczypospolitej Polskiej w praktyce „wykluczył możliwość odwołania od orzeczenia, nie przewidując drugiej, odwoławczej instancji postępowania regulacyjnego, która jest obowiązującą normą w sprawach prowadzonych na drodze na przykład postępowania administracyjnego czy postępowania sądowego”, zaś „rozwiązanie to, znamionujące «siłę» władztwa publicznoprawnego Komisji polegającą na prawie do wydawania ostatecznych orzeczeń o przeniesieniu własności Skarbu Państwa lub jednostek samorządu terytorialnego na rzecz wnioskodawcy, zostało wprowadzone w komentowanej ustawie - tak jak w innych ustawach wyznaniowych - w ślad za regulacją zastosowaną w ustawie o stosunku Państwa do Kościoła Katolickiego”. Autor ten zwrócił też uwagę na brzmienie art. 77 ust. 2 Konstytucji, zgodnie z którym ustawa nie

15 Zob. Z. Zarzycki, Glosa do wyroku Naczelnego Sądu Administracyjnego z dnia 20 grudnia 2007 r., „Przegląd Sejmowy” 2009, nr 5, s. 215-220. 
może nikomu zamykać drogi sądowej dochodzenia naruszonych wolności lub praw, oraz art. 45 ust. 1, który stanowi, że „[k]ażdy ma prawo do sprawiedliwego i jawnego rozpatrzenia sprawy [...] przez właściwy, niezależny, bezstronny i niezawisły sąd" 16 .

W tym stanie prawnym, który został w praktyce ukształtowany przez orzecznictwo TK i NSA, regulacja spraw majątkowych związków wyznaniowych charakteryzowała się m.in. tym, że: postępowanie przed komisjami regulacyjnymi zastępowało postępowanie sądowe; postępowanie regulacyjne miało charakter polubowny (ugodowy); zapadłe w tym postępowaniu orzeczenia lub zawarta ugoda miały moc prawną wyroku sądowego lub ugody sądowej; od orzeczeń komisji regulacyjnych (ich zespołów) nie przysługiwało odwołanie ${ }^{17}$.

Kluczowe znaczenie w przedmiotowej sprawie ma zmiana stanu prawnego, która jest wynikiem wyroku TK z 13 marca 2013 r. oraz późniejsze orzecznictwo sądów administracyjnych, oparte właśnie na orzeczeniu TK. Warto zaznaczyć, że orzeczenie to zostało wydane w pełnym składzie Trybunału przy sześciu zdaniach odrębnych (sygn. akt K 25/10; OTK ZU 2013, poz. 27; Dz.U. poz. 432) ${ }^{18}$.

Zanim jednak zostanie dokonana szczegółowa analiza orzeczenia TK, należy prześledzić chronologicznie ewolucję orzecznictwa, w szczególności NSA po wejściu w życie ustaw z 2002 r. reformujących sądownictwo administracyjne, tj. wprowadzeniu wojewódzkich sądów administracyjnych. W związku z tym Wojewódzki Sąd Administracyjny w Warszawie zajął stanowisko, że skoro Komisja Majątkowa nie jest organem administracji publicznej, a wydawane przez nią orzeczenia nie są decyzjami administracyjnymi ani innymi aktami administracyjnymi z zakresu administracji publicznej, to wniesiona skarga jest niedopuszczalna i podlega odrzuceniu ${ }^{19}$.

Następnie NSA postanowieniem z 26 listopada 2008 r. (sygn. akt II OSK 687/07; CBOSA) uznał, że zagadnienie to budzi poważne wątpliwości prawne i przekazał sprawę do rozstrzygnięcia składowi siedmiu sędziów NSA. Z kolei NSA, w składzie siedmiu sędziów, postanowieniem z 9 marca 2009 r. (sygn. akt II OPS $1 / 08)^{20}$ zawiesił postępowanie, w związku ze złożonym wnioskiem do TK, od którego orzeczenia zależało rozstrzygnięcie w przedmiotowej sprawie.

16 A. Czohara, T.J. Zieliński, Ustawa o stosunku państwa do gmin wyznaniowych żydowskich w Polsce. Komentarz, Warszawa 2012, s. 250-251.

17 Zob. D. Walencik, Czy działalności komisji regulacyjnych, op. cit., s. 497-498.

18 A. Krzywoń, Status jednostek samorzadu terytorialnego w ramach tzw. postępowań regulacyjnych. Glosa do wyroku TK z dnia 13 marca 2013 r., K 25/10, „Gdańskie Studia Prawnicze" 2013, nr 4, s. 21-30.

19 Zob. postanowienia WSA w Warszawie z: 23 stycznia 2007 r., sygn. akt I SA/Wa 65/07; 23 stycznia 2007 r., sygn. akt I SA/Wa 66/07; 14 sierpnia 2008 r., sygn. akt I SA/Wa 895/08; CBOSA.

20 Zob. także postanowienia NSA z: 15 listopada 2011 r.; 25 listopada 2013 r.; 3 kwietnia 2017 r.; CBOSA. 
W związku z tym TK wydał wyrok 13 marca 2013 r. ( sygn. akt K 25/10), który dotyczył m.in. art. 33 ust. 5 oraz art. 33 ust. 2 ustawy z 20 lutego 1997 r. o stosunku Państwa do gmin wyznaniowych żydowskich w Rzeczypospolitej Polskiej. Pierwszy przepis odpowiada art. 48a ust. 12 ustawy o stosunku Państwa do Polskiego Autokefalicznego Kościoła Prawosławnego, czyli obydwa przepisy mają takie samo brzmienie, tj. „Od orzeczenia zespołu orzekającego nie przysługuje odwołanie”. Drugi zaś odpowiada art. 48a ust. 9 oraz art. 48b ust. 1 ustawy o stosunku Państwa do Polskiego Autokefalicznego Kościoła Prawosławnego. Artykuł 33 ust. 2 ustawy z 20 lutego 1997 r. o stosunku Państwa do gmin wyznaniowych żydowskich w Rzeczypospolitej Polskiej brzmi: „Uczestnicy postępowania mogą zawrzeć ugodę przed zespołem orzekającym. Jeżeli ugoda nie została zawarta, zespół wydaje orzeczenie. Ugody i orzeczenia mają moc sądowych tytułów egzekucyjnych”. Odpowiadające mu przepisy, tj. art. 48a ust. 9 oraz art. 48b ust. 1, mają odpowiednio następujące brzmienie: „Uczestnicy postępowania regulacyjnego mogą zawrzeć ugodę przed zespołem orzekającym. Jeżeli ugoda nie została zawarta, zespół orzekający wydaje orzeczenie” oraz „Ugody i orzeczenia mają moc sądowych tytułów egzekucyjnych”.

W ten sposób na zasadzie argumentum a simili należy stwierdzić, że TK odniósł się do wszystkich postępowań regulacyjnych, w tym do art. 48a ust. 12 ustawy o stosunku Państwa do Polskiego Autokefalicznego Kościoła Prawosławnego, który w poprzednim stanie prawnym, utrwalonym przez orzecznictwo TK oraz NSA, wykluczał możliwość złożenia jakichkolwiek środków prawnych w stosunku do orzeczeń komisji regulacyjnych. Upraszczając, należy stwierdzić, że w przedmiotowej sprawie, zgodnie z sentencją wyroku TK z 13 marca 2013 r., art. 33 ust. 5 nie wyłącza innych niż odwołanie środków prawnych od orzeczenia Komisji Regulacyjnej.

W uzasadnieniu TK zwrócił uwagę, że dotychczasowe orzecznictwo sądów administracyjnych, czyli postanowienia odrzucające skargi na orzeczenia komisji regulacyjnych, zostało oparte na wymienionym wyżej postanowieniu NSA z 26 września 1991 r. (sygn. akt I SA 768/91). Rekapitulując jego treść:

- Komisja Majątkowa nie jest organem administracji państwowej ani samorządowej w rozumieniu Kodeksu postępowania administracyjnego, ani innym organem powołanym z mocy prawa do załatwienia spraw ze sfery administracji państwowej albo samorządowej,

- orzeczenie Komisji Majątkowej nie ma cech decyzji administracyjnej,

- od orzeczenia Komisji Majątkowej nie jest dopuszczalna skarga do NSA.

Trybunał Konstytucyjny zwrócił uwagę, że orzeczenia wojewódzkich sądów administracyjnych dotyczyły skarg na orzeczenia Komisji Majątkowej utworzonej na podstawie ustawy z 17 maja 1989 r. o stosunku Państwa do Kościoła Katolickiego w Rzeczypospolitej Polskiej, przy czym ze względu na zbliżone regulacje, w tym podobieństwo procedur, judykatura ta wpływa na Komisję Regulacyjną, której funkcjonowanie reguluje ustawa z 20 lutego 1997 r. o stosunku Państwa 
do gmin wyznaniowych żydowskich w Rzeczypospolitej Polskiej. Ponadto TK zaznaczył, że „orzeczenie Komisji nie jest orzeczeniem sądu powszechnego, gdyż Komisja nie jest organem władzy sądowniczej”, a „jej kognicja została określona w szczególny sposób”. Działalność Komisji, która polega na wydawaniu orzeczeń, według TK, „stanowi przejaw szeroko pojętej działalności administracji publicznej”. Władztwo administracyjne (imperium) bowiem może być również wykonywane przez inne organy i instytucje niepaństwowe, którym państwo właśnie przekazało do realizacji pewien zakres władztwa administracyjnego, co do określonej kategorii spraw.

Według TK stanowisko zajęte w uchwale z 24 czerwca 1992 r. (sygn. akt W 11/91) dotyczyło mediacyjno-polubownego charakteru postępowania regulacyjnego i, co za tym idzie, wymaga modyfikacji. Nie dotyczyło bowiem ono sytuacji, gdy nie zawarto ugody przed zespołem orzekającym i konieczne jest wydanie orzeczenia przez Komisję. Wówczas Komisja rozstrzyga spór między uczestnikami postępowania w sprawie zwrotu określonej nieruchomości, przyznania nieruchomości zamiennej lub wypłaty odszkodowania. Wynika z tego, że działalność Komisji Regulacyjnej stanowi przejaw szeroko rozumianej działalności administracji publicznej. Komisja zaś rozstrzyga jednostronnie i władczo o sytuacji prawnej indywidualnych podmiotów, które znajdują się poza Komisją oraz strukturą administracji rządowej. W ten sposób orzeczenie Komisji Regulacyjnej ma cechy zewnętrznego aktu administracyjnego, który jest wydawany $\mathrm{w}$ trybie postępowania administracyjnego, postępowanie regulacyjne zaś, które prowadzi do wydania orzeczenia przez zespół orzekający, stanowi postępowanie administracyjne, co wynika $\mathrm{z}$ art. 1 k.p.a. Zgodnie bowiem z tym artykułem Kodeks postępowania administracyjnego reguluje nie tylko postępowanie przed organami administracji publicznej, które należą do właściwości tych organów w sprawach indywidualnych, rozstrzyganych w drodze decyzji administracyjnych, ale także przed innymi organami państwowymi oraz „innymi podmiotami”, jeśli są one powołane ex lege lub na podstawie porozumień do załatwiania spraw indywidualnych rozstrzyganych w drodze decyzji administracyjnej. Co istotne, Trybunał nie przesądził ostatecznie tego, czy załatwiane przez Komisję sprawy mają charakter decyzji administracyjnej czy też rozstrzygnięć o cechach aktu administracyjnego sensu largo. W związku z tym, zdaniem TK, niezależnie od ostatecznej oceny orzeczenia Komisji Regulacyjnej, postępowanie regulacyjne przed Komisją jest procedurą administracyjną o znacznym stopniu autonomiczności, przy czym przepisy ogólnego postępowania administracyjnego są stosowane jeśli nie wprost, to odpowiednio.

Trybunał Konstytucyjny odniósł się również do terminu „odwołanie”, który znajduje się w art. 33 ust. 5 ustawy z 20 lutego 1997 r. o stosunku Państwa do gmin wyznaniowych żydowskich w Rzeczypospolitej Polskiej. Odwołanie od decyzji administracyjnej, zdaniem TK, jest rozpoznawane przez właściwy organ administracji publicznej i stanowi środek zaskarżenia o charakterze dewolutyw- 
nym. TK jednak zwrócił uwagę, że termin „odwołanie” oznacza także środek prawny rozpoznawany przez sąd powszechny od decyzji określonego organu i występuje w określonych aktach normatywnych.

W związku z tym sformułowanie „od orzeczenia zespołu orzekającego nie przysługuje odwołanie" oznacza, że postępowanie regulacyjne ma charakter jednoinstancyjny, co nie wyklucza stosowania innych środków zaskarżenia, które wynikają z procedury administracyjnej, np. złożenia do Komisji wniosku o wznowienie postępowania czy stwierdzenie nieważności orzeczenia. Według TK ustawodawca nie wykluczył w art. 33 ust. 5 ustawy z 20 lutego 1997 r. o stosunku Państwa do gmin wyznaniowych żydowskich w Rzeczypospolitej Polskiej dopuszczalności sądowej kontroli zgodności z prawem wydanego orzeczenia Komisji Regulacyjnej, a treść tego artykułu dopuszcza taką kontrolę. Ustawodawca bowiem „zdecydował się wyłączyć jedynie odwołanie, argument a contrario przemawia $\mathrm{w}$ tym wypadku za przyjęciem dopuszczalności sądowoadministracyjnej kontroli wydawanych orzeczeń”. W ten sposób, zdaniem TK, „Jednoinstancyjność określonego postępowania przed pozasądowymi organami władzy publicznej nie jest w żadnym wypadku przeszkodą w dochodzeniu praw na drodze sądowej i nie wyklucza możliwości kwestionowania zgodności wydanego orzeczenia z prawem w postępowaniu sądowoadministracyjnymi".

Wynika z tego, że orzeczenie Komisji stanowi przejaw szeroko rozumianej działalności administracji publicznej i podlega kontroli sądów administracyjnych. Uprawnionym zaś do wniesienia skargi, według TK, jest każdy, kto ma $\mathrm{w}$ tym interes prawny, a więc uczestnicy postępowania regulacyjnego oraz każda osoba trzecia, której interes prawny został naruszony orzeczeniem Komisji.

Trybunał Konstytucyjny odniósł się także do wcześniejszego orzecznictwa NSA, stwierdzając, że sąd administracyjny w szczególności w postanowieniu z 26 września 1991 r. (sygn. akt I SA 768/91) i w wyroku z 20 grudnia 2007 r. (sygn. akt II OSK 1570/06) nie wyjaśnił, dlaczego działalność Komisji Regulacyjnej nie stanowi przejawu „działalności administracji publicznej” oraz jej orzeczenie nie ma cech decyzji administracyjnej i nie jest na nie dopuszczalna skarga do NSA. Jednocześnie TK podkreślił, że w dniu 17 października 1997 r. weszła w życie Konstytucja Rzeczypospolitej Polskiej i uległ zmianie „kontekst normatywny badanych przepisów", w szczególności chodzi o art. 45 ust. 1 Konstytucji, zgodnie z którym każdy ma prawo do rozpatrzenia sprawy przez sąd, oraz art. 77 ust. 2 Konstytucji, który stanowi, że ustawa nie może nikomu zamykać sądowej drogi dochodzenia naruszanych wolności lub praw. Ponadto, zgodnie z art. 184 Konstytucji, NSA oraz inne sądy administracyjne sprawują, w zakresie określonym w ustawie, kontrolę działalności administracji publicznej. W związku z tym z dniem wejścia w życie Konstytucji nastąpiły zmiany w systemie prawnym, które polegają nie tylko na wprowadzeniu określonych norm konstytucyjnych, ale również „na zmianie treści norm wyprowadzanych z przepisów ustawowych w związku z obowiązkiem interpretacji obowiązujących ustaw w zgodzie z Konstytucją”. 
Ostatecznie Trybunał Konstytucyjnych uznał, że orzeczenie zespołu orzekającego w ramach Komisji Regulacyjnej stanowi rozstrzygnięcie sprawy spornej między uczestnikami postępowania regulacyjnego. Orzeczenie to ma zaś cechę jednostronnego władczego rozstrzygnięcia w sferze praw majątkowych, a „władcze kształtowanie sytuacji prawnej innych podmiotów oznacza wykonywanie określonych kompetencji z zakresu władztwa administracyjnego". W ten sposób wydawanie orzeczeń przez zespół orzekający Komisji Regulacyjnej stanowi, zdaniem TK, przejaw szeroko pojętej działalności administracji publicznej i do jej działalności mają zastosowanie ogólne regulacje prawa administracyjnego. W związku z tym termin „odwołanie” użyty w treści art. 33 ust. 5 ustawy z 20 lutego 1997 r. o stosunku Państwa do gmin wyznaniowych żydowskich w Rzeczypospolitej Polskiej należy uznać za zwykły środek odwoławczy w toku procedury administracyjnej, a postępowanie regulacyjne zaś za jednoinstancyjne. Jednocześnie nie oznacza to, że została zamknięta droga sądowa w zakresie kontroli zgodności orzeczeń Komisji z prawem.

Wyrok Trybunału, po jego opublikowaniu, tj. od 11 kwietnia 2013 r., w ocenie wyrażonej w licznych orzeczeniach sądów administracyjnych przesądził o możliwości wniesienia skarg na orzeczenia komisji regulacyjnych. W ten sposób od daty opublikowania wyroku TK została otwarta droga do zaskarżania orzeczeń Komisji do sądu ${ }^{21}$.

Na ten temat wypowiedział się również NSA, przy czym istotne znacznie miał wyrok NSA z 28 kwietnia 2017 r. (sygn. akt II OSK 2099/15; CBOSA). W treści jego uzasadnienia NSA stwierdził, że utrwalony w dotychczasowym orzecznictwie sądów administracyjnych pogląd, iż orzeczenia Komisji Regulacyjnej ds. Gmin Wyznaniowych Żydowskich, podobnie zresztą jak orzeczenia Komisji Majątkowej, działającej na podstawie ustawy z 17 maja 1989 r. o stosunku Państwa do Kościoła Katolickiego w Rzeczypospolitej Polskiej, nie są decyzjami administracyjnymi wydanymi przez „inny podmiot” ani innymi aktami z zakresu administracji publicznej i nie można ich zaskarżyć do sądu administracyjnego, stracił obecnie na aktualności i wymaga weryfikacji po wyroku interpretacyjnym TK z 13 marca 2013 r. W związku z tym NSA uznał, że orzeczenie Komisji należy

21 Zob. np. postanowienia WSA w Warszawie z: 17 stycznia 2018 r., sygn. akt I SA/Wa 2057/17; 18 stycznia 2018 r., sygn. akt I SA/Wa 1067/17; 23 stycznia 2018 r., sygn. akt I SA/Wa 2055/17; 31 stycznia 2018 r., sygn. akt I SA/Wa 2062/17; 7 lutego 2018 r., sygn. akt I SA/Wa 2063/17; 7 marca 2018 r., sygn. akt I SA/Wa 2054/17; 23 lipca 2018 r., sygn. akt I SA/Wa 2060/17; 24 lipca 2018 r., sygn. akt I SA/Wa 2057/17; 30 lipca 2018 r., sygn. akt I SA/Wa 2089/17; 1 sierpnia 2018 r., sygn. akt I SA/Wa 2065/17; 8 sierpnia 2018 r., sygn. akt I SA/Wa 2053/17; 20 sierpnia 2018 r., sygn. akt I SA/Wa 1067/17; 30 sierpnia 2018 r., sygn. akt I SA/Wa 2063/17; 31 sierpnia 2018 r., sygn. akt I SA/Wa 2175/17; 31 sierpnia 2018 r., sygn. akt I SA/Wa 2061/17; 11 września 2018 r., sygn. akt I SA/Wa 2055/17; 27 września 2018 r., sygn. akt I SA/Wa 2056/17; 23 listopada 2018 r., sygn. akt I SA/Wa 1972/18; CBOSA. 
zaliczyć do decyzji administracyjnych, wydawanych w postępowaniu jednoinstancyjnym. Taka decyzja jest, w ocenie NSA, decyzją ostateczną, od której przysługuje stronie prawo wniesienia skargi do sądu administracyjnego.

Pogląd ten NSA prezentował w wielu innych orzeczeniach, które dotyczyły orzeczeń Komisji Regulacyjnej ds. Gmin Wyznaniowych Żydowskich, stwierdzając ponadto, że „prawo wniesienia skargi do wojewódzkiego sądu administracyjnego na decyzję administracyjną obwarowane jest zachowaniem ustawowego terminu do jej wniesienia"22. Warto zaznaczyć, że takie samo stanowisko zajął NSA w stosunku do orzeczenia Międzykościelnej Komisji Regulacyjnej, utworzonej na podstawie ustawy z 17 maja 1989 r. o gwarancjach wolności sumienia i wyznania ${ }^{23}$.

W przypadku Komisji Regulacyjnej ds. Polskiego Autokefalicznego Kościoła Prawosławnego sądy administracyjne przed wyrokiem TK z 13 marca 2013 r. uznawały brak drogi sądowoadministracyjnej ${ }^{24}$. Następnie uznały dopuszczalność drogi sądowoadministracyjnej od orzeczeń Komisji Regulacyjnej Polskiego Autokefalicznego Kościoła Prawosławnego. W praktyce zaś stosowały wykładnię argumentum a simili, jeśli chodzi o interpretację art. 48a ust. 12 ustawy o stosunku Państwa do Polskiego Autokefalicznego Kościoła Prawosławnego.

W postanowieniu z 17 listopada 2015 r. (sygn. akt II OSK 422/15; CBOSA) NSA porównał rozwiązania przyjęte $\mathrm{w}$ czterech ustawach wyznaniowych, tj. w ustawie z: 17 maja 1989 r. o gwarancjach wolności sumienia i wyznania; 17 maja 1989 r. o stosunku Państwa do Kościoła Katolickiego w Rzeczypospolitej Polskiej; 20 lutego 1997 r. o stosunku Państwa do gmin wyznaniowych żydowskich w Rzeczypospolitej Polskiej oraz 4 lipca 1991 r. o stosunku Państwa do Polskiego Autokefalicznego Kościoła Prawosławnego. NSA uznał, że „[r]ozwiązania dotyczące postępowań regulacyjnych zawarte w czterech ustawach dobitnie pokazują, że ustawodawca zastosował tożsamy model co do sposobu uregulowania spraw majątkowych poszczególnych kościołów i gmin wyznaniowych żydowskich. Ta tożsamość rozwiązań dotyczy zarówno komisji powołanych do przeprowadzenia postępowań regulacyjnych, jak i samego postępowania regulacyjnego oraz sposobów zakończenia tego postępowania” przy czym „[w] skazane rozwiązania ustawowe dotyczące postępowań regulacyjnych mają jeszcze jedną wspólną istotną cechę, mianowicie wszystkie wprowadzone zostały do porządku prawnego przed wejściem w życie Konstytucji RP z 2 kwietnia 1997 r. Powyższe okoliczności powodują, że orzeczenia Trybunału Konstytucyjnego dotyczące danego postępowania regulacyjnego wpływają na wykładnię i ocenę rozwiązań

22 Zob. postanowienia NSA z 15 maja 2018 r., sygn. akt II OZ 450/18, II OZ 451/18; 12 czerwca 2018 r., sygn. akt II OZ 599/18; 27 lipca 2018 r., sygn. akt II OZ 725/18; CBOSA.

23 Zob. postanowienie NSA z 26 lutego 2019 r., sygn. akt II OZ 51/19; CBOSA.

24 Zob. postanowienia WSA w Warszawie z: 22 marca 2006 r., sygn. akt I SA/Wa 1896/05; 16 kwietnia 2009 r., sygn. akt I SO/Wa 64/06; CBOSA. 
dotyczących innych postępowań regulacyjnych. Takim właśnie orzeczeniem jest wyrok Trybunału Konstytucyjnego z dnia 13 marca 2013 r. sygn. akt K 25/10". Takie samo stanowisko zajął Wojewódzki Sąd Administracyjny w Warszawie ${ }^{25}$.

Wynika z tego, że dopuszczalność drogi sądowoadministracyjnej od orzeczeń Komisji Regulacyjnej ds. Polskiego Autokefalicznego Kościoła Prawosławnego jest ściśle związana z wyrokiem TK z 13 marca 2013 r. (sygn. akt K 25/10) oraz wyrokiem NSA z 28 kwietnia 2017 r. (sygn. akt II OSK 2099/15). W związku z tym należy uznać, że de lege lata, zgodnie z art. 48a ust. 12 ustawy o stosunku Państwa do Polskiego Autokefalicznego Kościoła Prawosławnego, orzeczenie Komisji Regulacyjnej należy zaliczyć do decyzji administracyjnych, wydawanych w postępowaniu jednoinstancyjnym. Taka decyzja jest decyzją ostateczną, od której stronie przysługuje prawo wniesienia skargi do wojewódzkiego sądu administracyjnego.

\section{Bibliografia}

Bendza W., Komisja Regulacyjna do Spraw Polskiego Autokefalicznego Kościoła Prawosławnego w świetle przepisów prawa i orzecznictwa, „Prawo i Religia” 2007, t. 1.

Bendza W., Regulacja kościelnych spraw majątkowych na przykładzie Kościoła prawosławnego w Polsce, Warszawa 2009.

Borecki P., Konstytucyjność wybranych regulacji spraw majątkowych Kościoła Katolickiego [w:] Pro bono Reipublicae. Ksiega jubileuszowa Profesora Michała Pietrzaka, red. P. Borecki, A. Czohara, T.J. Zieliński, Warszawa 2009.

Czohara A., Zieliński T.J., Ustawa o stosunku państwa do gmin wyznaniowych żydowskich w Polsce. Komentarz, Warszawa 2012.

Derdej P., Status prawny Polskiego Autokefalicznego Kościoła Prawosławnego w III Rzeczypospolitej, Warszawa-Białystok 2005.

Kiryłowicz S., Z dziejów prawosławia w II Rzeczypospolitej Polskiej. Niektóre problemy na tle polityki wyznaniowej państwa 1918-1939, Warszawa 1985.

Krzywoń A., Status jednostek samorządu terytorialnego w ramach tzw. postępowań regulacyjnych. Glosa do wyroku TK z dnia 13 marca 2013 r., K 25/10, „Gdańskie Studia Prawnicze" 2013, nr 4.

Kusztal A., Główne Kościoły chrześcijańskie w Polsce wobec integracji Rzeczypospolitej Polskiej z Unia Europejska, Opole 2014.

Strus Z., Postępowanie regulacyjne a ochrona praw osób trzecich, „Przegląd Sądowy” 1998, nr 3.

Walencik D., Czy działalności komisji regulacyjnych jest niezgodna z Konstytucją Rzeczypospolitej Polskiej? [w:] Pro bono Reipublicae. Ksiega jubileuszowa Profesora Michała Pietrzaka, red. P. Borecki, A. Czohara, T.J. Zieliński, Warszawa 2009.

25 Wyrok WSA w Warszawie z 12 grudnia 2017 r., sygn. akt I SA/Wa 922/17; CBOSA. 
Walencik D., Postępowanie regulacyjne przed Komisja Regulacyjna do Spraw Polskiego Autokefalicznego Kościoła Prawosławnego, „Śląskie Studia Historyczno-Teologiczne” 2008, t. 41, z. 1.

Zarzycki Z., Glosa do wyroku Naczelnego Sąu Administracyjnego z dnia 20 grudnia 2007 r., „Przegląd Sejmowy” 2009, nr 5. 

2

OPINIE BAS

D

WSPÓŁPRACA

MIĘDZYNARODOWA

KANCELARII SEJMU 

Beata Bińkowska-Artowicz

\title{
Restitution of Cultural Heritage Goods ${ }^{1}$
}

\author{
Restytucja dóbr dziedzictwa kulturowego
}

In response to the ECPRD request, the Bureau of Research provided the requester with information on restitution of cultural heritage goods. According to the author, the return of cultural goods acquired from a foreign country during a war or colonization is regulated in the Polish Act on Restitution of National Cultural Goods, which governs the implementation of the Directive on the return of cultural objects unlawfully removed from the territory of a Member State. The Republic of Poland was requested by Germany to return certain cultural goods, confiscated after World War II. However these requests were turned down because the goods were acquired as a result of the change of state borders. Before the above-mentioned Act came into force, the Polish state had returned some cultural goods to other countries. The Polish Ministry of Culture and National Heritage has a special unit which deals with restitution of artworks and keeps the Catalogue of the War Losses - The Division for Looted Art.

Keywords: ECPRD, culture

\begin{abstract}
W odpowiedzi na pytanie ECPRD Biuro Analiz Sejmowych przedstawiło informacje odnośnie do restytucji dóbr kultury. Zdaniem autorki zwrot dóbr kultury objętych w posiadanie w obcym państwie w okresie wojny lub kolonizacji podlega regulacji w polskiej ustawie o restytucji narodowych dóbr kultury, która implementuje dyrektywę w sprawie zwrotu dóbr kultury wyprowadzonych niezgodnie z prawem z terytorium państwa członkowskiego. Niemcy żądały zwrotu od Polski określonych dóbr kultury, skonfiskowanych po drugiej wojnie światowej. Polska odmówiła zwrotu, ponieważ dobra te zostały nabyte w następstwie zmian granic państwowych. Przed wejściem w życie ustawy Rzeczpospolita Polska dokonała zwrotu pewnych dóbr kultury na rzecz innych państw. Polskie Ministerstwo Kultury i Dziedzictwa Narodowego posiada jednostkę zajmującą się restytucją dzieł sztuki i prowadzącą Katalog Strat Wojennych - jest to Wydział Restytucji Dóbr Kultury.
\end{abstract}

Słowa kluczowe: ECPRD, kultura

Doktor nauk prawnych, ekspert ds. legislacji Biura Analiz Sejmowych •

Kancelaria Sejmu, Biuro Analiz Sejmowych, Wydział Analiz Prawnych, Zespół Prawa

Publicznego, WARSZAWA, POLSKA .

beata.binkowska-artowicz@sejm.gov.pl • https://orcid.org/0000-0002-9172-5458

1 Extended version of information „ECPRD Request 4320, Restitution of cultural heritage goods" prepared on April 2, 2020 as part of cooperation in The European Centre for Parliamentary Research and Documentation (Europejskie Centrum Badań Parlamentarnych i Dokumentacji); BAS-WAP-406/20. 


\section{Is there a legal diploma on the return of cultural heritage goods originally from another country and taken in the case of war or colonization, currently included in your country's bibliographic, archival or museum collections?}

In the Republic of Poland the above-mentioned matter is regulated in Chapter 4 of the Act of $25^{\text {th }}$ May 2017 on Restitution of National Cultural Goods (consolidated text Journal of Laws [Dziennik Ustaw RP] 2019, item $1591^{2}$ ). This Act governs the implementation of the Directive 2014/60/EU of the European Parliament and of the Council of 15 May 2014 on the return of cultural objects unlawfully removed from the territory of a Member State and amending Regulation (EU) No 1024/2012.

The provisions of the above-mentioned chapter apply to the return of a cultural object which has been transferred from the territory of a foreign state to the territory of the Republic of Poland if its return (to the territory of a foreign state from which the cultural object has been transferred or to which it should be returned under an international agreement binding the Republic of Poland) is to take place on the basis of rules of international law (Article 42). The procedure for the return of the cultural good depends on whether it concerns the national cultural good of the Republic of Poland.

Namely, in the case of the national cultural good of the Republic of Poland its return occurs after the permission issued by the Minister of Culture and National Heritage or the Director of the National Library of Poland or the Chief Director of the National Archives (Article 43 section 1, section 2). The permission is issued only after the opinion of the Minister of Foreign Affairs has been obtained.

The permission cannot be issued if the return of a cultural good is not in accordance with the norms of international law or where it significantly prejudices the interest of the cultural heritage of the Republic of Poland (Article $43 \mathrm{sec}$ tion 3).

In the case of the cultural good that does not qualify as a national cultural good of the Republic of Poland, its return occurs after the opinion of the Minister of Foreign Affairs (Article 43 section 8) has been obtained.

In both above-mentioned cases the cultural good shall be handed over to a foreign country requesting its return by the Minister of Culture and National Heritage. The method of transfer shall be determined by the Minister of Culture and National Heritage in agreement with the foreign state requesting reimbursement (Article 44 section 1).

If the cultural good belongs to the State Treasury, the handing over of a cultural good to a foreign state transfers the ownership of that property to that state

2 Full text in Polish: http://isap.sejm.gov.pl/isap.nsf/download.xsp/WDU20190001591/ T/D20191591L.pdf. 
(Article 44 section 2). If the cultural good belongs to other persons (including legal persons who are public finance entities), the transfer of the ownership may take place after such persons have given their consent. The declaration of consent shall be made in writing with a notarized signature and shall be submitted to the Minister of Culture and National Heritage, who shall deliver it to the foreign state requesting reimbursement at the embassy of that state in the Republic of Poland (Article 44 section 3).

\section{Has your country ever received a request to return mobile cultural heritage (bibliographic, archival or museological)? If so, what was the response and guidance followed?}

Yes, the Republic of Poland received two requests from the German state.

The first request concerned the Prussian Library - the collections from the former Prussian State Library (including the Varnhagen Collection, the Music Collection and Libri picturati). The Prussian Library is considered part of the collection of the Jagiellonian University Library in Krakow as a deposit of the State Treasury.

The Federal Republic of Germany also made efforts to regain the 25 aeroplanes from the collection of Hermann Goering. The aeroplanes were confiscated by the Polish authorities after World War II. They are nowadays located in the Polish Aviation Museum in Krakow.

The Republic of Poland refused to return both collections. The reason given is the principle of territoriality, because the collections were found by the authorities on the Polish territory (the so-called abandoned property) as a result of the change of the country's borders after World War II, which Poland did not start.

Also note the decision of the European Court of Human Rights in the case of Frans Heuer v. Poland of 9 December 2008 (No 13410/07). The case concerned the restitution of the paintings located in the National Museum in Warsaw, the National Museum in Wroclaw and the Wawel Royal Castle. The ECHR rejected the plaint and acknowledged that the expropriation of German property after the war was final and covered all cultural goods of the Germans ${ }^{3}$.

In both cases (the Prussian Library and the collection of Hermann Goering) the so-called substitute restitution is also mentioned as a rule to be applied, but the formal settlement of the dispute concerning both cases did not occur.

3 Source only in Polish: P. Sobański, Sytuacja prawna dawnych niemieckich dóbr kultury wywłaszczonych po II wojnie światowej, e.Palestra, 2016, item. 37/A, 275-285. 


\section{Has your country already made itself available to return some mobile cultural heritage (bibliographic, archival or museological) to countries of origin? Can you report on how the process went?}

There is no publication on the official sites about such cases under the rule of the abovementioned Act of $25^{\text {th }}$ May 2017 on Restitution of National Cultural Goods.

Before this Act entered into force, in 2012 the Republic of Poland returned Latvian liturgical treasures (to Jelgava and Riga), and the painting Landscape at Ornans by Gustave Courbet to the heirs of Mór Lipót Herzog ${ }^{4}$.

\section{Has your country already made any request for the return of national cultural heritage goods removed during wars / revolutions?}

Yes, there is a special entity in the Ministry of Culture and National Heritage The Division for Looted Art, which deals with restitution of artworks (http://lootedart.gov.pl/en/artworks-recovered). There are 50 cases in progress and each of them is processed individually. Depending on the legal situation of a national heritage object and the attitude of the opposing party, the negotiations end with the unconditional return of the object or settlement. The overarching goal of these actions is to return the lost work of art to the country ${ }^{5}$.

The legal basis of the proceedings is Chapter 2 of the Act of $25^{\text {th }}$ May 2017 on Restitution of National Cultural Goods. According to Article 14 section 2, the provisions of this Chapter shall also apply in cases of the return from the territory of a Member State of the European Union of the national cultural good of the Republic of Poland brought out of the territory of the Republic of Poland by 31 December 1992, as well as other cultural goods, where the law of a Member State of the European Union provides in these cases for rules of conduct such as those for the national cultural good of the Republic of Poland.

If it is suspected that the national cultural good of the Republic of Poland, taken in violation of the law from the territory of the Republic of Poland, is located in the territory of a State of the European Union, the Minister of Culture and National Heritage shall immediately notify, through IMI system ${ }^{6}$, the Euro-

4 Source only in Polish: https://www.rp.pl/Literatura/311069949-Co-zrobic-ze-spadkiem-nazistow.html.

5 Source only in Polish: http://www.dzielautracone.gov.pl/faq.

6 The IMI system is a module of the electronic information exchange system, in the internal market, adapted to the domain of return of cultural goods derived in breach of the law from the territory of a European Union Member State, established by the Regulation (EU) No 1024/2012 of the European Parliament and of the Council of 25 October 2012 on administrative cooperation through the Internal Market Information 
pean Union Member State of the suspected removal, in violation of the law, of the national cultural good of the Republic of Poland, giving information enabling it to be identified (Article 15 section 1). The Minister of Culture and National Heritage submits to the competent authority of a Member State of the European Union suspected of having brought out a national cultural good of the Republic of Poland from the territory of the Republic of Poland in breach of the Republic of Poland's law, an application for the search for that good and for action to establish the identity of its holder (Article 15 section 2).

The Minister of Culture and National Heritage, within 6 months from the date of notification by the Member State of the European Union of the discovery on its territory of the national cultural good of the Republic of Poland, in which there are grounds for considering that it was removed in violation of the law from the territory of the Republic of Poland, shall check whether it is a national cultural good of the Republic of Poland derived in violation of the law from the territory of the Republic of Poland (Article 16).

Where a national cultural good of the Republic of Poland is found in the territory of a Member State of the European Union, brought out of the territory of the Republic of Poland in breach of the law, the Minister of Culture and National Heritage shall take steps to return that good to the territory of the Republic of Poland, in accordance with the rules and within the time limits laid down by the law of that state, and shall immediately inform the competent authority of that state, in particular through IMI, to make a claim for the return of the national cultural good of the Republic of Poland to the territory of the Republic of Poland (Article 17).

\section{The entity responsible for cultural heritage has a list of}

\section{a) Mobile cultural heritage that has been taken from your country?}

Yes, it does. The Division for Looted Art keeps the Catalogue of the War Losses, (available in English under the following link http://lootedart.gov.pl/en/productwar-losses). The electronic database is the only national register of cultural property lost as a result of the Second World War from within the post-1945 borders of Poland. Its main aim is to inventory the best information gathered on the topic of sites which were plundered as a result of warfare. All the data logged in the data-

System and repealing Commission Decision 2008/49/EC ('the IMI Regulation') (Article 2 point 7 of the Act of 25th May 2017 on Restitution of National Cultural Goods). From the beginning of 2019 the Division for Looted Art in the Polish Ministry of Culture and National Heritage has sent over a 100 items of information about the lost cultural goods to the EU countries (Source only in Polish: http://cennebezcenne.pl/ wp-content/uploads/2020/10/2020-3-4-DEPARTAMENT.pdf). 
base forms the basis of searches for wartime losses and also any restitution activities undertaken by the Division. To date, information on over 63000 sites has been gathered (including complexes) ${ }^{7}$. The Catalogue is not an official public register.

b) Mobile cultural heritage originally from another country and part of the national collections?

No such catalogue has been published on the official sites.

$7 \quad$ Http://lootedart.gov.pl/en/The-Division-for-Looted-Art, site access 03.11.20. 
\begin{tabular}{l|l}
2 & \\
& OPINIE BAS
\end{tabular}

SPRAWY POSELSKIE 

Wojciech Odrowąż-Sypniewski

\title{
Tryb postępowania z wniesionym w VIII kadencji wnioskiem o wyrażenie przez Sejm zgody na pociągnięcie do odpowiedzialności cywilnej posłów ${ }^{1}$
}

\author{
Procedure for dealing with the motion submitted in the course of the \\ $8^{\text {th }}$ term of the Sejm requesting the Sejm to grant consent to bringing \\ Deputies to a civil law liability
}

\begin{abstract}
The author indicates that the legal structure of the Polish immunity regulations excludes the possibility of adopting a resolution by the Sejm on giving consent to bring several deputies to responsibility. In each individual case, the Sejm should consider a separate motion and adopt a separate resolution. Referring to the principle of discontinuity, the author concludes that regarding the two former Deputies, new motions for consent to bring them to a civil law liability should be submitted, while in the case of a Deputy holding a mandate also in the 9th term, the proceedings on the motion concerning him should be continued.
\end{abstract}

Keywords: immunity, Deputy, Constitution

Autor wskazuje, że konstrukcja prawna polskich rozwiązań immunitetowych wyklucza możliwość podjęcia przez Sejm uchwały w sprawie wyrażenia zgody na pociągnięcie do odpowiedzialności kilku posłów. W każdym indywidualnym przypadku Sejm powinien rozpatrywać oddzielny wniosek i podjąć oddzielną uchwałę. Powołując się na zasadę dyskontynuacji, autor konkluduje, że w sprawie dwóch byłych posłów powinny zostać złożone nowe wnioski o wyrażenie zgody na pociągnięcie do odpowiedzialności cywilnej, natomiast w przypadku posła posiadającego mandat również w IX kadencji postępowanie w sprawie dotyczącego go wniosku powinno być kontynuowane.

Słowa kluczowe: immunitet, poseł, Konstytucja

Ekspert ds. legislacji Biura Analiz Sejmowych •

Kancelaria Sejmu, Biuro Analiz Sejmowych, Wydział Analiz Prawnych, Zespół Prawa

Parlamentarnego, WARSZAWA, POLSKA •

wojciech.sypniewski@sejm.gov.pl • https://orcid.org/0000-0002-7704-5042

\section{Przedmiot opinii}

Przedmiotem opinii jest odpowiedź na pytanie: „czy skierowany w VIII kadencji Sejmu do Komisji Regulaminowej, Spraw Poselskich i Immunitetowych wniosek

$1 \quad$ Opinia na temat trybu postępowania $z$ wniesionym $w$ VIII kadencji wnioskiem o wyrażenie przez Sejm zgody na pociagnięcie do odpowiedzialności cywilnej posłów X.X., Y.Y. i Z.Z. sporządzona 6 grudnia 2019 r. na zlecenie Przewodniczącego Komisji Regulaminowej, Spraw Poselskich i Immunitetowych; BAS-WAKiU-107/19. 
o wyrażenie zgody na pociągnięcie do odpowiedzialności cywilnej posłów XX, YY i ZZ powinien zostać skierowany ponownie do Sejmu przez wnioskodawcę? Wniosek dotyczy łącznie trzech posłów, a w IX kadencji Sejmu tylko jedna z wymienionych osób piastuje mandat poselski”.

\section{Stan faktyczny}

W VIII kadencji Sejmu w dniu 28 lutego 2019 r. do sekretariatu Marszałka Sejmu wpłynął wniosek o wyrażenie zgody na pociągnięcie do odpowiedzialności cywilnej za naruszenie dóbr osobistych posłów XX, YY i ZZ, przedłożony przez oskarżycieli prywatnych Grupę Azoty Zakłady Chemiczne „Police” SA i WW. Wniosek został przedłożony w związku z postępowaniem cywilnym prowadzonym przez Sąd Okręgowy w Warszawie pod sygn. akt II C 96/19. Zważywszy, że wniosek z 28 lutego 2019 r. nie spełniał wymogów wynikających z ustawy z 9 maja 1996 r. o wykonywaniu mandatu posła i senatora (Dz.U. 2018, poz. 1799; dalej: u.w.m.p.s.) $)^{2}$, Marszałek Sejmu wezwał wnioskodawcę do uzupełnienia wniosku na podstawie art. 7c ust. 1a u.w.m.p.s. Wnioskodawca uzupełnił pismem z 2 kwietnia 2019 r. brakujące informacje. W konsekwencji Marszałek Sejmu, działając na podstawie art. 7c ust. $1 \mathrm{~b}$ w związku z art. 7c ust. 7 u.w.m.p.s. skierował wniosek ${ }^{3}$ w dniu 26 kwietnia 2019 r. do Komisji Regulaminowej, Spraw Poselskich i Immunitetowych. Do zakończenia VIII kadencji Sejmu (11 listopada 2019 r.) Komisja nie zakończyła rozpatrywania wniosku.

Okolicznością faktyczną, która ma istotny wpływ na dalszy tryb postępowania z wnioskiem, jest uzyskanie mandatu posła IX kadencji Sejmu przez Pana Posła YY. Pan XX w wyborach do Sejmu IX kadencji nie uzyskał reelekcji, zaś Pan ZZ w wyborach do Senatu uzyskał mandat senatora VIII kadencji.

\section{Model normatywny ochrony immunitetowej wynikającej z art. 105 ust. 1 zdanie drugie Konstytucji}

1. Jak trafnie wskazywano w powołanej opinii prawnej z 14 marca 2019 r., „pismo [ z 28 lutego 2019 r. - uwaga W.O.-S.] zawiera w istocie nie jeden, lecz trzy wnioski o wyrażenie zgody na pociągnięcie trzech posłów do odpowiedzialności cywilnej (z tytułu zarzutu popełnienia przez nich jednego tego samego czynu). Konstruk-

2 Opinia E. Gierach z 14 marca 2019 r., sygn. BAS-WAKiU-442/19. W opinii wskazano, że nie został spełniony wymóg wskazania miejsca urodzenia posłów, a także wymóg dokładnego określenia czynu, którego dotyczy wniosek.

3 Por. opinia BAS z 10 kwietnia 2019 r. (sygn. BAS-WAKiU-706/19) stwierdzająca, że uzupełniony wniosek spełnia wymogi formalne. 
cja prawna polskich rozwiązań immunitetowych wyklucza możliwość podjęcia przez Sejm uchwały w sprawie wyrażenia zgody na pociągnięcie do odpowiedzialności kilku posłów. W konsekwencji w analizowanym przypadku Sejm powinien $\mathrm{w}$ istocie rozpatrzeć trzy odrębne wnioski i podjąć trzy odrębne uchwały". Antycypując tok dalszych rozważań, warto w tym miejscu zaznaczyć, że o ile w VIII kadencji Sejmu konieczność proceduralnego rozdzielenia „wniosku” na etapie prac Komisji wiązała się z indywidualizacją ochrony immunitetowej i koniecznością odrębnego rozstrzygnięcia w kwestii zgody na pociągnięcie każdego $\mathrm{z}$ trzech posłów do odpowiedzialności cywilnej, o tyle w obecnym stanie faktycznym autonomizacja proceduralna każdego z „wniosków” jest konsekwencją swoistego uprzywilejowania wnioskodawców, których wnioski nie zostały rozpatrzone w zakończonej kadencji Sejmu (art. 11 ust. 4 u.w.m.p.s.). W obecnym stanie faktycznym tryb postępowania z żądaniami wnioskodawcy, które dotyczyły trzech posłów VIII kadencji Sejmu, zależeć będzie od ich aktualnego statusu prawnego, czyli od tego, czy pełnią oni mandat poselski w IX kadencji Sejmu.

Odpowiedź na pytanie o dalszy sposób postępowania z wnioskiem z 28 lutego 2019 r. wymaga rozstrzygnięcia trzech odrębnych zagadnień:

- czy ochrona wynikająca z art. 105 ust. 1 zdanie drugie Konstytucji kończy się wraz z upływem kadencji Sejmu?,

- czy immunitet senatora wynikający z art. 105 ust. 1 zdanie drugie Konstytucji znajduje zastosowanie do czynów wiążących się ze sprawowaniem mandatu posła zakończonej kadencji Sejmu?,

- czy art. 11 ust. 4 u.w.m.p.s. może znaleźć zastosowanie w sytuacji, gdy wniosek wniesiony został w zakończonej kadencji Sejmu, a osoba piastująca mandat posła zakończonej kadencji uzyskała mandat senatora?

2. Konstytucja RP przewiduje dwa rodzaje immunitetu parlamentarnego. Immunitet formalny (art. 105 ust. 2 Konstytucji) oznacza ograniczenie dopuszczalności ścigania posła za czyny stanowiące przestępstwo lub inne czyny, których popełnienie powoduje odpowiedzialność karną w znaczeniu konstytucyjnym (obejmującą, obok odpowiedzialności karnej w rozumieniu ustawowym, m.in. odpowiedzialność wykroczeniową czy karną skarbową). Pociągnięcie do odpowiedzialności karnej dopuszczalne jest wyłącznie po wyrażeniu zgody przez Sejm lub przez posła, który dopuścił się czynu karalnego. Ochrona wynikająca $\mathrm{z}$ art. 105 ust. 2 Konstytucji rozciąga się wyłącznie na czyny, które nie przynależą do sfery wykonywania mandatu poselskiego.

Immunitet materialny (indemnitet) wyłącza karalność czynów popełnionych przez parlamentarzystę $\mathrm{w}$ ramach wykonywania mandatu poselskiego. Za tego rodzaju czyny poseł odpowiada wyłącznie przed Sejmem (art. 105 ust. 1 Konstytucji). Ochrona wynikająca $z$ immunitetu materialnego nie dotyczy jednak czynów, których poseł dopuścił się w ramach działalności wchodzącej w zakres wykonywania mandatu, jeżeli naruszają one prawa osób trzecich. W takim wypadku pociągnięcie sprawcy do odpowiedzialności sądowej (karnej lub cywilnej) 
jest warunkowane wyrażeniem przez Sejm zgody. Działania wchodzące w zakres wykonywania mandatu, które naruszają prawa osób trzecich, podlegają ochronie niewynikającej z immunitetu materialnego, lecz ze specyficznej postaci immunitetu formalnego ${ }^{4}$. W przeciwieństwie jednak do immunitetu formalnego uregulowanego w art. 105 ust. 2 Konstytucji funkcja ochronna rozpatrywanego immunitetu obejmuje nie tylko odpowiedzialność karną, ale każdy rodzaj odpowiedzialności egzekwowanej przez sąd (a zatem również odpowiedzialność cywilną). Obydwa immunitety uregulowane w art. 105 ust. 1 Konstytucji (immunitet materialny oraz specyficzna forma immunitetu formalnego - tzw. mały immunitet formalny) przysługują posłowi jedynie wówczas, gdy jego działalność wpisuje się w sprawowanie mandatu. Teza ta jednoznacznie wynika ze zdania pierwszego zawartego $\mathrm{w}$ omawianym przepisie. W tych wypadkach, gdy czyn popełniony przez posła nie mieści się w zakresie wykonywania mandatu i nie narusza norm prawa karnego w rozumieniu konstytucyjnym, sprawca ponosi odpowiedzialność sądową na zasadach ogólnych (w procesie cywilnym). W sytuacji, gdy czyn popełniony poza sferą wykonywania mandatu narusza ustawę karną, poseł podlega ochronie wynikającej z immunitetu formalnego, o którym mowa w art. 105 ust. 2 Konstytucji.

Immunitet materialny ma charakter trwały, co wynika jednoznacznie z treści przepisu go ustanawiającego (art. 105 ust. 1 zdanie pierwsze). Po zakończeniu wykonywania mandatu poselskiego nie ma żadnych możliwości pociągnięcia posła do odpowiedzialności za działania mieszczące się w ramach sprawowania mandatu, jeżeli nie naruszały one praw osób trzecich. Warto zauważyć, że o ile w okresie wykonywania mandatu poseł podlega odpowiedzialności przed Sejmem, o tyle z chwilą wygaśnięcia mandatu również ten reżim odpowiedzialności prawnej nie będzie miał do niego zastosowania. Utrata mandatu powoduje, że wewnętrzny reżim odpowiedzialności dyscyplinarnej izby („odpowiedzialność przed Sejmem” - art. 105 ust. 1 zdanie drugie in principio) nie może mieć zastosowania do osoby niebędącej jej członkiem.

Bardziej złożona pozostaje ocena zakresu czasowego ochrony immunitetowej wynikającej z art. 105 ust. 1 zdanie drugie Konstytucji. W piśmiennictwie wyrażony został pogląd, że ochrona obejmująca działania wchodzące w zakres sprawowania mandatu i naruszające prawa osób trzecich ustaje wraz z zakończeniem kadencji ${ }^{5}$. Innymi słowy, za działania mieszczące się w ramach wyko-

4 K. Grajewski, Komentarz do art. 6a [w:] K. Grajewski, J. Stelina, P. Uziębło, Komentarz do ustawy o wykonywaniu mandatu posła i senatora, Warszawa 2014, s. 81; E. Gierach, Komentarz do art. 105 [w:] Konstytucja RP. Komentarz, t. II, Art. 87-243, red. M. Safjan, L. Bosek, Warszawa 2016, s. 343; postanowienie TK z 2 grudnia 2009 r., sygn. akt I CSK 140/09, OSNC 2010, nr 5, poz. 83; postanowienie TK z 26 listopada 2015 r., sygn. akt SK 8/13.

5 K. Grajewski, Odpowiedzialność posłów i senatorów na tle zasady mandatu wolnego, Warszawa 2009, s. 348-349. 
nywania mandatu poselskiego, które naruszają prawa osób trzecich, osoba pełniąca mandat poselski po jego wygaśnięciu miałaby podlegać odpowiedzialności na zasadach ogólnych (tj. zgoda Sejmu nie stanowiłaby warunku pociągnięcia do odpowiedzialności). K. Grajewski stwierdza, że immunitet uregulowany $\mathrm{w}$ art. 105 ust. 1 zdanie drugie jest immunitetem nietrwałym w przeciwieństwie do immunitetu, o którym mowa w art. 105 ust. 1 zdanie pierwsze, „choć taki wniosek mógłby wypływać z konstatacji o ścisłym związaniu tego immunitetu z zamiarem ochrony sprawowania funkcji przedstawicielskich oraz z immunitetem materialnym”. Immunitet, o którym mowa w art. 105 ust. 1 zdanie drugie, jest immunitetem procesowym, a „konstytucja nie stanowi, iż działa on również po wygaśnięciu mandatu parlamentarnego”. Zdaniem K. Grajewskiego Konstytucja w art. 105 ust. 1 zdanie drugie ochrania jedno z podstawowych praw parlamentu, jakim jest prawo do obradowania w pełnym, wyznaczonym przez wyborców składzie. „Natomiast w sytuacji, gdy osoba, która popełniła opisany czyn, nie jest już parlamentarzystą, trudno jest znaleźć powód jej ochrony immunitetem formalnym uregulowanym w art. 105 ust. 1 zdanie drugie Konstytucji. Inaczej mówiąc - nie ma żadnego uzasadnienia, by pociągnięcie do odpowiedzialności sądowej byłego parlamentarzysty za czyn, który nie jest nawet chroniony immunitetem materialnym (bo narusza prawa osób trzecich), miało być uzależnione od zgody Sejmu (Senatu) np. następnej kadencji. Przyznanie takiej ochrony byłemu parlamentarzyście jest zupełnie niezasadne - nie sprawuje on już mandatu przedstawicielskiego, zatem niejako znika przedmiot ochrony (prawo do obradowania w pełnym składzie przez parlament), a uprzednio sprawowany mandat jest chroniony immunitetem materialnym, który jest immunitetem trwałym"6.

Z przedstawionym wyżej stanowiskiem nie można się zgodzić. Po pierwsze, immunitety, o których mowa w art. 105 ust. 1 zdanie pierwsze i drugie Konstytucji, chronią nie tylko prawo parlamentu do obradowania w pełnym składzie, ale stanowią również bardzo doniosłe, z perspektywy ustrojowej, gwarancje wykonywania mandatu poselskiego. Zagrożenie prawa parlamentu do obradowania w pełnym składzie z natury rzeczy może się wiązać wyłącznie z postępowaniem karnym. Tylko w takim postępowaniu sąd może wymierzyć parlamentarzyście karę pozbawienia wolności, której wykonanie uniemożliwiłoby prowadzenie obrad w kompletnym składzie. Immunitet materialny i immunitet, o którym mowa w art. 105 ust. 1 zdanie drugie Konstytucji, chronią zaś nie tylko przed postępowaniem karnym, ale przed jakimkolwiek postępowaniem sądowym. Immunitety, o których mowa w art. 105 ust. 1 zdanie pierwsze i drugie, służą nie tylko ochronie niezależności i autonomii instytucji parlamentu, ale również stanowią gwarancję niezależności członków parlamentu i zapewniają im swobodę sprawowania mandatu. Ratio legis tej instytucji wiąże się z przekonaniem, że swoboda wykonywania mandatu poselskiego nie byłaby pełna, gdyby osoba wykonująca

\footnotetext{
$6 \quad$ Ibidem.
} 
mandat była narażona na działania służące bezzasadnemu uwikłaniu parlamentarzysty w proces sądowy.

Immunitet materialny nie obejmuje tych działań parlamentarzysty, mieszczących się w sferze sprawowania mandatu, którymi dopuścił się on naruszenia praw osób trzecich. Konstytucja warunkuje w tym wypadku dopuszczalność wszczęcia postępowania sądowego za zgodą właściwej izby. Znamienna jest różnica między obecną regulacją konstytucyjną a art. 7 ust. 1 tzw. małej Konstytucji ${ }^{7}$ ustanawiającym immunitet materialny. W poprzednio obowiązującym stanie prawnym ustawa zasadnicza ograniczała się do stwierdzenia, że: „Poseł nie może być pociągnięty do odpowiedzialności za działania wynikające z wykonywania mandatu ani w czasie trwania mandatu, ani po jego wygaśnięciu, chyba że narusza dobra osobiste innych osób”. W konsekwencji odpowiedzialność karna parlamentarzysty za działania naruszające dobra osobiste osób trzecich podlegała ochronie wynikającej z immunitetu formalnego (art. 7 ust. 2 małej Konstytucji), zaś wszczęcie postępowania cywilnego, służącego dochodzeniu roszczeń związanych $\mathrm{z}$ naruszeniem dóbr osobistych nie wymagało zgody Sejmu. W praktyce oznaczało to, że osoby, które uznawały, iż działania parlamentarzysty naruszyły ich dobra osobiste, bez żadnych przeszkód mogły występować na drogę sądową. W sytuacji, gdy zarzut formułowany w pozwie służył wyłącznie szykanowaniu osoby sprawującej mandat parlamentarny, dopiero wyrok sądu prowadził do wykazania jego bezzasadności. Przyznanie izbom prawa wyrażania zgody na pociągnięcie do odpowiedzialności sądowej za działania naruszające prawa osób trzecich daje gwarancję, że tego rodzaju postępowania nie będą służyły szykanom zagrażającym swobodzie wykonywania mandatu. Gwarancja ta nie ogranicza się jednak wyłącznie do okresu wykonywania mandatu poselskiego (co miało miejsce pod rządami małej Konstytucji), ale ma charakter permanentny i dotyczy również okresu po wygaśnięciu tego mandatu.

Stanowisko zakładające, że immunitet, o którym mowa w art. 105 ust. 1 zdanie drugie Konstytucji, jest immunitetem nietrwałym, oparte jest na argumentacji, która w pełni utożsamia tę instytucję z reżimem immunitetu formalnego, o którym mowa w art. 105 ust. 2 Konstytucji. W konsekwencji art. 105 ust. 1 zdanie drugie w zakresie, w jakim znajduje zastosowanie do odpowiedzialności karnej, zostaje pozbawiony znaczenia normatywnego. W proponowanym przez K. Grajewskiego ujęciu kwestia odpowiedzialności karnej za czyny naruszające prawa osób trzecich byłaby regulowana w art. 105 „podwójnie”. Kwestii tej dotyczyłby bowiem zarówno art. 105 ust. 1 zdanie drugie (jeżeli czyn naruszający prawa osób trzecich mieści się w zakresie wykonywania mandatu), jak i art. 105 ust. 2 w sposób ogólny regulujący kwestię odpowiedzialności karnej

$7 \quad$ Ustawa konstytucyjna z 17 października 1992 r. o wzajemnych stosunkach między władzą ustawodawczą i wykonawczą Rzeczypospolitej Polskiej oraz o samorządzie terytorialnym, Dz.U. nr 84, poz. 426. 
od dnia ogłoszenia wyników wyborów do dnia wygaśnięcia mandatu. W obu przypadkach mechanizm ochrony byłby tożsamy - zgodę na pociągnięcie do odpowiedzialności karnej wyraża Sejm (Senat), a oba immunitety mają charakter nietrwały. Warto jednak zauważyć, że z brzmienia art. 105 ust. 1 zdanie drugie w odróżnieniu od sposobu sformułowania ust. 2 - nie wynika, by przewidziane $\mathrm{w}$ tym przepisie gwarancje miały charakter ograniczony do okresu wykonywania mandatu. Treść tego przepisu, pozornie, z uwagi na użycie terminu „poseł”, może rodzić wątpliwość, czy sformułowana w nim zasada ma zastosowanie do byłego posła. Należy jednak uznać, że rozstrzygające znaczenie dla wykładni całego analizowanego zdania ma zastosowany w nim szyk. Wskazuje on, iż wyznaczona reguła odnosi się do „działalności”, o której mowa w zdaniu pierwszym („za taką działalność poseł odpowiada wyłącznie przed Sejmem, a w przypadku naruszenia praw osób trzecich może być pociągnięty do odpowiedzialności sądowej tylko za zgodą Sejmu"). Omawiane zdanie eksplikuje zatem zasady odnoszące się do odpowiedzialności za działalność wchodzącą w zakres sprawowania mandatu, o której mówi pierwsze zdanie. Za taką działalność piastun mandatu poselskiego ponosi odpowiedzialność przed Sejmem, a w sytuacji, gdy naruszył prawa osób trzecich, zainicjowanie odpowiedzialności sądowej wymaga zgody Sejmu. Proponowana przez K. Grajewskiego wykładnia art. 105 ust. 1 ignoruje związek między pierwszym i drugim zdaniem tego przepisu. Prowadzi ona do zasadniczego ograniczenia zakresu ochrony swobody wykonywania mandatu parlamentarnego. Wprawdzie poseł $\mathrm{w}$ okresie sprawowania mandatu pozostaje wolny od szykan związanych z bezzasadnym wszczynaniem procesów sądowych, jednak może obawiać się, że po wygaśnięciu mandatu zostanie uwikłany w postępowania sądowe dotyczące działań podejmowanych przez niego $\mathrm{w}$ ramach wykonywania mandatu. W konsekwencji trudno zgodzić się z tezą, że „przyznanie ochrony byłemu parlamentarzyście jest zupełnie niezasadne", a fakt, iż nie sprawuje on mandatu przedstawicielskiego powoduje, że „znika przedmiot ochrony". Obawa przed potencjalnym postępowaniem sądowym - inicjowanym wyłącznie w celu szykanowania osoby, która podjęła określone działania w toku wykonywania mandatu parlamentarnego - może skutecznie ograniczać swobodę jego wykonywania.

Na gruncie obowiązującego stanu prawnego brak jest wystarczających podstaw normatywnych, by kwestionować tezę, że zgoda Sejmu jest zawsze warunkiem pociągnięcia do odpowiedzialności sądowej za działania naruszające prawa osób trzecich, które podjęte zostały w ramach wykonywania mandatu. Warto zaznaczyć, że pogląd zbieżny do stanowiska prezentowanego w niniejszej opinii przedstawiony został w postanowieniu Trybunału Konstytucyjnego z 26 listopada 2015 r., sygn. akt SK 8/13. Odnosząc się do immunitetu, o którym mowa w art. 105 ust. 1 zdanie drugie Konstytucji, sąd konstytucyjny stwierdził, że „ma on szczególny zasięg czasowy, gdyż dotyczy również okresu po zakończeniu kadencji” (uzasadnienie pkt II. 2.2.5). 
Kolejnym argumentem przemawiającym za trwałością „małego immunitetu formalnego" jest konstrukcja zawarta w art. 11 ust. 4 u.w.m.p.s. Wprawdzie treść rozwiązań ustawowych nie może przesądzać o wykładni przepisów Konstytucji, a odmienne stanowisko przeczyłoby hierarchicznej nadrzędności ustawy zasadniczej w systemie prawa, to jednak kształt rozwiązań ustawowych jest wyrazem sposobu odczytania przez ustawodawcę norm konstytucyjnych. Analiza art. 11 ust. 4 będzie przedmiotem rozważań w dalszej części opinii. W tym miejscu warto ograniczyć się do stwierdzenia, że przepis ten oparty jest na założeniu, że upływ kadencji Sejmu nie oznacza, że wnioski na podstawie art. 105 ust. 1 zdanie drugie skierowane do „starego Sejmu” upadają, a egzekwowanie odpowiedzialności sądowej w tych sprawach jest możliwe na ogólnych zasadach. Gdyby tak było, to w przypadku wniosków o pociągnięcie do odpowiedzialności karnej (za czyny naruszające prawa osób trzecich w okresie kadencji starego Sejmu) wystarczające gwarancje dla prawa nowej izby do obradowania w pełnym składzie wynikałyby z art. 105 ust. 2 Konstytucji, zaś wnioski dotyczące odpowiedzialności cywilnej w takich sprawach nie wymagałby zgody nowego Sejmu. Przyjęta w art. 11 ust. 4 u.w.m.p.s. konstrukcja odwołuje się jednak do odmiennych założeń. Nakaz kontynuacji niezakończonego w starym Sejmie postępowania immunitetowego, które zainicjowane zostało wnioskiem na podstawie art. $7 \mathrm{~b}$ ust. 5 u.w.m.p.s. (cywilna odpowiedzialność sądowa) wobec osoby, która odnowiła swój mandat poselski, opierać się musi na założeniu, że czyn, stanowiący przedmiot tego postępowania podlega nadal ochronie wynikającej z art. 105 ust. 1 zdanie drugie Konstytucji, a zatem ochrona ta ma charakter trwały ${ }^{8}$. Jakkolwiek zatem treść przepisów ustawy nie może przesądzać o wykładni Konstytucji, to jednak przyjęta w art. 11 ust. 4 konstrukcja świadczy o tym, że ustawodawca odczytuje sens normatywny art. 105 ust. 1 zdanie drugie Konstytucji w sposób zbieżny ze stanowiskiem prezentowanym w opinii.

Kończąc tę część rozważań, warto odnotować, że w VIII kadencji Sejmu Komisja Regulaminowa, Spraw Poselskich i Immunitetowych na posiedzeniu w dniu 13 grudnia 2016 r., opiniując dla Marszałka Sejmu w trybie art. 17 ust. 1 pkt 2 regulaminu Sejmu wniosek oskarżyciela subsydiarnego XY (anonimizacja W.O.-S.) z dnia 11 lipca 2016 r. o wyrażenie zgody przez Sejm na pociągnięcie do odpowiedzialności karnej byłego posła YZ, podjęła uchwałę, w której stwierdziła, że „immunitet materialny chroni mandat przedstawicielski permanentnie - to jest od dnia jego nabycia, aż do śmierci osoby, której immunitet przysługuje. Jest

$8 \quad$ Trudno zarazem nie odnotować ułomności przyjętego w art. 11 ust. 4 rozwiązania. Nie sposób bowiem wskazać na racje, które stoją za uprzywilejowaniem wniesionych w starym Sejmie wniosków dotyczących osób, które odnowiły w nowym Sejmie swój mandat, względem wniosków dotyczących osób, które nie dokonały reelekcji. Przy założeniu trwałości ochrony immunitetowej wynikającej z art. 105 ust. 1 zdanie drugie konstrukcja ta rodzi wątpliwości na gruncie zasady równości. 
on niezbywalny, a pociągnięcie do odpowiedzialności posła za jego wcześniejsze działania, wchodzące $\mathrm{w}$ zakres sprawowania mandatu parlamentarnego, które naruszyły prawa osób trzecich, wymaga zgody Sejmu również po wygaśnięciu mandatu. Wobec powyższego Sejm ma obowiązek rozpatrzeć wniosek o wyrażenie zgody na pociągnięcie do odpowiedzialności sądowej byłego posła”. Jednocześnie odnosząc się do procedury, którą należałoby zastosować w Sejmie przy postępowaniu z wnioskiem, Komisja uznała, że „wskazane jest dokonanie wcześniej zmiany ustawy z dnia 9 maja 1996 r. o wykonywaniu mandatu posła i senatora w zakresie art. 6a i 7b oraz wprowadzenie niezbędnych zmian w przepisach regulaminu Sejmu, co do sposobu procedowania nad wnioskiem w Komisji i na sali sejmowej"'.

3. Odpowiedź na pytanie „czy immunitet senatora wynikający z art. 105 ust. 1 zdanie drugie Konstytucji znajduje zastosowanie do czynów wiążących się ze sprawowaniem mandatu posła zakończonej kadencji Sejmu?", rozpocząć trzeba od konstatacji, że w świetle przepisów ustawy zasadniczej posłom i senatorom przysługuje tożsama ochrona immunitetowa. Zgodnie $\mathrm{z}$ art. 108 Konstytucji do senatorów stosuje się odpowiednio przepisy art. 105 Konstytucji. Immunitet senatora wynikający z art. 105 ust. 1 zdanie drugie Konstytucji dotyczy jednak wyłącznie działań w ramach wykonywania mandatu senatora, które naruszają prawa osoby trzeciej. Ochrona wynikająca $\mathrm{z}$ tego przepisu nie obejmuje zatem żadnych innych działań podejmowanych w ramach innych funkcji publicznych, a w szczególności działań podejmowanych przed uzyskaniem mandatu senatora (w tym np. w ramach wykonywania mandatu posła zakończonej kadencji Sejmu). Podobnie w przypadku posła zakres ochrony immunitetowej związany z małym immunitetem formalnym nie dotyczy działalności wchodzącej w zakres sprawowania mandatu senatora zakończonej kadencji Senatu. Zakres ochrony wynikającej z analizowanego przepisu obejmuje wyłącznie sferę wykonywania mandatu posła (senatora) określonej kadencji Sejmu (Senatu). Innymi słowy, pociągnięcie do odpowiedzialności sądowej posła IX kadencji Sejmu za działania naruszające prawa osób, które miały miejsce np. w okresie V kadencji Sejmu, nie podlega ochronie immunitetowej z tytułu pełnienia mandatu posła IX kadencji. Zważywszy, że ochrona wynikająca z art. 105 ust. 1 zdanie drugie Konstytucji ma jednak charakter trwały (ochrona związana $\mathrm{z}$ wykonywaniem mandatu posła $\mathrm{V}$ kadencji), pociągnięcie takiego parlamentarzysty do odpowiedzialności sądowej będzie wymagało zgody izby (podobnie jak pociągnięcie do odpowiedzialności sądowej byłego posła $\mathrm{V}$ kadencji, który nie sprawuje obecnie mandatu poselskiego).

Na marginesie tych rozważań należy zauważyć, że zwolennicy stanowiska kwestionującego trwałość immunitetu, o którym mowa w art. 105 ust. 1 zdanie drugie, zmuszeni są do odpowiedzi na pytanie, dlaczego ustawodawca w art. 11

9 Opinia nr 21 Komisji Regulaminowej, Spraw Poselskich i Immunitetowych dla Marszałka Sejmu uchwalona na posiedzeniu w dniu 13 grudnia $2016 \mathrm{r}$. 
ust. 4 u.w.m.p.s. nakazał w nowej kadencji Sejmu kontynuację niezakończonych w starej kadencji postępowań, jeżeli dotyczą one czynów, które przestały podlegać ochronie immunitetowej. Czy takie ujęcie nie oznacza niekonstytucyjnego rozszerzenia zakresu ochrony małego immunitetu formalnego na działania podejmowane przed uzyskaniem mandatu (w okresie wykonywania mandatu posła zakończonej kadencji)? Ochrona immunitetowa jest wyjątkiem od konstytucyjnej zasady równości wszystkich wobec prawa, a tym samym rozszerzenie w ustawie zakresu ochrony immunitetowej dotyczącej sprawowania mandatu poselskiego względem zakresu wynikającego z art. 105 ust. 1 zdanie drugie rodziłoby wątpliwości w świetle ustawy zasadniczej.

Podsumowaniem tej części rozważań jest pogląd, że immunitet senatora wynikający z art. 105 ust. 1 zdanie drugie w związku z art. 108 Konstytucji chroni wyłącznie działania związane $\mathrm{z}$ wykonywaniem mandatu senatora określonej kadencji. Oznacza to, że pociągnięcie do odpowiedzialności sądowej (karnej lub cywilnej) za działania podejmowane przed uzyskaniem mandatu senatorskiego w okresie wykonywania mandatu posła zakończonej kadencji - wymagać będzie zgody Sejmu. Organem właściwym do wyrażenia zgody na pociągnięcie do odpowiedzialności cywilnej byłego posła, który aktualnie sprawuje mandat senatora, pozostaje Sejm. Trwałość ochrony immunitetowej wynikającej z art. 105 ust. 1 zdanie drugie powoduje, że egzekwowanie odpowiedzialności cywilnej w stosunku do byłego posła za działania podejmowane przez niego w okresie wykonywania mandatu wymaga ad infinitum zgody Sejmu bez względu na to, czy poseł odnowił po zakończeniu kadencji swój mandat poselski, czy też uzyskał w wyborach do Senatu mandat senatora albo nie wykonuje żadnego mandatu parlamentarnego. Zasada ta będzie miała zastosowanie również w odniesieniu do wszystkich innych form „odpowiedzialności sądowej”, o których mowa w art. 105 ust. 1 zdanie drugie, przy czym bardziej złożona pozostaje kwestia odpowiedzialności karnej. Możliwy jest bowiem szczególny przypadek, w którym byłemu posłowi pełniącemu aktualnie mandat senatora (albo odwrotnie - byłemu senatorowi pełniącemu mandat poselski) zarzucany jest czyn związany z wykonywaniem mandatu poselskiego (senatorskiego) w okresie zakończonej kadencji, który wiąże się z naruszeniem praw osób trzecich. W takim wypadku aktualny senator podlegałby podwójnej ochronie immunitetowej. Pociągnięcie go do odpowiedzialności karnej - zważywszy na trwałość immunitetu z okresu sprawowania mandatu poselskiego - wymagałoby zgody Sejmu. Wykonywanie mandatu senatora wiąże się jednak z ochroną immunitetową wynikającą z art. 105 ust. 2 w związku z art. 108 Konstytucji. W takim wypadku zgoda Sejmu na pociągnięcie senatora do odpowiedzialności karnej byłaby jednak niewystarczająca i egzekwowanie tej odpowiedzialności wymagałoby również zgody Senatu. Odrzucić należy tezę, że warunkiem odpowiedzialności karnej w opisywanej sytuacji byłaby wyłącznie zgoda Senatu, która niejako „konsumowałaby” zgodę Sejmu. Takie stanowisko bezzasadnie z perspektywy konstytucyjnej różnicowałoby sytuację 
prawną byłych parlamentarzystów w zależności od tego, czy w chwili inicjowania postępowania karnego sprawują mandat $\mathrm{w}$ drugiej izbie. Oznaczałoby to również, że w opisywanej sytuacji każda z izb mogłaby się stać gwarantem konstytucyjnych praw drugiej izby. Druga z wymienionych przyczyn jest powodem, dla którego odrzucić także należy tezę przeciwną, tj.: warunkiem pociągnięcia do odpowiedzialności karnej byłego posła a aktualnego senatora za działania związane z wykonywaniem mandatu posła jest jedynie zgoda Sejmu. Stanowisko takie stałoby w jaskrawej sprzeczności z założeniem, że każdej z izb przysługuje w pełni autonomiczna kompetencja w zakresie rozstrzygania spraw immunitetowych jej członków (tzw. autonomia jurysdykcyjna stanowiąca komponent powszechnie aprobowanej w doktrynie prawa konstytucyjnego zasady autonomii parlamentu).

W konsekwencji w sytuacji, gdy wniosek o pociągnięcie do odpowiedzialności cywilnej za czyn naruszający prawa osoby trzeciej, mieszczący się w zakresie wykonywania mandatu posła na Sejm zakończonej kadencji, dotyczy osoby, która aktualnie sprawuje funkcję senatora, organem właściwym do wyrażenia zgody jest Sejm. W przypadku jednak, gdy wniosek dotyczy odpowiedzialności karnej, zgodę na prowadzenie postępowania karnego $\mathrm{w}$ omawianej sytuacji wyrazić powinien zarówno Sejm, jak i Senat ${ }^{10}$.

4. Treść art. 11 ust. 4 u.w.m.p.s. przewiduje, że jeżeli po nadaniu biegu wnioskowi, o którym mowa $\mathrm{w}$ art. 7b ust. 1, 2 albo 5 lub w art. 10 ust. 4 u.w.m.p.s., a przed podjęciem przez Sejm lub Senat rozstrzygnięcia w tych sprawach, upłynie kadencja Sejmu, postępowanie w danej sprawie toczy się nadal w Sejmie lub w Senacie następnej kadencji, o ile poseł lub senator, którego wniosek dotyczy, został wybrany na tę kadencję. Omawiana zasada ustanawia wyjątki od zasady dyskontynuacji prac parlamentu w odniesieniu do wniosków dotyczących immunitetu lub nietykalności. Zasada dyskontynuacji prac parlamentarnych oznacza, że „wszystkie sprawy, wnioski i przedłożenia, w których nie doszło do zamknięcia prac parlamentarnych, uważa się za ostatecznie załatwione w sensie niedojścia do

10 Warto podkreślić, że opisywany zbieg ochrony immunitetowej wynikającej z różnych podstaw prawnych nie stanowi wyjątku w systemie polskiego prawa. Innymi przykładami takiej sytuacji są: (1) zbieg ochrony immunitetowej wynikającej z art. 105 ust. 2 i 5 Konstytucji oraz art. 15 Porozumienia ogólnego w sprawie przywilejów i immunitetów Rady Europy w przypadku parlamentarzystów, którzy są członkami Zgromadzenia Parlamentarnego Rady Europu (zob. P. Chybalski, Opinia prawna w sprawie zakresu ochrony immunitetowej posła na Sejm wchodzącego w skład Zgromadzenia Parlamentarnego Rady Europy, 26 lutego 2009 r.; BAS-WAUiP-3557/08, niepubl., oraz (2) zbieg ochrony wynikającej z art. 88 ustawy z 23 grudnia 1994 r. o Najwyższej Izbie Kontroli (t.j. Dz.U. 2019, poz. 489, ze zm.) z art. 105 ust. 2 w związku z art. 108 Konstytucji i art. 6a u.w.m.p.s., w sytuacji gdy wniosek o pociągnięcie do odpowiedzialności karnej dotyczy parlamentarzysty, który w przeszłości pełnił funkcje prezesa, wiceprezesa, dyrektora generalnego NIK lub kontrolera, a stawiany zarzut dotyczy podejmowanych w ramach tych funkcji czynności służbowych. 
skutku. Nie są więc one w żadnej formie przekazywane nowemu parlamentowi"11 Analizowany przepis ma m.in. zastosowanie do wniosków o wyrażenie zgody na pociągnięcie parlamentarzysty do odpowiedzialności karnej za przestępstwa ścigane $\mathrm{z}$ oskarżenia publicznego (art. $7 \mathrm{~b}$ ust. 1 u.w.m.p.s.) oraz przestępstwa ścigane z oskarżenia prywatnego (art. 7b ust. 2 u.w.m.p.s.) w sytuacji, gdy inkryminowane działania wchodziły w zakres sprawowania mandatu i jednocześnie naruszały prawa osób trzecich, a także wniosków o wyrażenie zgody na pociągnięcie parlamentarzysty do cywilnej odpowiedzialności sądowej za działania wchodzące w zakres sprawowania mandatu parlamentarnego i jednocześnie naruszające prawa osób trzecich (art. 7b ust. 5 w związku z art. 6a u.w.m.p.s.). Nakaz kontynuacji postępowania $\mathrm{w}$ „nowej” izbie warunkowany jest m.in. odnowieniem mandatu przez parlamentarzystę, którego wniosek dotyczy. Wyłączenie zasady dyskontynuacji w takich wypadkach zwalnia wnioskodawców z konieczności ponownego składania wniosków po ukonstytuowaniu się izb w nowej kadencji. Prima facie art. 11 ust. 4 u.w.m.p.s. mógłby rodzić wątpliwość, czy zasada w nim zawarta może znaleźć zastosowanie do wniosków skierowanych do Sejmu „starej” kadencji w sytuacji, gdy dotychczasowy poseł uzyskał w wyborach do Senatu mandat senatora. Zgodzić należy się jednak z poglądem, że „będzie ona miała zastosowanie tylko w takiej sytuacji, w której poseł mijającej kadencji zostanie wybrany do Sejmu kolejnej kadencji i - analogicznie - gdy senator upływającej kadencji uzyska mandat senatorski w Senacie kolejnej kadencji”. Wniosek taki wynika jednak z wykładni językowej, nie zaś z tego, że „nie jest możliwe, by np. w Sejmie rozpatrywano wniosek dotyczący posła poprzedniej kadencji, który aktualnie sprawuje mandat senatorski"12. Brzmienie art. 11 ust. 4 u.w.m.p.s. wyraźnie wskazuje, że w opisanej sytuacji chodzi o kontynuację postępowania, które (verba legis) „nadal” ma się toczyć „w Sejmie lub w Senacie następnej kadencji, o ile poseł lub senator, którego wniosek dotyczy, został wybrany na tę kadencję". Składnia analizowanego zdania oraz użycie przysłówka „nadal” (tj. w dalszym ciągu) wskazuje, że chodzi o kontynuację toku postępowania w tej samej izbie, w której zostało ono zainicjowane. Odmienna wykładania dopuszczająca w nowej kadencji prowadzenie postępowania w sprawie wniosku w izbie innej niż zostało ono pierwotnie wszczęte prowadzić musiałaby do konstatacji, że ustawodawca nie unormował niezbędnych dla kontynuacji takiego postępowania zasad określających tryb przekazywania wniosków między izbami. Ich brak w praktyce uniemożliwiałby realizację tak odczytywanej dyspozycji i wskazywałby na istnienie luki w prawie.

Wnioski wynikające $\mathrm{z}$ analizy zakresu temporalnego immunitetu, o którym mowa w art. 105 ust. 1 zdanie drugie Konstytucji, przeczą tezie generalnie kwe-

11 L. Garlicki, Komentarz do art. 98 [w:] Konstytucja Rzeczypospolitej Polskiej. Komentarz, t. I, red. L. Garlicki, Warszawa 1999, s. 30.

12 K. Grajewski, Uwagi do art. 11 [w:] Komentarz do ustawy o wykonywaniu mandatu posła i senatora, red. K. Grajewski, Warszawa 2014, s. 175-176. 
stionującej możliwość rozpatrywania w Sejmie wniosków dotyczących senatorów (a także w Senacie wniosków dotyczących posłów). Sytuacja taka będzie miała miejsce w odniesieniu do sądowej odpowiedzialności cywilnej dotyczącej czynów naruszających prawa osoby trzeciej i popełnionych w przeszłości w ramach wykonywania mandatu członka drugiej izby, a także w odniesieniu do odpowiedzialności karnej za takie czyny w sytuacji zbiegu zakresów ochrony wynikających $\mathrm{z}$ art. 105 ust. 1 zdanie drugie oraz art. 105 ust. 2 Konstytucji. Jak już zasygnalizowano, w drugim przypadku warunkiem prowadzenia postępowania karnego przeciwko parlamentarzyście jest zgoda na ściganie wyrażona przez obie izby.

\section{Wniosek}

Komisja Regulaminowa, Spraw Poselskich i Immunitetowych Sejmu IX kadencji powinna na podstawie art. 11 ust. 4 u.w.m.p.s. kontynuować postępowanie w sprawie wniesionego w VIII kadencji wniosku z 28 lutego 2019 r. o wyrażenie zgody na pociągnięcie do odpowiedzialności cywilnej posłów XX, YY i ZZ w zakresie, w jakim wniosek ten dotyczy Pana YY - posła na Sejm IX kadencji. W pozostałym zakresie wniosek z 28 lutego 2019 r. zgodnie z art. 11 ust. 4 u.w.m.p.s. podlega zasadzie dyskontynuacji. W odniesieniu do Pana XX (byłego posła na Sejm VIII kadencji) oraz Pana Senatora ZZ (byłego posła na Sejm VIII kadencji, a obecnie Senatora IX kadencji) pociągnięcie do cywilnej odpowiedzialności sądowej w sprawie, której dotyczył wniosek z 28 lutego 2019 r., wymaga złożenia przez wnioskodawcę ponownego wniosku na ręce Marszałka Sejmu.

\section{Bibliografia}

Chybalski P., Opinia prawna w sprawie zakresu ochrony immunitetowej posła na Sejm wchodzacego w skład Zgromadzenia Parlamentarnego Rady Europy, 26 lutego 2009 r.; BAS-WAUiP-3557/08, niepubl.

Garlicki L., Komentarz do art. 98 [w:] Konstytucja Rzeczypospolitej Polskiej. Komentarz, t. I, red. L. Garlicki, Warszawa 1999.

Gierach E., Komentarz do art. 105 [w:] Konstytucja RP. Komentarz, t. II, Art. 87-243, red. M. Safjan, L. Bosek, Warszawa 2016.

Grajewski K., Komentarz do art. 6a [w:] K. Grajewski, J. Stelina, P. Uziębło, Komentarz do ustawy o wykonywaniu mandatu posła i senatora, Warszawa 2014.

Grajewski K., Odpowiedzialność posłów i senatorów na tle zasady mandatu wolnego, Warszawa 2009.

Grajewski K., Uwagi do art. 11 [w:] Komentarz do ustawy o wykonywaniu mandatu posła i senatora, red. K. Grajewski, Warszawa 2014. 

\begin{tabular}{l|l}
2 & OPINIE BAS
\end{tabular}

VARIA 

Natalia Podraza

\title{
Społeczny oraz prawny obowiązek zawiadomienia o przestępstwie ściganym z urzędu'
}

\author{
Social and legal obligation to notify about an offense prosecuted ex officio
}

Pursuant to the Code of Penal Procedure, any person, upon having learned about the commission of a crime prosecuted ex officio, bears a social obligation to notify a Public Prosecutor or the Police about it. In case of certain crimes that social obligation is transformed into a legal one concerning an immediate notification to law enforcement authorities about the commission, attempt or preparation of any of these crimes. Failure to fulfil the legal obligation to notify law enforcement authorities shall result in committing a crime punishable by up to 3 years'imprisonment.

Keywords: Criminal Code, Code of Criminal Procedure, crime

Zgodnie z Kodeksem postępowania karnego każda osoba, dowiedziawszy się o popełnieniu przestępstwa ściganego z urzędu, ma społeczny obowiązek zawiadomienia o tym prokuratora lub Policję. Wobec niektórych przestępstw społeczny obowiązek ulega przekształceniu w prawny obowiązek niezwłocznego zawiadomienia organów ścigania o ich popełnieniu, usiłowaniu lub przygotowaniu. Zaniechanie wypełnienia prawnego obowiązku zawiadomienia organów ścigania powoduje popełnienie przestępstwa zagrożonego karą do 3 lat pozbawienia wolności.

Słowa kluczowe: Kodeks karny, Kodeks postępowania karnego, przestępczość

Doktorantka .

Uniwersytet Warszawski, Wydział Prawa i Administracji •

natalia.podraza@sejm.gov.pl . https://orcid.org/0000-0001-9817-7696

\section{Przedmiot opinii}

Przedmiotem opinii prawnej jest odpowiedź na następujące pytanie: „czy pracodawca po powzięciu informacji o możliwości popełnienia czynu zabronionego z art. 183a $₫ 6$ Kodeksu pracy lub art. $197 \$ 1-4$ Kodeksu karnego (poprzez złożenie skargi pisemnej przez pracownika) jest obowiązany zawiadomić organy ścigania o podejrzeniu popełnienia czynu zabronionego?”.

W opinii uwzględniono stan prawny na dzień jej sporząadzenia.

Niniejsza opinia nie odnosi się do konkretnego stanu faktycznego, lecz stanowi analizę stanu prawnego pod kątem problemów sformułowanych w pytaniu.

1 Opinia prawna dotycząca społecznego oraz prawnego obowiązku zawiadomienia o przestępstwie ściganym z urzędu sporządzona 7 września 2020 r. na zlecenie posła Klubu Parlamentarnego Koalicja Polska - Polskie Stronnictwo Ludowe - Kukiz15; BAS-WAP-1837/20. 
Przedstawione w niej stanowisko nie wiąże ani organów władzy publicznej, ani innych podmiotów.

W opinii uwzględniono regulacje następujących aktów prawnych:

- ustawa z 6 czerwca 1997 r. - Kodeks karny, t.j. Dz.U. 2020, poz. 1444; dalej: Kodeks karny lub k.k.,

- ustawa z 6 czerwca 1997 r. - Kodeks postępowania karnego, t.j. Dz.U. 2020, poz. 30, ze zm.; dalej: Kodeks postępowania karnego lub k.p.k.

\section{Uzasadnienie}

Zgodnie z art. 303 k.p.k. „Jeżeli zachodzi uzasadnione podejrzenie popełnienia przestępstwa, wydaje się z urzędu lub na skutek zawiadomienia o przestępstwie postanowienie o wszczęciu śledztwa”. Prawna dopuszczalność wszczęcia postępowania karnego uzależniona jest od występowania w określonych okolicznościach faktycznych takiego zespołu danych, który obiektywnie wywołuje prawdopodobieństwo popełnienia przestępstwa, natomiast $\mathrm{u}$ organu uprawnionego do ścigania przestępstw subiektywne przekonanie o wysokim stopniu podejrzenia jego popełnienia ${ }^{2}$. Informacje dotyczące możliwości popełnienia czynu zabronionego mogą pochodzić z różnych źródeł. W literaturze procesu karnego wskazuje się, że organy ścigania mogą posiadać informacje o możliwości popełnienia przestępstwa pochodzące z działalności własnej, która ukierunkowana jest na wykrywanie przestępstw i ściganie ich sprawców, jak również ze składanych przez określone podmioty, m.in. osoby fizyczne, w tym szczególności pokrzywdzonych, zawiadomień o możliwości popełnienia przestępstwa ${ }^{3}$.

Jak stwierdza J. Żylińska „w praktyce karno-procesowej najpowszechniejszym zewnętrznym źródłem informacji o przestępstwie jest zawiadomienie o przestępstwie” ${ }^{4}$. Zgodnie z art. $304 \$ 1$ k.p.k. „każdy, dowiedziawszy się o popełnieniu przestępstwa ściganego z urzędu, ma społeczny obowiązek zawiadomić o tym prokuratora lub Policję". Ustawodawca nakłada zatem na każdą osobę, która dowiedziała się o popełnieniu przestępstwa ściganego z urzędu, społeczny obowiązek o jego zawiadomieniu.

Instytucje państwowe i samorządowe mają natomiast prawny obowiązek niezwłocznego zawiadomienia o przestępstwie prokuratora lub Policję, a ponadto obowiązane są do przedsięwzięcia niezbędnych czynności do czasu przybycia organu powołanego do ścigania przestępstw lub do czasu wydania przez ten organ

2 T. Grzegorczyk, J. Tylman, Polskie postępowanie karne, Warszawa 2009, s. 610.

3 J. Łupiński, Społeczny obowiązek zawiadomienia o przestępstwie, „Prokuratura i Prawo" 2009, nr 1, s. 129-130.

4 J. Żylińska, Prawny obowiązek zawiadomienia o niektórych przestępstwach (art. 240 k.k.), „Prokuratura i Prawo” 2015, nr 10, s. 47. 
stosownego zarządzenia, aby nie dopuścić do zatarcia śladów i dowodów przestępstwa (art. $304 \$ 2$ k.p.k.). Brak wywiązania się z tego obowiązku przez instytucje państwowe i samorządowe może skutkować odpowiedzialnością karną osób odpowiedzialnych na podstawie art. 231 k.k. - wobec działania na szkodę interesu publicznego ${ }^{5}$.

Społeczny obowiązek zawiadomienia o przestępstwie ściganym z urzędu często interpretowany jest jako „społeczne uprawnienie”, ponieważ jego niewypełnienie (tj. niezawiadomienie mimo posiadanej wiedzy) nie jest związane z żadną sankcją natury karnej. Jedyne konsekwencje wobec osoby związane mogą być ewentualnie $\mathrm{z}$ odpowiedzialnością społeczną, a mianowicie z publicznym potępieniem jej zachowania polegającego na zaniechaniu zawiadomienia ${ }^{6}$.

Zawiadomienie o przestępstwie może zostać złożone w formie ustnej lub pisemnej. Zgodnie z art. $143 \$ 1$ k.p.k. przyjęcie ustnego zawiadomienia o przestępstwie wymaga spisania protokołu, natomiast na podstawie art. 304a k.p.k. „sporządza się wspólny protokół z przyjęcia ustnego zawiadomienia o przestępstwie i przesłuchania w charakterze świadka osoby zawiadamiającej”. Za zawiadomienie o możliwości popełnienia przestępstwa uznaje się także notatkę urzędową czy pismo zawiadamiające ${ }^{7}$.

Społeczny obowiązek zawiadomienia o przestępstwie powstaje wraz z momentem powzięcia przez osobę „wiedzy o jego popełnieniu”. Jak wskazuje J. Łupiński, „chodzi tutaj o «wiedzę» w rozumieniu ogółu wiarygodnych wiadomości o konkretnym zdarzeniu przestępczym, w świetle których popełnienie przestępstwa nie budzi wątpliwości, czy też o «dowiedzenie się» o popełnionym przestępstwie w znaczeniu uzyskania ogólnych informacji o przestępstwie i przekazanie ich organowi ścigania bez potrzeby ich obiektywizowania, wstępnego weryfikowania i oceniania przez zawiadamiającego" ${ }^{8}$. Wobec tego, wystarczające jest aby zawiadamiający przewidywał, że przekazywane przez niego organom ścigania informacje o popełnieniu przestępstwa są prawdziwe - mogą pochodzić one zatem z niesprawdzonych pogłosek czy podejrzeń ${ }^{9}$. Do przekroczenia granic społecznego obowiązku zawiadomienia o możliwości popełnienia przestępstwa będzie dochodzić natomiast w sytuacji, gdy zawiadamiający świadomie podnosi nieprawdziwe zarzuty popełnienia przestępstwa przez wskazaną przez niego osobę $^{10}$. Ponadto składanie przez osobę świadomie nieprawdziwego zawiado-

W. Grzeszczyk, Kodeks postępowania karnego. Komentarz, Warszawa 2005, s. 268.

6 M. Kurowski, Art. 304 [w:] Kodeks postępowania karnego, t. I, Komentarz aktualizowany, 2020, LEX.

7 L. Wilk, Obowiązek denuncjacji w prawie karnym (art. 240 k.k.), „Prokuratura i Prawo” 1999, nr 1, s. 21.

8 J. Łupiński, Społeczny obowiazek, op. cit., s. 140.

$9 \quad$ Ibidem.

10 S. Cora, Z problematyki zawiadomienia o przestępstwie, „Gdańskie Studia Prawnicze” 2003, t. XI, s. 266. 
mienia o popełnieniu przestępstwa może spowodować możliwość poniesienia przez nią odpowiedzialności karnej z art. 238 k.k. (fałszywe zawiadomienie) lub z art. 234 k.k. (fałszywe oskarżenie) ${ }^{11}$.

Określony w art. 304 k.p.k. społeczny obowiązek zawiadomienia o przestępstwie podlega ochronie prawnej z art. 148a k.p.k. oraz 156a k.p.k. Odpowiednie stosowanie art. 148a k.p.k. powoduje po stronie organu procesowego konieczność anonimizacji zawiadomienia o przestępstwie w zakresie, w jakim umożliwia ono dokonanie ustalenia miejsca zamieszkania lub miejsca zatrudnienia osoby zawiadamiającej. Organ procesowy obowiązany jest umieścić te dane oraz oryginały dokumentów w oddzielnym załączniku adresowym akt sprawy. Dane te mogą zostać udostępnione wyłącznie na wniosek organów państwowych oraz organów samorządu terytorialnego, jeżeli jest to niezbędne dla wykonywania ustawowych zadań tych organów lub na wniosek innych instytucji i osób, jeżeli przemawia za tym ich ważny interes ${ }^{12}$.

W kwestii ochrony prawnej pracownika składającego zawiadomienie o popełnieniu przestępstwa Sąd Najwyższy w wyroku z 2 września 2003 r. wskazał, że „przekazanie przez pracownika organom ścigania kopii dokumentów, potwierdzających złożone w trybie art. $304 \$ 1$ k.p.k. doniesienie o popełnieniu przestępstwa przez członków zarządu pracodawcy, w sytuacji, gdy istniały uzasadnione podstawy do złożenia doniesienia, nie jest naruszeniem podstawowych obowiązków pracowniczych"13.

Społeczny obowiązek zawiadomienia o popełnieniu przestępstwa wyłączony jest wobec przestępstw z oskarżenia prywatnego, przestępstw ściganych na wniosek pokrzywdzonego oraz niektórych podmiotów, tj.:

- adwokata - obrońcy lub adwokata niebędącego obrońcą osoby - który informację o popełnieniu przestępstwa uzyskał w związku ze świadczoną pomocą $\operatorname{prawną}^{14}$,

11 Zgodnie z art. 238 k.k. „Kto zawiadamia o przestępstwie, lub o przestępstwie skarbowym organ powołany do ścigania wiedząc, że przestępstwa nie popełniono, podlega grzywnie, karze ograniczenia wolności albo pozbawienia wolności do lat 2", natomiast stosownie do art. 234 k.k. „Kto, przed organem powołanym do ścigania lub orzekania w sprawach o przestępstwo, w tym i przestępstwo skarbowe, wykroczenie, wykroczenie skarbowe lub przewinienie dyscyplinarne, fałszywie oskarża inną osobę o popełnienie tych czynów zabronionych lub przewinienia dyscyplinarnego, podlega grzywnie, karze ograniczenia wolności albo pozbawienia wolności do lat 2".

12 B. Skowron, Art. 304 [w:] Kodeks postępowania karnego. Komentarz, Warszawa 2018.

13 Wyrok Sądu Najwyższego z 2 września 2003 r., sygn. akt I PK 389/02, OSNP 2004/18/309.

14 Zgodnie z art. 6 ust. 1 ustawy z 26 maja 1982 r. - Prawo o adwokaturze (t.j. Dz.U. 2019, poz. 1513, ze zm.) „Adwokat obowiązany jest zachować w tajemnicy wszystko, o czym dowiedział się w związku z udzielaniem pomocy prawnej”, a ponadto zgodnie z postanowieniem Sądu Apelacyjnego w Krakowie z 10 maja 2000 r., sygn. akt II AKz 
- duchownego, który o popełnieniu przestępstwa dowiedział się podczas spowiedzi (zgodnie z art. 178 pkt 2 k.p.k.),

- osób wykonujących czynności na podstawie ustawy z 19 sierpnia 1994 r. o ochronie zdrowia psychicznego, t.j. Dz.U. 2020, poz. $685^{15}$,

- Prezesa Instytutu Pamięci Narodowej - Komisji Ścigania Zbrodni przeciwko Narodowi Polskiemu, w związku z wykonywaniem zadań określonych w ustawie z 18 grudnia 1998 r. o Instytucie Pamięci Narodowej - Komisji Ścigania Zbrodni przeciwko Narodowi Polskiemu, t.j. Dz.U. 2019, poz. 1882, ze zm. ${ }^{16}$. Wobec niektórych przestępstw, które enumeratywnie wymienione zostały $\mathrm{w}$ art. $240 \$ 1$ k.k., społeczny obowiązek ulega przekształceniu w prawny obowiązek niezwłocznego zawiadomienia organów ścigania o ich popełnieniu (usiłowaniu lub przygotowaniu). Niewykonanie nałożonego obowiązku powoduje możliwość pociągnięcia osoby do odpowiedzialności karnej z art. $240 \$ 1$ k.k., który zagrożony jest karą do 3 lat pozbawienia wolności.

Prawny obowiązek zawiadomienia obejmuje następujące przestępstwa:

- ludobójstwo (art. 118 k.k.),

- udział w masowym zamachu (art. 118a k.k.),

- stosowanie środków masowej zagłady (art. 120 k.k.),

- wytwarzanie, gromadzenie lub obrót środkami masowej zagłady lub środkami walki (art. 121 k.k.),

- stosowanie niedopuszczalnych przez prawo międzynarodowe sposobów lub środków walki (art. 122 k.k.),

- zamach na życie lub zdrowie jeńców wojennych lub ludności cywilnej (art. 123 k.k.),

- inne przestępnego naruszenia prawa międzynarodowego (art. 124 k.k.),

- publiczne nawoływania do popełnienia przestępstw przeciwko pokojowi, ludzkości oraz przestępstw wojennych lub ich publiczne pochwalanie,

96/00, LEX nr 41723 „Zakaz dowodowy z art. 178 pkt 1 k.p.k. obejmuje wszystkie fakty, o których obrońca powziął wiadomość, pełniąc swą funkcję".

15 Zgodnie $\mathrm{z}$ art. 50 ust. 1 oraz 52 ust. 1 ustawy o ochronie zdrowia psychicznego „osoby wykonujące czynności wynikające z niniejszej ustawy są obowiązane do zachowania w tajemnicy wszystkiego, o czym powezmą wiadomość w związku z wykonywaniem tych czynności, a ponadto nie wolno ich przesłuchiwać jako świadków na okoliczność wypowiedzi osoby, wobec której podjęto czynności wynikające z niniejszej ustawy, co do popełnienia przez nią czynu zabronionego pod groźbą kary”.

16 Zgodnie z art. 40 ustawy o Instytucie Pamięci Narodowej - Komisji Ścigania Zbrodni przeciwko Narodowi Polskiemu „Jeżeli Prezes Instytutu Pamięci, w związku z wykonywaniem swoich zadań, stwierdzi, że w dokumentach znajdują się informacje o przestępstwach określonych $\mathrm{w}$ art. 5 ust. 1 pkt 2 ustawy z dnia 24 maja 2002 r. o Agencji Bezpieczeństwa Wewnętrznego oraz Agencji Wywiadu, zawiadamia o tym bezzwłocznie Szefa Agencji Bezpieczeństwa Wewnętrznego. Przepisu art. 304 Kodeksu postępowania karnego nie stosuje się". 
- zamach stanu (art. 127 k.k.),

- zamach na konstytucyjny organ RP (art. 128 k.k.),

- szpiegostwo (130 k.k.),

- zamach na życie prezydenta RP (art. 134 k.k.),

- zamach na jednostkę sił zbrojnych RP (art. 140 k.k.),

- zabójstwo (art. 148 k.k.),

- spowodowanie ciężkiego uszczerbku na zdrowiu (art. 156 k.k.),

- sprowadzenie niebezpieczeństwa powszechnego (art. 163 k.k.),

- zawładnięcie statkiem wodnym lub powietrznym - piractwo (art. 166 k.k.),

- bezprawne pozbawienia wolności (art. 189 k.k.),

- zgwałcenie wspólnie z inną osobą wobec małoletniego poniżej lat 15 lub wobec wstępnego, zstępnego, przysposobionego, przysposabiającego, brata lub siostry (art. $197 \$ 3$ k.k.),

- zgwałcenie ze szczególnym okrucieństwem (art. $197 \$ 4$ k.k.),

- seksualne wykorzystanie niepoczytalności lub bezradności (art. 198 k.k.),

- seksualne wykorzystanie nieletniego (art. 200 k.k.),

- wzięcie zakładnika (art. 252 k.k.)

- przestępstwo o charakterze terrorystycznym (w rozumieniu art. $115 \$ 20$ k.k. $\left.{ }^{17}\right)$.

Przestępstwo z art. $240 \$ 1$ k.k. ma charakter powszechny, jednakże, jak wskazuje się w judykaturze, czyn ten „penalizuje zachowania nie sprawców przestępstwa pierwotnego [tj. przestępstwa, którego dotyczy obowiązek denuncjacji dopisek N.P.] czy sprawców, którzy informując organy ścigania o popełnionym przestępstwie katalogowym mogliby narazić się na odpowiedzialność karną z powodu popełnienia jakiegokolwiek innego przestępstwa, pozostającego w ścisłym związku z przestępstwem pierwotnym, lecz osób, które w żaden sposób nie uczestniczyły w popełnieniu przestępstwa, a mają wiarygodną wiadomość o karalnym przygotowaniu albo usiłowaniu lub dokonaniu przestępstwa wymienionego $\mathrm{w}$ art. $240 \$ 1$ k.k. i nie zawiadamiają niezwłocznie organu powołanego do ścigania przestępstw"18. Od strony znamion podmiotowych przestępstwo

17 Przestępstwem o charakterze terrorystycznym jest czyn zabroniony zagrożony karą pozbawienia wolności, której górna granica wynosi co najmniej 5 lat, popełniony w celu: poważnego zastraszenia wielu osób, zmuszenia organu władzy publicznej Rzeczypospolitej Polskiej lub innego państwa albo organu organizacji międzynarodowej do podjęcia lub zaniechania określonych czynności, wywołania poważnych zakłóceń w ustroju lub gospodarce Rzeczypospolitej Polskiej, innego państwa lub organizacji międzynarodowej - a także groźba popełnienia takiego czynu.

18 Wyrok Sądu Apelacyjnego w Lublinie z 5 lutego 2009 r., sygn. akt II AKa 3/09, KZS 2009/5/59. Zob. także: wyrok Sądu Apelacyjnego w Białymstoku z 20 stycznia 2005 r., sygn. akt II AKa 345/04, OSAB 2005/3/43, wyrok Sądu Apelacyjnego w Krakowie z 21 października 2004 r., sygn. akt II AKa 200/04, LEX nr 143011. 
to może zostać popełnione wyłącznie umyślnie, w zamiarze bezpośrednim lub ewentualnym ${ }^{19}$.

Prawny obowiązek dokonania niezwłocznego zawiadomienia o przestępstwie powstaje w sytuacji, gdy informacja o jego popełnieniu (przygotowaniu lub usiłowaniu) cechuje się przymiotem wiarygodności. Niemniej przekonanie o wiarygodności informacji nie musi graniczyć z pewnością (zakładając, że wiarygodna w ocenie zawiadamiającego wiadomość w praktyce nie musi być prawdziwa), a wystarczające jest stwierdzenie takiego stopnia uprawdopodobnienia, który u rozsądnie oceniającego fakty człowieka wywołuje podejrzenie jego popełnienia, np. znalezienie zmasakrowanych ludzkich zwłok czy usłyszenie rozmowy dotyczącej planowania zamachu ${ }^{20}$. Osoba zawiadamiająca nie ma obowiązku szczegółowego weryfikowania wiadomości i nie będzie ponosić odpowiedzialności karnej z art. 238 k.k. (fałszywe zawiadomienie) w sytuacji, gdy nie doszło do popełnienia przestępstwa, mimo że okoliczności uzasadniały jego popełnienie ${ }^{21}$.

Obowiązek zawiadomienia o popełnieniu przestępstwa wymienionego w art. $240 \$ 1$ k.k. powinien zostać dokonany „niezwłocznie” - a więc w możliwie jak najkrótszym możliwym terminie od momentu powzięcia wiarygodnej informacji o popełnieniu czynu (bez zbędnej zwłoki) ${ }^{22}$. Jak trafnie zwracają uwagę M. Szewczyk, A. Wojtaszczyk, W. Zontek, „[w]ystępek opisany w art. $240 \$ 1$ jest przestępstwem formalnym z zaniechania, przy czym zestawienie obowiązku denuncjacji z koniecznością jego niezwłocznego wykonania oznacza, że ów występek może zostać dokonany nie tylko w sytuacji, gdy obowiązek denuncjacji nie zostaje spełniony w ogóle albo zostaje spełniony częściowo (tzn. nie dochodzi do przekazania żadnych informacji albo informacje zostają przekazane w węższym zakresie niż wymaga tego ustawa), lecz także w wypadku, gdy obowiązek taki zostaje spełniony, lecz nie w sposób niezwłoczny (tzn. zawiadomienie nie zostało

19 M. Szewczyk, A. Wojtaszczyk, W. Zontek, Art. 240 [w:] Kodeks karny. Część szczególna, t. II, cz. II, Komentarz do art. art. 212-277d, red. W. Wróbel, A. Zoll, Warszawa 2017. Wskazać należy, że zgodnie z wyrokiem Sądu Apelacyjnego we Wrocławiu z 27 czerwca 2019 r., sygn. akt II AKa 393/18, LEX nr 2704593 „zamiar bezpośredni polega na chęci realizacji wszystkich znamion czynu zabronionego przez sprawcę, to jest na podjęciu aktu woli obejmującego pewną realizację tych znamion, o tyle zamiar ewentualny (wynikowy) charakteryzuje się tym, że sprawca ma wyobrażenie określonego celu karalnego lub niekaralnego, i dążąc do jego osiągnięcia ma świadomość prawdopodobieństwa wyczerpania znamion czynu zabronionego, jednak niejako z góry akceptuje wszelkie skutki, które mogą powstać w związku z realizacją tego celu”. M. Banaś-Grabek, Art. 240 [w:] M. Banaś-Grabek, B. Gadecki, J. Karnat, Kodeks karny. Część szczególna. Art. 148-251. Komentarz, Warszawa 2020.

21 Ibidem.

22 T. Razowski, Art. 240 [w:] Kodeks karny. Część szczególna. Komentarz, red. J. Giezek, 2014, LEX. 
dokonane bez nieuzasadnionej zwłoki)"23. Wobec tego, niedochowanie wymogu „niezwłoczności” będzie skutkować odpowiedzialnością karną z art. $240 \$ 1$ k.k.

Adresatem zawiadomienia o przestępstwie musi być organ powołany do ścigania przestępstw ${ }^{24}$, lecz może ono zostać złożone w dowolnej formie. Ponadto brak jest wymogów co do jego szczegółowej treści. Zawiadomienie o przestępstwie może zatem ograniczać się do wskazania informacji odnoszących się do okoliczności czynu oraz ewentualnych osób, które brały w nim udział ${ }^{25}$. Ponadto, jak wskazał Sąd Najwyższy w wyroku z 12 października 2006 r., „Każdy skuteczny sposób zawiadomienia organów ścigania powinien być uznany za zadośćuczynienie obowiązkowi. Także więc anonimowe zawiadomienie czyni zadość obowiązkowi z art. $240 \$ 1$ k.k." ${ }^{26}$.

Prawny obowiązek denuncjacji jest wyłączony wobec osób, które zaniechały zawiadomienia, mając dostateczną podstawę do przypuszczenia, że organ powołany do ścigania przestępstw wie o przygotowywanym, usiłowanym lub dokonanym czynie zabronionym. Przestępstwa z art. $240 \$ 1$ k.k. nie popełniają także osoby, które zapobiegły popełnieniu przygotowywanego lub usiłowanego czynu zabronionego (art. $240 \$ 2$ k.k.). Dostateczną podstawą do przypuszczenia, że organ ścigania wie o przestępstwie będzie m.in. popełnienie przestępstwa w miejscu publicznym czy też obecność funkcjonariuszy publicznych podczas zdarzenia objętego obowiązkiem denuncjacji ${ }^{27}$. Natomiast do wyłączenia karalności za czyn z art. $240 \$ 1$ k.k. (ale już nie bezprawności czynu) dochodzi wobec pokrzywdzonego (art. $240 \$ 2$ a k.k.) oraz w sytuacji, gdy uchylenie się osoby od obowiązku zawiadomienia wynikało z obawy przed odpowiedzialnością karną grożącą jemu samemu lub jego najbliższym (art. $240 \$ 3$ k.k.). Bezkarność na czyn zabroniony mimo jego popełnienia wynika z tego, że prawo nie może wymagać od sprawcy czynu zabronionego samooskarżenia czy dostarczania dowodów przeciwko sobie lub najbliższym osobom ${ }^{28}$ (zgodnie z określoną w art. $74 \$ 1$ k.p.k. zasadą nemo se ipse accusare tenetur ${ }^{29}$ ).

23 M. Szewczyk, A. Wojtaszczyk, W. Zontek, Art. 240, op. cit.

Organem ścigania w Polsce jest w szczególności Prokuratura oraz Policja, lecz także m.in. Żandarmeria Wojskowa, Straż Graniczna, Centralne Biuro Antykorupcyjne, Agencja Bezpieczeństwa Wewnętrznego czy Służba Celno-Skarbowa.

25 J. Żylińska, Prawny obowiązek, op. cit., s. 55.

26 Wyrok Sądu Najwyższego Izba Karna z 12 października 2006 r., sygn. akt IV KK 247/06, OSNwSK 2006, nr 1, poz. 1961.

27 A. Marek, Art. 240 [w:] Kodeks karny. Komentarz, 2010, LEX.

28 Ibidem.

29 Zgodnie z art. $74 \$ 1$ k.p.k. „Oskarżony nie ma obowiązku dowodzenia swej niewinności ani obowiązku dostarczania dowodów na swoją niekorzyść”. 


\section{Bibliografia}

Banaś-Grabek M., Art. 240 [w:] M. Banaś-Grabek, B. Gadecki, J. Karnat, Kodeks karny. Część szczególna. Art. 148-251. Komentarz, Warszawa 2020.

Cora S., Z problematyki zawiadomienia o przestępstwie, „Gdańskie Studia Prawnicze” 2003 , t. XI.

Grzegorczyk T., Tylman J., Polskie postępowanie karne, Warszawa 2009.

Grzeszczyk W., Kodeks postępowania karnego. Komentarz, Warszawa 2005.

Kurowski M., Art. 304 [w:] Kodeks postępowania karnego, t. I, Komentarz aktualizowany, 2020, LEX.

Łupiński J., Społeczny obowiązek zawiadomienia o przestępstwie, „Prokuratura i Prawo” 2009, nr 1.

Marek A., Art. 240 [w:] Kodeks karny. Komentarz, 2010, LEX.

Razowski T., Art. 240 [w:] Kodeks karny. Czesść szczególna. Komentarz, red. J. Giezek, 2014, LEX.

Skowron B., Art. 304 [w:] Kodeks postępowania karnego. Komentarz, Warszawa 2018.

Szewczyk M., Wojtaszczyk A., Zontek W., Art. 240 [w:] Kodeks karny. Czesść szczególna, t. II, cz. II, Komentarz do art. art. 212-277d, red. W. Wróbel, A. Zoll, Warszawa 2017.

Wilk L., Obowiązek denuncjacji w prawie karnym (art. 240 k.k.), „Prokuratura i Prawo” 1999, nr 1 .

Żylińska J., Prawny obowiązek zawiadomienia o niektórych przestępstwach (art. 240 k.k.), „Prokuratura i Prawo” 2015, nr 10. 


\title{
Dorota Dzienisiuk
}

\section{Możliwość zawarcia umowy o pracę przez osobę ubezwłasnowolnioną całkowicie lub przez jej opiekuna prawnego $^{1}$}

\author{
Admissibility of concluding an employment contract by a completely \\ legally incapacitated person or through the legal guardian
}

\begin{abstract}
According to the author, it should be recognized that it is admissible to conclude an employment contract, to which a completely incapacitated person would be a party. In such a case, the contract should be concluded by a guardian of such a person. Employment of a totally legally incapacitated person should meet the requirements of the Act on Vocational and Social Rehabilitation and Employment of Disabled Persons, including those relating to the performance of work in sheltered employment conditions or in a position adapted by the employer to the needs of such person. The assessment of the admissibility of employing a completely legally incapacitated person in a kindergarten as a janitor should be performed assessing each case individually, taking into account the cause of incapacitation and the scope of facilitations introduced by the employer.
\end{abstract}

Keywords: labour law, natural person, disabled persons

Zdaniem autorki należy uznać, że możliwe jest zawarcie umowy o pracę, której stroną byłaby osoba ubezwłasnowolniona całkowicie. Umowę w takim wypadku zawiera opiekun osoby ubezwłasnowolnionej. Zatrudnienie takiej osoby powinno odpowiadać wymogom ustawy o rehabilitacji zawodowej i społecznej oraz zatrudnianiu osób niepełnosprawnych, w tym dotyczącym wykonywania pracy w warunkach pracy chronionej lub na stanowisku pracy przystosowanym przez pracodawcę do jej potrzeb. Ocena dopuszczalności zatrudnienia osoby ubezwłasnowolnionej całkowicie w przedszkolu na stanowisku woźnego powinna być przeprowadzana indywidualnie, z uwzględnieniem przyczyny ubezwłasnowolnienia i zakresu udogodnień wprowadzonych przez pracodawcę.

Słowa kluczowe: prawo pracy, osoba fizyczna, osoba ubezwłasnowolniona

Doktor hab. nauk prawnych, adiunkt -

Uniwersytet Warszawski, Wydział Prawa i Administracji, Katedra Prawa Ubezpieczeń,

WARSZAWA, POLSKA -

d.dzienisiuk@wpia.uw.edu.pl • https://orcid.org/0000-0002-0543-9114

1 Opinia prawna dotyczaca możliwości zawarcia umowy o pracę przez osobę ubezwłasnowolniona całkowicie lub poprzez jej opiekuna prawnego sporządzona 12 czerwca 2020 r. na zlecenie posła Koalicyjnego Klubu Parlamentarnego Lewicy (Razem, Sojusz Lewicy Demokratycznej, Wiosna Roberta Biedronia); BAS-WAP-986/20. 


\section{Przedmiot opinii}

Przedmiotem opinii jest poszukiwanie odpowiedzi na pytanie: „czy w świetle obowiązujących przepisów (m.in. ustawy z 27 sierpnia 1997 r. o rehabilitacji zawodowej i społecznej osób niepełnosprawnych) jest możliwe zawarcie umowy o pracę przez osobę ubezwłasnowolnioną całkowicie lub poprzez jego opiekuna prawnego? Chodzi o pracę na $1 \frac{1}{2}$ etatu jako woźnego w przedszkolu samorządowym”.

\section{Regulacja prawna dotycząca zdolności prawnej pracowników}

Zagadnienie, które stanowi temat niniejszej opinii, należy do najbardziej spornych w doktrynie prawa pracy od czasu uchwalenia Kodeksu pracy w 1974 r. ze względu na brzmienie i układ przedstawionych poniżej przepisów. Na ten temat wypowiadane są poglądy, które wzajemnie się wykluczają.

Podstawowym aktem prawnym określającym prawa i obowiązki pracowników i pracodawców jest ustawa z 26 czerwca 1974 r. - Kodeks pracy (t.j. Dz.U. 2019, poz. 1040, ze zm.; dalej: Kodeks pracy lub k.p.). Jeżeli stosunek pracy określonej kategorii pracowników regulują przepisy szczególne, przepisy Kodeksu pracy stosuje się w zakresie nieuregulowanym tymi przepisami (art. 5 k.p.). Dotyczy to m.in. ustawy z 27 sierpnia 1997 r. o rehabilitacji zawodowej i społecznej oraz zatrudnianiu osób niepełnosprawnych (t.j. Dz.U. 2020, poz. 426, ze zm.; dalej: ustawa o rehabilitacji).

Zgodnie $\mathrm{z}$ art. 300 k.p. w sprawach nieunormowanych przepisami prawa pracy do stosunku pracy stosuje się odpowiednio przepisy Kodeksu cywilnego, jeżeli nie są one sprzeczne $\mathrm{z}$ zasadami prawa pracy.

Na podstawie art. $8 \$ 1$ ustawy z 23 kwietnia 1964 r. - Kodeks cywilny (t.j. Dz.U. 2019, poz. 1145, ze zm.; dalej: Kodeks cywilny lub k.c.) każdy człowiek od chwili urodzenia ma zdolność prawną, czyli może być stroną stosunków prawnych. Zdolność do dokonywania czynności prawnych, czyli działania w obrocie prawnym, jest uregulowana w kolejnych przepisach Kodeksu cywilnego. Rozróżnia się pełną zdolność do czynności prawnych i ograniczoną zdolność do czynności prawnych.

Pełną zdolność do czynności prawnych nabywa się z chwilą uzyskania pełnoletności (art. 11 k.c.). Ograniczoną zdolność do czynności prawnych mają małoletni, którzy ukończyli lat trzynaście, oraz osoby ubezwłasnowolnione częściowo (art. 15 k.c.). Nie mają zdolności do czynności prawnych osoby, które nie ukończyły lat trzynastu, oraz osoby ubezwłasnowolnione całkowicie. Osoba, która ukończyła lat trzynaście, może być ubezwłasnowolniona całkowicie, jeżeli wskutek choroby psychicznej, niedorozwoju umysłowego albo innego rodzaju zaburzeń psychicznych, w szczególności pijaństwa lub narkomanii, nie jest w stanie kierować swym postępowaniem. Dla ubezwłasnowolnionego całkowicie ustana- 
wia się opiekę, chyba że pozostaje on jeszcze pod władzą rodzicielską. Czynność prawna dokonana przez osobę, która nie ma zdolności do czynności prawnych, jest nieważna (art. 12-14 k.c.).

Na podstawie art. $22 \$ 2$ k.p. pracownikiem może być osoba, która ukończyła 18 lat. Na warunkach określonych w dziale dziewiątym (o zatrudnianiu młodocianych, czyli osób, które ukończyły 15 lat, a nie przekroczyły 18 lat) pracownikiem może być również osoba, która nie ukończyła 18 lat. Ponadto w art. $304^{5}$ k.p. uregulowano wykonywanie pracy lub innych zajęć zarobkowych przez dziecko do ukończenia przez nie 16. roku życia (za zezwoleniem właściwego inspektora pracy). Przepisy te uzależniają od wieku tzw. zdolność pracowniczą lub pracowniczą zdolność prawną, czyli zdolność do występowania w stosunkach pracy w charakterze pracownika. Nie wprowadzają dodatkowych warunków, w szczególności dotyczących zdolności do czynności prawnych.

Na podstawie art. $22 \$ 3$ k.p. osoba ograniczona w zdolności do czynności prawnych może bez zgody przedstawiciela ustawowego nawiązać stosunek pracy oraz dokonywać czynności prawnych, które dotyczą tego stosunku. Jednakże gdy stosunek pracy sprzeciwia się dobru tej osoby, przedstawiciel ustawowy za zezwoleniem sądu opiekuńczego może stosunek pracy rozwiązać. Przepis ten umożliwia osobom ubezwłasnowolnionym częściowo dokonywanie czynności dotyczących stosunku pracy samodzielnie, bez konieczności uzyskania zgody przedstawiciela ustawowego, czego w innych sferach co do zasady wymaga art. 17 k.c.

Przyjmuje się, że przepis art. $22 \$ 3$ k.p. określa tzw. pracowniczą zdolność do czynności prawnych, uzależniając ją od co najmniej ograniczonej zdolności do czynności prawnych. Przepis ten nie odnosi się w swej treści do osób pozbawionych zdolności do czynności prawnych, czyli do skutku ubezwłasnowolnienia całkowitego.

W Kodeksie pracy brak jest przepisów, które dotyczyłyby osób ubezwłasnowolnionych całkowicie oraz ich zdolności do bycia pracownikiem. Jednak $\mathrm{z}$ art. $22 \$ 3$ k.p., w drodze prawniczego rozumowania a contrario w odniesieniu do przedstawionych wyżej reguł prawa cywilnego, można wyprowadzić normę, że osoby ubezwłasnowolnione całkowicie, jako pozbawione zdolności do czynności prawnych (nawet ograniczonej), nie mogą dokonywać czynności prawnych, które dotyczą stosunku pracy (np. same nawiązać umowy o pracę). W stosunku do Kodeksu cywilnego Kodeks pracy wprowadził szczególny wyjątek w zakresie zdolności do czynności prawnych obejmujący osoby o ograniczonej zdolności do czynności prawnych. Nie powinno się tego wyjątku rozszerzać na inny jakościowo przypadek braku zdolności do czynności prawnych.

Nie rozstrzyga to jednak problemu, czy osoba pozbawiona zdolności do czynności prawnych może być stroną stosunku pracy, jeżeli za tę osobę opiekun dokonywałby czynności dotyczących tego stosunku prawnego. $Z$ art. $8 \$ 1$ k.c. wynika przecież, że „każdy” ma zdolność prawną, a Kodeks pracy określając, kto 
może być pracownikiem, ustanawia jedynie ograniczenia ze względu na wiek. Ponadto w regulacji ustania stosunku pracy Kodeks pracy nie odnosi się do okoliczności, że do ubezwłasnowolnienia całkowitego może dojść w trakcie trwania stosunku pracy. Wśród przesłanek wygaśnięcia lub rozwiązania stosunku pracy bez wypowiedzenia nie uwzględniono szczególnych problemów dotyczących osób ubezwłasnowolnionych i ich pracodawców. Oznacza to, że osoba, którą ubezwłasnowolniono całkowicie, pozostaje pracownikiem do czasu rozwiązania stosunku pracy w jednym z trybów przewidzianych odpowiednimi przepisami.

Jako argument przeciwko dopuszczalności zatrudniania osób ubezwłasnowolnionych całkowicie podnosi się ich brak rozeznania, a w efekcie narażenie tych osób na wyzysk ze strony pracodawców. Nie w pełni zapobiega temu wymóg podpisania umowy o pracę przez opiekuna, gdyż bywa on zainteresowany własnymi korzyściami wynikającymi z pracy podopiecznego. W przypadku zbliżonego problemu zatrudniania dzieci poniżej 16. roku życia tego rodzaju obawom mają zapobiegać wymogi proceduralne nałożone przez art. $304^{5}$ k.p.

Ustawa o rehabilitacji dotyczy osób, których niepełnosprawność została potwierdzona w stosownym trybie. Nie posługuje się kategoriami „ubezwłasnowolnienie całkowite” lub „brak zdolności do czynności prawnych”. Dotyczy „osób niepełnosprawnych”. Ze względu na przesłanki ubezwłasnowolnienia całkowitego (niemożność kierowania swoim postępowaniem) można założyć, że z punktu widzenia ustawy o rehabilitacji osoba ubezwłasnowolniona jest zwykle osobą niepełnosprawną w stopniu znacznym, czyli osobą z naruszoną sprawnością organizmu, niezdolną do pracy albo zdolną do pracy jedynie w warunkach pracy chronionej i wymagającą, w celu pełnienia ról społecznych, stałej lub długotrwałej opieki i pomocy innych osób w związku z niezdolnością do samodzielnej egzystencji. Jak się wydaje, ewentualnie mogłaby to być także osoba zaliczona do umiarkowanego stopnia niepełnosprawności, czyli osoba z naruszoną sprawnością organizmu, niezdolna do pracy albo zdolna do pracy jedynie w warunkach pracy chronionej lub wymagająca czasowej albo częściowej pomocy innych osób w celu pełnienia ról społecznych. Można więc zauważyć, że w obu przypadkach dana osoba jest niezdolna do pracy lub zdolna do pracy jedynie w warunkach pracy chronionej i wymagająca wsparcia ze strony innych osób.

Warunki pracy chronionej to warunki związane z uzyskaniem statusu zakładu pracy chronionej albo zakładu aktywności zawodowej i spełnieniem wymagań, o których mowa w:

- art. 28 ustawy o rehabilitacji - dotyczące dla zakładu pracy chronionej warunków lokalowych i personelu, ale przede wszystkim odsetka zatrudnionych osób zaliczonych do znacznego lub umiarkowanego stopnia niepełnosprawności, w tym w szczególności psychicznie chorych, albo upośledzonych umysłowo zaliczonych do znacznego lub umiarkowanego stopnia niepełnosprawności, 
- art. 29 ustawy o rehabilitacji - dotyczące zakładu aktywności zawodowej, w tym warunków lokalowych, personelu, potrzeby utworzenia zakładu, przeznaczenia dochodów oraz odsetka zatrudnionych osób niepełnosprawnych, w tym zaliczonych do znacznego stopnia niepełnosprawności lub zaliczonych do umiarkowanego stopnia niepełnosprawności, u których stwierdzono autyzm, upośledzenie umysłowe lub chorobę psychiczną, w tym osób, w stosun$\mathrm{ku}$ do których rada programowa warsztatu zajęła stanowisko uzasadniające podjęcie zatrudnienia i kontynuowanie rehabilitacji zawodowej w warunkach pracy chronionej.

Zaliczenie do znacznego albo umiarkowanego stopnia niepełnosprawności nie wyklucza możliwości zatrudnienia danej osoby u pracodawcy niezapewniającego warunków pracy chronionej w przypadkach (art. 4 ust. 5 ustawy o rehabilitacji):

- przystosowania przez pracodawcę stanowiska pracy do potrzeb osoby niepełnosprawnej,

- zatrudnienia w formie telepracy.

Argumentem na rzecz dopuszczenia zawierania umów o pracę na rzecz osób ubezwłasnowolnionych całkowicie jest regulacja dotycząca dofinansowania do wynagrodzenia pracownika niepełnosprawnego, które przysługuje pracodawcy ze środków Państwowego Funduszu Rehabilitacji Osób Niepełnosprawnych. Na podstawie art. 26 ust. 1b ustawy o rehabilitacji dofinansowanie to zwiększa się o określone kwoty miesięczne w odniesieniu do osób niepełnosprawnych, którym orzeczono chorobę psychiczną, upośledzenie umysłowe lub całościowe zaburzenia rozwojowe.

Istotne znaczenie ma również to, że pracodawca, który zatrudnia pracownika niepełnosprawnego, może otrzymać ze środków Państwowego Funduszu Rehabilitacji Osób Niepełnosprawnych zwrot miesięcznych kosztów zatrudnienia pracowników pomagających pracownikowi niepełnosprawnemu w pracy oraz kosztów szkolenia tych pracowników - w zakresie czynności ułatwiających komunikowanie się z otoczeniem, a także czynności niemożliwych lub trudnych do samodzielnego wykonania przez pracownika niepełnosprawnego na stanowisku pracy (art. 26d ustawy o rehabilitacji).

Nie ma przeszkód prawnych, by ubezwłasnowolnione całkowicie osoby niepełnosprawne były uczestnikami warsztatów terapii zajęciowej. Zgodnie z art. 10a ust. 1 ustawy o rehabilitacji warsztat ma stworzyć osobom niepełnosprawnym niezdolnym do podjęcia pracy możliwość rehabilitacji społecznej i zawodowej w zakresie pozyskania lub przywracania umiejętności niezbędnych do podjęcia zatrudnienia. Jeżeli wykluczone byłoby zatrudnienie osób ubezwłasnowolnionych całkowicie, które w wyniku technik terapii zajęciowej rozwinęły swą zdolność do podjęcia zatrudnienia, koncepcję i działanie warsztatów w tym zakresie należałoby uznać za bezcelowe. 
W nauce prawa pracy wyrażane są poglądy, że osoby ubezwłasnowolnione całkowicie:

- nie mogą być pracownikami; przede wszystkim dlatego, że nie mają zdolności do czynności prawnych (art. 12 k.c.), a pogląd dopuszczający nawiązanie stosunku pracy za zgodą przedstawiciela ustawowego nie ma prawnego ani społecznego uzasadnienia ${ }^{2}$,

- mogą być pracownikami, ze względu na zachowaną zdolność prawnąa ; czynności prawne wykonuje za nie opiekun,

- mogą być pracownikami na potrzeby ustawy o rehabilitacji, np. za zgodą przedstawiciela ustawowego możliwe jest nawiązanie stosunku pracy również $\mathrm{z}$ osobą całkowicie ubezwłasnowolnioną, co znajduje zastosowanie w zakładach pracy chronionej ${ }^{4}$.

Ze względu na powyższe trwające od wielu lat kontrowersje i brak precyzyjnie rozstrzygającego tę kwestię orzecznictwa sądowego udzielenie jednoznacznej odpowiedzi na pytanie postawione w opinii jest trudne. Wydaje się jednak, że należy uwzględnić okoliczność, że ubezwłasnowolnienie całkowite nie oznacza utraty prawa do pracy. Zgodnie z art. 65 Konstytucji: „Każdemu zapewnia się wolność wyboru i wykonywania zawodu oraz wyboru miejsca pracy”. Prawo do pracy przysługuje „każdemu”, co jest szczególnie widoczne po porównaniu brzmienia tego postanowienia z art. 62 Konstytucji, który przewiduje, że: „Prawo udziału w referendum oraz prawo wybierania nie przysługuje osobom, które prawomocnym orzeczeniem sądowym są ubezwłasnowolnione lub pozbawione praw publicznych albo wyborczych". Również przepisy rangi ustawowej stawiają niekiedy wymóg pełnej zdolności do czynności prawnych (na przykład, z wyjątkami dotyczącymi małoletnich, art. 3 ustawy z 7 kwietnia 1989 r. - Prawo o stowarzyszeniach; t.j. Dz.U. 2019, poz. 713, ze zm.). Takiego wymogu nie wprowadzono do Kodeksu pracy.

Ubezwłasnowolnienie całkowite nie oznacza również pozbawienia danej osoby zdolności prawnej przysługującej „każdemu” na podstawie art. $8 \$ 1$ k.c. Wywołuje jedynie pozbawienie zdolności do czynności prawnych obejmujące niektóre osoby fizyczne (art. 12 k.c.).

Należy jednak wziąć pod uwagę także dobro ubezwłasnowolnionego i jego potencjalnych współpracowników oraz brzmienie art. 300 k.c., według którego do stosunków pracy przepisy Kodeksu cywilnego stosuje się „odpowiednio”, a nie wprost. Stosowane przepisy Kodeksu cywilnego nie mogą być sprzeczne z zasada-

2 L. Florek [w:] Kodeks pracy. Komentarz, Warszawa 2017, s. 194; J. Stelina, (Art. 22) [w:] Kodeks pracy. Komentarz, red. A. Sobczyk, 2020, Legalis.

3 M. Gersdorf [w:] M. Gersdorf, K. Rączka, J. Skoczyński, Kodeks pracy. Komentarz, Warszawa 2008, s. 119.

4 W. Muszalski [w:] Kodeks pracy. Komentarz, red. W. Muszalski, 2019, Legalis, z powołaniem na M. Gersdorf, Zawarcie umowy o prace, Warszawa 1985, s. 84 i n. 
mi prawa pracy. Jedną z podstawowych zasad tej gałęzi prawa jest prawo do pracy. Zgodnie z art. $10 \$ 1$ k.p.: „Każdy ma prawo do swobodnie wybranej pracy. Niko$\mathrm{mu}, \mathrm{z}$ wyjątkiem przypadków określonych w ustawie, nie można zabronić wykonywania zawodu”. Ustawa nie zabrania wyraźnie wykonywania pracy przez osoby pozbawione zdolności do czynności prawnych lub ubezwłasnowolnione całkowicie.

Podstawową zasadą prawa pracy jest jednak również obowiązek zapewniania pracownikom bezpiecznych i higienicznych warunków pracy (art. 15 k.p.). Dlatego dopuszczając co do zasady zatrudnienie osób ubezwłasnowolnionych całkowicie na podstawie stosunku pracy, należy podkreślić, że musi ono odpowiadać zachowanej przez daną osobę zdolności do pracy, szczególnie jeżeli dana osoba nie dysponuje orzeczeniem o stopniu niepełnosprawności. Dużą rolę pełniłoby tu orzeczenie lekarza medycyny pracy o dopuszczeniu do pracy.

Natomiast zwykle osoby o tak poważnych zaburzeniach, że uzasadniają ubezwłasnowolnienie całkowite, legitymują się również orzeczeniem o stopniu niepełnosprawności, najczęściej znacznym. Osoba taka powinna pracować w warunkach pracy chronionej lub na odpowiednio dostosowanym stanowisku pracy. Ze względu na rodzaj zaburzeń uzasadniających ubezwłasnowolnienie całkowite chodzi tu przede wszystkim o kontrolę nad osobą, która „nie jest w stanie kierować swym postępowaniem" (art. $13 \$ 1$ k.c.).

Z powyższych powodów wydaje się, że zatrudnienie osoby ubezwłasnowolnionej całkowicie w przedszkolu na stanowisku woźnego może budzić wątpliwości dotyczące spełnienia wymagań stawianych dopuszczalnej, bezpiecznej pracy osób niebędących w stanie kierować swoim postępowaniem. Ocena taka powinna być przeprowadzana indywidualnie, z uwzględnieniem przyczyny ubezwłasnowolnienia, w kontekście zakresu udogodnień lub usprawnień wprowadzonych w celu zatrudnienia danej osoby. Wydaje się jednak, że zakres dostosowania stanowiska pracy do potrzeb zatrudnianej osoby powinien być znaczny.

\section{Podsumowanie}

Dopuszczalność zawarcia umowy o pracę, której stroną byłaby osoba ubezwłasnowolniona całkowicie, nie jest rozstrzygnięta w przepisach. Kwestia ta jest przedmiotem wykluczających się poglądów doktryny prawa pracy. Należy jednak wziąć pod uwagę, że osoba ubezwłasnowolniona całkowicie zachowuje zdolność prawną wynikającą z Kodeksu cywilnego, a jej prawo do pracy jest uznane konstytucyjnie i nie jest wyłączone w aktach prawnych rangi ustawowej. Prawo do pracy jest również uznane za podstawową zasadę prawa pracy. Nie ma zatem wystarczających podstaw, żeby wyłączyć dopuszczalność zatrudnienia pracowniczego osób ubezwłasnowolnionych całkowicie.

Należy jednak również wziąć pod uwagę, że pracodawca odpowiada za bezpieczne i higieniczne warunki pracy swoich pracowników, w tym osób ubez- 
własnowolnionych całkowicie i ich współpracowników. Warunki pracy powinny zatem odpowiadać rodzajowi pracy i zachowanej przez daną osobę zdolności do pracy oraz wymogom ustawy z 27 sierpnia 1997 r. o rehabilitacji zawodowej i społecznej oraz zatrudnianiu osób niepełnosprawnych.

Dopuszczalność zatrudnienia osoby ubezwłasnowolnionej całkowicie w przedszkolu na stanowisku woźnego może budzić wątpliwości dotyczące spełnienia wymagań stawianych dopuszczalnej, bezpiecznej pracy osób niebędących w stanie kierować swoim postępowaniem. Ocena taka powinna być przeprowadzana indywidualnie, $\mathrm{z}$ uwzględnieniem przyczyny ubezwłasnowolnienia, w kontekście zakresu udogodnień lub usprawnień wprowadzonych w celu zatrudnienia danej osoby.

\section{Bibliografia}

Florek L. [w:] Kodeks pracy. Komentarz, Warszawa 2017.

Gersdorf M. [w:] M. Gersdorf, K. Rączka, J. Skoczyński, Kodeks pracy. Komentarz, Warszawa 2008.

Gersdorf M., Zawarcie umowy o prace, Warszawa 1985.

Muszalski W. [w:] Kodeks pracy. Komentarz, red. W. Muszalski, 2019, Legalis.

Stelina J., Art. 22 [w:] Kodeks pracy. Komentarz, red. A. Sobczyk, 2020, Legalis. 


\title{
Dobromir Dziewulak
}

\section{Edukacja prawna w szkolnictwie podstawowym i średnim w Polsce, wybranych państwach Unii Europejskiej oraz w Serbii i Wielkiej Brytanii ${ }^{1}$}

\author{
Legal education in primary and secondary education stages in Poland, \\ selected Member States of the European Union, as well as in Serbia \\ and in the United Kingdom
}

\begin{abstract}
A legal education program, as a general rule, is implemented in the educational systems of all European countries analysed in this article. Most often, however, as it is in Poland, it is not a separate school course, but legal topics are integrated with various school subjects. If a separate school subject called "Legal education" appears in school curricula, it is most often taught in general education schools as an optional course or in vocational and technical secondary schools - as a course supplementing the knowledge of the future graduate about the legal aspects of the profession taught.
\end{abstract}

Keywords: education, school system, European Union

Program edukacji prawnej co do zasady realizowany jest we wszystkich analizowanych w niniejszym artykule systemach oświatowych państw europejskich. Najczęściej jednak, tak jak w Polsce, nie jest to oddzielny przedmiot nauczania, a treści z dziedziny prawa zintegrowane są z różnymi przedmiotami. Jeżeli w szkolnych programach nauczania pojawia się oddzielny przedmiot o nazwie „edukacja prawna”, to najczęściej jest realizowany w szkołach ogólnokształcących, jako przedmiot fakultatywny lub w szkołach średnich zawodowych i technicznych, jako przedmiot uzupełniający wiedzę przyszłego absolwenta o prawnych aspektach nauczanego zawodu.

Słowa kluczowe: edukacja, szkolnictwo, Unia Europejska

Doktor nauk humanistycznych, adiunkt -

Uniwersytet Warszawski, Wydział Pedagogiczny, Katedra Dydaktyki i Pedeutologii,

WARSZAWA, POLSKA •

dobromir.dziewulak@uw.edu.pl • https://orcid.org/0000-0002-7974-8024

\section{Wstęp}

Pojęcie edukacji prawnej używane jest w literaturze przedmiotu dla określenia działalności edukacyjnej umożliwiającej przekazanie społeczeństwu podstawo-

1 Informacja na temat edukacji prawnej dzieci i młodzieży w szkolnictwie podstawowym $i$ średnim w wybranych państwach Unii Europejskiej oraz w Serbii i Wielkiej Brytanii sporządzona 26 maja 2020 r. na zlecenie posła Klubu Parlamentarnego Koalicja Obywatelska - Platforma Obywatelska, Nowoczesna, Inicjatywa Polska, Zieloni; BAS-ZSP-489/20. 
wej wiedzy na temat prawa, a w konsekwencji - zwiększenia świadomości prawnej. Celem jest poznanie zasad funkcjonowania prawa i porządku prawnego, kształtowanie świadomości własnych praw oraz wyrobienie nawyku postępowania zgodnie z obowiązującym prawem. Skuteczność edukacji prawnej w dużej mierze zależy od jej powszechności i jakości. Najczęściej zajmują się nią m.in. organizacje pozarządowe, instytucje samorządowe i/lub podmioty rządowe. Wśród podejmowanych działań można wskazać np. prezentowanie treści $\mathrm{w}$ internecie, prowadzenie dla obywateli otwartych szkoleń z zakresu prawa, wydawanie ulotek, książek i informatorów, organizowanie dla młodzieży wizyt edukacyjnych w instytucjach administracji rządowej i samorządowej, a także wprowadzanie tematyki prawnej do szkolnych programów nauczania.

\section{Kompetencje kluczowe a edukacja prawna}

Postępujące zmiany cywilizacyjne zmuszają do poszukiwania nowych rozwiązań edukacyjnych, umożliwiających jak najlepsze przygotowanie młodych pokoleń do zmieniającego się świata. Edukacja należy w państwach Unii Europejskiej do wyłącznych kompetencji poszczególnych państw członkowskich, co nie wyklucza proponowania i korzystania ze wspólnych inicjatyw, programów oraz różnego rodzaju przedsięwzięć umożliwiających np. ulepszanie procesu kształcenia.

W 2006 r. Parlament Europejski i Rada przyjęły zalecenie w sprawie kompetencji kluczowych w procesie uczenia się przez całe życie ${ }^{2}$. Kompetencje kluczowe zdefiniowano jako połączenie wiedzy, umiejętności i postaw odpowiednich do sytuacji życiowej, społecznej i zawodowej ucznia. Uznano, że w dobie obecnych przemian cywilizacyjnych są one niezbędne do osobistej samorealizacji, bycia aktywnym obywatelem, spójności społecznej i uzyskania szans na zatrudnienie w społeczeństwie wiedzy. Celem określenia katalogu takich kompetencji kluczowych miała być pomoc w dostarczeniu instytucjom edukacyjnym, nauczycielom, pracodawcom oraz osobom uczącym się narzędzia referencyjnego na poziomie europejskim, które mogłoby uaktualnić programy nauczania oraz metody i procesy kształcenia oraz dostosować je do zmieniających się potrzeb absolwentów szkół i uczelni wynikających z oczekiwań współczesnego rynku pracy.

W omawianym dokumencie zaproponowano osiem kompetencji kluczowych: 1) porozumiewanie się w języku ojczystym; 2) porozumiewanie się w językach obcych; 3) kompetencje matematyczne i podstawowe kompetencje naukowo-techniczne; 4) kompetencje informatyczne; 5) umiejętność uczenia się; 6) kompetencje społeczne i obywatelskie; 7) inicjatywność i przedsiębiorczość;

2 Zalecenie Parlamentu Europejskiego i Rady z 18 grudnia 2006 r. w sprawie kompetencji kluczowych w procesie uczenia się przez całe życie (2006/962/WE), https://eur-lex.europa.eu/legal-content/PL/TXT/PDF/?uri=CELEX:32006H0962\&from=EN. 
oraz 8) świadomość i ekspresja kulturalna. Spośród ośmiu kompetencji kluczowych żadna nie odnosi się wprost do edukacji prawnej, jednakże jej elementy można znaleźć w kompetencji szóstej (kompetencje społeczne i obywatelskie). Kompetencje społeczne i obywatelskie są definiowane jako kompetencje obejmujące pełny zakres zachowań przygotowujących osoby do skutecznego i konstruktywnego uczestnictwa w życiu społecznym i zawodowym, szczególnie w społeczeństwach charakteryzujących się coraz większą różnorodnością. Kompetencje obywatelskie mają być pomocne w przygotowaniu do pełnego i aktywnego uczestnictwa w życiu obywatelskim. Za niezbędną wiedzę, umiejętności i postawy powiązane $\mathrm{z}$ tą kompetencją uznano m.in. rozumienie wielokulturowych i społeczno-ekonomicznych wymiarów społeczeństw europejskich, a także wzajemnej interakcji narodowej tożsamości kulturowej i tożsamości europejskiej. Kompetencje obywatelskie powinny opierać się na znajomości pojęć demokracji, sprawiedliwości, równości, obywatelstwa i praw obywatelskich i ich stosowania przez różne instytucje na poziomach lokalnym, regionalnym, krajowym, europejskim i międzynarodowym. Powinny opierać się na poszanowaniu praw człowieka, w tym równości jako podstawy demokracji, oraz zrozumieniu różnic w systemach wartości różnych religii i grup etnicznych.

W konsekwencji nieustannych zmian cywilizacyjnych wpływających na nowe zmieniające się potrzeby rynku pracy Rada w 2018 r. przyjęła kolejne zalecenie w sprawie kompetencji kluczowych w procesie uczenia się przez całe życie ${ }^{3}$. Wykaz i definicje kompetencji kluczowych zostały nieco zmodyfikowane i uaktualnione. W nowym dokumencie wskazano następujące kompetencje kluczowe: 1) kompetencje w zakresie rozumienia i tworzenia informacji; 2) kompetencje w zakresie wielojęzyczności; 3) kompetencje matematyczne oraz kompetencje w zakresie nauk przyrodniczych, technologii i inżynierii; 4) kompetencje cyfrowe; 5) kompetencje osobiste, społeczne i w zakresie umiejętności uczenia się; 6) kompetencje obywatelskie; 7) kompetencje w zakresie przedsiębiorczości; 8) kompetencje w zakresie świadomości i ekspresji kulturalnej. Także i w tym dokumencie żadna z ośmiu kompetencji kluczowych w swojej nazwie nie odnosi się wprost do edukacji prawnej, jednakże, podobnie jak w zaleceniu PE i Rady z 2006 r., jej elementy można znaleźć w kompetencji szóstej. Kompetencje obywatelskie zdefiniowano jako zdolność odpowiedzialnego, obywatelskiego działania opartego na rozumieniu pojęć i struktur społecznych, gospodarczych, prawnych i politycznych, a także wydarzeń globalnych i zrównoważonego rozwoju. Kompetencje obywatelskie mają opierać się na znajomości podstawowych pojęć i zjawisk dotyczących osób, grup, organizacji zawodowych, społeczeństwa, gospodarki i kultury.

3 Zalecenie Rady z 22 maja 2018 r. w sprawie kompetencji kluczowych w procesie uczenia się przez całe życie (2018/C 189/01), https://eur-lex.europa.eu/legal-content/PL/ TXT/PDF/?uri=CELEX:32018H0604(01)\&from=EN. 
Poniżej przedstawiono szczegółowe informacje na temat sposobu realizacji edukacji prawnej w szkolnictwie w Polsce, Austrii, Czechach, Estonii, Finlandii, Francji, Hiszpanii, Niemczech, Serbii, Szwecji, Włoszech i Wielkiej Brytanii ${ }^{4}$.

\section{Polska}

W Polsce wśród katalogu obowiązkowych zajęć edukacyjnych ramowy plan nauczania dla publicznych szkół podstawowych i średnich nie przewiduje oddzielnego przedmiotu o tematyce edukacji prawnej. Jednakże problematyka ta realizowana jest w ramach przedmiotu „wiedza o społeczeństwie”. Jest to przedmiot obowiązkowy w klasie 8 szkoły podstawowej, a następnie we wszystkich typach szkół ponadpodstawowych - liceum ogólnokształcącym, technikum, branżowej szkole pierwszego i drugiego stopnia. „Wiedza o społeczeństwie” jest przedmiotem o charakterze interdyscyplinarnym korzystającym z dorobku nauk społecznych, a zwłaszcza z nauk socjologicznych, nauk o polityce i administracji oraz nauk prawnych. Zakres celów i treści kształcenia, w tym szczegółowe treści nauczania z obszaru edukacji prawnej, określa podstawa programowa kształcenia ogólnego dla przedmiotu zatytułowanego „wiedza o społeczeństwie” ${ }^{5}$. W szkole podstawowej przedmiot ten realizowany jest wyłącznie w klasie $8 \mathrm{w}$ wymiarze 2 godz. tygodniowo. Elementy edukacji prawnej zostały włączone do katalogu treści nauczania związanych m.in. z następującymi zagadnieniami:

- prawa człowieka: uczeń wykazuje różnice między prawami a wolnościami człowieka; wymienia prawa i wolności osobiste zawarte w Konstytucji RP; wymienia prawa dzieci i analizuje przepisy konwencji o ochronie praw dziecka; wymienia prawa i wolności polityczne zawarte w Konstytucji RP; wykazuje, że prawa człowieka muszą być chronione; przedstawia przykłady działań organizacji pozarządowych na rzecz ochrony praw człowieka; uzasadnia potrzebę przeciwstawiania się zjawiskom braku tolerancji wobec różnych mniejszości,

- nieletni wobec prawa: uczeń rozpoznaje zachowania związane z przemocą fizyczną i psychiczną, w tym werbalną, wobec siebie i innych; wymienia osoby i instytucje, które należy powiadomić w takich sytuacjach; wyjaśnia, na jakich zasadach nieletni odpowiadają za popełnienie wykroczeń i przestępstw,

4 W opracowaniu wykorzystano informacje zawarte w międzynarodowych raportach oświatowych, przede wszystkim w raporcie zatytułowanym Edukacja obywatelska w szkołach $w$ Europie 2017. Wykorzystano także materiały dostępne na stronach internetowych ministerstw edukacji i ministerstw sprawiedliwości analizowanych państw oraz na stronach internetowych międzynarodowych organizacji i stowarzyszeń zajmujących się problematyką edukacji prawnej. Dodatkowo wykorzystano materiały uzyskane z międzynarodowej sieci informacji o edukacji w Europie - Eurydice.

5 Podstawa programowa kształcenia ogólnego z komentarzem. Szkoła podstawowa. Wiedza o społeczeństwie, https://www.ore.edu.pl/wp-content/uploads/2017/05/wiedza-o-spoleczenstwie.-pp-z-komentarzem.-szkola-podstawowa-1.pdf. 
- udział obywateli w życiu publicznym - społeczeństwo obywatelskie: uczeń zna cnoty obywatelskie; przedstawia cele i formy działań organizacji pozarządowych aktywnych w społeczności lokalnej i regionie; przedstawia formy wpływania obywateli na decyzje władz samorządowych, przykłady realizacji lokalnych inicjatyw mieszkańców finansowanych z budżetów obywatelskich oraz podejmowanych przez młodzieżowe rady gminy/miasta,

- demokracja w RP: uczeń wymienia podstawowe cechy i funkcje państwa; wyjaśnia, czym zajmuje się władza państwowa; wyjaśnia zasadę przedstawicielstwa; wyjaśnia zasadę pluralizmu politycznego; wyjaśnia zasadę państwa prawa; wyjaśnia zasadę trójpodziału władzy.

W szkole ponadpodstawowej przedmiot „wiedza o społeczeństwie” realizowany jest w klasie 1 i 2 liceum oraz w klasie 4 i 5 technikum w wymiarze 1 godz. tygodniowo. W branżowej szkole pierwszego stopnia - w klasie 3 i w branżowej szkole drugiego stopnia - w klasie 1. Tygodniowy czasowy wymiar zajęć z przedmiotu „wiedza o społeczeństwie” wynosi 1 godz. tygodniowo dla każdego stopnia szkoły branżowej ${ }^{6}$.

Elementy edukacji prawnej zostały włączone do katalogu treści nauczania związanych m.in. z następującymi zagadnieniami ${ }^{7}$ :

- prawa człowieka i ich ochrona: uczeń wymienia „zasady ogólne” i katalog praw człowieka zapisane w Konstytucji RP; przedstawia sądowe środki ochrony praw i wolności w RP,

- prawo w RP: uczeń wyjaśnia, czym różnią się normy prawne od innych typów norm; wymienia podstawowe zasady prawa i wyjaśnia konsekwencje ich łamania; przedstawia źródła prawa w RP; rozpoznaje sprawy regulowane przez prawo cywilne, rodzinne, administracyjne i karne; wymienia obowiązujące w RP akty prawne niebędące źródłami prawa i wyjaśnia ich specyfikę (zakres rozszerzony); przedstawia kary i środki karne unormowane w Kodeksie wykroczeń i Kodeksie karnym w RP (zakres rozszerzony); wskazuje specyfikę poszczególnych rodzajów wykroczeń w RP oraz przestępstw (zakres rozszerzony).

Zgodnie $\mathrm{z}$ podstawami programowymi dla liceów i techników ${ }^{8}$ przedmiot realizowany jest w zakresie podstawowym i rozszerzonym. W obu przypadkach elementy edukacji prawnej zawarte są m.in. w ramach treści nauczania obejmujących takie obszary tematyczne, jak prawo i system prawny w RP, prawa człowieka i ich ochrona. Podobnie w podstawach programowych dla szkoły branżowej I stopnia elementy edukacji prawnej zawarte są m.in. w treściach nauczania

6 Rozporządzenie Ministra Edukacji Narodowej z 3 kwietnia 2019 r. w sprawie ramowych planów nauczania dla publicznych szkół, Dz.U. poz. 639, ze zm.

7 Podstawa programowa kształcenia ogólnego z komentarzem. Szkoła ponadpodstawowa: liceum ogólnokształcące, technikum oraz branżowa szkoła I i II stopnia. Wiedza o społeczeństwie, https://www.ore.edu.pl/2018/03/podstawa-programowa-ksztalcenia-ogolnego-dla-liceum-technikum-i-branzowej-szkoly-ii-stopnia/.

$8 \quad$ Ibidem. 
zatytułowanych „prawo w Rzeczypospolitej Polskiej”. Natomiast dla szkoły branżowej II stopnia podstawy programowe wskazują na kontynuację pogłębiania wymienionych wyżej zagadnień, w wyniku czego uczniowie powinni nabyć świadomość możliwości korzystania ze swoich praw.

Ze względu na charakter interdyscyplinarny przedmiotu „kształcenie w zakresie wiedzy o społeczeństwie" nie skupia się w nim wyłącznie na aspektach prawnych. Celem nauczania przedmiotu jest rozwijanie aktywności społecznej ucznia, zaangażowania w sprawy wspólnot, których jest członkiem, rozwijanie odpowiedzialności wobec innych, kształtowanie zdolności do planowania własnego rozwoju oraz świadomości i umiejętności korzystania ze swoich praw.

\section{Austria}

Na poziomie szkoły podstawowej i szkoły średniej pierwszego stopnia nie jest przewidziany oddzielny przedmiot poświęcony prawu. Tematyka prawna jest zintegrowana $\mathrm{z}$ zagadnieniami omawianymi podczas realizacji przedmiotów takich jak edukacja obywatelska, nauka o społeczeństwie czy historia. Oddzielne przedmioty posiadające w nazwie "prawo" (Recht) to - „ekonomia i prawo" (Wirtschaft und Recht) lub "polityka i prawo" (Politik und Recht) - realizowane są dopiero na poziomie szkoły średniej drugiego stopnia, ale tylko w szkołach średnich techniczno-zawodowych o profilu administracja, zarządzanie, rolnictwo i leśnictwo ${ }^{9}$.

Przedmioty znajdują się w programie nauczania w 4 klasie szkoły średniej drugiego stopnia (wiek uczniów 17/18 lat). Przedmiot realizowany jest przez cały rok szkolny w wymiarze 3 godz. tygodniowo, przy tygodniowym wymiarze wynoszącym dla wszystkich przedmiotów 28 godz.

Celem przedmiotu jest wyrobienie w uczniach nawyków związanych z:

- umiejętnością korzystania z legalnych źródeł informacji przy użyciu nowoczesnych baz danych,

- umiejętnością aktualizowania, rozszerzania i stosowania wiedzy na temat Austrii i świata,

- rozumieniem współczesnych tendencji społecznych wraz z krytycznym podejściem do konsumpcjonizmu,

- rozumieniem własnej podmiotowości obywatelskiej, zwłaszcza w obszarze Unii Europejskiej, zarówno w sektorze publicznym, jak i prywatnym,

- zdobyciem podstaw wiedzy prawniczej umożliwiającej podejmowanie niezależnych działań w ramach prostego postępowania prawnego,

- umiejętnością komunikowania się z ekspertami z dziedzin prawnych i ekonomicznych ${ }^{10}$.

9 Curriculum for the secondary college of business administration, https://www.abc. berufsbildendeschulen.at/download/1273/Lehrplan-HAK-VO-2004e.pdf.

10 Https://www.bildungsstandards.berufsbildendeschulen.at/sites/default/files/broschuere/BBS-Bildungsstandards-Broschuere-Wirtschaft-und-Recht-BHS.pdf. 
Zakres programu przedmiotów z elementami prawa obejmuje następujące obszary tematyczne:

- system prawny i organizacje międzynarodowe: prawa i wolności obywatelskie, funkcje najważniejszych organizacji międzynarodowych i systemy bezpieczeństwa zbiorowego,

- prawo europejskie: podstawowe struktury UE, zasady prawa UE i jego egzekwowanie, bezpieczeństwo zbiorowe w Europie,

- prawo austriackie: podstawowe pojęcia prawne i polityczne, rola jednostki w środowisku politycznym i prawnym; partie i ideologie, partnerzy społeczni,

- podstawowe struktury państwa: zasady austriackiej konstytucji; ustawodawstwo na szczeblu federalnym i landowym; administracja na szczeblu federalnym i landowym; samorząd; kontrola władzy wykonawczej; sądownictwo,

- stosowanie prawa w życiu codziennym: podstawy prawa cywilnego i rodzinnego; prawo spadkowe; prawo własności; zasady zawierania umów i ich egzekwowania; problemy z umowami i sposoby zabezpieczenia umów; prawo odszkodowawcze; właściciel mieszkania i prawo najmu; prawo ochrony konsumentów; prawo handlu elektronicznego; prawo karne; przestępstwa gospodarcze,

- egzekwowanie prawa: postępowanie administracyjne, postępowanie karne; poręczenie; postępowanie upadłościowe,

- podstawy prawa pracy oraz prawa autorskiego,

- prawo pracy: prawa i obowiązki związane ze stosunkiem pracy, funkcje przedstawiciela pracownika, rozwiązanie stosunku pracy, najważniejsze przepisy dotyczące ochrony pracowników.

Program przewiduje także realizację zadań praktycznych, do których zaliczono:

- zbieranie informacji prawnej i jej krytyczna ocena,

- korzystanie z systemów informacji prawnej i ofert administracji elektronicznej dostarczanych przez instytucje landowe i międzynarodowe,

- pobieranie formularzy, wniosków, petycji,

- korzystanie z internetowego rejestru nieruchomości i rejestru handlowego,

- nawiązanie kontaktu z firmą szkoleniową i uczestnictwo w szkoleniu o charakterze prawnym,

- aplikowanie o swój podpis elektroniczny,

- wykonanie korespondencji w sprawach przyjęcia lub odwołania się od decyzji administracyjnych (mandat, grzywna itp.).

\section{Czechy}

W systemie szkolnym Czech na poziomie szkoły podstawowej oraz średniej pierwszego i drugiego stopnia nie ma osobnego przedmiotu dotyczącego edukacji prawnej. Jedynie w nielicznych profilowanych programach szkół średnich technicznych i zawodowych (np. administracja przedsiębiorstw, finanse i rachunkowość, zarządzanie nieruchomościami) występuje przedmiot związany $\mathrm{z}$ tematyką edukacji prawnej. 
W szkole podstawowej, w klasach 1-5, elementy prawa znajdują się w zintegrowanym programie przedmiotu „człowiek i jego świat” (Člověk a jeho svět) ${ }^{11}$. Przedmiot realizowany jest w wymiarze 2 godz. tygodniowo.

Zagadnienia prawne zawarte w programie ramowym tego przedmiotu obejmują następującą tematykę: podstawowe prawa człowieka, prawa dziecka, prawa i obowiązki uczniów, własność prywatna, własność intelektualna ${ }^{12}$.

Uczeń, kończąc klasę 5 szkoły podstawowej, powinien umieć:

- identyfikować bliskie relacje pokrewieństwa w rodzinie, role członków rodziny i relacje między nimi,

- rozpoznawać zawody i ich wytwory,

- być tolerancyjnym wobec naturalnych różnic charakteryzujących jego samego, jego kolegów,

- identyfikować podstawowe różnice między jednostkami, bronić swoich opinii podczas określonych działań lub przyznać się do popełnionego błędu, uzgodnić z kolegami z klasy wspólną procedurę i rozwiązanie problemu,

- wskazać problemy w swoim bezpośrednim środowisku społecznym i przyrodniczym oraz zaproponować możliwe sposoby poprawy.

Na poziomie szkoły średniej pierwszego stopnia, w klasach 6-9, elementy edukacji prawnej nadal realizowane są w ramach przedmiotu „człowiek i jego świat”. Przedmiot realizowany jest zazwyczaj w wymiarze 1 godz. tygodniowo ${ }^{13}$. Zagadnienia prawne zawarte $\mathrm{w}$ tym programie to:

- obywatelstwo, konstytucja Republiki Czeskiej, podział władzy, organy i instytucje państwa, administracja centralna, władze lokalne, zasady demokracji, pluralizm polityczny, dialog społeczny i ich znaczenie; znaczenie i formy wyborów do zgromadzeń przedstawicielskich; naruszanie praw człowieka, zastraszanie, dyskryminacja,

- system prawny Republiki Czeskiej, znaczenie i funkcje systemu prawa; organy ochrony prawnej obywateli, system sądowy; norma prawna, regulacja, publikacja przepisów prawnych.

Uczeń, kończąc klasę 9 szkoły średniej, powinien umieć:

- rozróżniać zadania poszczególnych elementów władzy państwowej w Republice Czeskiej oraz ich organów i instytucji,

- wyjaśnić zalety demokratycznego systemu zarządzania państwem w codziennym życiu obywateli,

- wyjaśnić sens wyborów do zgromadzeń lokalnych i ogólnych w krajach demokratycznych i podać przykłady wpływu wyborów na codzienne życie obywateli,

11 Rámcový vzdělávací program pro základní vzdělávání, https://www.msmt.cz/vzdelavani/zakladni-vzdelavani/ucebni-dokumenty.

12 Ibidem,

13 Ibidem. 
- szanować prawo, umieć zapoznać się ze zrozumieniem z prostymi aktami prawnymi i rozumieć konsekwencje ich stosowania,

- rozpoznać zachowanie niezgodne z prawem, odróżnić wykroczenie od przestępstwa i podać ich przykłady.

Na poziomie szkoły średniej drugiego stopnia o profilu ogólnokształcącym edukacja prawna realizowana jest w ramach obowiązkowego przedmiotu „edukacja obywatelska i podstawy nauk społecznych" (Občanská výchova a základy společenských věd $)^{14}$.

Program przedmiotu przewiduje omówienie następujących zagadnień:

- prawo i wymiar sprawiedliwości: cel i przedmiot prawa, etyka i prawo,

- prawo w życiu codziennym: osobowość prawna, zdolność prawna,

- zbiór przepisów prawa Republiki Czeskiej: system prawny, rodzaje norm prawnych; umowy oraz ich znaczenie i treść,

- instytucje ochrony prawnej: funkcje i obowiązki, zawody prawnicze; cel i przebieg postępowania cywilnego; organy uczestniczące w postępowaniu karnym, ich obowiązki; system doradztwa prawnego, działalność i obowiązki poradni obywatelskich.

Po ukończeniu przedmiotu „podstawy nauk obywatelskich i nauk społecznych" uczeń powinien umieć ${ }^{15}$ :

- wyjaśnić, jaka jest różnica między normami moralnymi a normami prawnymi, wyjaśnić cel sankcji w przypadku naruszenia norm prawnych,

- wymienić organy państwowe wydające przepisy prawne oraz znać sposób ich publikacji,

- rozróżniać osoby fizyczne i prawne oraz podać odpowiednie przykłady,

- określić warunki nawiązania i zerwania stosunków prawnych (własność, zatrudnienie, małżeństwo),

- wskazać na konkretnych przykładach możliwe konsekwencje nieznajomości warunków umowy,

- wskazać sprawy rozstrzygane w postępowaniu cywilnym oraz karnym,

- odróżnić przestępstwo od wykroczenia oraz zdefiniować warunki odpowiedzialności karnej obywateli,

- wyjaśnić zakres działalności organów i instytucji ochrony prawnej,

- przestrzegać w swoim życiu obowiązującego prawa.

\section{Estonia}

W systemie szkolnym Estonii na poziomie jednolitej 9-klasowej szkoły podstawowej, która organizacyjnie połączona jest ze szkołą średnią pierwszego stopnia, nie jest przewidziany oddzielny przedmiot dotyczący edukacji prawnej. Jednakże ele-

14 Občanská výchova a základy společenských věd, https://www.sgo.cz/predmety/obcanska-vychova-a-zaklady-spolecenskych-ved.

15 Ibidem, 
menty problematyki prawnej zostały umieszczone w programie przedmiotu „wychowanie obywatelskie" (Kodanikuharidus) ${ }^{16}$, który przede wszystkim realizowany jest w klasach 7-9 w wymiarze 2 godz. lekcyjnych tygodniowo ${ }^{17}$. Zgodnie z efektami kształcenia uczeń po ukończeniu szkoły podstawowej powinien znać pojęcia i zagadnienia prawa nieletnich, znać możliwości egzekwowania swoich praw, wiedzieć, jak znaleźć akty prawne w krajowej bazie danych, rozumieć konieczność przestrzegania prawa i mieć świadomość konsekwencji ich nieprzestrzegania.

W programach 3-klasowej szkoły średniej drugiego stopnia zagadnienia prawne rozmieszczone zostały $\mathrm{w}$ różnych przedmiotach $\mathrm{z}$ dziedzin humanistyczno-społecznych (literatura, historia, nauka o społeczeństwie). Omawiane zagadnienia prawne koncentrują się na prawach człowieka, obowiązkach obywatelskich, przepisach prawa międzynarodowego i krajowego, prawach własności intelektualnej, prawach konsumenta.

Dla uczniów szczególnie zainteresowanych problematyką prawną krajowy program nauczania proponuje nieobowiązkowy przedmiot „system prawny” (Õigussuhe $)^{18}$. Przedmiot przeznaczony jest dla szkoły średniej drugiego stopnia w wieku 16-19 lat, ma charakter fakultatywnego kursu w wymiarze 35 godz. i może być realizowany w pierwszej, drugiej lub trzeciej klasie szkoły średniej. Program przedmiotu nie jest określony przez centralne władze oświatowe i całkowicie zależy od koncepcji nauczyciela oraz profilu szkoły, w której jest realizowany. Zazwyczaj jest to kurs zorientowany na przybliżenie uczniom problematyki studiów i zawodów prawniczych oraz możliwości podejmowania pracy w tym zawodzie. Kurs może obejmować analizę wybranego studium przypadku lub prowadzenie dyskusji na temat istotnych problemów społecznych w kontekście aspektów prawnych.

\section{Finlandia}

Kształcenie w szkole podstawowej połączonej ze szkołą średnią pierwszego stopnia jest obowiązkowe, trwa 9 lat i obejmuje uczniów w wieku od 7 do 16 roku życia. Organizacyjnie i programowo szkoła podstawowa podzielona jest na dwa segmenty edukacyjne: klasy 1-6 oraz klasy 7-9. W programie jednolitej 9-klasowej szkoły podstawowej nie jest przewidziany oddzielny przedmiot dotyczący edukacji prawnej. Jednakże elementy tej problematyki, jak demokracja, prawa człowieka i integracja, zostały częściowo włączone do programu przedmiotów: „historia z nauką o społeczeństwie”(Yhteiskunnan historia ja tiede) oraz „etyka” $(\text { Etiikka })^{19}$. Ponadto, w zależności od potrzeb i zainteresowań uczniów, szko-

16 Kodanikuhariduse programm, http://www.minuriik.ee/.

17 Http://www.minuriik.ee/.

18 Ogólnokrajowy program nauczania dla szkółśrednich (Gümnaasiumi riiklikõppekava, RT I, 14.01.2011, 2), https://www.riigiteataja.ee/akt/120092011002?leiaKehtiv.

19 Perusopetuslaki 628/1998, https://www.finlex.fi/fi/laki/ajantasa/1998/19980628. 
ła może zaproponować przedmioty fakultatywne, których zakres tematyczny leży w kompetencjach nauczyciela - może to być np. edukacja prawna. Należy zwrócić uwagę, że w fińskim szkolnictwie każdy nauczyciel szkoły podstawowej i średniej oprócz swojej kierunkowej dyscypliny jest także nauczycielem zagadnień z obszaru demokracji i praw człowieka ${ }^{20}$.

Programy nauczania poszczególnych przedmiotów, w tym przedmiotów do wyboru, bazują na pobudzeniu aktywności i samodzielności uczniów. Mocno akcentują i zachęcają nauczycieli do łączenia przedmiotów z różnych dziedzin i prowadzenia zajęć o charakterze interdyscyplinarnym. Program nauczania zakłada, że co roku każda szkoła podstawowa powinna określić co najmniej jeden ważny temat dla uczniów lub społeczności lokalnej. Temat ten ma stać się dla całej społeczności uczniowskiej i nauczycielskiej wiodącym zagadnieniem realizowanym w całorocznej działalności dydaktycznej, wychowawczej i obywatelskiej placówki szkolnej. Może być to np. problematyka zanieczyszczenia środowiska, samotność osób starszych, zdrowe żywienie, uczciwość obywatelska lub respektowanie prawa. Wybrany temat powinien stać się podstawowy motywem uczniowskich projektów realizowanych podczas interdyscyplinarnych lekcji lub może być wykorzystany do działalności pozalekcyjnej. Narzędzia dydaktyczne dobierane są w taki sposób, aby uwzględniały charakter przedmiotu i cele projektu, jednocześnie wspierając umiejętności uczniów w zakresie uczenia się, myślenia oraz rozwiązywania problemów podczas pracy zespołowej.

W Finlandii w ramach szkolnictwa średniego rozróżniamy szkołę średnią ogólnokształcącą - liceum $^{21}$ oraz szkołę średnią zawodową ${ }^{22}$. Obowiązujące w nich programy nauczania dzielą się na dwie grupy: ramowe zagadnienia obowiązkowe i przedmioty fakultatywne. W obowiązkowych ramowych programach obu typów szkół nie ma przedmiotu o nazwie „edukacja prawna”, ale taki przedmiot może znaleźć się, choć nie musi, wśród przedmiotów fakultatywnych. Przedmioty fakultatywne są ważnym komplementarnym elementem całego programu, gdyż to sami uczniowie wybierają zagadnienia i moduły przedmiotowe, którymi są zainteresowani, konstruując w każdym semestrze własny plan zajęć.

\section{Francja}

W systemie szkolnym Francji na poziomie szkoły podstawowej i szkoły średniej pierwszego stopnia nie jest przewidziany oddzielny przedmiot poświęcony edukacji prawnej. Na tych poziomach edukacyjnych tematyka dotycząca prawa zintegrowana jest $\mathrm{z}$ zagadnieniami omawianymi podczas realizacji obowiązkowego przedmiotu „kształcenie moralne i obywatelskie” (Enseignement moral et civique,

20 Https://www.oph.fi/fi/koulutus-ja-tutkinnot/perusopetus/historia-ja-yhteiskuntanoppi-perusopetuksessa.

21 Https://opintopolku.fi/wp/lukio-2/.

22 Https://minedu.fi/ammatillinen-koulutus. 
$\mathrm{EMC})^{23}$. Jednym $\mathrm{z}$ trzech głównych celów tego przedmiotu - obok poszanowania innych oraz zrozumienia i akceptacji wartości Republiki - jest zbudowanie kultury obywatelskiej uczniów, której podstawą ma być świadomość prawna i prawo, które według założeń programowych przedmiotu stanowi fundament demokracji. Wśród zagadnień prawnych przewidzianych w programie EMC znalazły się m.in. następujące obszary tematyczne: prawa człowieka i obywatela; równość kobiet i mężczyzn; prawa ucznia; mechanizmy równości wobec prawa; prawo do wolności wypowiedzi i wyznania; zasady codziennego życia regulowane przez prawo; egzekwowanie prawa; ochrona prawna osób dyskryminowanych.

Oddzielny przedmiot o charakterze edukacji prawnej realizowany jest na poziomie szkoły średniej drugiego stopnia. Oferowany jest uczniom ostatniej klasy (maturalnej) w liceach ogólnokształcących (3 godz. tygodniowo) i liceach technicznych (4 godz. tygodniowo). Nosi nazwę „prawo i najważniejsze wyzwania współczesnego świata" (Droit et grands enjeux du monde contemporain, DGEMC $)^{24}$. W liceach ogólnokształcących - wyłącznie w klasach o profilu humanistycznym - występuje jako fakultet, a w liceach technicznych - o ściśle określonym profilu zarządzanie, nauka i technologie - umieszczony jest w programie jako przedmiot obowiązkowy.

W liceach ogólnokształcących humanistycznych celem przedmiotu jest podniesienie świadomości uczniów na temat prawa oraz poszerzenie ich wiedzy na temat dalszej ścieżki kształcenia w zakresie podjęcia ewentualnych studiów z dziedziny prawa, politologii, stosunków międzynarodowych czy administracji publicznej.

W liceach technicznych o profilu „zarządzanie, nauka i technologie” celem przedmiotu jest uzupełnienie zagadnień z ekonomii, logistyki i zarządzania o segment przybliżający wiedzę absolwenta na temat prawnych aspektów całokształtu działalności gospodarczej. Podczas realizacji programu szczególną uwagę zwraca się na następujące zagadnienia: prawa pracodawcy, pracownika, konsumenta; rola umowy; odpowiedzialność cywilna; prowadzenie działalności gospodarczej.

Zgodnie z ogólnymi wytycznymi Ministerstwa Edukacji zawartymi w dokumencie $E$ Eduscol ${ }^{25}$, program DGEMC obejmuje zestaw 22 tematów, które mają umożliwić uczniom poznanie różnych obszarów prawa, np. prawo publiczne, prawo prywatne, prawo międzynarodowe. Są one omawiane i dyskutowane z uczniami w kontekście wybranych zagadnień, np. orzecznictwo, odpowiedzialność, przedsiębiorstwo, seks i prawo, ewolucja rodziny, życie-ciało-zdrowie, globalne zarządzanie, stosunki międzynarodowe, prawo UE.

23 Https//eduscol.education.fr/cid92405/l-emc-dans-classe-dans-ecole-dans-etablissement.html.

24 Https://eduscol.education.fr/cid59321/presentation.html\#lien0.

25 Https://eduscol.education.fr/cid59321/droit-et-grands-enjeux-du-monde-contemporain.html. 
Zaliczenie przedmiotu polega na prezentacji i obronie przez ucznia przygotowanego w ciągu całego roku szkolnego projektu o tematyce związanej z prawem. Oceniane są wiedza i umiejętności ucznia w zakresie: dziedzin prawa, umiejętności wyodrębnienia głównych problemów i proponowania rozwiązań oraz stosowania poprawnego słownictwa. Ocena wlicza się do średniej oceny świadectwa maturalnego.

\section{Hiszpania}

W systemie szkolnym Hiszpanii ani na poziomie szkoły podstawowej, ani średniej pierwszego i drugiego stopnia nie występuje oddzielny przedmiot poświęcony edukacji prawnej. Elementy szeroko rozumianej problematyki prawnej, takie jak demokracja, prawa człowieka, konstytucja, sądownictwo itp., realizowane są w ramach przedmiotów z obszarów humanistyczno-społecznych, np. „Wychowanie społeczno-obywatelskie”. Należy zwrócić uwagę, że specyfiką hiszpańskiego systemu oświatowego jest ustawowa samodzielność programowa szkolnictwa 17 wspólnot autonomicznych. Umożliwia ona - obok zestawu przedmiotów obowiązkowych wspólnych dla szkolnictwa w całej Hiszpanii - wprowadzenie do programów nauczania wspólnot autonomicznych szerokiej oferty przedmiotów fakultatywnych dostosowanych do regionalnych potrzeb, ale także do indywidualnych zainteresowań i zdolności uczniów. Decyzja dotycząca tematyki i programu fakultetów pozostaje w gestii poszczególnych szkół. Każda placówka szkolna może zaproponować w swojej ofercie programowej fakultet dotyczący edukacji prawnej.

W szkolnictwie średnim pierwszego stopnia za najbliższy problematyce edukacji prawnej można uznać przedmiot fakultatywny „wprowadzenie do przedsiębiorczości i działalności gospodarczej” realizowany w ramach ścieżki średniego kształcenia zawodowego ${ }^{26}$. Przedmiot skierowany jest do uczniów w wieku 15 lat będących w ostatniej klasie obowiązkowej szkoły średniej pierwszego stopnia, którzy decydują się na dalsze kształcenie zawodowe. Celem przedmiotu jest przybliżenie uczniom ustawodawstwa związanego z szeroko rozumianą przedsiębiorczością oraz przygotowanie do rozumienia i radzenia sobie w przyszłej pracy z podstawowymi przepisami.

Przedmiot realizowany jest w wymiarze 3 godz. tygodniowo. Oprócz zagadnień związanych z zarządzaniem i ekonomią program obejmuje także zagadnienia z następujących dziedzin:

- prawo pracy: prawa i obowiązki wynikające ze stosunku pracy, umowa o pracę, umowy zbiorowe,

26 Real Decreto 1105/2014, de 26 de diciembre, por el que se establece el currículo básico de la Educación Secundaria Obligatoria y del Bachillerato. Ministerio de Educación, Cultura y Deporte „BOE” núm. 3, de 3 de enero de 2015 Referencia: BOE-A-2015-37, https://www.boe.es/buscar/pdf/2015/BOE-A-2015-37-consolidado.pdf. 
- bezpieczeństwo: system ubezpieczeń społecznych, system świadczeń pracowniczych, bezrobocie, ochrona pracowników,

- podstawa prawna przedsiębiorstw: status przedsiębiorstw, struktura prawna organizacji firmy, podatki i kalendarz fiskalny przedsiębiorstwa.

\section{Niemcy}

W Niemczech za organizację ustrojów szkolnych oraz programy nauczania odpowiadają władze oświatowe poszczególnych krajów związkowych (landów) ${ }^{27}$. W związku z tym programy nauczania mogą znacznie różnić się w poszczególnych landach swym zakresem tematycznym i wymiarem czasowym. W systemie szkolnym Niemiec ani na poziomie szkoły podstawowej, ani szkoły średniej pierwszego stopnia nie jest przewidziany oddzielny przedmiot poświęcony prawu. Problematyka związana $z$ szeroko pojętym prawem najczęściej zintegrowana jest $\mathrm{z}$ zagadnieniami omawianymi podczas realizacji przedmiotów takich jak „edukacja obywatelska”, „nauka o społeczeństwie” czy „historia”.

W szkolnictwie średnim drugiego stopnia również brak jest przedmiotu o nazwie „edukacja prawna”, jednakże w szkołach średnich o profilu zawodowym tam, gdzie to może okazać się przydatne lub konieczne, często wprowadza się przedmiot, który umożliwia zapoznanie ucznia $\mathrm{z}$ aspektami prawnymi konkretnego zawodu, do wykonywania którego przygotowuje szkoła.

\section{Serbia}

W systemie szkolnym Serbii ani na poziomie jednolitej 8-klasowej szkoły podstawowej, która organizacyjnie połączona jest ze szkołą średnią pierwszego stopnia, ani 4-letniej szkoły średniej nie jest przewidziany oddzielny przedmiot dotyczący edukacji prawnej. Co do zasady zagadnienia edukacji prawnej są realizowane $\mathrm{w}$ formie międzyprzedmiotowe ${ }^{28}$. Głównym celem takiej interdyscyplinarności jest wyrobienie i utrwalenie w świadomości uczniów poczucia odpowiedzialności społecznej poprzez ich aktywność i świadomość obywatelską realizowaną w życiu klasy, szkoły, a także w środowisku lokalnym.

Ponadto elementy edukacji prawnej znajdują się w programie edukacji obywatelskiej (грађанско васпитағье) ${ }^{29}$ realizowanej w szkole podstawowej i średniej. Można je także znaleźć w szkolnictwie średnim w programach szkolnych dwóch przedmiotów: „socjologia z elementami praw obywatelskich” (Социологија ca елементима грађанских права) $)^{30}$ - dla średnich szkół zawodowych oraz „kon-

${ }^{27}$ Bundesministerium für Bildung und Forschung, https://www.bmbf.de/.

28 Основно образовање, https://www.vladars.net/sr-SP-Cyrl/Vlada/Ministarstva/ $\mathrm{mpk} / \mathrm{PAO} /$ Pages/Osnovno_obrazovanje.aspx.

${ }^{29}$ Https://www.gradjanske.org/wp-content/uploads/2014/11/050-Gra\%C4\%91ansko-vaspitanj-VII-OS.pdf.

30 Http://srednjaskolabrus.edu.rs/pdf77356/skolski_program_2016202077356.pdf. 
stytucja i prawa obywatelskie" (Устав и грађанска права) - dla szkół średnich ogólnokształcących) ${ }^{31}$.

Program przedmiotu „socjologia z elementami praw obywatelskich” obejmuje następujące obszary tematyczne: 1) struktura i organizacja społeczeństwa; 2) państwo i polityka; 3) konstytucja i państwo prawa; 4) prawa człowieka i wolności obywatelskie; 5) kultura i społeczeństwo; 6) zmiany społeczne i rozwój społeczeństwa. Przedmiot jest obowiązkowy i realizowany w wymiarze 1 lub 2 godz. tygodniowo we wszystkich klasach szkoły średniej zawodowej.

Wytyczne programowe przedmiotu „konstytucja i prawa obywatelskie” obejmują następujące zagadnienia: 1) konstytucja i państwo prawa; 2) demokracja i jej mechanizmy; 3) prawa człowieka i wolności obywatelskie; 4) tworzenie prawa oraz administracja centralna i lokalna. Jedna godzina nauki tygodniowo poświęcona jest temu tematowi we wszystkich typach szkół podstawowych. Przedmiot jest obowiązkowy i realizowany również w wymiarze 1 godz. tygodniowo we wszystkich klasach szkoły średniej ogólnokształcącej.

\section{Szwecja}

W Szwecji kształcenie w 9-letniej szkole podstawowej połączonej ze szkołą średnią pierwszego stopnia obejmuje uczniów w wieku od 7. do 16. roku życia. Szkoła średnia drugiego stopnia trwa 3 lata i przeznaczona jest dla uczniów w wieku od 16. do 19. roku życia. W programach szkoły podstawowej nie jest przewidziany oddzielny przedmiot o nazwie „edukacja prawna”. Jednakże elementy zagadnień prawnych mogą być realizowane w ramach przedmiotów o charakterze społeczno-humanistycznym. W programach szkoły średniej drugiego stopnia, której program oferuje wiele fakultatywnych obszarów tematycznych, uczniowie mogą wybrać ścieżkę edukacyjną z dziedziny prawa.

W szkole podstawowej, w której dominuje kształcenie o charakterze interdyscyplinarnym, najczęściej są to zagadnienia wychowania obywatelskiego omawiane w ramach tematów z języka ojczystego, historii lub podczas realizacji projektów edukacyjnych na rzecz szkoły lub środowiska lokalnego. W programie klas 1-3 szkoły podstawowej uczniowie poznają m.in. normy i zasady życia w środowisku szkolnym, zasady i konsekwencje dobrego i złego zachowania, podstawowe zasady ruchu drogowego, podstawowe prawa człowieka i prawa dziecka. Program klas 4-6 szkoły podstawowej obejmuje m.in. zagadnienia dotyczące praw mniejszości, funkcji sądownictwa, działalności organizacji samorządowych i społecznych. Natomiast w klasach 7-9 szkoły podstawowej elementy prawne pojawiają przy omawianiu zagadnień związanych m.in. z zagrożeniem

31 Standardy i wymagania przedmiotowe dla szkolnictwa średniego (Стандарди општих међупредметих компетенција за крај средюег образоваюа), https:// ceo.edu.rs/wp-content/uploads/obrazovni_standardi/Opsti_standardi_postignuca/ MEDJUPREDMETNE\%20KOMPETENCIJE.pdf. 
przestępczością internetową, pomówieniami, bezpodstawnymi oskarżeniami, z dyskryminacją, prawami i swobodami obywatelskimi ${ }^{32}$.

Zgodnie z założeniami szwedzkiego Ministerstwa Edukacji celem nieobowiązkowej szkoły średniej jest przygotowanie uczniów w wieku 16-19 lat do podjęcia aktywności zawodowej na rynku pracy lub kontynuowania nauki na wyższych szczeblach edukacji. Według opinii władz oświatowych sama szkoła nie jest w stanie przekazać całej wiedzy, której potrzebują uczniowie ${ }^{33}$. Natomiast ważne jest, aby stwarzała uczniowi jak najlepsze warunki do ukształtowania odpowiedzialności i samodzielności myślenia. Stąd m.in. takie zorganizowanie procesu edukacyjnego, aby uczniowie mogli dokonywać samodzielnych, odpowiedzialnych wyborów edukacyjnych co do profili, specjalności i ścieżek tematycznych zgodnych $\mathrm{z}$ ich zainteresowaniami ${ }^{34}$. Program szkoły średniej zbudowany jest w taki sposób, aby uczeń mógł świadomie stworzyć swój indywidualny program kształcenia, wykorzystując do tego celu szeroką ofertę przedmiotów do wyboru, proponujących tematykę z różnych dziedzin. Wśród nich znajduje się m.in. przedmiot $\mathrm{z}$ dziedziny prawa (Juridik), w ramach którego uczniowie mogą realizować trzy oddzielne kursy: prawo i społeczeństwo, prawo gospodarcze, prawo cywilne ${ }^{35}$.

Celem przedmiotu „prawo” jest zrozumienie szwedzkiego systemu prawnego poprzez możliwość praktycznej analizy rzeczywistych sytuacji i przypadków oraz rozwinięcie w uczniach umiejętności formułowania problemów, analizowania zjawisk, a także wyrobienie umiejętności interpretowania źródeł prawa.

Program kursu „prawo i społeczeństwo” obejmuje następujące zagadnienia:

- szwedzkie prawo konstytucyjne, ze szczególnym uwzględnieniem ochrony praw człowieka i dostępu do informacji publicznej,

- prawo międzynarodowe: prawo UE i międzynarodowa ochrona praw człowieka,

- prawo karne: doktryny prawa karnego, regulacje dotyczące walki z przestępczością, przepisy dotyczące kar,

- prawo proceduralne: przepisy dotyczące szwedzkiego systemu sądowego i procedur prawnych,

- związek między etyką i moralnością w społeczeństwie oraz ustawodawstwem i wykładnią prawa.

Program kursu „prawo gospodarcze” obejmuje następujące zagadnienia:

- prawo spółek i stowarzyszeń: formy prowadzenia działalności,

- umowy w prawie szwedzkim: umowy handlowe i ich skutki prawne,

32 Curriculum for the compulsory school, preschool class and school-age educare (revised 2018), https://www.skolverket.se/getFile?file=3984.

33 Https://www.skolverket.se/.

34 Https://www.skolverket.se/undervisning/gymnasiesarskolan/laroplan-program-och-amnen-i-gymnasiesarskolan.

35 Https://www.skolverket.se/download/18.4fc05a3f164131a74181062/1535372298215/ Law-swedish-school.pdf. 
- prawo najmu: prawa i obowiązki przedsiębiorstw jako najemców,

- prawo pracy: prawa i obowiązki pracodawcy wobec pracowników,

- prawo marketingowe: ustawodawstwo dotyczące marketingu i konkurencji dotyczące działalności gospodarczej,

- prawo własności intelektualnej: ochrona znaków towarowych, patentów i innych praw autorskich,

- prawo bankowe (kredytowe): kredyty, niewypłacalność, długi spółki, bankructwo,

- spory handlowe: różne sposoby rozwiązywania sporów biznesowych.

Program kursu „prawo cywilne” obejmuje następujące zagadnienia:

- prawo konstytucyjne, prawo karne i prawo procesowe: przegląd szwedzkiego prawa konstytucyjnego i jego związek z prawem UE i prawem międzynarodowym,

- prawo rodzinne i prawo spadkowe: zasady dotyczące związku partnerskiego i stosunków rodzinnych; spadki, testamenty, podział majątku,

- prawo umów: sposoby zawierania umów i ich skutki prawne,

- prawo konsumenckie i prawo sprzedaży: konsument a przedsiębiorstwa, kredyt konsumencki,

- prawa majątkowe: zasady dotyczące zakupu nieruchomości oraz inne prawa związane z użytkowaniem,

- prawo pracy: prawa i obowiązki pracownika,

- prawo ubezpieczeniowe: zasady dotyczące ubezpieczenia.

\section{Wielka Brytania (Anglia)}

Struktura organizacyjna systemu szkolnego Wielkiej Brytanii nie jest jednolita. Struktury oświatowe Anglii, Walii, Szkocji i Irlandii Północnej są regulowane odrębnymi przepisami. We wszystkich czterech częściach składowych (constituent part) występują inne typy szkól, inne programy, inne modele kształcenia nauczycieli oraz odmienne organizacje pracy szkolnej. Programy nauczania uzależnione są od typu szkoły (publiczne, prywatne) i profilu (ogólnokształcąca, zawodowa). W ramach typu i profilu szkoły dodatkowo wyodrębnione są profilowane ścieżki kształcenia, tak aby każdy uczeń mógł wykorzystać swoje zainteresowania i swój potencjał. W ramach wybranych profili uczeń ma także do wyboru odpowiedni poziom trudności, który odpowiada jego zdolnościom i możliwościom intelektualnym.

W Anglii w szkołach początkowych i średnich elementy edukacji prawnej mogą być realizowane w ramach nieobowiązkowego programu edukacji obywatelskiej (Citizenship education) ${ }^{36}$ lub jako zestaw zagadnień międzyprzedmiotowych, gdzie treści uwzględnione są w dziedzinowych programach nauczania na ogół związanych z naukami humanistycznymi bądź społecznymi. Edukacja

36 Https://www.teachingcitizenship.org.uk/about-citizenship/citizenship-curriculum. 
prawna może być również realizowana jako odrębny przedmiot przygotowujący do profilowych egzaminów kończących poszczególne klasy (poziomy edukacyjne) szkoły średniej. Programy nauczania układane są przez szkołę przy zapewnieniu dostosowania zakresu tematycznego do wymagań egzaminacyjnych określanych przez władze oświatowe Anglii ${ }^{37}$.

Uczniowie po 3 i 4 klasie szkoły średniej drugiego stopnia przystępują, odpowiednio, do następujących egzaminów ${ }^{38}$ :

- AS Level - egzamin po ukończeniu 3 klasy szkoły średniej drugiego stopnia,

- A Level - egzamin końcowy po ukończeniu 4 klasy szkoły średniej drugiego stopnia.

Zakres tematyczny egzaminów z przedmiotów wybranych przez ucznia i dotyczących edukacji prawnej obejmuje m.in.:

- sprawdzenie rozumienia prawa publicznego i prywatnego Anglii i Walii oraz umiejętności ich porównywania,

- wykazanie się umiejętnością konstruowania wniosków i przedstawiania argumentów prawnych poprzez odniesienie się do postępowania wybranych instytucji prawnych,

- badanie wykładni ustawowej i precedensowej sądów,

- sprawdzenie rozumienia zależności: prawo i społeczeństwo; prawo i moralność; prawo i sprawiedliwość,

- sprawdzenie umiejętności definiowania i interpretowania ze zrozumieniem następujących pojęć: praworządność, stanowienie prawa, tworzenie prawa parlamentarnego, ustawodawstwo delegowane oraz powody zastosowania ustawodawstwa delegowanego, precedens sądowy oraz jego wady i zalety,

- omówienie źródeł prawa UE i jego wpływ na prawo krajowe.

\section{Włochy}

W systemie szkolnym Włoch w programach szkół początkowych i średnich pierwszego stopnia elementy edukacji prawnej realizowane są podczas wychowania obywatelskiego i nauki o konstytucji. Przedmiot ten ma charakter interdyscyplinarny, a jego treści są realizowane w trakcie międzyprzedmiotowych projektów dydaktycznych.

Taki model nauczania, od roku szkolnego 2020/2021, ma zostać zastąpiony oddzielnym, obowiązkowym przedmiotem „edukacja obywatelska” (Educazione civica $^{39}$. Przedmiot przeznaczony będzie dla uczniów szkół początkowych oraz

37 National curriculum in England: citizenship programmes of study, https://www.gov. uk/government/publications/national-curriculum-in-england-citizenship-programmes-of-study.

38 Https://www.gov.uk/government/publications/gce-subject-level-conditions-and-requirements-for-law.

39 Linee guida per l'insegnamento dell'educazione civica, ai sensi dell'articolo 3 della legge 20 agosto 2019, n. 92, http://www.iccapraiaelimite.edu.it/news/linee-guida-per- 
średnich pierwszego i drugiego stopnia. Przewidywany roczny wymiar dydaktyczny ma wynieść 33 godziny lekcyjne.

W szkole podstawowej i średniej pierwszego stopnia przedmiot może być nauczany przez nauczyciela dowolnego przedmiotu. Na poziomie szkoły średniej drugiego stopnia przedmiot ma być nauczany przez nauczycieli, którzy uzyskają specjalne uprawnienia do jego prowadzenia. Mogą nimi być nauczyciele innych przedmiotów, którzy ukończą odpowiednie szkolenia i studia podyplomowe, lub osoby spoza grona pedagogicznego z odpowiednimi uprawnieniami (np. specjaliści z sektora pozarządowego, prywatnego, gospodarczego). Program przedmiotu przeznaczony dla szkół początkowych i średnich pierwszego stopnia będzie obejmował zagadnienia związane m.in. z konstytucją, prawem międzynarodowym, poznaniem mechanizmów funkcjonowania krajowych i unijnych instytucji. W programie przewidziano także edukację na rzecz obywatelstwa cyfrowego wraz z omówieniem problematyki cyberprzemocy i nękania w sieci.

Dla szkół średnich drugiego stopnia przewidziano osobne przedmioty o nazwie „prawo” (Legge) lub „prawo i ekonomia” (Legge ed economia) ${ }^{40}$. Planuje się, że programy przedmiotów będą dostosowane do profilu szkół średnich ogólnokształcących i średnich zawodowych. Programy mają zostać opublikowane przed rozpoczęciem roku szkolnego 2020/2021.

\section{Podsumowanie}

Program edukacji prawnej co do zasady realizowany jest we wszystkich analizowanych w niniejszym artykule systemach oświatowych państw europejskich. Najczęściej jednak, tak jak w Polsce, nie jest to oddzielny przedmiot nauczania, a treści z dziedziny prawa zintegrowane są z różnymi przedmiotami takimi jak „wychowanie obywatelskie” lub „edukacja obywatelska”. Innym rozwiązaniem jest zastosowanie formuły międzyprzedmiotowej, w której elementy edukacji prawnej pojawiają się w kontekście każdego przedmiotu. Jeżeli jednak w szkolnych programach nauczania pojawia się oddzielny przedmiot o nazwie „edukacja prawna”, to najczęściej jest realizowany w szkołach ogólnokształcących jako przedmiot fakultatywny lub w szkołach średnich zawodowych i technicznych jako przedmiot uzupełniający wiedzę przyszłego absolwenta o prawnych aspektach nauczanego zawodu.

W Polsce edukacja prawna jest realizowana w ramach przedmiotu „wiedza o społeczeństwie", obowiązkowego w klasie 8 szkoły podstawowej, a następnie

-linsegnamento-delleducazione-civica-ai-sensi-dellarticolo-3-della-legge-20-agosto-2019-n-92/.

40 Scuola secondaria di secondo grado, https://www.miur.gov.it/scuola-secondaria-di-secondo-grado. 
we wszystkich typach szkół ponadpodstawowych. W Austrii edukacja prawna na poziomie szkoły podstawowej i szkoły średniej pierwszego stopnia zintegrowana jest $\mathrm{z}$ zagadnieniami omawianymi podczas realizacji przedmiotów takich jak „edukacja obywatelska”, „nauka o społeczeństwie” czy „historia”. Oddzielne przedmioty „ekonomia i prawo” lub „polityka i prawo” są realizowane dopiero na poziomie szkoły średniej drugiego stopnia, ale tylko w szkołach średnich techniczno-zawodowych o profilu administracja, zarządzanie, rolnictwo i leśnictwo. W Czechach na poziomie szkoły podstawowej oraz średniej nie ma osobnego przedmiotu dotyczącego edukacji prawnej. Jedynie w nielicznych wąsko profilowanych programach szkół średnich zawodowych i technicznych występuje przedmiot przybliżający aspekty prawne kształconego zawodu. W Estonii na poziomie 9-klasowej szkoły podstawowej elementy problematyki prawnej zostały umieszczone w programie przedmiotu „wychowanie obywatelskie”. Niektóre szkoły średnie oferują możliwość wyboru nieobowiązkowego przedmiotu „edukacja prawna”, którego program układany jest przez nauczyciela i uczniów. W Finlandii w szkole podstawowej elementy edukacji prawnej zostały umieszczone w programach przedmiotów „historia z nauką o społeczeństwie” oraz „etyka” lub realizowane są w formie kształcenia interdyscyplinarnego. W szkole średniej kształcenie prawne może odbywać się przy wykorzystaniu przedmiotów fakultatywnych. We Francji na poziomie szkoły podstawowej i średniej pierwszego stopnia nie jest przewidziany oddzielny przedmiot poświęcony edukacji prawnej. Przedmiot „prawo i najważniejsze wyzwania współczesnego świata” realizowany jest w szkole średniej drugiego stopnia. W Hiszpanii nie ma oddzielnego przedmiotu „edukacja prawna” ani na poziomie szkoły podstawowej, ani średniej. Zagadnienia prawne realizowane są w ramach przedmiotów z obszarów humanistyczno-społecznych lub w formie zajęć fakultatywnych. W Niemczech w programach nauczania nie jest przewidziany oddzielny przedmiot poświęcony prawu. Jedynie w szkołach średnich o profilu zawodowym często wprowadza się przedmiot, który umożliwia zapoznanie ucznia z aspektami prawnymi konkretnego zawodu, do wykonywania którego przygotowuje szkoła. W Serbii ani na poziomie szkoły podstawowej, ani średniej nie jest przewidziany oddzielny przedmiot dotyczący edukacji prawnej. Elementy prawa znajdują się w programie edukacji obywatelskiej. W Szwecji elementy zagadnień prawnych mogą być realizowane $\mathrm{w}$ formule interdyscyplinarnej w ramach przedmiotów o charakterze społeczno-humanistycznym lub w formie przedmiotów do wyboru. W Wielkiej Brytanii (Anglii) treści edukacji prawnej mogą być realizowane jako zagadnienia międzyprzedmiotowe lub w formie odrębnego przedmiotu przygotowującego do profilowych egzaminów kończących poszczególne poziomy edukacyjne szkoły średniej. We Włoszech na poziomie szkół początkowych i średnich elementy edukacji prawnej realizowane są w ramach interdyscyplinarnego przedmiotu, którego program obejmuje zagadnienia wychowania obywatelskiego i nauki o konstytucji. 


\section{Bibliografia}

Стандарди општих међупредметих компетенција за крај средњег образовања), https://ceo.edu.rs/wp-content/uploads/obrazovni_standardi/Opsti_standardi_postignuca/MEDJUPREDMETNE\%20KOMPETENCIJE.pdf.

Curriculum for the compulsory school, preschool class and school-age educare (revised 2018), Https://www.skolverket.se/getFile?file=3984.

Curriculum for the secondary college of business administration, https://www.abc.berufsbildendeschulen.at/download/1273/Lehrplan-HAK-VO-2004e.pdf.

Gümnaasiumi riiklik oppekava, RT I, 14.01.2011, 2; https://www.riigiteataja.ee/ akt/120092011002?leiaKehtiv.

Kodanikuhariduse programm, http://www.minuriik.ee/.

Linee guida per l'insegnamento dell'educazione civica, ai sensi dellarticolo 3 della legge 20 agosto 2019, n. 92, http://www.iccapraiaelimite.edu.it/news/linee-guida-per-linsegnamento-delleducazione-civica-ai-sensi-dellarticolo-3-della-legge-20-agosto-2019-n-92/.

National curriculum in England: citizenship programmes of study; https://www.gov.uk/ government/publications/national-curriculum-in-england-citizenship-programmes-of-study.

Občanská výchova a základy společenských věd, Https://www.sgo.cz/predmety/obcanska-vychova-a-zaklady-spolecenskych-ved

Podstawa programowa kształcenia ogólnego z komentarzem. Szkoła podstawowa. Wiedza o społeczeństwie, https://www.ore.edu.pl/wp-content/uploads/2017/05/wiedza-o-spoleczenstwie.-pp-z-komentarzem.-szkola-podstawowa-1.pdf.

Podstawa programowa kształcenia ogólnego z komentarzem. Szkoła ponadpodstawowa: liceum ogólnokształcące, technikum oraz branżowa szkoła I i II stopnia. Wiedza o społeczeństwie, https:/www.ore.edu.pl/2018/03/podstawa-programowa-ksztalcenia-ogolnego-dla-liceum-technikum-i-branzowej-szkoly-ii-stopnia/.

Rámcový vzdělávací program pro základní vzdělávání, https://www.msmt.cz/vzdelavani/ zakladni-vzdelavani/ucebni-dokumenty

\section{Akty prawne}

Real Decreto 1105/2014, de 26 de diciembre, por el que se establece el currículo básico de la Educación Secundaria Obligatoria y del Bachillerato. Ministerio de Educación, Cultura y Deporte „BOE” núm. 3, de 3 de enero de 2015 Referencia: BOE-A-2015-37; https://www.boe.es/buscar/pdf/2015/BOE-A-2015-37-consolidado.pdf.

Rozporządzenie Ministra Edukacji Narodowej z 3 kwietnia 2019 r. w sprawie ramowych planów nauczania dla publicznych szkół, Dz.U. poz. 639, ze zm.

Zalecenie Parlamentu Europejskiego i Rady z 18 grudnia 2006 r. w sprawie kompetencji kluczowych w procesie uczenia się przez całe życie (2006/962/WE), https://eur-lex.europa.eu/legal-content/PL/TXT/PDF/?uri=CELEX:32006H0962\&from=EN. 
Zalecenie Rady z 22 maja 2018 r. w sprawie kompetencji kluczowych w procesie uczenia się przez całe życie (2018/C 189/01); https://eur-lex.europa.eu/legal-content/PL/ TXT/PDF/?uri=CELEX:32018H0604(01)\&from=EN.

\section{Strony internetowe}

Https://www.bildungsstandards.berufsbildendeschulen.at/sites/default/files/broschuere/ BBS-Bildungsstandards-Broschuere-Wirtschaft-und-Recht-BHS.pdf.

Http://www.minuriik.ee/.

Https://www.finlex.fi/fi/laki/ajantasa/1998/19980628.

Https://www.oph.fi/fi/koulutus-ja-tutkinnot/perusopetus/historia-ja-yhteiskuntanoppi-perusopetuksessa.

Https://opintopolku.fi/wp/lukio-2/.

Https://minedu.fi/ammatillinen-koulutus.

Https//eduscol.education.fr/cid92405/l-emc-dans-classe-dans-ecole-dans-etablissement.html.

Https://eduscol.education.fr/cid59321/presentation.html\#lien0.

Https://eduscol.education.fr/cid59321/droit-et-grands-enjeux-du-monde-contemporain.html.

Https://www.bmbf.de/.

Https://www.vladars.net/sr-SP-Cyrl/Vlada/Ministarstva/mpk/PAO/Pages/Osnovno_ obrazovanje.aspx.

Https://www.gradjanske.org/wp-content/uploads/2014/11/050-Gra\%C4\%91ansko-vaspitanj-VII-OS.pdf.

Http://srednjaskolabrus.edu.rs/pdf77356/skolski_program_2016202077356.pdf.

Https://www.skolverket.se/.

Https://www.skolverket.se/download/18.4fc05a3f164131a74181062/1535372298215/

law-swedish-school.pdf.

Https://www.teachingcitizenship.org.uk/about-citizenship/citizenship-curriculum.

Https://www.gov.uk/government/publications/gce-subject-level-conditions-and-requirements-for-law.

Https://www.miur.gov.it/scuola-secondaria-di-secondo-grado. 



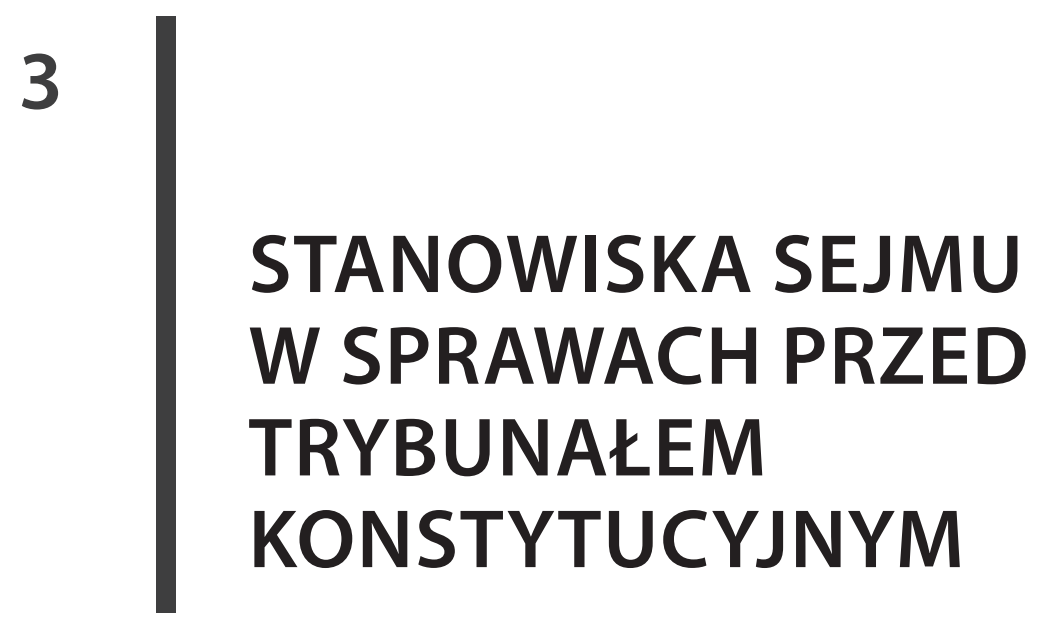





\title{
Zgodność z Konstytucją przepisu nowelizacji ustawy o odnawialnych źródłach energii oraz niektórych innych ustaw w zakresie terminu wejścia w życie ${ }^{1}$
}

\author{
Conformity to the Constitution of a provision of the Bill to Amend to the \\ Act on Renewable Energy Sources and Certain other Acts in Respect of the \\ Date of Entry into Force
}

\begin{abstract}
The Sejm's position is that the examined provision of the Act, which is being challenged by over a dozen communal and city councils, is in compliance with the principles of: non-retroactivity of the law, protection of trust towards the state and statutory law and constancy of tax law during a tax year, which are derived from the Constitution. The applicants demanded an examination of the constitutionality of the provision providing for a retroactive entry into force of the provisions giving new wording to the articles and the appendix to the Construction Law Act and the Act on Investments in Wind Farms. These provisions concern changes in the scope of the real estate tax on wind farms, which is the source of income for local self-government units. In the justification of the position, it was stated that the withdrawal from the cited constitutional principles is motivated by values approved in the Constitution.
\end{abstract}

Keywords: Constitutional Tribunal, taxes, local self-government

\footnotetext{
W stanowisku Sejmu stwierdzono, że zakwestionowany przez kilkanaście rad gmin i rad miejskich badany przepis ustawy jest zgodny z zasadami: nieretroakcji prawa, ochrony zaufania do państwa i stanowionego przez nie prawa oraz niezmienności prawa podatkowego w trakcie roku podatkowego, wywiedzionymi z Konstytucji RP. Wnioskodawcy domagali się zbadania konstytucyjności przepisu zakładającego wejście w życie z mocą wsteczną przepisów nadających nowe brzmienie artykułom i załącznikowi do ustawy - Prawo budowlane oraz ustawy o inwestycjach w zakresie elektrowni wiatrowych. Przepisy te dotyczą zmiany przedmiotowego zakresu podatku od nieruchomości od elektrowni wiatrowych, który stanowi źródło dochodów jednostek samorządu terytorialnego. W uzasadnieniu stanowiska stwierdzono, że odstąpienie od przywołanych wzorców konstytucyjnych motywowane jest wartościami aprobowanymi w ustawie zasadniczej. Słowa kluczowe: Trybunał Konstytucyjny, podatki, samorząd terytorialny

Doktor nauk prawnych, asystent -

Katolicki Uniwersytet Lubelski Jana Pawła II w Lublinie, Wydział Prawa, Prawa Kanonicznego i Administracji, Katedra Prawa Administracyjnego, LUBLIN, POLSKA • katarzyna.miaskowska-daszkiewicz@kul.lublin.pl • https://orcid.org/0000-0002-1898-8980
}

1 Sprawa zainicjowana wnioskiem Rady Gminy Świecie nad Osą z 20 sierpnia 2018 r. (sygn. akt K 4/19), połączonej ze sprawami o sygn. akt: K 5/19, K 6/19, K 7/19, K 8/19, K 9/19, K 10/19, K 11/19, K 12/19 i rozpoznawanej pod wspólną sygn. akt K 4/19, dotycząca ustawy z dnia 7 czerwca 2018 r. o zmianie ustawy o odnawialnych źródłach energii oraz niektórych innych ustaw, projekt stanowiska sporządzony 10 czerwca 2020 r.; BAS-WAK-831/19. 
Na podstawie art. 69 ust. 2 w związku z art. 42 pkt 3 ustawy z 30 listopada 2016 r. o organizacji i trybie postępowania przed Trybunałem Konstytucyjnym (t.j. Dz. U. 2019, poz. 2393), w imieniu Sejmu Rzeczypospolitej Polskiej przedkładam wyjaśnienia w sprawie zainicjowanej wnioskami Rady Gminy Świecie nad Osą z 20 sierpnia 2018 r. (sygn. akt K 4/19) oraz Rady Gminy Kobylnica z 31 maja 2019 r. (sygn. akt K 14/19), rozpoznawanych pod wspólną sygn. akt K 4/19, jednocześnie wnosząc o stwierdzenie, że art. 17 pkt 2 ustawy z 7 czerwca 2018 r. o zmianie ustawy o odnawialnych źródłach energii oraz niektórych innych ustaw (Dz. U. poz. 1276) jest zgodny z zasadami: nieretroakcji prawa, ochrony zaufania do państwa i stanowionego przez nie prawa oraz niezmienności prawa podatkowego w trakcie roku podatkowego, wywodzonymi z art. 2 Konstytucji, w związku $\mathrm{z}$ art. 167 ust. 3 Konstytucji.

Ponadto Sejm wnosi o umorzenie postępowania w pozostałym zakresie, na podstawie art. 59 ust. 1 pkt 2 ustawy o organizacji i trybie postępowania przed Trybunałem Konstytucyjnym, ze względu na niedopuszczalność wydania wyroku.

\section{Uzasadnienie}

\section{Uwagi wstępne}

W dniu 17 kwietnia 2019 r. do Kancelarii Sejmu wpłynęło zawiadomienie Prezes Trybunału Konstytucyjnego o wszczęciu postępowania przed Trybunałem Konstytucyjnym w sprawie wniosków: Rady Gminy Świecie nad Osą z 20 sierpnia 2018 r. (wpływ do TK - 21 sierpnia 2018 r.), sygn. akt K 4/19; Rady Gminy Lubowidz z 3 września 2018 r. (wpływ do TK - 6 września 2018 r.), sygn. akt K 5/19; Rady Gminy Dąbrowice z 3 września 2018 r. (wpływ do TK - 6 września 2018 r.), sygn. akt K 6/19; Rady Gminy Kamiennik z 3 września 2018 r. (wpływ do TK 6 września 2018 r.), sygn. akt K 7/19; Rady Gminy Rusiec z 4 września 2018 r. (wpływ do TK - 7 września 2018 r.), sygn. akt K 8/19; Rady Gminy Dygowo z 4 września 2018 r. (wpływ do TK - 7 września 2018 r.), sygn. akt K 9/19; Rady Miejskiej w Pelplinie z 6 września 2018 r. (wpływ do TK - 11 września 2018 r.), sygn. akt K 10/19; Rady Gminy Michów z 19 września 2018 r. (wpływ do TK 24 września 2018 r.), sygn. akt K 11/19 oraz Rady Gminy Stupsk z 26 września 2018 r. (wpływ do TK - 1 października 2018 r.), sygn. akt K 12/19.

Zarządzeniem Prezes TK wymienione wnioski zostały połączone w celu łącznego ich rozpoznania pod wspólną sygn. akt K 4/19, z uwagi na tożsamość przedmiotu spraw. Z tego samego względu do przywołanego postępowania dołączono wniosek Rady Gminy Kobylnica z 31 maja 2019 r. (wpływ do TK 5 czerwca 2019 r.), sygn. akt K 14/19, oraz wniosek Rady Miejskiej w Nowym Stawie z 18 czerwca 2019 r. (wpływ do TK - 25 sierpnia 2019 r.), sygn. akt K 19/19. 
Zarządzeniem Prezes Trybunału Konstytucyjnego z 21 kwietnia 2020 r. wnioski: Rady Gminy Lubowidz (sygn. akt K 5/19), Rady Gminy Dąbrowice (sygn. akt K 6/19), Rady Gminy Kamiennik (sygn. akt K 7/19), Rady Gminy Rusiec (sygn. akt K 8/19), Rady Gminy Dygowo (sygn. akt K 9/19), Rady Miejskiej w Pelplinie (sygn. akt K 10/19), Rady Gminy Michów (sygn. akt K 11/19), Rady Gminy Stupsk (sygn. akt K 12/19) i Rady Miejskiej w Nowym Stawie (sygn. akt K 19/19) zostały wyłączone do odrębnego rozpoznania.

Pod wspólną sygnaturą akt K 4/19 rozpoznawane są: wniosek Rady Gminy Świecie nad Osą (dalej: wniosek nr 1, wnioskodawczyni nr 1) oraz wniosek Rady Gminy Kobylnica (dalej: wniosek nr 2, wnioskodawczyni nr 2).

\section{Przedmiot kontroli}

1. Przedmiotem kontroli obie wnioskodawczynie uczyniły art. 17 pkt 2 ustawy z 7 czerwca 2018 r. o zmianie ustawy o odnawialnych źródłach energii oraz niektórych innych ustaw (Dz. U. poz. 1276; dalej: ustawa zmieniająca).

Kwestionowany przepis ma następujące brzmienie: „Ustawa wchodzi w życie po upływie 14 dni od dnia ogłoszenia, z wyjątkiem: [...] 2) art. 2 pkt 1 i 6 oraz art. 3 pkt 1, które wchodzą w życie z dniem następującym po dniu ogłoszenia, z mocą od dnia 1 stycznia 2018 r.".

Dla klarowności dalszego wywodu należy przywołać wskazane w treści kwestionowanego przepisu unormowania, zgodnie z którymi:

a) „W ustawie z dnia 7 lipca 1994 r. - Prawo budowlane (Dz. U. z 2018 r. poz. 1202) wprowadza się następujące zmiany: 1) w art. 3 pkt 3 otrzymuje brzmienie: «3) budowli - należy przez to rozumieć każdy obiekt budowlany niebędący budynkiem lub obiektem małej architektury, jak: obiekty liniowe, lotniska, mosty, wiadukty, estakady, tunele, przepusty, sieci techniczne, wolno stojące maszty antenowe, wolno stojące trwale związane z gruntem tablice reklamowe i urządzenia reklamowe, budowle ziemne, obronne (fortyfikacje), ochronne, hydrotechniczne, zbiorniki, wolno stojące instalacje przemysłowe lub urządzenia techniczne, oczyszczalnie ścieków, składowiska odpadów, stacje uzdatniania wody, konstrukcje oporowe, nadziemne i podziemne przejścia dla pieszych, sieci uzbrojenia terenu, budowle sportowe, cmentarze, pomniki, a także części budowlane urządzeń technicznych (kotłów, pieców przemysłowych, elektrowni jądrowych, elektrowni wiatrowych i innych urządzeń) oraz fundamenty pod maszyny i urządzenia, jako odrębne pod względem technicznym części przedmiotów składających się na całość użytkową»" (art. 2 pkt 1 ustawy zmieniającej);

a) „W ustawie z dnia 7 lipca 1994 r. - Prawo budowlane (Dz. U. z 2018 r. poz. 1202) wprowadza się następujące zmiany: [...] 6) w załączniku do ustawy wiersz «Kategoria XXIX - wolno stojące kominy i maszty oraz elektrownie wiatrowe» otrzymuje brzmienie: 


\begin{tabular}{|l|c|c|c|c|c|}
\hline & & \multicolumn{4}{|c|}{ Współczynnik wielkości obiektu (w) (wysokość w m) } \\
\hline & $\leq 20$ & $>20-50$ & $>50-100$ & $>100$ \\
\hline $\begin{array}{l}\text { Kategoria XXIX - wolno } \\
\text { stojące kominy i maszty } \\
\text { oraz części budowlane } \\
\text { elektrowni wiatrowych }\end{array}$ & 10,0 & 1,0 & 1,5 & 2,0 & 2,5 \\
\hline
\end{tabular}

(2 pkt 6 ustawy zmieniającej);

b) „W ustawie z dnia 20 maja 2016 r. o inwestycjach w zakresie elektrowni wiatrowych (Dz. U. poz. 961) wprowadza się następujące zmiany: 1) w art. 2 pkt 1 otrzymuje brzmienie: «1) elektrownia wiatrowa - instalację odnawialnego źródła energii, składającą się z części budowlanej stanowiącej budowlę w rozumieniu prawa budowlanego oraz urządzeń technicznych, w tym elementów technicznych, w której energia elektryczna jest wytwarzana $z$ energii wiatru, o mocy większej niż moc mikroinstalacji w rozumieniu art. 2 pkt 19 ustawy z dnia 20 lutego 2015 r. o odnawialnych źródłach energii (Dz. U. z 2018 r. poz. 1269 i 1276) [aktualnie: t.j. Dz. U. 2020, poz. 261, ze zm. - uwaga K.M.-D.]»" (art. 3 pkt 1 ustawy zmieniającej).

2. W odniesieniu do przedmiotu kontroli należy dodać, że w obu wnioskach posłużono się zakresową formułą zaskarżenia, co sugerowałoby, że inicjatorki niniejszego postępowania kwestionują nie brzmienie przepisu in extenso, ale jego treść w ograniczonym wymiarze.

Rada Gminy Świecie nad Osą domaga się zbadania konstytucyjności art. 17 pkt 2 ustawy zmieniającej „w zakresie, w jakim przewiduje wejście w życie z mocą wsteczną od dnia 1.01.2018 r. art. 2 pkt 1 i 6 oraz art. 3 pkt 1 tej Ustawy, nadających nowe brzmienie art. 3 pkt 3 i załącznikowi do Ustawy z dnia 7 lipca 1994 r. - Prawo budowlane (Dz. U. z 2018 r. poz. 1202 ze zm.) oraz art. 2 pkt 1 Ustawy z dnia 20 maja 2016 r. o inwestycjach w zakresie elektrowni wiatrowych (Dz. U. poz. 961)”.

Natomiast precyzując przedmiot zaskarżenia w swoim wniosku, Rada Gminy Kobylnica wskazała, iż wnosi o zbadanie art. 17 pkt 2 ustawy zmieniającej „w zakresie $\mathrm{w}$ jakim przewiduje on wejście $\mathrm{w}$ życie przepisu art. 2 pkt 1 i 6 oraz art. 3 pkt 1 tejże ustawy z mocą wsteczną, tj. od dnia 1 stycznia 2018 r.”.

W związku z powyższym należy odnotować, że analiza treści normatywnej zakwestionowanego przepisu i konfrontacja jej z przywołanymi zakresami zaskarżenia sformułowanymi we wnioskach prowadzi do konkluzji, że w istocie zawartość zaskarżonego art. 17 ust. 2 ustawy zmieniającej wyczerpuje przywołane przez wnioskodawczynie zakresy zaskarżenia. Przepis ten bowiem nie zawiera żadnej innej dodatkowej treści, która nie podlegałaby zaskarżeniu.

$\mathrm{Z}$ tego względu Sejm, odwołując się do zasady falsa demonstratio non nocet, która nakazuje odczytywać zakres zaskarżenia zgodnie $\mathrm{z}$ intencjami podmiotu uruchamiającego postępowanie przed sądem konstytucyjnym, skłania się ku zmianie sposobu oznaczenia przedmiotu kontroli i wskazania jako taki art. 17 pkt 2 ustawy zmieniającej, bez doprecyzowania jego zakresu. 
3. Szczegółowa analiza przedmiotu kontroli zostanie dokonana w części niniejszego stanowiska poświęconej analizie zgodności.

\section{Zarzuty wnioskodawczyń}

1. Wnioskodawczyni nr 1 zakwestionowała zgodność art. 17 pkt 2 ustawy zmieniającej z zasadami wywodzonymi z zasady demokratycznego państwa prawnego (art. 2 Konstytucji): zasadą lex retro non agit, zasadą zaufania obywatela do państwa i stanowionego przez nie prawa (pewności prawa), zasadą ochrony praw nabytych, zasadą przyzwoitej legislacji i zakazem zmiany przepisów podatkowych w trakcie trwania roku podatkowego. Jako przepis związkowy wskazano przy tym art. 167 Konstytucji, wyrażający zasadę samodzielności finansowej jednostek samorządu terytorialnego.

W uzasadnieniu zarzutów wnioskodawczyni nr 1 podkreśliła, że zmiany wprowadzone na mocy art. 17 pkt 2 ustawy zmieniającej mają istotne znaczenie dla gmin jako jednostek samorządu terytorialnego, ponieważ bezpośrednio determinują one wysokość ich dochodów. Wpływy z podatku od nieruchomości, in casu od elektrowni wiatrowych, stanowią bowiem źródło dochodów jednostek samorządu terytorialnego

Zgodnie $\mathrm{z}$ art. 2 ust. 1 pkt 3 ustawy z 12 stycznia 1991 r. o podatkach i opłatach lokalnych (t.j. Dz. U. 2019, poz. 1170, ze zm., dalej: u.p.o.l.), opodatkowaniu podatkiem od nieruchomości podlegają budowle lub ich części związane z prowadzeniem działalności gospodarczej. Dla potrzeb podatku od nieruchomości za budowlę uznaje się obiekt budowlany w rozumieniu przepisów prawa budowlanego niebędący budynkiem lub obiektem małej architektury, a także urządzenia budowlane $\mathrm{w}$ rozumieniu przepisów prawa budowlanego związane $\mathrm{z}$ obiektem budowlanym, które zapewniają możliwość użytkowania obiektu zgodnie z jego przeznaczeniem (art. 1a ust. 1 pkt 2 u.p.o.l.).

Wnioskodawczyni nr 1 wskazuje, iż: „, $[\mathrm{k}]$ ażda zatem zmiana definicji budowli w Prawie budowlanym (czy też prawie budowlanym rozumianym szeroko jako zbiór ustaw normujących kwestie związane $\mathrm{z}$ budownictwem) powoduje zmianę w zakresie opodatkowania budowli podatkiem od nieruchomości, który stanowi wyłączny dochód gmin" (wniosek nr 1, s. 4).

W wyniku konstrukcji zaskarżonej regulacji przyjętej 7 czerwca 2018 r. od 1 stycznia 2018 r. opodatkowaniu podlega część budowlana elektrowni wiatrowej bez urządzeń technicznych, podczas gdy w poprzednio obowiązującym stanie prawnym opodatkowaniu podlegała cała elektrownia wiatrowa (część budowlana wraz z częścią techniczną).

Wnioskodawczyni nr 1 argumentuje, że tym samym, ze względu na zmianę definicji budowli i definicji elektrowni wiatrowej oraz datę wejścia w życie tych zmian, jednostka samorządu terytorialnego przez nią reprezentowana została pozbawiona części swoich dochodów (swojej samodzielności finansowej). Ponadto na mocy wstecznego obowiązywania przepisów wskazanych w art. 17 pkt 2 
ustawy zmieniającej, zobowiązana została do zwrotu uiszczonego już podatku od nieruchomości od elektrowni wiatrowych posadowionych na jej terenie.

$\mathrm{Z}$ analizy wniosku nr 1 wynika, że wnioskodawczyni nr 1, dostrzegając pojemność normatywną art. 2 Konstytucji, diagnozuje naruszenie kilku zasad szczegółowych wywodzonych z tego wzorca kontroli.

Po pierwsze, argumentuje, że art. 17 pkt 2 ustawy zmieniającej narusza zasadę ochrony zaufania do państwa i stanowionego przez nie prawa, którą należy odnosić również do jednostek samorządu terytorialnego.

Po drugie, wywodzi złamanie zasady ochrony praw nabytych oraz interesów w toku.

Po trzecie, stwierdza naruszenie zasady lex retro non agit, przy jednoczesnym braku wskazania w uzasadnieniu ustawy zmieniającej wartości konstytucyjnej, która usprawiedliwiałaby zdiagnozowaną retroakcję. Wnioskodawczyni nr 1 powołując się na wyrok TK z 20 stycznia 2010 r., sygn. akt Kp 6/09 - wskazuje, że adresatem zasady lex retro non agit są także jednostki samorządu terytorialnego, ponieważ art. 2 Konstytucji wyznacza konstytucyjną sytuację prawną nie tylko jednostki, a więc obywateli i osób, ale również jednostek samorządu terytorialnego (wniosek nr 1, s. 5).

Po czwarte, wskazuje na przekroczenie wynikającego bezwzględnie z art. 2 Konstytucji zakazu zmiany prawa podatkowego w trakcie trwania roku podatkowego.

Po piąte wreszcie, wywodzi naruszenie przez kwestionowany przepis art. 167 Konstytucji, statuujący zasadę samodzielności samorządu terytorialnego, której jednym z elementów składowych jest zasada samodzielności finansowej.

We wniosku nr 1 argumentuje się, że Rada Gminy Świecie nad Osą działała $\mathrm{w}$ pełni racjonalnie, uchwalając budżet gminy w terminie ustawowym i w zgodzie z obowiązującym wówczas prawem, uwzględniając dochody z tytułu podatku od nieruchomości, których wysokość decydowała o skali planowanych przedsięwzięć. Dochody z tytułu podatku od nieruchomości za rok 2018 nie zostały określone w budżecie tej jednostki samorządu terytorialnego jako rezerwa lub lokata i na ich podstawie zostały zaplanowane konkretne wydatki. Podniesiono, że skoro zasadą jest, iż budżet jednostki samorządu terytorialnego nie przewiduje nadwyżki budżetowej, a gromadzone dochody nie stanowią rezerwy ani lokaty, to braki w zakresie dochodów skutkują niemożliwością pokrycia przewidywanych wydatków przede wszystkim związanych z realizacją zadań własnych. W konsekwencji, zwłaszcza w przypadku małych gmin, na terenie których zlokalizowane są elektrownie wiatrowe, prowadzi to do pogorszenia jakości życia ich mieszkańców (wniosek nr 1, s. 7).

W opinii wnioskodawczyni nr 1 powołane powyżej zasady konstytucyjne wynikające $\mathrm{z}$ art. 2 Konstytucji, w tym w szczególności zakaz zmiany przepisów prawa podatkowego $\mathrm{w}$ trakcie trwania roku podatkowego, jak i zasada samodzielności finansowej jednostek samorządu terytorialnego, nakazywały jej po- 
dejmowanie działań w zaufaniu do obowiązującego stanu prawnego i w żaden sposób nie pozwalały na przewidzenie, że władza ustawodawcza w trakcie roku budżetowego pozbawi ją znacznej części dochodów. „O ile więc w granicach określonych ustawą, zgodnie $\mathrm{z}$ art. 167 ust. 3 Konstytucji, ustawodawca może kształtować wysokość dochodów własnych gmin, w tym z tytułu podatku od nieruchomości, o tyle powinien w tym względzie mieć na uwadze również zasadę adekwatności wyrażoną w ust. 1 tego przepisu. Udział w dochodach publicznych powinien być odpowiedni do przypadających jednostkom samorządu terytorialnego zadań. Skoro więc następuje obniżenie tych dochodów bez zmniejszenia zadań oraz bez właściwej rekompensaty utraconych dochodów, to zasada ta jest zachwiana ze szkodą dla społeczności lokalnej, wobec której samorząd pełni funkcję służebną" (ibidem).

Ponadto wnioskodawczyni nr 1 zadeklarowała, że w pełni popiera i przyjmuje jako własne stanowisko wyrażone w ekspertyzie prawnej, załączonej do uchwały Rady Gminy Świecie nad Osą, a sporządzonej przez dr. hab. Rafała Dowgiera i dr. Artura Olechno z Uniwersytetu w Białymstoku, w związku z czym nie będzie powielała argumentów tam zawartych, wnosząc o uwzględnienie tych argumentów. W tym miejscu Sejm uznaje za stosowne podnieść, że jego wątpliwości budzi przywołana konstrukcja uzasadnienia wniosku, nakazująca poszukiwanie argumentacji na rzecz niezgodności z Konstytucją w ekspertyzie dołączonej do niego.

2. Z kolei we wniosku nr 2 zdiagnozowano problem konstytucyjny wyłącznie w perspektywie art. 2 Konstytucji RP, wskazując, że kwestionowana regulacja narusza zasadę zaufania do państwa i stanowionego przez nie prawa oraz zasadę nieretroakcji.

W uzasadnieniu zarzutów wnioskodawczyni nr 2 stwierdziła, że „w przedmiotowej sprawie Ustawa Nowelizująca bez wątpienia wprowadziła przepisami art. 17 pkt 2 niedozwoloną regulację retroaktywną, gdyż przepis ten przewiduje, że art. 2 pkt 1 i 6 oraz art. 3 pkt 1 Ustawy Nowelizującej (a zatem przepisy wpływające bezpośrednio na wymiar daniny) wchodzą w życie z dniem 30 czerwca 2018 r., z mocą od dnia 1 stycznia 2018 r. Wskazana regulacja godzi w zasadę lex retro non agit, stanowiącą istotny składnik zasady zaufania obywateli do państwa oraz zasady pewności prawa, wywodzących się z zasady demokratycznego państwa prawnego proklamowanej przez art. 2 Konstytucji RP" (wniosek nr 2, s. 14).

Jednocześnie, po dokonaniu analizy orzecznictwa Trybunału Konstytucyjnego, wnioskodawczyni nr 2 stwierdziła, że w świetle poglądów TK, w odniesieniu do przedmiotowej sprawy nie sposób wskazać okoliczności, które usprawiedliwiałyby odstępstwo od zasady lex retro non agit, bowiem w uzasadnieniu projektu ustawy zmieniającej „w zasadzie brak jest wytłumaczenia wprowadzenia zaskarżonego przepisu z mocą wsteczną [...] trudno byłoby racjonalnie twierdzić, iż retroaktywność wiązała się z potrzebą realizacji czy ochroną pewnej (bliżej nieokreślonej) zasady prawno-konstytucyjnej. Nie wskazują na to także zawarte 
w uzasadnieniu przewidywane skutki wprowadzenia zaskarżonej regulacji (społeczne, gospodarcze i finansowe)" (wniosek nr 2, s. 16).

We wniosku nr 2 wywiedziono ponadto, że nie można uznać za adekwatne usprawiedliwienie powołanie się projektodawcy na treść decyzji Komisji Europejskiej z 13 grudnia 2017 r., o sygn. SG-Grcffe(2017)D/19933, ponieważ decyzja ta „przewiduje zobowiązanie władz polskich (podjęte jeszcze w 2017 r.), aby zapewnić wejście w życie Ustawy Nowelizującej [ustawy zmieniającej - uwaga K.M.-D.] - w tym zmiany podatku od nieruchomości - nie później niż 1 stycznia 2018 r. Niewprowadzenie zmian w zakreślonym terminie nie tłumaczy więc wprowadzania przez ustawodawcę przepisów ze skutkiem retroaktywnym. [...] Stan, w którym to na gminy przerzucony został ciężar finansowy związany z brakiem odpowiednio szybkiego działania ustawodawcy (a więc do dnia 1 stycznia 2018 r.) nie jest z pewnością realizacją "przyjętego zobowiązania międzynarodowego». Deklaracja Rządu wprost odnosiła się do zmiany cen referencyjnych, a nie do wprowadzania zmian w prawie z mocą wsteczną. Tym samym deklaracja ta nie może stanowić uzasadnionej podstawy do dokonania odstępstwa od zasady lex retro non agit, wyrażonej pośrednio w art. 2 Konstytucji RP” (wniosek nr 2, s. 18).

\section{Analiza formalnoprawna}

1. W pierwszej kolejności rozważenia wymaga legitymacja wnioskodawczyń w niniejszej sprawie.

Postępowanie przed Trybunałem Konstytucyjnym zostało zainicjowane przez organy stanowiące jednostek samorządu terytorialnego. Zgodnie z art. 191 ust. 1 pkt 3 w związku $\mathrm{z}$ art. 188 Konstytucji, organy stanowiące jednostek samorządu terytorialnego mogą wystąpić do Trybunału z wnioskiem w sprawie zbadania zgodności ustaw z Konstytucją oraz z ratyfikowanymi umowami międzynarodowymi, których ratyfikacja wymagała uprzedniej zgody wyrażonej w ustawie. Ustanowiony w art. 191 ust. 2 Konstytucji warunek dopuszczalności złożenia wniosku do Trybunału Konstytucyjnego przez organ stanowiący jednostki samorządu terytorialnego polega na wymaganiu istnienia związku między zaskarżonym przepisem a sprawami objętymi zakresem działania tego rodzaju jednostek. Sposób rozumienia przesłanki „sprawy objęte zakresem działania” na gruncie art. 191 ust. 2 Konstytucji stanowi przedmiot utrwalonej linii orzeczniczej sądu konstytucyjnego, który uznaje ją za spełnioną wówczas, gdy kwestionowany przepis wyznacza kompetencje jednostki samorządu terytorialnego bądź dotyczy bezpośrednio spraw tej jednostki (zob. wyroki TK z: 9 czerwca 2010 r., sygn. akt K 29/07, i 13 lipca 2011 r., sygn. akt K 10/09).

2. Rozstrzygając kwestię legitymacji procesowej wnioskodawczyń w niniejszym postępowaniu, należy stwierdzić, że w świetle art. $15 \mathrm{w}$ związku z art. 11a ust. 1 pkt 1 ustawy z 8 marca 1990 r. o samorządzie gminnym (t.j Dz. U. 2020, poz. 713) są one organami stanowiącymi jednostek samorządu terytorialnego i wystąpiły z wnioskami do Trybunału na podstawie podjętych uchwał dołączo- 
nych do wniosków, czym zadośćuczyniono wymogowi płynącemu z art. 48 ust. 2 pkt 1 ustawy 30 listopada 2016 r. o organizacji i trybie postępowania przed Trybunałem Konstytucyjnym (t.j. Dz. U. 2019, poz. 2393; dalej: ustawa o TK).

Zgodnie z art. 4 ust. 1 pkt 1 lit. a ustawy z 13 listopada 2003 r. o dochodach jednostek samorządu terytorialnego (t.j. Dz. U. 2020, poz. 23, ze zm.) źródłami dochodów własnych gminy są wpływy z podatku od nieruchomości.

Zaskarżonym przepisem zastosowano mechanizm retroakcji w odniesieniu do art. 2 pkt 1 i 6 oraz art. 3 pkt 1 ustawy zmieniającej. Przepisy te zmodyfikowały zakres przedmiotowy opodatkowania podatkiem od nieruchomości elektrowni wiatrowych, obejmując nim wyłącznie ich części budowlane. Tym samym, zważywszy, że podstawą wymiaru podatku od nieruchomości w odniesieniu do budowli jest ich wartość (art. 4 ust. 1 pkt 3 u.p.o.l.), obniżeniu uległy wpływy podatkowe $\mathrm{w}$ gminach, na terenie których ulokowano tzw. farmy wiatrowe. Nie ulega więc wątpliwości, że kwestionowana regulacja ma wpływ na dochody jednostek samorządu terytorialnego, których organami są wnioskodawczynie, a tym samym dotyczy bezpośrednio ich spraw.

Warto odnotować, że w wyroku z 13 lipca 2011 r. (sygn. akt K 10/09) Trybunał, orzekając w pełnym składzie, wyraził pogląd, że „interes ekonomiczny (faktyczny) gminy [...] stanowi adekwatną przesłankę wystąpienia z wnioskiem do Trybunału Konstytucyjnego". Zdaniem Trybunału, ze względu na wyrażone w Konstytucji zasady dotyczące samodzielności jednostek samorządu terytorialnego, „trudno jest zaaprobować stanowisko, że przepisy oddziałujące w sposób bezpośredni na wysokość dochodów warunkujących sposób wykonywania przez gminę jej zadań nie dotyczą spraw objętych zakresem działania gminy”.

3. Ustalenie legitymacji procesowej wnioskodawczyń nie wyczerpuje zagadnień formalnoprawnych $w$ niniejszej sprawie, bowiem analiza treści uzasadnienia wniosku nr 1 ujawnia deficyty w jego warstwie argumentacyjnej, co wywołuje wątpliwości Sejmu co do dopuszczalności merytorycznego orzekania względem niektórych wzorców kontroli.

Sejm pragnie przypomnieć, że w art. 47 ust. 1 ustawy o TK sprecyzowane zostały wymogi, jakim powinny odpowiadać wnioski składane do Trybunału Konstytucyjnego, aby skutecznie zainicjować hierarchiczną kontrolę norm. Elementami niezbędnymi uzasadnienia wniosku, w świetle art. 47 ust. 2 ustawy o TK, są m.in.: „przywołanie treści kwestionowanego wnioskiem przepisu wraz z jego wykładnią” (pkt 1), „przywołanie wzorców kontroli wraz z ich wykładnią” (pkt 2), „określenie problemu konstytucyjnego i zarzutu niekonstytucyjności” (pkt 3) oraz „wskazanie argumentów lub dowodów na poparcie zarzutu niekonstytucyjności” (pkt 4).

Trybunał Konstytucyjny związany jest zarzutami określonymi w piśmie procesowym, pochodzącym od podmiotu uprawnionego do inicjowania postępowania. W tym zakresie zaś istotne znaczenie ma należyte uzasadnienie zarzutów. Wskazywane w piśmie procesowym argumenty „zawsze muszą być argumenta- 
mi „nadającymi się” do rozpoznania przez Trybunał Konstytucyjny” (wyrok TK z 19 października 2010 r., sygn. akt P 10/10).

Kontrola konstytucyjności ustaw przebiega na podstawie domniemania, że badane normy są zgodne z Konstytucją. Ciężar dowodu spoczywa na podmiocie kwestionującym zgodność ustawy z Konstytucją. Obowiązkiem wnioskodawcy jest więc przedstawienie argumentów, przemawiających za stwierdzeniem niezgodności zaskarżonych norm prawnych z normami powołanymi jako podstawa kontroli (zob. K. Wojtyczek, Ciężar dowodu i argumentacji w procedurze kontroli norm przez Trybunał Konstytucyjny, „Przegląd Sejmowy” 2004, nr 1, s. 17).

Nie jest więc wystarczające sformułowanie samej tezy o niekonstytucyjności zaskarżonego przepisu. Zdaniem Trybunału Konstytucyjnego: „Uzasadnienie musi spełniać określone wymagania, w tym przede wszystkim precyzyjnie wskazywać co najmniej jeden argument przemawiający za naruszeniem określonych wzorców kontroli. Nie realizują omawianych wymagań uwagi nazbyt ogólne, niejasne czy też czynione jedynie na marginesie innych rozważań. Należy przy tym odróżnić uzasadnienie pozorne i uzasadnienie błędne czy nietrafne. Postawienie bezzasadnego zarzutu prowadzi do uznania aktu normatywnego za zgodny z danym przepisem Konstytucji, ewentualnie do stwierdzenia nieadekwatności wzorca kontroli, natomiast błędne czy nietrafne uzasadnienie, o ile nie wpływa na rekonstrukcję nieprecyzyjnie sformułowanego zarzutu, nie ma znaczenia dla rozstrzygnięcia $\mathrm{w}$ przedmiocie zgodności aktu normatywnego z ustawą zasadniczą" (zob. np. wyrok TK z 5 czerwca 2014 r., sygn. akt K 35/11).

Zatem przepisy ustawy o TK nakładają na podmioty uprawnione do złożenia wniosku (pytania, skargi) do sądu konstytucyjnego pewne obowiązki, w tym wymóg uzasadnienia postawionego zarzutu, z powołaniem dowodów na jego poparcie. Trybunał Konstytucyjny, we wcześniejszym orzecznictwie, które zachowuje pełną aktualność na tle obowiązującego stanu prawnego, podkreślał, że „uzasadnienie zarzutów powinno opierać się na przedstawieniu we wniosku takiej argumentacji, która uprawdopodobni ewentualną niekonstytucyjność kwestionowanych przepisów. W szczególności argumentacja taka nie może opierać się jedynie na odczuciach czy wyobrażeniach wnioskodawcy, ale powinna być poparta merytorycznym uzasadnieniem, mogącym uwzględniać m.in. wcześniejsze orzecznictwo TK, praktykę stosowania prawa czy dorobek doktryny" (postanowienie TK z 6 listopada 2007 r., sygn. akt Tw 41/05; zob. także postanowienia TK z: 12 sierpnia 2005 r., sygn. akt Tw 23/05, i 29 sierpnia 2006 r., sygn. akt Tw 14/06). Samo werbalne sformułowanie zarzutu, czy też wskazanie, że kwestionowany przepis jest sprzeczny z innym przepisem aktu hierarchicznie wyższego nie może więc zostać uznane za uzasadnienie zarzutu w sensie procesowym. Zgodnie $\mathrm{z}$ art. 67 ustawy o TK Trybunał Konstytucyjny jest bowiem związany treścią oraz granicami rozpatrywanego wniosku, pytania prawnego lub skargi. Tym samym nie może on - wychodząc poza granice określone w piśmie inicjującym postępowanie - wyręczać inicjatora tego postępowania w doborze argumentacji 
adekwatnej do podnoszonych wątpliwości. Brak odpowiedniego uzasadnienia zarzutu niezgodności danego przepisu z przywołanymi wzorcami kontroli stanowi o uchybieniu przez wnioskodawcę ustawowej powinności określonej w art. 47 ust. 2 pkt 4 ustawy o TK i skutkuje brakiem możliwości jego rozpatrzenia przez sąd konstytucyjny oraz koniecznością umorzenia postępowania ze względu na niedopuszczalność wydania wyroku (art. 59 ust. 1 pkt 2 ustawy o TK).

4. Odnosząc poczynione ustalenia do pism procesowych inicjujących niniejsze postępowanie, należy odnotować, że we wniosku nr 1 sformułowano zarzut niezgodności art. 17 pkt 2 ustawy zmieniającej z art. 167 Konstytucji. Abstrahując od tego, że w petitum tego wniosku wzorzec ten jest wskazywany jako związkowy względem art. 2, natomiast $\mathrm{z}$ analizy jego uzasadnienia wynika, iż wnioskodawczyni nr 1 upatruje w przywołanym przepisie Konstytucji samodzielną podstawę kontroli, Sejm stwierdza, że w analizowanym wniosku nie dostrzega się złożonej treści art. 167 Konstytucji, który składa się z kilku jednostek redakcyjnych i pozwala na rekonstrukcję różnych norm konstytucyjnych. Zgodnie z brzmieniem tego przepisu: „Jednostkom samorządu terytorialnego zapewnia się udział w dochodach publicznych odpowiednio do przypadających im zadań” (ust. 1); „Dochodami jednostek samorządu terytorialnego są ich dochody własne oraz subwencje ogólne i dotacje celowe z budżetu państwa” (ust. 2); „Źródła dochodów jednostek samorządu terytorialnego są określone w ustawie” (ust. 3); „Zmiany w zakresie zadań i kompetencji jednostek samorządu terytorialnego następują wraz z odpowiednimi zmianami w podziale dochodów publicznych" (ust. 4).

Niewątpliwie zakresy normowania wymienionych ustępów są ze sobą funkcjonalnie powiązane i stanowią - w świetle ugruntowanego orzecznictwa konstytucyjnego - emanację zasady samodzielności jednostek samorządu terytorialnego w aspekcie finansowym, na którą powołuje się wnioskodawczyni nr 1 . Należy jednak podkreślić, że każdy z nich ma własną treść, a ocena, czy wyrażone w nich normy zostały zrealizowane albo przekroczone, powinna być przeprowadzona dla każdego ustępu osobno. Wnioskodawczyni nr 1, powołując art. 167 Konstytucji, wskazuje, iż „kwintesencją samodzielności finansowej jednostek samorządu terytorialnego jest art. 167 ust. 3 Konstytucji (...)" (wniosek nr 1, s. 6), dając tym samym wskazówkę, że w tym komponencie art. 167 Konstytucji upatruje wzorca kontroli. Ponadto we wniosku nr 1 podniesiono, że: „O ile więc w granicach określonych ustawą, zgodnie $\mathrm{z}$ art. 167 ust. 3 Konstytucji, ustawodawca może kształtować wysokość dochodów własnych gmin, w tym z tytułu podatku od nieruchomości, o tyle powinien w tym względzie mieć na uwadze również zasadę adekwatności wyrażoną w ust. 1 tego przepisu. Udział w dochodach publicznych powinien być odpowiedni do przypadających jednostkom samorządu terytorialnego zadań. Skoro więc następuje obniżenie tych dochodów bez zmniejszenia zadań oraz bez właściwej rekompensaty utraconych dochodów, to zasada ta jest zachwiana ze szkodą dla społeczności lokalnej, wobec której samorząd pełni funkcję służebną" (ibidem). 
Z perspektywy wymogów rządzących postępowaniem przed Trybunałem Konstytucyjnym, Sejm uznaje, że Rada Gminy Świecie nad Osą w żaden sposób nie uzasadniła, w jaki sposób zakwestionowany art. 17 pkt 2 ustawy zmieniającej koliduje z ust. 2 i ust. 4 art. 167 Konstytucji, co uzasadnia wniosek o umorzenie postępowania w zakresie badania zaskarżonej regulacji z tymi wzorcami kontroli, ze względu na niedopuszczalność wydania wyroku.

5. Przechodząc do wskazanego we wniosku $\mathrm{nr} 1$ wzorca wynikającego $\mathrm{z}$ art. 167 ust. 1 Konstytucji, trzeba podkreślić, że zgodnie ze stanowiskiem Trybunału Konstytucyjnego, z naruszeniem zasady adekwatności mamy do czynienia wówczas, gdy stosowanie zakwestionowanych przepisów prowadzi do sytuacji, w której „całokształt źródeł dochodów - przewidzianych przez prawo - dla jednostek samorządu terytorialnego danego szczebla nie zapewnia tym jednostkom udziału w dochodach publicznych «odpowiednio» do przypadających im zadań" (wyrok TK z 31 stycznia 2013 r., sygn. akt K 14/11, i cytowane tam orzecznictwo). Jak podkreślał Trybunał, zasada adekwatności ma przede wszystkim charakter dyrektywy programowej, adresowanej do ustawodawcy, „natomiast zasada adekwatności rozumiana jako wiążąca norma prawna ma dużo węższy zakres normowania sprowadzający się do zakazu przyznawania j.s.t. [jednostkom samorządu terytorialnego - dopisek K.M.-D.] środków finansowych na poziomie uniemożliwiającym wykonanie powierzonych im zadań”. Należy przy tym „uwzględnić szeroki margines oceny, jaki prawodawca konstytucyjny pozostawił legislatywie w związku z alokacją środków finansowych", a w kompetencji Trybunału Konstytucyjnego nie leży kontrola decyzji w tym zakresie z punktu widzenia ich trafności. Trybunał Konstytucyjny ingeruje w sferę swobody politycznej parlamentu jedynie w wypadku ewidentnie niewspółmiernego ukształtowania dochodów w relacji do kosztów ponoszonych w związku z realizacją przypadających samorządowi zadań, wówczas gdy dochodzi do „oczywistych dysproporcji” między zakresem zadań a środkami, w jakie wyposażone zostają jednostki samorządu terytorialnego. Podmiot, który kwestionuje zgodność aktu normatywnego z art. 167 ust. 1 Konstytucji, nie może ograniczyć się do wykazania, że dochody jednostek samorządu terytorialnego nie wystarczają na realizację zadań publicznych, ale musi przedstawić argumenty wskazujące na dysproporcję między zakresem zadań i dochodów administracji rządowej oraz poszczególnych szczebli samorządu terytorialnego (zob. wyrok TK z 7 czerwca 2001 r., sygn. akt K 20/00). „Chodzi o to, by wpływy z dochodów własnych, subwencji i dotacji zapewniały wszystkim samorządom możność wypełniania - przynajmniej na poziomie minimalnym - zadań, które ustawowo i obligatoryjnie są na samorząd nałożone. Tak należy rozumieć zasadę adekwatności” (wyrok z 25 lipca 2006 r., sygn. akt K 30/04).

W ocenie Sejmu we wniosku nr 1 nie wykazano w żaden sposób, że zaskarżona regulacja prowadzi do tak radykalnego ograniczenia ogółu dochodów Gminy Świecie nad Osą, że nie jest możliwe realizowanie przez nią przypisanych jej za- 
dań publicznych. Argumentacja zawarta w analizowanym piśmie procesowym ogranicza się w istocie do wskazania, że „braki w zakresie dochodów [jako konsekwencja przyjęcia kwestionowanej regulacji - uwaga K.M.-D] skutkują niemożliwością pokrycia przewidywanych wydatków przede wszystkim związanych z realizacją zadań własnych" (wniosek nr 1, s. 7).

W rezultacie Sejm stoi na stanowisku, że zarzut naruszenia zasady adekwatności wynikającej z art. 167 ust. 1 Konstytucji nie został uzasadniony zgodnie $\mathrm{z}$ wymogami płynącymi $\mathrm{z}$ art. 47 ust. 2 pkt 4 ustawy o TK i z tego względu postępowanie w zakresie badania zgodności z tym wzorcem konstytucyjnym podlega umorzeniu, na podstawie art. 59 ust. 1 pkt 2 ustawy o TK.

6. Sejm jest natomiast skłonny uznać, że wnioskodawczyni nr $1 \mathrm{w}$ sposób wystarczający dla skutecznego uruchomienia kontroli konstytucyjności wskazała w swoim wniosku argumenty przemawiające za naruszeniem przez art. 17 pkt 2 ustawy zmieniającej art. 167 ust. 3 Konstytucji. W perspektywie tego wzorca kontroli, wskazanego jako akcesoryjny względem zasad płynących z art. 2 Konstytucji, będzie więc prowadzona analiza zgodności.

7. W odniesieniu do postawionego we wniosku nr 1 zarzutu niezgodności art. 17 pkt 2 ustawy zmieniającej z wywodzonymi z art. 2 Konstytucji zasadami: ochrony praw nabytych oraz ochrony interesów w toku, Sejm podaje w wątpliwość, czy zasady te dotyczą sytuacji wnioskodawczyni nr 1 będącej organem stanowiącym jednostki samorządu terytorialnego, a także czy wnioskodawczyni nr 1 przedstawiła adekwatne argumenty na poparcie swojego wniosku. A tym samym, czy zostały wypełnione ustawowe wymagania wynikające $\mathrm{z}$ art. 47 ust. 2 pkt 4 ustawy o TK.

Trzeba bowiem zauważyć, że zgodnie z utrwalonym orzecznictwem Trybunału Konstytucyjnego, zasada ochrony praw nabytych i związana $\mathrm{z}$ nią zasada ochrony interesów w toku - niejako genetycznie - odnosi się do ochrony praw i interesów podmiotów prywatnych.

Jak podkreśla Trybunał Konstytucyjny, z zasady demokratycznego państwa prawnego, która została sformułowana w art. 2 Konstytucji, „wynika m.in. zasada lojalności państwa wobec obywatela. $\mathrm{Z}$ zasady tej Trybunał wyprowadził dalsze szczegółowe reguły, odnoszące się m.in. do sytuacji następowania po sobie zmian obowiązującego prawa. Wśród nich znajduje się reguła, która nakłada na ustawodawcę obowiązek ochrony praw nabytych i ochrony interesów będących w toku (zob. wyrok TK z 25 listopada 2010 r., sygn. K 27/09, OTK ZU nr 9/A/2010, poz. 109). Treścią zasady ochrony praw nabytych jest zapewnienie ochrony publicznych i prywatnych praw podmiotowych oraz zakaz arbitralnego znoszenia lub ograniczania praw podmiotowych, które przysługują jednostce lub innym podmiotom prywatnym występującym w obrocie prawnym. Trybunał zwrócił uwagę, że ochrona praw nabytych dotyczy praw, które zostały nabyte «słusznie», tzn. wyklucza to stosowanie analizowanej zasady w odniesieniu do praw nabytych contra legem i praeter legem oraz uzyskanych w sposób 
niedopuszczalny w demokratycznym państwie prawnym albo z naruszeniem zasady sprawiedliwości społecznej (zob. np. w wyroku TK z 24 lutego 2010 r., sygn. K 6/09, OTK ZU nr 2/A/2010, poz. 15). Ponadto, ochroną zostały objęte także ekspektatywy, czyli prawa tymczasowe, które mają charakter maksymalnie ukształtowany (zob. np. w wyroku TK z 24 października 2000 r., sygn. SK 7/00, OTK ZU nr 7/2000, poz. 256).

Tak rozumiana zasada ochrony praw nabytych, wiąże się ściśle z koncepcją praw podmiotowych i ekspektatyw maksymalnie ukształtowanych tych praw. A zatem zakres stosowania zasady praw nabytych obejmuje tylko takie przypadki, w których dana regulacja prawna stanowi źródło praw podmiotowych bądź ekspektatyw maksymalnie ukształtowanych tych praw (zob. np. w wyroku Trybunału Konstytucyjnego z 8 stycznia 2009 r., sygn. P 6/07, OTK ZU nr 1/A/2009, poz. 2). Zarzut naruszenia praw nabytych może w związku z tym być formułowany w wypadku wskazania konkretnego prawa podmiotowego (ewentualnie maksymalnie ukształtowanej ekspektatywy), które zostało odebrane lub ograniczone (por. wyrok TK z 7 listopada 2005 r., sygn. P 20/04, OTK ZU nr 10/A/2005, poz. 111)" (wyrok TK z 10 lutego 2015 r., sygn. akt P 10/11).

Jednocześnie $z$ analizy orzecznictwa Trybunału wynika, że ochrona praw nabytych nie ma charakteru bezwzględnego, a ocena dopuszczalności odstępstw od niej może być dokonana na tle konkretnej sytuacji z uwzględnieniem całokształtu okoliczności. Jako typowy przykład uzasadnienia dla naruszenia ochrony praw nabytych w orzecznictwie konstytucyjnym wskazuje się wymóg zapewnienia realizacji czy ochrony innej wartości istotnej dla systemu prawnego (ibidem). Jak wskazał Trybunał, m.in. w wyroku z 15 września 1999 r. (sygn. akt K 11/99), dopuszczalność ograniczeń nabytych praw podmiotowych wymaga a casu ad casum rozważenia, czy podstawą wprowadzonych ograniczeń są inne normy, zasady lub wartości konstytucyjne, którym w danej sytuacji należy dać pierwszeństwo; nie ma możliwości realizacji danej normy, zasady lub wartości konstytucyjnej bez naruszenia praw nabytych; wartościom konstytucyjnym, dla realizacji których prawodawca ogranicza prawa nabyte, można w danej konkretnej sytuacji przyznać pierwszeństwo przed wartościami znajdującymi się u podstaw zasady ochrony praw nabytych; prawodawca podjął niezbędne działania mające na celu zapewnienie jednostce warunków do przystosowania się do nowej regulacji (por. także wyrok TK z 17 listopada 2003 r., sygn. akt K 32/02).

Z orzecznictwa Trybunału na gruncie normatywnej konstrukcji systemu podatkowego wynika jednoznacznie, że „ustawodawca posiada w szczególności swobodę kształtowania systemu podatkowego. Konstytucja pozostawia szczególnie szeroką swobodę regulacyjną w zakresie wprowadzania i znoszenia zwolnień i ulg podatkowych. Swoboda w kształtowaniu materialnych treści prawa podatkowego jest jednak równoważona $\mathrm{z}$ istnieniem obowiązku przestrzegania konstytucyjnych standardów demokratycznego państwa prawnego. Do standardów tych należy w szczególności zasada ochrony zaufania jednostki do państwa 
i stanowionego przez nie prawa, a także ochrony praw nabytych oraz ochrony interesów w toku, które stanowią konkretyzację wymienionej zasady konstytucyjnej" (wyrok TK z 25 czerwca 2002 r., sygn. akt K 45/01). Trybunał stoi na stanowisku, że „zasada ochrony interesów w toku zapewnia ochronę jednostki w sytuacjach, w których rozpoczęła ona określone przedsięwzięcia na gruncie dotychczasowych przepisów. Chociaż zasada ta nie ma charakteru bezwzględnego, na ustawodawcy ciąży szczególny obowiązek ochrony interesów w toku w sytuacji wystąpienia następujących przesłanek: „1) przepisy prawa wyznaczają pewien horyzont czasowy dla realizowania określonych przedsięwzięć; 2) dane przedsięwzięcie ma charakter rozłożony w czasie; 3 ) jednostka faktycznie rozpoczęła realizację danego przedsięwzięcia w okresie obowiązywania danej regulacji”" (ibidem).

Obowiązkiem ustawodawcy, ze względu na ochronę interesów w toku, jest ustanowienie przepisów, „które umożliwią dokończenie przedsięwzięć rozpoczętych stosownie do przepisów obowiązujących w chwili ich rozpoczynania albo stworzą inną możliwość dostosowania się do zmienionej regulacji prawnej (zob. np. wyrok TK z 5 stycznia 1999 r., sygn. akt K 27/98, OTK ZU nr 1/1999, poz. 1)” (wyrok TK z 10 lutego 2015 r., sygn. akt P 10/11).

W świetle przywołanych obszernie wypowiedzi Trybunału trudno uznać, że jednostka samorządu terytorialnego, co istotne in casu - działająca w sferze imperium - może być uznana za beneficjenta zasady ochrony praw nabytych i interesów w toku. Należy przypomnieć, że samorząd terytorialny, w świetle art. 163 Konstytucji, jest częścią władzy publicznej, realizowanej w sposób zdecentralizowany (art. 15 Konstytucji), przejawiającej się m.in. - jak w realiach niniejszej sprawy - w sprawowaniu władztwa podatkowego. Przyznanie jednostkom samorządu terytorialnego osobowości prawnej, prawa własności i sądowej ochrony ich samodzielności należy zawsze postrzegać w perspektywie gwarancji prawidłowego wykonywania zadań publicznych (zob. wyrok TK z 20 lutego 2002 r., sygn. akt K 39/00), a nie jako uznanie ich za podmiot konstytucyjnych praw i wolności (z tego też względu Trybunał konsekwentnie odmawia zdolności skargowej jednostkom samorządu terytorialnego, zob. np. postanowienia TK z: 18 marca 2010 r., sygn. akt Ts 163/09, i 28 lipca 2009 r., sygn. akt Ts 202/08).

W dotychczasowym orzecznictwie Trybunał Konstytucyjny nie odnosił bezpośrednio do zasady ochrony praw nabytych oraz zasady ochrony interesów w toku do ochrony praw i interesów jednostek samorządu terytorialnego działających w sferze imperium (w odniesieniu do sfery dominium, zob. np. wyrok TK z 12 kwietnia 2005 r., sygn. akt K 30/03).

8. Niezależnie od poczynionych uwag krytycznych co do możliwości odnoszenia zasady ochrony praw nabytych oraz zasady ochrony interesów w toku do sytuacji jednostek samorządu terytorialnego w zakresie sprawowania przez nie władztwa podatkowego, należy wyrazić krytyczne stanowisko co do spełnienia przez wniosek nr 1 wymogu adekwatnego uzasadnienia zarzutów, które miały- 
by przemawiać za złamaniem przywołanych zasad. We wniosku tym wskazano jedynie na sprzeczność zakwestionowanej regulacji z zasadą ochrony praw nabytych oraz zasadą ochrony interesów w toku, jednak bez żadnej głębszej refleksji. W szczególności nie udowodniono, że możliwość zastosowania wyższej stawki podatku od elektrowni wiatrowej stanowiła prawo nabyte wnioskodawczyni nr 1 , w rozumieniu utrwalonym w orzecznictwie Trybunału Konstytucyjnego. Podobnie sprawa przedstawia się w odniesieniu do zasady ochrony interesów w toku.

Pamiętając, że motywy wystąpienia do Trybunału Konstytucyjnego muszą wskazywać precyzyjnie co najmniej jeden argument przemawiający za naruszeniem danego wzorca kontroli, którego to wymogu nie spełniają uwagi nazbyt ogólne, niejasne czy też czynione jedynie na marginesie innych rozważań (zob. np. wyrok TK z 5 czerwca 2014 r., sygn. akt K 35/11; postanowienia TK z: 13 stycznia 2015 r., sygn. akt K 44/13; 21 stycznia 2015 r., sygn. akt K 13/13), trzeba uznać, że uzasadnienie naruszenia omawianego wzorca kontroli nie jest wystarczające (por. wyrok TK z 28 listopada 2013 r., sygn. akt K 17/12).

Dodatkowo należy odnotować, że w podsumowaniu wniosku nr 1 znajduje się także postulat zbadania art. 17 pkt 2 ustawy zmieniającej z zasadą przyzwoitej legislacji, również wywodzoną z zasady demokratycznego państwa prawnego.

Trzeba mieć świadomość, że nakaz przestrzegania zasad poprawnej legislacji jest - zgodnie z poglądami Trybunału Konstytucyjnego - funkcjonalnie związany z zasadą nieretroakcji prawa, zasadą ochrony zaufania, bezpieczeństwa prawnego oraz pewności prawa (zob. np. wyroki TK z: 30 października 2001 r., sygn. akt K 33/00; 22 maja 2002 r., sygn. akt K 6/02; 7 stycznia 2004 r., sygn. akt K 14/03), wnioskodawczyni nr $1 \mathrm{w}$ żadnym innym miejscu wniosku oprócz podsumowania nie poświęca uwagi temu wzorcowi. Z tego względu należy uznać, że nie został spełniony pożądany w świetle ustawy o TK wymóg stosownego uzasadnienia stawianego zarzutu ani nawet rekonstrukcji treści normatywnej postulowanego wzorca.

W następstwie powyższego Sejm wnosi o umorzenie postępowania na podstawie art. 59 ust. 1 pkt 2 ustawy o TK w zakresie dotyczącym kontroli zgodności art. 17 pkt 2 ustawy zmieniającej z zasadami ochrony praw nabytych i interesów $\mathrm{w}$ toku oraz przyzwoitej legislacji, wywodzonymi z art. 2 Konstytucji, ze względu na niedopuszczalność wydania wyroku.

9. Podsumowując część stanowiska poświęconą analizie formalnoprawnej, należy wskazać, że uwzględniając korektę w zakresie przedmiotu kontroli oraz partykularnych wniosków o umorzenie postępowania, analizą zgodności objęty jest art. 17 ust. 2 ustawy zmieniającej w perspektywie wywodzonych $\mathrm{z}$ art. 2 Konstytucji zasad: nieretroakcji prawa, ochrony zaufania do państwa i stanowionego przez nie prawa (pewności prawa), zakazu zmiany prawa podatkowego $\mathrm{w}$ trakcie trwania roku podatkowego w związku z art. 167 ust. 3 Konstytucji (zasada samodzielności finansowej jednostek samorządu terytorialnego). 


\section{Analiza merytoryczna}

\section{- 1. Wzorce kontroli}

1. Podstawowym wzorcem kontroli jest w analizowanej sprawie art. 2 Konstytucji w brzmieniu: „Rzeczpospolita Polska jest demokratycznym państwem prawnym, urzeczywistniającym zasady sprawiedliwości społecznej”.

W treści art. 2 Konstytucji zostały wyrażone trzy zasady konstytucyjne: zasada państwa demokratycznego, zasada państwa prawnego oraz zasady sprawiedliwości społecznej. W odniesieniu do zasady państwa prawnego w doktrynie wyrażono pogląd, że „w związku z rolą, jaką odgrywa klauzula państwa prawnego dla ustrojowej charakterystyki państwa polskiego, jej wpływ na normatywną treść Konstytucji RP oraz oddziaływanie na płaszczyznę stanowienia i stosowania prawa można postawić pytanie: czy jest ona konstytucyjną klauzulą wiodącą, "zasadą-kluczem», klauzulą, z której należy wyprowadzać cały porządek konstytucyjny? Wydaje się że taką rolę klauzula państwa prawnego spełniała do 1997 r. Obecnie pełni ona nadal tę rolę w odniesieniu do formalnego aspektu państwa prawnego, w szczególności do płaszczyzny stanowienia prawa. W odniesieniu do aspektu materialnego należy stwierdzić, że obecnie ani doktryna, ani TK nie wywodzą nowych praw konstytucyjnych z art. 2 Konstytucji RP. Dla normatywnej treści wolności i praw człowieka kluczowe znaczenie ma natomiast obecnie art. 30 Konstytucji RP. To w zasadzie nienaruszalnej i niezbywalnej godności człowieka tkwi największy potencjał dla wydobywania z Konstytucji RP praw człowieka, dookreślania treści praw w ustawie zasadniczej wyrażonych oraz interpretowania konstytucyjnych klauzul limitacyjnych (L. Garlicki, Wolności i prawa jednostki, s. 63 i n.)" (P. Tuleja, Komentarz do art. 2 [w:] Konstytucja RP. Komentarz, t. I, Art. 1-86, red. M. Safjan, L. Bosek, Warszawa 2016, nb. 47).

Wnioskodawczynie zarzucają sprzeczność zaskarżonego przepisu ze szczegółowymi zasadami wywodzonymi z zasady demokratycznego państwa prawnego, a mianowicie z zasadami: ochrony zaufania do państwa i stanowionego przez nie prawa (pewności prawa), bezpieczeństwa prawnego, niezmieniania prawa podatkowego w ciągu roku podatkowego, a przede wszystkim zasadą niedziałania prawa wstecz.

2. Odczytując treść zasady nieretroakcji, Trybunał wskazał, że: „Zasada niedziałania prawa wstecz była wielokrotnie przedmiotem rozważań Trybunału Konstytucyjnego. Przekrojowej analizy wcześniejszego orzecznictwa odnoszącego się do zasady lex retro non agit Trybunał dokonał w wyroku z 3 października 2001 r. (sygn. K 27/01, OTK ZU nr 7/2001, poz. 209). W orzeczeniu tym Trybunał przypomniał, że zasada ta, będąca istotnym elementem systemów prawnych współczesnych państw demokratycznych, ma swoje korzenie w starożytności. W prawie rzymskim funkcjonowała już na gruncie Kodeksu Justyniana. W polskim porządku prawnym zasada lex retro non agit była przywołana już w XIV w. Była uznaną zasadą systemu prawnego II Rzeczypospolitej. 
W orzecznictwie Trybunału Konstytucyjnego utrzymuje się konsekwentnie jednolita linia rozumienia znaczenia zakazu retroaktywnego działania ustanowionej normy. W wyroku z 30 listopada 1988 r. (sygn. akt K 1/88, OTK w 1988 r., poz. 6, s. 81) Trybunał stwierdził, że: „Zasadę niedziałania prawa wstecz TK rozumie szerzej, nie tylko jako zakaz stanowienia norm prawnych, które nakazywałyby stosować nowo ustanowione normy prawne do zdarzeń, które miały miejsce przed ich wejściem w życie i z którymi prawo nie wiązało dotąd skutków prawnych (zasada lex retro non agit we właściwym tego słowa znaczeniu), lecz także jako zakaz stanowienia intertemporalnych reguł, które mają określić treść stosunków prawnych powstałych pod rządami dawnych norm, a trwających w okresie wejścia w życie norm nowo ustanowionych, jeżeli reguły te wywołują ujemne prawne (a w konsekwencji społeczne) następstwa dla bezpieczeństwa prawnego i poszanowania praw nabytych. [...] zasada zaufania do państwa wymaga, by mocy wstecznej nie nadawać przepisom, które regulują prawa i obowiązki obywateli i pogarszają ich sytuację prawną".

Pod rządami Konstytucji z 2 kwietnia 1997 r. Trybunał wielokrotnie przypominał, że „zgodnie z utrwaloną linią orzeczniczą Trybunału Konstytucyjnego zasada niedziałania prawa wstecz stanowi podstawę porządku prawnego. Kształtuje zasadę zaufania obywateli do państwa oraz stanowionego przez nie prawa. U podstaw tejże zasady leży wyrażona w art. 2 Konstytucji zasada demokratycznego państwa prawnego" (wyrok TK z 17 grudnia 1997 r., sygn. akt K 22/96). Trybunał Konstytucyjny podkreślał też, że „zasada lex retro non agit oraz zasada ochrony praw słusznie nabytych mają charakter zasad przedmiotowych, wyznaczających granice ingerencji władzy publicznej w sferę praw podmiotowych. Naruszenie tych zasad może uzasadniać zarzut niedopuszczalnego wkroczenia przez tę władzę w sferę konstytucyjnie chronionych praw lub wolności jednostki, co $\mathrm{w}$ konsekwencji prowadzi do stwierdzenia sprzecznego z porządkiem konstytucyjnym naruszenia tych praw lub wolności" (postanowienie TK z 17 lutego 1999 r., sygn. akt Ts 154/98). Trybunał stwierdzał też, że odstępstwo od zakazu retroaktywności jest dopuszczalne w szczególności wtedy, gdy „jest to konieczne dla realizacji wartości konstytucyjnej, ocenionej jako ważniejsza od wartości chronionej zakazem retroakcji” (wyrok TK z 31 stycznia 2001 r., sygn. akt P 4/99). Działanie prawa wstecz „nie oznacza naruszenia art. 2 Konstytucji, o ile tak wprowadzone przepisy polepszają sytuację prawną niektórych adresatów danej normy prawnej i zarazem nie pogarszają sytuacji prawnej pozostałych jej adresatów (por. [...] wyrok TK z 25 września 2000 r., sygn. akt K 26/99, OTK ZU nr 6/2000, poz. 186)” (wyrok TK z 8 marca 2005 r., sygn. akt K 27/03).

„Zgodnie z utrwalonym orzecznictwem Trybunału Konstytucyjnego zasada lex retro non agit, wywodzona obecnie $\mathrm{z}$ art. 2 Konstytucji, stanowi istotny składnik zasady demokratycznego państwa prawnego. Zasada niedziałania prawa wstecz wymaga, aby nie stanowić prawa, które nakazuje stosowanie nowo ustanowionych norm do sytuacji, które miały miejsce przed ich wejściem w życie. 
Odstępstwa od tej zasady dopuszczalne są w wyjątkowych okolicznościach, jeżeli przemawia za tym konieczność realizacji innej zasady konstytucyjnej, a realizacja tej zasady nie jest możliwa bez wstecznego działania prawa. Dopuszczalność odstępstwa od tej zasady zależy również od wagi wartości konstytucyjnych, które badana regulacja ma chronić (por. wyrok z 7 lutego 2001 r., sygn. K 27/00)" (wyrok TK z 20 stycznia 2010 r., sygn. akt Kp 6/09).

3. Jako wzorzec kontroli wnioskodawczynie wskazują zasadę ochrony zaufania jednostki samorządu terytorialnego do państwa i stanowionego przez nie prawa. Należy więc przypomnieć, że pomimo dyskusyjności zagadnienia czy i na ile jednostka samorządu terytorialnego może być uznawana za beneficjenta przywołanej zasady (por. wyrok TK z 25 maja 1998 r., sygn. akt U 19/97), Trybunał Konstytucyjny w nowszym orzecznictwie jednoznacznie zaaprobował ją jako wiążącą również w stosunkach między jednostkami samorządu terytorialnego a państwem (zob. wyroki TK z: 18 lipca 2006 r., sygn. akt U 5/04; 29 października 2010 r., sygn. akt P 34/08).

Trybunał Konstytucyjny wielokrotnie podkreślał, że zasada ochrony zaufania funkcjonalnie odnosi się zarówno do stanowienia, jak i do stosowania prawa przez organy władzy publicznej. Zgodnie z orzecznictwem konstytucyjnym dotyczącym zasady ochrony zaufania jednostki do państwa i stanowionego przez nie prawa, istota tej zasady sprowadza się do nakazu takiego stanowienia i stosowania prawa, by obywatel mógł układać swoje sprawy w zaufaniu, że nie naraża się na skutki prawne, których nie mógł przewidzieć w momencie podejmowania decyzji (zob. wyroki TK z: 2 czerwca 1999 r., sygn. akt K 34/98; 10 kwietnia 2001 r., sygn. akt U 7/00; 19 kwietnia 2005 r., sygn. akt K 4/05; 15 lutego 2005 r., sygn. akt K 48/04; 31 stycznia 2006 r., sygn. akt K 23/03).

Jak wskazał sąd konstytucyjny, „zasada zaufania społeczności lokalnej jednostki samorządu terytorialnego do państwa i stanowionego przez nie prawa, analogicznie do zasady zaufania obywateli do państwa i stanowionego przez nie prawa w ogólności, opiera się na pewności prawa, a więc takim zespole cech przysługujących prawu, które zapewniają bezpieczeństwo prawne oraz umożliwiają jednostkom samorządu terytorialnego decydowanie o swoim postępowaniu w oparciu o pełną znajomość treści obowiązującego tekstu prawnego oraz przesłanek działania organów państwowych i konsekwencji prawnych, jakie ich działania mogą wywołać (zob. wyrok TK z 18 lipca 2006 r., sygn. U 5/04)” ( wyrok TK z 31 stycznia 2013 r., sygn. akt K 14/11).

Jednocześnie jednak Trybunał podkreśla, że odczytywanie zasady zaufania jednostki samorządu terytorialnego do państwa i stanowionego przez nie prawa, ze względu na przynależność samorządu terytorialnego do sfery władzy publicznej, powinno być dokonywane z uwzględnieniem zasad lojalnej współpracy, zakładającej obustronne zaufanie między państwem a jednostkami samorządu terytorialnego (zob. wyrok TK z 12 marca 2007 r., sygn. akt K 54/05). 
W świetle wypowiedzi Trybunału, „zasada zaufania obywatela do państwa i stanowionego przez nie prawa opiera się na pewności prawa, a więc takim zespole cech przysługujących prawu, które zapewniają jednostce bezpieczeństwo prawne; umożliwiają jej decydowanie o swoim postępowaniu w oparciu o pełną znajomość przesłanek działania organów państwowych oraz konsekwencji prawnych, jakie jej działania mogą pociągnąć za sobą. Jednostka winna mieć możliwość określenia zarówno konsekwencji poszczególnych zachowań i zdarzeń na gruncie obowiązującego w danym momencie systemu, jak też oczekiwać, że prawodawca nie zmieni ich w sposób arbitralny. Bezpieczeństwo prawne jednostki związane z pewnością prawa umożliwia więc przewidywalność działań organów państwa, a także prognozowanie działań własnych" (wyrok TK z 14 czerwca 2000 r., sygn. akt P 3/00).

4. Kolejną z zasad wydobywanych $\mathrm{z}$ art. 2 Konstytucji w charakterze wzorca kontroli w niniejszej sprawie jest zakaz zmiany prawa podatkowego $\mathrm{w}$ trakcie trwania roku podatkowego. W odniesieniu do legislacji podatkowej Trybunał Konstytucyjny wyraził bowiem pogląd, że w dotychczasowym orzecznictwie wskazywano już, iż „nie jest w zasadzie dopuszczalne dokonywanie zmian obciążeń podatkowych w ciągu roku (orzeczenie z 29 marca 1994 r., K. 13/93, OTK w 1994 r., cz. I, s. 49-50). Zmiany takie, gdy chodzi o obecne ukształtowanie podatku dochodowego od osób fizycznych, «powinny wchodzić w życie przynajmniej na miesiąc przed końcem poprzedniego roku podatkowego (orzeczenie z 28 grudnia 1995 r., K. 28/95, OTK ZU Nr 3/1995, s. 204-205). Nie są to wprawdzie wymagania o bezwzględnie wiążącym charakterze, ale odstąpienie od nich dopuszczalne jest tylko, gdy przemawiają za tym uzasadnione argumenty prawne» (tamże, s. 448-449). [...] Trybunał w swoim orzecznictwie nie wyrażał nigdy stanowiska o absolutnym charakterze zakazu zmian w prawie podatkowym w ciągu roku podatkowego, w szczególności tam gdzie chodzi o cofnięcie ulg lub przywilejów. Zmiany takie zawsze jednak powinny być usprawiedliwione balansowaniem wchodzących w grę wartości konstytucyjnych" (wyrok TK z 25 kwietnia 2001 r., sygn. akt K 13/01).

5. Akcesoryjnym - względem art. 2 Konstytucji - wzorcem kontroli w niniejszej sprawie, w świetle woli wyrażonej przez Radę Gminy Świecie nad Osą, jest art. 167 ust. 3 Konstytucji: „Źródła dochodów jednostek samorządu terytorialnego są określone w ustawie". Przepis ten stanowi jeden z normatywnych wyrazów samodzielności finansowej jednostek samorządu terytorialnego. W doktrynie podkreśla się, że „Samodzielność finansowa j.s.t. podniesiona została do rangi konstytucyjnej w art. 167, który zawiera gwarancję zapewnienia samorządowi terytorialnemu udziału $\mathrm{w}$ dochodach publicznych odpowiednio do przypadających zadań (tzw. zasada adekwatności), stanowi o poszczególnych rodzajach dochodów samorządu oraz źródłach normatywnych, w których powinny one zostać określone. Przepis ten został określony w doktrynie mianem «konstytucji finansowej samorządu» ze względu na to, że definiuje zasady wyposażania 
j.s.t. w dochody" (A. Skoczylas, W. Piątek, Komentarz do art. 167 [w:] Konstytucja RP. Komentarz, t. II, Art. 87-243, red. M. Safjan, L. Bosek, Warszawa 2016, nb. 1).

Dokonując rekonstrukcji wzorca wynikającego z art. 167 ust. 3 Konstytucji, Trybunał wywiódł, że „zasada samodzielności finansowej gminy znajduje obecnie konstytucyjny wyraz m.in. w art. 167 ust. 3 wskazującym, iż «źródła dochodów jednostek samorządu terytorialnego są określone w ustawie». [...] Trybunał Konstytucyjny uważa, że unormowaniu zawartemu w art. 167 ust. 3 konstytucji przypisać należy dwojakie znaczenie prawne. Przede wszystkim traktować go należy jako przepis gwarantujący gminom odpowiedni poziom dochodów, pozwalający im na realizację konstytucyjnie wyznaczonych zadań (a przypomnieć należy, że - w myśl ogólnej zasady konstytucyjnej, wyrażonej w art. 16 ust. 2 samorządowi terytorialnemu przysługiwać ma istotna część zadań publicznych, a zadania te samorząd ma wykonywać w imieniu własnym i na własną odpowiedzialność), a także zastrzegający formę ustawy dla określania źródeł tych dochodów. Oznacza to, że na poziomie ustawowym muszą zostać sformułowane wszystkie rozstrzygnięcia podstawowe dla wyznaczenia rodzaju i charakteru prawnego poszczególnych źródeł dochodów, a tym samym - także rozstrzygnięcia wyznaczające sposób ustalania wysokości tych dochodów. Innymi słowy, ogólny poziom dochodów jednostki samorządu terytorialnego musi być możliwy do ustalenia już na podstawie regulacji ustawowej, czyli regulacja ta musi zachowywać odpowiedni stopień precyzji i szczegółowości, a nie może ograniczać się do blankietowych odesłań do regulacji wykonawczych.

Trybunał Konstytucyjny uważa jednak, że na tym nie wyczerpuje się znaczenie prawne art. 167 ust. 3, zwłaszcza gdy przepis ten interpretować w powiązaniu tak $\mathrm{z}$ art. 16, jak i z pozostałymi postanowieniami rozdziału VII konstytucji. Ustawowe zagwarantowanie źródeł dochodów pełni bowiem rolę instrumentalną wobec celu podstawowego, jakim jest zapewnienie jednostce samorządu terytorialnego (gminie) odpowiednich środków finansowych na realizację jej zadań. Art. 167 ust. 3 można więc traktować jako wyraz zasady ogólniejszej, gwarantującej gminie nie tylko pozostawienie do jej dyspozycji określonych środków finansowych (poprzez zagwarantowanie źródeł, z których wypływają), ale też gwarantującej gminie możliwość samodzielnego wykorzystywania tych środków, a tym samym dokonywania wydatków i kształtowania za ich pomocą zadań. Gdyby bowiem wykluczyć istnienie konstytucyjnych gwarancji dla samodzielności dokonywania wydatków, to ustawowe zagwarantowanie źródeł dochodów, a także samodzielnego wykonywania zadań, mogłoby okazać się iluzoryczne, bo pozyskane środki finansowe mogłyby być gminie odbierane bez jakichkolwiek ograniczeń" (wyrok TK z 24 marca 1998 r., sygn. akt K 40/97).

Należy nadto przypomnieć, w ślad za poglądami Trybunału Konstytucyjnego, że samodzielność finansowa jednostek samorządu terytorialnego nie ma charakteru absolutnego. Może ona zostać ograniczona w drodze ustawy pod warun- 
kiem, że owe ograniczenia znajdują uzasadnienie w konstytucyjnie określonych celach i chronionych wartościach. W ocenie Trybunału Konstytucyjnego „eliminacji określonych źródeł dochodów własnych nie można mylić z ich modyfikacjami, nawet gdy rezultat danej modyfikacji jest niekorzystny dla finansów gmin. Dopóki ustawodawca w sposób drastyczny nie naruszy samej istoty samodzielności finansowej gminy, przysługuje mu - pod warunkiem poszanowania innych norm, zasad i wartości konstytucyjnych daleko idąca swoboda w określaniu zarówno źródeł dochodów gmin, jak też poziomu tych dochodów” (wyrok TK z 15 grudnia 1997 r., sygn. akt K 13/97; zob. także wyrok TK z 3 listopada 1998 r., sygn. akt K 12/98).

\section{- 2. Analiza zgodności}

1. Przechodząc do merytorycznej oceny zarzutów sformułowanych w pismach inicjujących postępowanie w sprawie o sygn. akt K 4/19, uwzględniając korektę w zakresie przedmiotu kontroli oraz partykularnych wniosków o umorzenie postępowania, należy stwierdzić, co następuje.

Sejm zgadza się z tezą postawioną przez Radę Gminy Kobylnica, że ustawodawca z pełną świadomością zdecydował się na przyjęcie regulacji w kwestionowanym kształcie, czyli z zastosowaniem mechanizmu retroakcyjnego (wniosek nr 2, s. 19), jednakże nie podziela argumentów wnioskodawczyni nr 2, odnoszących się do tego, że zabieg ten nie był podyktowany żadną z wartości konstytucyjnych, którą należałoby chronić.

Wnioskodawczyni nr 2 formułuje w swoim wniosku twierdzenie o braku związku z którąkolwiek z poszczególnych wartości i zasad zakotwiczonych w Konstytucji, dodając: „w niniejszej sprawie nie sposób wskazać okoliczności, które w świetle orzecznictwa Trybunału Konstytucyjnego usprawiedliwiałyby odstępstwo od zasady lex retro non agit. W szczególności Rada Gminy Kobylnica nie zna (nie jest świadoma istnienia) zasady konstytucyjnej, której ochrona czy urzeczywistnienie uzasadniałoby wprowadzenie przepisu art. 17 pkt 2 Ustawy Nowelizującej" (wniosek nr 2, s. 15).

Analogiczne zastrzeżenie zgłoszono we wniosku nr 1, podkreślając, że badana regulacja została przyjęta przy jednoczesnym braku wskazania w uzasadnieniu ustawy zmieniającej wartości konstytucyjnej, która usprawiedliwiałaby zdiagnozowaną retroakcję (wniosek nr 1, s. 5).

Sejm jest skłonny uznać, że przedstawiona przez wnioskodawczynie argumentacja spełnia warunki formalne wymagane do zainicjowania postępowania przed sądem konstytucyjnym. Zarazem jednak pragnie wyrazić przekonanie, że podnoszony przez nie brak wykazania konstytucyjnej przesłanki zastosowania mechanizmu retroakcji w uzasadnieniu projektu ustawy zmieniającej, która wprowadziła sporne regulacje, nie przesądza o niekonstytucyjności przyjętego rozwiązania. Szczegółowość uzasadnienia projektu ustawy, zwłaszcza w przypadku aktów o znacznej obszerności, jest pozostawiona bowiem uznaniu usta- 
wodawcy, a spełnienie wymagań formalnych w tym zakresie jest na początku procesu legislacyjnego weryfikowane przez Marszałka Sejmu (zob. art. 34 ust. 7 uchwały Sejmu Rzeczypospolitej Polskiej z 30 lipca 1992 r. - Regulamin Sejmu Rzeczypospolitej Polskiej; t.j. M.P. 2019, poz. 1028, ze zm.).

Poza sporem w niniejszej sprawie jest to, że ustawodawca zdecydował się na zastosowanie mechanizmu retroakcji, bowiem $\mathrm{w}$ kwestionowanym przepisie wprost przewidział, że art. 2 pkt 1 i 6 oraz art. 3 pkt 1 wchodzą w życie z dniem następującym po dniu ogłoszenia ustawy zmieniającej, tj. 29 czerwca 2018 r., z mocą od dnia 1 stycznia $2018 \mathrm{r}$. Tym samym definicja obiektu budowlanego $\mathrm{w}$ odniesieniu do elektrowni wiatrowych na potrzeby ustalenia przedmiotu opodatkowania podatkiem od nieruchomości powinna być stosowana względem stanów faktycznych już od 1 stycznia 2018 r.

2. Dla przedstawienia ratio takiej decyzji prawodawczej należy pokrótce przedstawić zasady rządzące opodatkowaniem elektrowni wiatrowych podatkiem od nieruchomości.

Podatek ten od 26 września 2005 r. do 1 stycznia 2017 r. kształtowały przepisy ustawy z 7 lipca 1994 r. - Prawo budowane (t.j. Dz. U. 2019, poz. 1186, ze zm.; dalej: u.p.b.) oraz ustawy o podatkach i opłatach lokalnych. W orzecznictwie Naczelnego Sądu Administracyjnego (dalej: NSA) w stanie prawnym obowiązującym w przywołanym okresie przyjmowano, że budowlą w rozumieniu ustawy o podatkach i opłatach lokalnych są wyłącznie części budowlane urządzenia technicznego, jakim jest elektrownia wiatrowa. W związku z tym do podstawy opodatkowania podatkiem od nieruchomości nie wliczano wartości generatora, rotora z gondolą, wirnika, generatora, skrzyni biegów, komputera sterującego, transformatora, rozdzielni energetycznej, instalacji alarmowej zdalnego sterowania (zob. wyroki NSA z: 15 maja 2012 r., sygn. akt II FSK 2132/10; 5 stycznia 2010 r., sygn. akt II FSK 1101/08; 2 grudnia 2011 r., sygn. akt II FSK 1658/10; 30 lipca 2009 r., sygn. akt II FSK 202/08; 7 października 2009 r., sygn. akt II FSK 635/08; 16 grudnia 2009 r., sygn. akt II FSK 1184/08; 20 stycznia 2012 r., sygn. akt II FSK 1397/10). Orzecznictwo uznawało, że budowlą, stanowiącą przedmiot opodatkowania podatkiem od nieruchomości jest w związku z tym wyłącznie fundament i wieża.

Stan ten zmienił się wraz z wejściem w życie ustawy z 20 maja 2016 r. o inwestycjach w zakresie elektrowni wiatrowych (t.j. Dz. U. 2020, poz. 981). Jej mocą zmianie uległ art. 3 pkt 3 u.p.b., zawierający definicję budowli. W wyniku tej nowelizacji elektrownia wiatrowa w całości uznawana była za budowlę, a w konsekwencji podstawę opodatkowania podatkiem od nieruchomości stanowiła wartość całego wiatraka, zarówno jego części budowlanych, jak i technicznych. Regulacja ta zaczęła obowiązywać od 1 stycznia 2017 r. Ustalając wysokość stawki podatku od nieruchomości, organy jednostek samorządu terytorialnego, prowadząc własną politykę podatkową, brały więc pod uwagę wartość całego wiatraka. Efektem funkcjonowania takiego unormowania było z jednej strony zwiększe- 
nie dochodów jednostek samorządu terytorialnego w 2017 r., z drugiej jednak wzrost obciążeń podatkowych podmiotów prowadzących elektrownie wiatrowe. Wedle szacunków, w wyniku przywołanej zmiany, w przypadku przeciętnego wiatraka kwota podatku wzrosła z 20 tys. zł do 60-80 tys. zł rocznie i zgodnie $\mathrm{z}$ doniesieniami prasowymi, mieliśmy do czynienia $\mathrm{z}$ różnymi formami wymuszonego nierentownością przedsięwzięcia zakończenia prowadzenia działalności gospodarczej przez podmioty prowadzące elektrownie wiatrowe (https://www. gramwzielone.pl/energia-wiatrowa/27369/bankructwa-wlascicieli-wiatrakow-sa-faktem) lub brakiem zainteresowania w dalsze inwestycje w zakresie rozwijania odnawialnych źródeł energii, na co zwróciła uwagę Najwyższa Izba Kontroli w swojej informacji o wynikach kontroli „Rozwój sektora odnawialnych źródeł energii” z 15 listopada 2018 r. (https:/ /www.nik.gov.pl/pliklid, 18357, vp,20955. pdf, s. 15 i 41).

Dla uzupełnienia warto dodać, że taki scenariusz, zgodnie z którym doszło do wzrostu obciążeń podatkowych $\mathrm{z}$ tytułu opodatkowania elektrowni wiatrowych podatkiem od nieruchomości, nie był zamierzeniem autorów poselskiej inicjatywy dotyczącej przyjęcia ustawy o inwestycjach w zakresie elektrowni wiatrowych. Objęcie definicją budowli całego wiatraka (jego części budowlanych oraz technicznych) miało być ukierunkowane na podniesienie poziomu bezpieczeństwa funkcjonowania elektrowni wiatrowych poprzez odpowiednie rozszerzenie właściwości organów nadzoru budowlanego na całość konstrukcji. Wynikało to wprost z uzasadnienia projektu ustawy o inwestycjach w zakresie elektrowni wiatrowych: „W projekcie ustawy zaproponowano wykreślenie przepisu wprowadzającego podział elektrowni wiatrowych na części budowlaną i niebudowlaną. W proponowanym stanie prawnym cała elektrownia wiatrowa będzie obiektem budowlanym (budowlą), a tym samym zastosowanie do niej będą znajdować przepisy Prawa budowlanego dotyczące użytkowania obiektów budowlanych oraz dotyczących katastrof budowlanych" (druk sejmowy nr 315/ VIII kad.). Tymczasem w efekcie przyjętego rozwiązania doszło do wskazania jako przedmiot opodatkowania podatkiem od nieruchomości całego wiatraka, zarówno jego części budowlanej, jak i technicznej. Dawało to jednostkom samorządu terytorialnego podstawę do pobierania podatku od wartości całego wiatraka, co nawet przy niezmienionej stawce podatku od nieruchomości skutkowało zwiększonymi obciążeniami publicznoprawnymi dla przedsiębiorców prowadzących elektrownie wiatrowe.

3. Niezależnie od powyższego, rezultat w postaci zagrożenia płynności finansowej, a w efekcie upadłości producentów energii wytwarzanej przez wiatraki lub zahamowania nowych inwestycji, stanowi niepożądany stan z perspektywy zobowiązań międzynarodowych Polski, związanych z członkostwem w Unii Europejskiej (zob. art. 9 Konstytucji).

Wspólne ramy dla promowania energii ze źródeł odnawialnych w UE ustanawia dyrektywa Parlamentu Europejskiego i Rady 2009/28/WE z 23 kwietnia 
2009 r. w sprawie promowania stosowania energii ze źródeł odnawialnych zmieniająca i w następstwie uchylająca dyrektywy 2001/77/WE oraz 2003/30/WE (Dz. Urz. UE L 140 z 5 czerwca 2009 r., s. 16; dalej: dyrektywa 2009/28/WE). Zgodnie z jej art. 1, akt ten określa obowiązkowe krajowe cele ogólne w odniesieniu do całkowitego udziału energii ze źródeł odnawialnych w końcowym zużyciu energii brutto i w odniesieniu do udziału energii ze źródeł odnawialnych $\mathrm{w}$ transporcie.

W świetle art. 3 ust. 1 dyrektywy 2009/28/WE każde państwo członkowskie dba o to, aby jego udział energii ze źródeł odnawialnych w końcowym zużyciu energii brutto w 2020 r. odpowiadał co najmniej jego krajowemu celowi ogólnemu dla udziału energii ze źródeł odnawialnych w tym roku. W przypadku Polski, zgodnie z załącznikiem I część A do tej dyrektywy, cel krajowy wynosi 15\% udziału energii ze źródeł odnawialnych w końcowym zużyciu energii brutto w Polsce w 2020 r. Osiągnięcie celów wiążących powinno nastąpić poprzez stały wzrost udziału energii ze źródeł odnawialnych, aż do osiągnięcia poziomu zaplanowanego na rok 2020. Państwa członkowskie powinny wypełniać obowiązki określone w art. 3 dyrektywy 2009/28/WE poprzez wdrożenie środków skutecznie zaprojektowanych, przy czym państwa te mają obowiązek znaleźć się na orientacyjnej ścieżce wyznaczonej zgodnie z załącznikiem I część B albo osiągać wyższy udział (art. 3 ust. 2 dyrektywy 2009/28/WE). Dyrektywa ta traci moc ze skutkiem od 1 lipca 2021 r., ze względu na przyjęcie nowej dyrektywy Parlamentu Europejskiego i Rady (UE) 2001/2018 z 11 grudnia 2018 r. w sprawie promowania stosowania energii ze źródeł odnawialnych (Dz. Urz. UE L 328 z 21 grudnia 2018 r., s. 82), która wyznacza nową perspektywę temporalną wspierania rozwoju odnawialnych źródeł energii. Zgodnie z art. 3 przywołanej dyrektywy państwa członkowskie wspólnie zapewniają, aby udział energii ze źródeł odnawialnych w Unii w końcowym zużyciu energii brutto w 2030 r. wynosił co najmniej 32\%. Jednocześnie każde z państw członkowskich, w celu realizacji celu unijnego, ma obowiązek określić swój wkład krajowy w swoim zintegrowanym planie krajowym w dziedzinie energii i klimatu, zgodnie z art. 3-5 i 9-14 rozporządzenia Parlamentu Europejskiego i Rady (UE) 2018/1999 w sprawie zarządzania unią energetyczną i działaniami w dziedzinie klimatu, zmiany rozporządzeń Parlamentu Europejskiego i Rady (WE) nr 663/2009 i (WE) nr 715/2009, dyrektyw Parlamentu Europejskiego i Rady 94/22/WE, 98/70/WE, 2009/31/WE, 2009/73/WE, 2010/31/UE, 2012/27/UE i 2013/30/UE, dyrektyw Rady 2009/119/ WE i (EU) 2015/652 oraz uchylenia rozporządzenia Parlamentu Europejskiego i Rady (UE) nr 525/2013 (Dz. Urz. UE L 328 z 21 grudnia 2018 r., s. 1). Realizując to zobowiązanie, Polska w „Krajowym planie na rzecz energii i klimatu na lata 2021-2030. Założenia i cele oraz polityki i działania”, przyjętym przez Komitet do Spraw Europejskich 18 grudnia 2019 r., wyznaczyła jako jeden z celów klimatyczno-energetycznych na rok 2030: 21-23\% udziału odnawialnych źródeł energii w finalnym zużyciu energii brutto (https://www.gov.pl/web/aktywa-pan- 
stwowe/krajowy-plan-na-rzecz-energii-i-klimatu-na-lata-2021-2030-przekazany-do-ke).

Elektrownie wiatrowe stanowią istotny komponent źródła tzw. zielonej energii, a redukcja liczby elektrowni wiatrowych czy ograniczenie inwestycji w dalszych ich rozwój z całą pewnością nie przyczyni się do uzyskania pożądanego udziału energii ze źródeł odnawialnych. Brak wypełnienia powyższego zobowiązania skutkować może znaczącymi kosztami związanymi z transferem statystycznym energii z odnawialnych źródeł energii z państw członkowskich, które mają nadwyżkę, na co uwagę zwróciła Najwyższa Izba Kontroli w cytowanej informacji o wynikach kontroli „Rozwój sektora odnawialnych źródeł energii”.

Ponadto, w perspektywie przyjęcia ustawy o inwestycjach w zakresie elektrowni wiatrowych, nie jest wykluczone występowanie przez właścicieli elektrowni wiatrowych z roszczeniami w zakresie odszkodowań względem Skarbu Państwa, co również należy uznać za zagrożenie dla interesu publicznego i finansowego państwa. Zatem, w świetle powyższego, zmiana prawa w czerwcu 2018 r. ze skutkiem od 1 stycznia 2018 r. (art. 17 pkt 2 ustawy zmieniającej) miała także na celu ochronę Skarbu Państwa przed koniecznością wypłaty odszkodowań w przypadku uznania roszczeń ze strony inwestorów (właścicieli farm wiatrowych) z racji na ich nierówne traktowanie pod kątem podatkowym względem producentów pozostałych odnawialnych źródeł energii (biogaz, fotowoltaika, hydroenergetyka). Żaden z wytwórców przywołanych źródeł energii nie był bowiem zobowiązany do płacenia podatków od nieruchomości za urządzenia techniczne służące prowadzeniu działalności gospodarczej w zakresie wytwarzania energii ze źródeł odnawialnych.

Niezależnie od powyższego, troska o kondycję i utrzymanie odnawialnych źródeł energii w opinii Sejmu wynika także z zadania płynącego względem władz publicznych z art. 5 Konstytucji. Przepis ten przewiduje m.in., że Rzeczpospolita Polska zapewnia ochronę środowiska, kierując się zasadą zrównoważonego rozwoju.

4. Ponadto Sejm uznaje za nader przekonujące argumenty, jakimi posłużył się Minister Energii w piśmie z 16 września 2019 r. (dalej: pismo ME) skierowanym do zastępcy składu orzekającego Trybunału Konstytucyjnego w niniejszej sprawie, w którym wskazał on, że:

„Należy ponadto zaznaczyć, że przedmiotowa nowelizacja [art. 17 pkt 2 ustawy zmieniającej - uwaga K.M.-D.] związana była również z wykonaniem zobowiązań unijnych. Zgodnie z treścią decyzji Komisji Europejskiej w sprawie State aid SA.43697 (2015/N) - Poland - Polish support scheme for RES and relief for energy-intensive users (Załącznik nr 1) (Ustawa o odnawialnych źródłach energii - aukcyjny system wsparcia OZE oraz ulgi w opłacie OZE dla przedsiębiorstw energochłonnych) z dnia 13 grudnia 2017 r., sygnatura SG-Greffe(2017)D/19933 (w motywie 152) władze polskie zobowiązały się, że polski rząd dołoży wszelkich starań, aby zapewnić wejście w życie nowelizacji ustawy OZE - w tym zmia- 
ny podatku od nieruchomości - nie później niż 1 stycznia 2018 r., na zasadach obowiązujących przed dniem 1 stycznia 2017 r. Ponadto, w toku postępowania przed Dyrekcją Generalną do spraw Konkurencji Komisji Europejskiej w sprawie aukcyjnego mechanizmu wsparcia odnawialnych źródeł energii, zakończonego wydaniem ww. decyzji z dnia 13 grudnia 2017 r., Prezes Urzędu Ochrony Konkurencji i Konsumentów przekazał Ministrowi Energii formalną skargę złożoną przez inwestorów OZE, dotyczącą, w szczególności, niezgodnej z rynkiem wewnętrznym pomocy publicznej związanej ze zróżnicowanym traktowaniem farm wiatrowych na gruncie przepisów dotyczących podatku od nieruchomości (pismo DG COMP z dnia 24 maja 2017 r. B2/AB/MGA/ad D²017/050536 w sprawie SA.48045 (2017/FC) - Complaint concerning certain elements ofthe Polish support to RES producers). Powyższa skarga miała istotny wpływ na przebieg postępowania notyfikacyjnego w sprawie SA.43697, znacznie je wydłużając, skutkiem czego zachodziła poważna obawa, że nowelizacji nie da się uchwalić w 2017 r. W konsekwencji skargi inwestorów OZE z Komisją Europejską zostały uzgodnione rozwiązania opisane w motywie 152 decyzji w sprawie SA.43697. Należy podkreślić, że rozwiązaniem bazowym i docelowym do wdrożenia była wprowadzona zmiana sposobu opodatkowania elektrowni wiatrowych. Drugie z rozwiązań - polegające na dostosowaniu poziomu cen referencyjnych dla farm wiatrowych było rozwiązaniem awaryjnym. Wynika to z treści motywu 152, który stanowi, że: „The Polish authorities committed that, if for any reason independent from the Polish government the provisions for the real property fax would not be introduced in the RES Act in time, the reference prices for the wind technologies in the auctions to be held in 2018 will be amended in order to take into account a higher tax burden". Za taką niespodziewaną i niezależną od polskiego rządu przyczynę można uznać, np. przedłużające się konsultacje publiczne - obowiązkowy etap rządowego procesu legislacyjnego. To w takim kształcie, jako propozycja rozwiązania głównego i awaryjnego, polskie stanowisko zostało zaakceptowane przez Komisję Europejską.

Należy również wyjaśnić, że przyjęcie drugiego z omówionych przez Komisję rozwiązań (polegającego na dostosowaniu poziomu cen referencyjnych dla farm wiatrowych) pozwoliłoby na ograniczenie negatywnych konsekwencji na gruncie prawa pomocy publicznej związanych ze zróżnicowanym podatkowym traktowaniem farm wiatrowych, jedynie w zakresie związanym ściśle z aukcyjnym mechanizmem wsparcia OZE. Należy bowiem zwrócić uwagę, że zagadnienie dotyczące zasad opodatkowania podatkiem od nieruchomości farm wiatrowych zostało zaadresowane w decyzji w sprawie SA.43697 jedynie w takim w zakresie, w jakim kwestia ta miała wpływ na dopuszczalność pomocy publicznej w ramach analizowanego przez Komisję Europejską aukcyjnego mechanizmu wsparcia OZE. Wyłącznie z tego powodu w motywie 152 decyzji w sprawie SA.43697 Komisja dopuściła dwa alternatywne rozwiązania w zakresie opodatkowania farm wiatrowych. Wprowadzenie rozwiązania alternatywnego nie pozwalałoby natomiast na 
eliminację ryzyka zainicjowania przez Komisję Europejską formalnej procedury dochodzeniowej (na podstawie art. 108 ust. 2 Traktatu o funkcjonowaniu UE) w odniesieniu do samych zasad opodatkowania podatkiem od nieruchomości operatorów instalacji wytwarzających energię elektryczną. Otwarcie formalnej procedury dochodzeniowej, która, z dużym prawdopodobieństwem, mogłaby zostać zakończona wydaniem decyzji nakazującej zwrot pomocy publicznej przez innych wytwórców niż operatorzy farm wiatrowych, przyniosłoby negatywne skutki dla wielu wytwórców energii z OZE. Biorąc pod uwagę, że w ówczesnym czasie Komisja Europejska już dwukrotnie rozpoczynała formalną procedurę dochodzeniową dotyczącą pomocy publicznej w sprawach instrumentów podatkowych w Polsce (decyzja KE z dnia 19 września 2016 r. w sprawie pomocy państwa SA.44351 (2016/C) (ex 2016/EO) - Polska - Podatek od sprzedaży detalicznej w Polsce oraz decyzja KE z dnia 15 stycznia 2018 r. w sprawie pomocy państwa SA.46981 (20 16/C) (ex 20 16/N) - Polska - Zryczałtowany podatek od wartości sprzedanej produkcji w przemyśle okrętowym), z czego jedna z tych procedur została zakończona wydaniem decyzji negatywnej (decyzja Komisji (UE) 2018/160 z dnia 30 czerwca 2017 r. w sprawie pomocy państwa SA.44351 (2016/C) (ex 2016/NN) wdrożonej przez Polskę w odniesieniu do podatku od sprzedaży detalicznej, Dz. Urz. UE L 29 z 1.2.2018, s. 38), Rada Ministrów uznała, że przywrócenie poprzednich zasad opodatkowania farm wiatrowych podatkiem od nieruchomości stanowi optymalne rozwiązanie, które pozwoli na uniknięcie wieloletnich postępowań przed sądami unijnymi oraz da Komisji podstawę do oddalenia ww. skargi" (pismo ME, s. 6-7).

Po uwzględnieniu tych wyjaśnień trudno uznać, że rację ma wnioskodawczyni nr 2, twierdząc, że celem samym w sobie omawianych zmian była nie ochrona jakichkolwiek wartości, ale zmniejszenie obciążeń publicznoprawnych pewnej grupy przedsiębiorców. Jakkolwiek bowiem nowelizacja miała na celu zmniejszenie konkretnego rodzaju obciążeń podatkowych, do których doszło w sposób nieprzewidziany i które nigdy nie były celem ustawodawcy, to efekt ten nie stanowił celu samego w sobie. Należy go postrzegać raczej jako cel pośredni, narzędzie ochrony ważniejszych wartości - swobody prowadzenia działalności gospodarczej, równości podmiotów wobec prawa (w tym przypadku przedsiębiorców prowadzących elektrownie wiatrowe, którzy zostali obciążeni podatkiem nieproporcjonalnie większym niż pozostali producenci energii ze źródeł odnawialnych) czy bezpieczeństwa prawnego jednostki.

Trzeba bowiem przypomnieć, że wartością uzasadniającą przyjęcie zmian w definicji elektrowni wiatrowej jako budowli ze skutkiem retroakcyjnym była przede wszystkim swoboda działalności gospodarczej właścicieli elektrowni wiatrowych, którzy w wyniku zmiany definicji budowli uiszczali 3-4 razy wyższy podatek od nieruchomości. Jak podkreślało w swoim stanowisku Polskie Stowarzyszenie Energetyki Wiatrowej [dalej: PSEW]: „jest [owo obciążenie - uwaga K.M.-D.] obciążeniem finansowym niejednokrotnie poddającym w wątpliwość 
ekonomiczną zasadność przedsięwzięcia i będzie skutkowało niemożnością obsługi zadłużenia bankowego inwestycji oraz wiodło wprost do masowych bankructw przedsiębiorstw sektora energetyki wiatrowej" (Stanowisko Polskiego Stowarzyszenia Energetyki Wiatrowej w sprawie niezbędnych zmian prawa określającego podstawę naliczania podatku od nieruchomości od elektrowni wiatrowych, dostęp online: https://www.senat.gov.pl/gfx/senat/userfiles/_public/ k9/komisje/2017/kpcpp/materialy/143/stanowisko_psew-podatek_od_nieruchomosci_uoi.pdf).

5. Wprowadzone ustawą zmieniającą unormowania skutkujące zmianą definicji budowli przywróciły zasady opodatkowania podatkiem od nieruchomości, które obowiązywały przed 1 stycznia 2017 r., rozstrzygając tym samym liczne wątpliwości podnoszone przez jednostki samorządu terytorialnego w postępowaniach przed sądami administracyjnymi. Trzeba bowiem odnotować, że w związku ze zmianami normatywnymi w prawie budowlanym w zakresie definiowania elektrowni wiatrowej jako budowli powstał spór, dotyczący wpływu zmian $\mathrm{w}$ prawie budowlanym na określenie przedmiotu opodatkowania $\mathrm{w}$ podatku od nieruchomości. W interpretacjach wydawanych na wniosek właścicieli elektrowni organy podatkowe zajmowały niejednolite stanowisko. Natomiast wojewódzkie sądy administracyjne jednolicie opowiedziały się za poglądem o zmianie definicji budowli również na potrzeby podatku od nieruchomości i tym samym za opodatkowaniem elektrowni wiatrowej jako budowli składającej się z części budowlanych i elementów technicznych. W tym stanie NSA postanowieniem z 15 maja 2018 r. przedstawił do rozpoznania składowi siedmiu sędziów następujące zagadnienie prawne budzące poważne wątpliwości: „Czy w stanie prawnym obowiązującym od 1 stycznia $2017 \mathrm{r}$. budowlą w rozumieniu art. 1a ust. 1 pkt 2 ustawy z dnia 12 stycznia 1991 r. o podatkach i opłatach lokalnych (Dz.U. z 2016 r., poz. 716 ze zm.) w zw. z art. 3 pkt 1 ustawy z dnia 7 lipca 1994 r. Prawo budowlane (Dz.U. z 2016 r., poz. 290 ze zm.) jest tylko część budowlana (wzniesiona z użyciem wyrobów budowlanych) elektrowni wiatrowej czy też budowlę tę stanowi fundament, wieża i elementy techniczne elektrowni wiatrowej, o których mowa w art. 2 pkt 1 i 2 ustawy z dnia 20 maja 2016 r. o inwestycjach w zakresie elektrowni wiatrowych (Dz.U. z 2016 r., poz. 961)?”.

Odpowiadając na tak sformułowany problem, NSA w powiększonym składzie wywiódł, iż „wypada tu zaznaczyć, że w wyniku zmian legislacyjnych dokonanych ustawą z dnia 7 czerwca 2018 r. o zmianie ustawy o odnawialnych źródłach energii oraz niektórych innych ustaw (Dz. U. z 2018 r. poz. 1276), m.in. $\mathrm{w}$ art. 3 pkt 3 u.p.b., katalog budowli zawarty w art. 3 pkt 3 u.p.b. został jednoznacznie uzupełniony o „części budowlane urządzeń technicznych (kotłów, pieców przemysłowych, elektrowni jądrowych, elektrowni wiatrowych i innych urządzeń)". Ustawodawca przywrócił zatem w tym zakresie brzmienie przepisu w stanie prawnym obowiązującym do 15 lipca 2016 r. Oznacza to, że w świetle obowiązujących obecnie unormowań nie budzi polemik identyfikacja przedmio- 
tu opodatkowania podatkiem od nieruchomości” (wyrok NSA w składzie 7 sędziów z 22 października 2018 r., sygn. akt II FSK 2983/17).

Takie odczytanie przez NSA konsekwencji przyjęcia zmian w definicji elektrowni wiatrowej jako budowli jest zbieżne z zamierzeniami projektodawców ustawy zmieniającej, którzy w uzasadnieniu do projektu ustawy podkreślili, iż „W zakresie zmian wprowadzanych $\mathrm{w}$ art. 2, wejście w życie zmiany dotyczącej art. 3 pkt 3 ustawy - Prawo budowlane, zawierającej definicję budowli oraz dotyczącej załącznika do tej ustawy, spowoduje wprowadzenie jednolitych i przejrzystych zasad opodatkowania podatkiem od nieruchomości" (druk sejmowy nr 2412/VIII kad.), czego wymaga z kolei standard płynący z art. 217 Konstytucji.

Jak wynika ze stanowiska PSEW, „[u]trzymanie poprzedniego stanu niepewności co do przedmiotu opodatkowania spowodowałoby wieloletnie spory inwestorów z gminami, co w konsekwencji oznaczałoby bankructwo większości farm wiatrowych w kraju. Potwierdzają to pierwsze instalacje, które niestety już musiały zgłosić upadłość nie wytrzymując takiego obciążenia” (dostęp online: https://podatki.gazetaprawna.pl/artykuly/1230231,gminy-nie-straca-na-zmianach-podatkow-od-wiatrakow.html).

Podsumowując powyższe ustalenia, należy uznać, że wbrew twierdzeniom zawartym we wnioskach, okoliczności uzasadniające odstąpienie od zasady lex retro non agit $\mathrm{w}$ analizowanym przypadku motywowane są wartościami aprobowanymi konstytucyjnie. Tym samym kontestowana regulacja spełniła przesłanki usprawiedliwiające, w świetle orzecznictwa Trybunału Konstytucyjnego, dopuszczalność retroaktywnego działania prawa (m.in. wyrok TK z 12 maja 2009 r., sygn. akt P 66/07).

Uzupełniająco należy także wskazać, że mechanizm retroakcji akceptowany jest przez ustawodawcę zwykłego, który przewidział możliwość jego zastosowania, „jeżeli zasady demokratycznego państwa prawnego nie stoją temu na przeszkodzie" (art. 5 ustawy z 20 lipca 2000 r. o ogłaszaniu aktów normatywnych, t.j. Dz. U. 2019, poz. 1461). Na gruncie analizowanej sprawy, antycypując ustalenia dotyczące oceny co do zgodności kwestionowanej regulacji z dalszymi zasadami wywodzonymi z art. 2 Konstytucji, trzeba stwierdzić, że art. 17 ust. 2 ustawy zmieniającej należy kwalifikować jako dopuszczalny wyjątek od reguły prospektywnego działania prawa.

6. Odnosząc się do zarzutu naruszenia zasady ochrony zaufania do państwa i stanowionego przez nie prawa, trzeba uznać za stosowne wskazanie, że prace nad projektem ustawy zmieniającej, który trafił pod obrady parlamentu z przedłożenia rządowego, poprzedzone były szeroko zakrojonymi konsultacjami społecznymi, których początek datowany jest na czerwiec 2017 r. Kontestowany przepis z przyczyn technicznych nie mógł istnieć w swojej ostatecznej wersji na etapie konsultacji publicznych, te bowiem były prowadzone w 2017 r., kiedy wciąż istniały realne szanse na wejście w życie ustawy do końca 2017 r. Skutek retroaktywny nie był zatem wówczas rozważany jako potrzebny. Natomiast 
nie można uznać, że wprowadzenie art. 17 pkt 2 ustawy zmieniającej było dla gmin zaskoczeniem. Przepis ten pojawił się na etapie rządowych prac legislacyjnych, określenie takiej daty wstecznej stosowania nowych definicji było środkiem do osiągnięcia zamierzonych celów w sytuacji, kiedy wejście w życie całego aktu opóźniało się z uwagi na skomplikowany proces legislacyjny, $\mathrm{w}$ tym proces uzgodnień. Jednostki samorządu terytorialnego, śledząc przebieg prac nad projektem ustawy zmieniającej (dostępnym do publicznej wiadomości), mogły uwzględnić w swoich założeniach planów budżetowych ewentualne zmiany, jakie zakładał ów projekt $\mathrm{w}$ zakresie zmiany przedmiotu opodatkowania podatkiem od nieruchomości.

W odpowiedzi na uwagi krytyczne podczas debaty parlamentarnej nad kwestionowanym przepisem sekretarz stanu w Ministerstwie Energii Grzegorz Tobiszowski, wskazywał, że: „w świetle tego, co mówią niektórzy przedstawiciele samorządów, że budowały budżet, mając inne założenia, chcę powiedzieć, iż informacja na temat planowanego przepisu znana była publicznie od czerwca 2017 r., czyli rok temu. Wraz z rozpoczęciem procedowania i międzyresortowych ustaleń upubliczniliśmy ustawę, założenia i ten przepis. Ponadto rozpowszechnialiśmy informacje przez pana dyrektora reprezentującego departament i ministerstwo. Mówiliśmy o tym podczas negocjacji i konsultacji społecznych, wskazując na intencję przepisu. Dzięki tym informacjom niektóre gminy zwróciły się do nas z prośbą o zinterpretowanie planowanego przepisu. Roztropni posiadali informację. Sądzę, że wszyscy ją mieli. Pozostała kwestia włodarzy miast, którzy w sporze $\mathrm{z}$ rządem chcą osiągnąć pewne rozstrzygnięcia. Myślę, że po dzisiejszej prezentacji na Radzie Ministrów warto, żeby parlamentarzyści przyjrzeli się, jak dzięki uszczelnieniu podatkowemu wzrosły przychody z podatków w samorządach. Samorządy często krzyczą, że mają dokonywać pewnych przedsięwzięć, jeśli chodzi o plany inwestycyjne, a nie mają na to środków uzupełniających. Tymczasem bardzo znacząco (nie o 1\% lub 5\%) wzrosły przychody samorządów dzięki uszczelnieniu systemu podatkowego. Dotyczy to kolejnych lat, począwszy od 2016 r. Można dochodzić swoich praw, ale myślę, że ci, którzy właściwie oceniają rzeczywistość i zachowują się racjonalnie mogli swoje budżety konstruować inaczej. Po drugie, mogli zastosować ulgi, które leżą w możliwości podejmowania przez nich decyzji, prowadząc politykę fiskalną w swoich gminach. Dziękuję parlamentarzystom za głosy, ale zapewniam, że ministerstwo nikogo nie chciało zaskakiwać lub być przeciwko samorządom, wręcz przeciwnie, mówiliśmy o planowanych przepisach od dawna, aby szczególnie wójtowie mogli racjonalnie budować swoje budżety" [Pełny zapis przebiegu posiedzenia Komisji do Spraw Energii i Skarbu Państwa (nr 103), 22 maja 2018 r., s. 23-24].

$\mathrm{W}$ podobnym tonie, uzasadniając przyjęcie retroaktywnego skutku zmiany $\mathrm{w}$ zakresie definicji elektrowni wiatrowej na potrzeby opodatkowania jej podatkiem od nieruchomości, sekretarz stanu w Ministerstwie Energii G. Tobiszowski wypowiedział się podczas 63. posiedzenia Sejmu Rzeczypospolitej Polskiej 
w dniu 5 czerwca 2018 r.: „jeśli chodzi o wycofanie się z podatku - to pytanie zadał pan poseł Mężydło - w kontekście innowacyjności i nowoczesnych technologii, to tak, rzeczywiście w ustawie, jak państwo wiecie, uwzględniamy kwestie modernizacji i kładziemy akcent na to, żeby pojawiły się najnowsze technologie, które stosujemy, jeśli chodzi o OZE i wiatraki, na polskim rynku. Natomiast jeśli chodzi o wycofanie się z podatku, to jednak uważamy, że jeżeli poprawiamy status podatkowy osób, które są objęte tym podatkiem, to nawet jeśli działamy pół roku do tyłu, to jesteśmy w zgodzie z konstytucją, bo tutaj poprawiamy tę sytuację. Wiemy, że niektóre gminy podnoszą tę kwestię, natomiast chcę powiedzieć, że prace konsultacyjne, jak państwo wiecie, [...] trwały ponad rok, i już wtedy mówiliśmy, że takie regulacje wejdą w życie. Stąd przedstawialiśmy tę informację również na spotkaniach z instytucjami, które reprezentują gminy wiejskie, i tam to podawaliśmy, dlatego też gminy, które planowały swój budżet, miały już informację, że taka regulacja powinna się pojawić w ustawie, która będzie uchwalana w połowie roku. W związku z tym uważamy, że nie powinniśmy, jeśli chodzi o rozstrzygnięcia, mieć problemu, ale jak mówię, nie chcę wypowiadać się za stosowne sądy" (Sprawozdanie stenograficzne z 63. posiedzenia Sejmu Rzeczypospolitej Polskiej w dniu 5 czerwca 2018 r. (pierwszy dzień obrad)), Warszawa 2018, s. 25-26).

W kontekście uzasadnienia wniosku nr 1 Sejm zauważa, że wnioskodawczyni nr 1 postrzega, iż zmiana przepisów ustawowych w zakresie definicji przedmiotu opodatkowania w trakcie roku spowodowała naruszenie zasad ochrony zaufania do państwa i stanowionego przez nie prawa oraz samodzielności finansowej gminy, rozumianej jako gwarancja odpowiedniego, niezmiennego poziomu dochodów jednostki samorządu terytorialnego.

Jak wskazuje Trybunał, „zasady ochrony zaufania obywatela do państwa i prawa oraz bezpieczeństwa prawnego wynikają z klauzuli demokratycznego państwa prawnego i mają charakter wiążący dla ustawodawcy. Odstąpienie od tych zasad mogłoby nastąpić w sytuacji szczególnej konieczności uzasadnionej interesem publicznym” (wyrok TK z 12 stycznia 2000 r., sygn. akt P 11/98). Jednocześnie „zasad tych nie można jednak rozumieć jako nakazu niezmienności prawa i zakazu ingerencji ustawodawcy w stosunki prawne rozciągnięte w czasie, zwłaszcza w tych dziedzinach życia społecznego, które podlegają szybkim zmianom faktycznym, jak to ma miejsce w polskiej gospodarce. Zasady te wyznaczają natomiast warunki, od których zależy ocena dopuszczalności zmian stanu prawnego" (wyrok TK z 7 maja 2001 r., sygn. akt K 19/00).

Trybunał wielokrotnie przypominał również, że zasada niezmienności prawa podatkowego w trakcie roku podatkowego również nie ma charakteru bezwzględnego. Zgodnie z poglądem Trybunału wyrażonym w wyroku z 25 kwietnia 2001 r., sygn. akt K 13/01, „Trybunał w swoim orzecznictwie nie wyrażał nigdy stanowiska o absolutnym charakterze zakazu zmian $\mathrm{w}$ prawie podatkowym w ciągu roku podatkowego, w szczególności tam gdzie chodzi o cofnięcie 
ulg lub przywilejów. Zmiany takie zawsze jednak powinny być usprawiedliwione balansowaniem wchodzących w grę wartości konstytucyjnych".

Uwzględniając te ustalenia trybunalskie, Sejm staje na stanowisku, że ustawodawcy przyjmującemu kwestionowane we wnioskach unormowanie przyświecała konieczność interwencji uzasadnionej tymi samymi wartościami konstytucyjnymi, które usprawiedliwiały odstąpienie od zakazu retroaktywności, a które zostały omówione w punkcie V.2.2-5 niniejszego stanowiska.

7. Warto także dodać, że przyjęcie kwestionowanego przepisu ustawy zmieniającej nie oznaczało automatycznie obowiązku zwrotu inwestorom nadpłaconego podatku od nieruchomości za okres od 1 stycznia 2018 r. do 30 czerwca 2018 r. Nadpłata powstała na skutek zapłacenia jednostce samorządu terytorialnego przez pierwsze miesiące roku 2018 rat uwzględniających opodatkowanie części technicznych elektrowni, mogła zostać przeksięgowana na poczet kolejnych rat podatku za rok 2018, a nawet przyszłych zobowiązań podatkowych inwestora z tytułu podatku od nieruchomości w kolejnych latach. W ten sposób jednostki samorządu terytorialnego mogły zachować uzyskane środki w swojej dyspozycji, planując na kolejny rok podatkowy (2019) niższe wydatki, bez konieczności poszukiwania środków na zwrot podatku inwestorom. Rozwiązanie takie zakładało oczywiście dialog i współpracę jednostek samorządu terytorialnego i podmiotów prowadzących elektrownie wiatrowe, jednak z doniesień PSEW wynika, że przedsiębiorcy taką gotowość wykazywali (dostęp online: https://podatki.gazetaprawna.pl/ artykuly/1230231,gminy-nie-straca-na-zmianach-podatkow-od-wiatrakow.html).

Jednocześnie trzeba wskazać na możliwość skorzystania przez jednostki samorządu terytorialnego, które w wyniku przyjętej w art. 17 pkt 2 ustawy zmieniającej regulacji utraciły część swoich dochodów planowanych na rok 2018, z uwagi na zmniejszenie wpływów z tytułu podatku od nieruchomości (od elektrowni wiatrowych), $\mathrm{z}$ instrumentu korekty do informacji finansowej w perspektywie danych o podstawowych dochodach podatkowych, mających wpływ na wysokość subwencji z budżetu państwa. Zgodnie z art. 32 ust. 2 ustawy o dochodach jednostek samorządu terytorialnego jednostki te mogą do 30 czerwca roku bazowego korygować dane o planowanych dochodach. Stosowna korekta, uwzględniająca zmniejszony dochód z tytułu podatku od nieruchomości, mogłaby mieć wpływ na uzyskanie większej kwoty subwencji z budżetu centralnego. Ograniczenie temporalne zgłoszenia korekty powiązane jest $\mathrm{z}$ harmonogramem prac nad budżetem centralnym, do którego wydatków zaliczane są subwencje ogólne i który planuje także wpływy z wpłat korekcyjno-wyrównawczych z przeznaczeniem na część równoważącą subwencji ogólnej.

8. Powyższe argumenty uzasadniają wniosek Sejmu o stwierdzenie, że art. 17 pkt 2 ustawy zmieniającej jest zgodny z zasadami: nieretroakcji prawa, ochrony zaufania do państwa i stanowionego przez nie prawa oraz niezmienności prawa podatkowego $\mathrm{w}$ trakcie roku podatkowego, wywodzonymi z art. 2 Konstytucji, w związku z art. 167 ust. 3 Konstytucji. 


\section{Bibliografia}

NIK, „Rozwój sektora odnawialnych źródeł energii” raport z 15 listopada 2018 r., https:// www.nik.gov.pl/pliklid, 18357, vp,20955.pdf.

Skoczylas A., Piątek W., Komentarz do art. 167 [w:] Konstytucja RP. Komentarz, t. II, Art. 87-243, red. M. Safjan, L. Bosek, Warszawa 2016.

Sprawozdanie stenograficzne $z$ 63. posiedzenia Sejmu Rzeczypospolitej Polskiej $w$ dniu 5 czerwca 2018 r. (pierwszy dzień obrad), Warszawa 2018.

Stanowisko Polskiego Stowarzyszenia Energetyki Wiatrowej w sprawie niezbędnych zmian prawa określającego podstawę naliczania podatku od nieruchomości od elektrowni wiatrowych, https://www.senat.gov.pl/gfx/senat/userfiles/_public/k9/komisje/2017/kpcpp/materialy/143/stanowisko_psew-podatek_od_nieruchomosci_uoi. pdf.

Tuleja P., Komentarz do art. 2 [w:] Konstytucja RP. Komentarz, t. I, Art. 1-86, red. M. Safjan, L. Bosek, Warszawa 2016.

Wojtyczek K., Ciężar dowodu i argumentacji w procedurze kontroli norm przez Trybunał Konstytucyjny, „Przegląd Sejmowy” 2004, nr 1.

Https://www.gramwzielone.pl/energia-wiatrowa/27369/bankructwa-wlascicieli-wiatrakow-sa-faktem.

Https://www.gov.pl/web/aktywa-panstwowe/krajowy-plan-na-rzecz-energii-i-klimatu-na-lata-2021-2030-przekazany-do-ke.

Https://podatki.gazetaprawna.pl/artykuly/1230231,gminy-nie-straca-na-zmianach-podatkow-od-wiatrakow.html. 


\title{
Zgodność z Konstytucją przepisu ustawy o Straży Granicznej w zakresie określenia czasu wolnego lub wynagrodzenia w zamian za czas służby przekraczający normy służby ${ }^{1}$
}

\author{
Conformity to the Constitution of the provision of the Act on the Border \\ Guard in the aspect of determining time off or remuneration in exchange \\ for service time exceeding service standards
}

\begin{abstract}
In the position of the Sejm a statement was proposed that the appealed provision of the Act on the Border Guard, in the area in which it stipulates that an officer entitled to a functional allowance is not entitled to time off from service in exchange for service overtime exceeding service standards, is compliant with the indicated provision of the European Social Charter drawn up in Turin on $18^{\text {th }}$ October 18 1961. The Applicant emphasized that the legislator did not comply with the provisions of the ESC, for he deprived Border Guard officers serving in independent or managerial positions of the right to free time or remuneration for the time of service performed in overtime. In the justification of the position, it was stated that Article 4 of the ESC does not determine the extent of additional remuneration that employees are entitled to for overtime work. Therefore the national legislator has been left with far-reaching freedom to define the rules of remuneration of employees.
\end{abstract}

Keywords: Constitutional Tribunal, Border Guard

\begin{abstract}
W stanowisku Sejmu zaproponowano stwierdzenie, że zaskarżony przepis ustawy o Straży Granicznej w zakresie, w jakim stanowi, że funkcjonariuszowi uprawnionemu do dodatku funkcyjnego nie przysługuje czas wolny od służby w zamian za czas służby przekraczający normę, jest zgodny ze wskazanym przepisem Europejskiej Karty Społecznej sporządzonej w Turynie 18 października 1961 r. Zdaniem wnioskodawcy ustawodawca nie przestrzega postanowień EKS, bowiem pozbawia funkcjonariuszy Straży Granicznej pełniących służbę na stanowiskach samodzielnych lub kierowniczych prawa do czasu wolnego albo wynagrodzenia za czas służby pełnionej w godzinach ponadnormatywnych. W uzasadnieniu stanowiska stwierdzono, że z art. 4 EKS nie wynika zakres dodatkowego wynagrodzenia przysługujący pracownikom za pracę w godzinach nadliczbowych. Ustawodawcy krajowemu pozostawiono więc daleko idącą swobodę z zakresie dookreślenia zasad wynagrodzenia pracowników.
\end{abstract}

Słowa kluczowe: Trybunał Konstytucyjny, Straż Graniczna

Doktor hab. nauk prawnych, profesor UJD .

Uniwersytet Humanistyczno-Przyrodniczy im. Jana Długosza w Częstochowie,

Wydział Prawa i Ekonomii, kierownik Katedry Prawa Ustrojowego i Porównawczego,

CZESTOCHOWA, POLSKA -

b.przywora@ujd.edu.pl . https://orcid.org/0000-0002-8809-3971

\footnotetext{
$1 \quad$ Sprawa dot. wniosku Zarządu Głównego Niezależnego Samorządnego Związku Zawodowego Funkcjonariuszy Straży Granicznej z siedziba w Warszawie $z 29$ stycznia 2019 r., dotyczącego ustawy o Straży Granicznej (Dz.U. z 2019, poz. 147 ze zm.), (sygn. akt K 17/19), stanowisko sporządzone 26 listopada 2019 r.; BAS-WAKU-1915/19.
} 
Na podstawie art. 69 ust. 2 w związku z art. 42 pkt 3 ustawy z 30 listopada 2016 r. o organizacji i trybie postępowania przed Trybunałem Konstytucyjnym (Dz. U. poz. 2072, ze zm.), w imieniu Sejmu Rzeczypospolitej Polskiej przedkładam stanowisko w sprawie z wniosku Zarządu Głównego Niezależnego Samorządnego Związku Zawodowego Funkcjonariuszy Straży Granicznej z siedzibą w Warszawie z 29 stycznia 2019 r. (sygn. akt K 17/19), jednocześnie wnosząc o stwierdzenie, że art. 37 ust. 3a ustawy o Straży Granicznej (Dz. U. 2019, poz. 147, ze zm.) jest zgodny z art. 4 pkt 2 Europejskiej Karty Społecznej sporządzonej w Turynie 18 października 1961 r. (Dz. U. 1999, nr 8, poz. 67, ze zm.).

W pozostałym zakresie Sejm wnosi o umorzenie postępowania na podstawie art. 59 ust. 1 pkt 4 ustawy o organizacji i trybie postępowania przed Trybunałem Konstytucyjnym ze względu na utratę mocy obowiązującej przed wydaniem orzeczenia przez Trybunał.

\section{Uzasadnienie}

\section{Przedmiot kontroli i zarzuty wnioskodawcy}

1. Do Kancelarii Sejmu wpłynęło zawiadomienie Prezes Trybunału Konstytucyjnego o wszczęciu postępowania przed Trybunałem Konstytucyjnym w sprawie z wniosku Zarządu Głównego Niezależnego Samorządnego Związku Zawodowego Funkcjonariuszy Straży Granicznej z siedzibą w Warszawie (dalej: wnioskodawca lub Zarząd Główny NSZZ FSG) z 29 stycznia 2019 r. (sygn. akt K 17/19).

Wnioskodawca jako przedmiot kontroli wskazuje:

- art. 37 ust. 3 ustawy z 12 października 1990 r. o Straży Granicznej (Dz.U. 2017, poz. 2365, ze zm.; dalej: ustawa o SG) w zakresie, w jakim w zamian za czas służby przekraczający normy czasu służby przyznaje funkcjonariuszowi Straży Granicznej czas wolny od służby w tym samym wymiarze - z art. 4 ust. 2 Europejskiej Karty Społecznej sporządzonej w Turynie 18 października 1961 r. (Dz. U. 1999, nr 8 poz. 67, ze zm.; dalej: EKS lub Europejska Karta), - $\quad$ art. 37 ust. 3 a ustawy o SG z art. 4 ust. 2 EKS.

W dacie złożenia wniosku art. 37 ust. 3 ustawy o SG miał następujące brzmienie: „W zamian za czas służby przekraczający normę określoną w ust. 2 funkcjonariuszowi przysługuje czas wolny od służby w tym samym wymiarze", natomiast art. 37 ust. 3a ustawy o SG, w dacie złożenia wniosku, stanowił: „Przepisu ust. 3 nie stosuje się do funkcjonariusza uprawnionego do dodatku funkcyjnego. Funkcjonariuszowi uprawnionemu do dodatku funkcyjnego przysługuje czas wolny od służby w zamian za czas służby przekraczający normę określoną w ust. 2, pełnioną przed uzyskaniem uprawnienia do tego dodatku".

Wnioskodawca, w odniesieniu do art. 37 ust. 3 ustawy o SG, podkreśla, że ustawodawca nie przestrzega postanowień art. 4 ust. 2 EKS, bowiem nie zapewnił funkcjonariuszom Straży Granicznej „ani zwiększonego wynagrodzenia za 
służbę w godzinach nadliczbowych, ani prawa do wypoczynku w zwiększonym wymiarze, a prawa te nie zostały zapewnione innymi środkami przewidzianymi przez art. 4 EKS”, a w konsekwencji „dojść należy do wniosku, że art. 37 ust. 3 Ustawy o SG jest niezgodny $z$ art. 4 ust. 2 EKS przez to, że nie przewiduje prawa funkcjonariusza Straży Granicznej do zwiększonego wymiaru czasu wolnego z tytułu służby pełnionej w godzinach ponadnormatywnych" (wniosek, s. 11). Zatem w przekonaniu wnioskodawcy art. 37 ust. 3 ustawy o SG ,jest sprzeczny z art. 4 ust. 2 EKS w zakresie, w jakim w zamian za czas służby przekraczający normy czasu służby przyznaje funkcjonariuszowi Straży Granicznej czas wolny od służby w tym samym a nie zwiększonym - wymiarze" (wniosek, s. 12).

Wnioskodawca zarzuca także niezgodność art. 37 ust. 3a ustawy o SG z art. 4 ust. 2 EKS z racji tego, że „funkcjonariuszowi uprawnionemu do dodatku funkcyjnego nie przysługuje $\mathrm{w}$ żadnym wymiarze czas wolny od służby za służbę w godzinach nadliczbowych" (wniosek, s. 12). Uprawnionymi do dodatku funkcyjnego są funkcjonariusze pełniący stanowiska „kierownicze lub samodzielne” (art. 108 ust. 1 pkt 3 ustawy o SG). Wnioskodawca zwraca uwagę, że do dodatku funkcyjnego uprawnieni są funkcjonariusze zajmujący:

- najwyższe stanowiska służbowe w Straży Granicznej,

- stanowiska kierownicze średniego i niskiego szczebla,

- stanowiska „samodzielne”, niemające charakteru kierowniczego (wniosek, s. 12).

W ocenie wnioskodawcy ustawodawca jednakowo potraktował „starszych stopniem funkcjonariuszy SG pełniących służbę na stanowiskach samodzielnych i kierowniczych niższego i średniego szczebla, jak i funkcjonariuszy pełniących najwyższe stanowiska kierownicze”, a ,zgodnie z art. 4 ust. 2 EKS ograniczenie prawa do zwiększonej gratyfikacji dotyczyć może jedynie funkcjonariuszy pełniących najwyższe funkcje kierownicze" (wniosek, s. 12). Zdaniem wnioskodawcy art. 37 ust. 3a ustawy o SG „przez to, że pozbawia funkcjonariuszy Straży Granicznej pełniących służbę na stanowiskach samodzielnych lub kierowniczych prawa do czasu wolnego $\mathrm{z}$ uwagi na służbę $\mathrm{w}$ godzinach ponadnormatywnych albo wynagrodzenia za czas służby pełnionej w godzinach ponadnormatywnych, a także przez to, że nie przyznaje tej grupie funkcjonariuszy prawa do czasu wolnego w zwiększonym wymiarze albo wynagrodzenia w zwiększonej stawce za ponadnormatywny czas służby, jest w całości niezgodny z art. 4 ust. 2 EKS" (wniosek, s. 13).

Podsumowując, wnioskodawca stwierdza, że: „[a]rt. 4 ust. 2 EKS konstruuje prawo pracownika do otrzymywania zwiększonego wynagrodzenia (albo czasu wolnego w zwiększonym wymiarze) za pracę w godzinach nadliczbowych. Prawo to przysługuje także funkcjonariuszom służb mundurowych. Dopuszczalne jest ustanawianie wyjątków od tej reguły, ale jedynie w stosunku do pracowników (funkcjonariuszy) najwyższego szczebla, piastujących kluczowe stanowiska kierownicze. Jednakże nawet w stosunku do tej grupy niedopuszczalne jest konstru- 
owanie norm nieprzewidujących limitu czasu pracy. Ponadto niedopuszczalne jest obchodzenie uprawnień pracowniczych z art. 4 ust. 2 EKS poprzez kwalifikowanie pracowników średniego szczebla jako pracowników na stanowiskach kierowniczych" (wniosek, s. 13-14). Ustawodawca w art. 37 ust. 3 ustawy o SG przyznaje wprawdzie funkcjonariuszom Straży Granicznej za służbę w godzinach nadliczbowych prawo do czasu wolnego, jednakże tylko w takim samym wymiarze, co godzi w art. 4 ust. 2 EKS w zakresie, w jakim nie przyznaje funkcjonariuszom czasu wolnego w zwiększonym wymiarze, a jedynie w równym wymiarze. Natomiast art. 37 ust. 3a ustawy o SG „pozbawia funkcjonariuszy uprawnionych do dodatku funkcyjnego w ogóle prawa do czasu wolnego w zamian za służbę pełnioną w zwiększonym wymiarze. Nie zapewnia również prawa do stosownej rekompensaty pieniężnej w zwiększonym wymiarze. W konsekwencji uznać należy, że przepis ten pozostaje w całości w sprzeczności z art. 4 ust. 2 EKS” (wniosek, s. 14).

\section{Analiza formalna}

1. Wniosek, z którym wystąpił wnioskodawca, ma podstawę prawną w art. 191 ust. 1 pkt 4 Konstytucji, zgodnie z którym: z wnioskiem w sprawach, o których mowa w art. 188 Konstytucji (tj. zgodności ustaw i umów międzynarodowych z Konstytucją, zgodności ustaw z ratyfikowanymi umowami międzynarodowymi, których ratyfikacja wymagała uprzedniej zgody wyrażonej w ustawie, zgodności przepisów prawa, wydawanych przez centralne organy państwowe z Konstytucją, ratyfikowanymi umowami międzynarodowymi i ustawami, zgodności z Konstytucją celów lub działalności partii politycznych, skargi konstytucyjnej, o której mowa w art. 79 ust. 1 Konstytucji) do Trybunału Konstytucyjnego wystąpić mogą: ogólnokrajowe organy związków zawodowych.

Zgodnie z $\$ 25$ ust. 6 Statutu Niezależnego Samorządnego Związku Zawodowego Funkcjonariuszy Straży Granicznej, uchwalonego w Serocku 23 września 2015 r., do zadań i uprawnień Zarządu Głównego NSZZ FSG należy w szczególności: „1) reprezentowanie Związku wobec władz, administracji państwowej i samorządu terytorialnego oraz podmiotów gospodarczych, a także innych organizacji i instytucji” oraz „6) opiniowanie projektów aktów prawnych oraz przedstawianie wniosków i postulatów dotyczących treści tworzonych aktów prawnych".

W świetle art. 46 ustawy z 30 listopada 2016 r. o organizacji i trybie postępowania przed Trybunałem Konstytucyjnym (Dz. U. poz. 2072, ze zm.; dalej: ustawa o TK): „Pismami procesowymi są wnioski, pytania prawne i skargi konstytucyjne, a także inne wnioski i oświadczenia uczestników postępowania, wnoszone do Trybunału w toku postępowania poza rozprawą".

Natomiast art. 47 ustawy o TK stanowi: „1. Wniosek złożony przez podmiot, o którym mowa w art. 191 ust. 1 pkt 1-5 Konstytucji, zawiera: 1) oznaczenie podmiotu uprawnionego do złożenia wniosku; 2) podanie podstawy prawnej 
działania podmiotu uprawnionego do złożenia wniosku; 3) oznaczenie rodzaju pisma procesowego; 4) określenie kwestionowanego aktu normatywnego lub jego części; 5) wskazanie wzorca kontroli; 6) uzasadnienie. 2. Uzasadnienie, o którym mowa w ust. 1 pkt 6, zawiera: 1) przywołanie treści kwestionowanego wnioskiem przepisu wraz z jego wykładnią; 2) przywołanie treści wzorców kontroli wraz z ich wykładnią; 3) określenie problemu konstytucyjnego i zarzutu niekonstytucyjności; 4) wskazanie argumentów lub dowodów na poparcie zarzutu niekonstytucyjności. [...]”.

Kontrola konstytucyjności ustaw opiera się na domniemaniu, że badane normy są zgodne z Konstytucją. Ciężar dowodu spoczywa na podmiocie kwestionującym zgodność ustawy z Konstytucją. Obowiązkiem wnioskodawcy jest przedstawienie argumentów, przemawiających za stwierdzeniem niezgodności zaskarżonych norm prawnych z normami powołanymi jako podstawa kontroli (zob. K. Wojtyczek, Ciężar dowodu i argumentacji w procedurze kontroli norm przez Trybunat Konstytucyjny, „Przegląd Sejmowy” 2004, nr 1, s. 17).

Nie jest wystarczające sformułowanie samej tezy o niekonstytucyjności zaskarżonego przepisu. Zdaniem Trybunału Konstytucyjnego: „Uzasadnienie musi spełniać określone wymagania, w tym przede wszystkim precyzyjnie wskazywać co najmniej jeden argument przemawiający za naruszeniem określonych wzorców kontroli. Nie realizują omawianych wymagań uwagi nazbyt ogólne, niejasne czy też czynione jedynie na marginesie innych rozważań. Należy przy tym odróżnić uzasadnienie pozorne i uzasadnienie błędne czy nietrafne. Postawienie bezzasadnego zarzutu prowadzi do uznania aktu normatywnego za zgodny z danym przepisem Konstytucji, ewentualnie do stwierdzenia nieadekwatności wzorca kontroli, natomiast błędne czy nietrafne uzasadnienie, o ile nie wpływa na rekonstrukcję nieprecyzyjnie sformułowanego zarzutu, nie ma znaczenia dla rozstrzygnięcia $\mathrm{w}$ przedmiocie zgodności aktu normatywnego z ustawą zasadniczą" (wyrok TK z 5 czerwca 2014 r., sygn. akt K 35/11).

Przepisy ustawy o TK nakładają na podmioty uprawnione do złożenia wniosku (pytania, skargi) do sądu konstytucyjnego pewne obowiązki, w tym wymóg uzasadnienia postawionego zarzutu, z powołaniem dowodów na jego poparcie (art. 47 ust. 2 pkt 4 ustawy o TK). Trybunał Konstytucyjny we wcześniejszym orzecznictwie, które zachowuje pełną aktualność także w obowiązującym stanie prawnym, podkreślał, że: „[...] uzasadnienie zarzutów powinno opierać się na przedstawieniu we wniosku takiej argumentacji, która uprawdopodobni ewentualną niekonstytucyjność kwestionowanych przepisów. W szczególności argumentacja taka nie może opierać się jedynie na odczuciach czy wyobrażeniach wnioskodawcy, ale powinna być poparta merytorycznym uzasadnieniem, mogącym uwzględniać m.in. wcześniejsze orzecznictwo TK, praktykę stosowania prawa czy dorobek doktryny" (postanowienie TK z 6 listopada 2007 r., sygn. akt Tw 41/05; zob. także postanowienia TK z: 12 sierpnia 2005 r., sygn. akt Tw 23/05, i 29 sierpnia 2006 r., sygn. akt Tw 14/06). Samo werbalne sformułowanie zarzutu, 
czy też wskazanie, że kwestionowany przepis jest sprzeczny z innym przepisem aktu hierarchicznie wyższego, nie może więc zostać uznane za uzasadnienie zarzutu w sensie procesowym.

2. W pierwszej kolejności Sejm wskazuje na przesłankę dającą podstawę do umorzenia postępowania na podstawie art. 59 ust. 1 pkt 4 ustawy o TK, ze względu na to, że akt normatywny w zakwestionowanym zakresie utracił moc obowiązującą przed wydaniem orzeczenia przez Trybunał. Sejm zwraca uwagę, że kwestionowane przez wnioskodawcę przepisy podlegały zmianom. Mianowicie, art. 37 ust. 3 ustawy o SG, w dniu złożenia wniosku, miał następujące brzmienie: „W zamian za czas służby przekraczający normę określoną w ust. 2 funkcjonariuszowi przysługuje czas wolny od służby w tym samym wymiarze”, natomiast art. 37 ust. 3a ustawy o SG, w dniu złożenia wniosku, stanowił: „Przepisu ust. 3 nie stosuje się do funkcjonariusza uprawnionego do dodatku funkcyjnego. Funkcjonariuszowi uprawnionemu do dodatku funkcyjnego przysługuje czas wolny od służby w zamian za czas służby przekraczający normę określoną w ust. 2, pełnioną przed uzyskaniem uprawnienia do tego dodatku".

Przepisy te zostały zmienione na mocy ustawy z 19 lipca 2019 r. o zmianie ustawy o zaopatrzeniu emerytalnym funkcjonariuszy Policji, Agencji Bezpieczeństwa Wewnętrznego, Agencji Wywiadu, Służby Kontrwywiadu Wojskowego, Służby Wywiadu Wojskowego, Centralnego Biura Antykorupcyjnego, Straży Granicznej, Służby Ochrony Państwa, Państwowej Straży Pożarnej, Służby Celno-Skarbowej i Służby Więziennej oraz ich rodzin oraz niektórych innych ustaw (Dz. U. poz. 1635; dalej: ustawa zmieniająca).

Mianowicie, art. 37 ust. 3 ustawy o SG zmieniony został przez art. 3 pkt 1 lit. c ustawy zmieniającej i stanowi: „W zamian za czas służby przekraczający normę określoną w ust. 2 funkcjonariuszowi przysługuje w okresie rozliczeniowym czas wolny od służby w tym samym wymiarze albo po zakończeniu okresu rozliczeniowego rekompensata pieniężna, o ile w terminie 10 dni od zakończenia okresu rozliczeniowego nie wystąpi z wnioskiem o udzielenie czasu wolnego od służby w tym samym wymiarze".

Jak wynika z projektu ustawy (druk sejmowy nr 3604/VIII kad.): „Zmiany w ustawach pragmatycznych poszczególnych formacji resortu spraw wewnętrznych i administracji mają na celu wprowadzenie regulacji w zakresie rekompensaty pieniężnej w zamian za czas służby przekraczający normę 40-godzinnego tygodnia służby, w okresach rozliczeniowych od 1 stycznia do 30 czerwca danego roku oraz od 1 lipca do 31 grudnia danego roku" (uzasadnienie, s. 5).

W tym stanie Sejm wskazuje na przesłankę dającą podstawę do umorzenia postępowania na podstawie art. 59 ust. 1 pkt 4 ustawy o TK, ze względu na to, że akt normatywny w zakwestionowanym zakresie utracił moc obowiązującą przed wydaniem orzeczenia przez Trybunał.

Z orzecznictwa Trybunału Konstytucyjnego wynika też m.in., że „ocena prowadzącej do umorzenia postępowania - utraty mocy obowiązującej aktu 
normatywnego dokonuje się nie na podstawie formalnego stwierdzenia wyeliminowania kontrolowanego przepisu z systemu prawa, lecz z perspektywy możliwości wywołania przezeń skutków prawnych. Innymi słowy, „wykładnia zwrotu «akt normatywny utracił moc obowiązującą» [...] powinna zmierzać do oceny, czy zaskarżona norma prawna została usunięta z porządku prawnego nie tylko w sensie formalnoprawnym, lecz także w tym zakresie, czy uchylony przepis nadal wywiera określone skutki dla obywateli i czy może być nadal zastosowany w praktyce" (postanowienie TK z 13 października 1998 r., sygn. akt SK 3/98; zob. także postanowienia TK z: 18 listopada 1998 r., sygn. SK 1/98; 30 grudnia 1999 r., sygn. SK 16/99). Trwałości tej linii orzeczniczej nie podważyło ani uchwalenie Konstytucji, ani ustaw o TK (postanowienie TK z 5 kwietnia 2016 r., sygn. akt K 3/15).

Trybunał Konstytucyjny podkreśla, że „nie może orzekać co do przepisu, który nie został wskazany przez wnioskodawcę, czy też [...] został wskazany następczo jako reakcja na zmianę stanu prawnego. Celem sprawowanej przez Trybunał kontroli jest usunięcie stanu niezgodności konkretnych przepisów z Konstytucją, a przedmiotem konfrontacji z konstytucyjnymi zasadami i wartościami jest norma, której treść utrwala moment złożenia wniosku. Trybunał kończy prowadzone postępowanie, jeżeli stwierdzi, że przedmiot kontroli już „nie istnieje", a ewentualny wyrok nie spowoduje żadnych konsekwencji w systemie prawa" (postanowienie TK z 5 kwietnia 2016 r., sygn. akt K 3/15).

W świetle powyższego na podstawie art. 59 ust. 1 pkt 4 ustawy o TK Sejm wnosi o umorzenie postępowania w zakresie badania zgodności art. 37 ust. 3 ustawy o SG z art. 4 ust. 2 EKS ze względu na utratę mocy obowiązującej przed wydaniem orzeczenia przez Trybunał.

3. Natomiast art. 37 ust. 3 a ustawy o SG zmieniony został przez art. 3 pkt 1 lit. c ustawy zmieniającej i stanowi: „Przepisu ust. 3 nie stosuje się do funkcjonariusza uprawnionego do dodatku funkcyjnego". Przepis ten w dniu wystąpienia Z wnioskiem miał następujące brzmienie: „Przepisu ust. 3 nie stosuje się do funkcjonariusza uprawnionego do dodatku funkcyjnego. Funkcjonariuszowi uprawnionemu do dodatku funkcyjnego przysługuje czas wolny od służby w zamian za czas służby przekraczający normę określoną w ust. 2, pełnioną przed uzyskaniem uprawnienia do tego dodatku".

Mając na względzie przywoływane wyżej ugruntowane orzecznictwo Trybunału Konstytucyjnego oraz biorąc pod uwagę niewielki zakres zmian w odniesieniu do tego przepisu, zasadne jest poddanie go ocenie merytorycznej. Jest to uzasadnione również tym, że wnioskodawca spełnił wymóg formalny uzasadnienia postawionego zarzutu, z powołaniem dowodów na jego poparcie. Wnioskodawca jako wzorzec kontroli wskazuje art. 4 ust. 2 EKS, w świetle którego: „W celu zapewnienia skutecznego wykonywania prawa do sprawiedliwego wynagrodzenia, Umawiające się Strony zobowiązują się: uznać prawo pracowników do zwiększonej stawki wynagrodzenia za pracę w godzinach nadliczbowych, z zastrzeżeniem 
wyjątków w przypadkach szczególnych”. W ocenie wnioskodawcy „art. 37 ust. 3a Ustawy o SG przez to, że pozbawia funkcjonariuszy Straży Granicznej pełniących służbę na stanowiskach samodzielnych lub kierowniczych prawa do czasu wolnego $\mathrm{z}$ uwagi na służbę $\mathrm{w}$ godzinach ponadnormatywnych albo wynagrodzenia za czas służby pełnionej w godzinach ponadnormatywnych, a także przez to, że nie przyznaje tej grupie funkcjonariuszy prawa do czasu wolnego w zwiększonym wymiarze albo wynagrodzenia w zwiększonej stawce za ponadnormatywny czas służby, jest w całości niezgodny z art. 4 ust. 2 EKS” (wniosek, s. 13).

\section{Analiza zgodności art. 37 ust. 3a ustawy o SG z art. 4 ust. 2 EKS}

\section{Wzorzec kontroli}

Europejska Karta Społeczna sporządzona w Turynie 18 października 1961 r. jest podstawowym aktem prawa europejskiego, gwarantującym ochronę praw socjalnych, w szczególności związanych z zatrudnieniem i zabezpieczeniem społecznym. Europejska Karta traktuje prawa społeczne jako prawa człowieka oraz zapewnia im ochronę prawną (zob. A. Świątkowski, Karty społeczne Rady Europy, „Państwo i Prawo”, 2003, nr 8, s. 36-37; zob. też: B. Przywora, Europejska Karta Społeczna jako wzorzec kontroli prawa $w$ świetle orzecznictwa Trybunału Konstytucyjnego [w:] Ochrona praw człowieka w Europie: Aksjologia, instytucje, nowe wyzwania, t. 3, red. J. Jaskiernia, K. Spryszak, Toruń 2017, s. 202-211; także: M. Wujczyk, Europejski Komitet Praw Społecznych Rady Europy jako ponadnarodowy organ ochrony praw człowieka [w:] Instytucje ochrony praw człowieka, red. B. Szmulik, A. Pogłódek, B. Przywora, Warszawa 2015, s. 258; zob. także: A. M. Świątkowski, Karta Praw Społecznych Rady Europy, Warszawa 2006, s. 1; uzasadnienie do wyroku TK z 21 stycznia 2014 r. sygn. akt P 26/12).

W systemie normatywnym EKS znajduje się katalog praw człowieka, zaliczanych do praw człowieka tzw. drugiej generacji, ale także mechanizm kontrolny, w którym szczególne znaczenie ma Europejski Komitet Praw Społecznych (EKPS) - jeden $\mathrm{z}$ organów traktatowych w dziedzinie międzynarodowej ochrony praw człowieka (A. Gadkowski, Europejski Komitet Praw Społecznych w systemie organów traktatowych międzynarodowej ochrony praw człowieka, „Adam Mickiewicz University Law Review” 2014, vol. 3, s. 75).

Polska ratyfikowała Europejską Kartę (niezrewidowaną) w 1998 r. (Dz. U. 1999, nr 8, poz. 67), z wyłączeniem niektórych postanowień. W odniesieniu do art. 4 EKS (prawo do sprawiedliwego wynagrodzenia) Polska wyłączyła z ratyfikacji jedynie jej ust. 1, w świetle którego strony zobowiązują się uznać prawo pracowników do wynagrodzenia zapewniającego im i ich rodzinom godziwy poziom życia. Natomiast Polska ratyfikowała pozostałe ustępy art. 4 EKS. Wśród nich jest ust. 2, z którego wynika, że strony zobowiązują się uznać prawo pracowników do zwiększonej stawki wynagrodzenia za pracę w godzinach nadliczbowych, z zastrzeżeniem wyjątków w przypadkach szczególnych. Ratio przemawiającym 
za przyznaniem zwiększonej stawki wynagrodzenia jest wzmożony wysiłek, wymagany od pracownika za wykonanie pracy w okresie przekraczającym prawne normy czasu pracy (uzasadnienie do wyroku TK z 21 stycznia 2014 r., sygn. akt P 26/12; zob. też: M. Nowak, Prawo do godziwego wynagrodzenia za pracę. Regulacja prawna i treść, Łódź 2007, s. 258).

W konsekwencji strony umowy międzynarodowej zobowiązane są uznać prawo pracowników do zwiększonej stawki wynagrodzenia za pracę w godzinach nadliczbowych, z zastrzeżeniem wyjątków w przypadkach szczególnych. Wskazany artykuł nie ma charakteru absolutnego, przemawia za tym klauzula „z zastrzeżeniem wyjątków w przypadkach szczególnych”. Europejska Karta nie wskazuje jednak tych przypadków ani też nie wskazuje wymaganego minimalnego zwiększenia stawki wynagrodzenia. Nie określił tego także Europejski Komitet Praw Społecznych, zwany także Komitetem Niezależnych Ekspertów Rady Europy (uzasadnienie do wyroku TK z 21 stycznia 2014 r. sygn. akt P 26/12, i powoływane tam streszczenie prawa precedensowego EKPS, przygotowane przez sekretariat Europejskiej Karty Społecznej [w:] Przewodnik po europejskiej Karcie Społecznej, Warszawa 2002, s. 122).

Europejski Komitet Praw Społecznych uznał za zgodne z art. 4 ust. 2 EKS pozbawienie prawa do dodatków za pracę w godzinach nadliczbowych pracowników, którzy zajmują stanowiska kierownicze ( $\mathrm{z}$ racji wysokich, co do zasady, wynagrodzeń tej kategorii pracowników) oraz funkcjonariuszy publicznych, przy czym w odniesieniu do tej grupy podkreślono, że niedopuszczalne jest pozbawienie dodatku wszystkich pracowników sektora publicznego, a tylko „wysokich funkcjonariuszy publicznych” (uzasadnienie do wyroku TK z 21 stycznia 2014 r., sygn. akt P 26/12).

W konsekwencji należy uznać, że „dopuszczalne jest przyjęcie rekompensaty tylko w jednej formie (tylko czas pracy lub tylko dodatkowe wynagrodzenie)”, jednakże „wymiar rekompensaty musi być zawsze zwiększony w stosunku do czasu faktycznie przepracowanego" (L. Nawacki, Zasady rekompensowania pracy w godzinach nadliczbowych [w:] Europejska Karta Społeczna: Wyzwania i możliwości. 25. rocznica przystąpienia Polski do Rady Europy, red. L. Nawacki, A. Szałek, M. Wujczyk, Warszawa 2016, s. 76). Ponadto „dopuszczalne jest ograniczenie rekompensowania pracy w godzinach nadliczbowych niektórych grup pracowników pełniących szczególne funkcje (zarządzanie, bezpośredni udział w tworzeniu polityki), nie może to jednak oznaczać całkowitego odejścia od rekompensowania pracy w godzinach nadliczbowych" (ibidem).

\section{Analiza merytoryczna}

Problem w rozpoznawanej sprawie sprowadza się do tego, czy zaskarżony art. 37 ust. 3a ustawy o SG w zakresie, w jakim „pozbawia funkcjonariuszy Straży Granicznej pełniących służbę na stanowiskach samodzielnych lub kierowniczych prawa do czasu wolnego $\mathrm{z}$ uwagi na służbę w godzinach ponadnormatywnych 
albo wynagrodzenia za czas służby pełnionej w godzinach ponadnormatywnych, a także przez to, że nie przyznaje tej grupie funkcjonariuszy prawa do czasu wolnego w zwiększonym wymiarze albo wynagrodzenia w zwiększonej stawce za ponadnormatywny czas służby" (wniosek, s. 13) jest zgodny z art. 4 ust. 2 EKS?

Sejm zwraca uwagę, że problem rekompensat za godziny nadliczbowe był już przedmiotem rozważań w orzecznictwie Trybunału Konstytucyjnego. Wówczas przedmiotem zaskarżenia był art. 42 ust. 4 ustawy z 21 listopada 2008 r. o pracownikach samorządowych (Dz. U. 2019, poz. 1282, ze zm., dalej: u.p.s.), w świetle którego: „Pracownikowi samorządowemu za pracę wykonywaną na polecenie przełożonego w godzinach nadliczbowych przysługuje, według jego wyboru, wynagrodzenie albo czas wolny w tym samym wymiarze, z tym że wolny czas, na wniosek pracownika, może być udzielony w okresie bezpośrednio poprzedzającym urlop wypoczynkowy lub po jego zakończeniu”.

Zdaniem Trybunału Konstytucyjnego zaskarżony art. 42 ust. 4 u.p.s. „w zakresie, w jakim dotyczy pracowników samorządowych zarządzających w imieniu pracodawcy zakładem pracy, mieści się w pojęciu «szczególnych przypadków», o których mowa w art. 4 ust. 2 EKS. Pracownicy należący do tej grupy sami organizują swoją pracę i pracę podwładnych, nie są na bieżąco kontrolowani, toteż mogą część oficjalnego czasu pracy poświęcić na czynności niezwiązane ze stosunkiem pracy. Z reguły też ich wynagrodzenie za pracę jest relatywnie wysokie, co pozwala przyjąć, że przynajmniej w części rekompensuje ono także ewentualną pracę ponadwymiarową. Dlatego należy uznać, że art. 42 ust. 4 u.p.s. w zakresie, w jakim dotyczy pracowników zarządzających w imieniu pracodawcy zakładem pracy, jest zgodny z art. 4 ust. 2 EKS" (uzasadnienie do wyroku TK z 21 stycznia 2014 r., sygn. akt P 26/12). Z powyższego należałoby wywieść, że art. 42 ust. 4 u.p.s., który nie przewiduje prawa pracownika samorządowego do zwiększonej stawki wynagrodzenia albo zwiększonego wymiaru czasu wolnego z tytułu pracy wykonywanej na polecenie przełożonego w godzinach nadliczbowych, jest niezgodny z unormowaniami art. 4 ust. 2 EKS - ratyfikowanej umowy międzynarodowej stanowiącej źródło powszechnie obowiązującego prawa (B. Przywora, Zgodność z Konstytucja RP rekompensat za prace pracownika samorzadowego w godzinach nadliczbowych na polecenie przełożonego, „Samorząd Terytorialny" 2018, nr 1-2, s. 85; zob. też: S. Płażek, Problemy z wynagrodzeniem pracowników samorządowych po wejściu w życie nowego rozporządzenia płacowego z 15 maja 2018 r., „Finanse Komunalne” 2019, nr 1-2, s. 149-150; zob. też wniosek Rzecznika Praw Obywatelskich z dnia 3 sierpnia 2015 r. do Trybunału Konstytucyjnego, znak III.7040.73.2014.L).

Warto zwrócić uwagę także na wyrok TK z 29 listopada 2016 r. (sygn. akt SK 18/15), w którym Trybunał orzekł, że „art. 32 ust. 1 ustawy z 27 lipca 2001 r. o służbie zagranicznej (...) w zakresie, w jakim nie przewiduje dodatkowego wynagrodzenia za pracę w godzinach nadliczbowych dla pracowników służby zagranicznej wykonujących obowiązki służbowe w placówce zagranicznej, jest 
zgodny z art. 64 ust. 2 w związku z art. 31 ust. 3 Konstytucji Rzeczypospolitej Polskiej". W uzasadnieniu do tego orzeczenia Trybunał Konstytucyjny podkreślił zadania placówek zagranicznych i warunki, w jakich funkcjonują. Szczególny ich charakter stawia pracowników placówek zagranicznych w odmiennej sytuacji od członków korpusu służby cywilnej zatrudnionych w kraju. W ocenie TK praca „W placówce zagranicznej oznacza zgodę na potencjalnie większe obciążenie pracą. Dlatego też nie można podzielić zdania skarżącego, że brak wynagrodzenia lub czasu wolnego za pracę w godzinach nadliczbowych, wykonywaną w ramach służby zagranicznej w polskiej placówce dyplomatycznej narusza art. 64 ust. 2 w związku z art. 31 ust. 3 Konstytucji”".

Ustawa o SG należy do tzw. pragmatyk pracowniczych, czyli ustaw szczególnych, które - w sposób odmienny od ustawy z 26 czerwca 1974 r. Kodeks pracy (t.j. Dz.U. 2019, poz. 1040, ze zm.) - regulują stosunki pracy określonych grup pracowniczych, wyodrębnionych $\mathrm{z}$ reguły według kryterium rodzaju pracy, powiązanego $\mathrm{z}$ kryterium charakteru podmiotu zatrudniającego. $\mathrm{Z}$ zakwestionowanego przez wnioskodawcę art. 37 ust. 3a ustawy o SG wynika, że do funkcjonariusza uprawnionego do dodatku funkcyjnego nie stosuje się art. 37 ust. 3 ustawy o SG, dotyczącego rekompensaty za pracę w godzinach nadliczbowych. Zgodnie bowiem $\mathrm{z}$ art. 108 ust. 1 pkt 3 ustawy o SG funkcjonariusze otrzymują dodatek funkcyjny na stanowisku kierowniczym lub samodzielnym.

Mając na względzie powyższe ustalenia, uprawnione jest sformułowanie następujących wniosków.

$\mathrm{Z}$ art. 4 pkt 2 EKS nie wynika zakres dodatkowego wynagrodzenia przysługujący pracownikom za pracę $\mathrm{w}$ godzinach nadliczbowych. Zatem pozostawiono ustawodawcy krajowemu daleko idącą swobodę z zakresie dookreślenia zasad wynagrodzenia pracowników. Można nawet stwierdzić, że każda stawka wynagradzania przewyższająca stawkę podstawową wypłacaną pracownikom w ramach dobowych i tygodniowych norm czasu pracy będzie spełnia wymogi $\mathrm{z}$ art. 4 pkt 2 EKS (stanowisko Marszałka Sejmu w sprawie przed TK o sygn. akt P 26/12). W innym stanowisku Sejm podkreślił, że „art. 97 ust. 6 u.s.c. [ustawie o służbie cywilnej - dopisek B.P.] w zakresie, w jakim pracownikowi służby cywilnej, który nie pobiera dodatku funkcyjnego lub nie zarządza w imieniu pracodawcy zakładem pracy, w zamian za pracę wykonywaną na polecenie przełożonego w godzinach nadliczbowych przyznaje czas wolny w tym samym wymiarze, jest niezgodny z art. 4 ust. 2 EKS" (stanowisko Marszałka Sejmu w sprawie przed TK o sygn. akt K 20/15, s. 32).

Sejm podziela prezentowane wyżej stanowisko także w odniesieniu do funkcjonariusza Straży Granicznej, uprawnionego do dodatku funkcyjnego (tj. do funkcjonariusza na stanowisku kierowniczym lub samodzielnym). Jest to w ocenie Sejmu szczególny przypadek, mieszczący się w granicach dopuszczalnego wyjątku przewidzianego w art. 4 ust. 2 EKS. Funkcjonariusze na stanowisku kierowniczym lub samodzielnym otrzymują bowiem dodatek funkcyjny za zwięk- 
szoną dyspozycyjność w pracy. Ponadto funkcjonariuszowi uprawnionemu do dodatku funkcyjnego przysługuje:

- czas wolny od służby w zamian za czas służby przekraczający normę określoną w ust. 2 albo

- rekompensata pieniężna, o której mowa w ust. 3,

za czas służby pełnionej przed dniem uzyskania uprawnienia do tego dodatku (art. 37 ust. 3 b ustawy o SG).

W ocenie Sejmu przyjęte kryterium zróżnicowania sytuacji prawnej funkcjonariuszy Straży Granicznej, w kwestii sposobu rekompensowania pracy w godzinach nadliczbowych, znajduje racjonalne uzasadnienie w celu ustawy o Straży Granicznej: ochronie „granicy państwowej, kontroli ruchu granicznego oraz zapobiegania i przeciwdziałania nielegalnej migracji” (art. 1 ustawy o SG), ten zaś z kolei znajduje mocne zakotwiczenie w wartościach konstytucyjnych, np. „Rzeczpospolita Polska strzeże niepodległości i nienaruszalności swojego terytorium, zapewnia wolności i prawa człowieka i obywatela oraz bezpieczeństwo obywateli” (art. 5 Konstytucji), czy „ograniczenia w zakresie korzystania z konstytucyjnych wolności i praw mogą być ustanawiane tylko w ustawie i tylko wtedy, gdy są konieczne w demokratycznym państwie dla jego bezpieczeństwa lub porządku publicznego [...]. Ograniczenia te nie mogą naruszać istoty wolności i praw (art. 31 ust. 3 Konstytucji).

W świetle powyższych ustaleń należy przyjąć, że art. 37 ust. 3a ustawy o SG jest zgodny $z$ art. 4 pkt 2 EKS.

\section{Bibliografia}

Gadkowski A., Europejski Komitet Praw Społecznych w systemie organów traktatowych międzynarodowej ochrony praw człowieka, „Adam Mickiewicz University Law Review" 2014, vol. 3 .

Nawacki L., Zasady rekompensowania pracy w godzinach nadliczbowych [w:] Europejska Karta Społeczna: Wyzwania i możliwości. 25. rocznica przystapienia Polski do Rady Europy, red. L. Nawacki, A. Szałek, M. Wujczyk, Warszawa 2016.

Nowak M., Prawo do godziwego wynagrodzenia za pracę. Regulacja prawna i treść, Łódź 2007.

Płażek S., Problemy z wynagrodzeniem pracowników samorządowych po wejściu w życie nowego rozporzadzenia płacowego z 15 maja 2018 r., „Finanse Komunalne” 2019, nr 1-2.

Przewodnik po europejskiej Karcie Społecznej, Warszawa 2002.

Przywora B., Europejska Karta Społeczna jako wzorzec kontroli prawa w świetle orzecznictwa Trybunału Konstytucyjnego [w:] Ochrona praw człowieka w Europie: Aksjologia, instytucje, nowe wyzwania, t. 3, red. J. Jaskiernia, K. Spryszak, Torun 2017. 
Przywora B., Zgodność z Konstytucją RP rekompensat za prace pracownika samorzadowego w godzinach nadliczbowych na polecenie przełożonego, „Samorząd Terytorialny” 2018, nr 1-2.

Świątkowski A.M., Karta Praw Społecznych Rady Europy, Warszawa 2006.

Świątkowski A., Karty Społeczne Rady Europy, „Państwo i Prawo” 2003, nr 8.

Wojtyczek K., Ciężar dowodu i argumentacji w procedurze kontroli norm przez Trybunat Konstytucyjny, „Przegląd Sejmowy” 2004, nr 1.

Wujczyk M., Europejski Komitet Praw Społecznych Rady Europy jako ponadnarodowy organ ochrony praw człowieka [w:] Instytucje ochrony praw człowieka, red. B. Szmulik, A. Pogłódek, B. Przywora, Warszawa 2015. 


\section{Recenzenci „Zeszytów Prawniczych BAS” w 2020 r.}

- Dr hab. Anna Barczak, prof. US - Uniwersytet Szczeciński, Wydział Prawa i Administracji - Szczecin, Polska

- Prof. dr hab. BogumiŁ Brzeziński - Uniwersytet Mikołaja Kopernika w Toruniu, Wydział Prawa i Administracji - Toruń, Polska

- Prof. dr hab. Janina Ciechanowicz-McLean - Uniwersytet Gdański, Wydział Prawa i Administracji - GdAŃsk, Polska

- Dr Daria Danecka - Polska Akademia Nauk, Instytut Nauk Prawnych WARsZAWA, POLSKA

- Dr hab. Kinga Flaga-GieruszyńsKa, prof. US - Uniwersytet Szczeciński, Wydział Prawa i Administracji - Szczecin, Polska

- Prof. dr hab. Bernadetta Fuchs - Uniwersytet Śląski w Katowicach, Wydział Prawa i Administracji - Katowice, Polska

- Dr Aleksandra Gawrysiak-ZabŁocka - Uniwersytet Kardynała Stefana Wyszyńskiego w Warszawie, Wydział Prawa i Administracji - WARszawa, PolsKa

- Dr hab. RadosŁaw Giętkowski, prof. UG - Uniwersytet Gdański, Wydział Prawa i Administracji - GdAŃsk, Polska

- Prof. dr hab. Jacek Górecki - Uniwersytet Śląski w Katowicach, Wydział Prawa i Administracji - Katowice, Polska

- Dr Marta Kisielowska - Uniwersytet Jagielloński w Krakowie, Wydział Prawa i Administracji - KRAKów, PolsKa

- Dr hab. Katarzyna Kubuj - Polska Akademia Nauk, Instytut Nauk Prawnych - WARszawa, Polska

- Dr BolesŁaw KurzęPa - Politechnika Rzeszowska im. Ignacego Łukasiewicza, Wydział Zarządzania - Rzeszów, PolskA 
- Prof. dr hab. Maciej Marsza£ - Uniwersytet Wrocławski, Wydział Prawa, Administracji i Ekonomii - WrocŁaw, Polska

- Dr Magdalena Michalak - Uniwersytet Łódzki, Wydział Ekonomiczno-Socjologiczny - ŁóDź, PoLSKA

- Dr Micha£ MiŁosz - Uniwersytet Gdański, Wydział Prawa i Administracji GdańsK, PolsKa

- Dr hab. Krzysztof Mularski, prof. UAM - Uniwersytet im. Adama Mickiewicza w Poznaniu, Wydział Prawa i Administracji - Poznań, Polska

- Prof. dr hab. Tomasz Nieborak - Uniwersytet im. Adama Mickiewicza w Poznaniu, Wydział Prawa i Administracji - Poznań, Polska

- Prof. dr hab. Zbigniew Ofiarski - Uniwersytet Szczeciński, Wydział Prawa i Administracji - Szczecin, Polska

- Dr Marcin Olechowski - Uniwersytet Warszawski, Wydział Prawa i Administracji - Warszawa, Polska

- Prof. zw. dr hab. StanisŁaw Owsiak - Uniwersytet Ekonomiczny w Krakowie, Wydział Finansów i Prawa - Kraków, Polska

- Dr hab. RadosŁaw Pastuszko - Uniwersytet Marii Curie-Skłodowskiej, Wydział Prawa i Administracji - Lublin, Polska

- Dr Piotr Pietrasz - Uniwersytet w Białymstoku, Wydział Prawa BiaŁystok, Polska

- Dr hab. Robert Piszko, prof. US - Uniwersytet Szczeciński, Wydział Prawa i Administracji - Szczecin, Polska

- Dr hab. Krzysztof Prokop, prof. ucz. - Uniwersytet Przyrodniczo-Humanistyczny w Siedlcach, Wydział Nauk Społecznych - Siedlce, Polska

- Dr hab. Marta Romańska, prof. UJ - Uniwersytet Jagielloński w Krakowie, Wydział Prawa i Administracji - KRAKów, Polska

- Dr hab. Pawe£ Sobczyк, prof. UO - Uniwersytet Opolski, Wydział Prawa i Administracji - Opole, Polska

- Dr Lucyna Staniszewska - Uniwersytet im. Adama Mickiewicza w Poznaniu, Wydział Prawa i Administracji - Poznań, Polska

- Prof. dr hab. Wanda Stojanowska - Uniwersytet Kardynała Stefana Wyszyńskiego w Warszawie, Wydział Prawa i Administracji - Warszawa, POLSKA

- Dr Aleksandra Syryt - Uniwersytet Kardynała Stefana Wyszyńskiego w Warszawie, Wydział Prawa i Administracji - Warszawa, Polska 
- Dr MaŁgorzata Szalewska - Uniwersytet Mikołaja Kopernika w Toruniu, Wydział Prawa i Administracji - Toruń, Polska

- Dr Bartosz Szczurowski - Uniwersytet Jagielloński w Krakowie, Wydział Prawa i Administracji - KRAKów, Polska

- Prof. zw. dr hab. Marek Wierzbowski - Uniwersytet Warszawski, Wydział Prawa i Administracji - WARszaWA, POLSKA

- Dr hab. MirosŁaw Wincenciak - Uniwersytet w Białymstoku, Wydział Prawa - BiAŁYstok, Polska

- Dr hab. ElżBIETA ZĘBEK, prof. UWM - Uniwersytet Warmińsko-Mazurski w Olsztynie, Wydział Prawa i Administracji - Olsztyn, Polska

- Dr hab. Agnieszka ZióŁkowska, prof. UŚ - Uniwersytet Śląski w Katowicach, Wydział Prawa i Administracji - Katowice, Polska 